\title{
Ziekteverzuim wegens overspanning : een onderzoek naar de aard van overspanning, de hulpverlening en het verzuimbeloop
}

Citation for published version (APA):

Schröer, C. A. P. (1993). Ziekteverzuim wegens overspanning : een onderzoek naar de aard van overspanning, de hulpverlening en het verzuimbeloop. [Doctoral Thesis, Maastricht University]. Datawyse / Universitaire Pers Maastricht. https://doi.org/10.26481/dis.19930219cs

Document status and date:

Published: 01/01/1993

DOI:

10.26481/dis.19930219cs

Document Version:

Publisher's PDF, also known as Version of record

Please check the document version of this publication:

- A submitted manuscript is the version of the article upon submission and before peer-review. There can be important differences between the submitted version and the official published version of record.

People interested in the research are advised to contact the author for the final version of the publication, or visit the DOI to the publisher's website.

- The final author version and the galley proof are versions of the publication after peer review.

- The final published version features the final layout of the paper including the volume, issue and page numbers.

Link to publication

\footnotetext{
General rights rights.

- You may freely distribute the URL identifying the publication in the public portal. please follow below link for the End User Agreement:

www.umlib.nl/taverne-license

Take down policy

If you believe that this document breaches copyright please contact us at:

repository@maastrichtuniversity.nl

providing details and we will investigate your claim.
}

Copyright and moral rights for the publications made accessible in the public portal are retained by the authors and/or other copyright owners and it is a condition of accessing publications that users recognise and abide by the legal requirements associated with these

- Users may download and print one copy of any publication from the public portal for the purpose of private study or research.

- You may not further distribute the material or use it for any profit-making activity or commercial gain

If the publication is distributed under the terms of Article $25 \mathrm{fa}$ of the Dutch Copyright Act, indicated by the "Taverne" license above, 
ZIEKTEVERZUIM WEGENS OVERSPANNING 


\title{
ZIEKTEVERZUIM WEGENS OVERSPANNING
}

Een onderzoek naar de aard van overspanning, de hulpverlening en het verzuimbeloop

\author{
PROEFSCHRIFT \\ ter verkrijging van de graad van doctor, \\ aan de Rijksuniversiteit Limburg te Maastricht, \\ op gezag van de Rector Magnificus, Prof. Mr. M.J. Cohen, \\ volgens het besluit van het College van Dekanen, \\ in het openbaar te verdedigen op \\ vrijdag, 19 februari 1993 om 14.00 uur \\ door \\ Cornelis Antonius Paulus Schröer
}

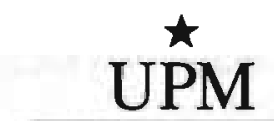

UNIVERSITAIRE PERS MAUSTRICHT 
Promotor:

Prof. Dr. H. Philipsen

Co-promotor:

Dr. F.J.N. Nijhuis

Beoordelingscommissie:

Prof Dr. J.J.C.B. Bremer (voorzitter)

Prof. Dr. Tj. de Boorder

Prof. Dr. J.A. Knottnerus

Prof. Dr. M.M.W. Richartz

Dr. P.G.W. Smulders (NIPG/TNO)

CIP DATA KONINKLIJKE BIBLIOTHEEK DEN HAAG

Schröer, Cornelis Anlonius Paulus

Ziekteverzuim wegens overspanning : een onderzoek naar de aard van overspanning, de hulpverlening en het ver zuimbeloop / Cornelis Antonius Paulus Schröer. -

Maastricht : Universitaire Pers Maastricht. - Ill.

Proefschrift Maastricht. - Met lit. opg. - Met

samenvatting in het Engels.

ISBN 90-5278-058-7

NUGI 757/741

Trefw. stross / ziekteverzuım

Boekverzorging: Datawyse I Universitaire Pers Maastricht

Het onderzoek is mede mogelijk gemaakt door financiële steun van Medische

Dienst van het GAK te Amsterdam 


\section{Inhoudsopgave}

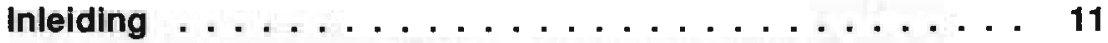

Achtergronden van het onderzoek . . . . . . . . . . 11

De toename van arbeidsongeschiktheid ... . . . . . . . . . . . . . 11

De toename van arbeidsongeschiktheid op psychische gronden . . . . . . . 15

Het ziekteverzuim wegens psychische aandoeningen . . . . . . . . . . 17

De aard van de psychische aandoeningen . . . . . . . . . . . . . . . . . 19

De ontwikkeling van de psychische morbiditeit . . . . . . . . . . . . . . 19

Knelpunten in de professionele hulpverlening . . . . . . . . . . . . . 21

Conclusies en beschouwing ....................... 23

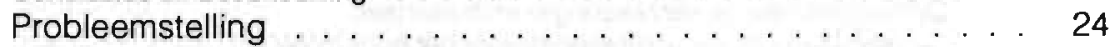

Opbouw van dit proefschrift ................. . . . 25

De conceptualisering van overspanning ..........

Gebruik en betekenis van de term overspanning in de medische

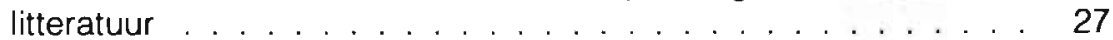

Het gebruik van de term overspanning . . . . . . . . . . . . . . . . . 28

De betekenis van de term overspanning . . . . . . . . . . . . . . . . . . 29

3 Een panelonderzoek naar de betrouwbaarheld van de verzekeringsgeneeskundige diagnostiek van overspanning . . Verklaringen van verschillen in verzuimduur op grond van procesanalyses . . . . 63 
De aanschrijving van de potentiele respondenten . . . . . . . . . . . . . 81

De respons van de verzekerings- en huisartsen . . . . . . . . . . . . . . . 83

De gevolgen van de non-respons voor het onderzoek . . . . . . . . . . 85

Beschrijving van de verzamelde data . . . . . . . . . . . . . . . 86

Inleiding . . . . . . . . . . . . . . . . . . . . . . . 86

Persoonskenmerken . . . . . . . . . . . . . . . . . . 86

Bedrijfskenmerken . . . . . . . . . . . . . . . . . . . . . . . . . . . 87

Kenmerken van de arbeidsplaats . . . . . . . . . . . . . . . . . . . . . 87

Ziektegeschiedenis . . . . . . . . . . . . . . . . . . . . . . 87

Het ziektebeeld . . . . . . . . . . . . . . . . . . . . . . . . . . . . . . . . 8

Ziektegedrag en hulpverleningscontacten $\ldots \ldots \ldots 8$

Kenmerken van de huisarts $\ldots \ldots \ldots \ldots$

Gedrag van de huisarts . . . . . . . . . . . . . . . . . . . . . . . . . . . . . . . 89

Kenmerken van de verzekeringsgeneeskundige . . . . . . . . . . . . . . . . 89

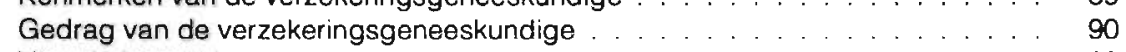

Enkele kenmerken van de onderzoekspopulatie . . . . . . . 91 


\section{Methode van onderzoek naar de invloed van wachttijden in de} curatieve sector op het verzuimbeloop . . . . . . . . . . . . . . . 133

10.4 De omvang van de wachttijden bij de verzekeringsgeneeskundige begeleiding

Methode van datanalyse ter verklaring van verschillen In wi]ze van verzuimbeëindiging en verzulmduur . . . . . . . . . 
$12.1 \quad$ Inleiding . . . . . . . . . . . . . . . . 163

12.2 De invloed van persoonskenmerken op terugkeer . . . . . . . 164

12.3 De invloed van bedrijfskenmerken op terugkeer . . . . . . . . . 166

12.4 De invloed van arbeidsplaatskenmerken op terugkeer . . . . . . 168

12.5 De invloed van de ziektegeschiedenis op terugkeer . . . . . . . 170

12.6 De invloed van ziektekenmerken op terugkeer . . . . . . . . 171

12.7 De invloed van ziektegedrag op terugkeer . . . . . . . . . . 172

12.8 De invloed van kenmerken van de huisarts (praktijk) op terugkeer 173

12.9 De invloed van het gedrag van de huisarts op terugkeer . . . . 175

12.10 De invloed van kenmerken van de verzekeringsgeneeskundige op terugkeer . . . . . . . . . . . . . . . . . . 176

12.11 De invloed van het gedrag van de verzekeringsgeneeskundige op terugkeer . . . . . . . . . . . . . . . . 177

12.12 Samenvatting van de eerste bevindingen . . . . . . . . . 178

12.13 Naar een integraal model voor de verklaring van terugkeer . . . 179

12.14 Een padanalyse van determinanten van terugkeer . . . . . . . . 180

12.15 Conclusies en beschouwing . . . . . . . . . . . . . 183

13 De verklaring van de aard van het verloop $\ldots \ldots \ldots \ldots$

$13.1 \quad$ Inleiding . . . . . . . . . . . . . . . . 185

13.2 De invloed van persoonskenmerken op de aard van het verloop . 186

13.3 De invloed van bedrijfskenmerken op de aard van het verloop .. 187

13.4 De invloed van arbeidsplaatskenmerken op de aard van het verloop . . . . . . . . . . . . . . . . . . . . 188

13.5 De invloed van de ziektegeschiedenis op de aard van het verloop 189

13.6 De invloed van ziektekenmerken op de aard van het verloop ... 190

13.7 De invloed van ziektegedrag op de aard van het verloop . . . . 191

13.8 De invloed van kenmerken van de huisarts (praktijk) op de aard van het verloop . . . . . . . . . . . . . . . . . 192

13.9 De invloed van het gedrag van de huisarts op de aard van het verloop

13.10 De invloed van kenmerken van de verzekeringsgeneeskundige op de aard van het verloop

13.11 De invloed van het gedrag van de verzekeringsgeneeskundige op de aard van het verloop

13.12

13.13

Samenvatting van de eerste bevindingen . . . . . . . . . 196

Naar een integraal model voor de verklaring van de aard van het verloop

13.14 Een padanalyse van determinanten van de aard van het verloop . 198 
$14.1 \quad$ Inleiding . . . . . . . . . . . . . . . . . . . . . . 201

14.2 De invloed van persoonskenmerken op de verzuimduur . . . . . 202

14.3 De invloed van bedrijfskenmerken op de verzuimduur . . . . . . 203

14.4 De invloed van arbeidsplaatskenmerken op de verzuimduur . . 203

14.5 De invloed van de ziektegeschiedenis op de verzuimduur . . . . 205

14.6 De invloed van ziektekenmerken op de verzuimduur . . . . . . . 206

14.7 De invloed van ziektegedrag op de verzuimduur . . . . . . . . 207

14.8 De invloed van kenmerken van de huisarts(praktijk) op de

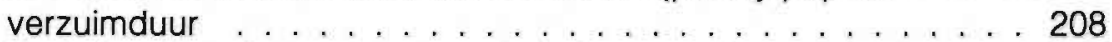

14.9 De invloed van het gedrag van de huisarts op de verzuimduur . . 209

14.10 De invloed van kenmerken van de verzekeringsgeneeskundige op de verzuimduur . . . . . . . . . . . . . . . . . . 210

14.11 De invloed van het gedrag van de verzekeringsgeneeskundige op de verzuimduur . . . . . . . . . . . . . . . . . . . . 211

14.12 Samenvatting van de eerste bevindingen . . . . . . . . . . 211

14.13 Naar een integraal model voor de verklaring van de verzuimduur . 212

14.14 Een padanalyse van determinanten van de verzuimduur . . . . 213

14.15 Conclusies en beschouwing . . . . . . . . . . . . . . . . 215

15 Conclusles en beschouwing . . . . . . . . . . . . . 217

$15.1 \quad$ Inleiding . . . . . . . . . . . . . . . . . . 217

15.2 De aard van overspanning . . . . . . . . . . . . . . . 217

15.3 Het (verzuim)beloop van overspanning . . . . . . . . . . . . . 221

15.4 De hulpverlening aan overspannen werknemers . . . . . . . . 222

15.5 De verklaring van de verschillen in wijze van verzuimbeëindiging en in verzuimduur . . . . . . . . . . . . . . . . . . . . 225

$15.6 \quad$ Algemene slotopmerkingen . . . . . . . . . . . . . . . . 228

15.6.1 Het generalisatiedomein van de onderzoeksresultaten . . . . . . . . 228

15.6.2 De betekenis van de onderzoeksresultaten voor de verklaring van trends in ziekteverzuim en arbeidsongeschiktheid

15.6.3 Aanbevelingen voor onderzoek en beleid . . . . . . . . . . . . 233

Samenvatting . . . . . . . . . . . . . . . . . 237

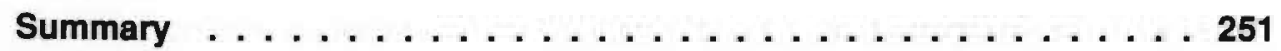

Litteratuur . . . . . . . . . . . . . . . . . . 265

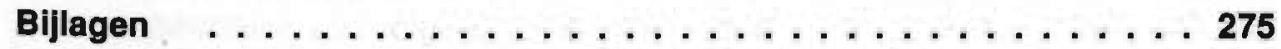

Bijlage 3.1 Overzicht van toegelaten diagnosecodes . . . . . . . . . 275

Bijlage 3.2 Voorbeeld gestandaardiseerde casusomschrijving . . . . . . 275

Bijlage 6.1 Overzicht vergelijkingspopulaties . . . . . . . . . . . . . 276

Bijlage 8.1 Volledige stroomdiagram overspannen werknemers . . . . . 277 
Bijlage 11.1 Overzicht variabelen terugkeer-analyse . . . . . . . . . . 278

Bijlage 11.2 Overzicht variabelen verloop-analyse . . . . . . . . . . . . 280

Bijlage 11.3 Overzicht variabelen verzuimduur-analyse . . . . . . . . . . 282

Bijlage 12.1 Samenhang sexe en leeftijd met wijze van verzuimbeëindiging . 284

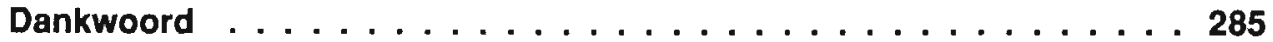

Curriculum vitae $\ldots \ldots \ldots$. . . . . . . . . . . . . . 287

Publicaties van de auteur $\ldots \ldots \ldots$. . . . . . . . . 288 


\section{Hoofdstuk 1}

\section{Inleiding}

\subsection{Achtergronden van het onderzoek}

\subsubsection{De toename van arbeidsongeschiktheid}

Sinds de invoering van de WAO in 1967 en later de AAW in 1975 is het aantal uitkeringsgerechtigden krachtens de arbeidsongeschiktheidswetten, WAO en $A A W$, en de ABP-wet explosief gegroeid. De verhouding tussen actieven en alle uitkeringsgerechtigden tezamen is mede onder invloed van de toename van ziekteverzuim en blijvende arbeidsongeschiktheid gedaald van 9,9:1 in 1960 tot 2,9:1 in 1989. (Vrooman en Kemp, 1990) Bedroeg in 1970 het bestand van arbeidsongeschikten 232.700 bij een instroom in dat jaar van 52.330, in 1989 was dit aantal toegenomen tot 845.000 bij een instroom van 109.200. Volgens Knepper (1990) is er zelfs bij deze cijfers nog sprake van een onderschatting van de uitstoot. Omdat een deel van hen die langer dan éen jaar ziek zijn, voor minder dan $15 \%$ c.q. $25 \%$ arbeidsongeschikt verklaard wordt, ontvangen velen geen AAWMAO-uitkering, maar komen onder werkloosheidsregelingen te vallen.

Het totale bestand van arbeidsongeschikten krachtens de WAO/AAW toont gedurende het laatste decennium een gestage toename van 660.000 in 1981 tot 821.000 in 1990, hetgeen afgezet tegen de ontwikkeling van de beroepsbevolking een toename betekent van $11,5 \%$ in 1980 - via een daling tot $11,2 \%$ in 1984 - naar $11,8 \%$ in 1990. Het bestand van arbeidsongeschikte ambtenaren is in die periode toegenomen van 55.000 in 1981 tot 73.000 in 1990: een toename van bijna $33 \%$ ! (Broersen et al., 1991)

De belangrijkste bijdrage aan de toename leveren de demografische ontwikkelingen van de laatste decennia. Een simpele verklaring voor de groei van het aantal arbeidsongeschikten is namelijk de toename van het aantal verzekerden als gevolg van de groei van de potentiële en actieve beroepsbevolking. De toename van de beroepsbevolking zou volgens berekening van Vrooman en Kemp (1990) 44\% van de toename van het aantal arbeidsongeschikten verklaren.

Als we naar het risicocijfer voor WAO/AAW-intrede kijken, dan zien we dat deze in $19811,4 \%$ bedroeg, daalde tot $1,1 \%$ in 1985 en sindsdien is gestegen tot $1,5 \%$ in 1990. Bij ambtenaren bedragen de risicocijfers voor het Invalideitspensioen 1,4\% in 1980 en 1,3\% in 1990. (Broersen et al., 1991) 
Deze cijfers suggereren dat de toename van het aantal arbeidsongeschikten ook grotendeels bepaald wordt door een geringe mate van uitstroom.

In figuur 1.1 laten we de ontwikkeling van de WAO/AAW-instroom over de jaren tachtig zien afgezet tegen de ontwikkeling van de beroepsbevolking in termen van het aantal verzekerden krachtens de WAO/AAW.

Deze figuur toont dat de laatste tien jaar de ontwikkeling van de instroom de meeste jaren per saldo achter is gebleven bij de groei van de beroepsbevolking. Sinds 1986 is evenwel, een op zich nog onverklaarde, trendbreuk in de ontwikkeling van de instroom opgetreden waarbij de toename van de instroom sneller is gaan verlopen dan die van de beroepsbevolking. Vanaf 1989 is sprake van een onevenredig grote instroom

Figuur 1.1 Ontwikkeling WAO/AAW-instroom

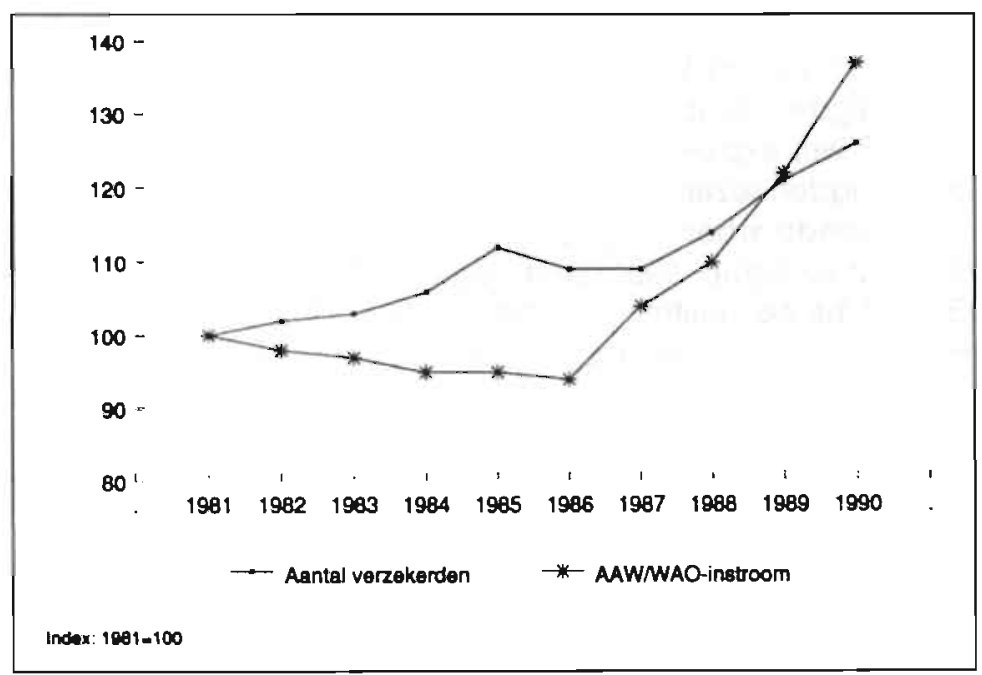

Bron: GMD, Statistische Informatie, Uitgaven 1985 tot en met 1990

Als oorzaken voor de toename van het aantal arbeidsongeschikten worden naast de uitbreiding van de beroepsbevolking een aantal factoren aangeduid. Deze hebben vooral betrekking op de gezondheidszorg en het arbeidsbestel.

Wat de gezondheidszorg betreft, is gewezen op de gezondheidstoestand van de Nederlandse (beroeps)bevolking, de uitbreiding van het ziektebegrip, en de afstemming tussen curatieve, bedrijfs- en verzekeringsgeneeskundige sector.

$E_{r}$ is in verschillend verband gewezen op de tegenstelling tussen de, naar objectieve maatstaven als levensverwachting, verbeterende gezondheidstoestand van de Nederlandse bevolking en de toename van het aantal arbeidsongeschikten. (Hilverink, 1978; Van den Bosch en Petersen, 1980; Prins, 1990) De dalende sterftecijfers onder arbeidsongeschikten wordt als uitdrukking van deze tegenstrijdigheid gezien. (Hilverink, 1978) Deze perceptie van tegenstrijdigheid negeert 
echter een alternatieve hypothese, namelijk dat lagere arbeidsongeschiktheidsdrempels een positieve invloed kunnen uitoefenen op de levensverwachting, omdat ze kwetsbare werknemers ontlasten van gezondheidsrisico's in het werk. Wordt een subjectieve maatstaf als beleving van de gezondheid gekozen dan blijken onderzoekers elkaar tegen te spreken. Smulders en Bloemhoff (1991) nemen op basis van gegevens van de Leefsituatieonderzoeken van het CBS in het algemeen een verbetering van de gezondheidsbeleving waar. Bax (1985) ziet daarentegen een achteruitgang.

De uitbreiding van het ziektebegrip wordt mede verantwoordelijk gesteld voor de toename van het aantal arbeidsongeschikten. (Giel, 1976; Bax, 1985; Vrooman en Kemp, 1990) Deze zou een toename van aanbod van welzijnsproblemen teweeg gebracht hebben en daarmee het door Philipsen (1976) gesignaleerde "gezondheidszorgprobleem van een ongedefinieerde invoer" versterkt hebben. Van der Wal en Buijs (1982) en Saan (1986) wijzen erop dat tal van niet-medische problemen als werkconflicten, dreigend ontslag of andere problematische arbeidsomstandigheden ten grondslag liggen aan ziekmeldingen, die uiteindelijk tot arbeidsongeschiktheid kunnen leiden. Giel (1976) signaleert in deze context als ontwikkeling, dat ziektegedrag als element in het ziektebegrip is ingevoerd. Daardoor zou de causale keten tussen ziekte en arbeidsongeschiktheid verstoord geraakt zijn. Arbeidsongeschiktheid vloeit niet langer alleen voort uit ziekte, maar ziekte ook uit arbeidsongeschiktheid die van Giel de betekenis krijgt van medische sanctionering van ziektegedrag. Later hebben ook Merens-Riedstra (1981) en Luijckx (1982) in hun onderzoeken dit verschijnsel aangetroffen.

De twee laatstgenoemde ontwikkelingen zouden vooral een verklaring kunnen bieden voor de toename van het aantal arbeidsongeschikten wegens psychische aandoeningen.

Ontegenzeggenlijk heeft de toelating van psychische aandoeningen als legitieme grond van arbeidsongeschiktheid in 1953 dit proces gefaciliteerd, maar onduidelijk is waarom dan pas vele jaren later een drastische toename van ziekteverzuim en arbeidsongeschiktheid op psychische gronden heeft plaatsgevonden. Ook is enige invloed toegeschreven aan de herformulering van het negatief ziektebegrip naar een positief gezondheidsbegrip door de Wereld Gezondheids Organisatie in 1977. Gezien het feit dat de stijging van de psychische arbeidsongeschiktheid al eerder ingezet is, lijkt deze herformulering van het gezondheidsbegrip echter meer een bevestiging van een maatschappelijke ontwikkeling dan het uitzetten van een nieuwe koers.

$\mathrm{Er}$ is ondanks jarenlange discussies waarin weliswaar over de wenselijkheid van scheiding tussen behandeling en controle geen consensus bereikt is maar wel over de noodzaak van een betere afstemming, nog steeds sprake van een geringe bemoeienis van de huisarts met de gevolgen van het ziekteproces voor de participatie van de patiënt in het arbeidsbestel. De jarenlange discussie over afstemming betreft ook de institutionele scheiding tussen Ziektewet en WAO. (Buys, 1984; Bax, 1985) De duurzaamheid van dit gebrek aan afstemming verklaart misschien wel een hoger ziekteverzuim- en arbeidsongeschiktheidsniveau in Nederland ten opzichte van de haar omringende landen maar slechts in beperkte mate de toename van het aantal arbeidsongeschikten. De wijze waarop de curatieve sector en de instellingen 
van sociale zekerheid met het probleem van ziekteverzuim en arbeidsongeschiktheid omgaan, oefent in elk geval geen remmende werking uit.

Wat de invloed van het arbeidsbestel aangaat, worden met name de volgende drie factoren verantwoordelijk gesteld: veranderingen in arbeidsomstandigheden, het functioneren van het stelsel van sociale zekerheid en de ontwikkelingen op de arbeidsmarkt.

Bij de arbeidsomstandigheden betreft het vooral factoren die de geestelijke en emotionele belasting verhogen: beperkte regelmogelijkheden, monotonie, rolonduidelijkheden, over- en onderbelasting, het grotere beroep op sociaal-technische vaardigheden als gevolg van nieuwe technologieën en flexibilisering van organisaties, een geringere aansluiting van het werk op opleiding en ervaring van de werknemer, de onzekerheid ten gevolge van continue bezuinigingen, afslankingen en reorganisaties, omvang van de werkweek en fysiek belastende omstandigheden als tempodwang en tijdsdruk. (Bax, 1985; Hilverink, 1978; Knepper, 1989; Vroege, 1983; Vrooman en Kemp, 1990; Grosfeld, 1991; Smulders en Bloemhoff, 1991) In combinatie met de afname van puur fysieke belasting zou deze ontwikkeling vooral de toename van psychische aandoeningen moeten bevorderen.

Volgens vele auteurs moet de toename van het aantal arbeidsongeschikten vooral toegeschreven worden aan de relatief gunstige uitkeringsvoorwaarden van de arbeidsongeschiktheidswetten ten opzichte van de werkloosheidsregelingen. (Bosch en Petersen, 1980; Bijlsma en Koopmans, 1982; Bax, 1985) Met name het, inmiddels zonder zichtbare resultaten afgeschafte, wetsartikel dat in de mate van arbeidsongeschiktheid de verminderde kans op werkgelegenheid verdisconteerd mocht worden, en de afname van de vraag naar arbeidskrachten worden als stimulansen gezien voor het gebruik van de WAO. Een groot deel van de arbeidsongeschiktheid zou aldus verborgen werkloosheid inhouden. (Verkade, 1978; Van der Pas, 1979; Kuné, 1980) Bijlsma en Koopmans (1982) en Hunfeld (1980) benadrukken dat veel bedrijven met behulp van deze procedure oudere, minder productieve werknemers konden doen afvloeien in het kader van de opvoering van de arbeidsproductiviteit. Deze stellingnames - met uitzondering van de laatste wellicht - worden enigszins ontkracht door de bevindingen dat arbeidsongeschikten zich op een aantal parameters van de gezondheid negatief onderscheiden van werklozen (Van der Horst, 1988), de betrekkelijke ongevoeligheid van de toename vuor economische schommelingen, en de toename van Invaliditeitspensioenen krachtens de ABP-wet. Eerder lijkt er sprake van een verhoogde uitstoot van minder gezonde werknemers in het kader van de opvoering van de arbeidsproductiviteit. (Vrooland, 1980; Bijlsma en Koopmans, 1982; Prins, 1990) De invloed van de arbeidsmarkt op de toename van het bestand van arbeidsongeschikten is evenwel niet alleen gelegen in een uitstoot van arbeidskrachten maar ook in kansen op reïntegratie. (Hunfeld, 1980) Volgens Vrooman en Kemp (1990) zou 14\% van de groei van het aantal arbeidsongeschikten het gevolg zijn van de slechte arbeidsmarktpositie van arbeidsongeschikten. Van Zaal (1975) wijst erop dat er mogelijk ook een andere wijze van beïnvloeding plaats vindt: mensen met een marginale positie op de arbeidsmarkt kunnen door onzekerheid dermate belast zijn, dat zij ziek en arbeidsongeschikt worden. 
Bax (1985) ziet als aanvullende factor de afname van de mate waarin arbeid centraal staat in de levensbeschouwing. Deze ontwikkeling wordt ook door Bosch en Petersen (1980) als verklaring vermeid.

\subsubsection{De toename van arbeidsongeschiktheid op psychische gronden}

De stijging van het aantal arbeidsongeschikt verklaarde werknemers is vooral gebaseerd op de toename van uitval wegens ziekten van de bewegingsorganen en wegens psychische aandoeningen. Elk jaar is het aandeel van deze twee diagnosegroepen op het totaal toegenomen. Het aantal werknemers dat jaarlijks arbeidsongeschikt verklaard wordt met als diagnose éen der psychische aandoeningen, is sterker gestegen dan het aantal jaarlijks arbeidsongeschikt verklaarden op grond van welke andere diagnosegroep dan ook. Werden in 1968 nog slechts 4.100 verzekerden op psychische gronden arbeidsongeschikt verklaard, in 1989 was dit aantal gegroeid tot 35.100. Dit betekende een forse stijging van het aandeel van de diagnosegroep psychische aandoeningen op de totale WAO/AAW-instroom van $11 \%$ naar $30 \%$ in 1990 . Als we het jaarlijks risicopercentage voor de beroepsbevolking om psychisch arbeidsongeschikt te raken bekijken, dan blijkt dit tussen 1981 en 1986 te variëren tussen 0,30 en $0,32 \%$ om daarna te stijgen tot $0,46 \%$ in 1990 . Op het totale bestand van arbeidsongeschikten krachtens de AAW en de WAO is het aandeel van arbeidsongeschikten wegens psychische aandoeningen van 1981 tot 1990 toegenomen van $21 \%$ tot $28 \%$. Onder ambtenaren van $35 \%$ tot $50 \%$. In absolute termen is er een toename bij niet-ambtenaren van 135.500 tot 227.400 , een toename van $68 \%$. Naast de instroomontwikkeling is ook hier de beperkte uitstroom van psychisch arbeidsongeschikten gedurende de laatste jaren als oorzaak aan te wijzen. Zo werden op een totaal van 196.102 psychisch arbeidsongeschikten eind 1988 in het jaar 198911.828 gevallen beëindigd waarvan slechts 5.114 - ongeveer $2,5 \%$ op jaarbasis - wegens werkhervatting.

In figuur 1.2 geven we ontwikkeling van de WAO/AAW-instroom van die gevallen weer waarbij een diagnose is gesteld uit de groep psychische aandoeningen. Deze is zowel afgezet tegen de ontwikkeling van de beroepsbevolking als tegen de ontwikkeling van de WAO/AAW-instroom ten gevolge van ziekten der bewegingsorganen als die ten gevolge van de overige diagnosegroepen.

Opvallend genoeg blijken de ontwikkelingen van de arbeidsongeschiktheid als gevolg van psychische aandoeningen en die als gevolg van de ziekten der bewegingsorganen in de periode tot en met 1986 vrijwel gelijk op te gaan met die van de beroepsbevolking. Vanaf 1986 is er een onevenredige toename warbij die ten gevolge van psychische aandoeningen het meest uitgesproken is. De ontwikkeling van de arbeidsongeschiktheid op grond van de overige aandoeningen blijt aanzienlijk achter bij die van de beroepsbevolking. Er is daar zelfs sprake van een relatieve afname. 
Figuur 1.2 Ontwikkeling WAO/AAW-instroom wegens psychische aandoeningen

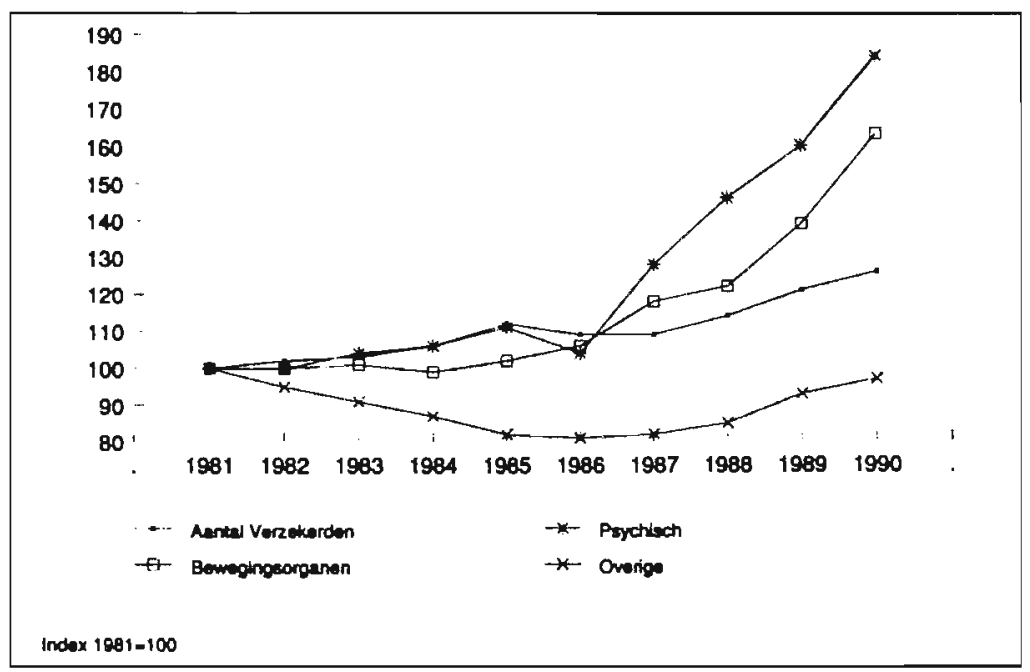

Bron: GMD, Statistische Informatie, Uitgaven 1985 tot en met 1990

Bank- en verzekeringswezen, gezondheidszorg, onderwijs en overheidsbedrijven blijken relatief grote leveranciers van psychisch arbeidsongeschikten. (Knepper, 1990) Het overheids- en onderwijzend personeel neemt daarbij een bijzondere positie in. Het aantal afkeuringen onder hen is weliswaar geringer dan onder WAO-verzekerden maar het aandeel van psychische arbeidsongeschiktheid ligt hier aanzienlijk hoger. Dit aandeel lag bij deze werknemers in 1977 al op $31 \%$ met een uitschieter voor onderwijzend personeel van $\pm 50 \%$. (Van der Putten, 1983; Knepper, 1990) $\mathrm{Bij}$ onderwijspersoneel in Amsterdam bedroeg in de periode 1982-1985 het aandeel van psychische arbeidsongeschiktheid op het totaal $77 \%$. (Verbeek, 1989)

Hoewel overspanning langzamerhand met onderwijsgevenden geassocieerd wordt als vroeger silicose met mijnwerkers, is deze aandoening onder vrijwel alle werknemerscategorieën een belangrijke grond voor arbeidsongeschiktheid. Dat overspanning niet uitsluitend een arbeidsongeschiktheidsgrond is voor hoofdarbeiders, wordt ondersteund door de bevinding dat in een industriëel grootbedrijf productieen technisch onderhoudsmedewerkers een twee maal zo hoog risico op WAO-intrede wegens psychische aandoeningen bleken te lopen als kantoorbedienden. (Van Dijk et al., 1987).

Als verklaringen voor deze toename is, naast de reeds eerder genoemde uitbreiding van het ziektebegrip, achteruitgang in subjectieve gezondheidsbeleving en toename van geestelijk en emotioneel belastende arbeidsomstandigheden, vooral verandering in diagnostiek aangevoerd.

Het belang van de arbeidsomstandigheden wordt nog eens benadrukt door het verband dat meerdere onderzoekers aangetroffen hebben tussen de toename van 
het aantal psychisch arbeidsongeschikten en de productiviteitsstijging. Deze laatste heeft een uitstoting tot gevolg van werknemers met een geringere belastbaarheid, zoals zwakbegaafden, slecht opgeleiden en ouderen. Zij nemen bovendien op de arbeidsmarkt een zwakke positie in. (Knepper, 1989 en 1990)

De toegenomen geneigdheid van verzekeringsartsen om naar aanleiding van lichamelijke klachten een psychische aandoening als diagnose te stellen, wordt nogal eens als oorzaak genoemd. Deze wordt gestimuleerd door de verruiming van het ziektebegrip (Van Zaal, 1975; Buijs, 1984; Vrooman en Kemp, 1990), door de protoprofessionalisering van werknemers ten opzichte van de wijze waarop de gezondheidszorg psychosociale problemen binnen haar werkterrein opgenomen heeft, en door de afname van het taboe op het hebben van psychische problemen. (Ter Heine, 1983; Knepper, 1989 en 1990) De suggestie die van dit soort argumenten uitgaat, luidt dat er eerder sprake is van een verschuiving in diagnose dan van een groter probleemaanbod. Dit lijkt evenwel in strijd met de bevinding dat juist die diagnosegroepen waarbij vaak sprake kan zijn van gesomatiseerde psycho-sociale problemen, eveneens hun aandeel op het bestand van arbeidsongeschikten hebben zien toenemen. (Bijlsma en Koopmans, 1982)

\subsubsection{Het ziekteverzuim wegens psychische aandoeningen}

Bij de vaststelling van het precieze aandeel van psychische aandoeningen op het totale ziekteverzuim wordt de onderzoeker gehinderd door het grote aantal verzuimgevallen waarbij geen diagnose vastgesteld is. Deze zijn in aantal zeer omvangrijk maar bijna alle van zeer korte duur. Zinvoller dan het aandeel op het totaal aantal verzuimgevallen zijn derhalve maatstaven als het aandeel op het verzuimpercentage, het aantal verzuimgevallen op het totaal aantal werknemers dan wel het verzuimpercentage bij die gevallen die langer dan vier of zes weken duren of het percentage werknemers dat zich wegens een psychische aandoening ziek meldt.

De ontwikkeling van het ziekteverzuim in zijn geheel toont een wat wisselender beeld dan die van de blijvende arbeidsongeschiktheid. Van 1960 tot 1979 was er sprake van een stijging van het meldings- en verzuimpercentage. Daarna is bij beide een lichte daling ingetreden.

Een relatief groter aantal ziekmeldingen wegens psychische aandoeningen is niet waarneembaar. Afgezet tegen de ontwikkeling van de beroepsbevolking is er over de latste twintig jaren per saldo zelfs sprake van een daling van het verzuimrisico voor dit type aandoeningen. Er is wel een duidelijke toename vast te stellen van het aandeel van psychische aandoeningen op het ziekteverzuimpercentage van 7,0\% in 1961 naar $16,8 \%$ in 1989. Een stijging die vooral toegeschreven kan worden aan de relatief sterke toename van de verzuimduur. Hoewel deze in de loop der jaren slechts in geringe mate veranderde voor alle verzuimgevallen samen en de laatste jaren op een lager niveau ligt dan ooit, is de gemiddelde verzuimduur van de gevallen wegens psychische aandoeningen voortdurend toegenomen. In 20 jaar is ongeveer een verdubbeling opgetreden van gemiddeld anderhalve maand tot ruim twee en halve maand nu. 
In figuur 1.3 worden het percentage ziekmeldingen en de gemiddelde verzuimduur van de verzuimgevallen gedurende het laatste decennium voor verzuimgevallen wegens psychische aandoeningen, verzuimgevallen wegens ziekten der bewegingsorganen en voor de overige verzuimgevallen afzonderlijk gepresenteerd. Deze gegevens hebben betrekking op de omslagleden van alle bedrijfsverenigingen.

Figuur 1.3 Ontwikkeling van het ziekteverzuim wegens psychische aandoeningen*
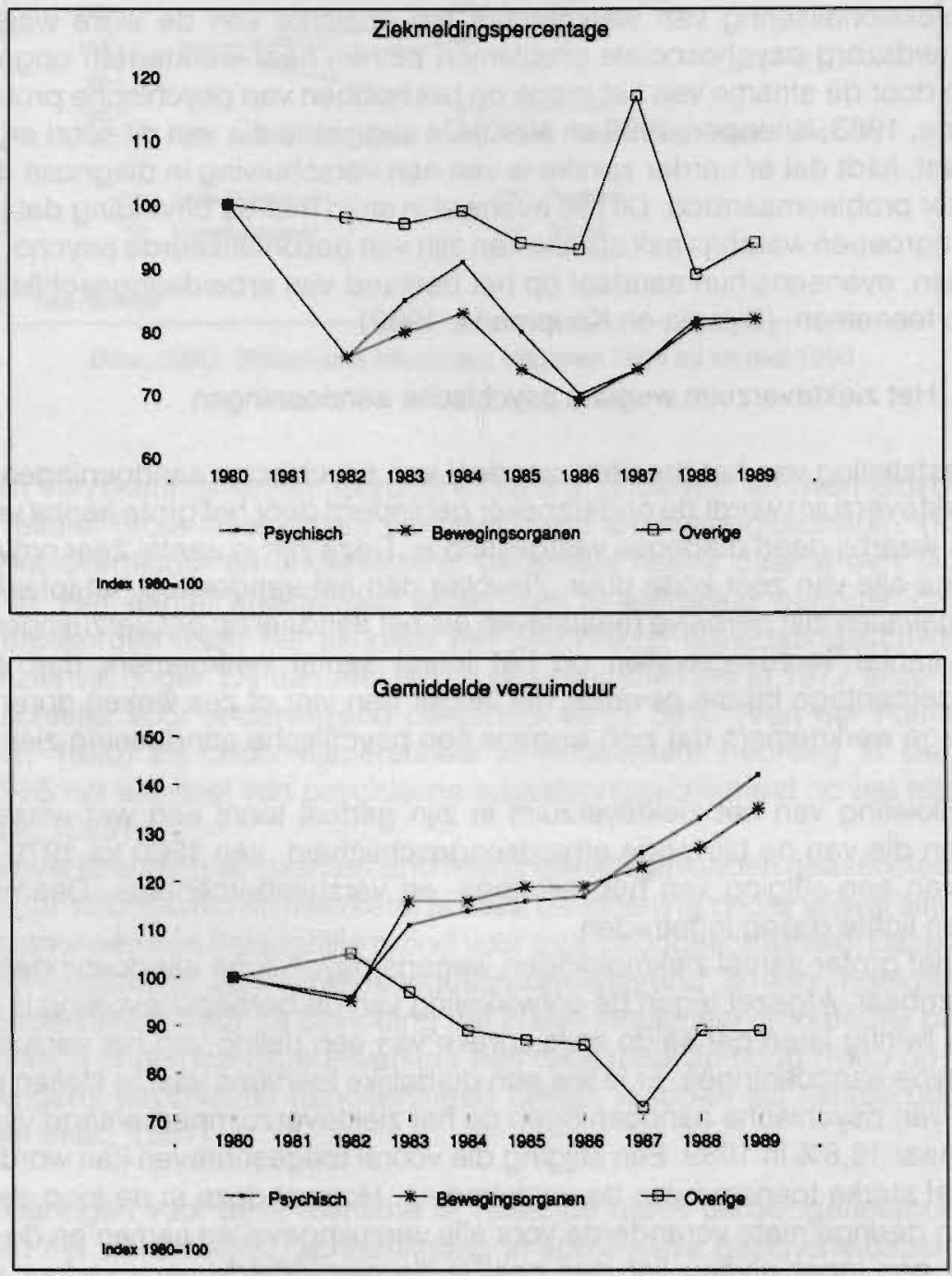

Bron: SVR, Stand Ziektegeldverzekering, Uitgaven 1981 tot en met 1989

* Over 1981 zijn geen verzuimcijfers beschikbaar als gevolg van verandering in jaartoekenning op basis van aanvangsdatum tot en met 1980 naar beëindigingsdatum van het verzuim vanaf 1982 . 
Met De Klerk c.s. (1982, 1983 en 1985) moet vastgesteld worden dat er in de tijd niet zozeer een toename van het aantal ziekmeldingen wegens psychische aandoeningen is waar te nemen maar dat de gemiddelde verzuimduur langer is geworden. Dit in samenhang met een verhoogde kans op WAO-intrede. Een ontwikkeling die parallel loopt met het ziekteverzuim wegens ziekten der bewegingsorganen. Het ziet er naar uit dat werknemers die wegens een psychische aandoening het werk staken, meer dan het geval is bij andere aandoeningen problemen ondervinden met werkhervatting.

\subsubsection{De aard van de psychische aandoeningen}

De explosieve toename van psychische arbeidsongeschiktheid komt vrijwel geheel voor rekening van een aantal ziektebeelden die samengevat kunnen worden onder verschillende benamingen als neurosen, "minor psychiatric illness", nerveus-functionele klachten, surmenage of overspanning. (Van der Maas, 1975; Van der Putten, 1981 en 1985) Van de 186 verschillende diagnosecodes, die GMD-artsen kunnen toekennen aan gevallen van psychische arbeidsongeschiktheid, blijken 10 codes aan $75 \%$ der gevallen toegekend. De voornaamste zijn: depressies, neurotische stoornissen en aanpassingsreacties. (De Klerk et al., 1985) De Klerk c.s. (1982) en Van Eck (1991) berekenen het aandeel van aanpassingsreacties, neurosen en depressies op het totaal aantal WAO-intreders wegens psychische aandoeningen over 1989 op $75 \%$ à $80 \%$.

Van de door het GAK geadministreerde verzuimgevallen van drie maanden of langer makkten in de tweede helft van 1984 de diagnosesubcategorieën die overspanning betreffen, gezamenlijk $95 \%$ uit van alle verzuimgevallen op grond van psychische aandoeningen. (Tromp, 1985) Ook bij het onderzoek van Verbeek (1989) bedraagt het aandeel van overspanning op het totaal der invalideitsverklaringen wegens psychische aandoeningen 95\%. Van Eck (1991) komt met een berekening waaruit blijkt dat over 1987 ruim 95 à $97 \%$ van alle verzuimgevallen wegens psychische aandoeningen bestaan uit gevallen waarbij als diagnose situatieve of exogene reactie (ruim $90 \%$ ) of fysische functiestoornis met psychische oorzaken gesteld is.

Deze cijfers blijken vrij constant in de verzuimgeschiedenis gezien de bevinding van De Groot (1959) dat in 1953 95\% van de verzuimgevallen wegens psychische aandoeningen uit neurosen bestond.

\subsubsection{De ontwikkeling van de psychische morbiditeit}

Een aantal verklaringen voor de toename van arbeidsongeschiktheid wegens psychische aandoeningen gaan uit van een toename van de psychische morbiditeit (onder de actieve beroepsbevolking).

Statistieken met betrekking tot hulpverlening door de Geestelijke Gezondheidszorg suggereren eveneens een duidelijke toename van aanvragen en uitvoeringen van behandelingen. Het aantal cliënten van de GGZ-instellingen in Nederland is toegenomen van 168.000 in 1980 tot 308.000 in 1990 . Oftewel van $1,2 \%$ van de bevolking tot $2,9 \%$. Hoewel hier sprake is van een prevalentiemaat, is een toename van 
hulpverleningsincidentie aannemelijk. Vermoedelijk is er sprake van onderschatting gezien de aanwezigheid van wachtlijsten die een ontmoedigend effect hebben op hulpbehoevenden.

Daar staat tegenover, dat er ook sprake is van een verschuiving van intramurale naar ambulante behandeling of combinaties daarvan die eveneens hogere cliëntencijfers produceren. Ten slotte kan de instelling van de RIAGG's in 1982 bijgedragen hebben aan een betere bereikbaarheid van de GGZ.

Degenen, die van de toename van psychische aandoeningen overtuigd zijn, voeren daarvoor, naar indeling van Hutschemaekers (1991), een viertal verklaringen aan:

- De toename is een gevolg van een toename in geestelijke belasting onder meer als gevolg van industrialisatie en urbanisatie of van verandering in gezinsstructuur. Aan deze ontwikkelingen kunnen de druk van de werkloosheid en onzekerheid van behoud van werk, de arbeidsomstandigheden en de afname van emotionele steun uit sociale en familienetwerken toegevoegd worden. (Bax, 1985; Bijl en Ketting, 1991)

In deze lijn ligt de verklaring dat de invidualiseringstendens een toename van psychische morbiditeit teweegbrengt. Daarbij valt vooral te denken aan de verzwakking van het sociaal netwerk, onder andere als gevolg van de huisvestingspolitiek die samenvalt met een grotere sociale en geografische mobiliteit, waardoor het probleemoplossend vermogen van werknemers afneemt. Ook wordt met individualisering gedoeld op de geneigdheid om psychische problemen vooral als eigenschap van de individuele werknemer op te vatten en het vaak in combinatie hiermee afwentelen van deze problemen op de sociale zekerheid in de vorm van arbeidsongeschikt verklaren. (Bax, 1985; Ter Heine, 1983; Knepper, 1989)

In een inventarisatie van onderzoeksresultaten vond De Ridder (1988) weliswaar positieve, maar zwakke verbanden tussen life events en psychopathologie en stresshantering. Overtuigender bleken de relaties met de aanwezigheid van een sociaal netwerk als buffer tegen stress. De directe werking van sociale netwerken bleek naar gelang de kwaliteit daarvan zowel positief als negatief op psychopathologie te kunnen zijn.

- De toename is een gevolg van een snellere ( $h$ )erkenning van psychische problemen. In dit verband moet ook het door De Swaan gesignaleerde verschijnsel van protoprofessionalisering geplaatst worden. Mechanic (1989) stelt vast dat in de Verenigde Staten geen toename van psychische morbiditeit plaatsvindt maar wel een toename van hulpvraag en hulpaanbod. Deze blijken nog niet volledig op elkaar afgestemd.

- De toename is het gevolg van de uitbreiding van de sociale zekerheid waardoor meer ruimte is ontstaan voor behandeling van psychische problemen.

- De toename is het gevolg van veranderingen in het "labelingsproces". Arbeidsongeschiktheid bij aandoeningen zonder duidelijk somatisch substraat dient gelegitimeerd te worden. In dit verband wordt de verzameling van psychische aandoeningen als restcategorie in de ziekteclassificatie opgevat.

Wat de morbiditeit in de huisartsenpraktijk betreft, is er evenwel, over de laatste decennia bekeken, minder duidelijkheid omtrent een eventuele toename.

In 1967 bleek de categorie psychische aandoeningen bij mannen 9\% en bij vrouwen $10 \%$ - althans voor de leeftijdcategorie van 15 tot 65 jaar - te vertegen- 
woordigen van het totaal aantal consulten van huisartsen. (Oliemans, 1969) Het aandeel van consulten wegens psychische en sociale problemen bleek enkele. jaren later becijferd op 12 a 15\%. (Van Mierlo en Smits, 1974; Lamberts en Hartman, 1982) Van der Lisdonk (1990) komt over de periode 1971-1988 gemiddeld tot een jaarlijks nieuw aanbod van nerveus-functionele klachten door $10,3 \%$ van de mannelijke en $15,4 \%$ van de vrouwelijke praktijkpopulatie. Daarbij bleek de piek te vallen in 1975, waarna geleidelijk een daling ingetreden is naar een niveau van rond de $10 \%$.

Over de ontwikkelingen gedurende de laatste decennia van de prevalentie van psychische morbiditeit in de bevolking ontbreken ons gegevens.

\subsubsection{Knelpunten in de professionele hulpverlening}

In de ziekteverzuim- en arbeidsongeschiktheidslitteratuur is in ruime mate aandacht geschonken aan de rol van de gezondheidszorg. De Groot wees in 1958 reeds op het verschijnsel iatrogeen verzuim. Buijs (1984) inventariseert in zijn litteratuuronderzoek onder meer de volgende knelpunten die Philipsen (1966) eerder onder aandacht bracht:

- De organisatie van de gezondheidszorg.

Deze leidt tot lange wachttijden (Tordoir et al., 1978; Soeters, 1983) en verlenging van opnameduren.

- De wijze waarop de curatieve sector de gevalsbehandeling uitvoert.

Deze houdt onder meer in dat niet-medische problemen gemedicaliseerd worden, veel verwijzingen plaatsvinden, de werksituatie en in het bijzonder het werkverzuim niet in de behandeling betrokken wordt, en een groot aanbod van diagnostische en therapeutische verrichtingen gedaan wordt. (Draaisma en Smulders, 1978)

- Het gebrek aan samenwerking en aan communicatie binnen de curatieve sector, tussen de curatieve sector, bedrijfsgezondheidszorg en verzekeringsgeneeskundigen (Merens-Riedstra en Van Ende, 1973; Draaisma en Smulders, 1978; Wiersma, 1980; Groothoff, 1980) en het gebrek aan communicatie tussen arts en patient. (Schouten, 1982)

- De scheiding tussen behandeling en controle.

Deze houdt het gebrek aan samenwerking en communicatie in stand en het verontachtzamen van de verhouding tussen werk en ziekte in de curatieve behandeling. (Holthuis, 1980)

Ook binnen de sociaal-medische sector zijn knelpunten aan te wijzen, bij voorbeeld de scheiding en de gebrekkige afstemming tussen de begeleiding van de verzekeringsgeneeskundigen belast met de controle inzake de Ziektewet en de begeleiding vanwege de GMD in geval van blijvende arbeidsongeschiktheid.

Psychisch arbeidsongeschikten vormen bij dit alles een bijzonder weerbarstige categorie voor curatieve sector, bedrijfsartsen en verzekeringsgeneeskundigen.

Omtrent de efficiëntie van de curatieve sector, gemeten door het percentage wachtdagen, d.w.z.: dagen die verloren gaan als gevolg van tijdverlies tussen verwijzing en behandeling en dergelijke, op het totaal aantal verzuimde dagen, lopen de bevindingen voor de categorie psychische aandoeningen uiteen. Tordoir C.S. (1978) vond een percentage van 15 , dat is $5 \%$ onder het gemiddelde, terwijl 
Soeters (1983) een percentage van 25 tegenover gemiddeld $17 \%$ aantrof. Soeters vermeldt dat twee derde van die wachtdagen toegeschreven kon worden aan stuurloze perioden, d.w.z.: perioden zonder enig behandelingsplan.

Huisartsen blijken deze categorie nauwelijks te (kunnen) verwijzen. (Ormel en Giel, 1983) Slechts 5 à $7 \%$ van het totale aanbod van nerveus-functionele klachten blijkt voor verwijzing in aanmerking te komen. (Van de Lisdonk, 1990) Op het moment van WAO-intrede - de werknemer verzuimt dan reeds éen jaar wegens een psychische aandoening en is in vrijwel alle gevallen in contact geweest met de huisarts bleek in 1980 slechts $42,7 \%$ in contact geweest te zijn met een psychiater of een instelling van Geestelijke Gezondheidszorg. (De Klerk, 1985) Dit verschijnsel beperkt zich overigens niet tot WAO-intreders. Wel blijkt het verwijzingspercentage van WAO-intreders nog altijd hoger dan dat van de gemiddelde populatie huisartspatiënten met psychische problemen. (Lamberts en Hartman, 1982; Ormel en Giel, 1983; Giel et al., 1991) Ook in de Verenigde Staten en Groot-Brittannië is het een "normaal" beeld dat slechts een minderheid van mensen met geestelijke gezondheidsproblemen gespecialiseerde hulp ontvangt en dat binnen de gezondheidszorg de huisarts het merendeel van de contacten voor zijn rekening neemt. (Goldberg en Huxley, 1980; Link en Dohrenwend, 1989; Mechanic, 1989)

In geval van psychische aandoeningen lijken derhalve verwijzing, diagnostiek, althans binnen de curatieve sector, en opname een geringere invloed te hebben op de verzuimduur dan het geval is bij andere aandoeningen. Lancée (1988) wijst er overigens op dat er in geval van psychische aandoeningen wel veel tijd verloren gaat aan uitsluitingsonderzoek en (selectie)wachttijden bij de RIAGG. Hoe invaliderend een overmaat aan uitsluitingsonderzoeken kan werken toont onder meer Post (1985). Bovendien doen zich bij psychische aandoeningen andere dan de bovengenoemde knelpunten in sterkere mate voor. Verbeek (1989) signaleert een gebrek aan kennis en vaardigheid in de bedrijfsgezondheidszorg, als het gaat om het voorkomen of begeleiden van gevallen van overspanning.

Maasen (1985) benadrukt het probleem van afwezigheid van algemene criteria om in geval van herstel van overspanning arbeidsgeschiktheid vast te stellen, een probleem dat zich volgens Lancée (1988) bij alle psychische aandoeningen voor blijkt te doen. Als gevolg van de uitbreiding van het ziektebegrip ondervinden verzekeringsgeneeskundigen grotere problemen met het stellen van criteria voor arbeidsongeschiktheid. (Bax, 1985) Met name zijn dat criteria als stoornis in verzekeringsgeneeskundige zin, d.w.z. er moet sprake zijn van ziekte en/of gebrek en daarmee samenhangend een verminderd arbeidsvermogen en aan de eisen met betrekking tot uitvoering van het werk kan niet voldaan worden. (Van Eck, 1990) Van Eck komt in zijn onderzoek naar het verzekeringsgeneeskundig handelen tot de bevinding dat de verzekeringsgeneeskundige bij het stellen van de diagnose overspanning sterk afhankelijk is van de informatie van de verzuimende werknemer. De relatie tussen klachten en presentatie, de consistentie van het verhaal van de werknemer, en het verzuimverleden vormen vaak de enige parameters voor diagnosestelling en arbeidsgeschiktheidsbepaling.

In een vergelijkend onderzoek onder WAO-intreders met een diagnose uit de categorie psychische aandoeningen en die met een diagnose uit andere categorieën komt De Klerk (1985) tot een aantal interessante bevindingen met betrekking 
tot de diagnostiek van verzekeringsgeneeskundigen, de uitwisseling van informatie met de behandelende sector en de reîntegratie(activiteiten).

Er blijken bij psychische aandoeningen vaker verschillen in diagnose op te treden. Aan ongeveer $20 \%$ van degenen die arbeidsongeschikt verklaard worden op basis van psychische aandoeningen, blijkt tijdens de Ziektewetperiode een andere diagnose toegekend te zijn. Er worden meer verzekeringsgeneeskundig-diagnostische onderzoeken op de werknemer verricht en minder onderzoeken op de werkplek. (Knepper, 1990)

Bovendien worden er minder contacten gelegd tussen verzekeringsgeneeskundigen en behandelaars. De verzekeringsarts blijkt vaker uitsluitend op eigen informatie af te gaan.

De artsen en de arbeidsdeskundigen van het GMD blijken bij de categorie psychische aandoeningen relatief vaker de hoogste arbeidsongeschiktheidsklasse 80 $100 \%$, d.w.z.: volledig arbeidsongeschikt, te adviseren. Oorzaak hiervan is dat artsen en arbeidsdeskundigen in veel minder mate beperkte werkhervatting mogelijk achten. Het is alles of niets. De GMD blijkt in geval van reïntegratie ook meer tijd nodig te hebben. Een bevinding die ondersteund wordt door Besseling (1986).

Het percentage dat jaarlijks via werkhervatting de periode van arbeidsongeschiktheid beëindigt, varieert in de periode 1984 tot en met 1989 van 2,5 tot $3,0 \%$. Dit is nauwelijks hoger dan het gemiddelde voor alle diagnosegroepen tezamen, waar dit cijfer tussen de 2 en 2,5\% schommelt, hoewel de populatie psychisch arbeidsongeschikten aanzienlijk jonger is. Voor jongeren met psychische aandoeningen schijnen de kansen op reïntegratie lager te liggen dan voor hun leeftijdgenoten met andere aandoeningen. (De Klerk, 1985; Knepper, 1990)

\subsubsection{Conclusies en beschouwing}

Met betrekking tot de psychische aandoeningen die grotendeels gevallen van overspanning betreffen, bestaan er tegenstrijdige tendensen zowel tussen ziekteverzuim en arbeidsongeschiktheid als tussen morbiditeit in de eerstelijn en in de tweedelijn. Deze suggereren dat er niet zozeer sprake is van toename van het aantal gevallen van overspanning alswel van een verlenging van de duur van de aandoening, een langere behandelingsduur en een afname van kans op reïntegratie in het arbeidsbestel.

Onderzoek naar de toename van psychische arbeidsongeschiktheid zou zich bij voorkeur moeten richten op factoren die de toename kunnen verklaren van de duur of van de definitieve uitval uit het arbeidsproces onder werknemers die op een gegeven moment aan een psychische aandoening lijden. Daarom verdienen met name factoren die verband houden met de professionele hulpverlening, de aandacht. Daarnaast zou de aandacht gericht moeten zijn op arbeids- en arbeidsmarktomstandigheden en op aspecten van het functioneren van het stelsel van sociale zekerheid die van invloed zijn op de terugkeer naar de werkkring of reïntegratie elders in het arbeidsbestel. 


\subsection{Probleemstelling}

De kennis van zaken met betrekking tot de specifieke toename van arbeidsongeschiktheid wegens psychische aandoeningen beperkt zich hoofdzakelijk tot globale epidemiologische data en een groot aantal noties omtrent mogelijke oorzaken. Gericht empirisch onderzoek ontbreekt grotendeels.

Vragen als: welke factoren bepalen of een werknemer overspannen raakt, welke factoren leiden in dat geval tot de beslissing tot ziekmelding, welke factoren beïnvloeden de duur en de wijze waarop de ziekteperiode beëindigd wordt, en wat houdt het ziektebeeld overspanning in, zijn tot op heden nauwelijks onderzocht.

Uiteraard heeft dit ook tot gevolg dat effectieve interventies voorafgaand aan of tijdens de arbeidsongeschiktheid niet te beschrijven zijn. Illustratief in dit verband is de slotstelling van W.Spit, voorzitter van de ARBO-raad, bij de door het NCGV georganiseerde conferentie "Categorie V: arbeidsongeschikt wegens psychische stoornissen": "Deze conferentie is in hoge mate stressbevorderend. Haar deelnemers worden zonder oplossing van het probleem naar huis gestuurd". (Spit, 1991) Ook voor een leek is waarneembaar dat in zijn omgeving werknemers overspannen raken en "in de ziektewet lopen", zonder dat duidelijk is wat zij nu mankeren, waarom zij niet kunnen werken, en welke behandeling zij ondergaan.

Het onderzoek waarvan door ons in dit proefschrift verslag gedaan wordt, heeft tot doel antwoorden te geven op de volgende vraagstellingen:

- Wat is de aard van overspanning oftewel wat is de betekenis van het begrip overspanning en hoe manifesteert de aandoening overspanning zich in klachten en verschijnselen?

- Welke hulpverlening wordt verleend aan werknemers die zich wegens overspanning hebben ziekgemeld?

- Op welke wijze en in welke mate bepalen persoons-, bedrijfs-en arbeidsplaatsgebonden factoren, verzuimverleden, kenmerken van de overspanning, het ziektegedrag en de hulpverlening de verzuimduur en de wijze van verzuimbeëindiging?

Het onderzoek is derhalve niet zozeer gericht op de verklaring van het ontstaan en de omvang van overspanning onder de beroepsbevolking, maar houdt zich bezig met de beschrijving van het ziektebeeld en de hulpverlening bij overspanning, en met de verklaring van het beloop. Het is gesitueerd in het proces van secundaire preventie. Gegeven dat overspanning zich voordoet bij een werknemer, wordt de vraag gesteld: wat zijn de te verwachten gebeurtenissen?

Het onderzoek omvat allereerst een systematische litteratuurstudie naar het gebruik en de betekenis van overspanning. Vervolgens heeft een onderzoek plaatsgevonden naar de kwaliteit van de verzekeringsgeneeskundige diagnostiek. Ten slotte is als voornaamste bestanddeel van deze studie een veldonderzoek uitgevoerd onder werknemers die zich ziekgemeld hebben wegens overspanning, en de huisartsen en verzekeringsgeneeskundigen die bij de gevalsbehandeling en -begeleiding betrokken zijn geweest.

Dit veldonderzoek is bedoeld om de ontstaanswijze van overspanning en de klachten en verschijnselen die aan de ziekmeldingen voorafgaan, bij deze werkne- 
mers vast te leggen om naast de eerder ondernomen litteratuurstudie ook een empirische analyse van het ziektebeeld overspanning te realiseren. Voorts is op basis van het veldonderzoek nagegaan, wat de invloed van het functioneren van de gezondheidszorg op de totale verzuimduur is. Dit volgens de opzet van en als aanvulling op eerdere onderzoeken van Tordoir c.s. (1978) en Soeters (1983). Ten slotte is het veldonderzoek ondernomen om op correlationele wijze te kunnen onderzoeken welke kenmerken betreffende persoon, bedrijf, arbeidsplaats, verzuimverleden, en kenmerken van en hulpverlening door huisarts en verzekeringsgeneeskundige, verschillen in afloop van het ziekteverzuim en verschillen in verzuimduur bij degenen die naar hun werkkring terugkeren, beïnvloeden.

Naar de wijze van dataverzameling kan het veldonderzoek beschouwd worden als een prospectief cohortonderzoek onder overspannen werknemers. Naar vraagstelling en wijze van datanalyse is het veldonderzoek beschrijvend en exploratief. Een vergelijkende opzet was op grond van het onderzoeksbudget niet haalbaar, terwijl een toetsend onderzoek als gevolg van gefragmenteerde onderzoeksresultaten en gebrekkige theorievorming met betrekking tot determinanten van verzuimbeloop, zowel in het algemeen als in het bijzonder bij overspanning, niet de aangewezen opzet leek.

\subsection{Opbouw van dit proefschrift}

In hoofdstuk 2 wordt het gebruik en de betekenis van overspanning in de geneeskundige litteratuur in Nederland besproken. Tevens wordt aandacht besteed aan de vraag, in hoeverre overspanning een typisch Nederlands begrip en verschijnsel is door na te gaan, of er met verwante begrippen soortgelijke verschijnselen in de ons omringende landen beschreven worden. In hoofdstuk 3 wordt de operationalisatie van overspanning in de verzekeringsgeneeskundige diagnostiek en een onderzoek naar de interbeoordelaar-betrouwbaarheid van de verzekeringsgeneeskundige diagnose beschreven.

Hoofdstuk 4 is gewijd aan een bespreking aan de hand van de onderzoekslitteratuur van de bevindingen omtrent de determinanten van verzuimduur en WAO-intrede. Dit hoofdstuk besluit met een tweetal modellen waarin deze determinanten samengevat worden. Deze modellen zijn uitgangspunt voor de analyses van het verzuimbeloop in de hoofdstukken 12 tot en met 14.

In hoofdstuk 5 wordt de opzet van het veldonderzoek beschreven. Met name wordt uitgebreid op de procedure van selectie en werving der respondenten en op de respons ingegaan. Voorts worden de gevolgen van selectie en non-respons voor de geldigheid van de resultaten besproken. Ten slotte wordt een overzicht geboden van de opzet van de dataverzameling.

In hoofdstuk 6 wordt een korte beschrijving gegeven van de samenstelling van de onderzoekspopulatie naar persoons- en arbeidskenmerken. Hoofdstuk 7 biedt een beschrijving van de ziektebeelden die waargenomen zijn bij de respondenten. Daarna volgt een beschrijving van het verzuim- en ziektebeloop. Hoofdstuk 8 is gewijd aan het ziektegedrag in de pre-medische fasen en de inschakeling van de hulpverlening. De beschrijving van de laatste besluit met een zogenaamd stroom- 
diagram. Het hoofdstuk wordt besloten met een beschrijving van de contacten tussen de overspannen werknemer en het bedrijf.

Vervolgens wordt in hoofdstuk 9 een beschrijving gegeven van de aard van de hulpverlening door huisarts en andere instanties uit de curatieve sector en in hoofdstuk 10 van de begeleiding door de verzekeringsgeneeskundige sector. Zowel hoofdstuk 9 als hoofdstuk 10 wordt besloten met de beschrijving van analyses van de invloeden van wachttijden in de curatieve gezondheidszorg respectievelijk de verzekeringsgeneeskundige begeleiding op de verzuimduur.

In hoofdstuk 11 wordt een beschrijving gegeven van de opzet die onder meer de bewerking van data tot variabelen en de methode van statistische analyse inhoudt die bij de analyses van de voorspellers van de wijze van verzuimbeëindiging en de verzuimduur in geval van werkhervatting gebruikt is. In de hoofdstukken 12,13 en 14 worden de resultaten van deze analyses besproken met betrekking tot de determinanten van respectievelijk terugkeer naar de werkkring, aard van het verloop en verzuimduur in geval van terugkeer.

Dit proefschrift wordt in hoofdstuk 15 afgesloten met een samenvatting en bespreking van de belangrijkste bevindingen uit het onderzoek. 


\section{Hoofdstuk 2}

\section{De conceptualisering van overspanning}

2.1 Gebruik en betekenis van de term overspanning in de medische litteratuur*

\subsubsection{Inleiding}

Overspanning is een term die door veel artsen en leken wordt gebezigd om bepaalde gezondheidsklachten onder éen begrip samen te vatten. Door de meeste artsen wordt ze als een lekenterm beschouwd en derhalve als hoogstens bruikbaar voor eenvoudige uitleg van de diagnose aan de patiënt of zijn omgeving.

Dat de kwaliteit van lekentermen niet onder hoeft te doen voor termen uit de professionele diagnostische nomenclatuur, toont een onderzoek van Omark (1980) onder leken naar de betekenis van nervous breakdown. Zij bleken met een redelijke tot grote mate van consensus in staat de aetiologische factoren, de symptomen en de duur te specificeren.

Overigens blijkt uit het professioneel taalgebruik dat men bij vermijding van de term overspanning kiest voor gelijkluidende termen als surmenage en neurasthenie. Ook de ontwikkeling van een uitgebreid diagnostisch systeem als de DSM-III blijkt de behoefte aan deze begrippen niet te verminderen. Immers de DSM-III is ontwikkeld vanuit de patiëntenpopulatie van de psychiatrie en de klinische psychologie, terwijl huisartsen en verzekeringsgeneeskundigen geconfronteerd worden met een patiëntenpopulatie die voor het merendeel buiten het domein van de specialisten blijft. Aan het gebruik van de term overspanning zijn enkele problemen verbonden. Allereerst wordt ze nogal eens gebruikt om ernstigere psychopathologie te verhullen en aldus functioneert de term overspanning als containerbegrip voor alle psychische problematiek. Voorts ontbreekt een inhoudelijke definiëring van het begrip overspanning op basis waarvan ze als officieel begrip in de geneeskunde ingevoerd kan worden. (Kraft, 1972)

Voor ons is de onduidelijkheid rondom het begrip overspanning reden geweest een onderzoek uit te voeren naar het gebruik en de betekenis van de term overspanning in de geneeskundige litteratuur.

\footnotetext{
* Paragraaf 2.1 is een geactualiseerde samenvatting van twee eerdere publicaties. Zie: Schröer et al.,
} 1987 en Schröer et al., 1988. 
Daartoe zijn op systematische wijze (hand)boeken, diagnostische classificaties, tijdschriftartikelen, dissertaties en scripties geanalyseerd. Dit aan de hand van geîndexeerde trefwoorden als overspanning, surmenage, neurasthenie, overstrain, burnout en aanverwante termen of op basis van verwijzingen. Het Nederlands Tijdschrift voor Geneeskunde, Huisarts en Wetenschap, Het Nederlands Tijdschrift voor Psychiatrie, Het Tijdschrift voor Sociale Geneeskunde, later Het Tijdschrift voor Sociale Gezondsheidszorg, en Het Tijdschrift voor Verzekeringsgeneeskunde zijn daarbij volledig geanalyseerd.

Voor het litteratuuronderzoek naar gebruik en betekenis van aanverwante termen in buitenlandstalige publicaties is gebruik gemaakt van de litteratuurbestanden EMBASE, MEDLARS, PSYCHINFO, DIMDI en QUESTEL.

\subsubsection{Het gebruik van de term overspanning}

In de handboeken komt de term overspanning slechts één keer voor. Ze wordt omschreven als een "populaire, geen vaktechnische term ... dikwijls ten onrechte opgevat als een gevolg van langdurig te hard werken (surmenage) of een te grote psychische belasting." (Ladee, 1976)

In twee ziekteclassificaties treffen we eveneens de term overspanning aan maar zonder nadere omschrijving: de Engelse E-lijst, een huisartsgeneeskundige morbiditeitsclassificatie (Van Es, 1974), en het verzekeringsgeneeskundig diagnostisch codeboek van de GMD. (Wouters, 1984)

In de overige vaklitteratuur treffen we vanaf 1881 tot 1987 meer dan 40 publicaties aan waarin de term overspanning één of meermalen gebezigd wordt. De term verschijnt op één uitzondering na uitsluitend in de periodes 1881-1910 en na 1950 . De eerste publicatie die geheel aan het verschijnsel overspanning is gewijd, verschijnt in 1960. (Michels, 1960) In de jaren zeventig volgen meer publicaties over overspanning. Weyel (1970) beschrijft uitvoerig de symptomatologie. Kraft (1972) schrijft een monografie, waarin het ontstaan, de oorzaken, het klinisch beeld, de epidemiologie, de diagnostiek, het verloop, de therapie en de preventie uitvoerig aan bod komen. Deze monografie alsmede tien stellingen van de auteur (Kraft, 1975) vormen de basis voor de Studiedagen voor Sociale Verzekeringsgeneeskundige 1975, waar o.a. Giel, Rooymans en Van der Maas hun licht laten schijnen over het verschijnsel overspanning. (Verslag, 1975) Ook Maasen (1985) en Kocken (1984) gaan vanuit bedrijfsgeneeskundig respectievelijk huisartsgeneeskundig perspectief uitgebreid op het verschijnsel overspanning in.

Op basis van het gebruik van de term overspanning in de medische litteratuur is het niet eenvoudig een balans op te maken over de status van overspanning als vakterm.

In de hand- en woordenboeken is geen plaats ingeruimd, wel in ziekteclassificaties en overige litteratuur. De auteurs die overspanning beschrijven, maken deel uit van de huisartsgeneeskunde, de psychiatrie, of de bedrijfs- en verzekeringsgeneeskunde.

Het gebruik van de term overspanning is ook in de tijd gezien geen constant verschijnsel. Voor de hand ligt de veronderstelling dat termen als surmenage en neurasthenie die de term overspanning uit het medisch taalgebruik verdringen, op 
grond van hun vreemdtaligheid waardoor ze zich beter lenen voor het jargon dat in een afstand tot leken moet voorzien. Toch kan de variatie in gebruik van de term overspanning niet toegeschreven worden aan het uitwijken naar deze synoniemen. Zoals we later tonen, blijkt de mate waarin het gebruik van deze termen plaats vindt. juist sterk samen te hangen met het gebruik van de term overspanning.

Veeleer hangt het samen met de belangstelling van de geneeskunde voor de invloed van psycho-sociale factoren op de gezondheid. Zo bestond er in de tweede helft van de vorige eeuw ook van medisch zijde grote belangstelling voor de "Sociale Quaestie". De eerste helft van deze eeuw kenmerkte de geneeskunde zich meer door haar gerichtheid op organische of persoonlijkheidsdefecten als oorzaak van ziekte. De opmars in die jaren van de farmacologie en de psycho-analyse zijn wat dat betreft illustratief. Als gevolg van de maatschappelijke, industriële en economische ontwikkelingen na de tweede wereldoorlog ontstaat een hernieuwde oriëntatie op de invloed van maatschappelijke en omgevingsfactoren op de gezondheid.

\subsubsection{De betekenis van de term overspanning}

De relevantie van de term overspanning is niet alleen afhankelijk van het gebruik. De medische taal is een levende taal en derhalve in ontwikkeling. Om als vakterm een plaats te veroveren en te behouden is het noodzakelijk dat overspanning een begrip is met een éenduidige en zelfstandige betekenis.

Hoewel het gebruik van de term overspanning niet in alle gevallen vergezeld gaat van een definitie, valt de betekenis meestal af te leiden uit de context waarin de term gebruikt wordt. Eind vorige eeuw werd overspanning voornamelijk als synoniem gebruikt voor overlading of overmatige c.q. overdreven inspanning. Met overspanning wordt dus een aetiologische factor in het ontstaan van diverse ziektebeelden aangeduid.

$\mathrm{Na} 1950$ zien we een kentering optreden ten gunste van het gebruik van de term overspanning om het ziektebeeld zelf aan te duiden. In eerste instantie gaat het dan om een beschrijving van een symptomatologie. Overspanning wordt als een syndroom getypeerd. Kraus (1955) omschrijft "neurotische overspannenheid" als een toestand waarin zich enkele symptomen van een niet volledig ontwikkeld hyperaesthetisch-emotioneel syndroom voordoen, met als specifiek kenmerk "een zuiver psychische genese" en benadert daarmee de opvatting van overspanning als ziektebegrip. Michels (1960) spreekt van een "overspanningssyndroom" als gevolg van (teveel aan) spanning. Weyel (1970) omschrijft overspanning als een decompensatie die herkenbaar is aan somatische verschijnselen. Ook hij benadrukt de psycho-sociale bepaaldheid van overspanning. Kraft (1972) ten slotte geeft de volgende en meest volledige definitie van overspanning: "Er is téveel aan spanningen opgeroepen door een voor het individu in té korte tijd een té grote prikkelaanbod (emotioneel-kwantitatief), hetgeen zowel passief-receptief als actief-productief verkregen kan worden, waardoor na verloop van tijd als gevolg van onvoldoende geestelijke verwerking onlustgevoelens in dusdanige graad optreden, dat zich psychisch en somatisch klachten van diverse aard openbaren". Overspanning valt volgens Kraft (1975) onder het medisch ziektebegrip, omdat er sprake is van functionele insufficiëntie en van een typische fasering van begin, verloop met 
symptomen, en einde. Kraft's definitie wordt onder meer onderschreven door Kocken (1984) en Maasen (1985). De laatste auteur is evenwel van mening dat overspanning geen diagnostische eenheid is maar een klinische manifestatie van het neurastheen syndroom. Door Kocken (1984) worden overspanningstoestanden geplaatst onder de categorie subacute decompensatietoestanden. Zijn omschrijving sluit aan bij die van Kraft. Als bijzondere vorm vermeldt hij managerziekte-syndroom. Huygen c.s. (1984) beschrijven een ziektecategorie nerveus-functionele klachten waarvan overspanning deel uitmaakt. Zij noemen de volgende kenmerken: er zijn geen lichamelijke afwijkingen constateerbaar die de klachten kunnen verklaren, en het is zeer waarschijnlijk, dat de oorzaak van de klachten op psycho-sociaal gebied ligt. Niet gespecificeerd wordt, wanneer er sprake is van overspanning.

Hoewel overspanning momenteel als een zelfstandig ziektebeeld opgevat wordt, bestaat er toch aarzeling bij een aantal auteurs of zelfs afwijzing (Van der Pas, 1975; Maasen, 1985) om overspanning als nosologische entiteit te beschouwen. Dit is overigens wel te begrijpen vanuit de ontwikkeling van het ziektebegrip zelf. In een reductionistische denkwijze waarin afzonderlijke ziekte-eenheden en monocausaliteit uitgangspunten vormen, is voor overspanning minder plaats dan in een fysiologische oftewel procesbenadering van ziekte waarbij meerdere oorzaken ten grondslag liggen aan een samenhangend stelsel van klachten en/of stoornissen. (Hughes, 1985)

\subsubsection{Synoniemen voor de term overspanning}

Overspanning is in Nederland onder meer synoniem gesteld aan het hyperaesthetisch-emotionele syndroom (Weyel, 1970), aan surmenage (o.a. Weyel, 1970 en Maasen, 1985) aan neurasthenie (Rooymans, 1975; Verhaest, 1976) en aan nervous breakdown. (Weyel, 1970)

Smit (1952) somt daarnaast nog de volgende lijst van synoniemen op: neurose, neurotische klachten, psychogene reacties, functionele bezwaren, psychasthenie, nervositas, overwerktheid en oververmoeidheid. In de huisartsgeneeskunde zien we overspanning nogal eens ondergebracht onder bredere termen als nerveusfunctionele klachten of psychoneurose.

Evenals in Nederland is er ook in de Verenigde Staten in de loop der jaren een uitgebreid vocabulair opgebouwd om het verschijnsel overspanning aan te duiden. Cohen en White geven in 1950 een opsomming: neurasthenie, angstneurose, neurocirculatoire asthenie, nerveuze uitputting, het syndroom van Da Costa, het effort syndrome, het irritable heart syndrome, soldiers heart enzovoorts. In Duitsland heeft men termen gehanteerd als Überforderungssyndrom, Erschöpfungsdepression, Neurasthenie, Tätigkeitsnerose, Nervenzusammenbruch, funktionellen Syndrom, psychovegetatives Syndrom en vegetative Dystonie. In Frankrijk hanteert men naast neurasthénie vooral surmenage. De laatste jaren is er vanuit de Verenigde Staten een opmars te zien van de populariteit van de termen adjustment disorder die opgenomen is in de DSM-III, burnout en chronic fatigue syndrome.

Wij beperken onze bespreking tot de in betekenis meest verwante en in internationaal opzicht belangrijkste termen: het hyperaesthetisch-emotionele syndroom, sur- 
menage, neurasthenie c.q. neurastheen syndroom en adjustment disorder. Al deze termen zijn overgenomen uit de ons omringende landen. De conceptuele ontwikkelingen in die landen worden eveneens besproken ten einde ook zicht te krijgen op het internationale karakter van het verschijnsel overspanning. Hoewel de term burnout door velen ook als synoniem van overspanning opgevat wordt, kan deze toch duidelijk afgebakend worden als een voorstadium van overspanning onder beroepsgroepen waarvan de werkzaamheden het verlenen van persoonlijke diensten inhouden, zoals bij onderwijzers, verpleegkundigen en politieagenten het geval is. Kenmerkend zijn gevoelens van emotionele uitputting, een proces van motivatieverlies, verlies aan eigen waardering van de persoonlijke bekwaamheid en verandering van werkattitude. (Duxbury et al., 1984; Schaufeli, 1990)

\section{Hyperaesthetisch-emotionele syndroom (HES)}

Dit begrip betekent letterlijk dat er sprake is van een aantal tegelijkertijd optredende verschijnselen van overgevoeligheid en van emotionele uitbarstingen. Het is voor het eerst in 1910 door Bonhöfer beschreven als exogene reactievorm, d.w.z.: het syndroom volgt op lichamelijk ingrijpende processen. Als voorbeelden noemt hij infectieziekten en kraambed. (Bonhöfer, 1910; Kraus, 1955; Peters, 1977) Later is het syndroom ook toegepast bij aandoeningen met (soort)gelijke symptomen maar met psychische oorzaken. (Peters, 1977) Kraus voegt als mogelijke oorzaak toe een lichamelijke surmenage als gevolg van langdurig werken in een te hoog tempo zonder voldoende rust. De symptomen zijn een sterk gevoel van zwakte, verhoogde vermoeibaarheid, een verminderd uithoudingsvermogen, zwakte in alertheid en concentratie, allerlei overgevoeligheden, prikkelbaarheid, emotionele uitbarstingen, hoofdpijnen, schrikachtigheid, angstdromen en wanen. Kraus (1955) duidt in een uitvoerig betoog over dit syndroom - dat hij uitdrukkelijk de status van ziekteeenheid onthoudt - als verschil tussen dit syndroom en (neurotische) overspannenheid aan dat bij de laatste het syndroom niet volledig ontwikkeld is en dat de oorzaken psychisch van aard zijn.

Door de meeste auteurs in Nederland wordt het hyperaesthetisch-emotionele syndroom dan ook niet zozeer als synoniem dan wel als (eén der) symptomatologie(ën) van overspanning opgevat. In de beschrijvingen van de klinische beelden van overspanning (in engere zin) en in vele beschrijvingen van het neurastheen syndroom komen de klachten die behoren tot het hyperaesthetisch-emotionele syndroom, op de voorgrond.

\section{Surmenage}

Met uitzondering van Kraft (1972, 1976 en 1991) worden zowel in het schriftelijk als in het mondeling taalgebruik surmenage en overspanning als synoniemen gehanteerd. (Weyel, 1970; Orlemans en Ten Doesschate, 1976; Wouters, 1984; Maasen, 1985; Boenink et al., 1986; Gerritsen, 1988) Kraft maakt aanvankelijk een onderscheid tussen deze twee termen door de term surmenage te reserveren voor het overwerkt zijn oftewel door surmenage als mentale overbelasting op te vatten tegenover overspanning als psychische overbelasting, maar soms laat hij het onderscheid vallen. (Kraft, 1980) Door geen der andere auteurs is dit onderscheid overigens overgenomen. 
Vrijwe! overeenkomstig met de bevindingen omtrent overspanning treffen we de term surmenage in de Nederlandstalige medische litteratuur vooral aan tussen 1895 en 1920 en na 1950.

In tegenstelling tot overspanning treffen we de term surmenage in de Nederlandse litteratuur in veel mindere mate vergezeld van nadere uiteenzettingen over de aard en betekenis van deze term. Door middel van de context moet de lezer opmaken wat onder surmenage verstaan moet worden. We treffen surmenage ook aan in diverse na-oorlogse ziekteclassificaties, onder andere in de "Nomenclatuur ten behoeve van de codering van ziekte en ongevallen 1954." Naast neurastheen syndroom, hyperaesthetisch-emotioneel syndroom en constitutionele nervositas is zij éen der subcodes van de rubriek asthenische reacties. (De Groot, 1959) Momenteel vormt in de actuele verzekeringsgeneeskundige ziekteclassificatie "surmenage ten gevolge van overbelasting" samen met reactieve depressie en acute stressreactie één diagnose, namelijk: "situatieve of exogene reactie."

Surmenage vindt haar herkomst in de Franse taal waar het een identieke betekenis heeft als overspanning ten onzent. Vooral in de periodes 1880-1920 en 1950-1970 - vrijwel gelijk op- en afgaand van het gebruik van de termen overspanning en surmenage in Nederland - komt deze term in de Franstalige medische vaklitteratuur voor. In de eerste periode overheersen de psychiatrische publicaties, in de tweede periode zien we veel belangstelling voor surmenage in de arbeidsgeneeskundige litteratuur.

Aanvankelijk werd surmenage voornamelijk beschreven in psychiatrische studies omtrent de oorzaken van neurasthenie. In de jaren 80 van de vorige eeuw verschenen van de hand van Charcot diverse publicaties waarin de "surmenage intellectuelle" als één der oorzaken van het ontstaan van neurasthenie werden genoemd (Verhaest en Pierloot, 1981). Dat het gebruik van de term surmenage al voor de laatste eeuwwisseling stevig ingeburgerd was, blijkt uit de vermelding van surmenage in een Amerikaans medisch woordenboek uit die tijd. (Tuke, 1882) Daarin wordt surmenage als een Franstalig begrip opgevoerd en omschreven als de lichamelijke of geestelijke conditie voortgebracht door overbelasting of overdruk. Door verschillende auteurs wordt surmenage ("physique et mental") omschreven als een nerveuze uitputting die kan leiden tot het ontstaan van ziektes, met name psychopathieën, of een belangrijke factor is in het ontstaan van neurasthenie. (Verhaest en Pierloot, 1981)

In deze periode blijkt in het Franstalige dus met surmenage op de eerste plaats een aetiologische factor aangeduid te worden, zij het dat bij Toulouse en Tuke surmenage tevens als een lichamelijke en geestelijke aandoening op zichzelf wordt beschouwd die op haar beurt tot decompensaties kan leiden. Deze tweeslachtigheid met betrekkking tot het begrip surmenage is tot nu toe aanwezig gebleven.

In de Nederlandse litteratuur heeft al vroeg een duidelijkere verschuiving in betekenis van aetiologische factor naar aandoening plaatsgevonden, de ontwikkeling van de term overspanning op de voet volgend. Daar duikt de term surmenage voor het eerst op in 1887, wanneer tweemaal verwezen wordt naar de discussie in Frankrijk over de gevolgen van "surmenage intellectuel". (Ned T Geneesk, 1887) In die betekenis gebruiken ook Jelgersma (1898) in zijn Leerboek der functioneele 
neurosen en Mouton (1901) de term surmenage. Beide auteurs zien de surmenage als éen der oorzaken van neurasthenie.

Later zien we bij Jelgersma (1907) de term surmenage beschreven als een toestand van het individu onder andere als gevolg van een overmaat aan werk. Daarmee staat surmenage voor het eerst voor een aandoening. Jelgersma onderscheidt een tweetal vormen van surmenage: de "surmenage intellectuel" die zich bij kinderen voordoet, wanneer het in zijn mentale ontwikkeling te vroeg aan een belasting wordt blootgesteld waarvoor het niet rijp is, en de "surmenage normal" die op volwassen leeftijd kan optreden. In dat geval doen zich verschijnselen voor als teleurstellingen, angsten, kwellingen bij personen die niet opgewassen blijken tegen de eisen van de strijd om het bestaan.

In 1938 zien we bij Desoille surmenage als beroepsziekte aangemerkt. Hij verstaat onder surmenage een toestand van diepgaande asthenie, machteloosheid en echte adynamie, waarbij organische oorzaken niet aantoonbaar zijn. (Bégoin, 1958) In de periode 1950-1970 treffen we de term surmenage veelvuldig aan in diverse studies van vermoeidheid en stress, waarbij vooral sociaal-geneeskundigen en arbeidspsychologen de boventoon voeren.

In 1956 komt Brun tot een onderscheid tussen constitutionele neurasthenie en een zogenaamde surmenage of uitputtingsvorm van neurasthenie. Bij de laatste schetst Brun een ontstaansproces dat veel overeenkomst toont met de stresstheorie van Selye. (Pauchard, 1981)

Le Guillant c.s. (1956) vatten in een onderzoek onder telefonistes surmenage ("direct des processus nerveux") weer op als een aetiologische factor die, indien ze het stadium van onomkeerbaarheid bereikt, tot een "echte neurose" leidt. De symptomatologie van deze "névrose des téléphonistes" zoals de auteurs die beschrijven, gelijkt sterk op het hyperaesthetisch-emotionele syndroom. Op de voorgrond treden verschijnselen als nerveuze vermoeidheid, stemmings- en karakterveranderingen, slaapproblemen, allerlei somatische symptomen en uit dit alles voortvloeiende levensproblemen. De auteurs merken zelf op dat dit klinisch beeld dat van neurasthenie benadert.

Bégoin (1958) ziet surmenage als een aetiologische factor in het ontstaan van "le syndrome de la fatigue nerveuse". Het klinisch beeld dat Bégoin daarvan schetst, komt vrijwel geheel overeen met dat van de névrose des téléphonistes bij Le Guillant c.s. Wel legt Bégoin een grotere nadruk op de verstoringen in de sociale leven. De "fatigue nerveuse" wordt door hem verwant genoemd aan de neurasthenie.

Andlauer en Kaufmann (1959) vatten surmenage eveneens op als een aetiologische factor. Daarbij gaan zij in op de vraag of deze op zijn beurt vanuit het milieu of endogeen ontstaat. Surmenage kan volgens Andlauer en Kaufmann leiden tot mentale problemen die zich kunnen uiten in de neurasthene vorm dan wel in neuropathisch-hysteriforme verschijnselen.

Baruk (1959) ziet surmenage ook als een aetiologische factor. Surmenage kan op zich vrij lang verdragen worden maar bij tegenslag leiden tot lichamelijke ongemakken als slecht slapen, vermoeidheid, spijsverteringsklachten e.d. Deze toestand vat hij samen onder het begrip "fatigue nerveuse" dat hij synoniem stelt aan neurasthenie. 
Bize en Goguelin (1956) omschrijven surmenage als "la conséquence d'une activité dont la rhytme est exagéré et prolongé sans moment de détente, sans possibilité de récupération réparatrice. La mésure physiologique individuelle est dépassée. On entre dans la pathologie ... parce qu'il est souvent impossible de mettre un terme à l'effort".

Voor hen is surmenage min of meer een overgangstoestand waarin een individu komt te verkeren bij aanhoudende inspanning. Het stadium surmenage wordt voorafgegaan door dat van vermoeidheid en leidt, indien de inspanning blijft aanhouden, tot uitputting oftewel slijtage (usure). Dit laatste stadium noemen Bize en Goguelin pathologisch. Het organisme wordt dan diepgaand geïntoxiceerd. Zij duiden dit stadium dan ook aan met de term surmenage-maladie. Analoog aan het General Adaption Syndrome van Selye onderscheiden zij drie fasen bij de surmenage-maladie: de alarmfase, de fase van gejaagdheid (fébrilité) en de fase van depressie of apathie. In tegenstelling tot de eerder aangehaalde auteurs vatten Bize en Goguelin surmenage niet als een zuiver aetiologische factor (het zich overwerken of overspannen) op maar als een ziektebeeld (overwerkt of overspannen zijn) dat zich op de scheidslijn bevindt van aetiologische factor en het ziektebeeld dat op surmenage volgt. Daarin benaderen ze vrij dicht de conceptualisering van Weyel (1970) ten aanzien van overspanning. In vergelijking met het overspanningsbegrip van Kraft geeft het surmenagebegrip van Bize en Goguelin nauwelijks ruimte aan acutere vormen van overspanning.

Missenard c.s. (1960) volgen met hun typering van "la fatigue surmenage" als overgangstoestand tussen "la fatigue aigue" (acute vermoeidheid) en "l'épuisement" (uitputting) de opvatting van Bize en Goguelin. De fatigue surmenage wordt door hen beschreven als een chronische vermoeidheid. Deze manifesteert zich in allerlei lichamelijke en psychische klachten, gedragsveranderingen en neuro-vegetatieve stoornissen. Deze symptomen - en dat achten Missenard c.s. kenmerkend voor de fatigue surmenage - blijven in rust voortbestaan.

Noch Bize en Goguelin noch Missenard c.s. laten zich evenwel uit over de vraag of surmenage een nosologische entiteit vormt.

Sivadon (1969) vat de fatigue-surmenage die door hem op overeenkomstige wijze als door Missenard omschreven wordt, op als een aetiologische factor die tot ongevallen en ziektes "predisponeert".

$\mathrm{Na} 1970$ zien we de term surmenage nog slechts een enkele keer verschijnen in de Franstalige medische vaklitteratuur.

De precieze betekenis van de term surmenage, d.w.z. aetiologische factor of het ziektebeeld zelf, blijkt dus tot op de dag van vandaag nog steeds niet vastgelegd. Dat surmenage in Frankrijk niet algemeen als nosologische entiteit opgevat wordt, wordt geillustreerd door het ontbreken van de term surmenage in het destijds toonaangevende Manuel de Psychiatrie van Ey (1963). Dit in tegenstelling tot "L'asthénie névrotique".

In Nederland vinden we na een onderbreking van tientallen jaren de term surmenage weer terug in de jaren vijftig, onder andere bij Grewel (1951) die spreekt over het ziektebeeld van de "surmenage", door hem ook met overbelasting aangeduid, en bij Weyel (1961 en 1970) die surmenage eveneens opvat als een ziektebeeld en 
deze nader omschrijft als respectievelijk objectief overbelast zijn en overspannen (geraakt zijn).

Tegelijkertijd zien wij surmenage gebruikt in de betekenis van aetiologische factor die al dan niet een rol zou kunnen spelen in het ontstaan van neurasthenie (Stam, 1962), die als sociaal belastende factor leidt tot een neurastheen syndroom (Kuijpers, 1966), of die kan leiden tot symptomatisch-psychotische beelden en het hyperaesthetisch-emotionele syndroom. (Kraus, 1968)

Vanaf 1970 geeft de Nederlandse vaklitteratuur toch blijk van een voorkeur om surmenage op te vatten als een ziektebeeld - in dat geval nogal eens met behulp van de term surmenage-syndroom -, waarbij opvalt dat nadere omschrijvingen van het ziektebeeld ofwel achterwege blijven ofwel met een enkele term als overbelasting of overspanning afgedaan wordt.

De meest uitgebreide uiteenzettingen over surmenage treffen we aan in een tweetall artikelen van Terluin (1984 en 1986). Hoewel door Terluin surmenage synoniem geacht aan overspanning, neurasthenie, HES e.d., verkiest hij deze boven andere termen wegens de "neutrale gevoelswaarde". Hij vat surmenage op als een zelfstandig ziektebeeld dat als zodanig gediagnosticeerd kan worden.

In eerste instantie geeft Terluin (1984) een vijftal criteria om de diagnose surmenage te stellen, namelijk:

1. het klachtenpatroon. Het patroon dat Terluin schetst, komt overeen met het hyperaesthetisch-emotionele syndroom.

2. de klachtenduur. Hierbij stelt Terluin een grens van twee maanden. Indien deze overschreden is, blijt de aanwezigheid surmenage niet uitgesloten, maar treedt dan als comorbiditeit op.

3. de aanwezigheid van overbelasting.

4. uitsluiting van een klassieke psychiatrische aandoening.

5. uitsluiting van een belangrijke lichamelijke aandoening.

Door het aanleggen van de laatste twee criteria blijkt Terluin's conceptualisering van surmenage stricter dan Kraft's overspanningsbegrip, omdat met name een tweetal door Kraft beschreven vormen van overspanning, namelijk overspanning als complicatie en decompensatietoestanden inhouden dat in het ontstaan c.q. het verloop van de surmenage andere aandoeningen juist wel aanwezig zijn.

Later voegt Terluin (1986) nog twee criteria toe, namelijk de ernst van de klachten. d.w.z. in geval van surmenage is het individu niet in staat de normale dagelijkse bezigheden uit te voeren, en een voorgeschiedenis van "normaal" functioneren.

Surmenage wordt eveneens door van den Burg c.s. (1988) als zelfstandig ziektebeeld opgevat. Door deze auteurs wordt het heterogene klachtenbeeld benadrukt. Hun omschrijving van surmenage sluit vrij nauw aan bij de definitie van Kraft (1972) van overspanning. Opvallend is dat zij bij de afbakening tussen depressie en surmenage voor de laatste kenmerkend vinden dat het betrokken individu zowel wat betreft de situatie als de oorzaken over een reëel ziekteinzicht beschikt en actief is, d.w.z.: de patiënt voelt zich overactief en werkt nog. Het laatste kenmerk is in tegenspraak met de opvattingen van Terluin en Kraft, die juist het niet kunnen functioneren benadrukken.

Orlemans en Ten Doesschate(1976) geven een uitgebreide beschrijving van de symptomatologie van "het zogenaamde surmenagesyndroom". Deze toont sterke 
gelijkenis met die van het hyperaesthetisch-emotionele syndroom en van de overspanning. Opvallend is dat deze auteurs van mening zijn dat functionele hartklachten vaak de eerste tekenen zijn van het surmenagesyndroom. Goudsmit (1977) geeft een zelfde beschrijving van surmenage.

In de praktische diagnostiek zien we een wisselende constellatie ten aanzien van surmenage en overspanning. Soms wordt alleen surmenage vermeld (Timmer en Koten, 1982; Lamberts en Hartman, 1982), soms alleen overspanning (Van Es, 1974), soms beide (De Klerk et al., 1983; Boenink et al., 1986). Timmer en Koten beschrijven daarbij surmenage als een stoornis die zich tijdelijk voordoet bij gezonde personen in een crisissituatie of anders gebaseerd is op een neurotische aanleg of op persoonlijkheidsstoornissen. In dat geval is surmenage een gevolg van verminderde stresstolerantie en voortdurend (latent) aanwezig.

\section{Neurasthenie of neurastheen syndroom}

In 1869 ontwikkelde Beard in de Verenigde Staten het begrip neurasthenia. Neurasthenia is een uit Griekstalige elementen opgebouwde term die letterlijk staat voor (zenuw)vezel-on-vermogen: neuron-a-sthenos. Hij omschreef deze als een chronisch, functionele ziekte van het centrale zenuwstelsel met schade aan het zenuwstelsel. De lichamelijke symptomen zijn allerlei pijnen, hartkloppingen, krampen, sensibiliteitsstoornissen, jeuk, zweten en flushes en de psychische zijn prikkelbaarheid, onrust, fobiën en angsten, concentratiestoornissen en stemmingsdalingen, terwijl daarnaast algemene klachten als slapeloosheid en moeheid kunnen optreden. Tot de verschijnselen kunnen ook sexuele stoornissen en verslaving behoren. Als oorzaak zag hij de psychische overbelasting die tot uitputting van het zenuwstelsel leidde. Zijn formule luidde: beschaving + Amerikaanse beschaving + uitputtend klimaat + nerveuze constitutie + overwerk en overmatig piekeren of buitensporige toegeeflijkheid aan lusten en hartstochten = een aanval van neurasthenie of nerveuze uitputting. (Abbey en Garfinkel, 1991) Beard deelde met de introductie van neurasthenie de neurosen op in neurasthenie, hysterie en hypochondrie. (Verhaest, 1976)

De term neurasthenie werd al snel in diverse landen in West-Europa ingevoerd en is inmiddels over de gehele wereld ingeburgerd in het medisch taalgebruik. Niet alleen in de Verenigde Staten en West-Europa maar ook in landen als de SowjetUnie (Beljaew, 1974; Dogle en Yakovleva, 1982) en China. (Kleinman, 1982) In Groot-Brittannië werd neurasthenie een geliefde diagnose voor ziekteverzuimonderzoek. (De Groot, 1959; Verhaest, 1976)

Het meest populair was het begrip tot de eerste decennia van de twintigste eeuw; daarna zien we evenals bij overspanning en surmenage een afnemend gebruik. $\mathrm{Na}$ de tweede wereldoorlog wordt weer vaker op het begrip teruggevallen, met name in de jaren zeventig

In de jaren vijftig wordt het gebruik van de term neurasthenie sterk beperkt door het verschijnen van talloze synoniemen. (Cohen en White, 1951; Verhaest, 1976) Momeriteel lijkt de term neurasthenie in de DSM-IV (1991) een come-back te gaan beleven als subcategorie van de somatoforme stoornissen.

Al snel ontsponnen zich discussies met betrekking tot oorzaken en de aard van het ziekteproces van neurasthenie. Voorts vond een proces plaats van afzonderingen 
van ziektebeelden die oorspronkelijk onder het breder begrip neurasthenie vielen maar later een eigen nosologische entiteit aangemeten kregen. (Verhaest, 1976) De bindende elementen van het begrip neurasthenie bleven de opvatting dat er sprake was van een overprikkeling van het zenuwstelsel, en de symptomatologie, zij het dat er bij de laatste duidelijke accentverschillen lagen.

In de Verenigde Staten, bij voorbeeld, fungeerde neurasthenia oorspronkelijk als een containerbegrip waarmee vele psychische aandoeningen aangeduid werden zoals angsttoestanden, obsessies, dwangmatigheden en fobieën. Na de afzondering van vele afzonderlijke ziektebeelden bleef er van neurasthenie slechts een aandoening met nauwelijks meer aan symptomatologie dan alleen vermoeidheid over. (Chatel en Peele, 1970; Berger, 1973)

Hoewel tijdens de jaren vijftig en zestig de ambivalentie in de Verenigde Staten met betrekking tot het gebruik van de term gegroeid is (Chatel en Peele, 1970), kreeg de term toch een plaats in diverse internationale en nationale ziekteclassificaties waaronder de DSM-II die verscheen in 1978. In de DSM-III werd voor dit begrip geen plaats meer ingeruimd. De samenstellers verkozen boven een classificatie van ziektebeelden aan de hand van begrippen met allerlei discutabele surplusbetekenissen een multiaxiaal diagnosestelsel dat zo dicht mogelijk aansluit bij de empirische dimensies van psychische ziektebeelden. In het ontwerp voor de DSM-IV (1991) wordt voorgesteld om neurasthenie als diagnose op te nemen onder de categorie somatoforme stoornissen. Neurasthenie wordt daar beschreven als een aandoening die zich voornamelijk manifesteert door een onverklaarde chronische vermoeidheid of gevoelens van zwakte of uitputting met een duur van ten minste zes maanden.

De term neurasthenie is vooral in de Duits- en Franstalige litteratuur verder uitgewerkt. Vooral rond de eeuwwisseling verschenen enkele studies speciaal gewijd aan dit ziektebeeld. Freud deelt bij zijn onderscheid tussen Aktualnerosen en Psychonerosen de neurasthenie bij de eerste in. Zijn conceptualisering van neurasthenie sluit nauw aan bij die van Beard. (Verhaest, 1976) In "Les états neurasthéniques" onderscheidt De la Tourette (1899) de ware neurasthenie die vooral het gevolg is van overmatig werken gepaard met zorgen en inspanningen, van de erfelijke of constitutionele neurasthenie en de "association hystéro-neurasthénique". In de omschrijving van De Fleury (1902) is neurasthenie gelijk aan overspanning.

Janet voerde in 1903 het onderscheid tussen de begrippen neurasthenie en psychasthenie in. Met neurasthenie duidt hij het ziektebeeld zelf aan, met psychasthenie een constitutioneel kenmerk dat predisponeert tot recidiverende neurasthenie. (Van Dantzig en Waage, 1962; Jongerius, 1984) Bovendien splitste hij fobieën, obsessies en dwangmatigheden als afzonderlijke ziektebeelden af van neurasthenie. (Berger, 1973)

Internationaal is met de bijdrage van Janet de discussie voorgoed op gang gebracht over de vraag of neurasthenie door uitwendige, lichamelijke, dan wel door erfelijke of endogene factoren veroorzaakt werden. (Verhaest, 1976; Jongerius, 1984) 
Parallel aan de ontwikkelingen in Frankrijk werd in de Verenigde Staten een onderscheid gemaakt tussen major (d.w.z. verworven) en minor (d.w.z. erfelijk bepaalde) neurasthenia. (Berger, 1973) In Duitsland sprak men van in dit verband van respectievelijk "wirkliche Neurasthenie" en "Pseudoneurasthenie". (Bleuler, 1975)

Veel Duitse auteurs hangen het standpunt aan dat overbelasting primaire oorzaak is (Hoffmann, 1967) In 1975 spreekt Bleuler daarentegen als zijn opvatting uit, dat neurasthenie weliswaar door overmatige inspanning versterkt kan worden, maar in wezen neurotisch bepaald is.

De term neurasthenie werd in het Nederlands taalgebruik geïntroduceerd via een vertaling van een Duitse publicatie. Het zijn evenals bij overspanning, hyperaesthetisch-emotionele syndroom en surmenage vooral de publicaties in Duitsland en Frankrijk geweest die het denken in Nederland beïnvloed hebben.

Vanaf 1886 zien wij publicaties in Nederland waarin het ziektebeeld neurasthenie meer of minder uitgebreid besproken wordt. Aanvankelijk wordt neurasthenie vooral opgevat als een klinisch beeld gelijkend op het hyperaesthetisch-emotionele syndroom. In tegenstelling tot overspanning of surmenage wordt neurasthenie ook nogal eens verbonden aan psychiatrische ziektebeelden als agorafobie en dwangmatigheid. (Huet, 1886) Carp (1947) betitelt neurasthenie dan ook als vergaarbak. Jelgersma (1898) verbindt neurasthenie duidelijk aan overspanning als aetiologische factor, maar geeft daarbij in aansluiting op de internationale discussie wel aan dat de diepere oorzaak van neurasthenie niet alleen gelegen hoeft te zijn in uitwendig belastende factoren maar ook op erfelijkheid gebaseerd kan zijn. De geschiedenis toont dat ook in Nederland het gebruik van de term neurasthenie permanent vergezeld gaat van stellingnames omtrent de vraag of deze het gevolg is van overbelasting, zoals Beard (1869) oorspronkelijk stelde, (Smit, 1952) of het gevolg is van erfelijk-constitutionele zwakte (Grewel, 1951), dan wel van onverwerkte conflicten, zoals Rümke en Kuiper stellen. (Verhaest, 1976) Alleen Stam (1952) en Verhaest (1976) laten, zoals Kraft bij overspanning, open dat de aandoening door meerdere oorzaken kan ontstaan.

Als specifiek voor neurasthenie ten opzichte van het hyperaesthetisch-emotionele syndroom zien Kraus (1955), Rümke en Verhaest (1976) dat bij neurasthenie de lichamelijke klachten, met name vermoeidheidsklachten, voorop staan.

Meermalen wordt er gesproken over neurasthene karakters of persoonlijkheden waarbij negatieve waardeoordelen maar nauwelijks verhuld uitgesproken worden. Neurastheen wordt dan gebezigd als synoniem aan klaaggeneigd of hypochonder. Op iets serieuzere wijze werken Van Dantzig en Waage (1972) het door Janet ingevoerde onderscheid tussen neurasthenie en psychasthenie uit. Bij neurasthenie stellen zij "een subjectief kwellend onmachtsbeleven" voorop. Met name bij acute gevallen zien zij veelvuldig de aanwezigheid van een psychasthene karakterstructuur, d.w.z. overmatig precies, perfectionistisch, onzeker en controlegeneigd. Verhaest en Pierloot (1980) konden overigens voor deze samenhang geen empirische bevestiging vinden.

In Nederland kreeg neurasthenie aanvankelijk ook als ziektebeeld opgevat steeds meer de betekenis van een symptomatologie. We zien dan ook dat de term neurasthenie plaats maakt voor de term neurastheen syndroom. 
Kuijpers (1966) stelt op grond van een onderzoek onder een populatie huisartspatiẻnten, dat dit syndroom dat hij indeelt bij de psychosomatische aandoeningen, zich kenmerkt door de trias van klachten moeheid, hoofdpijn en duizeligheid. Evenals voor alle psychosomatische aandoeningen stelt hij als diagnostisch vereiste een overwegende betekenis van psychosociale milieufactoren in het ontstaan en continuering van de klachten. Kocken (1984) beschouwt het neurasthene syndroom als éen der vormen van de functionele syndromen naast onder meer het gastro-intestinaal, nek-rug- en het hyperaesthetisch-emotionele syndroom. Hij onderscheidt het neurasthene syndroom van overspanning door overspanning als een subacuut decompensatoire aandoening op te vatten.

Verhaest (1976) werkt de neurasthene neurotische reactie vanuit de omschrijving "een subjectief kwellend onmachtsbeleven, klachten van moeheid of overdreven vermoeibaarheid en begeleidende functionele klachten" uit aan de hand van een vragenlijst voorgelegd aan 183 patiënten van een psychiatrische polikliniek. $\mathrm{Na}$ analyse door middel van een hiërarchische clusteranalyse besluit hij tot een drietal typen van symptomenclusters: het depressieve, het hyperaesthetisch-emotionele en het somatische. Het laatste beschouwt hij als het neurasthene syndroom.

Jongerius (1984) definieert het neurasthene syndroom als een falende aanpassing bij een verstoring van het evenwicht tussen draagkracht en draaglast die leidt tot lichamelijke symptomen en psycho-emotionele klachten. Gevoelens van machteloosheid staan daarbij voorop. Als verschijningsvormen noemt hij onder meer het hyperventilatiesyndroom, reactieve en gemaskeerde depressie, spanningshoofdpijn en het hyperaesthetisch-ernotionele syndroom. Zijn omschrijving van het neurasthene syndroom komt sterk overeen met Kraft's conceptualisering van overspanning. Verschillen zijn dat volgens Jongerius decompensatie, d.w.z. het niet langer kunnen functioneren in éen of meer sociale activiteiten, niet altijd hoeft te volgen op de ontwikkeling van een neurastheen syndroom. Evenmin wordt een verstoring van de psychische balans in alle gevallen gevolgd wordt door een neurastheen syndroom.

Voor Maasen (1985) is het neurastheen syndroom identiek aan overspanning voor zover ze optreedt als reactie op milieufactoren en in het bijzonder psycho-sociale stressfactoren.

\section{Adjustment disorder/aanpassingsstoornis}

Deze term maakt deel uit van de in de Verenigde Staten ontwikkelde classificatie van psychiatrische ziektebeelden DSM-II die in 1952 verscheen en in 1980 opgevolgd werd door de DSM-III. Met deze uitgave verdween de term neurasthenie uit de classificatie.

Criteria voor de diagnose aanpassingstoornis zịn:

- een falende aanpassing aan een identificeerbare psycho-sociale stressor,

- dit falen openbaart zich binnen drie maanden,

- er is sprake van een verminderd functioneren in de beroepsrol en/of andere sociale rollen,

- een brede symptomatologie die in hevigheid onevenredig is met de algemene ernst van de stressor,

- verdwijnen van de verschijnselen na het verdwijnen van de stressor dan wel het bereiken van een nieuw evenwicht, 
- een maximale duur van zes maanden,

- er is geen sprake van een andere psychiatrische stoornis of van een normaal rouwproces.

Door Maasen (1985) is de adjustment disorder als éen van de vormen van overspanning opgevat, terwijl Gerritsen (1988) adjustment disorder vrijwel overeen vindt komen met overspanning. Een deel van dit meningsverschil ligt in de afweging hoe gevallen van overspanning waarbij lichamelijke klachten of depressieve klachten op de voorgrond staan, in te delen. Maassen kiest voor respectievelijk somatisatiestoornis en dysthyme stoornis ondanks enkele aanvullende criteria waaraan overspanningsgevallen veelal niet voldoen, terwijl Gerritsen benadrukt dat in de typologie van adjustment disorders ook typen geformuleerd zijn onder de termen depressed moods en physical complaints. Vooralsnog lijkt het erop, dat zeker de gevallen van overspanning "in engere zin" binnen de DSM-III goed in te delen zijn onder de adjustment disorders, indien de tijdscriteria met soepelheid gehanteerd worden. In het ontwerp van de DSM-IV (1991) wordt onder meer voorgesteld het criterium van een maximale duur van zes maanden te laten vervallen en deze termijn in plaats daarvan te benutten als demarcatiegrens tussen acute en chronische aanpassingstoornissen.

Het begrip aanpassingsstoornis is overigens niet onomstreden. Gewezen wordt op de vaagheid van criteria en verwarring met onder meer de $V$-codes die verwijzen naar patiënten die wel een reële hulpvraag presenteren aan de geestelijke gezondheidszorg maar bij wie geen stoornis vastgesteld kan worden. (Noshpitz en Coddington, 1990)

\subsection{Het ziektebeeld overspanning}

De eerste uitvoerige omschrijving van het ziektebeeld komt van Michels (1960). Hij onderscheid drie typen van overspanning:

- overspanning "geprovoceerd door psychische en somatische afwijkingen en minderwaardigheden". Overspanning treedt dan op als eerste symptoom van een beginnende ziekte b.v. schizofrenie of van een bestaande b.v. epilepsie.

- overspanning "bij normale belastbaarheid als gevolg van overbelasting". De beschrijving van dit ziektebeeld toont grote gelijkenis met die van neurasthenie door Beard. Volgens Michels wordt de overspanning als resultante opgevat van een verstoring van de verhouding tussen spanning en weerstand en van het besef van deze verstoring. Ook een irreële inschatting van een verstoord evenwicht met name bij zeer scrupuleuse personen kan oorzaak van overspanning zijn.

- "pseudo-overspanning" d.w.z. ondanks een normale belastbaarheid is er sprake van overbelasting als gevolg van de geneigdheid zich te overbelasten ter compensatie van "schuldige tekortkomingen". Hier speelt de persoonlijkheid van de patiënt die kan leiden tot slechte werkhygiëne, een overheersende rol.

Weyel (1970) ziet alle overspanning als resultante van een afnemend endogeen verweer tegen toenemende stress. Bij het optreden van overspanningsverschijnselen als reactie op een lichamelijke aandoening spreekt Weyel van een somatische genese. Onder stress verstaat hij de "zuiver sociale stress", de invloeden op het normenstelsel en de levensstijl van de patiënt, en een irreëel levens- en verwach- 
tingspatroon van de patiënt. Realiteit, milieu en persoonlijkheidsstructuur ziet hij derhalve als de drie aetiologische factoren van overspanning. In het algemeen stelt hij de symptomatologie van het hyperaesthetisch-emotionele syndroom als kenmerkend voor overspanning. Volgens Weyel kan overspanning echter, indien de persoonlijkheid een doorslaggevende invloed heeft, ook de vorm van een neurotische decompensatie aannemen, namelijk een dwangneurotische, een hysterisch-functionele of een psycho-somatische decompensatie. Bij de laatste kunnen zich verschijnselen voordoen als maagzweer, astma-aanvallen of hypertensie.

Kraft (1972) beschrijft een viertal vormen, waarin zowel de beschrijvingen van Michels als van Weyel geïntegreerd blijken:

- complicerende beelden: er is sprake van overspanning gepaard gaande aan een lichamelijke of psychische aandoening, die de weerstand verzwakt en zo een toestand van stress bevordert. Deze vorm verschilt van de andere niet zozeer in symptomatologie als wel in de mogelijke oorzaak en behandelingsaanpak. Deze vorm lijkt op het eerste door Michels beschreven type, maar Kraft legt zich minder vast op de causale richting.

- gemaskeerde beelden: de overspanning wordt manifest door middel van een psychosomatose, bij voorbeeld maagzweer, colitis, hypertensie, of door middel van conversie-hysterische verschijnselen als verlamming, pijnen en flauw vallen. Overspanning fungeert hier in tegenstelling tot de eerste en de laatste vorm als een aetiologische factor.

- decompensatietoestanden: de overspanning, die hier ook meer als aetiologische factor optreedt, heeft geleid tot uitputting met apathie of tot psychotische verschijnselen. Psychosomatoses als gevolg van langdurige stress met uitputting rekent Kraft eveneens tot decompensatietoestanden. Anders dan Weyel definieert Kraft een decompensatietoestand als een onomkeerbaar proces.

- overspanning in engere zin. Bij deze vorm presenteert de overspanning zich direct en zelfstandig met de symptomatologie van het hyperaesthetisch-emotionele syndroom.

De symptomatologie oftewel het klinisch beeld op zichzelf beschouwt Kraft (1975) als onvoldoende basis om overspanning vast te stellen. Inzicht in de aetiologie van de klachten is een noodzakelijke voorwaarde voor diagnosestelling.

Bij Kocken (1984) zien we overspanning omschreven als een subacuut optredende decompensatietoestand die verschillende uitingsvormen kan aannemen, namelijk:

- een hyperaesthetisch-emotioneel syndroom.

- een neurastheen syndroom.

- depressief gedrag.

- een functioneel syndroom zoals spierspanningshoofdpijn, hyperventilatiesyndroom, en gastro-intestinaal syndroom.

Maasen (1985) ziet drie verschijningsvormen van overspanning. Deze corresponderen volgens Maasen met een drietal diagnoses uit de DSM-III (1980):

- acute overspanning (aanpassingsstoornis) berustend op een slechte aanpassing aan een herkenbare psychosociale stressor. Het acute bestaat daarin dat het 
tijdsverloop tussen stressor en aandoening maximaal drie maanden mag bedragen.

- chronische overspanning (dysthyme stoornis), een lichtere vorm van depressie. De chroniciteit bestaat in de duur van ten minste twee jaar.

- neurasthenie als levenshouding (somatisatiestoornis) waarbij een reeks van lichamelijke klachten zich gedurende een aantal jaren voordoen.

Parallel met deze drie verschijningsvormen beschrijtt Maasen drie symptomencomplexen: het hyperaesthetisch-emotionele syndroom, het depressieve en het somatische symptomencluster. In tegenstelling tot Maasen beschouwt Gerritsen (1988) alleen de categorie aanpassingstoornissen uit de DSM-III als grotendeels overeenstemmend met overspanning. Als belangrijk verschil ziet Gerritsen de tijdsvoorwaarde die aan adjustment disorders, d.w.z. tussen oorzaak en verschijnselen mag maximaal drie maanden liggen, wordt gesteld.

Opvallend is dat zowel Maassen als Kocken aan de verschijningsvormen van overspanning, zoals Kraft die ingedeeld heeft, uitdrukkelijk een (reactieve) depressie toevoegen.

De verschijnselen van overspanning zijn gezien de verscheidenheid van verschijningsvormen uitermate heterogeen. Het hyperaesthetisch-emotionele syndroom alleen al omvat een enorme verzameling lichamelijke klachten en stemmingsveranderingen zoals moeheid, gebrek aan concentratie, overgevoeligheid voor drukte en lawaai, gejaagdheid, huilen, libidoverlies, depressiviteit, duizeligheid, hoofdpijn enzovoorts. Als we daarenboven de psychosomatoses, conversiehysterische verschijnselen, fysieke en psychische decompensaties erbij betrekken komen een reeks van cardiovasculaire klachten, pijnklachten, en stemmings- en gedragsstoornissen in aanmerking als symptomen van - mogelijke - overspanning. Zonder een grondig aetiologisch en pathofysiologisch onderzoek zal in een groot aantal gevallen overspanning onopgemerkt blijven.

\subsection{Conclusies en beschouwing}

Waarneembaar is een continu, zij het in een overeenkomstige mate van wisselvalligheid, gebruik van diverse begrippen om bepaalde ziektebeelden te benoemen die onder de term overspanning beschreven zijn. Dit gebruik beperkt zich niet tot onze landsgrenzen, maar blijkt ook in de ons omringende landen onder synoniemen als surmenage en neurasthenie aanwezig. De karakteristieke symptomatologie van het hyperaesthetisch-emotionele syndroom is eveneens internationaal beschreven. Overspanning is derhalve niet een cultuurbepaalde "dutch disease" evenmin als neurasthenia een "american disease" is, maar doet zich overal voor. In hoeverre een relatief hoge incidentie van dit ziektebeeld in Nederland de associatie met het "dutch disease"-beeld van overspanning rechtvaardigt, is op grond van gebrek aan internationaal goed vergelijkbare gegevens moeilijk vast te stellen.

Zolang deze begrippen bestaan, is onder andere als bezwaar ingebracht dat ze nogal eens gebruikt worden als verlegenheids- of gelegenheidsdiagnose. Met name wordt daarbij gedoeld op medische beoordelingen in de context van verzekeringsclaims. Zo stelde in 1923 Buzzard met betrekking tot neurasthenia dat het 
begrip neurasthenie een "legal construct with no clinical base" is. Oftewel "a label to direct a legal decision for compensation". (Figlio, 1982) Ook tegenwoordig nog wordt de aanwezigheid van diagnoses als situatieve of exogene reactie in de verzekeringsgeneeskundige diagnoseclassificatie wel eens betiteld als "restgroep" voor niet nader te specificeren psychische aandoeningen. (Van Eck, 1990)

Daarenboven wordt er gewezen op het meestal ontbreken van deze termen in psychiatrische diagnoseclassificaties en op het zeer geringe gebruik van de term in de klinisch-psychiatrische diagnostiek. (Chatel en Peele, 1970) Daarbij moet opgemerkt worden dat overspanning geen ziektebeeld is dat als regel beschouwd wordt als voldoende indicatie voor psychiatrische behandeling, laat staan voor opname.

Het bezwaar van het gebruik als verlegenheidsdiagnose suggereert een derde bezwaar, namelijk dat de conceptualisering te vaag is. De empirische bewijsvoeringen ontbreekt echter bij deze argumentatie. Overigens kan men evengoed stellen dat bij de diversiteit van de fenomenologie van ziektebeelden die ontstaan als gevolg van heterogene psycho-sociale aetiologische factoren, en die leiden tot een onvermogen tot functioneren en noodzaak van ziektegedrag, juist een algemeen ziektebegrip als overspanning zinvoller toegepast kan worden dan specifiekere begrippen die mank gaan aan een onverifieerbaar of therapeutisch zinloos betekenissurplus.

Zelfs bij de meest uitgewerkte diagnoseclassificaties resteert een categorie gevallen die moeilijk plaatsbaar zijn. De momenteel internationaal zeer populaire DSM-III blijkt gezien de kritiek die de diagnose aanpassingsstoornis ten deel valt, zijn grenzen te vinden bij de classificatie van patiënten die typisch als gevallen van overspanning zijn te beschouwen. Zelfs een brede en daarom becritiseerde categorie als aanpassingsstoornis blijkt niet alle gevallen van overspanning te kunnen omvatten.

Er blijkt internationaal een blijvende behoefte bestaan aan concepten die naar verschijnselen van overspanning verwijzen. Lijkt de term neurasthenie nu bijna geheel uit de gratie, de laatste jaren komen de termen burnout en chronic fatigue syndrome in zwang. (Abbey en Garfinkel, 1991)

Indien we proberen de moderne conceptualisering van overspanning inhoudelijk samen te vatten dan komen we tot de bevinding dat de term overspanning een ziekteproces aanduidt. Er is sprake van een lichamelijk en geestelijk onwelbevinden en een noodzaak tot het aannemen van de ziekerol.

Overspanning is herkenbaar aan de volgende kenmerken:

- aanwezigheid van een verstoring van het evenwicht tussen psychische, in het bijzonder emotionele, belasting en belastbaarheid.

Opvallend is dat juist bij de begripsvorming van een aandoening als overspanning een theoretisch begrip, namelijk dat van een - dynamisch - evenwicht, uit de arbeidsgeneeskunde centraal staat. Op deze wijze wordt bij overspanning een substraat verondersteld dat overigens in tegenstelling tot dat van vele somatische aandoeningen alleen waarneembaar is bij verstoring daarvan. 
- de verstoring is waarneembaar aan de manifestatie van verscheidene lichamelijke en psychische klachten die per geval in een wisselende constellatie optreden.

Meest genoemde klachten zijn: moeheid, prikkelbaarheid, hoofdpijn, slapeloosheid, gebrek aan concentratievermogen, angst, gejaagdheid en duizeligheid. Het onwelbevinden is gezien de algemeenheid van de klachten in beperkte mate gespecificeerd.

De aanwezigheid van dergelijke klachten op zich voldoen niet om het ziektebeeld overspanning vast te stellen. De twee volgende kenmerken zijn noodzakelijke voorwaarden:

- een onvermogen tot sociaal functioneren ongeacht de duur van de aanloop en de daarbij optredende premorbide verschijnselen.

Met de drie tot nog toe genoemde kenmerken zijn in de conceptualisering de drie elementen van het ziektebegrip, namelijk stoornis, ziektegevoel en ziektegedrag vertegenwoordigd.

- de verstoring van het evenwicht is een directe reactie op psycho-sociale factoren al dan niet onder stimulans van exogene of endogene factoren.

Het besluiten tot een diagnose overspanning louter op grond van bovengenoemde klachten en een onvermogen om deze te verklaren vanuit lichamelijke of geestelijke defecten is in strijd met de bestaande conceptualisering. Aannemelijk gemaakt moet worden dat de oorzaak gelegen is in een psycho-sociale factor.

- de verschijnselen kunnen onvoldoende verklaard worden vanuit lichamelijke of geestelijke defecten.

Dit kenmerk sluit niet uit dat dergelijke defecten een rol spelen in het ontstaan van overspanning. Zij kunnen een rol spelen in het ontstaan of verloop als aetiologische factor dan wel decompensatoir gevolg van overspanning. Wel vormen zij een onvoldoende verklaring voor het niet kunnen functioneren.

Samenvattend kan overspanning als volgt gedefinieerd worden:

"Overspanning is een dusdanige verstoring van het evenwicht tussen psychische belasting en psychische belastbaarheid als gevolg van veranderingen in individuele belastbaarheid en/of psycho-sociale belasting, dat bij het getroffen individu een proces ontstaat van verminderd vermogen tot sociaal functioneren, gepaard gaande met lichamelijke klachten, stemmings- en/of gedragsveranderingen". 


\section{Hoofdstuk 3}

\section{Een panelonderzoek naar de betrouwbaarheid van de verzekeringsgeneeskundige diagnostiek van overspanning}

\subsection{Inleiding}

De gescheiden ontwikkeling van de theoretische conceptualisering van het begrip overspanning en de verzekeringsgeneeskundige praktijk van toekenning van diagnosecodes aan gevallen van ziekteverzuim leidt tot een aantal problemen met betrekking tot de kennisontwikkeling omtrent overspanning.

Voor de toekenning van een diagnose aan verzuimgevallen hanteren de verzekeringsgeneeskundigen die belast zijn met de controle en begeleiding in het kader van de uitvoering van de Ziektewet, een diagnosecodeboek uitgegeven door de Federatie van Bedrijfsverenigingen. Deze is gebaseerd op de ICD-9.

Met betrekking tot overspanning zijn de volgende diagnosecodes van belang: 300: "neurosen", 301: "persoonlijkheidsstoornissen", 306: "fysiologische functiestoornissen door psychische oorzaken", 309: "situatieve of exogene reactie", waarbij ter toelichting reactie op stress, surmenage door overbelasting, en reactieve depressie vermeld staan, en 311: "depressie niet elders vermeld".

De praktijk leert dat verzekeringsgeneeskundigen deze codes gemakkelijk onderling verwisselen.

Bij een perfecte overeenstemming tussen theoretische conceptualisering en diagnostische praktijk zouden alle ziekteverzuimgevallen waarbij sprake is van overspanning, door elke verzekeringsgeneeskundige als zodanig herkend en ondubbelzinnig gediagnostiseerd moeten kunnen worden. Dit blijkens de toekenning van de diagnosecode situatieve of exogene reactie in geval van overspanning in engere zin. Overspanning in de vorm van psychosomatische of conversiehysterische reacties zouden dan volledig moeten corresponderen met de diagnose fysiologische functiestoornissen door psychische oorzaken. Bij de decompensatoire vormen zou het meest voor de hand liggen dat als hoofddiagnose situatieve of exogene reactie gesteld wordt maar met een nevendiagnose afhankelijk van de aard van de decompensatie. Bij een gecompliceerde overspanning daarentegen zou situatieve 
of exogene reactie als nevendiagnose aangemerkt kunnen worden, waarbij de hoofddiagnose afhankelijk is van de aard van de basale aandoening.

Een onderzoek naar de mate van overeenstemming tussen (verzekerings)artsen in de diagnostiek van overspanning heeft ten onzent nog niet plaatsgevonden. Wel is door Gerritsen (1988) een vragenlijstonderzoek gedaan naar consensus onder verzekeringsgeneeskundigen over de symptomen en aetiologische factoren die bij surmenage zouden behoren. De resultaten hiervan komen overeen met wat hierover in de litteratuur vermeld is. Hoe deze ziektekenmerken in een diagnostisch proces afgewogen worden tegenover andere aandoeningen, is door Gerritsen niet onderzocht. Dit betekent onder meer dat onbekend is in hoeverre conclusies met betrekking tot primair of secundair onderzoeksmateriaal vertekend kunnen zijn door individuele of collectieve bias van de diagnostiserende artsen.

In een onderzoek naar het proces van psychiatrische diagnosestelling (aan de hand van de DSM-III) trof Brown (1987) diverse contextuele factoren aan die het resultaat beïnvloeden. Tot deze factoren behoorde de vereiste de diagnose te formuleren in termen van de classificatie. Daarbij bleek de diagnostiserende arts geneigd te zijn bevindingen dusdanig aan te passen, dat er op een of andere manier een categorie van toepassing bleek. In de Nederlandse verzekeringsgeneeskundige diagnostiek is er a forteriori sprake van een dwangsituatie: na zes weken dient krachtens de Ziektewet een diagnosecode aan het ziektegeval toegekend te worden op straffe van verlies van uitkeringsgerechtigdheid van de werknemer.

Evenmin is bekend of eventuele verschillen in toekenning van de diagnose overspanning tevens het gevolg kunnen zijn van een gebrekkige conceptualisering van overspanning.

De diagnose situatieve of exogene reactie wordt door velen als verlegenheidsdiagnose of ronduit als legitimatiediagnose gezien. De druk die op verzekeringsgeneeskundigen gelegd wordt om sociale problemen door middel van ziekteverzuim tijdelijk - op te lossen door met name deze diagnose toe te kennen als grond van arbeidsongeschiktheid, heeft meermalen tot protesten geleid. (Gerritsen, 1988; Van Eck, 1990)

Bovendien is de hoeveelheid informatie waarover een verzekeringsgeneeskundige bij het toekennen van een diagnose beschikt, zeer beperkt. De arts is afhankelijk van de informatie die de werknemer, het dossier en de curatieve sector verschaffen. De mogelijkheden om zelfstandig de patiënt te onderzoeken zijn beperkt. (Luyckx, 1982) Zeker in het geval dat er sprake kan zijn van overspanning, moet de verzekeringsgeneeskundige nogal eens afgaan op de geloofwaardigheid die gebaseerd wordt op de congruentie tussen klachten en uiterlijk, de consistentie van het verhaal, en het verzuimverleden. (Van Eck, 1990)

Ten slotte geschiedt de wijze van vastlegging van de diagnose aan de hand van een diagnosecodeboek dat vrijwel uitsluitend een opsomming van aandoeningen en bijbehorende codes bevat zonder richtlijnen aan de hand van welke klachten, symptomen en andere ziekteverschijnselen de code toegekend dient te worden. Precieze criteria voor het stellen van de diagnose overspanning kan de verzekeringsgeneeskundige daaruit niet afleiden. (Gerritsen, 1988) 
Bovendien hebben Koten en Timmer (1980) er op gewezen dat de door de Nederlandse verzekeringsgeneeskundigen gehanteerde classificatie als ICD-versie meer toegesneden is op acute dan op chronische en resttoestanden. Ze geeft te weinig aan wat de aard van de functionele beperkingen en arbeidsongeschiktheid is. Voor de verzekeringsgeneeskundige die op de eerste plaats een oordeel moet vormen over de arbeidsgeschiktheid en vervolgens op zoek gaat naar een van minder belang geachte diagnosecode, betekent dit alles dat aan de exactheid van de toegekende diagnosecode minder belang gehecht wordt. De aanwezigheid en het veelvuldig gebruik van open diagnosecodes als "overige en niet-gespecificeerde aandoeningen van ..." verraadt dat deze dubbelzinnigheid van het diagnostisch proces bij de verzekeringsgeneeskundige geinstitutionaliseerd is.

Om deze redenen is door ons een onderzoek ondernomen met als tweeledige probleemstelling:

- In welke mate is er sprake van overeenstemming in diagnose tussen verschillende artsen bij het ziektebeeld overspanning?

- In welke mate is overeenstemming tussen artsen alsnog bereikbaar in die gevallen waarbij in eerste instantie een verschillende diagnose gesteld wordt?

\subsection{Opzet van het onderzoek}

In het onderzoek zijn verzuimgevallen betrokken die gemeld zijn aan éen der districtskantoren van het GAK en in een spreekuursituatie ter beoordeling voorgelegd zijn aan de aldaar werkzame verzekeringsgeneeskundigen. Dit districtskantoor is een andere dan waar het veldonderzoek dat in de hoofdstukken 5 tot en met 14 besproken wordt, heeft plaatsgevonden.

Per verzekeringsgeneeskundige - in totaal betrof het zes artsen - is een willekeurige steekproef getrokken uit de spreekuren. De verzekeringsgeneeskundigen zijn direct na afloop, d.w.z. binnen én à twee uur, over al die gevallen waarbij de arts tijdens het contact een nieuwe diagnose had gesteld, ondervraagd door een lid van het onderzoeksteam. Herhalingscontacten met werknemers zonder wijziging van diagnose werden niet in het onderzoek betrokken. Uit overwegingen van privacy en het gevaar van selectieve uitval is afgezien van audiovisuele registratiemethodes of directe observatie als (aanvullende) methode van dataverzameling.

Aan de verzekeringsgeneeskundigen werden per geval de volgende vragen voorgelegd:

Welk diagnosenummer heeft $u$ toegekend?

Welk nevendiagnosenummer heeft $\mathrm{u}$ toegekend?

Indien deze geen betrekking bleken te hebben op een code die stond voor een aandoening die op theoretische gronden tot het domein van overspanning kon behoren, werd het desbetreffende geval niet in het onderzoek opgenomen.

Een overzicht van de toegelaten diagnosecodes en de daarbij behorende omschrijvingen zijn opgenomen in bijlage 3.1

Over de aldus geselecteerde gevallen werden de volgende vragen gesteld: 
Welke gegevens heeft $\mathrm{u}$ bij de toekenning van de diagnose gebruikt? Uit welke bronnen zijn deze gegevens afkomstig?

Welke gegevens hebben eventueel daarbij de doorslag gegeven? Heeft $u$ andere diagnoses overwogen, en zo ja welke?

In totaal zijn er zodoende per verzekeringsgeneeskundige drie of vier spreekuren in het onderzoek betrokken. Deze procedure leverde in totaal 112 voor het onderzoek geschikte verzuimgevallen op, variërend per spreekuur van 1 tot 11 en per verzekeringsgeneeskundige van 10 tot 24 .

De door ons ingewonnen informatie is vervolgens voor elk geval omgezet in gestandaardiseerde casusbeschrijvingen. Deze zijn alle 112 voorgelegd aan een uit vier leden bestaand panel. Zij kregen ieder afzonderlijk eveneens de bovengenoemde vragen voorgelegd. Uiteraard met uitzondering van de vraag naar de informatiebronnen. Dit panel bestond uit twee huisartsen, een psychiater en een (gepensioneerde) verzekeringsgeneeskundige.

Een tweetal voorbeelden van de wijze waarop de casus is voorgelegd aan de leden van het panel, wordt weergegeven in bijlage 3.2.

$\mathrm{Na}$ een eerste beoordelingronde zijn die gevallen geselecteerd waarover het panel onderling dan wel het panel ten opzichte van de betrokken verzekeringsgeneeskundige een andere diagnose stelde. Deze zijn in een tweede ronde aan drie leden van het panel - de betrokken verzekeringsgeneeskundigen en de tweede huisarts konden niet in de tweede ronde betrokken worden - voorgelegd met vermelding van de diagnoses die de betrokken verzekeringsgeneeskundige en deze drie panelleden hebben gesteld. Dit gebeurde zonder vermelding wie van de andere beoordelaars welke diagnose gesteld had, en zonder vermelding hoeveel beoordelaars de verschillende diagnoses gesteld waren.

Bij onze procedure van ondervraging van het panel hebben wij ons laten leiden door enkele principes van de Delphi-methode. (Fink et al., 1984; Linstone en Turoff, 1984).

Kenmerken van deze methode zijn:

- de panelleden geven onafhankelijk en anoniem hun beoordelingen. Dit om een maximum aan informatie te verkrijgen dank zij uitschakeling van dominantieverhoudingen en "group think"-verschijnselen.

- het beoordelingsproces kent ten minste twee rondes waarbij de panelleden in elke volgende ronde naast de oorspronkelijke informatie toegevoegde informatie krijgen gebaseerd op de beoordelingen van het panel in de voorgaande ronde. Zodoende worden panelleden in staat gesteld hun oordeel te herzien.

- naarmate het panel en het aantal beoordelingsrondes groter zijn en het persoonlijk contact geringer is, neemt de betrouwbaarheid van de methode toe.

- ze wordt bij voorkeur toegepast voor beoordelingsprocessen in groepen met betrekking tot onderwerpen waarover een grote mate van onduidelijkheid en/of verschil van mening bestaat. Een populair onderwerp voor deze methode zijn toekomstscenario's.

- ze bespaart tijd en kosten verbonden aan groepsbijeenkomsten.

- de vraagstellingen aan panelleden zijn meestal zeer open. 
Eisen die gesteld worden aan de toepassing van de Delphi-methode zijn:

- het probleem is goed gedefinieerd.

- de data zijn betrouwbaar.

- de panelleden zijn representatief dan wel het panel is heterogeen.

- de leiding van het panel is objectief en deskundig en waarborgt de anonimiteit.

In dit onderzoek werd de onafhankelijkheid/anonimiteit gewaarborgd door een individuele, schriftelijke beoordelingswijze door de vier panelleden zonder vermelding van wie de gegevens afkomstig waren.

De heterogeniteit werd bepaald door de samenstelling uit drie verschillende medische disciplines. Bij de representativiteit kunnen evenwel gelet het geringe aantal van vijf beoordelaars, te weten de betrokken verzekeringsgeneeskundige en de vier panelleden, vraagtekens gesteld worden. Dit onderzoek moet daarom als exploratief beschouwd worden.

De betrouwbaarheid van de data werd gemaximaliseerd door de snelle afname van de gegevens direct na het spreekuur van de verzekeringsgeneeskundige aan de hand van het zojuist opgemaakte of bijgewerkte dossier.

De vraagstelling was in tegenstelling met de algemene toepassing van de Delphimethode min of meer gesloten: het betrof keuzes uit een beperkt aantal diagnosecodes en de overwegingen van die keuzes. Dit kwam evenwel de precisie van de probleemstelling ten goede.

In ons onderzoek was het aantal beoordelingsrondes beperkt tot twee. Gezien de geslotenheid van de vraagstelling lag een derde ronde niet voor de hand. Meer dan keuzeverschillen was er niet voor te leggen.

Als maatstaf voor consensus en interbeoordelaar-betrouwbaarheid is de proportie van overeenstemmende oordelen op het totaal geen adequate maatstaf, omdat deze geen rekening houdt met de kans op overeenstemming op toevalsbasis. (Schouten, 1985) Als maat voor overeenstemming tussen beoordelaars is daarom gebruik gemaakt van Cohen's $\mathbf{K}$. (Cohen, 1960) De formule is aangepast voor dichotome categorieën (Collis, 1985) De kappa-formule corrigeert voor toevalsverwachtingen. Met het oog op de verstorende invloed van de wisselende randverdelingen, als gevolg van de vrijheid van de beoordelaars ten aanzien van de verdeling van hun diagnoses over de diagnosecodes, op de hoogte van deze maat is tevens ter evaluatie de K-max. berekend. (Umesh et al., 1989) We hebben de kappa's berekend tussen de tien paren beoordelaars die binnen een vijftal samengesteld kunnen worden.

Kennis omtrent de prevalentie van overspanning onder de onderzoekspopulatie was bij geen der beoordelaars aanwezig.

\subsection{Resultaten van het onderzoek}

De 112 gevallen kregen door de vijf beoordelaars bij de eerste beoordeling de volgende diagnoses toegekend: 
Tabel 3.1 Diagnosestelling eerste ronde

\begin{tabular}{|c|c|c|c|c|c|}
\hline Beoordelaar: & $\begin{array}{l}\text { Verzek. } \\
\text { geneesk. }\end{array}$ & $\begin{array}{l}\text { Huis- } \\
\text { arts } 1\end{array}$ & $\begin{array}{l}\text { Huis- } \\
\text { arts } 2\end{array}$ & Psychiater & $\begin{array}{l}\text { Ex-verzek. } \\
\text { geneeskund }\end{array}$ \\
\hline \multicolumn{6}{|l|}{ Diagnose: } \\
\hline 309: situatieve/exogene reactie & 27 & 26 & 22 & 25 & 19 \\
\hline 300: neurosen & & & & 1 & \\
\hline 301: persoonlijkheidsstoornis & & 3 & & & \\
\hline 306: psychogene functiestoornis & & 21 & 3 & 1 & 5 \\
\hline 311: depressie niet elders vermeld & & & 1 & 3 & 2 \\
\hline Totaal overspanning: & 27 & 50 & 26 & 30 & 26 \\
\hline infectie & & 1 & 2 & 1 & 1 \\
\hline II: nieuwvormingen & & & 1 & & \\
\hline (overige) psychische & & 3 & 3 & 2 & 7 \\
\hline VI: zenuwstelsel en zintuigen & 2 & 5 & 5 & 4 & 4 \\
\hline VII: circulatieapparaat & 4 & 1 & 3 & 2 & 5 \\
\hline VIII: ademhalingswegen & 1 & & 2 & 2 & 3 \\
\hline IX: spijsverteringsorganen & 10 & 6 & 10 & 8 & 7 \\
\hline XII: huid & 1 & & 1 & 2 & 1 \\
\hline XIII: bewegingsorganen & 51 & 32 & 51 & 49 & 40 \\
\hline 780: patiênt gezien, geen diagnose & 7 & 8 & 3 & 3 & 10 \\
\hline XVII: verwondingen en vergiftingen & 9 & 6 & 4 & 9 & 8 \\
\hline Totaal geen overspanning: & 85 & 62 & 85 & 82 & 86 \\
\hline
\end{tabular}

Meest opvallende bevinding is het sterk afwijkend beoordelingspatroon van één der huisarts-panelleden ten aanzien van het toekennen van de diagnosecode 306 : fysiologische functiestoornissen met psychische oorzaken. De reden hiervan moet gezocht worden in een verschil in beoordelingsattitude ten opzichte van die gevallen waarin lichamelijke klachten gepresenteerd worden zonder aanwijsbare fysieke afwijkingen. Bij vier van de vijf beoordelaars geldt het principe dat zonder dergelijke bevindingen die lichamelijke oorzaken uitsluiten, de diagnose conform het klachtenpatroon gesteld moet worden. Voor genoemd huisarts-panellid gold als uitgangspunt dat bij het ontbreken van enige verificatie van lichamelijke oorzaken als diagnose stoornis met psychische oorzaak verkozen moet worden. In samenhang hiermee moet het geringer aantal diagnoses in de categorie ziekten der bewegingsorganen van deze beoordelaar gezien worden.

Een tweede bevinding is dat de betrokken verzekeringsgeneeskundigen binnen de reeks diagnoses die staan voor overspanning, slechts code 309 toekennen. In de praktijk blijkt men minder geneigd nadere specificatie aan te brengen, wanneer men eenmaal het oordeel geveld heeft dat het ziekteverzuim gebaseerd is op overspanning.

Ten slotte valt op dat, als we corrigeren voor de afwijkende attitude van het huisarts-panellid, het aantal overspanningsgevallen voor de vijf beoordelaars vrijwel gelijk liggen. Dit hoeft evenwel niet in te houden dat het om dezelfde gevallen gaat. Daarom geven wij in tabel 3.2 een overzicht van de aantallen gevallen waarover consensus of dissensus bestaat. 
Daarbij maken wij een onderscheid tussen consensus/dissensus omtrent toekenning van 309 en toekenning van $300,301,306,309$ of 311 , in het vervolg aangeduid met $309^{+}$.

Tabel 3.2 Overeenstemming beoordelaars

\begin{tabular}{|c|c|c|c|c|}
\hline & \multicolumn{2}{|c|}{ Volledig panel } & \multicolumn{2}{|c|}{$\begin{array}{l}\text { Panel zonder } \\
\text { huisarts } 1\end{array}$} \\
\hline Overeenstemming over 309 & \multicolumn{2}{|l|}{14} & \multicolumn{2}{|l|}{17} \\
\hline Verschil van mening omtrent & \multirow{2}{*}{\multicolumn{2}{|c|}{8}} & & \\
\hline $300,301,306,309$ of 311 & & & \multicolumn{2}{|l|}{7} \\
\hline Overeenstemming over $309^{+}$ & 22 & $20 \%$ & 24 & $21 \%$ \\
\hline Verschil van mening over $309^{+}$ & 31 & $28 \%$ & 9 & $8 \%$ \\
\hline Overeenstemming geen $309^{+}$ & 59 & $53 \%$ & 79 & $71 \%$ \\
\hline Totaal & 112 & $100 \%$ & 112 & $100 \%$ \\
\hline
\end{tabular}

In bijna driekwart van de gevallen waarbij theoretisch sprake kan zijn van overspanning blijken de vijf beoordelaars overeenkomstige besluiten te nemen over de vraag of er al dan niet sprake is van een of andere vorm van overspanning. Bij overeenstemming over diagnostiek in geval van onverklaarde lichamelijke klachten op grond van afwezigheid van een somatisch substraat en van een aanwijsbare aetiologische stressfactor, hetgeen gebruikelijk aangelegde criteria zijn bij verzekeringsgeneeskundigen voor de diagnose overspanning (Van Eck, 1990), kan over meer dan $90 \%$ van de gevallen overeenkomst in diagnose worden bereikt.

Vanzelfsprekend rijst de vraag wat voor type gevallen verschil van mening ontlokt aan de beoordelaars. Daartoe hebben wij een logistische regressie-analyse uitgevoerd met als onafhankelijke variabelen de aan- of afwezigheid in de gevalsrapportage door de verzekeringsgeneeskundige van nekklachten, rugklachten, beenklachten, maag- of darmklachten, hoofdpijn/nerveuze klachten en emotionele klachten.

Alhoewel het klachtenpatroon als geheel geen voldoende verklaring kunnen bieden voor het ontbreken van consensus, blijkt de aanwezigheid van rugklachten als enige significant samen te hangen met het verschil in overeenstemming.

In tabel 3.3 worden de overeenstemmingsmaten gepresenteerd met betrekking tot de beoordeling of een geval al dan niet behoort tot de groep diagnosecodes $309^{+}$. 
Tabel 3.3 Interbeoordelaar-betrouwbaarheid ten aanzien van overspanning

\begin{tabular}{llll}
\hline & K & K-max & ratio \\
\hline verzekeringsgeneeskundige: huisarts 1 & .53 & .55 & .96 \\
verzekeringsgeneeskundige: huisarts 2 & .93 & .95 & .98 \\
verzekeringsgeneeskundige: psychiater & .83 & .87 & .95 \\
verzekeringsgeneeskundige: ex-verzek.geneesk. & .88 & .91 & .97 \\
huisarts 1: huisarts 2 & .55 & .57 & .96 \\
huisarts 1: psychiater & .55 & .57 & .96 \\
huisarts 1: ex-verzekeringsgeneeskundige & .55 & .57 & .96 \\
huisarts 2: psychiater & .81 & .86 & .94 \\
huisarts 2: ex-verzekeringsgeneeskundige & .85 & .89 & .96 \\
psychiater: ex-verzekeringsgeneeskundige & .81 & .86 & .94 \\
& & & \\
algemene interbeoordelaar-betrouwbaarheid: & .71 & & \\
\hline
\end{tabular}

De kappa's voor overspanning variëren van .53 tot .93. De lagere scores zijn, zoals op grond van de gegevens gepresenteerd in de eerste tabel verwacht mocht worden, afkomstig uit de paren met het huisarts-panellid. Indien we dit panellid buiten beschouwing laten variëren de kappa's tussen .81 en .93 .

De algemene overeenstemmingsmaat onder de vijf beoordelaars tezamen bedraagt .71. Als we een correctie aanbrengen voor de verschillen in de marginale verdelingen liggen alle verhoudingsgetallen tussen de waargenomen en maximale overeenstemming boven de .94. Dat wil zeggen: gegeven de aanwezige verschillen in selectiecriteria is de overeenstemming tussen de beoordelaars over welke gevallen in aanmerking komen voor een diagnose van overspanning vrijwel maximaal.

Om te illustreren wat de kappa als maat voor overeenstemming tussen beoordelaars inhoudt, geven we voor de twee beoordelingsparen van de verzekeringsgeneeskundige en de beide huisartsen in de volgende tabel weer, over hoeveel gevallen overeenstemming dan wel verschil in beoordeling opgetreden is. Deze tabel maakt duidelijk dat het aantal gevallen waarin een "positieve diagnose" van de verzekeringsgeneeskundige niet bevestigd wordt door de andere beoordelaars, uitermate gering is. Dit geldt ook voor huisarts 1 . Voorts wordt duidelijk dat de lagere kappa-waarde van het beoordelingspaar huisarts 1 en verzekeringsgeneeskundige vrijwel geheel het gevolg is van een ruimere toekenning van de diagnose overspanning door huisarts 1 ten opzichte van de andere beoordelaars. Een negatief oordeel van de verzekeringsgeneeskundige blijkt in de overige gevallen op een enkele uitzondering na bevestigd door de drie andere panelleden. 
Tabel 3.4 Beoordelingsmatrix huisartsen en verzekeringsgeneeskundige

\begin{tabular}{llrlr} 
& $\begin{array}{l}\text { Huisarts 1 } \\
\text { Overspannen: }\end{array}$ & \multicolumn{2}{l}{$\begin{array}{l}\text { Huisarts 2 } \\
\text { Overspannen: }\end{array}$} \\
Verzekeringsgeneeskundige & $\mathrm{Ja}$ & Nee: & Ja: & Nee: \\
\hline Overspannen: Ja & 26 & 1 & 25 & 2 \\
Overspannen: Nee & 24 & 61 & 1 & 83 \\
& $\mathrm{~K}=.53$ & & $\mathrm{~K}=.93$ & \\
\hline
\end{tabular}

Bij de tweede beoordeling, waarin drie panelleden hun diagnostisch oordeel konden herzien aan de hand van een anoniem overzicht van de toegekende codes door de verzekeringsgeneeskundige en de panelleden tijdens de eerste ronde. blijkt de verdeling van de diagnoses in beperkte mate veranderd.

De belangrijkste verandering heeft betrekking op de cruciale categorieën. De mate van overeenstemming over overspanning blijkt onder invloed van de kennis van de oordelen van anderen toegenomen tot bijna $80 \%$. Dit voornamelijk door de aanpassing van het oordeel van huisarts 1 . De kappa's voor de beoordelingen tussen de panelleden is in de meeste gevallen toegenomen en variëert nu van .61 tot $.93 \mathrm{bij}$ een algemene overeenstemmingsmaat van .77. Voor het overige blijkt het oordeel van de drie bij beide rondes betrokken panelleden redelijk stabiel. De kappa's tussen de drie beoordelingsparen bedragen bij de panelleden $.82, .87$ en .92 .

Tabel 3.5 Overeenstemming beoordelaars na eerste respectievelijk tweede beoordelingsronde

\begin{tabular}{lcccc}
\hline & Eerste ronde & \multicolumn{2}{l}{ Tweede ronde } \\
\hline $\begin{array}{l}\text { Overeenstemming over } 309 \\
\text { Verschil van mening omtrent }\end{array}$ & 14 & & 15 & \\
$300,301,306,309$, of 311 & 8 & $20 \%$ & 22 & $20 \%$ \\
Overeenstemming over $309^{+}$ & 22 & $28 \%$ & 24 & $21 \%$ \\
Verschil van mening over $309^{+}$ & 31 & $53 \%$ & 66 & $59 \%$ \\
Overeenstemming geen $309^{+}$ & 59 & $100 \%$ & 112 & $100 \%$ \\
Totaal & 112 & & & 7 \\
\hline
\end{tabular}

\subsection{Conclusies en beschouwing}

Aangezien de beoordelaars zonder enige instructie onzerzijds en slechts voorzien van informatie over de patiënt en het diagnosecodeboek van de Federatie van Bedrijfsverenigingen hun diagnose moesten toekennen, kan gesteld worden dat de beoordeling omtrent de vraag of er al dan niet sprake is van overspanning, in geringe mate beïnvloed wordt door de persoon van de beoordelaar. Met enige 
instructie omtrent de aan te leggen criteria voor diagnosecode 306 valt te verwachten dat de overeenstemmingsmaten tussen verschillende beoordelaars in het algemeen ruim boven .75 zullen liggen.

Vele diagnosecategorieën uit het fijnmazigere maar ook van uitgebreidere instructies voorziene en in een context van veel grotere hoeveelheid informatie over de te beoordelen patiënt uitgevoerde DSM-III blijven onder deze grens. De "overall kappa" bedroeg daar voor een eerste onderzoek .68, waarbij de kappa voor de meest aan overspanning verwante diagnose adjustment disorders 67 bedroeg. Een tweede onderzoek met verfijnde criteria leverde waarden op van respectievelijk .72 en .68. Een ander onderzoek naar de interbeoordelaar-betrouwbaarheid in de psychiatrische diagnostiek leverde met uitzondering van mentale retardatie, psycho-organisch syndroom en alcoholisme lagere waarden op. (Spitzer en Fleiss, 1974) Hoewel het verschil uitmaakt of men tussen brede diagnostische groepen moet differentiëren of binnen één diagnosegroep, moeten wij bij gebrek aan betere gegevens met deze vergelijking volstaan.

De vraag of de diagnosecodes 309 en aanverwante een valide operationalisatie zijn van het theoretische begrip overspanning, kan uiteraard langs deze weg niet beantwoord worden. Wel stellen wij vast, dat de verzekeringsgeneeskundige diagnostiek een betrouwbaar instrument is, als het gaat om de interbeoordelaar-betrouwbaarheid. 


\section{Hoofdstuk 4}

\section{Determinanten van verzuimduur en WAO-intrede}

\subsection{Inleiding}

In dit hoofdstuk wordt ingegaan op de stand van zaken van het onderzoek naar factoren die de verzuimduur en de afloop van het verzuim - in het bijzonder de WAO-intrede - beïnvloeden. Omdat onderzoek met betrekking tot determinanten van de (verschillen in) verzuimduur van de afzonderlijke diagnosegroepen tot op heden nauwelijks verricht is, moet voor het zoeken naar determinanten van het beloop van ziekteverzuim wegens overspanning teruggevallen worden op algemener onderzoek. Achtereenvolgens bespreken wil de bevindingen van de onclerzoekslitteratuur met betrekking tot bedrijfsgebonden en individuele verschillen in (gemiddelde) verzuimduur, met betrekking tot de invloed van hulpverleningsprocessen op de verzuimduur en met betrekking tot bedrijfsgebonden en individuele verschillen in WAO-toetreding(spercentages). Dit alles mondt uit in een tweetal onderzoeksmodellen die als basis dienen voor de dataverzameling en de methode van analyse.

\subsection{Determinanten van verzuimduur}

Binnen de tot op heden verrichte onderzoeken ter verklaring van verschillen in (gemiddelde) verzuimduur zijn er een drietal benaderingen aan te wijzen.

De eerste benadering, in Nederland vooral gestimuleerd door de onderzoeken van Philipsen (1969), poogt door middel van correlationele analyses verschillen tussen bedrijuen te verklaren.

De tweede benadering zoekt eveneens door middel van correlationele analyses verklaringen te vinden voor verschillen in gemiddelde verzuimduur op individueel niveau.

De derde benadering, vooral bekend door de onderzoeken van Tordoir c.s. (1978) en Soeters (1983), poogt individuele verschillen in verzuimduur te verklaren vanuit een analyse van gezondheidszorgprocessen tijdens de verzuimperiode.

Hoewel ons onderzoek in de lijn ligt van de tweede en de derde benadering, is de relevantie van determinanten van bedrijfsgebonden verschillen in gemiddelde verzuimduur voor onderzoek naar individuele verschillen gelegen in de wijze 
waarop bedrijfskenmerken naar individuele kenmerken vertaald kunnen worden. Dit houdt in dat typische bedrijfskenmerken zoals bedrijfsomvang gehanteerd worden als contextuele variabelen. Bovendien komen, zij het op geaggregeerd niveau, ook de invloed van individuele kenmerken in deze benadering aan bod.

In onderstaande besprekingen van de onderzoeksbevindingen waarvan een groot deel is ontleend aan de inventarisatie van Smulders (1984), met betrekking tot de verklaring van verzuimduur en WAO-intrede hebben we de verklarende variabelen telkens in de volgende rubrieken ingedeeld: persoonskenmerken, organisatiekenmerken, kenmerken van de arbeidsplaats, verzuimbeleid en -begeleiding, verzuimverleden oftewel ziektegeschiedenis, gezondheidstoestand en ziektekenmerken, en gezondheidszorg en ziektegedrag. Daarbij zijn die kenmerken waarvoor in enig onderzoek een verband is aangetroffen met (gemiddelde) verzuimduur vetgedrukt.

\subsubsection{Bedrijfsgebonden verschillen in gemiddelde verzuimduur}

Sinds 1968, toen het proefschrift van Philipsen over bedrijfsgebonden verschillen in ziekteverzuim gepubliceerd werd, is er in Nederland een schat aan litteratuur verschenen omtrent determinanten van verschillen tussen bedrijven in verzuimomvang, meldingsfrequentie en gemiddelde verzuimduur.

Als belangrijkste determinanten van verschillen in gemiddelde verzuimduur tussen middelgrote bedrijven vond Philipsen (1969) bedrijfsomvang, gemiddelde leeftijd van het personeel en uitkeringsvoorwaarden, d.w.z. al dan niet doorbetaling van wachtdagen e.d. Voorts werd enige invloed aangetroffen van wijze van uitvoering van de Ziektewet, ontwikkeling van de personeelsfunctie, en hinderlijke fysieke werkomstandigheden. Daarbij geldt overigens dat de wijze van uitvoering van de Ziektewet eerder als gevolg dan als oorzaak van verzuimomvang beschouwd moet worden, aangezien de keuze voor verzekering in de vorm van een omslagstelsel in plaats van het dragen van een eigen risico nogal eens voortvloeit uit de relatieve verzuimomvang van een bedrijf ten opzichte van de andere bedrijven in dezelfde bedrijistak.

Met behulp van 19 bedrijtskenmerken plus de verzuimfrequentie kon Philipsen $62 \%$ van de verschillen in verzuimduur tussen bedrijven verklaren.

Een replicatie van de studie van Philipsen werd in 1980/1981 door Smulders (1984a) ondernomen. Alleen uitkeringsvoorwaarden en wijze van uitvoering van de Ziektewet blijken wederom dezelfde invloed uit te oefenen. Het verband met bedrijfsomvang blijkt nu zwakker en omgekeerd. Als nieuwe determinanten komen naar voren: urbanisatiegraad, percentage werknemers in ploegendienst, scholingsgraad, aantal hiërarchische niveaus en reputatie op de arbeidsmarkt.

De onderzoeken van Philipsen en Smulders vonden beide plaats onder een vergelijkbare populatie van mannelijke werknemers bij middelgrote bedrijven in de industriële sector. De genoemde verschillen in resultaten lijken dus vooral toe te schrijven aan het verschil in tijdstip van onderzoek.

Dat verschillen in populatie eveneens verschillen in resultaten te zien kunnen geven, blijkt uit het onderzoek van Nijhuis en Soeters (1982). Zij vergeleken verschillen in gemiddelde verzuimduur tussen bedrijven uit zowel de industriële als de dienstensector. Zij deden dit voor drie personeelscategorieën afzonderlijk, namelijk het mannelijk uitvoerend, het vrouwelijk uitvoerend en het mannelijk indirect personeel. 
Voor de eerste categorie - het meest vergelijkbaar met de populaties van Philipsen en Smulders - vonden zij een hoger gemiddelde verzuimduur in bedrijven die zich kenmerken door een grotere mate van verstoring van het productieproces bij ziekteverzuim, een geringere mate van taakverandering, meer activiteiten om werknemers met blijvende gezondheidsproblemen van aangepast werk te voorzien en een gemiddeld lager opleidingsniveau van het personeel.

Bij enkele van de hier gevonden verbanden doemt onmiddellijk het causaliteitsprobleem op. Het scheppen van aangepast werk kan oorzaak zijn van kortere verzuimduren maar evengoed het gevolg van een omvangrijkere gezondheids- en verzuimproblematiek.

Voor vrouwelijk uitvoerend personeel vonden Nijhuis en Soeters dat het percentage buitenlandse werknemers en het deel uitmaken van de industriële sector gepaard gaan aan een hogere gemiddelde verzuimduur van het bedrijf.

Voor mannelijk indirect personeel is het beeld weer anders. De gemiddelde verzuimduur blijkt nu langer bij bedrijven met ongunstige uitkeringsvoorwaarden, van een geringere omvang, met meer hinderlijke psycho-sociale arbeidsomstandighedenen en met een hoger percentage buitenlandse werknemers.

Bij deze weergave hebben wij ons beperkt tot die variabelen die een verband toonden bij partiële correlaties van de 19e orde (Philipsen, 1969; Smulders, 1984a) of bij multipele regressie-analyse. (Nijhuis en Soeters, 1982) Partiële correlaties van een lagere (inclusief nulde) orde geven een veel omvangrijker en wisselender patroon van samenhangen.

Hoe wisselend de resultaten van onderzoeken naar determinanten van verzuimduur kunnen zijn als gevolg van verschillen in populatie, operationalisatie, tijdstip van meting, en analysetechniek blijkt nog eens duidelijk uit de publicatie "Balans van 30 jaar ziekteverzuimonderzoek" waarin Smulders (1984) een overzicht biedt van de resultaten van 318 onderzoeken naar de determinanten van diverse verzuimmaten die deels op bedrijfs- en deels op individueel niveau zijn uitgevoerd.

\section{Kenmerken van het personeelsbestand}

Naarmate de gemiddelde leeftijd van het personeel hoger ligt, blijkt de gemiddelde verzuimduur per bedrijf hoger. (Philipsen, 1969; Ris, 1978) De invloed van leeftijd op verzuimduur moet overigens niet alleen toegeschreven worden aan een biologisch bepaald verouderingsproces dat bij ziekte herstel vertraagt of uitsluit, maar ook aan een -vaak slechts vermeend - verminderd aanpassingsvermogen aan technologische en sociale veranderingen op de werkplek als gevolg waarvan de positie binnen het bedrijf en op de arbeidsmarkt onder druk komt te staan.

Nijhuis en Soeters (1982) vonden een positief verband met het percentage buitenlandse werknemers. Aangezien het hier niet een verband betrof met de gemiddelde verzuimduur van buitenlandse werknemers alleen, kan niet uitgesloten worden dat hier sprake is van een indirect verband met een lage scholingsgraad van het werk. Over de invloed van de gemiddelde urbanisatiegraad zijn de bevindingen verdeeld. (Philipsen, 1969; Dijkstra, 1977; Smulders, 1984a)

\section{Organisatiekenmerken}

De kenmerken van organisatie en productieproces zijn voor het overgrote deel niet van invloed gebleken bij de onderzoeken van Philipsen (1969), Dijkstra (1977) en 
Ris (1978). Smulders (1984a) vond zoals we eerder zagen wel een positief verband met een slechte reputatie op de arbeidsmarkt en een gering aantal hiërarchische niveaus, terwijl Philipsen (1969) voor deze beide kenmerken geen relatie aantrof met de gemiddelde verzuimduur.

Ten aanzien van de relatie met bedrijfsomvang zijn de resultaten nog wisselender. Sommige onderzoekers troffen geen enkel verband aan. (Dijkstra, 1977; Ris, 1978) Andere wel, maar zij vonden in sommige gevallen een negatief verband (Philipsen, 1969; Nijhuis en Soeters, 1982) en in andere gevallen een positief verband. (Ten Broeke, 1979)

Dijkstra (1977) vond een positief verband aan met de mate van heterogeniteit van het productieproces.

Voorts bleken bedrijven die hun personeelsomvang inkrimpen, geen verlenging van de gemiddelde verzuimduur te zien te geven. (Dijkstra, 1974; Ris, 1978) Autonomie in bedrijfsvoering, arbeidsintensiteit en kwetsbaarheid op de markt bleken evenmin van invloed. (Philipsen, 1969)

\section{Kenmerken van de arbeidsplaats}

Ten aanzien van werkinhoud bleken verschillen tussen bedrijven in taakvariatie geen (Dijkstra, 1977) of een negatieve (Ris,1978; Nijhuis en Soeters, 1982) invloed uit te oefenen. Verschillen in scholingsgraad van het werk of - indirect gemeten gemiddeld opleidingniveau bleken niet (Philipsen, 1969) of van positieve invloed (Ris, 1978; Nijhuis en Soeters, 1982). De mate van formalisering van het werk bleek nu eens geen (Ris, 1978) dan weer een positief (Ekkers et al., 1980) effect te hebben. De productietechnologie is niet van invloed gebleken. (Philipsen, 1969)

Een werkprobleem als onderbezetting bleek niet van invloed (Ris, 1978), maar wel complexiteit van de taak, namelijk positief (Ekkers et al., 1980).

Bedrijven met meer hinderlijke fysieke werkomstandigheden bleken nu eens geen (Ekkers et al., 1980) dan weer wel (Philipsen, 1969; Ris, 1978) een hogere gemiddelde verzuimduur te hebben.

De bevindingen omtrent de samenhang met leiderschapsstijl waren eveneens wisselend. (Cassee, 1966; Philipsen, 1969; Dijkstra, 1977) Dijkstra (1977) vond, dat bedrijven met stabiele groepsrelaties een kortere gemiddelde verzuimduur hebben. Verschillen in invloed op en participatie in beslissingen bleken niet van invloed. (Ramondt, 1968; Philipsen, 1969; Ris, 1978)

Evenmin kon de invloed aangetoond worden van groepsgrootte en percentage werknemers met een lage senioriteit. (Philipsen, 1969; Dijkstra, 1977; Dijkstra, 1977a; Ris, 1978) Philipsen (1969) noch Ris (1978) vonden een verband met het percentage werkers in ploegendienst.

\section{Verzuimbeleid en verzuimbegeleiding}

In een vergelijking tussen een tweetal soortgelijke bedrijven is door De Groot (1954) een relatie met controlebeleid aangetroffen. Dit verband had betrekking op de controle-instantie, d.w.z.: het bedrijf dat de controle deels door de bedrijfsarts deels door het GAK liet uitvoeren, had een kortere gemiddelde verzuimduur dan het bedrijf waar alleen de bedrijfsarts het ziekteverzuim controleerde. Door Holthuis (1961), Philipsen (1969) en Ris (1978) is een gemiddeld langer verzuimduur aantroffen bij zogenaamde omslagleden van het GAK. Het onderhouden van contacten 
met de curatieve sector door de bedrijfsarts bleek naar de bevindingen van De Groot (1954) een duurbeperkend effect op het ziekteverzuim te hebben.

Wat betreft het aanhouden van wachtdagen voor uitkering van ziektegelden werd door alle onderzoekers een positief verband met de gemiddelde verzuimduur gevonden. (De Groot, 1958; Philipsen, 1966 en 1969)

Omtrent de relatie tussen aanwezigheid en uitgebreidheid van personeelsafdelingen of bedrijfsgezondheidszorgdiensten en de gemiddelde verzuimduur blijken de onderzoeksresultaten verdeeld. Philipsen (1969) vond een negatief verband, Dijkstra (1977) geen verband en Ris (1978) een positief verband wat betreft bedrijfsgezondheidszorg en negatief wat betreft de personeelsafdelingen.

Omtrent de samenhang van de mate van activiteiten en contacten in het kader van individuele verzuimbegeleiding bleken verbanden of positief of afwezig. (Dijkstra, 1977; Ris, 1978)

Het probleem bij deze categorie variabelen is het vaststellen van een causale relatie. Alleen door middel van longitudinaal onderzoek kan vastgesteld worden, of aspecten van verzuimbeleid voorafgaan dan wel volgen op een bepaalde verzuimomvang. Voor begeleidingsactiviteiten geldt dat hun aanwezigheid en omvang juist afhankelijk kan zijn van de duur van het verzuim.

Bij deze bedrijfsvergelijkende benadering zijn geen onderzoeken uitgevoerd, waarbij op een of andere wijze verzuimverleden, gezondheidstoestand of ziektekenmerken, ziektegedrag en kenmerken van de curatieve gezondheidszorg als verklarende variabele zijn opgenomen.

\subsubsection{Individuele verschillen in (gemiddelde) verzuimduur}

Het merendeel der verzuimonderzoeken binnen de correlationele benadering hanteert als maat voor individuele verschillen in verzuimduur de verschillen in gemiddelde verzuimduur tussen individuele werknemers of de gemiddelde verzuimduur per geval. (Smulders, 1984) Grosfeld (1988) hanteert vier maten naast elkaar, te weten: het aantal verzuimdagen, de gemiddelde verzuimduur, de frequentie van het verzuim dat langer duurt dan twee weken, en de frequentie van het verzuim dat langer duurt dan zes weken. De voorspellers van deze verschillende verzuimparameters blijken in zijn onderzoek dan ook nogal te verschillen.

Soeters (1983) en Kaiser (1992) hebben, voor zover ons bekend is, als enige onderzoek verricht waarin niet de gemiddelde duur van alle verzuimen over een bepaalde periode per werknemer maar het verschil in verzuimduur tussen afzonderlijke gevallen van ziekteverzuim als afhankelijke variabele is opgenomen. Daarbij heeft Soeters zijn onderzoekspopulatie beperkt tot verzuimgevallen die beëindigd zijn door werkhervatting.

\section{Persoonskenmerken}

Met betrekking tot sexe vond Soeters (1983) geen verband. Grosfeld (1988) vond daarentegen dat vrouwen in beperkte mate langer verzuimen dan mannen. Bij Smulders (1984) blijkt dat deze inconsistentie in onderzoeksresultaten zich voort- 
durend heeft voorgedaan in het ziekteverzuimonderzoek. In de meerderheid van de onderzoeken bleken vrouwen overigens gemiddeld korter te verzuimen.

In vrijwel alle studies blijkt een positief verband tussen leeftijd en gemiddelde verzuimduur: oudere werknemers doen gemiddeld langer over werkhervatting dan jongere. (Gordon et al., 1959; Ekker, 1966; Walker en De la Mare, 1971; Smulders 1984; Grosfeld 1988) Een uitzondering hierop zijn de bevindingen van Soeters (1983) en Kaiser (1992). Aangezien Soeters zijn analyse beperkt heeft tot werkhervatters, is het aannemelijk dat in de andere onderzoeken de samenhang tussen leeftijd en WAO-intrede, hetgeen gepaard gaat met een formele verzuimduur van 52 weken, de samenhang tussen leeftijd en verzuimduur heeft bepaald. Kaiser heeft zijn populatie niet alleen beperkt tot langdurige verzuimgevallen maar ook tot de leeftijdscategorie van 20 tot 40 jaar. Een andere uitzondering is het onderzoek van Eitner (1966) onder de gehele werkende bevolking van de DDR. Schröer et al. (1984) vonden wel een positief verband bij industriële werknemers, maar geen verband bij werknemers uit de dienstensector.

Het opleidingsniveau bleek bij Soeters niet van invloed. In het onderzoek van Grosfeld daarentegen bleek opleidingsniveau van alle persoonskenmerken het sterkst samen te hangen met verzuimduur en wel in negatieve richting. Andere onderzoeken geven op dit punt wisselende resultaten te zien. (Smulders, 1984). Bij Schröer c.s. (1984) werd alleen een - positief - verband aangetroffen bij industriële werknemers. Kaiser (1992) vond een positief verband met het opleidingsniveau bij verzuimgevallen die niet veroorzaakt zijn door klachten aan het bewegingsapparaat.

Gehuwden blijken in bijna alle onderzoeken gemiddeld langer te verzuimen dan ongehuwden. Dit verband met burgerlijke staat blijkt voor vrouwen niet altijd aanwezig. (Smulders, 1984) Grosfeld (1988) vindt een omgekeerd, zij het zwak, verband. Bij onderzoek naar de invloed van het aantal kinderen is de ene keer een U-vormig verband (Shepherd en Walker, 1958), de andere keer geen verband (Petermann, 1975; Schröer et al., 1984) gevonden. Wat nationaliteit betreft zijn de bevindingen wisselend. (Smulders, 1984; Grosfeld, 1988) Grosfeld (1988), Soeters (1983) en Schröer c.s. (1984) vonden geen van allen een duidelijke samenhang met urbanisatiegraad.

Grosfeld (1988) ten slotte vond een sterke samenhang met privébelasting. Met betrekking tot relationele belasting bleken zijn bevindingen wisselend.

\section{Organisatiekenmerken}

In de verzuimlitteratuur treffen wij nauwelijks onderzoeken aan waarin structurele of culturele organisatiekenmerken als contextuele variabelen opgenomen zijn ter verklaring van individuele verzuimverschillen. O'Muircheartaigh (1975) vond geen, Ten Broeke (1979) een positieve en Schröer c.s. (1984) vonden alleen bij industriële werknemers een negatieve relatie met omvang van het bedrijf. Grosfeld (1988) vond alleen zeer zwakke verbanden met een aantal organisatiekenmerken, hetgeen echter verklaard kan worden door het geringe aantal bedrijven dat deelnam aan het onderzoek, terwijl deze bovendien in geringe mate van omvang verschilden. Het enige sterke verband dat Grosfeld aantrof was dat met de mate waarin het gezag ge(de)centraliseerd is binnen de organisatie. 


\section{Kenmerken van de arbeidsplaats}

In de meeste onderzoeken wordt op individueel niveau een positieve samenhang met het aantal dienstjaren gevonden, ook indien correctie voor leeftijdsverschillen is aangebracht. (Smulders, 1984) Grosfeld (1988) en Schröer c.s. (1984) vonden geen samenhang.

Indirect, want op grond van het al dan niet via een ziekenfonds verzekerd zijn tegen ziektekosten, is door Soeters (1983) een negatief verband gevonden tussen inkomensniveau, hetgeen nauw samenhangt met werkniveau, en verzuimduur. De negatieve samenhang met werkniveau wordt bevestigd door de resultaten van Grosfeld (1988). Shepherd en Walker (1958) vonden een U-vormig verband. Daarentegen vonden Schröer c.s. (1984) geen enkel verband. Evenmin vonden zij een verband tussen regelcapaciteit en verzuimduur. Wat betreft de aard van het werk vond Grosfeld (1988) dat werknemers in productieafdelingen en vooral technisch personeel langer verzuimen dan andere werknemers. Daarnaast vond Grosfeld zwakke verbanden met variabelen die de Person-Environment Fit in het werk beschrijven.

Zowel Walker en Guest (1952) als O'Muircheartaigh (1975) en Grosfeld (1988) vonden een negatieve samenhang tussen gemiddelde verzuimduur en taakvariatie c.q. een positieve met routinisering. Deze bevindingen worden enigzins gerelativeerd door het experimenteel onderzoek van Van Beinum c.s. (1967) waarbij effecten van taakroulatie op verzuimduur uitbleven. Uit het onderzoek van Walker en Guest (1952) kwamen als determinanten van verzuimduur ook naar voren tempodwang, vaardigheid, taakonderbreking en groepsgrootte. Met betrekking tot het laatste vond O'Muircheartaigh geen verband.

Grosfeld (1988) vond slechts een zwak positief verband met tempodwang. Schröer c.s. (1984) vonden bij industriële werknemers een positief verband met werkdruk. Verschillende onderzoekers troffen langere gemiddelde verzuimduren aan bij tariefwerk. (Buzzard en Shaw, 1952; Schmidt, 1967; O'Muircheartaigh, 1975; Kruidenier, 1982)

Pugh c.s. (1959) en Kruidenier (1982) vonden een negatief respectievelijk geen verband met het hiërarchisch niveau waarop de werknemer functioneert.

Soeters (1983) vond een negatief verband met werkzekerheid - evenals Owens (1966) en Schröer c.s. (1984) bij mannelijke werknemers in de dienstensector - en arbeidssatisfactie. Geen verband wordt door Soeters (1983) aangetroffen met het aantal werkinconveniënten. Kaiser (1992) vond evenmin een verband met de zwaarte van het werk. Schröer c.s. (1984) vonden wel een positief verband tussen hinder van fysieke werkomstandigheden en verzuimduur maar alleen bij mannen. Met betrekking tot hinder van psycho-sociale werkomstandigheden vonden zij geen enkel verband. O'Muircheartaigh (1975) trof een positief verband aan met het eigen oordeel van de werknemer over de zwaarte van het werk. Met afzonderlijke werkinconveniënten zoals blootstelling aan weersomstandigheden, tilwerk en staand werk werden wel positieve verbanden gevonden door respectievelijk Gordon c.s. (1959), Semmence (1973) en Griffiths c.s. (1979). Ook Grosfeld vond een verband met fysieke werkbezwaren. Dat gold in veel mindere mate voor psychische werkinconveniënten. Shannon c.s. (1976) vonden geen relatie tussen verzuimduur en mate van blootstelling aan lood. 
De bevindingen omtrent de invloed van onregelmatige werktijden zijn wisselend. Kruidenier (1982) en Grosfeld (1988) vonden langere verzuimduren bij ploegendienstwerkers. Tan (1967) en Schröer c.s. (1984), bij industriële werknemers, daarentegen vonden een langere gemiddelde verzuimduur bij niet-ploegendienstwerkers, terwijl Taylor (1967), Chevrolie (1969), Taylor c.s. (1972), O'Muircheartaigh (1975) en Petermann (1975) geen verbanden aantroffen. Walker en De La Mare (1971) vonden bij drie groepen werknemers in twee verschillende bedrijven éenmaal een negatief verband en tweemaal geen verband. Vermoedelijk moeten de aangetroffen negatieve verbanden toegeschreven worden aan het bij ploegendienstonderzoek veel voorkomende verschijnsel "Healthy Worker Effect".

Walker en De La Mare (1971) vonden geen, maar Grosfeld (1988) een negatief verband met overwerk. De bevindingen van Barr (1967) over de relatie met werktijdfactor zijn wisselend. Kruidenier (1982) en Grosfeld vonden een langere verzuimduur bij part-timers. Schröer c.s. (1984) vonden geen enkel verband tussen het part-time werken en gemiddelde verzuimduur. Met reistijd tussen woning en werk is geen verband gevonden. (Bryson, 1968)

Met sociale steun op het werk trof Grosfeld (1988) nauwelijks enig verband aan. Schröer c.s. (1984) troffen bij industriële werknemers wel een verzuimbeperkend effect van deze variabele aan evenals van de mate waarin werknemers informatie ontvangen over de gang van zaken in het bedrijf.

\section{Gezondheidstoestand en ziektekenmerken}

Soeters (1983) vond een samenhang tussen verzuimduur per verzuimgeval en kenmerken als ziekteverleden, ervaren gezondheid en de aanwezigheid van meerdere diagnoses. Grosfeld (1988) vond met betrekking tot de mate waarin psychische en psychosomatische klachten geuit werden, matig respectievelijk zeer sterk positieve verbanden met de verzuimduur. Schröer c.s. (1984) vonden bij mannen als belangrijkste voorspeller van de gemiddelde verzuimduur de VOEG-score. Eveneens werd door Grosfeld (1988) een matig c.q. sterk positief verband aangetroffen met slecht slapen, de mate van roken, van alcoholconsumptie en van medicijnengebruik. Andere leefgewoonten blijken een matige invloed uit te oefenen. Lichamelijke beperkingen bleken een verschillende maar steeds zwakke tot matige samenhang te tonen met verzuimduur. Deze laatste bevinding is evenwel twijfelachtig op grond van de geringe "respons" op deze variabelen in het onderzoek van Grosfeld. Daar staat tegenover dat ook Schröer c.s. (1984) een positief verband aantroffen, maar uitsluitend bij industriële werknemers.

Opvallend genoeg zijn er wel bevindingen gepresenteerd voor de verschillen in verzuimduur tussen diagnosegroepen, maar de diagnose als zodanig wordt nauwelijks als onafhankelijke variabele naast andere onderzocht. Een uitzondering is het onderzoek van Soeters (1983). De door hem gekozen variabele diagnose ziekte der bewegingsorganen versus alle overige diagnoses blijkt de verzuimduur niet te voorspellen.

\section{Ziektegedrag en gezondheidszorg}

Soeters vond, dat de verzuimduur korter was, naarmate werknemers vaker op eigen initiatief de huisarts raadpleegden en men ontevredener was over het functioneren van de huisarts. Opmerkelijk is zijn bevinding dat werknemers die een huisarts 
hebben met een grotere praktijkomvang, een kortere verzuimduur hebben. Grosfeld (1988) vond een positieve samenhang met bezoek aan de huisarts. Kaiser (1992) vond een duurverlengende invloed van de inschakeling van specialisten.

\section{Verzuimbeleid en -begeleiding}

In alle onderzoeken blijkt de aanwezigheid en de hoogte van een uitkering in verband met loonderving positief met verzuimduur samen te hangen. (Buzzard en Shaw, 1952; Forssman, 1961; Ager en Raffle, 1973; O'Muircheartigh, 1975; Fenn, 1981)

Zowel Holthuis (1961) als Kaiser (1992) vonden een verband met de wijze van verzuimcontrole door verzekeringsgeneeskundigen. Met aspecten daarvan als tijdsverloop tussen ziekmelding en eerste controle en intensiteit van controle vond ook De Groot (1970) een - in beide gevallen positief - verband. Dat gold ook voor de uitoefening van controle als zodanig. (De Groot, 1970; Fenn, 1981) Schröer c.s. (1984) vonden bij deze categorie variabelen geen relatie met verzuimduur. Kaiser (1992) vond ook dat de verzuimduur beînvloed wordt door tal van kenmerken van de verzekeringsgeneeskundige zoals het al dan niet tegelijk uitoefenen van de functie van bedrijfsarts, de daarmee sterk verband houdende taakopvatting, het werkzaam zijn in teamverband, de drukte op het spreekuur en de professionaliteit. Het onderhouden van contacten van de kant van collega's met langdurig zieke werknemers blijkt de verzuimduur te beperken. (Soeters, 1983)

\subsubsection{Verklaringen van verschillen in verzuimduur op grond van procesanalyses}

Een geheel andere benadering van de verklaring van verzuimduur geeft de procesanalytische benadering. In deze benadering van de verzuimduur gaat de aandacht vooral uit naar het functioneren van de gezondheidszorg. Een kwart eeuw geleden wees Philipsen (1966) erop, hoe nieuwe, maar langdurige behandelingen ter genezing van ernstige aandoeningen, toename van therapeutische en diagnostische mogelijkheden en daaruit ontstane wachttijden, wachttijden voor ziekenhuisopname, en slechte coördinatie tussen curatieve en sociaal-medische sector elk de verzuimduur verlengen. De gezondheidszorg is er met al deze ontwikkelingen voor patiënt en arts niet eenvoudiger op geworden. Hoe complex de mogelijk door de verzuimende werknemers af te leggen routes door de gezondheidszorg kunnen zijn, toont het ondanks de overvloedige uitwerking nog onvolledige stroomdiagram van Buijs (1985). De vele potentiële actoren brengen vele variabelen met zich mee die elk uiteindelijk de resulterende ziekteverzuimduur vastleggen. Een uitgewerkt systeem van variabelen die het aantal verwijzingen, het aantal opnames en de ligduur bepalen, biedt het schema van Van Aert en Hoeksma (1980) waarin genoemd worden: urbanisatiegraad, regio, praktijkgrootte van de huisarts, ervaring van de huisarts, specialisten- en beddendichtheid, afstand tot het ziekenhuis en de percentages bejaarden en ziekenfondsverzekerden.

Bij de procesanalyse staan de begrippen verwijzingswachtdagen en stuurloze periode centraal. Tordoir c.s. (1978) en in hun voetspoor Soeters (1983) verstaan onder verwijzingswachtdagen die dagen tijdens een periode van ziekteverzuim gedurende welke er geen voortgang in behandeling plaats vindt als gevolg van tijdsverloop tussen verwijzing en behandeling. Onder stuurloze periodes verstaan 
zij de tijd die verstrijkt na de beëindiging of tijdens het onderbreken van een behandeling, zonder dat er enige koers door de behandelende arts is uitgezet.

Hier worden de verschillen in individuele verzuimduur per verzuimgeval als zodanig als afhankelijke variabele gekozen. Berekend wordt hoe elke verzuimperiode opgebouwd is uit behandelingsdagen, verwijzingswachtdagen tussen twee behandelingen, en stuurloze dagen tussen twee behandelingsactiveiten of tussen einde behandeling en werkhervatting. In eerste instantie wordt de verzuimduur verklaard uit het aandeel van deze dagen op de totale verzuimduur. Vervolgens kan ertoe overgegaan worden door middel van correlationele analyses de omvang van deze fasen afzonderlijk te verklaren.

Tordoir c.s. (1978) deden een onderzoek onder 862 werknemers, werkzaam in de Randstad, verzekerd bij het GAK, en die vier weken of langer achtereen wegens ziekte verzuimden. Soeters (1983) verrichtte in Zuid-Limburg een replicatieonderzoek waaraan 213 werknemers, werkzaam bij 51 bedrijven uit de industriële, de diensten- en de overheidssector, deelnamen. Het betrof hier dus niet uitsluitend GAK-verzekerden. Wel is zijn populatie beperkt tot bedrijven en instellingen met een minimale omvang van 50 personeelsleden.

In beide onderzoeken zijn acht soorten wachttijden onderscheiden:

1 tussen datum ziekmelding en eerste consult. Deze gaat uit van de werknemer en wordt ook wel met de term uitstelgedrag aangeduid.

De zes soorten verwijzingswachttijden:

2 tijdens verwijzingen van huisarts naar specialist,

3 tijdens verwijzingen van huisarts naar paramedicus,

4 tijdens verwijzingen van specialist naar specialist,

5 tussen een opdracht tot en uitvoering van een verrichting,

6 tussen een diagnostische verrichting en eerstvolgende contact met opdrachtverlener

7 voorafgaand aan een ziekenhuisopname

en ten slotte

8 de stuurloze perioden.

Zowel bij de GAK-verzekerden in de Randstad als bij die in Zuid-Limburg bedroeg het aandeel van de wachttijden op de totale verzuimduur $19,5 \%$. Gecorrigeerd voor leeftijdsverschillen ligt het percentage in Zuid-Limburg op 22,1\%. In beide regio's droegen vooral de wachtdagen ten gevolge van de verwijzing van de huisarts naar de specialist en de wachttijden in verband met diagnostische verrichtingen daaraan bij. Daarnaast bleek in de Randstad ook een aanzienlijke bijdrage afkomstig van wachttijd in het kader van uitvoering van opdrachten. In Zuid-Limburg is de rol van de stuurloze perioden opvallend. Bijna één derde van de totale wachttijd was daaraan toe te schrijven. Ook de wachttijd voor ziekenhuisopname bleek een aanzienlijk aandeel te hebben.

Voor de niet-GAK-verzekerden bleek het aandeel van de gezamenlijke wachttijden geringer. Voor verzekerden bij zelfstandige bedrijfsverenigingen bedroeg dat $9,6 \%$, voor ambtenaren $16,6 \%$. Daarbij was er bij ambtenaren een relatief geringer aandeel te zien van wachttijden als gevolg van stuurloze perioden en een groter aandeel van wachttijden als gevolg van wachtdagen bij ziekenhuisopname. 
Voor de diagnosegroep psychische aandoeningen lag het aandeel van alle soorten wachttijden tezamen op $15 \%$ in de Randstad en op $25 \%$ in Zuid-Limburg. Daarvan is in Zuid-Limburg $70,4 \%$ het gevolg van stuurloze perioden.

De belangrijkste onafhankelijke variabelen ter verklaring van verschillen in verzuimduur zijn in deze benadering allereerst de aard van de aandoening zelf die ten slotte in belangrijke mate bepaalt of en naar wie er verwezen wordt, en de kenmerken van de gezondheidszorg en het ziektegedrag van de patiënt, in het bijzonder het uitstelgedrag ten aanzien van werkhervatting.

Tot de kenmerken van de gezondheidszorg waarmee samenhangen met verwijsgedrag gevonden zijn, behoren het aanbod van en de afstand tot intramurale voorzieningen, specialistendichtheid, omvang van de huisartspraktijk (Boots 1983) en de breedte van de taakopvatting van de huisarts. Tot de patiëntkenmerken behoren diens verzoek om verwijzing en leeftijd. Een andere determinant van verwijsgedrag bleek urbanisatiegraad te zijn. Vermoedelijk betreft dit een indirect verband via aanbod van intramurale voorzieningen, specialisten- en huisartsendichtheid.

Soeters (1983) kon met behulp van dit soort variabelen en variabelen die op het werk betrekking hebben, in zijn onderzoek slechts $14 \%$ van het verschil in het aantal verwijzingen per verzuimgeval verklaren. Specialistendichtheid en onduidelijkheid van de eerste behandelingsactiviteiten bleken als enige van de door Soeters onderzochte variabelen van invloed. Naast het verwijzingsgedrag zelf is voor het aantal verwijzingswachtdagen de afstemming tussen de daaruit voortvloeiende vraag naar gezondheidszorgvoorzieningen en het aanbod van deze bepalend gebleken.

Voor de verklaring van verschillen in het aantal stuurloze dagen zijn als belangrijke variabelen uit het onderzoek van Soeters naar voren gekomen: het ziekteverleden, de diagnose, de wijze van ziektekostenverzekering, het raadplegen van de huisartsen en arbeidssatisfactie. Werknemers die geen ziekteverleden hebben, wegens een andere aandoening dan aan het bewegingsapparaat verzuimen, bij het ziekenfonds zijn aangesloten, vaker de huisarts inschakelen en/ot een geringe arbeidssatisfactie tonen, hebben meer stuurloze dagen tijdens hun verzuimperiode.

\subsection{Determinanten van WAO-intrede}

Evenals bij de verzuimduur komt de rol van de diagnose(groep) die ten grondslag ligt aan de ziekmelding, als verklarende variabele van arbeidsongeschiktheid nauwelijks aan de orde. WAO-intrede wordt als een ongedifferentieerd verschijnsel benaderd. Een uitzondering vormt Hellinga (1991). Hij trof evenwel bij een onderzoek in een groot industriëel bedriff geen noemenswaardige verschillen aan ten aanzien van diagnose. Bij WAO-intrede wegens psychische aandoeningen speelden dezelfde factoren een rol als bij die wegens andere diagnosen. Hellinga concludeert dan ook dat de determinanten van psychische arbeidsongeschiktheid dezelfde zijn als die voor arbeidsongeschiktheid in het algemeen. 


\subsubsection{Verschillen in arbeidsongeschiktheidskansen gemeten op bedrijfsniveau}

Op dit niveau zijn met betrekking tot WAO-intrede slechts een beperkt aantal onderzoeken verricht. De onderstaande bevindingen zijn voornamelijk afkomstig uit het onderzoek van Nijhuis en Soeters (1982).

\section{Persoonskenmerken}

Met de gemiddelde leeftijd en het percentage boven 55 -jarigen van het personeelsbestand vonden Nijhuis en Soeters bij mannen een negatief verband.

Hier speelt evenwel het probleem van de causale richting een belangrijke rol, omdat het aannemelijker is dat hogere WAO-instroom tot verjonging leidt dan dat de aanwezigheid van oudere werknemers de WAO-instroom beperkt. Zij vonden positieve verbanden met het percentage vrouwen, het percentage buitenlandse werknemers en de gemiddelde urbanisatiegraad bij éen of meer personeelscategorieën. Bij mannen bleek een gemiddeld hoger opleidingsniveau tot lagere instroompercentages te leiden.

Een aantal van de hier bevonden verbanden zoals met nationaliteit en opleidingsniveau verwijst naar een mogelijke relatie tussen werkomstandigheden en WAO-intrede.

\section{Organisatiekenmerken}

Nijhuis en Soeters vonden geen verbanden met sector en aantal hiërarchische niveaus. Wel bleek er een positieve samenhang met de bedrijfsgrootte bij mannelijke werknemers. Eveneens was dat het geval bij het toepassen van andere afvloeiingsregelingen, hetgeen een maatstaf is voor het plaatsvinden van reorganisaties. Met de mate van autonomie van het bedrijf werden negatieve samenhangen gevonden bij uitvoerend personeel. Voor mannen bleek er een positieve samenhang met de uitgebreidheid van de organisatie van de personeelsvertegenwoordiging - evenwel niet met de gepercipieerde invloed daarvan op de bedrijfsvoering en een negatieve met die van de afdeling personeelszaken. De uitgebreidheid van bedrijfsgezondheidszorg bleek niet van invloed.

De storingsgevoeligheid van de organisatie voor ziekteverzuim en arbeidsongeschiktheid bleek evenmin van invloed.

\section{Arbeidsplaatskenmerken}

Nijhuis en Soeters vonden bij mannelijk uitvoerend personeel een negatieve relatie tussen WAO-intrede en overwerk en bij alle mannen een positieve relatie tussen werken in ploegendienst en WAO-intrede. Met verandering van taken werd alleen bij vrouwelijk uitvoerend personeel een negatief verband gevonden.

Zowel Nijhuis en Soeters als Van 't Hullenaar en Van Koningsveld (1986) vonden een relatie tussen werkomstandigheden - met name de fysiek belastende - en het percentage blijvend arbeidsongeschikten. Met het aantal dienstjaren, de productiewijze, het belonings- en beoordelingbeleid, opleidings- en omscholingsfaciliteiten, werkstructurering en de mate van werkzekerheid vonden Nijhuis en Soeters geen samenhangen. Een goed functionerend werkoverleg alsook het werken in teamverband blijkt bij mannen de WAO-intrede te beperken. 


\section{Verzuimbeleid}

Bedrijven die (voor een deel van de periode) de Ziektewet voor eigen rekening nemen en/of zelf de controle uitvoeren, blijken minder WAO-intreders te kennen dan de zogenaamde omslagleden (Draaisma, 1983) Zij zijn meer geneigd werknemers tijdens de Ziektewetperiode te reïntegreren. Nijhuis en Soeters vonden alleen bij mannelijk uitvoerend personeel een positief en voor vrouwelijk uitvoerend een negatief verband met uitkeringsvoonwaarden.

Een actief arbeidsomstandighedenbeleid bleek bij Nijhuis en Soeters samen te hangen met een hogere WAO-intrede bij mannelijk personeel. Vermoedelijk is binnen deze relatie de WAO-intrede eerder oorzaak dan gevolg. Zij vonden geen verbanden met controlebeleid, de uitgebreidheid van overlegstructuren inzake ziekteverzuim, opsporingsbeleid met betrekking tot riskante arbeidsomstandigheden en met actief beleid om blijvend arbeidsongeschikten aangepast werk te bieden.

\subsubsection{Verschillen in arbeidsongeschiktheidskansen gemeten op individueel niveau}

In het algemeen worden de determinanten van WAO-intrede onderzocht door een vergelijking te maken tussen WAO-intreders en algemene werknemerspopulaties. De enige uitzondering daarop is het determinantenonderzoek waarin naast de algemene benadering ook binnen een groep werknemers die minimaal vijf maanden verzuimen wegens ziekte, een vergelijking gemaakt wordt tussen werkhervatters en WAO-intreders. (Aarts et al., 1982)

\section{Persoonskenmerken}

In vrijwel elk onderzoek op dit terrein is de bevinding gedaan dat leeftijd een onontkoombare factor is in de verklaring van de kans op arbeidsongeschiktheid. Dit wordt meestal toegeschreven aan de relatief slechtere gezondheidstoestand en belastbaarheid van oudere werknemers.

Afgezien daarvan moet, in het verlengde van wat wij eerder stelden over de betekenis van de variabele leeftijd, de reden vooral gezocht worden in de slechtere arbeidsmarktpositie van oudere werknemers. (Aarts et al., 1982; Aarts en De Jong, 1987) Dit laatste verklaart de bevinding dat vrijwillig ontslag, waardoor de gang naar arbeidsongeschiktheid voorkomen kan worden door verandering van baan, bij werknemers uit oudere leeftijdscategorieën nauwelijks voorkomt. (De Winter, 1991) Bovenop leeftijd is ook sexe van invloed gebleken. Voor vrouwen geldt met het klimmen der jaren een sterkere stijging van het arbeidsongeschiktheidsrisico dan voor mannen. (Van der Putten, 1982; Roeleveld et al., 1982; Vroege, 1983) Na correctie voor leeftijdsverschillen vonden Aarts c.s. (1982) geen samenhang met sexe.

Later is echter gebleken dat bij correctie voor het verschil tussen mannen en vrouwen in aantal ziekmeldingen vrouwen een lager WAO-toetredingsrisico hebben. De verklaring hiervoor zou niet gezocht moeten worden in verschil in leeftijd, functieniveau of omvang van het dienstverband maar veeleer in de invloed van vooroordelen jegens de noodzaak van het toekennen van arbeidsongeschiktheids- 
uitkeringen aan vrouwen die geen kostwinner zijn. (Bijlsma en Koopmans, 1986 en 1987)

Roeleveld c.s. (1982) en Knepper (1990) stellen een ongunstige invloed van een laag opleidingsniveau vast. Deze invloed wordt bewerkstelligd door de zwaardere fysieke belasting in het werk waaraan lager opgeleiden blootstaan. Hellinga (1991) vond dan ook een verhoogd risico voor werknemers uit lagere functiegroepen. Aarts c.s. (1982) vonden wel een verschil in opleidingsniveau tussen WAO-toetreders en WAO-verzekerden maar niet tussen WAO-intreders en werkhervatters, hetgeen suggereert dat de relatie tussen WAO-intrede en opleidingsniveau het gevolg is van een groter risico voor lager opgeleiden van het ontstaan van langdurig ziekteverzuim.

\section{Organisatiekenmerken}

Bedrijfsgrootte blijkt een niet-lineair verband te tonen met arbeidsongeschiktheidsrisico. Roeleveld c.s. (1982) vonden een hogere WAO-intrederisico onder werknemers werkzaam bij middelgrote, d.w.z.: met 150 tot 300 werknemers, bedrijven.

\section{Kenmerken van de arbeidsplaats}

Over de relatie tussen type arbeid en kans op blijvende arbeidsongeschiktheid lopen de bevindingen van Van Dijk (1985 en 1987), Hellinga (1991) en De Winter (1991) uiteen. Bij grote industriële bedrijven vonden Van Dijk en Hellinga hogere intredecijfers onder productiepersoneel in vergeleking met onderhouds- (alleen bij Van Dijk) en kantoorpersoneel. De Winter vond juist lagere ciffers onder productiepersoneel in een viertal bedrijven ten opzichte van andere personeelscategorieën. Uit het determinantenonderzoek bleek een hoger toetredingsrisico voor lager gesalariëerden. (Aarts et al., 1982; Aarts en De Jong, 1987)

Volgens Roeleveld c.s. (1982) die een retrospectief case-controlonderzoek uitvoerden in de grafische bedrijfstak, speelde de wijze van leidinggeven en de organisatie van het werk geen rol maar wel de inhoud van het werk, een werktijd van langer dan 45 uur per week en een aantal fysiek en psychisch belastende arbeidsomstandigheden. De fysieke betroffen het veel moeten bukken, tillen en sjouwen, het veel in één houding werken, een stoffige omgeving en het werken met tolueen. De psychische betroffen veel concentratie vereisend werk, tijdsdruk, gebrek aan afwisseling, geringe mate van plezier in het werk, en werk dat beneden het niveau van kennen en kunnen ligt. Niet van invloed bleken arbeidsomstandigheden als ploegendienst, temperatuurwisselingen, stank, lawaai en gebrek aan frisse lucht. Een verhoogd risico voor ploegendienstwerkers werd wel door Hellinga (1991) aangetroffen.

Het determinantenonderzoek van De Jong c.s. (1981) trof naast positieve samenhangen tussen arbeidsongeschiktheid en fysieke belasting ook een negatieve aan met promotiemogelijkheden.

De Winter (1991) daarentegen vond geen verband tussen arbeidsongeschikt worden en materiële werkomstandigheden, de kwaliteit van de directe werkorganisatie, de verhouding met leiding en collega's of waardering voor de werkkring.

Op het ontbreken van een verband tussen arbeidsomstandigheden en gezondheid zou volgens De Winter in zijn onderzoek een verstorend effect van invloed geweest kunnen zijn van de positieve relatie die hij aantrof tussen waardering van arbeidsomstandigheden en leeftijd. Aangenomen althans dat deze waardering een getrou- 
we afspiegeling vormt van belastende factoren in de arbeid. Aldus komt De Winter tot de slotsom dat de relatie tussen arbeidsomstandigheden en arbeidsongeschiktheid niet rechtstreeks is, maar loopt via arbeidsbelasting en verwerkingsvermogen naar het ontwikkelen van problemen met het werk en met de gezondheid en uiteindelijk naar arbeidsongeschiktheid.

Ook een gebrek aan binding aan het bedrijf is als factor van belang gebleken. (Aarts et al., 1982).

Voor de veronderstelling dat leidinggevenden een geringere kans hebben arbeidsongeschikt te raken, kon De Winter (1991) geen aanwijzingen vinden.

\section{Ziektegeschiedenis en verzuimverleden}

Het eerder aangehaalde determinantenonderzoek bracht eveneens een relatie met zowel het eerder optreden van klachten als met het verzuimverleden aan het licht (Aarts et al., 1982; Aarts en De Jong, 1987) Ook De Winter (1991) en Kompier et al (1986) vonden een positieve samenhang met het verzuimpercentage resp. langdurig verzuim van de laatste vijf jaren voor uitval. Knepper (1990) daarentegen stelt de afwezigheid van enige relatie met het verzuimverleden vast op basis van de bevinding dat meer dan de helft van de psychisch arbeidsongeschikten in het laatste jaar voor de ziekmelding minder dan twee weken in totaal verzuimden.

\section{Ziektekenmerken}

Op basis van een cohortonderzoek onder werknemers van de gemeente Arnsterdam in 1953-1954 kwam Van der Putten C.s. (1989) tot de conclusie dat demografische en functiekenmerken betere voorspellers zijn van toekomstige arbeidsongeschiktheid dan gezondheidsklachten en bevindingen van medisch onderzoek. Bij patiënten van een psychiatrische polikliniek vonden Staal c.s. (1989) geen verband tussen de mate van psychopathologie en sociale beperkingen zoals ten aanzien van de beroepsrol.

De Winter (1991) vond een negatief verband tussen subjectieve gezondheid en WAO-intrederisico. Eveneens bleek de mate waarin men gezondheidsproblemen met de werkbelasting ondervindt van invloed evenals de omvang van het ziektegedrag dat gezien de aard van de items beter als medische consumptie opgevat kan worden.

\subsection{Conclusies en beschouwing}

Opvallend zijn de vele inconsistenties in de bevindingen met betrekking tot de samenhangen tussen verklarende variabelen van allerlei aard enerzijds en de (gemiddelde) verzuimduur en de kans op WAO-intrede anderzijds. Voor een groot deel is dit gelegen in populatieverschillen en verschillen in tijdstip van waarneming. Ook verschillen in analysetechnieken zijn als verklaring aan te voeren. Daarvan getuigen de onderzoeken die meer dan éen statistische analysetechniek hanteren. Voor de vooruitgang van de kennis in de zin van verwijdering van variabelen uit het hypothetische model ter verklaring van verzuimduur en arbeidsongeschiktheid vormt dit een ernstige hinderpaal. De plaats van variabelen als leeftijd, sexe en bepaalde arbeidsomstandigheden in het model lijkt nog het meest verzekerd. Doch 
ook bij deze variabelen zijn er onderzoeken met afwijkende resultaten. Van vele andere variabelen kan nauwelijks gezegd worden dat hun veronderstelde invloed onweerlegbaar is gebleken. Opvallend is de beperkte aandacht in de correlationele benaderingen voor verschillen in wijze van functioneren van de gezondheidszorg. Deels is dit verklaarbaar vanuit het gegeven dat de meeste onderzoeken binnen één natie uitgevoerd worden. Dit heeft tot de voor de hand liggende slotsom geleid dat het overbodig is invariante structuurkenmerken van de gezondheidszorg op hun invloed te onderzoeken. Deze aanname wordt gevolgd door de onterechte implicatie dat er geen verschillen binnen de gezondheidszorg zijn in praktische uitvoering. Alleen in de procesanalytische benadering blijken deze met sprekende resultaten op hun invloed onderzocht.

Eveneens opmerkelijk is de onderbelichting in de correlationele studies van de rol van de aard van de aandoening. Het lijkt erop alsof verzuim en arbeidsongeschiktheid ongedifferentieerde verschijnselen zijn. Een ander type bezwaren dat tegen de gangbare onderzoekspraktijk is in te brengen, betreft de keuze of constructie van afhankelijke variabelen. Nogal bedenkelijk is de wijze waarop met de wettelijk bepaalde maximum termijn voor uitkering krachtens de Ziektewet omgegaan wordt, waardoor ongeacht de stand van zaken op de 366ste verzuimdag de verzuimduur begrensd is tot 365 dagen. Dit betekent dat opname van WAO-intreders in verzuim(duur)statistieken een vertekening van de gemiddelde ziekteduur geeft. In de meeste gevallen betreft dit een onderschatting, omdat de arbeidsongeschiktheidsperiode ruim één tot meerdere jaren duurt. In enkele gevallen een overschatting, omdat het anticiperen op WAO-intrede leidt tot afwachten van hetgeen de GMD aan reïntegratieactiviteiten zal ontplooien. Ook treden in de verzuimstatistieken verdelingseffecten op als gevolg van een kunstmatige tweetoppigheid. Naast dit nadeel wordt het verzuimonderzoek geconfronteerd met het nadeel dat determinanten van WAO-intrede de invloed van determinanten van verzuimduur bij reïntegratie kunnen vertekenen, voorzover zij verschillend zijn. De afwijkende bevinding van Soeters (1983) dat leeftijd geen invloed heeft op de verzuimduur bij werkhervatters vormt een illustratie hiervan. Tot op heden echter lijkt men ervan uit te gaan dat WAO-intrede een vorm van langdurig ziekteverzuim is en dat beide door dezelfde condities beïnvloed worden. (Vroege, 1982)

Omgekeerd worden samenhangen van sommige onafhankelijke variabelen met WAO-intredekansen gecontamineerd als gevolg van hun samenhangen met kans op langdurig verzuim. Een illustratie hiervan zijn de bevindingen van Bijlsma en Koopmans (1986 en 1987) dat een samenhang tussen sexe en WAO-intrede voor werknemerspopulaties ontbreekt maar wel aanwezig blijkt, als het populaties zieke werknemers betreft. Hetzelfde deed zich bij voor bij de relatie tussen opleidingsniveau en WAO-intrede in het determinantenonderzoek. (Aarts en De Jong, 1982)

De gemiddelde verzuimduurmaten per bedrijf, individu of geval blijken bovendien onderhevig te zijn aan de verstorende invloed van verzuimfrequenties, hetgeen niet altijd door middel van statistische technieken volledig is te controleren.

Eén van de mogelijke oplossingen om de bezwaren te ondervangen is het indelen van verzuimgevallen in verzuimduurklassen. Dit lost een deel van het probleem van de scheve verdeling op. Maar deze benadering is eerder gebaseerd op een verklaring van verschillen in verzuimfrequentie tussen duurklassen dan van verzuimduur als zodanig. Om tot zinvolle uitspraken over determinanten van verzuim- 
duur te komen is het selecteren van één verzuimduurklasse, bij voorbeeld de gevallen die een minimumduur bij voorbeeld vier weken of drie maanden te boven gaan en onder de maximum termijn van 52 weken blijven, te verkiezen.

\subsection{De onderzoeksmodellen}

Voor de beantwoording van probleemstellingen die gericht zijn op verklaringen van verzuimduur en arbeidsongeschiktheidsrisico, is onderzoek op basis van individuen als eenheid van waarneming onontbeerlijk.

In ons onderzoek hanteren wij drie modellen. Allereerst de procesanalytische methode die bijzonder geschikt is voor het beschrijven van de effecten van ziektegedrag, gezondheidszorg en sociaal-medische begeleiding.

Vervolgens wordt een correlationele analyse op individueel niveau uitgevoerd ter verklaring van de wijze van verzuimbeëindiging. In ons onderzoek onderscheiden wij werkhervatting in de werkkring waar de ziekmelding plaatsvond, deze wijze betitelen wij in het vervolg als terugkeer, en drie verloopsvormen te weten: ontslagname met werkhervatting elders, ontslagname gevolgd door werkloosheid en overschrijding van de maximumtermijn van 52 weken van de Ziektewet, in het vervolg gemakshalve aangeduid als WAO-intrede. Een tweede correlationele analyse is gericht op de verklaring van verschillen in verzuimduur bij de groep werknemers waarbij terugkeer naar de werkkring heeft plaatsgevonden. Dus met uitsluiting van alle gevallen waarbij de verzuimperiode met een of andere vorm van verloop is beëindigd.

Voor nadere toelichting omtrent de selectie en constructie van de variabelen en de keuze van analysetechnieken verwijzen wij naar hoofdstuk 11.

\subsubsection{Beschrijving van het procesanalytisch model}

In dit model wordt de duur van het ziekteverzuim ontleed in bestanddelen van perioden die afgebakend worden door ziektegedrag en hulpverlening.

In onze versie van het model zijn de soorten wachttijden niet onderscheiden, omdat afgewacht moet worden in hoeverre bij overspannen werknemers bij wie een ander verwijzingspatroon verwacht mag worden, differentiatie van wachttijden voorkomt. Het aantal verwijzingen kan verschillen alsmede de instantie waarheen. Dit zal bij overspannen werknemers eerder een instelling van Geestelijke Gezondheidszorg of van Maatschappelijk Werk zijn. Uiteraard is dit schema modelmatig en kunnen de drie middelste fasen elkaar afwisselen. Voorts is de structuur van dit model niet alleen van toepassing op de curatieve sector maar, met enige aanpassing, ook op de begeleiding vanuit de verzekeringsgeneeskundige sector, waar de afstemming tussen GAK en GMD wachttijden kunnen teweegbrengen. Eveneens kunnen verzekeringsgeneeskundigen stuurloze perioden creëren voor de werknemers, indien de curatieve sector uitbehandeld is en werkhervatting op de een of andere wijze nog niet plaatsgevonden heeft en de verzekeringsgeneeskundige geen beëindigingsbeleid ontplooit. Ook kunnen verzekeringsgeneeskundigen uitstelgedrag ten toon spreiden, namelijk enerzijds tussen verzuimmelding en eerste contact en anderzijds tussen laatste contact en het vaststellen van datum werkhervatting. 
Figuur 4.1 Opbouw verzuimduur uit actieve en niet-actieve perioden

- Tijdsverloop melding-hulpverlenerscontact
- Duur actieve hulpverlening
- Wachttijdlen
- Stuurloze perioden
+ Tljdsverioop einde hulpverlening-einde verzuim
$=$ Totale verzuimduur

\subsubsection{Beschrijving van de correlationele modellen}

Voor zowel de wijzen van verzuimbeëindiging als verzuimduur is het door ons geconstrueerde model, met uitzondering van de afhankelijke variabele, gelijk. De meest bijzondere toevoeging aan de gangbare modellen is het onderscheid tussen enerzijds werkhervatting in de stricte betekenis van terugkeer naar de werkgever en anderzijds diverse vormen van verloop, waarvan WAO-intrede er een is. Reden daarvan is het grote aantal variabelen die in een of ander onderzoek van invloed bleken op verzuimduur en/of WAO-intrede. Bovendien is het nauwelijks mogelijk om aan te geven in hoeverre de determinanten van verzuimduur en WAO-intrede werkelijk verschillen, aangezien in geen enkel onderzoek de gevonden verbanden tussen die determinanten en verzuimduur gecorrigeerd zijn voor effecten van WAO-intrede. Evenmin is van elk der variabelen definitief te bepalen of de invloed reëel is, op een schijnverband berust, of artefact is. Daarom zijn de modelelementen vrij globaal aangeduid en gaan er noodzakelijkerwijze nuances verloren.

Bij de ordening van de categorieën van onafhankelijke variabelen is uitgegaan van een veronderstelde causale orde die aan de in de hoofdstukken 11 tot en met 14 beschreven padanalyses ten grondslag liggen.

Bij persoonskenmerken betreft het variabelen als leeftijd, sexe, opleidingsniveau, life events, woonsituatie en sociale steun.

Bij bedrijfskenmerken zijn we geïnteresseerd in de invloed van sector, bedrijfsomvang. de aan-/afwezigheid van reorganisaties en personeelsvoorzieningen als bedrijfsgezondheidszorg.

Onder arbeidsplaatskenmerken verstaan we onder meer functie, lengte dienstverband, werktijden, zwaarte van het werk, hinder van fysieke en psycho-sociale werkomstandigheden, vrijheid in het werk en sociale verhoudingen.

Met ziektekenmerken wordt verwezen naar de aard, de ziekteverschijnselen, de oorzaak en de ernst van de overspanning.

Ziektegedrag verwijst naar de op de actuele ziekte-episode betrekking hebbende activiteiten die de werknemer onderneemt om de klachten en problemen te verhelpen.

Voorbeelden zijn uitstelgedrag ten aanzien van het raadplegen van een huisarts en voor de ziekmelding.

Bij de kenmerken van de curatieve sector spelen leeftijd, opleiding en ervaring van (huis)artsen, praktijkkenmerken, taakopvatting, diagnosestelling en beleid een rol. 
Figuur 4.2 Determinanten van verzuímduur en wijze van verzuimbeëindiging

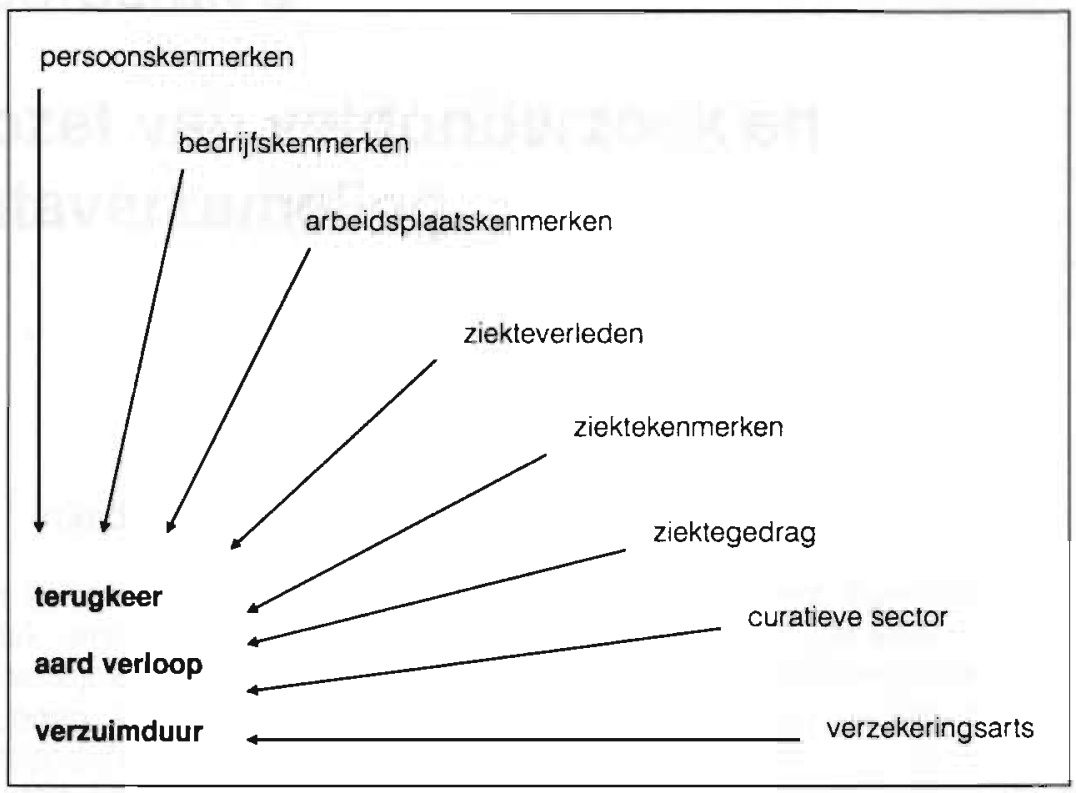

Voor de verzekeringsgeneeskundigen betreft het naast de meeste kenmerken genoemd bij de curatieve sector met name de bekendheid met de werknemer en het bedrijf.

Voor de verdere uitwerking van het model en voor de gespecificeerde verwachtingen omtrent de invloed van de daarin opgenomen onafhankelijke variabelen op de wijze van verzuimbeëindiging en de verzuimduur verwijzen we naar hoofdstuk 11 tot en met 14. 



\section{Hoofdstuk 5}

\section{Opzet van veldonderzoek en dataverzameling}

\section{$5.1 \quad$ Inleiding}

$\mathrm{Na}$ een korte beschrijving van de onderzoeksopzet in het algemeen wordt dit hoofdstuk vervolgd met een beschrijving en motivering van de selectiecriteria die toegepast zijn bij de samenstelling van de onderzoekspopulatie en bij de keuze van databronnen. Vervolgens wordt de concrete uitvoering van de selectie- en wervingsprocedure, de deelname aan het onderzoek en de invloed van de deelname op de resultaten beschreven. Tot besluit van dit hoofdstuk wordt beschreven welke data verzameld zijn.

\subsection{Opzet en methodologische verantwoording van het onderzoek}

Gekozen is voor een prospectief cohortonderzoek waarbij het cohort gevormd wordt door ongeveer 125 overspannen werknemers uit een in plaats en tijd nader te bepalen populatie. Van een dergelijk cohort kunnen periodiek via interviews de relevante kenmerken en gebeurtenissen vastgelegd worden over de periode voorafgaand aan het eerste interview en de gebeurtenissen tussen tussen twee opeenvolgende interviews. Het eerste interview dient daarbij zo spoedig mogelijk na de vaststelling van een ziekteverzuim wegens overspanning plaats te vinden. Door deze opzet wordt de betrouwbaarheid van de verschafte informatie zo min mogelijk door geheugenverlies aangetast. Bovendien geldt als voordeel van deze longitudinale opzet ten opzichte van een louter transversaal en retrospectief onderzoek dat informatie over een aantal kenmerken en gebeurtenissen niet vertekend worden door gevoelens en percepties die gekleurd zijn door de beleving van de afloop van de verzuimperiode.

Als belangrijkste nadeel van een dergelijke opzet geldt, ook in dit geval, dat het onderzoek een groot beslag legt op menskracht en middelen, waardoor de omvang van de onderzoeksgroep beperkt moet blijven. Dit heeft er toe geleid dat een vergelijkend onderzoek tussen werknemers die verzuimen wegens verschillende aandoeningen achterwege is gebleven. 
Om enig vergelijkend perspectief te bieden op de onderzoeksresultaten is zoveel mogelijk gebruik gemaakt van door het GAK geregistreerde gegevens. Het aantal variabelen dat voor ons onderzoek bruikbaar is gebleken, was echter te gering voor dit doel. De meeste gegevens hebben betrekking op uitkerings- en beheerstechnische aspecten van ziekteverzuim. De wel bruikbare gegevens worden in de volgende twee beschrijvende hoofdstukken waar mogelijk als vergelijkingsmaatstaven gepresenteerd.

Dit alles betekent dat over de onderzoeksresultaten onduidelijkheid bestaat in hoeverre zij specifiek gelden voor overspannen werknemers dan wel voor alle werknemers die gedurende langere tijd verzuimen. Daartoe dienen replicatieonderzoeken opheldering te verschaffen.

Dit onderzoek is daarom descriptief en, gezien de in het vorige hoofdstuk beschreven stand van zaken in het verzuimonderzoek, exploratief van aard.

\subsection{Onderzoekspopulatie en steekproef}

\subsubsection{Keuze van het wervings- en selectiemedium}

Aangezien de probleemstelling van dit onderzoek gericht is op werknemers in loondienst die zich wegens overspanningsklachten ziekgemeld hebben, is gekozen voor een selectie via bedrijfsverenigingen en hun verzekeringsgeneeskundigen.

Omdat volgens de voorschriften van de Ziektewet de verzekeringsgeneeskundige uiterlijk na zes weken een diagnosecode moet toekennen aan het verzuimgeval, passeren na verloop van tijd alle gevallen die langer duren dan zes weken, de verzekeringsgeneeskundige ter diagnosestelling.

Het gebruik is dat verzekeringsgeneeskundigen na vier weken verzuim de werknemer op het spreekuur uitnodigen."

Een nadeel kan zijn dat selectie langs deze weg weerstand tot onderzoeksdeelname kan oproepen bij potentiële respondenten, omdat men sancties vreest, hetzij bij het verstrekken van gevoelige informatie, hetzij bij weigering van deelname. In eerdere onderzoeken echter is van deze weerstand weinig gebleken. (Luyckx, 1982; Kaiser, 1992)

Van selectieprocedures via huisartsen, bedrijfsartsen of werkgevers is wegens grotere nadelen afgezien.

Selectie via de huisarts heeft weliswaar als voordeel dat de spreiding van werknemers over de bedrijven en instellingen alsmede over de verschillende wijzen van verzuimcontrole en -begeleiding zo ruim mogelijk is, maar deze werkwijze stuit op een vijftal bezwaren.

Ten eerste bezoeken niet alle verzuimende werknemers hun huisarts en een bezoek houdt bovendien niet in dat de aandoening die aan het ziekteverzuim ten grondslag

- Inmiddels is intern vastgelegd dat de verzekeringsgeneeskundige binnen twee weken overleg voert met de lekenrapporteur en, op instigatie van de sociale partners, dat de verzekeringsgeneeskundige zelf de werknemer binnen de vier weken ziet. 
ligt, ter sprake komt. Hoewel het misschien een minderheid betreft, kan deze groep juist van belang zijn voor de resultaten van het onderzoek met betrekking tot de effecten van het inschakelen en het handelen van huisartsen.

Ten tweede is een huisarts minder strict dan de verzekeringsgeneeskundige genoodzaakt tot het stellen van diagnoses, aangezien de huisarts meer gericht is op het vaststellen van de hulpvraag als zodanig en het zoeken naar adequate hulpverlening.

Ten derde heeft de huisarts vaak geen zicht op de arbeids- en verzuimsituatie van de patiënt. In vele gevallen vormen deze dan ook geen onderdeel van het gesprek. (Buijs, 1985)

Ten vierde zou om een redelijke mate van spreiding van variabelen met betrekking tot kenmerken en handelingen van de huisarts te bereiken, de deelname van een groot aantal huisartsen vereist zijn.

Ten vijfde ten slotte is de incidentie van overspannen werknemers per huisartspraktijk te laag om in korte tijd bij een beperkt aantal huisartsen voldoende respondenten te werven, gesteld dat huisartsen bij een dergelijke lage incidentie nog voldoende alertheid kunnen opbrengen om potentiële respondenten te signaleren.

Selectie en werving via de bedrijfsarts zou inhouden dat een groot deel van de verzuimgevallen buiten het onderzoek zou vallen, omdat er, met name bij de kleinere bedrijven, geen bedrijfsarts werkzaam is. De variatie in bedrijfskenmerken zou daardoor aanzienlijk beperkt worden. Bovendien zijn niet alle bedrijfsartsen van meet af aan met de verzuimbegeleiding belast of op de hoogte van de reden van het ziekteverzuim.

De weg via de werkgever geeft in de eerste plaats onoverkomelijke bezwaren vanwege privacyproblemen. De aard van de aandoening die het verzuim teweeg brengt, behoeft trouwens geenszins bekend te zijn bij de werkgever. In de tweede plaats geldt ook hier dat de spreiding van de onderzoekspopulatie over bedrijven beperkt zou worden.

Uit logistieke overwegingen is gekozen voor selectie en werving via verzekeringsgeneeskundigen werkzaam bij éen der districtskantoren van het GAK. Het GAK verzorgt voor 17 bedrijfsverenigingen uit zowel de industriële als de dienstensector de uitvoering van de Ziektewet". Van alle werknemers is $60 \%$ door een bij het GAK aangesloten bedrijfsvereniging in verzekering genomen. Bovendien wordt bij $46 \%$ het verzuim direct gecontroleerd en begeleid door de verzekeringsgeneeskundigen van het GAK. Het GAK bevat derhalve een grote variatie aan bedrijven en beroepen in haar verzorgingspopulatie. Een nadeel is dat selectie van en via verzekeringsgeneeskundigen van een beperkt aantal bedrijfsverenigingen inhoudt dat de populatie naar woonplaats, bedrijfstak en bedrijfsgrootte - de zeer grote bedrijven en de overheidssector vallen als eigen risicodrager af - beperkt is.

Analyse van het effect van andere verzuimbegeleidingsprocedures met name die bij overheidspersoneel en risicogroepen voor overspanning zoals onderwijzers, politieagenten en verpleegkundigen valt zodoende buiten dit onderzoek. Replica-

* Inmiddels bedraagt dit aantal 13. Het totaal aantal bedrijfsverenigingen is geslonken van 26 naar 19. 
ties zullen daarom opheldering moeten verschaffen omtrent de generaliseerbaarheid van de resultaten van dit onderzoek voor niet bij het GAK verzekerde werknemerspopulaties.

Dat geldt ook voor de beperking tot éen regio. Uit vergelijking van de meldingspercentages en de gemiddelde verzuimduur voor de diagnosegroep psychische aandoeningen is echter gebleken dat de populatie uit deze regio in dit opzicht nauwelijks afwijkt van de landelijke GAK-populatie.

Hoewel er sprake is van een verregaande formalisering van de werkwijze van verzekeringsgeneeskundigen, wordt de bepaling van de arbeidsgeschiktheid en de keuze van begeleidingsactiviteiten vrijwel geheel aan hun individuele oordeel overgelaten (Van Eck, 1990). Het geringe aantal verzekeringsgeneeskundigen kan er dus toe leiden dat de waar te nemen spreiding in handelwijzen beperkt is.

\subsubsection{De keuze van selectiecriteria}

Met de keuze voor de bedrijfsverenigingen en de aldaar werkzame verzekeringsgeneeskundigen is ook het diagnostisch instrument vastgelegd. De verzekeringsgeneeskundigen beoordelen de mate van arbeidsgeschiktheid op basis van informatie van de rapporteur, het dossier, de bij de curatieve sector ingewonnen informatie en de bevindingen uit het spreekuur(onderzoek). Bij gebleken arbeidsongeschiktheid wordt er een diagnosecode toegekend. Deze diagnosecode is ontleend aan de in hoofdstuk 3 vermelde classificatie die door de gezamenlijke bedrijfsverenigingen op basis van de ICD-9 opgesteld is.

Op grond van het theoretisch begrip overspanning en de daarbij behorende verzameling klinische beelden die in hoofdstuk 2 beschreven zijn, zouden verzuimgevallen uit het merendeel van de diagnosegroepen in aanmerking komen voor opname in het onderzoek. Zelfs al zou er een tijdrovende "screening" plaatsvinden door verzekeringsgeneeskundigen, dan nog zou de kans op toestroom van vals positieve gevallen dermate groot kunnen zijn, dat de onderzoekskosten te hoog oplopen om een voldoende aantal overspannen werknemers te selecteren. In veel gevallen, met name binnen het domein van diagnosecodes waaronder voor een onbekend deel fysieke decompensaties of psychosomatosen schuil gaan, zou pas na afname van één of meer interviews duidelijk worden of er sprake is van overspanning. Daarom is gekozen voor die diagnosecodes die éénduidig een vorm van overspanning representeren.

Daarmee wordt het onderzoek vooral beperkt tot die verzuimgevallen, waarbij de verzekeringsgeneeskundige overspanning "in engere zin" herkent.

Een tweede consequentie van de keuze voor werving en selectie via verzekeringsgeneeskundigen is dat de verzuimgevallen in de regel vier weken of langer bedragen. Dit op grond van de procedure van diagnosestelling die de verzekeringsgeneeskundige normaliter volgt.

Overigens vormt de selectie van verzuimgevallen van vier weken of langer geen bezwaar, omdat naar ons inzicht dit ook wel een minimale termijn is om te kunnen spreken van overspanning. Korter durende verzuimen als reacties op stress onderscheiden zich niet erg van baaldagen en dergelijke waarin een periode van korte rust blijkbaar voldoende is om het niet al te ernstig verstoorde evenwicht tussen psychische belasting en psychisch belastbaarheid te herstellen. Een voordeel van 
de grens van vier weken is dat in vergelikbare ondezoeken (Tordoir et al., 1978; Soeters, 1983 dezelfde grens gehanteerd is.

Behave criteria ais aansluiting bij een bedrifsvereniging, diagnose en minimale. verzuimduur is het, gelet op de probleemstelling, ook noodzakelijk het onderzoek te beperken tot werknemers die in Nederland woonachtig zijn. Dit laatste is gedaan ter constanthouding van structurele kenmerken van de gezondheidszorg.

\subsubsection{De keuze van de databromen}

Op grond van de probleemstellingen, die onder meer op de maniestatie van de overspanning en ds hulpveriening gericht zin, is gekozen voor mondelinge interviews met de werknemer, de huisarts en de verzekeringsgeneeskundige.

Bij de werknemer betret het een serie interviews. Ahereerst een uitgebreid begininterview voor de vastlegging van de beginemmeken van de werkemer, het bedrift en de arbeidsplaats. Daama vervolginterviews om de vier a zes weken, voomamelik ten behoeve van de registratie van gezondheidszorgcontacten. Deze zijn voortgezet tot het moment van verzumbesindiging. Voor het moment van verzumbeeindiging is een speciaal vervolginterview ontworpen orn de wijze van verzuimbeeindiging en de laatste gezondheidszorgcontacten vast te leggen. Overweging daarbij is het bereiken van een zo gering mogelijk verlies van informatie over het ontstaan en de verschijnselen van overspanning en over de handelingen van de diverse actoren. Dit protocol komt ongeveer overeen met dat van Soeters (1983).

Bovendien is gekozen voor het afnemen van een laatste interview én jaar na datum ziekmelding om na te gaan of er verzuimbeëindiging heeft plaatsgevonden en, als dat het geval bleek, of deze geleid heeft tot (een stabiele) werkhervatting, en in hoeverre herstel van de aandoening als zodanig bereikt is.

Voorts is gekozen voor het interviewen van huisartsen - althans, indien zij betrokken blijken bij de gevalsbehandeling - en verzekeringsgeneeskundigen. Het laatste hield tevens een verzameling van gegevens uit het dossier in. Dit met het oog op een zo betrouwbaar mogelijke vastlegging van verzuimdata, kenmerken van huisartsen en verzekeringsgeneeskundigen, presentatie van de overspanning, en hulpverlening.

Bij de huisarts betreft het een eenmalig interview direct na het begininterview van de werknemer. Het risico van vermindering van informatieretentie heeft in deze zwaarder gewogen dan van het niet voltooid zijn van de behandeling. Latere behandelingsactiviteiten konden immers ook in vervolginterviews met werknemers vastgelegd worden.

Bij de verzekeringsgeneeskundige is niet alleen een interview direct na het eerste interview van de werknemer afgenomen, maar ook een tweede ongeveer een jaar na datum ziekmelding. Op deze wijze zou een zo volledig mogelijk beeld van de activiteiten van de verzekeringsgeneeskundige en van de eindtoestand van de werknemer vastgelegd kunnen worden.

Om budgettaire redenen is bij voorbaat afgezien van interviews met andere actoren. Ten aanzien van specialisten en bedrijfsartsen werd bovendien verwacht dat een deel van de populatie geen contacten zou hebben met deze hulpverleners. De overweging de privacy van de werknemer te beschermen heeft de doorslag gegeven voor de beslissing af te zien van interviews met de werkgever of andere 
personen op het bedriji. Belangrijkste consequentie hiervan is geweest dat een aantal bedrijfskenmerken zoals autonomie van het bedrijf en bepaalde kenmerken van verzuimbeleid die volgens de onderzoekslitteratuur van invloed zijn op verzuimduur en WAO-intrede, niet als variabelen in dit onderzoek konden worden opgenomen.

\subsubsection{De uitvoering van de selectie en werving van de respondenten}

In de periode 31 oktober 1988 t/m 30 juni 1989 zijn door de verzekeringsgeneeskundigen, of in een enkel geval door hun assistenten, van één der districten van het GAK werknemers geselecteerd op grond van de volgende criteria:

- de werknemer maakt een ziekteverzuimperiode door die de duur van vier weken overschreden had of naar verwachting zou gaan overschrijden.

- de verzekeringsgeneeskundige heeft voor de eerste maal gedurende deze verzuimperiode op basis van de Nummerlijst en Alfabetische Lijst van ziekte- en ongevallendiagnoses gebaseerd op de ICD-9, van de Federatie van Bedrijfsverenigingen, één der volgende diagnoses gesteld:

300: neurosen

301: persoonlijkheidsstoornissen

306: fysiologische functiestoornissen door psychische oorzaken

309: situatieve of exogene reactie

311: depressie niet elders vermeld.

- de werknemer is woonachtig binnen Nederland

Op deze wijze zijn door de verzekeringsgeneeskundigen en de administratie ongeveer 250 potentiële respondenten vastgelegd. Daarna vond controle plaats door de onderzoeker op de juiste toepassing van bovenvermelde criteria. In geval van aanlevering van een verzuimgeval voor het verstrijken van vier weken verzuim na datum ziekmelding is bovendien gecontroleerd op overschrijding van de vierweken-grens.

Uit dit steekproefkader zijn 208 verzekerden aangeschreven. Dit hield enerzijds verband met de maximale verwerkingscapaciteit van gemiddeld vijf respondenten per week bij de onderzoekers en anderzijds met een op budgettaire gronden vastgesteld streefgetal van 125 respondenten. Vanuit de inschatting dat $50 \%$ van de aangeschreven werknemers positief zou reageren, is, indien gedurende een week meer dan 10 werknemers aangeleverd werden, door de onderzoeker een a-selecte steekproef van 10 aan te schrijven werknemers getrokken.

Gezien het verschil in alertheid waarmee de verzekeringsgeneeskundigen de potentiële respondenten selecteerden, is besloten de steekproef te proportioneren. Dit ter vermijding van het gevaar dat er een te scheve verdeling over de rayons zou ontstaan in de onderzoeksgroep. Dit hield in dat voor vijf van de zeven rayons een limiet van 20 respondenten gesteld is. Daarbij is voor het rayon dat door twee half-time werkende verzekeringsgeneeskundigen verzorgd wordt, voor beide afzonderlijk 10 als limiet gesteld. Voor een zesde rayon is de limiet op 15 gesteld op grond van een bovengemiddeld aandeel van woonachtigen buiten Nederland in dit rayon. 
Voor het zevende rayon dat geringer van omvang is, omdat het aan eén bedrijf is gebonden, is als limiet 10 gesteld.

Deze verdeling is gebaseerd op de bevinding dat tijdens het jaar dat voorafging aan het veldonderzoek in alle rayons een gelijk aantal ziekmeldingen op grond van de in dit onderzoek betrokken diagnoses en met een duur van 30 dagen of langer geregistreerd waren. Enige uitzondering was het bedrijfsgebonden rayon, waar dit aantal de helft van de andere rayons bedroeg.

\subsubsection{De aanschrijving van de potentiële respondenten}

Bij de wervingsprocedure zijn een aantal maatregelen getroffen om de vertrouwelijkheid van de deelname en informatieverschaffing door de respondent te waarborgen.

De 208 potentiële respondenten ontvingen vanwege het hoofd van de Medische Dienst van het GAK-districtskantoor een brief waarin het doel van het onderzoek werd uitgelegd. Tevens is daarin toegezegd dat de informatie die de respondenten ten behoeve van het onderzoek van de Rijksuniversiteit Limburg verstrekken, vertrouwelijk behandeld zou worden. Dit betrof ook de informatie of men al dan niet tot deelname bereid was. Bovendien is uitdrukkelijk toegezegd dat noch deelname noch verstrekte informatie hoe dan ook gevolgen zou kunnen hebben voor de uitkering.

Door middel van een bijgevoegde antwoordkaart en -enveloppe konden de aangeschreven werknemers rechtstreeks aan de onderzoekers kenbaar maken of zij al dan niet bereid waren tot deelname aan het onderzoek.

Hoewel een dergelijke aanschrijvingswijze het risico van een lagere (positieve) respons inhoudt, is hiervoor gekozen met het oog een maximale bescherming van de privacy.

Een week na de aanschrijving werd aan alle aangeschrevenen een rappel verzonden.

\subsection{De deelname aan het onderzoek}

\subsubsection{De respons van de werknemers}

De 208 aangeschreven werknemers reageerden als weergegeven in tabel 5.1

Tabel 5.1 Bereidheid tot deelname aan het onderzoek

\begin{tabular}{lrl}
\hline Positief: & 114 & $55 \%$ \\
Negatief: & 45 & $22 \%$ \\
Geen reactie: & 49 & $24 \%$ \\
\hline
\end{tabular}

Het bereikte responspercentage van 55 ligt lager dan dat van 70 à 86 bij andere onderzoeken onder langverzuimers. (Soeters, 1983) Bij die onderzoeken heeft er evenwel geen selectie naar diagnosegroep plaatsgevonden. Verwacht mag worden dat overspannen werknemers minder geneigd of in staat zijn interviews af te 
Iaten nemen. Ten opzichte van onderzoek onder een in dit opzicht beter vergelijkbare groep blijkt de respons van ons onderzoek ongeveer even hoog. Een enquête van Bureau Intomart in 1985 onder WAO-toetreders uit de diagnosegroep psychische aandoeningen gaf een respons van $51 \%$ te zien. (Besseling, 1987) Ook in het determinantenonderzoek bleken werknemers met psychische aandoeningen ondervertegenwoordigd. (Aarts et al., 1982)

Omtrent eventuele motieven of redenen voor het achterwege laten van enige reactie is ons uiteraard niets bekend. Van de ruim $75 \%$ die wel reageerden, gaf ongeveer $30 \%$ te kennen niet tot deelname bereid te zijn. In eerste instantie was dit aantal groter, maar zeven respondenten die aanvankelijk niet tot deelname bereid waren, bleken na telefonische navraag toch bereid aan het onderzoek deel te nemen.

Deze telefonische navraag werd overigens in de eerste plaats gedaan om na te gaan, welke motieven ten grondslag lagen aan het niet tot deelname bereid zijn. Bij geen der bereikte werknemers vormden negatieve ervaringen met het GAK of met eerdere onderzoeken een reden. In sommige gevallen vond men op grond van positieve ervaringen met het GAK deelname aan het onderzoek overbodig. In een aantal andere gevallen vormde tijdgebrek - met name bij snelle werkhervatters - een belemmering tot deelname. In een enkel geval betrof het de ernst van de aandoening. Voor twee der werknemers die in eerste instantie positief reageerden, is dit laatste reden geweest om alsnog van deelname aan het onderzoek af te zien.

Van alle 114 deelnemers is het eerste interview afgenomen. Dit vond plaats op een tijdstip tussen 5 en 31 weken na de ziekmelding bij een gemiddelde van 9,6 weken. Bij $70 \%$ van de respondenten vond het eerste interview binnen twee maanden plaats, bij $90 \%$ binnen drie maanden.

In dertien gevallen was het tijdsverloop tussen ziekmelding en interview langer dan drie maanden. Deels is dit het gevolg van de omstandigheid, dat de verzekeringsgeneeskundige de werknemer pas na twee maanden of langer na de ziekmelding voor het eerst op het spreekuur ontmoette, namelijk in zes gevallen, deels van een diagnosewijziging in een lopend geval van ziekteverzuim en deels van vertraagde doorgifte.

Het tijdsverloop had nogal eens tot gevolg dat een aantal respondenten het werk reeds hervat had en/of niet langer onder behandeling waren in verband met hun aandoening. Voor hen werden in geval van werkhervatting het begin- en het verzuimbeëindigingsinterview tegelijkertijd afgenomen.

In een groot aantal gevallen bleek het ziekteproces al enige tijd voor het tijdstip van ziekmelding begonnen, hetgeen van invloed geweest kan zijn op de betrouwbaarheid van de antwoorden op vragen die daarop betrekking hebben.

Alle respondenten waren na afloop van het eerste interview bereid hun medewerking te verlenen aan de vervolginterviews en aan het slotinterview dat én jaar na datum ziekmelding plaatsvond. De vervolginterviews zijn, afhankelijk van de behandelings- of begeleidingsvoortgang en de bereikbaarheid van de respondent, om de vier à acht weken telefonisch afgenomen tot het einde van de ziektewetperiode. Van twee respondenten konden als gevolg van overlijden c.q. het overlijden van hun partner niet alle vervolginterviews en evenmin het slotinterview afgenomen worden. 
Bij het slotinterview bleken nog eens drie respondenten onbereikbaar, terwijl één respondent deelname daaraan alsnog weigerde. Van de overige 108 respondenten konden alle interviews afgenomen worden.

Aan alie 114 respondenten is gevraagd om toestemming voor het afnemen van interviews bij de betrokken huisarts en GAK-arts.

Deze toestemming diende door de respondent schriftelijk vastgelegd te worden in een verklaring waarin tevens uitdrukkelijk de toezegging van de onderzoekers vastgelegd werd dat deze geen informatie zouden uitwisselen.

Ten aanzien van de huisartsen was het resultaat als volgt.

In vijf gevallen was er geen huisarts betrokken. Dit was reden voor de onderzoeker om in deze gevallen van een toestemmingsverzoek af te zien. In vier gevallen wenste de respondent geen toestemming te geven. In twee gevallen werd daarbij wel toestemming gegeven voor het interviewen van de verzekeringsgeneeskundige.

In 105 gevallen werd dus toestemming voor het afnemen van een interview bij de huisarts verleend.

Ten aanzien van de verzekeringsgeneeskundigen gaven drie respondenten geen toestemming voor een interview over hun ziektegeval. Van deze respondenten gaf er éen wel toestemming tot het interviewen van de huisarts.

Door 111 respondenten werd dus toestemming verleend voor het afnemen van een interview bij de verzekeringsgeneeskundige.

Samengevat is het beeld van de mate van medewerking als volgt.

Tabel 5.2 Mate van deelname van de respondenten

\begin{tabular}{lrr}
\hline Aantal respondenten & 114 & $100 \%$ \\
Toestemming vervolginterviews & 114 & $100 \%$ \\
$\quad$ Uitgevallen tijdens vervolg & 2 & \\
Geen deelname eindinterview & 4 & \\
Volledig geinterviewd & 108 & $95 \%$ \\
Huisarts betrokken & 109 & $96 \%$ \\
Toestemming huisarts & 105 & $92 \%$ \\
Toestemming verzekeringsgeneeskundige & 111 & $97 \%$
\end{tabular}

\subsubsection{De respons van de verzekerings- en huisartsen}

Alle acht in het geselecteerde district werkzame verzekeringsgeneeskundigen waren tot medewerking bereid.

Zij waren van doel en werkwijze van de begin- en eindinterviews op de hoogte gesteld bij de instructie en voorlichting over de selectie en werving der respondenten.

Ook zijn ze regelmatig op de hoogte gehouden van de vorderingen van het onderzoek, hetgeen de motivatie tot deelname bevorderde.

De respons van de kant van de huisartsen was uitzonderlijk hoog. 
De ontwikkeling met betrekking tot de responsgeneigdheid van huisartsen op schriftelijke enquêtes blijkt te variëren van 42 tot $81 \%$, waarbij de trend is dat het percentage daalt. (Van der Wouden, 1988). De cijfers voor mondelinge interviews zijn ons niet bekend.

Hoewel het onderzoek van Van der Wouden suggereert dat informatie vooraf geen effect heeft, is dit door ons wel gedaan, omdat wij hechten aan een principieel correcte procedure. De huisartsen in de onderzoeksregio zijn daarom voor het begin van de interviewcampagne op de hoogte gesteld van aard, doel en werkwijze van het onderzoek door middel van een rondschrijven van de onderzoekers. Voorts is in het Bulletin van het Coördinatiepunt Eerste Lijn dat drie maanden na het begin van de interviewcampagne verscheen, een uitgebreidere beschrijving van het onderzoek opgenomen waarin tevens de tot dan toe ruime medewerking van de huisartsen aangestipt werd. Na het verlenen van de toestemming van de respondent werd de huisarts rechtstreeks telefonisch door de onderzoekers benaderd met de mededeling dat hun patiënt in het onderzoek betrokken was en toestemming had verleend voor het interviewen van de huisarts.

Aangezien het nogal eens voorkwam, dat in het onderzoek meer patiënten van éen huisarts deelnamen zijn uiteindelijk 82 huisartsen uit 70 praktijken benaderd met de vraag om medewerking. Bij éen der respondenten betrof het een huisarts die tijdelijk waargenomen had. Deze bleek onvindbaar en kon derhalve niet benaderd worden. Van de 81 bereikte huisartsen waren 80 tot deelname bereid, waarbij éen interview niet kon doorgaan als gevolg van ernstige ziekte van de huisarts. Slechts éen huisarts die twee respondenten onder zijn hoede had, weigerde na enige tijd geaarzeld te hebben zijn medewerking. Dit op grond van bezwaren tegen computermatige opslag van gegevens.

Aldus werden met betrekking tot 101 respondenten interviews afgenomen bij 79 huisartsen uit 68 praktijken. Een huisarts die de zorg had over twee respondenten, was daarbij niet bereid alle vragen te beantwoorden, onder meer die over de omvang van de praktijk, een vraag overigens waarmee meer huisartsen moeite hadden.

Samenvattend kan gesteld worden dat de deelname van de kant van de artsen vrijwel maximaal was. Het volgend overzicht vat de respons van huisartsen samen, getotaliseerd op het aantal respondenten.

Tabel 5.3 Respons huisartsen

\begin{tabular}{lrr}
\hline Toestemming interview huisarts & 105 & $100 \%$ \\
Onbereikbaar & 1 & \\
Bereikt & 104 & \\
$\quad$ Negatief & 2 & \\
Positief & 102 & \\
Uitgevallen voór afname interview & 1 & \\
Interviews afgenomen & 101 & $96 \%$ \\
\hline
\end{tabular}

De 79 deelnemende huisartsen, die de behandeling verzorgden van 101 respondenten, werden geïnterviewd op een tijdstip gelegen tussen 6 en 32 weken na 
datum ziekmelding en tussen 2 en 31 weken na de datum van het eerste consult in verband met de onderzochte ziekte-episode. In een groot aantal gevallen was de betrokkenheid van de huisarts reeds beëindigd. Bij 31 respondenten was tevens sprake van werkhervatting en nog eens 14 stonden op het punt het werk te hervatten.

\subsubsection{De gevolgen van de non-respons voor het onderzoek}

Uiteraard is het bij een responspercentage van 55\% van belang een non-responsanalyse uit te voeren ten einde na te gaan in hoeverre aard en mate van respons beïnvloed zijn door factoren als sexe, leeftijd, aard van de overspanning, of verzuimduur. Dit vooral met het oog op generalisatie van beschrijvende uitspraken naar de populatie van langdurige verzuimen wegens overspanning. Ten aanzien van verklarende uitspraken geldt dit belang overigens minder, mits de onderzoeksgroep met betrekking tot de belangrijkste variabelen voldoende variatie vertoont.

De gegevens met betrekking tot de gehele groep van potentiële respondenten, in het vervolg door ons aangeduid met steekproef, zijn als volgt verkregen.

Het dossier van het GAK bevat naast persoonlijke aantekeningen van de verzekeringsgeneeskundige een groene kaart. Deze groene kaart wordt gebruikt om enkele gegevens met betrekking tot persoons- en verzuimkenmerken vast te leggen. Dit op grond van hun belang voor de werkzaamheden van de rapporteur Ziektewet. Deze gegevens betreffen naast naam, adres en woonplaats onder meer sexe, leeftijd, bedrijfsvereniging, rayonnummer, data verzuimmeldingen en herstelmeldingen c.q. het bereiken van de maximale termijn van de Ziektewet, klacht- c.q. diagnosecodes van rapporteur respectievelijk verzekeringsgeneeskundige, percentage arbeidsongeschiktheid krachtens de WAO, en burgerlijke staat.

Met uitzondering van naam en adres - dit om redenen van privacybescherming en burgerlijke staat wegens de onbetrouwbaarheid van de registratie hiervan hebben wij van deze gegevens gebruik gemaakt. Daarbij is ter waarborg van de anonimiteit niet aan het GAK gemeld wie van de groep potentiële, aangeschreven respondenten deel hebben genomen aan het onderzoek of van deelname afzagen. Aldus werd een analyse mogelijk van enkele algemene kenmerken van de populatie overspannen werknemers en van de verschillen tussen de groep die deelnam, en de groep die niet deelnam aan het onderzoek.

Voor een toetsing der verschillen is bij dichotome en nominale variabelen gebruik gemaakt van de $x^{2}$-toetsing en bij op intervalniveau gemeten variabelen van univariate variantieanalyse met toepassing van de F-toets.

De resultaten van de non-responsanalyse die gedetailleerder vermeld zijn in de hoofdstukken 6 en 7, zijn bemoedigend. Alleen naar leeftijdsverdeling is de samenstelling van de deelnemers in lichte mate afwijkend. De jongste werknemerscategorie blijkt ondervertegenwoordigd ten gunste van de oudste. De verdeling over leeftijdscategorieën is als gevolg daarvan minder scheef, hetgeen gunstig is voor de analyse van verbanden tussen leeftijd en andere kenmerken. Voor de absolute waarden in de beschrijvende tabellen gepresenteerd heeft de afwijkende leeftijdsverdeling vrijwel geen effect.

In samenhang met het verschil in leeftijdsverdeling is eveneens sprake van een wat langere gemiddelde verzuimduur van de groep deelnemers als gevolg van een 
oververtegenwoordiging van de groep werknemers met een verzuimduur van zes tot twaalf maanden. Ook hier is sprake van een gelijkere verdeling van de werknemers over de verzuimduurklassen als gevolg van de non-respons.

Omtrent de aard van overspanning en de wijze van verzuimbeëindiging gedetailleerder dan "hersteld-verklaring", spontane werkhervatting of het bereiken van "ZW-Max." verschaft de groene kaart geen gegevens.

Een tweede type non-respons betreft de geschetste uitval van andere interviews dan het begininterview met de werknemer. Bij 94 (82\%) respondenten heeft, afgezien van een eventuele non-respons op afzonderlijke vragen, een volledige dataverzameling kunnen plaatsvinden. Omdat niet voor alle beschrijvende en verklarende analyses alle data(bronnen) benodigd zijn, is besloten alle 114 respondenten in ons onderzoek te houden.

\subsection{Beschrijving van de verzamelde data}

\subsubsection{Inleiding}

In het onderzoek zijn gegevens verzameld met betrekking tot persoonskenmerken, bedrijfskenmerken, kenmerken van de arbeidsplaats, ziektegeschiedenis, ziektebeeld, ziektegedrag en hulpverleningscontacten, kenmerken en gedrag van de huisarts, kenmerken en gedrag van de verzekeringsgeneeskundige en ten slotte de verzuimkenmerken. Ter vermijding van misverstanden zij hier vermeld dat niet van alle gegevens in het onderzoek waarover in de volgende hoofdstukken gerapporteerd wordt, gebruik gemaakt is.

\subsubsection{Persoonskenmerken}

Tijdens de selectie en werving c.q. het begininterview met de werknemer zijn gegevens vastgelegd met betrekking tot geslacht, geboortedatum, het hoogste voltooide opleidingsniveau, door middel van woonplaats de verstedelijkingsgraad, thuissituatie, d.w.z. of men alleen of samenwoont en met wie: ouders, partners, kinderen of anderszins. Voorts is een inventarisatie gemaakt van ingrijpende levensgebeurtenissen: scheiding van ouders tijdens jeugd, ernstige ziekte of overlijden van huisgenoten, zelf doorgemaakte ernstige ziekte, onvrijwillig ontslag etc. en of men steun ondervindt bij persoonlijke problemen, en zo ja van wie: huisgenoten, familieleden, vrienden etc.

Ten slotte is de door Rotter ontwikkelde Locus of Control-vragenlijst afgenomen in de door Andriessen (1972) voor Nederland aangepaste versie. Deze vragenlijst is er op gericht aan de hand van meningen over 14 uitspraken vast te stellen in welke mate mensen van oordeel zijn dat ze hun maatschappelijke lotgevallen te danken hebben aan eigen inzet (interne oriëntatie) dan wel aan geluk of inzet van machtige anderen (externe oriëntatie). 


\subsubsection{Bedrijfskenmerken}

Aan de hand van hel GAK-dossier is de bedrijfstak vastgelegd waarin de werknemer werkzaam is. In het begininterview met de werknemer zijn gegevens verzameld over het aantal personeelsleden, de aanwezigheid van en de mate van tevredenheid over een ondernemingsraad, de vorm van bedrijfsgezondheidszorg en de vorm van bedrijfsmaatschappelijk werk.

Voorts is gevraagd naar veranderingsprocessen in het bedrijf gedurende het laatste jaar voor datum ziekmelding. Ten slotte is aan de werknemer gevraagd, of deze klachten over de werksituatie heeft geuit, bij wie en met welk resultaat.

\subsubsection{Kenmerken van de arbeidsplaats}

De werknemer is tijdens het begininterview gevraagd naar zijn of haar functie, het aantal jaren dat men werkzaam is bij de huidige werkgever, de omvang en de regelmaat van de werktijden, het voorkomen van overwerk, hoeveelheid en tempo van het werk, de afstemming van werkniveau op opleiding en ervaring, ontplooiingsmogelijkheden en promotiekansen, beslissingsvrijheid in de uitvoering van het werk en in werktijden, of men in teamverband dan wel solistisch werkt, de verhouding met de chef en collegae, arbeidssatisfactie en veranderingen in het werk gedurende het laatste jaar voor datum ziekmelding.

Ook is gevraagd naar de verwachting met betrekking tot behoud van de arbeidsplaats en in geval van een negatief vooruitzicht naar de reden daarvan.

Ten slotte is gevraagd naar hinder van 14 fysieke en 9 psycho-sociale werkurnstandigheden aan de hand van een gestructureerde vragenlijst die in een onderzoek naar determinanten van ziekteverzuim en arbeidsongeschiktheid in Zuid-Limburg ontwikkeld is. (Nijhuis en Soeters, 1982; Schröer et al., 1984) Deze bevat onder meer vragen naar hinder van trilling, ongevalsrisico en koude/warmte respectievelijk hinder van ploegendienst, geestelijk zwaar werk en eentonig werk.

\subsubsection{Ziektegeschiedenis}

Bij het begininterview met de werknemer is gevraagd naar het aantal verzuimen van het laatste jaar en naar verzuimen langer dan drie maanden. Van de laatste werd ook de reden vastgelegd. De huisarts is gevraagd naar eerdere episodes van overspanning.

Voorts zijn op basis van het GAK-dossier gegevens vastgelegd met betrekking tot de frequentie en de totale omvang van de verzuimen gedurende de laatste twee jaar en het aantal verzuimen gedurende de laatste vijf jaar die overspanning als diagnose toegekend kregen.

\subsubsection{Het ziektebeeld}

Van het ziektebeeld zijn de volgende gegevens vastgelegd:

- de klachten en verschijnselen die ten grondslag lagen aan de verzuimmelding. Dit betreft zowel lichamelijke als stemmingsklachten alsmede gedragsmatige veranderingen. Deze gegevens zijn zowel door middel van het interview met de werkne- 
mer als met de huisarts en de verzekeringsgeneeskundige aan de hand van open vrigen verzamold

- do oorzaken van overspanning. Deze gegevens zijn door middel van een open vraag zowel bij de werknemer als bij de huisarts en de verzekeringsgeneeskundige verworven.

- de (zelf)diagnoses

- ernst van overspanning: deze is gemeten door middel van de omvang van functionele beperkingen. Naast de voor iedere werknemer geldende werkstaking betreft dit het zich moeten onthouden van activiteiten in de privésfeer. Aan de werknemer is gevraagd of dit het geval was en welke activiteiten dit betrof.

Voorts is aan de werknemer de zogenaamde SCL-90 voorgelegd. Met de afname van deze Nederlandstalige versie van de door Derogatis c.s. uitgewerkte Hopkins Symptom Checklist is beoogd zowel aard als ernst van psychopathologie te meten. De lijst omvat 90 klachten waarvan de respondent dient aan te geven in hoeverre hij/zij van elk van deze klachten de laatste zeven dagen hinder ondervonden heeft. Deze multidimensionele vragenlijst meet in zijn geheel psychoneuroticisme, terwijl delen van de vragenlijst agorafobie, angst, depressie, somatische klachten, wantrouwen/persoonlijke insensitiviteit, woede/vijandigheid en slaapstoornissen meten. (Arrindell en Ettema, 1976)

In het eindinterview met de werknemer is deze vragenlijst opnieuw voorgelegd om ook op dat moment een beeld te krijgen van de gezondheidstoestand en van eventuele verschillen met die ten tijde van het begininterview.

Voordeel van het gebruik van deze vragenlijst is, naast de mogelijkheid om een indruk te krijgen van de stemmingsbeelden en de ernst van de overspanning, dat aan de hand van referentiewaarden die voor normale en patiëntenpopulaties voorhanden zijn, de relatieve ernst van overspanning als aandoening ten opzichte van andere aandoeningen vastgesteld kan worden.

\subsubsection{Ziektegedrag en hulpverleningscontacten}

Gedurende de gehele reeks interviews is de werknemer gevraagd naar contacten met hulpverleners, de wijze waarop die contacten tot stand kwamen, en wat de inhoud van die contacten was. Daarbij zijn alle soorten hulpverlening betrokken: huisartsen, specialisten, bedrijfsarts, verzekeringsgeneeskundigen, instellingen van Geestelijke Gezondheidszorg. Algemeen Maatschappelijk Werk en andere eerstelijnsvoorzieningen, personeelswerkers, alternatieve therapeuten, advocaten etc. Ook is bij elk interview gevraagd naar contacten met het bedrijf.

De werknemer is voorts bij het eerste interview gevraagd naar het tijdsverloop tussen het ontstaan van de klachten en de ziekmelding, het tijdsverloop tussen ziekmelding en consultatie van de huisarts, naar de invloed van werkomstandigheden op het besluit tot ziekmelding en naar belemmeringen om het werk te hervatten. Aan de huisarts is gevraagd welke klachten en problemen door de patiënt op het eerste consult tijdens deze ziekte-episode gepresenteerd zijn.

Ten slotte is de werknemer bij het eerste interview gevraagd naar de voor- en nadelen van het verzuim en naar gedragsveranderingen, onder meer wat betreft roken en alcoholconsumptie. 


\subsubsection{Kenmerken van de huisarts}

Door middel van het interview met de huisarts zijn gegevens omtrent sexe, leeftijd, opleidingsplaats, vestigingsplaats, praktijkomvang en praktijktype vastgelegd.

Voorts is gevraagd naar het aantal dienstjaren in de huidige praktijk en als huisarts in het algemeen. Ook is gevraagd naar eerder uitgeoefende medische beroepen, medische belangstellingen en medische nevenwerkkringen.

De mate van integratie van de huisarts in de eerstelijn (huisartsen van andere praktijken, Algemeen Maatschappelijk Werk, gezinszorg, wijkverpleging), met de Geestelijke Gezondheidszorg (RIAGG, psychiatrische inrichtingen, vrij gevestigde psychiaters of psychologen) en met de de bedrijfs- en verzekeringsgeneeskunde is vastgesteld door te vragen of er met elk van die instanties contacten onderhouden worden, en zo ja of deze incidenteel, regulier of structureel van aard zijn.

Vervolgens is met behulp van een tweetal vragenlijsten gevraagd naar werkwijzen die gehanteerd worden om onzekerheid te reduceren, (Foets et al., 1991) en naar de taakopvattingen omtrent een aantal psycho-sociale problemen. Voor de meting van de taakopvatting is gebruik gemaakt van de door De Ridder en Visser (1987) aangepaste versie van de vragenlijst van Grol met uitzondering van de items hulp bieden bij hyperventilatie en behandelen van chronische moeheid.

Ten slotte is met betrekking tot de patiënt gevraagd hoe lang deze bij de huisarts bekend is.

\subsubsection{Gedrag van de huisarts}

Gegevens over het gedrag van de huisarts zijn verzameld door middel van het interview met de huisarts en de inventarisatie van gezondheidszorgcontacten bij de werknemer.

Aan de huisarts is door middel van open vragen geïnformeerd naar zijn diagnose, zijn visie op de oorzaken en zijn beleid, d.w.z.: medicaties, verwijzingen, terugbestelling, adviezen aan de patiënt etc. Daarbij is specifiek gevraagd naar zijn beleid inzake het werk van de patiënt. Ook is gevraagd naar contacten gelegd door de huisarts met andere hulpverleners.

Door middel van de inventarisatie bij de werknemer van de gezondheidszorgcontacten zijn het aantal contacten met de huisarts, de tijdstippen van de contacten en de activiteiten die uit de contacten resulteerden, vastgelegd.

\subsubsection{Kenmerken van de verzekeringsgeneeskundige}

De verzekeringsgeneeskundigen zijn bij het interview over de eerste tot hun rayon behorende respondent ondervraagd over hun leeftijd, opleidingsplaats, beroepsverleden en "praktijkjaren", hun werkrelaties en de tijdsbesteding per patiënt.

Bij elk interview werd gevraagd naar de mate van bekendheid met het bedrijf van de patiënt: onbekend, bekend, contact-verzekeringsgeneeskundige of aan het bedrijf gebonden, naar de aanwezigheid van bedrijfsgezondheidszorg, de ziekteverzuimkenmerken van het bedrijf en de opstelling van het bedrijf tegenover ziekteverzuim, belastende factoren in de arbeid van de patiënt, en of ze de patiënt via eerdere contacten kenden. 


\subsubsection{Gedrag van de verzekeringsgeneeskundige}

Gegevens over het gedrag van de verzekeringsgeneeskundige zijn evenals in het geval van de huisarts verzameld door middel van de interviews met de verzekeringsgeneeskundige en de inventarisatie van gezondheidszorgcontacten bij de werknemer.

Aan de verzekeringsgeneeskundige is gevraagd welke overwegingen geleid hebben tot het stellen van de diagnose overspanning en welke oorzaken naar zijn mening ten grondslag lagen aan de overspanning.

Met behulp van de gegevens uit het dossier en uit de interviews met de verzekeringsgeneeskundigen is per geval het tijdsverloop tussen datum ziekmelding en eerste spreekuurcontact nagegaan. Voorts is nagegaan hoeveel spreekuurcontacten hebben plaatsgevonden en van elk contact op wiens initiatief, op welke datum en wat de reden voor de oproep voor en het resultaten van elk contact waren.

Tevens is gevraagd hoevaak de verzekeringsgeneeskundige bij elk geval contact heeft opgenomen met het bedrijf of andersom en met de huisarts of andersom, wat uit deze contacten resulteerde, en hoe groot het aantal verzoeken om inlichtingen bij specialisten was.

In geval van melding bij het GMD is gevraagd naar het tijdstip en de reden. Voorts is gevraagd naar het aantal "hersteld-verklaringen" en andere acties van de kant van de verzekeringsgeneeskundige.

Ten slotte is gevraagd naar de tevredenheid van de verzekeringsgeneeskundige over zijn eigen optreden en dat van eventueel andere betrokkenen: patiënt, huisarts, specialist, bedrijf, bedrijfsarts en GMD.

\subsubsection{Verzuimkenmerken}

Aan de hand van het GAK-dossier is van elke werknemer de datum van ziekmelding, de datum van verzuimbeëindiging en de wijze waarop het verzuim beëindigd is, vastgelegd. Dat laatste houdt in of er sprake is van volledige of gedeeltelijke werkhervatting bij de eigen of bij een nieuwe werkgever, van al dan niet vrijwillig ontslag of van ontslag op medische gronden, van continuering van het verzuim op grond van een andere aandoening, van het bereiken van de maximum termijn van de Ziektewet - éen jaar - , van overlijden of van pensionering en dergelijke. De informatie met betrekking tot de wijze van verzuimbeëindiging is eveneens verworven door middel van het laatste vervolginterview en het eindinterview met de werknemer. Voorts is in geval van werkhervatting over de periode tussen de datum van werkhervatting en de datum waarop het een jaar geleden was dat de ziekmelding plaatsvond, nagegaan hoe vaak, hoeveel weken in totaal en op grond van welke diagnose(s) ziekteverzuim heeft plaatsgevonden. 


\section{Hoofdstuk 6}

\section{Enkele kenmerken van de onderzoekspopulatie}

\subsection{Inleiding}

In dit hoofdstuk geven we een beschrijving van de onderzoekspopulatie naar de belangrijkste kenmerken op het moment van de ziekmelding. Dat betreft enkele persoonskenmerken als sexe, leeftijd en opleidingsniveau, een tweetal bedrijfskenmerken, namelijk bedrijfstak en bedrijfsgrootte, een aantal beroeps- en arbeidsplaatskenmerken en het verzuimverleden. Daarbij zullen, waar mogelijk, respondenten en weigeraars vergeleken worden.

Om een beeld te krijgen in hoeverre de populatie van overspannen werknemers ten opzichte van werknemers die langdurig verzuimen op grond van andere aandoeningen, verschilt met betrekking tot sexe, leeftijd en bedrijfstak, is een vergelijking gemaakt op basis van het ISM-bestand van het GAK. Dit bestand bevat $6 \%$ van alle ziektegevallen met een verzuimduur van ten minste vier weken of langer. De steekproef is gebaseerd op een selectie naar willekeurig geselecteerde geboortedata. Voor ons onderzoek hebben wij gebruik gemaakt van de volgende data: sexe, leeftijd, bedrijfstak, diagnose, verzuimduur en wijze van verzuimbeëindiging en enkele gegevens met betrekking tot handelingen van verzekeringsgeneeskundigen.

Daarbij hebben wij uit het ISM-bestand al die gevallen geselecteerd waarvan de ziekmelding in de kalenderjaren 1988 en 1989 plaatsvond bij het districtskantoor van het GAK, waar ons onderzoek verricht is.

Omdat er ons geen gegevens ter beschikking staan met betrekking tot de samenstelling van de populatie GAK-verzekerden naar sexe, leeftijd e.d., zijn wij genoodzaakt onze toevlucht te nemen tot vergelijking met de Zuid-Limburgse beroepsbevolking in het algemeen, hoewel deze ook niet GAK-verzekerden omvat. Zodoende beschikken we over een minimale mogelijkheid om met betrekking tot een aantal arbeidsplaatskenmerken na te gaan of deze bij overspannen werknemers anders zijn dan bij de beroepsbevolking.

Als referentiegroepen fungeren de deelnemers aan de enquête beroepsbevolking 1989 (CBS, 1990) en 1.002 deelnemers aan een enquête onder werknemers, werkzaam in Zuidelijk Limburg bij bedrijven met meer dan 50 personeelsleden. Deze enquête vond plaats in het kader van ziekteverzuimonderzoek in 1981. 
(Schröer et al., 1984) Bij vergelijking met deze referentiegroepen moet er rekening mee gehouden worden dat de verzuimgevallen betrekking hebben op de omslagleden van het GAK. Deze vormen ongeveer $46 \%$ van de beroepsbevolking in loondienst. Gezien de vele verschillende populaties waarmee de groep respondenten in dit en de volgende hoofdstukken worden vergeleken, is in bijlage 6.1 een overzicht opgenomen van de vergelijkingsgroepen en hun belangrijkste kenmerken.

\subsection{Sexe, leeftijd en opleiding}

Naar sexe blijkt de groep respondenten een getrouwe afspiegeling van de populatie. Het aandeel van vrouwelijke werknemers bedraagt een kleine $30 \%$. Dit aandeel blijkt bijna $50 \%$ hoger dan dat van vrouwelijke werknemers onder de langdurige verzuimgevallen wegens andere diagnoses dan overspanning. Ten opzichte van de actieve beroepsbevolking waarin de verdeling tussen mannen en vrouwen ongeveer $70 / 30 \%$ bedraagt, blijken mannen en vrouwen in gelijke mate vertegenwoordigd in de groep overspannen werknemers. Het risico voor andere langdurige aandoeningen ligt voor vrouwen derhalve lager.

Tabel 6.1 Sexe en leeftijd

\begin{tabular}{|c|c|c|c|c|}
\hline & $\begin{array}{l}\text { Respondenten } \\
N=114\end{array}$ & $\begin{array}{l}\text { Weigeraars } \\
N=94\end{array}$ & $\begin{array}{l}\text { Steekproef } \\
\text { Overspannen } \\
N=208\end{array}$ & $\begin{array}{l}\text { Steekproef } \\
\text { Overige } \\
N=709\end{array}$ \\
\hline Mannen & $72 \%$ & $71 \%$ & $72 \%$ & $80 \%$ \\
\hline Vrouwen & $28 \%$ & $29 \%$ & $28 \%$ & $20 \%$ \\
\hline $\mathrm{t} / \mathrm{m} 29$ jaar & $26 \%$ & $49 \%$ & $37 \%$ & $32 \%$ \\
\hline 30-39 jaar & $28 \%$ & $22 \%$ & $26 \%$ & $25 \%$ \\
\hline $40-49$ jaar & $25 \%$ & $18 \%$ & $22 \%$ & $24 \%$ \\
\hline 50 jaar en ouder & $20 \%$ & $10 \%$ & $15 \%$ & $20 \%$ \\
\hline Gemididelde leeftijd & 37,7 & 34,8 & 36,4 & 37,6 \\
\hline
\end{tabular}

Van de groep overspannen werknemers blijkt ruim $35 \%$ jonger dan 30 en ruim $60 \%$ jonger dan 40 jaar oud. De gemiddelde leeftijd bedraagt 36,4 jaar.

Bij de groep respondenten blijkt er in de samenstelling naar leeftijdscategorieën een ondervertegenwoordiging aanwezig van de jongste en tevens de grootste groep en een toenemende oververtegenwoordiging naarmate het oudere en tevens steeds kleinere groepen betreft. Dit is het gevolg van een hoge non-respons (60\%) onder overspannen werknemers jonger dan 30 jaar. Uit de vergelijking met de $6 \%$-steekproef uit langdurige verzuimgevallen, niet berustend op overspanning, blijkt dat de jongste leeftijdscategorie onder overspannen werknemers ruimer vertegenwoordigd is dan onder werknemers die om andere redenen langdurig verzuimen. Bij de oudste leeftijdscategorie blijkt het omgekeerde het geval. 
De leeftijdsverdeling van de steekproef blijkt trouwens redelijk overeen te komen met die van de Zuid-Limburgse beroepsbevolking. In 1981 bedroeg de gemiddelde leeftijd 35,8 (Schröer, 1984) tegenover 36,4 in 1989 bij overspannen werknemers.

Ten opzichte van de Zuid-Limburgse beroepsbevolking die qua samenstelling naar opleidingsniveau niet veel afwijkt van de Nederlandse (ETIL, 1983), is in de steekproef alleen de categorie met lager onderwijs evenredig vertegenwoordigd. De groepen met een lager beroeps- of middelbare opleiding zijn oververtegenwoordigd. Omdat deze verdeling binnen de steekproef in sterke mate bepaald wordt door de afwijkende samenstelling naar opleidingsniveau van de populatie van GAK-verzekerden, beperken we ons tot de conclusie dat overspanning geen typische aandoening voor een bepaald opleidingsniveau is.

\subsection{Bedrijfstak en bedrijfsgrootte}

Van de voor ons onderzoek relevante bedrijfskenmerken is in de GAK-bestanden alleen de bedrijfstak volgens de indeling van de bedrijfsverenigingen aangesloten bij het GAK vastgelegd. Tabel 6.2 toont de verdeling.

Voor een goed begrip dient vermeld moet worden dat belangrijke bedrijfstakken ais bouwnijverheid, detailhandel, gezondheidszorg, onderwijs en werknemers bij de overheid met de status van ambtenaar buiten de door het GAK verzorgde populatie vallen.

Gezien het grote aantal bedrijfstakken afgezet tegen de omvang van de steekproef hebben wij tevens de subtotalen voor de industriële en dienstensector vermeld.

Tabel 6.2 Sector en bedrijfstak

\begin{tabular}{|c|c|c|c|c|}
\hline & $\begin{array}{l}\text { Respon } \\
N=114\end{array}$ & $\begin{array}{l}\text { Weigeraars } \\
N=83\end{array}$ & $\begin{array}{l}\text { Steekproef } \\
\text { Overspannen } \\
N=197\end{array}$ & $\begin{array}{l}\text { Verzekerden } \\
\text { Landelijk } \\
\mathrm{N}=1.900 .300\end{array}$ \\
\hline Metaal en elektrotechniek & $11 \%$ & $16 \%$ & $13 \%$ & $7 \%$ \\
\hline Metaalnijverheid. & $17 \%$ & $13 \%$ & $15 \%$ & $15 \%$ \\
\hline Overige industrie & $13 \%$ & $14 \%$ & $14 \%$ & $10 \%$ \\
\hline Industrie & $41 \%$ & $43 \%$ & $42 \%$ & $32 \%$ \\
\hline Overheidsdiensten & $9 \%$ & $19 \%$ & $13 \%$ & $7 \%$ \\
\hline Banken e.a. & $27 \%$ & $27 \%$ & $27 \%$ & $31 \%$ \\
\hline Overige diensten " & $23 \%$ & $11 \%$ & $18 \%$ & $30 \%$ \\
\hline Diensten & $59 \%$ & $57 \%$ & $58 \%$ & $68 \%$ \\
\hline
\end{tabular}

* Zuivel-, Hout-en meubel, Textiel, Grafische industrie. Steen en cement e.a., Chemie en Voeding e.a.

** Haven e.a., Koopvaardij, Vervoer, Horeca e.a. en Overige bedrijfstakken. 
Als we de respons per bedrijfstak bekijken, dan blijkt dat alleen vanuit de tak overheidsdiensten die grotendeels bestaat uit WSW-werknemers, de deelname achterblijft. Naar sector bekeken is de respons evenredig

Uit de vergelijking met de landelijke populatie werknemers die via de omslagleden verzekerd zijn bij het GAK, blijkt dat de industriële sector met uitzondering van de metaalnijverheid enigszins is oververtegenwoordigd en de overige diensten met uitzondering van de overheidsdiensten ondervertegenwoordigd. Dit kan niet worden toegeschreven aan bedrijfstakgebonden verschillen in incidentie van verzuim wegens overspanning. Vermoedelijk is er sprake van een regionale afwijking in bedrijfstakstructuur.

Naar personeelssterkte zijn alle typen bedrijven van klein tot groot in de onderzoeksgroep vertegenwoordigd. Bijna de helft $(44 \%)$ van de respondenten is werkzaam in een bedrijf met minder dan 50 personeelsleden, $32 \%$ in een bedrijf met 50 tot en met 499 en $25 \%$ in bedrijven 500 of meer personeelsleden. Overeenkomstig het karakter van de omslagleden van het GAK is het aandeel van grote bedrijven in de onderzoeksgroep naar verhouding lager dan in de actieve beroepsbevolking het geval is.

\subsection{Beroep, diensttijd en arbeidsomstandigheden}

Naar functie is de spreiding aanzienlijk. Van directeur tot loketbeambte of magazijnbediende. Ten tijde van de ziekmelding waren twee respondenten werkloos. De overige waren werkzaam in kaderfuncties (16\%), administratieve beroepen (13\%), huishoudelijke of dienstverlenende functies $(10 \%)$, als chauffeur of in commerciële functies $(21 \%)$, een indirect $(10 \%)$ of direct $(27 \%)$ bij de productie betrokken functie. De beroepsgroep van transport- en productiewerknemers blijkt - ook ten opzichte van de Zuid-Limburgse beroepsbevolking - meer dan evenredig vertegenwoordigd, de overige zijn ondervertegenwoordigd. Voor een groot deel is dit toe te schrijven aan de afwijkende samenstelling van de bij het GAK verzekerde populatie.

De gemiddelde lengte van het dienstverband bedroeg op het moment van ziekmelding 8.7 jaar. Ongeveer $16 \%$ was korter dan éen jaar in dienst, $9 \%$ had één dienstjaar voltooid, terwijl $5 \%$ het 25 -jarig jubileum achter de rug had. Het aandeel van de groep die minder dan één jaar in dienst is, is opvallend groot.

Het overgrote merendeel werkt in full-time dienstverband (82\%). Als part-timer werkt $16 \%$. Dit betreft voornamelijk vrouwen. In ploegendienst werkt $9 \%$, terwijl $21 \%$ anderszins onregelmatige tijden werkt. De overigen hebben vaste werktijden. Zuid-Limburg is al eerder gebleken een regio te zijn waarin onregelmatige werktijden relatief vaker voorkomen dan elders in Nederland. (Schröer et al., 1984) De werkweek varieert van 9 uur tot ruim boven de 60 uur per week. Van de respondenten rapporteert $71 \%$ wel eens te veel werk te moeten verrichten. Voor $53 \%$ ligt het arbeidstempo hoog. Overwerk wordt regelmatig verricht door $61 \%$. Ongeveer $30 \%$ vindt het werk niet in overeenstemming met de gevolgde opleiding en/of de opgedane ervaring. Slechts $8 \%$ ziet reële promotiekansen. Van de respondenten 
werkt $65 \%$ in groepsverband, terwijl de overigen solistisch werk verrichten. Eun goede of uitstekende relatie met de chef vermeldt $55 \%$, met collegae $85 \%$. Voor problemen op het werk kan $68 \%$ wel ergens in het bedrijf terecht, $32 \%$ kan echter bij niemand voor hulp aankloppen. (Zeer) tevreden over het werk is $69 \%$, (zeer) ontevreden $23 \%$. Als positieve aspecten worden vooral de inhoud van het werk $(47 \%)$, de onderlinge verhoudingen (39\%) en de vrijheid in het werk $(37 \%)$ genoemd. Als negatieve aspecten die overigens in veel mindere mate gerapporteerd worden, worden de onderling verhoudingen (42\%), de arbeidsomstandigheden en de werktijden (beide 34\%) genoemd.

Wat betreft de continuering van de werkkring, verwacht $40 \%$ bij de huidige werkgever te vertrekken. Belangrijkste gronden zijn ontevredenheid (17\%) en gezondheidsproblemen (13\%)

Ten opzichte van de bevindingen van de werknemersenquête in Zuid-Limburg profileert de groep overspannen werknemers zich door het vaker vermelden van een hoog arbeidstempo (53\% versus $36 \%$ ), te veel werk (71\% versus $27 \%$ ), overwerk ( $71 \%$ versus $27 \%$ ) en minder vooruitzichten op promotie ( $8 \%$ versus $16 \%$ ). Voorts blijkt de groep overspannen werknemers in iets mindere mate het werk passend te vinden bij hun opleiding en ervaring en meer hinder te ondervinden van fysieke en psycho-sociale arbeidsomstandigheden. Ten opzichte van het Leefsituatieonderzoek van het CBS uit 1986 blijkt de onderzochte groep zich vooral te onderscheiden door een geringere kans op promotie, minder mogelijkheid tot ontplooiing in het werk en een hoger arbeidstempo. (Smulders en Bloemhoff, 1991) Overigens blijkt uit een onderzoek onder langdurig verzuimende werknemers uit meer bedrijfstakken en uit meer diagnosegroepen dan in ons onderzoek dat ook deze zich in vrijwel dezelfde opzichten onderscheiden van de totale beroepsbevolking. (Aarts et al., 1982)

\subsection{Verzuimverleden}

Volgens de registratie van het GAK blijkt er bij ruim 40\% van de overspannen werknemers gedurende de laatste twee voorgaande jaren eerder sprake geweest te zijn van langdurig verzuim. Een eerder langdurig verzuim wegens surmenage was het geval bij ruim $20 \%$.

Tegenover de incidentiecijfers van de gehele GAK-populatie is dit een zeer hoog percentage. Vergeleken echter met de bevinding van Tordoir c.s. (1978), dat bijna $40 \%$ van de langverzuimers uit alle diagnosegroepen gedurende de laatste twee jaar op grond van dezelfde aandoening waren uitgevallen, blijkt dit echter weer mee te vallen.

Er blijken bij toetsing door middel van F- of $x^{2}$-toets geen statistisch significante verschillen aanwezig tussen respondenten en weigeraars wat betreft hun verzuimverleden, d.w.z.: beide groepen verschilden gedurende de laatste twee jaar voor de ziekmelding vrijwel niet in verzuimfrequentie of in voorkomen van langdurig verzuim wegens overspanning. Wel lag de frequentie van langdurig verzuim wegens andere redenen dan overspanning iets hoger bij de respondenten dan bij de weigeraars. 
Tabel 6.3 Verzuimverleden

\begin{tabular}{llll}
\hline & $\begin{array}{l}\text { Respondenten } \\
\mathrm{N}=114\end{array}$ & $\begin{array}{l}\text { Weigeraars } \\
\mathrm{N}=94\end{array}$ & $\begin{array}{c}\text { Steekproef } \\
\mathrm{N}=208\end{array}$ \\
\hline $\begin{array}{l}\text { Meldingsfrequentie per jaar } \\
\text { Langdurig verzuim * }\end{array}$ & $\begin{array}{l}1,7 \\
43 \%\end{array}$ & $\begin{array}{l}1,7 \\
39 \%\end{array}$ & $\begin{array}{l}1,7 \\
41 \%\end{array}$ \\
Langdurig verzuim wegens overspanning & $22 \%$ & $21 \%$ & $21 \%$ \\
\hline
\end{tabular}

- Inclusief langdurig verzuim wegens overspanning

\subsection{Conclusies en beschouwing}

De responsverhoudingen zijn in het algemeen goed te noemen. De belangrijkste uitzondering betreft de relatief hoge uitval onder overspannen werknemers uit de leeftijdscategorie tot 30 jaar. In hoeverre dit consequenties met zich meebrengt voor het optreden van selectiebias naar andere kenmerken van de onderzochte groep, is ons niet bekend.

De iets geringere deelname van werknemers bij overheidsdiensten vormt geen extra belemmering voor de interpretatie van de resuitaten van dit onderzoek voor de door het GAK verzorgde populatie. Wel lijkt de industriële sector als gevolg van de keuze van de onderzoeksregio enigszins ondervertegenwoordigd.

In hoofdstuk 7 zal nog besproken worden of de non-respons ook samenhangt met verzuimduur en wijze van verzuimbeëindiging.

De groep overspannen werknemers vormt in de meeste opzichten een redelijke representatie naar de meeste persoons- en beroepskenmerken van de beroepsbevolking. In het algemeen kan men vaststellen dat overspanning een aandoening is die bij alle denkbare categorieen werknemers voorkomt.

Opvallend is dat de onderzoeksgroep naar eigen ondervinden zwaarder belast is in het werk en geringere ontwikkelingskansen heeft. Of dit ook van invloed is op het ontstaan van overspanning komt in het volgend hoofdstuk ter sprake. 


\section{Hoofdstuk 7}

\section{Ziektebeeld en beloop}

\subsection{Inleiding}

In dit hoofdstuk worden de resultaten van het veldonderzoek gepresenteerd die betrekking hebben op de kenmerken van het ziekteproces zelf.

Eerst wordt het ziektebeeld beschreven. Het betreft de klachten en verschijnselen die de aanleiding tot de ziekmelding zijn geweest, de aard van de aandoening en de oorzaken die volgens respondent, huisarts en verzekeringsgeneeskundige geleid hebben tot het ontstaan van overspanning. Deze beschrijving wordt besloten met een typologie van overspanning op basis van symptomatologie en oorzaken. Daarna wordt het ziektebeloop beschreven. Dit omvat de duur van de klachten, de verzuimduur, de wijze van verzuimbeëindiging en de mate waarin herstel optreedt. Evenals in hoofdstuk 6 wordt bij de beschrijving van de verzuimduur en de WAOintrede aandacht geschonken aan de invloed van de non-respons.

\subsection{Het ziektebeeld van de overspannen werknemers}

\subsubsection{De klachten en verschijnselen}

De respondenten is een open vraag voorgelegd naar de klachten en verschijnselen die voor hen aanleiding waren tot ziekmelding over te gaan. Daarbij zijn alle lichamelijke klachten en stemmingsveranderingen genoteerd. Deze zijn, waar mogelijk, door ons samengevoegd tot bekende symptomatologieën als het hyperaesthetisch-emotionele syndroom en het hyperventilatiesyndroom.

Ruim drie kwart van de respondenten rapporteerde klachten behorend bij het hyperaesthetisch-emotionele syndroom zoals huilen, concentratiezwakte, nervositeit, slapeloosheid, moeheid, eetstoornissen, hoofdpijn, depressiviteit, lusteloosheid, prikkelbaarheid, zweten en duizeligheid.

Bij een tweetal respondenten was er sprake van enkel aggressieve c.q. depressieve gevoelens, waarbij andere klachten uit het syndroom ontbraken. In éen geval deden zich psychotische verschijnselen voor. De respondent voelde geen controle meer over zichzelf, hoorde stemmen en functioneerde naar eigen zeggen als een robot.

In bijna een kwart van de gevallen was er alleen sprake van lichamelijke klachten. 
Tabel 7.1 Klachtenbeeld

$N=114$

Hyperaesthetisch-emotioneel

Aggressief

Depressief

Psychotische verschijnselen

Totaal psychische klachten

Grieperig, malaisegevoel

Nek-, rug- en armklachten

Maag-en darmklachten

Collaps, hyperventilatiesyndroom

Diffuse lichamelijke klachten

Totaal lichamelijke klachten

Geen klachten
$74 \%$

$1 \%$

$1 \%$

$1 \%$

$76 \%$

$4 \%$

$3 \%$

$4 \%$

$7 \%$

$6 \%$

$23 \%$

$1 \%$

Eén respondent rapporteerde geen enkele klacht. Deze gaf aan eigenlijk niet ziek maar, gezien de omstandigheden dat het arbeidscontract afliep en zijn echtgenote spoedig het werk na een bevalling zou hervatten, niet gemotiveerd te zijn om de werkzaamheden nog voort te zetten.

Wat betreft het klachtenbeeld blijken er zich geen verschillen voor te doen tussen mannen en vrouwen. Ouderen hebben vaker dan jongeren lichamelijke klachten. $\mathrm{Na}$ standaardisatie voor leeftijdsverschillen met de populatie is de verhouding tussen psychische en lichamelijke klachten in geringe mate gewijzigd: 78 versus $21 \%$.

Naast de open vraag naar het klachtenpatroon bij de actuele aandoening is ter exploratie ook de Nederlandse versie van de SCL-90 voorgelegd. (Arrindell en Ettema, 1986) Daarin worden 90 klachten voorgelegd. Aan de respondenten wordt gevraagd op een 5-puntsschaal van "helemaal niet" tot "heel erg" aan te geven in welke mate zij de laatste zeven dagen van elk van deze klachten hinder hebben ondervonden.

Deze vragenlijst is vooral toegepast bij ambulante psychiatrische patiënten. Ze heeft een multidimensionele structuur die factoranalytisch evenwel niet erg constant gebleken is. Tegenover dit nadeel staat het voordeel dat de betrouwbaarheid van de acht subschalen gemeten volgens Cronbach's $\alpha$ hoog is evenals de test-hertest-betrouwbaarheid (Arrindell en Ettema, 1986) en dat de betekenis van de dimensies een goede mogelijkheid bieden diverse stemmingsbeelden van overspanning in beeld te brengen. De psychoneuroticisme-schaal in zijn geheel duidt het actueel algemeen niveau van psychische en lichamelijk disfunctioneren aan. De acht dimensies staan voor gevoelens van agorafobie, angst, depressie, somatisch lijden, insufficiëntie van denken en handelen, wantrouwen en gevoeligheid tegenover anderen, vijandigheid en slaapproblemen. In ons onderzoek bedroeg de 
$\alpha$-score voor de gehele schaal .98 en voor de subschalen variërend van . 81 voor hostiliteit tot .93 voor depressie en wantrouwen.

De vragenlijst is in het kader van dit onderzoek opgenomen om te verkennen of de groep overspannen werknemers zich in mate van psychoneuroticisme profileren ten opzichte van andere populaties, in welke mate de diverse stemmingsbeelden binnen een groep van overspannenen voorkomen, en of er samenhang is met verzuimduur, wijze van verzuimbeëindiging, en herstel.

De zes volgende items scoorden gemiddeld genomen het hoogst: je gespannen voelen $(3,3)$, te veel over dingen piekeren $(3,3)$, zenuwachtigheid of van binnen trillen $(3,1)$, moeilijk in slaap kunnen komen $(3,0)$, nare gedachten of ideeën niet kwijt kunnen raken, $(2,9)$ en een onrustige of gestoorde slaap $(2,9)$.

De gemiddelde scores op de acht onderliggende dimensies en de gemiddelde totale score voor psychoneuroticisme worden tezamen met drie referentiescores in tabel 7.2 gepresenteerd. Twee van deze referentiescores betreffen een aselecte steekproef van 1.009 personen uit de "normale" bevolking en een populatie van 2.118 patiënten die aangemeld waren bij psychiatrische poliklinieken in het gehele land. (Arrindell en Ettema, 1986) Bij deze referentiescores is standaardisatie voor de leeftijdsverdeling binnen de onderzoeksgroep toegepast. Voorts is als referentiegroep een groep poliklinische patiënten toegevoegd die in verband met buikklachten of lage rugpijn contact hadden met een internist of neuroloog. (Meeuwesen et al., 1992) Bij deze groep waren we niet in staat de scores voor leeftijd te standaardiseren. Aangezien op het moment van het eerste interview 15 respondenten verklaarden hersteld te zijn en tevens het werk reeds hervat te hebben, zijn hun scores buiten beschouwing gelaten.

De verschillen van de vergelijkingspopulaties ten opzichte van de respondenten zijn getoetst met behulp van de Student's t-toets.

Tabel 7.2 Gemiddelde scores op de SCL-90

\begin{tabular}{|c|c|c|c|c|c|}
\hline & $\begin{array}{l}\text { Aantal } \\
\text { ltems }\end{array}$ & $\begin{array}{l}\text { Respon- } \\
\text { denten } \\
\mathrm{N}=99\end{array}$ & $\begin{array}{l}\text { Normale } \\
\text { populatie } \\
N=1.009\end{array}$ & $\begin{array}{l}\text { Poli- } \\
\text { kliniek } \\
N=102\end{array}$ & $\begin{array}{l}\text { Polikliniek } \\
\text { Psychiatrie } \\
\mathrm{N}=2.118\end{array}$ \\
\hline Agorafobie & 7 & 12 & $8^{* n \pi}$ & $9^{* * * *}$ & $14^{*}$ \\
\hline Angst & 10 & 24 & $13^{n+* *}$ & $17^{\star \star \star *}$ & $26^{\text {ns }}$ \\
\hline Depressie & 16 & 37 & $22^{n+k}$ & $27^{n s}$ & $41^{\circ}$ \\
\hline $\begin{array}{l}\text { Somatische klachten } \\
\text { Insufficiëntie van denken }\end{array}$ & 12 & 26 & $17^{* * *}$ & $24^{* * *}$ & $26^{\text {ns }}$ \\
\hline en handelen & 9 & 21 & $13^{* * * *}$ & $17^{* * * *}$ & $22^{\text {ns }}$ \\
\hline $\begin{array}{l}\text { Wantrouwen en interpersoon- } \\
\text { lijke sensitiviteit }\end{array}$ & 18 & 36 & $25^{* * * *}$ & $28^{* * *}$ & $38^{\text {ns }}$ \\
\hline Woede-Hostiliteit & 6 & 11 & $8^{* * *}$ & $8^{* * *}$ & $11^{\text {ns }}$ \\
\hline Slaapproblemen & 3 & 9 & $5^{* * *}$ & $7^{=* *}$ & $8^{n n=}$ \\
\hline Psychoneuroticisme & 90 & 190 & $120^{* * *}$ & $152^{\text {ma* }}$ & $202^{\text {ns }}$ \\
\hline
\end{tabular}

*** $=p<.001 ; "=p<.05 ;$ ns=niet significant

Voor vrijwel alle subschalen en de psychoneuroticismeschaal blijken de gemiddelde scores van de respondenten aanzienlijk dichter bij die van poliklinisch-psychiatrische patienten te liggen dan bij de doorsnee bevolking. Slaapproblemen blijken 
bij de respondenten het sterkst aanwezig. Dit stemt overeen met de bevinding van Van Eck (1990) bij 51 overspannen werknemers dat slaapstoornissen de vaakst $(51 \%)$ vermeide klacht is. De overspannen werknemers blijken minder last te hebben van gevoelens van agorafobie en depressie dan patiënten bij een psychiatrische polikliniek. Voor de overige klachtengroepen noch voor de totale score zijn er statistisch significante verschillen tussen de groep respondenten en de poliklinisch-psychiatrische patiënten.

De gemiddelde scores van de respondenten blijken op alle dimensies, met uitzondering van somatische klachten, aanzienlijk hoger te liggen dan die van polikliniekpatiënten met buik- of lage rugklachten. Daarbij komt nog, dat laatstgenoemde groep voor twee derde uit vrouwen bestaat die, zoals bekend, meer geneigd zijn tot rapportage van gezondheidsklachten dan mannen. Daardoor is de score van deze groep opwaarts geflatteerd ten opzichte van de andere groepen.

Zoals verwacht mag worden, liggen de meeste scores - uitzonderingen zijn insufficintie van denken en handelen en woede-hostiliteit - bij vrouwen iets hoger dan bij mannen, maar deze verschillen zijn naar maatstaf van de Student's t-toets niet significant. De totale score voor psychoneuroticisme bedragen bij de mannen en vrouwen die ten tijde van het eerste interview nog niet hersteld waren noch het werk hervat hadden, respectievelijk 187,6 en 196,9. Voor de totale groep respondenten zijn de scores iets lager: 176,3 bij mannen en 183,9 bij vrouwen.

Hoewel de SCL-90 niet voor diagnostische doeleinden is ontworpen, geven deze resultaten aan dat het in die gevallen van verzuim die gediagnostiseerd worden als overspanning, niet enkel om "grijze" gevallen en sociaal verzuim gaat die met een label gelegitimeerd moeten worden, maar dat er uitdrukkelijk sprake is van psychisch lijden. De ernst van de klachten ligt in een orde van grootte die men zou kunnen verwachten van een subklinische of eerstelijnspopulatie van psychische aandoeningen. Daarmee wordt de houdbaarheid van de bewering dat de diagnose overspanning een verzekeringsgeneeskundig label is voor dubieuze ziektegevallen, zwaar op de proef gesteld.

\subsubsection{De aard van de aandoening}

Gevraagd naar het eigen oordeel over de aard van de ziekte gaven de respondenten als "zelfdiagnose" de omschrijvingen weergegeven in tabel 7.3.

De eigen bewoordingen van de respondenten bij de omschrijving van de aard van de aandoening verraden geen protoprofessionalisering in het taalgebruik. Medisch jargon ontbreekt vrijwel. Rechtstreeks geeft meer dan een kwart te kennen overspannen te zijn. Indien de eigen bewoordingen gewogen worden, dan blijkt echter $90 \%$ aan te geven aan overspanning te lijden. De overige $10 \%$ heeft, ten tijde van het eerste interview, de overtuiging aan een andere - meestal onbekende lichamelijke - aandoening te lijden. 


\begin{tabular}{lc}
\hline & $\mathrm{N}=112$ \\
\hline Overspanning & $29 \%$ \\
Spanningen, stress & $26 \%$ \\
Depressie, agressie & $4 \%$ \\
Zenuwen & $3 \%$ \\
Werkdruk, te veel te verwerken & $7 \%$ \\
Reactie op situatie, gebeurtenis(sen) & $13 \%$ \\
Ingestort & $3 \%$ \\
Lichamelijke aandoening & $7 \%$ \\
Anders & $4 \%$ \\
\hline
\end{tabular}

\subsection{De oorzaken van de overspanning}

Gevraagd naar de oorzaken van de aandoening gaven 106 respondenten één of meer factoren aan die zoveel mogelijk ingedeeld zijn in eén van de volgende categorieën: werksituatie, thuissituatie, persoonlijkheid of lichamelijk functioneren. Niet alle aangegeven oorzaken waren indeelbaar. In een aantal gevallen werd gewag gemaakt van algemene factoren als overbelasting of spanningen. Er bleken vijf respondenten te zijn die, althans bij het begininterview, geen enkel idee hadden wat de oorzaak zou kunnen zijn.

Ook de betrokken huisartsen en verzekeringsgeneeskundigen zijn ondervraagd over de oorzaken van de aandoening. Op één uitzondering na konden alle huisartsen één of meer oorzaken aangeven. In een tweetal gevallen had de verzekerings:geneeskundige geen idee van de oorzaken.

Bij de respondenten zelf noemt een overgrote meerderheid de werksituatie als oorzaak van de aandoening. De omvang van deze groep, bijna $70 \%$, ligt enigszins hoger dan de 50 à 60\% uit ander onderzoeken. (Knepper, 1990; Gründemann et al., 1991) Voor zover men een in de werksituatie gelegen oorzaak kan specificeren, blijkt de werkdruk het vaakst genoemd te worden, namelijk 31 keer, gevolgd door slechte verhoudingen met leidinggevenden, openlijke conflicten en onvrede over de werksituatie als zodanig. In vijf gevallen speelde ontslagdreiging een rol. In ruim een kwart van de gevallen wordt de thuissituatie als oorzaak aangeduid. De belangrijkste aspecten zijn hier problemen van huisgenoten of familie, overlijden van naasten en relatieproblemen. In veel mindere mate worden dubbele belasting, financiële problemen, traumatische jeugdervaringen en post-partus depressie genoemd. De eigen persoonlijkheid en de lichamelijke constitutie worden door de respondenten nauwelijks als oorzaken genoemd. De laatste antwoordcategorie heeft zelfs een lagere frequentie dan het aantal respondenten dat van mening is aan een lichamelijke aandoening te leiden. Dit impliceert dat het inzicht in de psycho-sociale bepaaldheid van de aandoening nog groter is dan de inventarisatie van de zelfdiagnose suggereert.

Er blijkt geen samenhang aanwezig tussen de genoemde oorzaken en de sexe of leeftijd van de respondent. 
Tabel 7.4 Oorzaken aandoening

\begin{tabular}{lccc}
\hline & $\begin{array}{l}\text { Respondent: } \\
\mathrm{N}=106\end{array}$ & $\begin{array}{l}\text { Huisarts: } \\
\mathrm{N}=97\end{array}$ & $\begin{array}{l}\text { Verzekeringsgeneeskundige: } \\
\mathrm{N}=109\end{array}$ \\
\hline Werksituatie & $70 \%$ & $59 \%$ & $73 \%$ \\
Thuissituatie & $25 \%$ & $38 \%$ & $25 \%$ \\
Persoonlijkheid & $3 \%$ & $27 \%$ & $16 \%$ \\
Lichamelijk & $3 \%$ & $16 \%$ & $1 \%$ \\
Overbelasting & $8 \%$ & & \\
Spanningen & $6 \%$ & $3 \%$ & $4 \%$ \\
Anders & & $142 \%$ & $117 \%$ \\
Aantai oorzaken & $113 \%$ & & \\
\hline
\end{tabular}

De huisartsen neigen, vaker dan de verzekeringsgeneeskundigen en de respondenten zelf, ertoe meer dan eén oorzaak van de aandoening aan te geven. Daarbij valt op dat de werksituatie, hoewel deze nog steeds in de meerderheid van de gevallen als (én der oorzaken) genoemd wordt, verhoudingsgewijs minder vaak en thuissituatie en constitutionele factoren aanzienlijk vaker door de huisartsen als oorzaak aangeduid worden. Vooral het verschil in het aantal keren dat de persoonlijkheid genoemd wordt, is opvallend.

De verzekeringsgeneeskundigen zien ongeveer even vaak als de respondenten het werk of de thuissituatie als oorzaak. Duidelijk komt naar voren dat verzekeringsgeneeskundigen geneigd zijn zich bij de visie van de respondent aan te sluiten. Het aandeel van de werksituatie komt overeen met de bevindingen van Van Eck (1990). Deze trof evenwel in de rapportages van de verzekeringsgeneeskundigen, waarbi] meer oorzaken per respondent aangeduid werden dan in ons onderzoek, bij $63 \%$ der gevallen de thuissituatie en/of de persoonlijkheid als één der oorzaken aangemerkt. Ook in ons onderzoek blijkt de verzekeringsgeneeskundige geneigd om in een aantal gevallen, zij het wat minder dan de huisarts, de persoonlijkheid van de respondent als oorzaak toe te voegen. Een lichamelijke oorzaak wordt slechts in éen enkel geval genoemd.

Als we de visie van huisarts en verzekeringsgeneeskundige die beide in de meeste gevallen de respondent als voornaamste bron van informatie blijken te benutten, vergelijken, lijkt het erop dat een aantal respondenten hun informatie selectief verschaffen naar gelang hun rolverwachtingen ten aanzien van artsen. Een huisarts wordt beschouwd als een instantie voor het verhelpen van lichamelijke ongemakken, terwijl bij een verzekeringsgeneeskundige het niet werken gelegitimeerd moet worden.

De discrepantie tussen de visie van de huisarts en die van de respondent kan deels ook verklaard worden uit de wijze waarop de huisarts met de respondent communiceert. In 21 gevallen (24\%) heeft de huisarts de patiënt niet op de hoogte gesteld van zijn of haar visie op de oorzaken van de aandoening. Dit gebeurt vaker in het geval dat volgens de huisarts de oorzaak in de persoonlijkheid van de respondent ligt, en minder vaak, indien de huisarts het werk als oorzaak ziet. Er wordt dus selectief informatie gefilterd. 
Het aantal gevallen waarin zowel respondent als huisarts als verzekeringsgeneeskundige overeenstemming tonen in visie over de oorzaken van de overspanning, bedraagt slechts $29 \%$. Dan betreft het voornamelijk eensgezindheid met betrekking tot het oordeel dat uitsluitend de werksituatie oorzaak van de aandoening is. Dit lage percentage is vooral het gevolg van het veelvuldig vermelden van meer dan één oorzaak voor het ontstaan van de aandoening. Als we de visie op de oorzaken toespitsen op de vragen of de werksituatie dan wel de thuissituatie (mede) oorzaak van de aandoening is, komt er een grotere mate van overeenstemming tussen de drie beoordelaars naar voren. In $64 \%$ van de gevallen was er eensgezindheid over de vraag of de werksituatie al dan niet had bijgedragen aan het ontstaan van de aandoening. Over de vraag of de thuissituatie al dan niet had bijgedragen, was er in $63 \%$ der gevallen eensgezindheid. De kappa varieert van .41 tot .54 voor het oordeel omtrent de werksituatie en van .30 tot .61 voor dat omtrent de thuissituatie. De hoogste scores betreffen de mate van overeenstemming tussen respondent en verzekeringsgeneeskundige.

\subsection{De aard van de oversparıning}

In ons onderzoek zijn zoals eerder vermeld zowel de 114 werknemers alsmede, in 101 gevallen, de bij hun ziektegeval betrokken huisarts en, in 111 gevallen, de betrokken verzekeringsgeneeskundige ondervraagd over wat hen bekend was aan klachten en verschijnselen, wat zij als oorzaak zagen en wat op grond daarvan hun (zelf)diagnose was. Op basis van deze gegevens is door ons een indeling gemaakt van de respondenten naar de aard van overspanning, waarbij primair het klachtenpatroon en secundair de oorzaken als uitgangspunten gekozen zijn.

Daarbij dienen een tweetal opmerkingen geplaatst te worden. De drie bronnen zijn niet geheel onafhankelijk. Vooral de verzekeringsgeneeskundige blijkt in sterke mate afhankelijk van de informatie die de patiënt hem verschaft. Dit doet zich ook, zij het in iets mindere mate, bij de huisarts voor.

Als gevolg van de selectieve presentatie van de patiënt naar de artsen toe en van de selectieve opname van informatie door de artsen op hun beurt blijkt het beeld dat de huisarts van het ziektegeval heeft, nogal eens beperkt tot een somatisch aspect. De verzekeringsgeneeskundige blijkt sterk geneigd van de patiënt aan te nemen dat de oorzaak van de overspanning in het werk is gelegen.

Bij divergentie van klachten en verschijnselen zijn we vooral afgegaan op de informatie die de patiënt ons direct verstrekt heeft, omdat deze contextvrij is, d.w.z.: er was geen gerichte hulpvraag of noodzaak tot verzuimlegitimatie die de informatieverschaffing kon vervormen. Bij verschillen in menig tussen de respondent en de beide artsen in de duiding van de oorzaken is afgegaan op het oordeel van de artsen, daar van hen verondersteld mag worden dat zij minder geneigd zijn tot attributie van de oorzaak buiten de patiënt. Dit evenwel onder de voorwaarde dat de artsen het in die gevallen met elkaar eens waren. 
Tabel 7.5 Verdeling naar type overspanning

$N=114$

\begin{tabular}{lr}
\hline Overspannıngsklachten ten gevolge van: & \\
Incident op werk & $11 \%$ \\
Incident in prive-sfeer & $11 \%$ \\
Chronische werkstress & $27 \%$ \\
Chronische stress in prive-sfeer & $5 \%$ \\
Fysieke handicap & $1 \%$ \\
Psychische handicap & $7 \%$ \\
Veroudering/involutie & $3 \%$ \\
Overwerkt zijin of uitputting & $6 \%$ \\
& \\
Lichamelijke klachten ten gevolge van: & \\
Werkstress & $13 \%$ \\
Stress in de privé-situatie & $4 \%$ \\
& \\
Somatische fixatie & $4 \%$ \\
Fysieke decompensatie & $4 \%$ \\
Psychische decompensatie & $2 \%$ \\
Niet indeelbaar & $2 \%$
\end{tabular}

Het type overspanning dat het meest voorkomt onder onze onderzoeksgroep, blijkt overspanningsklachten, d.w.z. klachten behorend bij het hyperaesthetisch-emotionele syndroom, als gevolg van langdurige spanningen op het werk te zijn. Dit maakt ongeveer $25 \%$ van het totaal uit. Daarna volgt het type lichamelijke klachten ten gevnlge van - meestal langdurige - werkstress. Samen nemen deze twee categorieen $40 \%$ van alle gevallen voor hun rekening. Voorts komt overspanning als gevolg van een enkel incident, hetzij op het werk, hetzij in de privésfeer nogal eens voor. Deze twee nemen samen ruim $20 \%$ der gevallen voor hun rekening. De categorieën die verwijzen naar een verminderde belastbaarheid als oorzaak, omvatten samen ruim $10 \%$ der gevallen. Het aandeel van de andere categorieën blijtt onder de $10 \%$.

\subsection{Het ziektebeloop}

\subsubsection{De verzuimduur}

Ten aanzien van de duur van het verzuim wordt in de volgende tabel een vergelijking gegeven tussen de groep respondenten, de weigeraars, de totale steekproef waaruit de respondenten afkomstig waren, en een $6 \%$-steekproef van alle verzuimgevallen in 1988 en 1989 uit hetzelfde district met dezelfde diagnosecodes als de steekproef en een minimumduur van vier weken." Deze laatste is niet gebonden door de beperking dat de betrokken werknemer door de verzekeringsgeneeskundige gezien is. Vandaar dat een relatief groot aantal gevallen in deze groep vrij kort van duur is.

- Zie hooldstuk 6. 
De duur van het verzuim, zoals geregistreerd door het GAK, varieert voor de gehele groep respondenten van 4 tot 52 weken. De ondergrens is het gevolg van het selectiecriterium dat de minimale verzuimduur vier weken moet bedragen. De gemiddelde verzuimduur bedraagt 23,8 weken. De groep die afzag van deelname aan het onderzoek, verzuimde gemiddeld vier weken korter.

Voor de gehele steekproef bedraagt de gemiddelde verzuimduur 22,0 weken en voor de gevallen van overspanning uit de $6 \%$-steekproef 23,6 weken.

Tabel 7.6 Verzuimduur overspannen werknemers

\begin{tabular}{|c|c|c|c|c|}
\hline & $\begin{array}{l}\text { Respondenten } \\
N=114\end{array}$ & $\begin{array}{l}\text { Weigeraars } \\
N=90\end{array}$ & $\begin{array}{l}\text { Steekproef } \\
N=204\end{array}$ & $\begin{array}{l}6 \% \text {-Steekproe } \\
N=195\end{array}$ \\
\hline $4 \mathrm{t} / \mathrm{m} 8$ weken & $26 \%$ & $33 \%$ & $29 \%$ & $31 \%$ \\
\hline $9 \mathrm{t} / \mathrm{m} 12$ weken & $13 \%$ & $14 \%$ & $14 \%$ & $17 \%$ \\
\hline $13 \mathrm{t} / \mathrm{m} 25$ weken & $25 \%$ & $30 \%$ & $27 \%$ & $16 \%$ \\
\hline $26 t / m 51$ weken & $11 \%$ & $3 \%$ & $7 \%$ & $12 \%$ \\
\hline 52 weken & $25 \%$ & $19 \%$ & $22 \%$ & $24 \%$ \\
\hline Gemiddelde duur & 23,8 & 19.5 & 22,0 & 23,6 \\
\hline Excl. WAO-intreders & 14,9 & 11,9 & 13,5 & 14,3 \\
\hline
\end{tabular}

De gemiddelde verzuimduren voor deze overspanningsgevallen liggen aanzienlijk hoger dan de gemiddelde verzuimduur van ongeveer 16 weken inclusief en 12 weken exclusief de WAO-intreders die zowel Tordoir c.s. (1978) destijds in de Randstad bij GAK-verzekerden als Soeters (1983) later in Zuid-Limburg bij middelgrote bedrijven vaststelden. Ook liggen ze iets boven de niveaus van de verzuimgevallen wegens aandoeningen van het bewegingsapparaat uit de $6 \%$-steekproef en die wegens overige aandoeningen uit de 6\%-steekproef. Inclusief de WAO-intreders bedragen de gemiddelde verzuimduren bij de beide laatsigenoemde diagnosegroepen 20,6 en 18,4 weken en bij uitsluiting van WAO-intreders 13,2 en 12,7 weken.

Vastgesteld kan worden dat de gemiddeld te verwachten verzuimduur bij werknemers die vier weken verzuimen wegens overspanning, hoger ligt dan bij andere aandoeningen en - althans voor de populatie GAK-verzekerden bij omslagleden ruim vijf maanden bedraagt. Als we de WAO-intreders - ruim een vijfde van het totaal - buiten beschouwing laten, bedraagt de gemiddeld te verwachten verzuimduur ruim drie maanden. De verschillen tussen de verzuimduur in geval van overspanning en de verzuimduur in geval van andere aandoeningen wordt bij verwijdering van WAO-intreders geringer, hetgeen erop wijst dat de verschillen in verzuimduur tussen de diagnosegroepen vooral het effect zijn van verschillen in WAO-intrederisico. Eveneens blijkt na uitschakeling van dit WAO-intrederseffect op de gemiddelde verzuimduur het verschil in verzuimduur tussen de onderzoeksgroep uit 19881989 en vergelijkbare gevallen uit de jaren zeventig eveneens geringer.

De gemiddelde duur van het verzuim in geval van hersteld verklaring is bij de deelnemers aan het onderzoek drie weken langer dan bij de weigeraars. Dit is een statistisch significant verschil: $F=4.72 ; p=03$. Dit blijkt vooral toe te schrijven aan 
oververtegenwoordiging van werknemers die zes maanden of langer verzuimen. Voor alle vijf de verzuimduurklassen blijkt overigens het verschil in verdeling statistisch $\left(x^{2}=3.27\right)$ niet significant. Omdat de selectie ten gevolge van de respons tot een gelijkere verdeling over de verzuimduurklassen geleid heeft, is het beter mogelijk dan in geval van een evenredige spreiding om tot uitspraken te komen over verbanden tussen verzuimduur of WAO-intrede en andere variabelen. Wel is enige voorzichtigheid geboden met betrekking tot generalisaties van beschrijvende uitspraken over verzuimduur en wijze van verzuimbeëindiging.

\subsubsection{Wijze van verzuimbeëindiging}

Maar nauwelijks iets meer dan de helft van de overspannen werknemers blijkt terug te keren naar de werkkring waarin men voor de ziekmelding werkzaam was. Ook degenen die na herstel van overspanning het verzuim continueerden als gevolg van een andere aandoening of niet in aanmerking kwam voor een uitkering krachtens de Ziektewet, keerden uiteindelijk niet terug, maar raakten op een uitkering aangewezen. In totaal hebben 25 respondenten de maximum termijn van de Ziektewet bereikt waarvan 23 uitsluitend wegens overspanning. Omdat aan slechts een gering deel, namelijk ongeveer 10\% (Van Eck, 1991), van deze categorie geen WAO-uitkering wordt toegekend, kan gesteld worden dat éen op de vijf werknemers die wegens overspanning ten minste vier weken verzuimen, arbeidsongeschikt verklaard wordt.

Van de respondenten keerden er 24 niet naar hun werkkring terug, omdat ze elders aan het werk konden en ontslag konden nemen, of ontslag moesten nemen of kregen zonder uitzicht op een nieuwe werkkring.

In totaal blijkt de periode van ziekteverzuim door ruim één derde van de overspannen werknemers arbeidsloos oftewel met een uitkeringssituatie te worden beëindigd.

Als we het verzuimbeloop meten op een moment dat één jaar na datum ziekmelding ligt, dan blijkt de uitval nog omvangrijker.

Een overzicht van deze bevindingen geeft tabel 7.7. Daarbij zij vermeld dat het WAO-intredepercentage hier, in tegenstelling tot wat tabel 7.6 suggereert, bij het aantal respondenten dat 52 weken of langer wegens ziekte verzuimd heeft, 20 bedraagt, omdat bij twee respondenten WAO-intrede plaatsvond als gevolg van continuering van het verzuim wegens een anderssoortige aandoening.

De verhoudingen wijken aanzienlijk af ten opzichte van de bevindingen van Soeters (1983). Het aandeel van de werkhervatters bedroeg in zijn populatie $87 \%$, van de WAO-intreders $11 \%$ en van de werklozen $2 \%$. Ook Tordoir c.s. (1978) kwamen tot een veel lager percentage WAO-intreders, namelijk 13. Daarbij moet rekening gehouden worden met populatieverschillen zoals een ruimere verdeling over de bedrijfstakken en sectoren en een beperking tot bedrijven met 50 of meer personeelsleden (alleen bij Soeters) en uiteraard het ontbreken van selectie naar diagnose bij beide onderzoeken. Uit de cijfers van de $6 \%$-steekproef blijkt dat voor aandoeningen van het bewegingsapparaat en de overige aandoeningen het percentage WAO-intreders respectievelijk $19 \%$ en $14 \%$ bedraagt. Desalniettemin kan 
vastgesteld worden dat de trend die door ons in het eerste hoofdstuk geschetst is, namelijk van een hoger WAO-intrederisico onafhankelijk van de ontwikkeling van het aantal ziektegevallen, zich duidelijk weerspiegelt in de genoemde verschillen.

Tabel 7.7 Wijze van verzuimbeëindiging

\begin{tabular}{lcc}
\hline & $\begin{array}{l}\text { Bij verzuim- } \\
\text { beëindiging } \\
\mathrm{N}=114\end{array}$ & $\begin{array}{l}\text { Eén jaar na } \\
\text { ziekmelding } \\
\mathrm{N}=103\end{array}$ \\
\hline $\begin{array}{l}\text { Volledig hervat in eigen werk } \\
\text { Gedeeltelijk hervat in eigen werk }\end{array}$ & $\begin{array}{c}50 \% \\
4 \%\end{array}$ & $39 \%$ \\
Terugkeer & $54 \%$ & $23 \%$ \\
Elders in dienst getreden & $12 \%$ & \\
Werkloos na ontslag & $6 \%$ & $9 \%$ \\
Na ontslag op medische gronden & $3 \%$ & $22 \%$ \\
Werkloos & $9 \%$ & \\
WAO-intrede & $20 \%$ & \\
Continuering verzuim wegens andere aandoening & $3 \%$ & \\
VUT & $1 \%$ & $7 \%$ \\
Overleden & $1 \%$ & \\
Niet uitkeringsgerechtigd & $1 \%$ & \\
Anders & $5 \%$ & \\
\hline
\end{tabular}

De bevinding dat overspannen werknemers in vergelijking met werknemers met andere aandoeningen een verhoogd risico op WAO-intrede hebben, valt vijiwel in het niet bij de totale uitval uit de werkkring waarin de werknemer ten tijde van de ziekmelding werkzaam was. Het moment van verzuimbeëindiging houdt voor $46 \%$ van de werknemers vertrek bij de werkgever in. Een jaar na de datum van ziekmelding is het verloop toegenomen tot ongeveer $60 \%$.

\subsubsection{Verzuimbeëindiging en herstel}

We beschikken over een drietal herstelmaten. Allereerst een algemene subjectieve maat, namelijk de uitspraak van de respondent of deze zich al dan niet hersteld voelt, het aantal ziekmeldingen wegens overspanning in de periode tussen werkhervatting en de peildatum eén jaar na ziekmelding, en de SCL-90-score op dezelfde peildatum. Het aantal ziekmeldingen is uiteraard alleen toepasbaar in geval van werkhervatting en sterk afhankelijk van de duur van de onderzochte verzuimperiode.

Van de 75 respondenten die hun oorspronkelijke werk hervatten dan wel elders het werk hervat hebben, bleken er acht binnen een jaar na de datum van de ziekmel- 
ding die aanleiding was voor het onderzoek, zich eenmalig en én zich drie keer wegens overspanning ziekgemeld te hebben.

Tabel 7.8 Oordeel mate van herstel

\begin{tabular}{lc}
\hline & $N=100$ \\
\hline Geheel hersteld & $38 \%$ \\
Aanzienlijk hersteld & $33 \%$ \\
Enigszins hersteld & $14 \%$ \\
Nauwelijks hersteld & $7 \%$ \\
In het geheel niet hersteld & $8 \%$ \\
\hline
\end{tabular}

Eén jaar na datum ziekmelding voelt het merendeel $(71 \%)$ zich hersteld van de overspanning. De groep die zich enigszins hersteld voelt (14\%), is ongeveer even groot als de groep die zich nauwelijks of in het geheel niet hersteld voelt (15\%).

Een kleine $40 \%$ van de respondenten meldt in het geheel geen ziekteverschijnselen meer te ondervinden, terwijl bij $60 \%$ zich wel éen of meer klachten voordoen.

Als we kijken naar de verdeling van het gevoel van herstel over de categorieën naar wijze van verzuimbeëindiging dan blijken de WAO-intreders weliswaar aanzienlijk minder vaak hersteld dan de overigen, maar is er bij de overigen sprake van een omvangrijke groep "zieke hervatters" of "zieke werklozen".

Slechts twee WAO-intreders vermelden geen restverschijnselen van de overspanning te ondervinden. Bij bijna de helft van die respondenten die in de loop van het Ziektewetjaar door de verzekeringsgeneeskundige hersteld verklaard zijn, is er nog steeds sprake van restverschijnselen.

Bij de groep WAO-intreders is men duidelijk vaker van oordeel niet hersteld te zijn dan wel. Een zevental WAO-intreders - bijna een derde - geeft aan geheel of aanzienlijk hersteld te zijn. Daar staat een bijna tweemaal zo groot aantal respondenten tegenover dat zich niet hersteld voelt en toch het werk hervat heeft of werkloos is. De bevinding met betrekking tot "herstelde WAO-intreders" is minder verrassend, als men bedenkt dat het criterium voor arbeidsongeschiktheid voor de Ziektewet alleen betrekking heeft op het voor het verzuim uitgeoefende beroep. Er kan in deze gevallen sprake zijn van het uit de ziekmakende werksfeer houden van de werknemer.

Tabel 7.9 Samenhang WAO-intrede en herstel

\begin{tabular}{lll}
\hline & WAO-intreders & $\begin{array}{l}\text { Overigen } \\
N=75\end{array}$ \\
& $N=22$ & N=75 \\
\hline Geen restverschijnselen & $10 \%$ & $48 \%$ \\
Geheel/aanzienlijk hersteld & $32 \%$ & $82 \%$ \\
\hline
\end{tabular}

Naast een herstelmaat gebaseerd op een eigen algemeen oordeel beschikken we ook over de scores die de afname van de SCL-90 bij het laatste interview heeft 
opgeleverd. De gemiddelde scores op de SCL-90 en haar subschalen worden getoond in tabel 7.10. Daarbij zijn de respondenten onderscheiden in WAO-intreders en overigen. Tevens zijn ter vergelijking nogmaals de scores van de "normale populatie" en die van de patiënten van psychiatrische poliklinieken weergegeven.

Tabel 7.10 Gemiddelde scores SCL-90 één jaar na datum ziekmelding

\begin{tabular}{|c|c|c|c|c|c|c|}
\hline \multirow{2}{*}{ 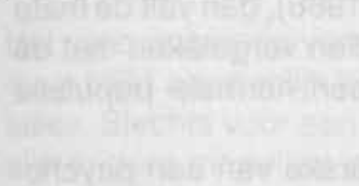 } & \multicolumn{2}{|c|}{$\begin{array}{l}\text { Respondenten } \\
\text { excl. WAO } \\
\mathrm{N}=85\end{array}$} & \multicolumn{2}{|c|}{$\begin{array}{l}\text { Respondenten } \\
\text { WAO-intreders } \\
N=23\end{array}$} & \multirow[t]{2}{*}{$\begin{array}{l}\text { Normale } \\
\text { populatie } \\
\mathrm{N}=1.009\end{array}$} & \multirow[t]{2}{*}{$\begin{array}{l}\text { Polikliniek } \\
\text { Psychiatrie } \\
N=2.118\end{array}$} \\
\hline & Begin & Eind & Begin & Eind & & \\
\hline Agorafo & 1 & 9 & 12 & 1 & 8 & 14 \\
\hline Angst & 23 & 16 & 26 & 26 & 13 & 25 \\
\hline Depressie & 34 & 24 & 38 & 36 & 22 & 41 \\
\hline Somatische klachten & 25 & 20 & 28 & 28 & 17 & 26 \\
\hline Insufficiëntie & 20 & 16 & 22 & 24 & 13 & 22 \\
\hline Wantrouwen-sensitiviteit & 34 & 28 & 35 & 39 & 25 & 38 \\
\hline Woede-Hostiliteit & 11 & 9 & 11 & 11 & 8 & 11 \\
\hline Slaapproblemen & 8 & 6 & 10 & 9 & 5 & 8 \\
\hline Psychoneuroticisme & 174 & 136 & 196 & 200 & 120 & 202 \\
\hline
\end{tabular}

De scores op de SCL-90 en de subschalen liggen nu voor die respondenten die volgens verzekeringsgeneeskundige criteria hersteld verklaard zijn, aanzienlijk lager. Bij toepassing van de Student's t-toets voor gepaarde steekproeven zijn de verschillen significant met een waarschijnlijkheidswaarde van .004 of kleiner. De scores liggen evenwel nog altijd hoger dan die van een normale populatie. Deze verschillen zijn volgens de Student's t-toets significant met een waarschijnlijkheidsniveau lager dan .01 bij de totale score, terwijl bij de subschalen de waarschijnlijkheidsniveaus beneden .05 liggen. De gemiddelde scores voor de subschalen liggen bij de groep WAO-intreders rondom de waarden van de poliklinische populatie. De totale psychoneuroticisme-score bedraagt voor hen 199,6 en is vrijwel gelijk aan de score van de poliklinisch-psychiatrische subpopulatie. Bij toepassing van de Student's t-toets blijken deze twee groepen bij geen enkele (sub)score statistisch significant te verschillen. Naar maatstaven van de SCL-90 is de groep WAO-intreders reëel lijdend aan een psychische aandoening.

De mate van herstel naar SCL-90 maatstaven is dus in het geheel genomen niet indrukwekkend. Bij de overspannen werknemers die het werk hervat hebben of ontslag hebben genomen, zijn de scores gedaald, maar er is een jaar na de ziekmelding nog steeds een groot verschil ten opzichte van de normale populatie in onder andere de totale psychoneuroticisme-score. Bijna een derde van deze respondenten blijkt overigens een jaar na de ziekmelding een hogere score te vertonen dan bij het begininterview.

Opvallend genoeg is de totale score van WAO-intreders nauwelijks veranderd. $\mathrm{Er}$ blijkt een geringe toename van klachten met betrekking tot agorafobie, insufficiëntie van denken en handelen, en wantrouwen of interpersoonlijke sensitiviteit. Gezien 
de aard van deze klachten lijkt een verklaring op grond van legitimatiebehoefte minder aannemelijk dan een verklaring op grond van de belasting die uitgaat van (onbegrepen) arbeidsongeschiktheid als zodanig. Overigens blijkt bijna de helft van de WAO-intreders de tweede keer lager te scoren op de SCL-90 schaal.

Indien als - negatieve - herstelindicatie het percentage respondenten genomen wordt dat een score vertoonde boven het, naar sexe gespecificeerde, gemiddelde van de populatie poliklinische patiënten (Arindell en Ettema, 1986), dan valt de mate van herstel binnen de populatie eveneens tegen. Zeker, indien vergeleken met de mate waarin deze bovengemiddelde patiëntenscores in een normale populatie voorkomen.

Is er binnen een "normale" populatie bij minder dan 5\% sprake van een psychoneuroticisme-score boven het gemiddelde van een populatie poliklinisch-psychiatrische patiënten, binnen de groep overspannen respondenten was dit in de beginfase van het verzuim ongeveer $30 \%$ en een jaar later bijna $25 \%$. Op groepsniveau blijkt er in geringe mate sprake van een afname van psychopathologie volgens de normen van de SCL-90. Op de afzonderlijke dimensies wordt meer vooruitgang geboekt, maar overal valt de vergelijking met de normale populatie qua aanwezigheid van psychopathologie ten nadele van de respondenten uit.

Als we als criteria voor een volledig herstel stellen dat de respondent door de verzekeringsgeneeskundige hersteld verklaard moet zijn, zich zelf aanzienlijk of volledig hersteld moet voelen, geen restverschijnselen moet hebben, en een SCL90-score onder het gemiddelde van poliklinisch-psychiatrische patiënten, dan blijkt slechts $30 \%$ éen jaar na de datum van ziekmelding volledig hersteld. De bevinding dat de overspannen werknemers zo moeizaam herstellen, sluit overigens aan bij resultaten uit eerdere onderzoeken onder enigszins vergelijkbare populaties. (Mann et al., 1981; Ormel en Giel, 1983)

\subsection{Conclusies en beschouwing}

Het ziektebeeld dat overspannen werknemers direct rapporteren, kan blijkens de het klachtenpatroon, de zelfdiagnose, en de attributie van oorzaken nauwelijks op somatisatie of protoprofessionalisering berusten. In het algemeen kan men stellen dat het merendeel reële klachten van psychische en/of lichamelijke aard heeft die veroorzaakt zijn door aanwijsbare factoren uit het psycho-sociale milieu. Als we de SCL-90-vragenlijst als maatstaf hanteren, dan komt het niveau van geestelijk gezondheid van overspannen werknemers vrijwel overeen met dat van poliklinischpsychiatrische patiënten.

Het inzicht van de werknemer in zijn ziekte stemt in redelijke mate overeen met de conclusies van de verzekeringsgeneeskundige en de huisarts. Wel valt op dat de laatste niet altijd (volledig) betrokken wordt bij het probleem naar aanleiding, waarvan de ziekmelding heeft plaatsgevonden. Voorts blijkt de huisarts de oorzaak wat vaker te zoeken in de lichamelijke of geestelijke constitutie van de werknemer. In een door ons, op basis van klachtenbeeld en oorzaak, ontwikkelde typologie van 13 typen overspanning blijken bijna alle gevallen goed indeelbaar. Als gevolg van de selectiewijze van overspannen werknemers waardoor voornamelijk werknemers 
in het onderzoek betrokken zijn wier overspanning zich rechtstreeks manifesteert in een hyperaesthetisch-emotioneel syndroom, zijn bepaalde typen overspanning, gezien de scheve verdeling van de respondenten over de categorieën, vermoedelijk in ons onderzoek oververtegenwoordigd. Analyse van de invloed van het type overspanning op het verdere (verzuim)beloop is in ons onderzoek slechts zeer beperkt mogelijk.

Het verzuimbeloop van de overspannen werknemer blijkt opmerkelijk. De verzuimduur blijkt aanzienlijk hoger te liggen ten opzichte van allerlei vergelijkbare populaties. Slechts voor een deel is dit verklaarbaar uit het eveneens in vergelijking met alle andere mogelijke populaties hoger liggende percentage WAO-intreders. Gezien de bevindingen van de in het eerste hoofdstuk geschetste trends is dit op zich niet zo verrassend. Wel is de bevinding opmerkelijk dat de WAO-intreders slechts de helft uitmaken van de totale groep die na de ziekmelding niet meer terugkeert naar het bedrijf. Een jaar na datum ziekmelding blijkt ongeveer $60 \%$ de oorspronkelijke werkkring verlaten te hebben. Naast de ruim $20 \%$ uitkeringsgerechtigden krachtens de WAO, is dan bijna $10 \%$ werkloos. Dit betekent, dat een ziekmelding wegens overspanning bij overschrijding van een duur van vier weken in de meeste gevallen voorbode is van vertrek bij de werkgever. Anders gesteld: de kans op succesvolle reïntegratie bij de werkgever gedurende het Ziektewetjaar is buitengewoon laag: nog geen $40 \%$.

Naast de terugkeer blijkt ook het herstel als zodanig moeizaam. Naar eigen rapportage blijft de meerderheid een jaar na de ziekmelding nog last houden van restverschijnselen, hoewel bijna $70 \%$ - bij WAO-intreders ruim $30 \%$ - zich aanzienlijk of geheel hersteld voelt. Ook naar maatstaf van de SCL-90 valt de mate van herstel tegen. Het verschil ten opzichte van de normale populatie blijkt na een jaar onder degenen die door de verzekeringsgeneeskundige hersteld verklaard zijn, weliswaar verminderd maar nog altijd aanzienlijk, terwijl bij de WAO-intreders er zelfs sprake is van een geringe toename. Hoewel onder deze laatsite categorie de helft enige vooruitgang toont, lijkt er sprake van een nadelig effect op de geestelijke gezondheid uit te gaan, waarschijnlijk als gevolg van de nieuw verworven status van arbeidsongeschikte. Na een jaar blijkt slechts $30 \%$ van de overspannen werknemers in alle opzichten hersteld. 


\section{Hoofdstuk 8}

\section{Ziektegedrag en hulpverlening}

\subsection{Inleiding}

In dit hoofdstuk wordt een beschrijving gegeven van het ziektegedrag en de hulpverlening. Eerst wordt een beeld gegeven van de pre-medische fasen, d.w.z. enerzijds de tijd die verstrijkt tussen de manifestatie van klachten en problemen en de ziekmelding, anderzijds de tijd tussen de manifestatie van klachten en problemen en het leggen van het eerste contact met de hulpverlening. Daarna wordt een overzicht geboden van de soorten hulpverlening die ingeschakeld worden bij overspannen werknemers. Dit overzicht wordt besloten met een stroomdiagram van overspannen werknemers.

Ten slotte bieden wij een beschrijving van de contacten die tussen de overspannen werknemer en het bedrijf onderhouden worden.

Voor de details van de behandeling door de huisarts en van de begeleiding door de verzekeringsgeneeskundige en de invloed van de curatieve sector en de verzekeringsgeneeskundigen op de verzuimduur verwijzen wij naar de volgende twee hoofdstukken.

\subsection{Het besluit tot ziekmelding}

Te verwachten valt dat ziekmelding volgt op de klachten en niet andersom. Bij overspanning is dit laatste evenwel niet uitgesloten, omdat overspannenen nogal eens een slecht inzicht in hun eigen functioneren tonen of omdat ziekmelding plaats vindt naar aanleiding van en gelijktijdig met of snel volgend op een ingrijpende gebeurtenis, bij voorbeeld ontslag op staande voet, een onverwacht conflict of overlijden.

Dit blijkt dan ook uit tabel 8.1 die een samenvatting geeft van de antwoorden op de vraag naar het tijdstip waarop de klachten ontstonden die tot de ziekmelding leidden.

Opvallend is de ruime mate van uitstelgedrag. Twee derde loopt langer dan twee maanden en een derde zelfs langer dan een jaar met overspanningsverschijnselen rond alvorens tot ziekmelding over te gaan. Van de 48 respondenten die langer dan zes maanden met klachten rondliepen, waren er overigens 10 die naar eigen opgave gedurende de laatste twaalf maanden voor de ziekmelding al eerder thuisgebleven waren wegens dezelfde of soortgelijke klachten. 
Tabel 8.1 Duur klachten op de datum van ziekmelding

\begin{tabular}{lc}
\hline & $N=113$ \\
\hline Na datum ziekmelding ontstaan & $4 \%$ \\
Op datum ziekmelding ontstaan & $9 \%$ \\
Korter dan één week & $5 \%$ \\
1 tot 2 weken & $2 \%$ \\
2 weken tot 1 maand & $3 \%$ \\
1 tot 2 maanden & $12 \%$ \\
2 tot 3 maanden & $4 \%$ \\
3 tot 6 maanden & $19 \%$ \\
6 maanden tot 1 jaar & $9 \%$ \\
1 jaar of langer & $34 \%$ \\
\hline
\end{tabular}

Hoewel de grenzen enigszins willekeurig zijn, blijkt de overspanning vanuit het perspectief van de aanlooptijd in ongeveer $20 \%$ van de gevallen vrij acuut, d.w.z.: korter dan eén week voor de ziekmelding, opgetreden te zijn, terwijl er in ruim $40 \%$ sprake is van een zeer langdurige aanloop tot overspanning: zes maanden of langer tot de ziekmelding. Vergelijking van deze gegevens met die van andere populaties is niet mogelijk, omdat het uitstelgedrag ten aanzien van ziekmeldingen bij ons weten nog geen onderwerp van studie is geweest.

Als voordelen van de ziekmelding worden door $65 \%$ de rust ten opzichte van de spanningen op het werk en door $35 \%$ een grotere activiteit thuis genoemd. Een kleine $20 \%$ ziet overigens geen enkel voordeel aan het verzuim. Als nadelen vallen verveling, door ruim $30 \%$ genoemd, en het missen van contacten, door ruim $25 \%$ genoemd, op.

De invloed van de werksituatie op ziekmelding ten gevolge van overspanning hoeft niet alleen gelegen te zijn in het ontstaan van overspanning zelf, zoals in het vorige hoofdstuk is besproken, maar ook in de totstandkoming van het besluit tot ziekmelding, ook al is de oorzaak van de overspanning niet in de werksituatie gelegen. Gründemann c.s. (1991) spreken in dit verband van een causale respectievelijk conditionele relatie tussen werksituatie en ziekte(verzuim)proces.

Gevraagd welke werkgebonden factoren voortzetting van het werk onmogelijk maakten en aldus de conditie vormden voor ziekmelding, werden de volgende antwoorden gegeven:

Tabel 8.2 Werkgebonden factoren als conditie voor ziekmelding

\begin{tabular}{lllr}
\hline & $\begin{array}{l}\text { Totale groep } \\
N=108\end{array}$ & $\begin{array}{l}\text { Werk oorzaak } \\
N=71\end{array}$ & $\begin{array}{l}\text { Werk geen oorzaak } \\
N=37\end{array}$ \\
\hline Geen & $48 \%$ & $34 \%$ & $76 \%$ \\
Conflict / werksleer & $21 \%$ & $30 \%$ & $5 \%$ \\
Werkstress / werkdruk & $13 \%$ & $14 \%$ & $11 \%$ \\
Ontslag(dreiging) & $10 \%$ & $15 \%$ & $0 \%$ \\
Lichamelijke belasting & $3 \%$ & $1 \%$ & $5 \%$ \\
Anders & $5 \%$ & $6 \%$ & $3 \%$ \\
\hline
\end{tabular}


In bijna de helft der gevallen speelden specifieke werkomstandigheden geen directe rol bij de beslissing tot ziekmelding. Daar betrof het de gezondheidstoestand als zodanig of aan de privésituatie gebonden factoren. Verrassend genoeg was dit het geval bij een derde van de respondenten die de werksituatie als (mede)oorzaak van hun overspanning aangaven. Voor iets meer dan de helft der verzuimgevallen had naar de mening van de werknemer met enige interventie in de werksituatie een verzuim als gevolg van overspanning vermeden kunnen worden. De verdeling van de concrete verzuimaanleiding hangt grotendeels samen met de door de respondenten aangegeven oorzaken van hun aandoening. Van het totale aantal respondenten die werkgebonden factoren als oorzaak vermelden, geeft $66 \%$ ook het werk als aanleiding tot de ziekmelding aan. Bij degenen volgens wie de oorzaak van de aandoening geheel buiten het werk ligt, is dat toch nog bijna $25 \%$. In totaal blijkt de werksituatie dus in $75 \%$ van alle gevallen als oorzaak van en/of als conditie voor de ziekmelding geweest te zijn. Deze omvang komt ongeveer overeen met de bevindingen van Gründemann c.s. (1991).

Hoewel het besluit tot ziekmelding een afweging van pro's en contra's kan betekenen, wordt een jaar later door geen der respondenten getwijfeld aan de juistheid van de beslissing.

\subsection{De inschakeling van de hulpverlening}

De inschakeling van de diverse hulpverleners uit de curatieve sector waartoe wij ook het Algemeen Maatschappelijk Werk, klinisch psychologen en fysiotherapeuten rekenen, wordt weergegeven in tabel 8.3. Daarbij zijn alle verwijzingen en behandelingen als gevolg van comorbiditeit buiten beschouwing gelaten met uitzondering van die comorbiditeiten die de werknemer dusdanig emotioneel belasten, dat de overspanning uitgelokt of bevorderd is.

In vrijwel alle gevallen - er zijn slechts vijf uitzonderingen - wordt de huisarts door de overspannen werknemer geraadpleegd. In drie gevallen gebeurt dit op advies van andere hulpverleners.

De Geestelijke Gezondheidszorg en de fysiotherapeuten worden voornamelijk door middel van verwijzing ingeschakeld.

De RIAGG is in $14 \%$ van de gevallen bij de hulpverlening betrokken. Het betreft naar maatstaf van de psychoneuroticisme-score wel de ernstigere gevallen. De instellingen van Geestelijke Gezondheidszorg samen bleken betrokken bij $18 \%$ der gevallen. Dit is minder vaak dan de somatische specialisten (20\%). Dit ligt in de lijn van de bevindingen van De Klerk c.s. (1985) die overigens geen correctie voor comorbiditeit aangebracht hebben, dat een kwart van de werknemers die wegens psychische aandoeningen arbeidsongeschikt verklaard worden, onder behandeling geweest is van een somatisch specialist en dat het aandeel van de Geestelijke Gezondheidszorg daarbij achterblijft. In bijna alle gevallen komen de contacten met specialisten tot stand via verwijzing. Het vaakst worden neurologen ( $8 x)$, radiologen $(7 x)$ en internisten betrokken bij de diagnostiek of behandeling. Verder zijn cardiologen, urologen, KNO-artsen, een longarts, een algemeen, een orthopedisch en een kaakchirurg betrokken geweest. 
Tabel 8.3 Ingeschakelde hulpverieners uit de curatieve sector

\begin{tabular}{lcc}
\hline & $\begin{array}{c}\text { Ingeschakeld } \\
\mathrm{N}=114\end{array}$ & $\begin{array}{l}\text { Direct ingeschakeld } \\
\text { door de werknemer } \\
\mathrm{N}=114\end{array}$ \\
\hline Huisarts & $95 \%$ & $92 \%$ \\
Somatisch specialist & $20 \%$ & $3 \%$ \\
Fysiotherapeut & $10 \%$ & $0 \%$ \\
RIAGG & $14 \%$ & $3 \%$ \\
Psycholoog/Psychiater & $8 \%$ & $2 \%$ \\
Opname GGZ-instelling & $5 \%$ & $0 \%$ \\
Geestelijke Gezondheidszorg* & $18 \%$ & $5 \%$ \\
Algemeen Maatschappelijk Werk & $6 \%$ & $3 \%$ \\
Totaal aantal hulpverleners** & $158 \%$ & $105 \%$ \\
\hline
\end{tabular}

* Aangezien sommige respondenten met meer dan én hulpverlener uit de GGZ contact hebben gehad, ligt het totaal van die hulpverleningsinstanties binnen de GGZ hoger dan de GGZ als geheel, "* Aangezien voor een werknemer meer dan één hulpverlener ingeschakeld kan worden, liggen de percentages boven de 100.

De hulpverleners uit de "alternatieve" gezondheidszorg zijn niet in dit overzicht van de curatieve sector opgenomen. Van de 114 respondenten bezochten er $11(10 \%)$ hulpverieners uit deze sector. In drie gevallen werd de respondent door de huisarts hierheen verwezen. De overige contacten vonden zonder verwijzing van andere hulpverleners plaats. Onder meer zijn een gebedsgenezer, een handoplegger, NAN-therapeuten, kinesiologen en homeopaten ingeschakeld.

Voorts waren er ook hulpverleners betrokken die buiten de gezondheidszorg werkzaam zijn. De meest voorkomende waren de rechtskundige hulpverlening (8x) en het arbeidsbureau (6x).

Voor een beschrijving van de inschakeling van de bedrijf(gezondheidszorg) en van het GAK en de GMD verwijzen we naar respectievelijk paragraaf 8.5 en hoofdstuk 10.

Het tijdstip van inschakeling van de huisarts blijkt in de meeste gevallen min of meer met het tijdstip van ziekmelding samen te vallen. In de helft der gevallen in dezelfde week. Strict genomen blijkt bijna 30\% eerst de huisarts te raadplegen en daarna tot ziekmelding over te gaan. Dit komt overeen met de bevindingen van Tordoir c.s. (1978) en Soeters (1983).

Er blijkt een bijna gelijke verdeling tussen het aantal gevallen waarbij de ziekmelding minimaal een week voorafgaat aan het eerste consult van de huisarts en het aantal gevallen waarbij deze minimaal een week daarop volgt. Dit komt overeen met de bevindingen van Terluin (1986). Ten opzichte van het moment van ontstaan van de klachten blijkt er wederom een aanzienlijke variatie in tijdverloop aanwezig. Het wachten met het consulteren van de huisarts hangt overigens nauwelijks samen met het wachten met ziekmelding. (Pearson's $r=.11$; ns) 
Tabel 8.4 Relatie ziekmelding-eerste consult huisarts

\begin{tabular}{lcl}
\hline & Eerste consult & $\begin{array}{l}\text { Eerste consult } \\
\text { na de ziekrnelding } \\
\mathrm{N}=114\end{array}$ \\
\hline Consult $\geq 1$ maand tevoren & $\mathrm{N}=114$ & \\
Consult $<1$ maand tevoren & $8 \%$ & \\
Consult en melding zelfde week & $11 \%$ & $63 \%$ \\
Consult $<1$ maand nadien & $47 \%$ & $23 \%$ \\
Consult $\geq 1$ maand nadien & $17 \%$ & $4 \%$ \\
Geen consult (na ziekmelding) & $10 \%$ & $10 \%$ \\
\hline
\end{tabular}

De presentatie van de problemen door de patiënt aan de huisarts, zoals dat door de huisarts is waargenomen, blijkt niet geheel te corresponderen met de diagnostiek van de verzekeringsgeneeskundige en de presentatie tijdens de interviews. Meer dan een derde meldt zich uitsluitend met lichamelijke klachten bij de huisarts. Zagen we in het vorige hoofdstuk een verdeling tussen de presentatie van psychische versus lichamelijke klachten van $3: 1$, bij de huisarts is de verdeling $5: 3$. Een drietal verklaringen zijn voor dit verschil aan te voeren: de selectieve waarneming door huisartsen, de opvatting van patiënten dat een bezoek aan de huisarts gelegitimeerd dient te worden door de presentatie van een lichamelijke klacht, en de gedragswijze van patiënten om de huisarts slechts voor lichamelijke bijverschijnselen of voor comorbiditeiten in te schakelen en niet ten behoeve van de oplossing van de gezondheidsproblemen die tot de ziekmelding geleid hebben.

Tabel 8.5 Presentatie aandoening aan huisarts

\begin{tabular}{lc}
\hline & $\mathrm{N}=99$ \\
\hline Hyperaesthetisch-emotionele syndroom & $32 \%$ \\
Psycho-sociaie problemen & $28 \%$ \\
Lichamelijke klachten & $36 \%$ \\
Anders & $3 \%$ \\
\hline
\end{tabular}

Ter bevestiging van het aanbod van comorbiditeiten geldt dat het totaal aantal lichamelijke klachten 48 bedroeg. De meest voorkomende lichamelijke aandoeningen betreffen het spijsverteringsstelsel (15 gevallen) en het bewegingsapparaat (12).

Het ligt voor de hand de conclusie te trekken dat er enige samenhang moet bestaan tussen de omvangrijke presentatie van lichamelijke klachten en het verwijzen naar somatische specialisten en fysiotherapeuten. Ruim $40 \%$ van degenen die naar zo'n specialist of fysiotherapeut zijn verwezen, kwamen echter niet met lichamelijke klachten bij de huisarts, terwijl een evengroot aandeel van degenen die naar de GGZ of het AMW zijn verwezen, in eerste instantie juist wel met lichamelijke klachten bij de huisarts kwam. De presentatie van de patiënt blijkt dus weinig invloed uit te oefenen op het verwijzingsgedrag van de huisarts. 


\subsection{De route door de hulpverlening}

De route door de hulpverlening wordt door ons weergegeven in een stroomdiagram dat een vereenvoudiging is van het diagram van Buijs (1985). Beloopaspecten als ziek doorwerken en (gedeeltelijk) hersteld c.q. arbeidsgeschikt en handelingsaspecten van hulpverleners zoals verwijzen of zelf behandelen zijn niet in het het diagram opgenomen. Voorts is de indeling in hulpverleningssoorten aangepast aan het ziektebeeld van deze onderzoekspopulatie. In het stroomdiagram in figuur 8.1 wordt aangegeven hoeveel respondenten welke hulpverleners bereiken, langs welke weg ze dat doen, en de positie van tijdstip van hulpverlening ten opzichte van de ziekmelding. We hebben daarbij voor de volledigheid vooruitlopend op paragraaf 8.5 en hoofdstuk 10 de bedrijfsarts, bedrijfsmaatschappelijk werker, de verzekeringsgeneeskundige en de GMD in het diagram opgenomen. Ter vereenvoudiging worden alleen hulpverleners en routes weergegeven die door minimaal vijf respondenten bij de contactregistraties zijn vermeld. Voor een volledige weergave van de stroomdiagram verwijzen wij naar bijlage 8.1

Figuur 8.1 Stroomdiagram overspannen werknemers door de hulpverlening

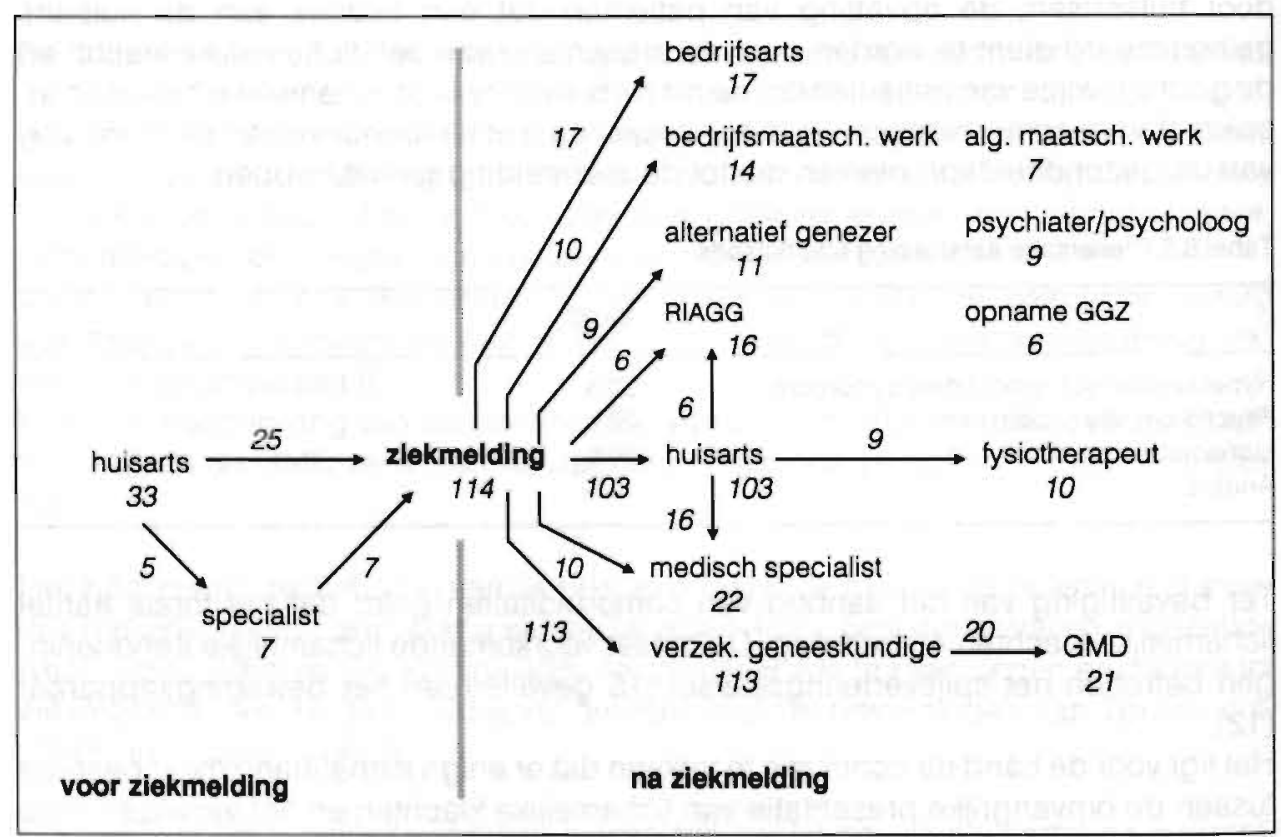

Het merendeel van de hulpverlening komt pas na de ziekmelding op gang. Alleen huisartsen en specialisten blijken nogal eens betrokken in de aanloop naar het verzuim. Met uitzondering van de huisarts geldt voor alle hulpverleners, ongeacht of het eerste contact met de werknemer voor de ziekmelding plaatsvond of daarna, dat zij na de ziekmelding contact hadden met de werknemer. 
Bij 11 respondenten was er na de ziekmelding geen enkel contact met de huisarts, d.w.z. bij vijf heeft er nooit contact met de huisarts plaatsgevonden in verband met de onderzochte ziekte-episode, bij zes is er na de ziekmelding niet opnieuw contact gelegd.

Uit de stroomdiagram wordt niet alleen duidelijk, wie de - in kwantitatief opzicht belangrijkste hulpverleners zijn, maar ook de toestroom naar en het verwijzingsgedrag van de hulpverleners. Fysiotherapeuten, bij voorbeeld, zijn vrijwel geheel afhankelijk van verwijzing door huisartsen, terwijl de alternatieve genezer een typisch "eindpunt" is in de (zelf)verwijzingsketen. De vrij gevestigde psychiater of psycholoog wordt op zeer diverse wijze ingeschakeld. De huisarts blijkt het startpunt voor zeer diverse verwijzingen. De verwijzingen spelen zich vrijwel geheel af binnen de curatieve of de verzekeringsgeneeskundige sector. Sectoroverschrijdende verwijzingen komen maar in een sporadisch geval voor.

\subsection{Contacten tussen respondent en bedrijf}

Bij de contacten met het bedrijf onderscheiden we de professionele hulpverleningscontacten met bedrijfsartsen en bedrijfsmaatschappelijk werkers enerzijds en de sociale contacten met collegae en leidinggevenden anderzijds.

Niet bij alle bedrijven zijn professionele hulpverleners werkzaam, hetgeen de mogelijkheid beperkt om langs deze weg problemen met betrekking tot de aandoening uit de weg te helpen. Een overzicht van de beschikbaarheid en inschakeling geeft de volgende tabel. De twee respondenten die bij datum ziekmelding werkloos waren, zijn bij de onderstaande tabellen buiten beschouwing gelaten.

Conform het landelijk beeld, kan iets minder dan $40 \%$ van de respondenten een beroep doen op een bedrijfsarts. Een kwart op een bedrijfsmaatschappelijk werker. Aangezien bedrijfsmaatschappelijk werk slechts in een tweetal bedrijven zonder bedrijfsgezondheidszorgvoorziening voorkomt, hebben in totaal 44 (40\%) van de respondenten de beschikking over een bedrijfsarts en/of bedrijfsmaatschappelijk werk. Het betreft voornamelijk werknemers in dienst van grotere bedrijven.

Tabel 8.6 Professionele hulpverlening in het bedrijf

\begin{tabular}{llll}
\hline & $\begin{array}{l}\text { Beschikbaar } \\
\mathrm{N}=112\end{array}$ & $\begin{array}{l}\text { Ingeschakeld } \\
\mathrm{N}=112\end{array}$ & $\begin{array}{l}\text { Gemiddeld aantal contacten } \\
\mathrm{N}=112\end{array}$ \\
\hline Bedrijfsarts & $38 \%$ & $18 \%$ & 2,3 \\
Bedrijfsmaatschappelijk werk & $26 \%$ & $13 \%$ & 3,8 \\
\hline
\end{tabular}

In slechts 18 gevallen is er een bedrijfsarts aan te pas gekomen. Daarvan kwamen er drie contacten op initiatief van de werknemer zelf tot stand. De meeste contacten zijn op initiatief van de bedrijfsarts zelf gelegd, al dan niet op instigatie van sociaal-medische teams binnen de bedrijven. Het tijdstip van inschakeling varieert sterk, maar het contact vindt op eén uitzondering na in alle gevallen na de ziekmelding plaats. In vier gevallen binnen één maand na de ziekmelding, in zeven gevallen tussen eén en drie maanden, en in zeven gevallen later dan na drie 
maanden waarvan in twee gevallen zelfs na zes maanden. Het aantal contacten na de ziekmelding bedroeg gemiddeld 2,3. De bedrijfsarts handelde de meeste gevallen zelfstandig af, d.w.z.: van de 18 gevallen "verwees" de bedrijfsarts vier werknemers door, namelijk twee naar het RIAGG, één naar de bedrijfsmaatschappelijk werker en één naar een psycholoog.

Hoewel er minder bedrijfsmaatschappelijk werkers beschikbaar zijn, ligt de betrokkenheid van deze hulpverlening nauwelijks achter bij die van de bedrijfsarts. Bovendien worden bedrijfsmaatschappelijk werkers in een vroeger stadium ingeschakeld, namelijk in zes gevallen binnen éen maand en in vijf gevallen tussen eén en drie maanden. Het gemiddeld aantal contacten ligt hoger: 3,8 . Ook hier vindt de inschakeling in bijna alle gevallen na de ziekmelding plaats. In zes gevallen wordt het contact door de bedrijfsmaatschappelijk werker zelf gelegd, al dan niet op instigatie van sociaal-medische teams, in vier gevallen door het bedrijf, de huisarts of de verzekeringsgeneeskundige en in drie gevallen door de werknemer zelf. In slechts één geval is er sprake van, dat de bedrijfsmaatschappelijk werker is ingeschakeld op initiatief van de bedrijfsarts.

Als professionele hulpverlener is de bedrijfsmaatschappelijke werker in de verwijzingsketen een eindpunt. Geen enkele respondent wordt door deze "verwezen" naar een andere hulpverlener.

Overigens hebben negen werknemers zowel met de bedrijfsarts als de bedrijfsmaatschappelijk werker contact gehad. Per saldo bedraagt het aantal werknemers dat met éen van beide of beide functionarissen contact gehad hebben, 23 oftewel $20 \%$.

Als we de inschakeling van bedrijfsartsen en bedrijfsmaatschappelijke werkers afzetten tegen de aard van de overspanning, dan blijken deze hulpverleners in respectievelijk slechts $10 \%$ en $15 \%$ van de gevallen van overspanning wegens acute of chronische werkstress ingeschakeld te zijn. De belangrijkste oorzaak daarvan is dat dit type overspanning relatief vaker voor blijkt te komen in bedrijven zonder professionele hulpverlening. Voor zover wel aanwezig blijkt de bedrijfsarts in de helft der gevallen en de bedrijfsmaatschappelijk werker in de meeste gevallen ingeschakeld.

Ten tijde van het begininterview had 105 oftewel $94 \%$ van de respondenten, afgezien van de professionele hulpverleners, op enigerlei wijze contact gehad met het bedrijf gedurende de periode van het ziekteverzuim. Voor de overige zeven $(6 \%)$ bleek dat niet het geval. Van zes personen was niet duidelijk wat de aard was van de werkverhouding met de persoon, met wie zij contact onderhielden. De 105 hadden met de volgende personen of instanties contact gehad. 
Tabel 8.7 Sociale contacten met het bedrijf

$N=112$

\begin{tabular}{lr}
\hline Collegae & $59 \%$ \\
Chel & $45 \%$ \\
Directie & $23 \%$ \\
Personeelszaken & $8 \%$ \\
Anderssoortig & $18 \%$ \\
Onbekend met wie & $5 \%$ \\
Geen enkel contact & $6 \%$
\end{tabular}

Deze contacten konden allerlei vormen aannemen: bij 53 (47\%) respondenten vond bezoek plaats bij de respondent thuis en/of kwam er een telefoontje, een brief of een kaart van de kant van het bedrijf. In 40 gevallen (35\%) betrof het een bezoek van de respondent aan het bedrijf. De inhoud kon van alles en nog wat betreffen. Bij 18 respondenten werden oplossingen voor de problemen besproken, terwijl bij drie wel de oorzaken aan bod kwamen maar geen oplossingen.

Het patroon van de contacten kan in theorie varieren van éenmalig, incidenteel over een langere periode, regelmatig, toenemend of afnemend met de ziekteduur. Een toename van contacten namen we niet waar. We geven de bevindingen voor de wijzen van verzuimbeëindiging afzonderlijk.

Tabel 8.8 Patroon van contacten met het bedrijf

\begin{tabular}{lcccc}
\hline & Allen & Hervat & \multicolumn{2}{c}{ Ontslag(name) WAO-intrede } \\
& $N=106$ & $N=60$ & $N=24$ & $N=22$ \\
\hline Geen contact & $8 \%$ & $8 \%$ & $13 \%$ & $5 \%$ \\
Onregelmatig & $25 \%$ & $10 \%$ & $38 \%$ & $55 \%$ \\
Regelmatig & $66 \%$ & $82 \%$ & $50 \%$ & $41 \%$ \\
\hline
\end{tabular}

In twee derde van de gevallen wordt er over de gehele verzuimperiode regelmatig contact onderhouden. Dit is vooral het geval bij respondenten die terugkeren naar het bedrijf. Bij WAO-intreders en respondenten die het werk elders hervatten, zijn de contacten relatief vaker onregelmatig of aflopend qua frequentie. Voor een goed begrip van deze cijfers zij vermeld dat bij deze contacten ook de contacten inbegrepen zijn waartoe het initiatief door de respondent genomen is. Het minder regelmatige contact bij vertrekkers lijkt derhalve te wijzen op een wederzijds aanvaardings- en aanpassingsproces naar een nieuwe arbeidsstatus.

De sociale contacten met het bedrijf worden door de respondenten aanzienlijk vaker positief dan negatief gewaardeerd, namelijk: in bijna $70 \%$ der gevallen tegenover $14 \%$. Meestal is een negatieve waardering gevolg van de bevinding dat er geen oplossing van de problemen wordt geboden, en soms dat er geen enkel begrip wordt getoond. Eenzijdige nadruk van de kant van de leidinggevende op werkhervatting wordt eveneens negatief gewaardeerd. 
Tabel 8.9 Waardering sociale contacten met bedrijf

\begin{tabular}{llll}
\hline & $\begin{array}{l}\text { Gehele groep } \\
N=88\end{array}$ & $\begin{array}{l}\text { Werk (mede) oorzak } \\
N=58\end{array}$ & $\begin{array}{l}\text { Werk geen oorzaak } \\
N=30\end{array}$ \\
\hline Positief & $68 \%$ & $60 \%$ & $83 \%$ \\
Neutraal & $18 \%$ & $21 \%$ & $13 \%$ \\
Negatief & $14 \%$ & $19 \%$ & $3 \%$ \\
\hline
\end{tabular}

Als we de waardering van de contacten afzetten tegen de door de werknemer zelf gepercipiêerde oorzaak van de aandoening dan blijken werknemers naar wier mening de overspanning niet veroorzaakt wordt door in werk gelegen factoren, zich vaker positief over de contacten uit te laten dan de anderen. Negatieve waardering komt alleen van de kant van de respondenten door wie werkgebonden factoren (mede) als oorzaak van de aandoening gezien wordt. Ook blijkt er een verband te bestaan tussen de waardering van de contacten en de wijze van verzuimbeëindiging. Onder degenen die terugkeren, is de waardering aanzienlijk vaker positief.

\subsection{Conclusies en beschouwing}

Bestudering van het ziektegedrag van overspannen werknemers ievert ais beiangrijke bevinding op dat er in ruime mate sprake is van uitstelgedrag, zowel ten aanzien van de ziekmelding als ten aanzien van de inschakeling van de hulpverlening. Twee derde van de respondenten heeft dan al twee maanden last van gezondheidsklachten, terwijl dit voor een derde al langer dan een jaar het geval is. De huisarts, in verreweg de meeste gevallen de eerst geraadpleegde hulpverlener, wordt daarentegen door slechts $20 \%$ van de respondenten meer dan een maand voor de ziekmelding geraadpleegd.

De invloed van werkgebonden factoren op de beslissing tot ziekmelding is groot. Voor ruim de helft is de werksituatie directe aanleiding tot ziekmelding. Bij diegenen waarbij de overspanning geen verband houdt met de werksituatie, is deze in een kwart der gevallen toch aanleiding tot ziekmelding. Slechts een kwart van de ziekmeldingen houdt geen enkel verband met de werksituatie.

De stroomdiagram waarin het patroon van de ingeschakelde hulpverlening weergegeven is, toont dat, afgezien van huisarts en verzekeringsgeneeskundige, overspannen werknemers een zeer heterogene route door de gezondheidszorg volgen. Ten aanzien van de ingeschakelde hulpverlening is - niet voor de eerste keer in een onderzoek vastgesteld (Ormel en Giel, 1983) - ook de beperkte inzet van de Geestelijke Gezondheidszorg en het Algemeen Maatschappelijk Werk opvallend. Wel geldt overigens dat de Geestelijke Gezondheidszorg, met name het RIAGG, vooral betrokken wordt bij ernstiger overspannen werknemers.

Dat de onderzochte categorie patiënten met typisch geestelijke gezondheidsproblemen even gemakkelijk doorverwezen blijkt te worden naar somatische specialisten en fysiotherapeuten, kan nauwelijks verklaard worden door de presentatie van de patiënt. Weliswaar wordt de huisarts bij ruim een derde van de gevallen 
geconfronteerd met somatische klachten, maar het verwijzingsgedrag blijkt geenszins bepaald door de wijze van presentatie.

Uit het stroomdiagram valt ook op te maken dat verwijzing van de curatieve sector naar de bedrijfsgezondheidszorg een zeldzaamheid is.

De beperkte beschikbaarheid van bedrijfsartsen en bedrijfsmaatschappelijk werk is bekend. Slechts $40 \%$ van de werknemers beschikt over een dergelijke hulpverlening. Het blijkt dat bij langdurig verzuim wegens overspanning slechts in de helft der gevallen dat hulpverlening op het bedrijf beschikbaar is, deze ook metterdaad geeffectueerd wordt en in een aantal gevallen bovendien nog in een vrij laat stadium. Van preventieve inschakeling, althans voorafgaand aan en zo mogelijk ter voorkoming van ziekmelding, is vrijwel niets gebleken.

In het algemeen wordt tijdens de ziekteperiode contact onderhouden tussen de overspannen werknemer en het bedrijf. Wel blijken de contacten bij degenen die niet naar de oorspronkelijke werkkring terugkeren, minder regelmatig onderhouden te worden. Omdat het patroon van contacten bij uitvallers vooral een daling van de frequentie van de contacten na enige tijd laat zien, lijkt er sprake van een beiderzijds - anticipatieproces met betrekking tot het vertrek. 


\section{Hoofdstuk 9}

\section{De curatieve sector en het verzuimbeloop}

\section{$9.1 \quad$ Inleiding}

Dit hoofdstuk bestaat uit twee gedeelten. Het eerste gedeelte is gewijd aan de beschrijving van de wijze waarop de curatieve sector, in het bijzonder de huisarts, hulp verlenen aan de overspannen werknemer. $\mathrm{Na}$ een beschrijving van een aantal kenmerken van de huisartsen komen achtereenvolgens de behandelwijze van de huisarts en de contacten met de overige hulpverleners uit de curatieve sector aan de orde.

Het tweede gedeelte beschrijft de werkwijze en de resultaten van het replicatieonderzoek naar de invloed van wachttijden in de gezondheidszorg op de verzuimduur. Zoals we in hoofdstuk 4 beschreven, is één der benaderingen van de verklaring van individuele verschillen in verzuimduur gestoeld op het ontleden van de verzuimperiode in een aantal fasen, waarin op één of andere wijze stagnatie optreedt in de behandeling of begeleiding van de zieke werknemer. Op een soortgelijke wijze als Tordoir c.s. (1978) en Soeters (1983) is door ons een berekening gemaakt van het aandeel van de wachttijden en stuurloze perioden op de totale verzuimduur. Eerst worden de methode van dit replicatie-onderzoek en de verschillen met bovenvermelde onderzoeken beschreven. Daarna volgt de presentatie van de resultaten.

\subsection{De hulpverlening door de curatieve sector}

\subsubsection{Kenmerken van de huisarts}

Bij de behandeling van 109 respondenten was een huisarts betrokken. Aan het onderzoek namen 78 huisartsen deel. Zij verzorgden de behandeling van 101 respondenten. In de navolgende tabel presenteren wij de verdeling van de groep betrokken huisartsen naar sexe en leeftijd, waarbij een vergelijking gemaakt wordt met de verdeling zoals aangetroffen door Van Dam en Hingstman (1988) bij de landelijke populatie huisartsen. 
De verdeling naar sexe en leeftijd van de aan ons onderzoek deelnemende huisartsen is conform de landelijke verdeling. Dit houdt in dat slechts $10 \%$ van de huisartsen van het vrouwelijk geslacht is. Om deze reden is voor ons niet na te gaan in hoeverre er verschillen in behandeling en in resultaten van behandeling optreden als effect van sexeverschillen tussen huisartsen.

Tabel 9.1 Huisartskenmerken

\begin{tabular}{lll}
\hline & $N=78$ & $\begin{array}{c}\text { Landelijk } \\
N=6.614\end{array}$ \\
\hline Sexe & \\
Man & & \\
Vrouw & $90 \%$ & $87 \%$ \\
& $10 \%$ & $13 \%$ \\
Leeftijd & & \\
$\leq 34$ & & \\
$35-44$ & $15 \%$ & $18 \%$ \\
$45-54$ & $54 \%$ & $50 \%$ \\
$>55$ & $18 \%$ & $16 \%$ \\
\hline
\end{tabular}

Van de 78 huisartsen waren $12(15 \%)$ korter dan vijf jaar werkzaam als huisarts, een drietal (5\%) vijf jaar of langer, maar korter dan vijf jaar in de actuele praktijk werkzaam, terwijl de overige $63(81 \%)$ vijf jaar of langer werkzaam waren in de actuele praktijk. Landelijk is dit laatste cijfer lager, namelijk $68 \%$. Naast hun beroep als huisarts oefende $70 \%$ een andere medische beroep uit. Een groot deel, namelijk $24 \%$, is tevens werkzaam als verzekeringsgeneeskundige of als bedrijfsarts.

Tabel 9.2 Praktijkkenmerken

\begin{tabular}{lcc}
\hline & $\mathrm{N}=78$ & $\begin{array}{c}\text { Landelijk } \\
\mathrm{N}=6.614\end{array}$ \\
\hline Praktijkvorm & \\
Solo & $39 \%$ & $55 \%$ \\
Meermans-praktijk & $52 \%$ & $39 \%$ \\
Gezondheidscentrum & $10 \%$ & $8 \%$ \\
Praktijkgrootte & & \\
$\leq 2000$ & $4 \%$ & $25 \%$ \\
$2001-3000$ & $53 \%$ & $57 \%$ \\
$>3000$ & $38 \%$ & $16 \%$ \\
onbekend & $1 \%$ & $3 \%$ \\
\hline
\end{tabular}

De cijfers met betrekking tot praktijkvorm en praktijkgrootte tonen aanzienlijke verschillen met de landelijke. In onze onderzoeksgroep blijken er minder huisartsen als solist te werken en meer huisartsen in grote dan in kleine praktijken, terwijl het aandeel van de middelgrote praktijken gelijk is. Voor de provincie Limburg komen de verdelingen tussen de onderzoeksgroep en de populatie naar praktijkvorm wel overeen. Voor het verschil in verdeling naar praktijkomvang kunnen we als enige 
verklaring bedenken dat een aantal huisartsen in ons onderzoek de omvang van de gezamenlijke praktijk heeft opgegeven in plaats van de individuele praktijk.

Nagegaan is in hoeverre huisartsen structureel, regelmatig, incidenteel, dan wel in het geheel geen contact onderhouden met hulpverleners uit de eerstelijn, met de Geestelijke Gezondheidszorg en met bedrijfs- en verzekeringsartsen.

De meeste huisartsen onderhouden regelmatig contact met collegae uit andere praktijken. Het betreft vooral deelname aan waarneemgroepen, Balintgroepen, PHV-bijeenkomsten en dergelijke. De contacten met andere hulpverleners uit de eerstelijn zijn voornamelijk ofwel incidenteel van aard, d.w.z. naar aanleiding van gevalsbehandelingen, ofwel structureel, met name als gevolg van instelling van home-teams of het verbonden zijn aan gezondheidscentra. Met de gezinszorg blijken de contacten iets minder intensief dan met het Algemeen Maatschappelijk Werk en de wijkverpleging.

Het beeld van de intensiteit van de samenwerking met het Algemeen Maatschappelijk Werk en de wijkverpleegkunde komt vrijwel overeen met de bevindingen van De Jonge (1988) onder een landelijke steekproef van huisartsen. Voor de samenwerking met andere huisartsen en de gezinszorg zijn geen vergelijkbare gegevens voorhanden.

Tabel 9.3 Contacten huisarts met eerstelijnswerkers

\begin{tabular}{lllll}
\hline $\mathrm{N}=78$ & Geen & Incidenteel & Regelmatig & Structureel \\
\hline Huisartsen & $0 \%$ & $9 \%$ & $73 \%$ & $18 \%$ \\
Algemeen Maatschappelijk Werk & $3 \%$ & $35 \%$ & $21 \%$ & $42 \%$ \\
Wijkverpleegkunde & $1 \%$ & $40 \%$ & $19 \%$ & $40 \%$ \\
Gezinszorg & $4 \%$ & $52 \%$ & $12 \%$ & $32 \%$ \\
\hline
\end{tabular}

De relaties met RIAGG, vrij gevestigde psychiaters of psychologen, bedrijfsartsen en verzekeringsgeneeskundigen bestaan slechts uit incidentele contacten naar aanleiding van gevalsbehandelingen. Bij de laatste twee typen contacten zijn de contacten die voortvloeien uit nevenwerkzaamheden als verzekerings- of bedrijfsarts, buiten beschouwing gelaten.

Tabel 9.4 Contacten huisarts met GGZ, bedrijfs- en verzekeringsartsen

\begin{tabular}{lrlll}
\hline $\mathrm{N}=78$ & Geen & Incidenteel & Regeimatig & Structureel \\
\hline RIAGG & $0 \%$ & $87 \%$ & $12 \%$ & $1 \%$ \\
Vrij gevestigden & $43 \%$ & $55 \%$ & $1 \%$ & $0 \%$ \\
Bedrijfsartsen & $5 \%$ & $93 \%$ & $1 \%$ & $0 \%$ \\
Verzekeringsartsen & $5 \%$ & $93 \%$ & $1 \%$ & $0 \%$ \\
\hline
\end{tabular}

De huisartsen zijn gevraagd welke methoden - een negental werden voorgelegd zij gebruikelijk toepassen ter reductie van onzekerheden die in een consult kunnen optreden. Daarbij blijken het terugbestellen van de patiënt en het achteraf consulteren van collegae-huisartsen de populairste methoden. Het minst in zwang bleken 
verwijzing en het voorschrijven van medicijnen. Hoewel het geringe animo voor doorverwijzen en medicatie beïnvloed kunnen zijn door sociale wenselijkheid, komt het ons voor dat in de antwoorden op deze vraag de geneigdheid van huisartsen om patiënten zolang mogelijk in eigen beheer te houden duidelijk weerspiegeld wordt. Ook de bevindingen van Foets c.s. (1991) onder een landelijke steekproef stemmen grotendeels met de onze overeen. Wel blijken de Limburgse huisartsen minder dan hun collegae elders in Nederland geneigd tot het aanvragen van laboratorium- en röntgenonderzoeken. Hier doet zich waarschijnlijk het effect van het Diagnostisch Coördinerend Centrum te Maastricht gevoelen dat sedert jaren door middel van terugkoppeling de huisartsen stimuleert in zorgvuldige selectie van deze aanvragen. (Pop en Winkens, 1989)

Factoranalyse leidt tot een tweetal dimensies waarop zes van de acht items indeelbaar waren: een open benadering, zowel naar de patiënt als naar collegae toe, en een medicaliserende benadering.

Tabel 9.5 Omgang van huisartsen met onzekerheid

Percentage huisartsen die de volgende manieren van omgang met onzekerheid in een consult (helemaal) hun stijl vinden:

\begin{tabular}{|c|c|c|}
\hline & $\begin{array}{l}\text { Limburg } \\
\mathrm{N}=76\end{array}$ & $\begin{array}{l}\text { Landelijk } \\
\text { (Foets C.S., 1991) } \\
\mathrm{N}=161\end{array}$ \\
\hline Aanvragen van laboratorium en röntgendiagnostiek²) & 34 & 67 \\
\hline Consulteren (direct) van collega huisarts(en $)^{1)}$ & 36 & 33 \\
\hline De onzekerheid aan de patiênt laten blijken ${ }^{1)}$ & 52 & 45 \\
\hline Consulteren (direct) van specialist(en)2) & 48 & 35 \\
\hline De echte probleemgevallen (achteraf) bespreken met collega's ${ }^{1)}$ & 69 & 64 \\
\hline De patiënt vragen na een paar dagen terug te komen & 69 & 80 \\
\hline Het eerst eens met een medicijnvoorschrift proberen ${ }^{2)}$ & 10 & 32 \\
\hline Zo snel mogelijk verwijzen & 1 & 4 \\
\hline De echte probleem gevallen (achteraf) bespreken met specialisten & 47 & 32 \\
\hline
\end{tabular}

1): Item behoort tot de schaal open stijl van omgang met onzekerheid.

2): Item behoort tot de schaal medicaliserende stijl van omgang met onzekerheid.

De huisartsen kregen ook tien psycho-sociale problemen voorgelegd met de vraag, in hoeverre ze deze tot hun taak als huisarts vonden behoren. De huisartsen blijken vooral werk- en sexuele problemen tot hun taak te rekenen. Het minst rekenen de huisartsen het tot hun taak om wanen te behandelen, patiënten met verslavingsproblematiek te begeleiden en ontspanningstherapie te bieden. Deze bevindingen stemmen in het algemeen overeen met die van De Ridder en Visser (1987) en Foets c.s. (1991). Met betrekking tot de meeste van de voorgelegde problemen is de verhouding overigens ongeveer fifty-fifty. Wel valt op, dat de problemen waarmee overspannen werknemers in de meeste gevallen te maken hebben, namelijk de werk- en relatieproblemen, door een ruime meerderheid van de huisartsen als een deel van hun taak gezien wordt. De Ridder en Visser vonden verder een sterk verband $(r=.62)$ tussen deze taakopvatting en het naar eigen opgave van huisartsen daadwerkelijk behandelen van de genoemde problemen. 
Tabel 9.6 Taakopvatting van huisartsen ten opzichte van psycho-sociale problemen

Percentage huisartsen die de volgende psycho-sociale problemen volledig of grotendeels tot hun taak rekenen

\begin{tabular}{|c|c|c|c|}
\hline & $\begin{array}{l}\text { Limburg } \\
N=76\end{array}$ & $\begin{array}{l}\text { Landelijk } \\
\text { (Foets c.s., } \\
1991 \text { ) } \\
\mathrm{N}=161\end{array}$ & $\begin{array}{l}\text { Drie regio's } \\
\text { (De Ridder en } \\
\text { Visser, 1987) } \\
N=208\end{array}$ \\
\hline Adviseren bij opvoedingsmoeilijkheden ${ }^{1)}$ & 40 & 59 & 43 \\
\hline Begeleiden van ex-psychiatrische patiënten²) & 56 & 60 & 45 \\
\hline Bespreken relatieproblemen echtpaar ${ }^{1)}$ & 65 & 58 & 50 \\
\hline Hulp bieden bij suïcidale neigingen 2$)$ & 64 & 48 & 55 \\
\hline Behandeling van lichte vorm van straatvrees ${ }^{2)}$ & 49 & 52 & 43 \\
\hline Bespreken van langdurige problemen op het werk ${ }^{1)}$ & 75 & 72 & 63 \\
\hline Ontspanningstherapie bij spanningsklachten ${ }^{1)}$ & 42 & 21 & 28 \\
\hline Hulp bieden bij sexuele moeilijkheden 1 ) & 74 & 60 & 61 \\
\hline Hulp bieden bij verslavingsproblematiek ${ }^{2)}$ & 26 & 25 & 21 \\
\hline Behandelen van wanen 2 ) & 19 & 13 & 17 \\
\hline
\end{tabular}

1): Item behoort tot de schaal psycho-sociale taakopvatting

2): Item behoort tot de schaal sociaal-psychiatrische taakopvatting

Factoranalyse leidt tot een tweetal factoren: een taakopvatting volgens welke het vooral tot de taak van de huisarts behoort om zich bezig te houden met levensproblemen, en een taakopvatting volgens welke de ondersteuning van patiënten met ernstige psychische problemen deel uitmaakt van de taak van de huisarts. Deze zijn respectievelijk aangeduid met psycho-sociale taakopvatting en sociaal-psychiatrische taakopvatting.

\subsubsection{De activiteiten van de huisarts}

Zoals in het vorige hoofdstuk is uiteengezet hadden in totaal 108 respondenten éen of meer keren contact met een huisarts. Voor de ziekmelding hadden 33 respondenten contact met hun huisarts, na de ziekmelding 103. Bij 11 respondenten was er na de ziekmelding geen enkel contact, d.w.z.: bij vijf heeft er geen enkel contact met de huisarts plaatsgevonden, bij zes is er na de ziekmelding niet opnieuw contact gelegd.

Zoals gebruikelijk begint het activiteitenpatroon van de huisarts met het "doorschouwen" van het door de patiënt aangeboden probleem, of dit nu uitmondt in het toekennen van een diagnostisch label of niet. Gevraagd naar hun diagnose bij het eerste contact in de onderzochte ziekte-episode - een contact dat dus ook voor de ziekmelding plaats heeft kunnen vinden - gaven enkelen aan geen diagnose gesteld te hebben. Een kleine meerderheid stelde een diagnose in termen van psycho-sociale problemen. De overigen besloten tot een somatische aandoening dan wel tot een combinatie van beide.

Het aantal huisartsen die enkel tot een somatische aandoening besloten, ligt tussen het aantal van 36 respondenten die uitsluitend lichamelijk klachten presenteerden, en dat van acht die ervan overtuigd waren aan een lichamelijke aandoenig te lijden. Overigens hadden twee van de 16 respondenten bij wie de huisarts enkel een 
Tabel 9.7 Diagnose huisarts

$N=100$

Psycho-sociale problemen

$62 \%$

Somatische aandoening

$14 \%$

Combinatie

$11 \%$

Geen diagnose gesteld

$11 \%$

somatische diagnose stelde, in het geheel geen somatische klachten gepresenteerd. De overige 14 hadden wel verscheidene lichamelijke klachten geuit. Ondanks het feit dat allen langer dan vier weken het werk verzuimden wegens overspanning, kwam de ze aard van de aandoening bij éen op de zeven huisartsen dus in het geheel niet over.

Gemiddeld ziet de huisarts de overspannen werknemer gedurende de verzuimperiode 5.2 maal. De contactfrequentie varieert van één, namelijk in ongeveer $15 \%$ der gevallen tot meer dan 10 in iets minder dan $10 \%$ der gevallen. De behandelingsduur van de huisarts bedraagt gemiddeld 13,6 weken oftewel ruim drie maanden. Er zijn evenwel grote verschillen in behandelingsduur tussen de respondenten. Een groot aantal respondenten is langer dan zes maanden bij de huisarts onder behandeling. De intensiteit van de contacten tussen huisarts en werknemer varieert tijdens de verzuimperiode tussen eenmaal per week en eenmaal per 39 weken bij een gemiddelde van ongeveer eens per zeven weken. Aangezien de spreiding in sterke mate bepaald wordt door de gevallen van eenmalig contact is ook de intensiteit berekend voor werknemers die twee maal of vaker met de huisarts contact hebben gehad. In dat geval varieert de intensiteit van énmaal per week tot eens in de 26 weken bij een gemiddelde van eens per vier weken.

Het beleid dat de huisarts ten tijde van het interview rapporteerde gevoerd te hebben of van plan te zijn alsnog te voeren, is in de volgende tabel weergegeven. Uiteraard zijn er door de huisarts ook combinaties van beleidslijnen vermeld.

Tevens is in deze tabel weergegeven wat de huisarts volgens de respondent gedurende de behandeling heeft afgesproken of gesuggereerd. Ook hier was meer dan één antwoord mogelijk. Om de tijdsperiode waarover beide informanten rapporteerden, zoveel mogelijk overeen te laten komen, zijn van de werknemer alleen de rapportages over de eerste twee maanden van de verzuimperiode bij dit overzicht betrokken. Overigens blijkt het beleid dat na twee maanden gevoerd wordt, het beeld niet veel te veranderen. Alleen het aantal verwijzingen naar specialisten en fysiotherapeuten neemt enigszins toe. Voor een goed begrip zij vermeld dat de meeste verwijzingen naar specialisten betrekking hebben op somatische specialisten.

De huisarts blijkt volgens beide bronnen een grote variëteit in hulpaanbod te bieden aan overspannen werknemers.

Er doen zich op bepaalde punten grote verschillen in rapportage voor die niet geheel zijn toe te schrijven aan het geringe verschil in het aantal respondenten 
Tabel 9.8 Beleid(splan) huisarts

\begin{tabular}{lll}
\hline & $\begin{array}{l}\text { Huisarts: } \\
\mathrm{N}=99\end{array}$ & $\begin{array}{l}\text { Werknemer: } \\
\mathrm{N}=103\end{array}$ \\
\hline Rust & $38 \%$ & $69 \%$ \\
Terugkomen & $50 \%$ & $52 \%$ \\
Diagnostiek & $10 \%$ & $14 \%$ \\
Voorschrift kalmeringsmiddel & $18 \%$ & $46 \%$ \\
Voorschrift (andere) medicamenten & $21 \%$ & $28 \%$ \\
Verwijzing naar specialist & $9 \%$ & $10 \%$ \\
Verwijzing naar fysiotherapeut & $5 \%$ & $8 \%$ \\
Verwijzing naar RIAGG & $5 \%$ & $5 \%$ \\
Verwijzing naar A.M.W. & $8 \%$ & $4 \%$ \\
Actieadvies algemeen & $8 \%$ & $6 \%$ \\
Leefregel & $7 \%$ & $2 \%$ \\
\hline
\end{tabular}

waarop de rapportage betrekking heeft, of aan het verschil in tijdsspanne waarover de activiteiten van de huisarts gemeten zijn. Het blijkt dat in veel meer gevallen medicijnen, met name psychofarmaca, voorgeschreven worden dan de huisarts geneigd is te rapporteren. Even merkwaardig zijn de verschillen tussen het aantal keren dat de huisarts leefregels en actie, met name naar het werk toe, zegt te adviseren en dat de respondenten deze rapporteren. Vermoedelijk ligt dit deels aan het minder directieve karakter van dit soort uitkomsten van huisartsconsulten. Dit verklaart misschien ook het verschil in rapportage van verwijzingen naar het Algemeen Maatschappelijk Werk.

De belangrijkste activiteiten betreffen volgens de huisarts het adviseren van rust en het terugbestellen van de patiënt. Volgens de werknemers zijn de belangrijkste activiteiten van de huisarts het adviseren rust te nemen, terugbestellen en het voorschrijven van psychofarmaca. De laatste weergave komt overeen met de gebruikelijke wijze waarop huisartsen patiënten met psychische problemen behandelen. (Ormel en Giel, 1983)

Het totaal aantal verwijzingen door de huisartsen, inclusief die naar alternatieve genezers en bedrijfsmaatschappelijk werkers, bedraagt volgens de rapportages van de 108 respondenten die de huisarts bezochten, 42. We geven in de volgende tabel het volledige verwijzingsgedrag van de huisarts weer. Tevens geven we het aandeel van de verwijzingen door de huisarts op het totaal aantal respondenten die een hulpverlener raadpleegden.

Het meest verwijzen huisartsen naar somatische specialisten en fysiotherapeuten: 23 keer. Door de huisarts zelf is in totaal 14 keer een respondent naar een instelling van Geestelijke Gezondheidszorg verwezen. Bij twee derde van de gevallen waarin ten behoeve van de respondent de GGZ ingeschakeld wordt, gebeurt dit zonder tussenkomst van de huisarts. Dat er geen verwijzingen zijn naar de verzekeringsgeneeskundige wekt geen bevreemding, als we beseffen dat vrijwel elke respondent min of meer automatisch opgeroepen zou worden voor het spreekuur van de 
Tabel 9.9 Verwijzingsgedrag huisarts

\begin{tabular}{lll}
\hline N=108 & Verwezen door huisarts & $\begin{array}{l}\text { Aandeel verwijzing huisarts } \\
\text { op totaal van inschakeling }\end{array}$ \\
\hline Somatisch specialist & $13 \%$ & $61 \%$ \\
Fysiotherapeut & $8 \%$ & $82 \%$ \\
RIAGG & $6 \%$ & $35 \%$ \\
AMW & $4 \%$ & $57 \%$ \\
Psycholoog/psychiater & $3 \%$ & $33 \%$ \\
Alternatieve genezer & $3 \%$ & $27 \%$ \\
Opname GGZ & $2 \%$ & $33 \%$ \\
Bedrijfsmaatschappelijk werker & $1 \%$ & $7 \%$ \\
\hline
\end{tabular}

verzekeringsgeneeskundige. Het valt op dat verwijzingen naar bedrijfsartsen geheel ontbreken.

In het hulpverlenersnetwerk blijken vanuit de huisarts de lijnen primair richting somatische hulpverlening te lopen. Verwijzingslijnen naar de Geestelijke Gezondheidszorg zijn er veel minder, terwijl de lijnen naar de sociaal-geneeskundige sector vrijwel geheel ontbreken.

Naast het beleid in het algemeen zijn de huisartsen en de respondenten ook expliciet gevraagd naar het beleid ten aanzien van het werk van de patiënt. Dit kwam geheel neer op het bespreken van de werksituatie en het geven van adviezen aan patiënten. De antwoorden van huisarts en patiënten blijken nu wat minder uiteen te lopen. Alleen vermeldt een groot deel van de respondenten van de huisarts het advies gekregen te hebben de werkstaking voort te zetten, waar de huisarts vermeldt tot werkstaking geadviseerd te hebben.

Het werk was, naar opgave van de huisarts zelf, in meer dan de helft van de gevallen geen onderwerp van beleid en evenmin van bespreking. In de overige gevallen was het vooral een advies van de huisarts om het werk te staken. Overigens gaven slechts zeven huisartsen aan dit ook concreet tegenover hun patiënt uitgesproken te hebben.

Advisering tot werkhervatting bleek nauwelijks onderdeel van het beleid van de huisarts. Ook advisering met betrekking tot acties die de respondent op en/of ten aanzien van het werk zou kunnen ondernemen, komt nauwelijks voor.

Tabel 9.10 Advies huisarts ten opzichte van het werk

\begin{tabular}{lcc}
\hline & Huisarts: & Werknemer: \\
& $N=90$ & $N=114$ \\
\hline Werk staken & $31 \%$ & $23 \%$ \\
Werkstaking continueren & $6 \%$ & $16 \%$ \\
Werk (gedeeltelijk) hervatten & $1 \%$ & $1 \%$ \\
Elders te solliciteren & $4 \%$ & $5 \%$ \\
Ontslagname op medische gronden & $1 \%$ & $1 \%$ \\
Actie te ondernemen op werk & $6 \%$ & $4 \%$ \\
Geen advies & $51 \%$ & $51 \%$ \\
\hline
\end{tabular}


Door ons is ook geprobeerd te achterhalen in hoeverre de huisarts geneigd is zich met andere hulpverleners te verstaan bij deze categorie patiënten. Gevraagd is of de huisarts naar aanleiding van het eerste consult contact met andere hulpverleners heeft opgenomen. Dit gebeurde in $11 \%$ van de gevallen.

\subsubsection{De contacten met de overige hulpverleners uit de curatieve sector}

Van de 114 respondenten zijn er 109 bij de huisarts langs geweest. Voor 60 van hen was de huisarts de enige hulpverlener binnen de curatieve sector met wie zij contact hebben gehad. De 49 overigen zijn bij éen of meer van de andere hulpverleners uit de curatieve sector onder behandeling geweest. De gemiddelde frequentie van de contacten en de gemiddelde duur van de behandelingen berekend over deze 49 respondenten staan in tabel 9.11 vermeld.

Voor alle hulpverleners geldt, ook in het geval dat het eerste contact met de werknemer voor de ziekmelding plaatsvond, dat zij na de ziekmelding contact hadden met de werknemer.

Tabel 9.11 Aantal contacten en behandelingsduur in de curatieve sector

\begin{tabular}{lccc}
\hline N=114 & $\begin{array}{c}\text { Betrokken bij } \\
\text { behandeling }\end{array}$ & $\begin{array}{c}\text { Gemiddeld aantal } \\
\text { contacten }\end{array}$ & $\begin{array}{l}\text { Gemiddelde duur } \\
\text { in weken }\end{array}$ \\
\hline Somatisch specialist & $19 \%$ & 3,8 & 13,3 \\
Fysiotherapeut & $9 \%$ & 17,8 & 9,0 \\
RIAGG & $14 \%$ & 8,7 & 16,4 \\
Algemeen Maatschappelijk Werk & $6 \%$ & 8,3 & 21,0 \\
Psycholoog of Psychiater & $8 \%$ & 13,9 & 9,3 \\
Opname GGZ & $4 \%$ & 2,2 & 22,3 \\
\hline
\end{tabular}

De frequentie van de contacten ligt veruit het hoogst bij de fysiotherapeuten gevolgd door vrijgevestigde psychologen of psychiaters, RIAGG, en Algemeen Maatschappelijk Werk. Per hulpverlener ligt het gemiddeld aantal contacten op 6,6.

Voor de respondenten geldt een gemiddelde van bijna 10 hulpverleningscontacten met de curatieve sector na hun ziekmelding. Dit aantal ligt lager dan bij de populaties van Soeters (1983), waar het gemiddelde 14,5 bedraagt, en Tordoir c.s. (1978), waar het gemiddelde 13,6 bedraagt. De duur van de behandeling varieert sterk. Voor elke hulpverlener is de standaarddeviatie hoger dan het gemiddelde van de behandelingsduur.

\subsection{Methode van onderzoek naar de invloed van wachttijden in de curatieve sector op het verzuimbeloop}

Ons onderzoek naar de invloed van wachttijden in de curatieve sector op het verzuimbeloop wijkt in een drietal opzichten af van die van Tordoir c.s. (1978) en Soeters (1983). 
Ten eerste is er bij de berekening van het aandeel der wachttijden door ons een minder verfijnd onderscheid gemaakt ten aanzien van de soorten wachttijden. Dit geldt niet voor de wachttijd die verloopt tussen het moment van de ziekmelding en het moment van het eerste behandelingscontact. Deze ontstaat meestal, zij het niet uitsluitend, als gevolg van het uitstelgedrag van de patiënt. In een aantal gevallen is er al sprake van behandeling en is het tijdsverloop na de ziekmelding afhankelijk van het moment waarop een vervolg- of verwijzingsconsult of -verrichting is vastgesteld.

Ook in ons onderzoek is het verschil berekend tussen ziekmelding en eerste consult. De overige wachttijden zijn door ons als één geheel berekend. De reden daarvan is de geringe mate van verwijzing, diagnostische verrichtingen en opnames. In tegenstelling tot Soeters, is bij de aanwezigheid van gelijktijdige behandelingen niet gekozen voor de "belangrijkste", maar zijn ze tezamen beschouwd als éen behandelingsproces.

De stuurloze periodes zijn op gelijke wijze als voorgaande onderzoeken berekend. Een tweede verschil is gelegen in de teleenheid. Tordoir c.s. en Soeters werken met dagen als eenheid. Door ons is de voorkeur gegeven aan weken. De reden is gelegen in de opvatting dat het tellen in dagen een schijnexactheid inhoudt. Enerzijds omdat meestal bijkomstigheden bepalend zijn voor het feit of een bepaald consult op een dinsdagmorgen of een woensdagmiddag plaatsvindt, anderzijds omdat respondenten in de meeste gevallen, zeker als de aandoening overspanning is, niet in staat zijn om over perioden van gemiddeld vier weken telkenmale exact te onthouden op welke dag een bepaalde gebeurtenis heeft plaatsgevonden.

Het dercle verschil is de definitie van behandelaar. Niet alleen medici en paramedici uit de curatieve sector zijn door ons als behandelaar opgevat. Immers afgezien van huisarts en GGZ zijn de meeste hulpverleners van overspannen werknemers buiten de curatieve sector werkzaam. Tot de populatie van hulpverleners behoren, zoals in het vorige deel beschreven, ook (bedrijfs)maatschappelijke werkers, bedrijfsartsen en "alternatieve" genezers.

\subsection{Resultaten}

\subsubsection{De omvang van de wachttijden}

In onderstaande tabel wordt een overzicht gegeven van het aandeel van de drie categorieën wachttijden op de totale verzuimduur. Deze gegevens betreffen de gehele groep respondenten. Tevens zijn ter vergelijking de bevindingen van Soeters (1983) en Tordoir c.s. (1978) opgenomen. Hun populaties betreffen GAK-verzekerden die werkzaam zijn in respectievelijk Zuid-Limburg en in de Randstad en vier weken of langer verzuimden. Ze omvatten alle diagnosegroepen.

De enige overeenkomst met de andere populaties is het aandeel van de gemiddelde wachttijd voor het eerste consult. Omdat in deze populatie de gemiddelde verzuimduur langer is, houdt dit in dat er langer gewacht wordt met het inroepen van een hulpverlener. Gemiddeld gaat het echter om een paar dagen. Uit de verdeling van dit type wachtdagen blijkt overigens dat het beeld in sterke mate 
Tabel 9.12 Aandeel wachttijden op totale verzuimduur

\begin{tabular}{|c|c|c|c|c|c|c|}
\hline \multirow[b]{2}{*}{ Wachttijd voor le consult } & \multicolumn{2}{|c|}{$\begin{array}{l}\text { Overspannen } \\
\text { Zuid-Limburg } \\
1988 / 1989 \\
N=107 \\
\text { Aantal weken }\end{array}$} & \multicolumn{2}{|c|}{$\begin{array}{l}\text { Alle diagnoses } \\
\text { Zuid-Limburg } \\
1981 / 1982 \\
N=137 \\
\text { Aantal weken }\end{array}$} & \multicolumn{2}{|c|}{$\begin{array}{l}\text { Alle diagnoses } \\
\text { Randstad } \\
1974 / 1975 \\
\mathrm{~N}=862 \\
\text { Aantal weken }\end{array}$} \\
\hline & 0,5 & $2 \%$ & 0,1 & $1 \%$ & 0,3 & $2 \%$ \\
\hline Verwijzingswachttijden & 0,9 & $4 \%$ & 2,1 & $13 \%$ & 2,6 & $16 \%$ \\
\hline Stuurloze perioden & 5,1 & $21 \%$ & 1.0 & $6 \%$ & 0,3 & $2 \%$ \\
\hline Totaal wachttijden & 6,5 & $27 \%$ & 3,2 & $20 \%$ & 3,2 & $20 \%$ \\
\hline Gemiddelde verzuimduur & 24,3 & $100 \%$ & 16,5 & $100 \%$ & 16,3 & $100 \%$ \\
\hline
\end{tabular}

bepaald wordt door het uitbijterfenomeen. Eén geval heeft een wachttijd aangehouden van 20 weken en neemt daarmee ruim $35 \%$ van het totaal voor zijn rekening. Als dit geval buiten beschouwing wordt gelaten, bedraagt de gemiddelde wachttijd 0,3 weken.

De verschillen met de bevindingen van Soeters worden voor een groot deel verklaard door de selectie naar diagnose. Het aandeel van de wachttijden in de totale verzuimduur van werknemers met psychische aandoeningen bedroeg bij Soeters $25 \%$, hetgeen nauwelijks verschilt van ons resultaat. Omdat het aandeel van de stuurloze periode bij diezelfde categorie $18 \%$ bedroeg, is het aandeel van de verwijzingswachtdagen en de wachttijd voor het eerste consult dus $7 \%$ bij Soeters. Dit betekent dus dat, ondanks het verschil in tijd en populatie, de omvang en verdeling der wachttijden in Zuid-Limburg voor werknemers met psychische aandoeningen constant is.

Een tweede conclusie is dat het aandeel van de verwijzingswachtdagen aanzienlijk lager ligt bij werknemers die wegens overspanning respectievelijk psychische aandoeningen verzuimen, dan bij werknemers die wegens andere aandoeningen verzuimen. Een verklaring daarvoor zou gelegen kunnen zijn in een geringer aantal respondenten dat verwezen wordt, hetgeen leidt tot een geringer aantal diagnostische verrichtingen, op de uitslag waarvan gewacht kan worden. Bij $54 \%$ van de respondenten is er van verwijzing en dergelijke in het geheel geen sprake. Een vrijwel gelijk cijfer geeft Soeters echter voor het aandeel niet-verwezenen voor de totale groep langdurige verzuimgevallen: $57 \%$. De verwijzingsgraad voor overspannen werknemers wijkt blijkbaar nauwelijks af van die van de totale populatie langverzuimers. Bij de respondenten die wel aan het risico van verwijzingswachttijden onderhevig zijn, bedraagt de omvang der wachttijden overigens gemiddeld 1,8 weken. Er blijft dus wel sprake van een enigszins kortere verwijzingswachttijd. Ook hier doet zich echter wel een uitbijtersfenomeen voor. Vier personen nemen met gemiddeld 15,5 weken ongeveer twee derde van alle wachttijden samen voor hun rekening. Daar staan 34 personen tegenover waarvan de wachttijd 0 weken bedraagt. Bij de overige 15 repondenten bedraagt de gemiddelde wachttijd 2,3 weken. 
Tabel 9.13 Verdeling wachttijden

\begin{tabular}{|c|c|c|c|c|}
\hline & $\begin{array}{l}\text { Aantal } \\
\text { gevallen }\end{array}$ & $\begin{array}{l}\text { Totaal aan- } \\
\text { tal weken }\end{array}$ & Aandeel & $\begin{array}{l}\text { Gemiddeld } \\
\text { aantal weken }\end{array}$ \\
\hline \multicolumn{5}{|c|}{ Duur melding hulpverlening } \\
\hline 0 weken & 93 & 0 & $0 \%$ & 0,0 \\
\hline 1-5 weken & 17 & 37 & $65 \%$ & 2,2 \\
\hline 20 weken & 1 & 20 & $35 \%$ & 20,0 \\
\hline Totaal & 111 & 57 & $100 \%$ & 0,5 \\
\hline \multicolumn{5}{|c|}{ Verwijzingswachttijden } \\
\hline Geen verwijzing & 61 & - & - & - \\
\hline 0 weken & 34 & 0 & $0 \%$ & 0,0 \\
\hline 1-7 weken & 15 & 35 & $36 \%$ & 2,3 \\
\hline 10-16 weken & 4 & 52 & $64 \%$ & 13,0 \\
\hline Totaal & 111 & 97 & $100 \%$ & 0,9 \\
\hline \multicolumn{5}{|l|}{ Stuurloze perioden } \\
\hline 0 weken & 46 & 0 & $0 \%$ & 0,0 \\
\hline 1-11 weken & 47 & 228 & $42 \%$ & 4,9 \\
\hline 14-19 weken & 7 & 111 & $20 \%$ & 15,9 \\
\hline 25-41 weken & 7 & 211 & $38 \%$ & 30,1 \\
\hline Totaal & 107 & 550 & $100 \%$ & 5,1 \\
\hline
\end{tabular}

De totale omvang van de stuurloze perioden is bij overspannen werknemers beduidend groter dan bij andere categorieën. Ruim $20 \%$ van alle verzuimdagen bestaat daaruit.

Hoewel hier in mindere mate sprake is van een uitgesproken uitbijterfenomeen, is de verdeling onder de respondenten scheef. Van alle respondenten ondervonden er $40 \%$ in het geheel geen stuurloze periode. Dat is minder dan gebruikelijk bij langverzuimers, daar Soeters bij ruim $70 \%$ geen stuurloze periodes aantrof. Bij de respondenten met stuurloze periodes nemen zeven personen $40 \%$ van het totaal van stuurloze perioden voor hun rekening en nog eenzelfde aantal $20 \%$.

Nadere inspectie van de gegevens wijst uit dat een hoge score op de ene soort wachttijd in geen enkel geval gepaard gaat met een extreem hoge score op een andere soort. Het is of lang uitstellen van het hulpverleningscontact of lange wachttijden of lange stuurloze perioden.

Verwijzingswachttijden komen voor bij de meerderheid van degenen die naar specialisten, RIAGG, of vrijgevestigde psychiaters of psychologen verwezen zijn. Bij degenen die naar alternatieve genezers, voor opname in een GGZ-instelling, of naar een hulpverlener buiten de (para)medische sector zijn verwezen, komen ze echter nauwelijks voor.

Lange stuurloze perioden daarentegen doen zich vooral voor bij degenen die naar hulpverleners buiten de (para)medische sector zijn verwezen, of in het geheel niet zijn verwezen. Bij de overigen komen ze nauwelijks voor. Deze bevinding is weinig verrassend op grond van de omschrijving van wat een stuurloze periode inhoudt: 
er is geen behandeling aan de gang en er is geen enkel plan voor behandeling uitgezet.

\subsubsection{De relatie tussen wachttijden en verzuimbeloop}

Degenen die niet direct binnen een week na de ziekmelding contact hebben gelegd met een hulpverlener, blijken in mindere mate het werk te hervatten en iets langer te verzuimen. De verschillen blijken echter bij toetsing door middel van de $x^{2}$-toets respectievelijk de F-toets statistisch niet significant.

De relatie tussen verwijzingswachttijden en beloop ligt iets gecompliceerder. De groep die verwezen wordt, heeft een gemiddelde verzuimduur die aanzienlijk hoger ligt dan de groep die niet verwezen wordt. De gemiddelde duur bedraagt bij de verwezenen 30,3 weken. Dit wordt grotendeels veroorzaakt, doordat driekwart van de WAO-intreders op enigerlei wijze doorverwezen wordt. Van de overigen wordt $40 \%$ doorverwezen.

Als er doorverwezen wordt, blijkt de aanwezigheid van wachttijden nauwelijks van invloed op de duur van het verzuim, maar wel en op een onverwachte manier op de afloop. Degenen die geen wachttijden hebben "opgelopen", blijken voor het merendeel het werk niet te hervatten, voornamelijk als gevolg van WAO-intrede. De samenhang kan dus als U-vormig beschouwd worden.

Tabel 9.14 Samenhang wachttijden en verzuimbeloop

\begin{tabular}{llllll}
\hline & & Hervat & Ontslag(name) & WAO-intrede & Gemiddelde duur \\
\hline $\begin{array}{l}\text { Uitstelgedrag } \\
\text { Geen uitstel }\end{array}$ & $\mathrm{N}=87$ & $60 \%$ & $20 \%$ & $21 \%$ & 23,7 \\
$\quad$ Uitstel & $\mathrm{N}=18$ & $44 \%$ & $28 \%$ & $28 \%$ & 26,7 \\
& & & & & \\
$\begin{array}{l}\text { Verwijzingswachttijd } \\
\text { Geen verwijzing }\end{array}$ & $\mathrm{N}=52$ & $71 \%$ & $19 \%$ & $10 \%$ & 18,8 \\
$\begin{array}{l}\text { Geen wachttijd } \\
\text { Wachttijd }\end{array}$ & $\mathrm{N}=32$ & $34 \%$ & $25 \%$ & $41 \%$ & 30,5 \\
& $\mathrm{~N}=17$ & $65 \%$ & $11 \%$ & $24 \%$ & 30,0 \\
$\begin{array}{l}\text { Stuurloze periodes } \\
\text { Geen }\end{array}$ & & & & & \\
$\quad$ Kort & $\mathrm{N}=42$ & $52 \%$ & $12 \%$ & $36 \%$ & 30,8 \\
Lang & $\mathrm{N}=46$ & $72 \%$ & $20 \%$ & $9 \%$ & 16,4 \\
\hline & $\mathrm{N}=13$ & $31 \%$ & $46 \%$ & $23 \%$ & 32,1 \\
\hline
\end{tabular}

De samenhang tussen de lengte van stuurloze perioden en verzuimbeloop geeft eveneens een U-vormig beeld zoals bij de verwijzingswachttijden. De groepen zonder stuurloze perioden en met zeer lange stuurloze perioden tonen een gemiddelde duur van 30,8 respectievelijk 32,1 weken, terwijl de groep met relatief korte stuurloze perioden gemiddeld 16,4 weken verzuimt. De kans op werkhervatting is het hoogst bij de groep met de korte stuurloze perioden, terwijl het aandeel van de WAO-intreders het hoogst is bij de groep zonder stuurloze perioden. Opvallend is de aanwezigheid van langdurige stuurloze perioden bij degenen die ontslag nemen. De verzuimduur wordt hier bepaald door het afwachten van een nieuwe 
werkkring of een overeenkomst tussen verzekeringsgeneeskundige en werknemer over een datum waarop de ziektewetuitkering gestaakt wordt. Deze processen behoeven en krijgen nauwelijks ondersteuning vanuit de curatieve sector.

Samenvattend kan gesteld worden dat het risico voor WAO-intrede en lange verzuimduren hoger is bij de groepen met uitstelgedrag, zonder verwijzingswachttijden en waarbij stuurloze periodes of ontbreken of langdurig zijn.

De eerdere bevinding dat lange wachttijden van het ene soort vrijwel altijd samengaan met afwezigheid van het andere soort, kan een verklaring vormen voor de U-vormige samenhangen. Daarom zijn de uitstelperiode, wachttijden en stuurloze perioden opgeteld en zijn de samenhangen met duur en afloop op basis van het totaal onderzocht.

Tabel 9.15 Samenhang totaal wachttijden en verzuimbeloop

\begin{tabular}{|c|c|c|c|c|c|}
\hline & & Hervat & Ontslag(name) & WAO-intrede & Gemiddelde duur \\
\hline 0 weken & $\mathrm{N}=29$ & $55 \%$ & $10 \%$ & $34 \%$ & 24,6 \\
\hline $1-4$ weken & $N=27$ & $81 \%$ & $4 \%$ & $15 \%$ & 20,9 \\
\hline 5-12 weken & $N=28$ & $50 \%$ & $36 \%$ & $14 \%$ & 20,5 \\
\hline 14-44 weken & $N=17$ & $41 \%$ & $35 \%$ & $24 \%$ & 31,6 \\
\hline
\end{tabular}

WAO-intrede blijkt nu relatief vaker voor te komen onder werknemers die in het geheel geen wachttijden of stuurloze perioden hebben doorgemaakt of juist langdurige. Degenen die ontslag nemen of krijgen al dan niet gevolgd door een nieuwe werkkring, blijken relatief vaker langere wachttijden of stuurloze perioden door te maken.

\subsection{Conclusies en beschouwing}

Binnen de curatieve sector is in beginsel de huisarts de spil van de hulpverlening aan overspannen werknemers. Enerzijds is dit het gevolg van de structurele positie die de huisarts als poortwachter naar andere gezondheidszorgvoorzieningen inneemt, anderzijds is dit gelegen in de taakopvatting van de meerderheid der huisartsen die inhoudt dat de huisarts een aangewezen instantie is voor de behandeling van onder meer werk- en relatieproblemen. Een taakopvatting die bovendien ondersteund wordt door de nota "Basistakenpakket van de huisarts" van de Landelijke Huisartsen Vereniging. (Van Dijk en Hogervorst, 1991)

Niet alle overspannen werknemers echter bieden hun aandoening aan de huisarts ter behandeling aan. Andere presenteren hun aandoening zo onduidelijk dat de huisarts de overspanning niet opmerkt. Naast de kleine $5 \%$ die de huisarts helemaal niet raadpleegt, blijkt in nog eens meer dan $10 \%$ der gevallen de huisarts slechts ingeschakeld bij lichamelijke comorbiditeiten. Bij maximaal $85 \%$ der werknemers komt de overspanning bij de huisarts wel duidelijk op tafel. 
De feitelijke hulpverlening van de huisarts blijkt in de meerderheid der gevallen te bestaan uit het adviseren van rust, het voorschrijven van medicijnen, waarbij vooral sprake is van psychofarmaca, die huisartsen blijkens de opgave van hun patiënten veel vaker voorschrijven dan zij zelf rapporteren, en een uitnodiging aan de patiënt om nog eens op gesprek te komen.

Verwijzen doet de huisarts veel minder. Als verwijzing plaatsvindt, geschiedt dit vaker naar specialisten en fysiotherapeuten dan naar het RIAGG of het Algemeen Maatschappelijk Werk. In verreweg de meeste gevallen houdt de huisarts de patiënt onder eigen hoede. Daar staat tegenover dat in een groot aantal gevallen de patiënt zelfstandig of via andere hulpverleners zijn weg vindt naar andere hulpverleningsinstanties.

In iets meer dan de helft der gevallen blijft de werksituatie onbesproken, hoewel de aandoening waarvoor de huisarts geraadpleegd wordt, tot meer dan vier weken verzuim leidt en in de meeste gevallen gezien wordt als (mede) veroorzaakt door de werksituatie. Voorzover dit wel het geval is, blijkt de huisarts vooral tot werkstaking te adviseren of, indien deze reeds heeft plaatsgevonden, de werkstaking te ondersteunen.

Opvallend is in dit verband het vrijwel ontbreken van verwijzingen naar de bedrijfsen verzekeringsgeneeskundige sector. Ook is er van de kant van de huisarts bijna geen enkel contact gelegd met bedrijfs- of verzekeringsgeneeskundigen. Slechts in een enkel geval heeft een huisarts contact opgenomen met de werkgever of de verzekeringsgeneeskundige. Het wordt aan de verzekeringsgeneeskundige overgelaten om contact op te nemen met de huisarts. De algemeen door huisartsen ondersteunde opvatting dat behandeling van langdurige werkproblemen tot de taak van de huisarts behoren, wordt bij de meeste gevalsbehandelingen van overspannen werknemers niet in praktijk gebracht.

Het probleem van de wachttijden en de stuurloze perioden in de gezondheidszorg doet zich ook en nog steeds voor bij werknemers die verzuimen wegens overspanning. Ruim een kwart van alle verzuimdagen gaat hieraan verloren. Daarvan wordt het overgrote deel voor rekening genomen door stuurloze perioden. Verwijzingen en het uitstellen door de werknemer van het eerste bezoek aan een hulpverlener, meestal de huisarts, leiden tot een veel geringer tijdverlies. Bij de verwijzingen is dit deels het gevolg van het betrekkelijk geringe aantal verwijzingen. Daarbij blijken overigens vrijwel uitsluitend de verwijzingen naar de Geestelijke Gezondheidszorg met wachttijden gepaard te gaan. Zowel uitstelgedrag als verwijzingswachttijden als stuurloze perioden blijken verschijnselen te zijn die zich slechts bij een beperkt deel van de respondenten voordoen, namelijk bij 15 a $20 \%$, wat betreft de eerste twee, en bij $60 \%$, wat betreft de stuurloze periodes. Daarbij blijken deze drie vormen van stagnatie niet cumulatief, maar alternatief op te treden.

Het aandeel van de wachttijden en de stuurloze perioden op de totale verzuimduur lijkt, gezien de bijna gelijke bevindingen van Soeters begin jaren tachtig, een vrij constant gegeven te zijn.

Tussen uitstelgedrag en verzuimbeloop bestaat nauwelijks enige relatie. Wel geldt dit voor verwijzingen en verwijzingswachttijden. Verwijzingen leiden tot lange ver- 
zuimduren - gemiddeld ruim een half jaar -, waarbij verrassend genoeg de wachttijden met name optreden bij werkhervatters en in mindere mate bij WAO-intreders. Stuurloze periode hebben een U-vormige samenhang met verzuimduur en de wijze van verzuimbeëindiging. Zowel het ontbreken van stuurloze perioden als een lange duur daarvan blijken samen te kunnen gaan met een lange verzuimduur en een grotere kans op WAO-intrede.

Deze laatste bevinding geeft aanleiding tot de veronderstelling dat de volgende twee processen kunnen plaatsvinden in de curatieve gezondheidszorg bij de behandeling van overspannen werknemers: er vindt enerzijds een intensieve begeleiding plaats bepaald door de ernst en/of de behandelbaarheid van de overspanning, waarbij een langdurig verzuim onvermijdelijk is, en er treedt anderzijds een nonchalance op die, ongeacht de ernst van de overspanning, de werknemer af doet glijden naar de status van langdurige of blijvende arbeidsongeschiktheid. 


\section{Hoofdstuk 10}

\section{De verzekeringsgeneeskundige en het verzuimbeloop}

\section{$10.1 \quad$ Inleiding}

Evenals in het vorige hoofdstuk wordt begonnen met een beschrijving van enkele kenmerken van de verzekeringsgeneeskundigen en van de door hen ondernomen begeleidingsactiviteiten. Daarna volgt een berekening van de wachttijden die binnen het uitvoeringscircuit van Ziektewet en WAO kunnen ontstaan als gevolg van tijdsverloop tussen ziekmelding en eerste spreekuurcontact met de werknemer, tussen het laatste spreekuurcontact en verzuimbeëindiging, en het tijdsverloop als gevolg van overdracht van de gevalsbegeleiding door de verzekeringsgeneeskundige van het GAK aan de GMD, indien er een kans bestaat op WAO-intrede.

\subsection{Enkele kenmerken van de verzekeringsgeneeskundigen}

De acht in het onderzoek betrokken verzekeringsgeneeskundigen zijn allen mannen, in leeftijd variërend van 37 tot 43 jaar. Drie zijn korter, vijf langer dan vijf jaar als verzekeringsgeneeskundige werkzaam. Op de afwezigheid van éen of twee vrouwen na vormt deze groep een representatieve vertegenwoordiging van de populatie GAK-verzekeringsgeneeskundigen. (Van Eck, 1990) Zes werken full-time als verzekeringsgeneeskundige, twee half-time in combinatie met een half-time werkkring als huisarts. Eenn verzekeringsgeneeskundige heeft als werkgebied eén enkel bedrijf, zes hadden een geografisch rayon als werkgebied en éen had zowel een geografisch gebied als een aantal bedrijven als werkterrein. Allen zijn met betrekking tot één of meerdere bedrijven contact-verzekeringsgeneeskundige, d.w.z.: zij zijn contactpersoon naar het bedrijf toe vanwege de medische dienst van het GAK.

In $32 \%$ van de gevallen kende de verzekeringsgeneeskundige de respondent reeds van voor de actuele verzuimperiode. De overige $68 \%$ der respondenten waren de betrokken verzekeringsgeneeskundige tot dan toe onbekend. Voor een groot deel is dit het gevolg van rayonwijzigingen en onderlinge vervangingen, aangezien $25 \%$ van de respondenten op grond van eerder langdurig verzuim wel ooit contact gehad had met een andere verzekeringsgeneeskundige van het district waartoe de respondent behoort. 
De volgende tabel verschaft inzicht in de mate waarin verzekeringsgeneeskundigen bekend zijn met de bedrijven waarbij de respondenten werkzaam zijn.

Tabel 10.1 Mate van bekendheid met bedrijf

\begin{tabular}{lc}
\hline & $\mathrm{N}=109$ \\
\hline Onbekend & $62 \%$ \\
Bekend & $24 \%$ \\
Contact-verzekeringsgeneeskundige & $6 \%$ \\
Bedrifsgebonden rayon & $8 \%$ \\
\hline
\end{tabular}

In bijna twee derde van de gevallen kent de verzekeringsgeneeskundige het bedrijf niet. Niet verrassend is dan ook dat in bijna de helft van de gevallen de verzekeringsgeneeskundige niet kan aangeven welke gezondheidsrisico's de arbeidsplaats van de respondent inhoudt, en evenmin of er enige voorziening ten behoeve van bedrijfsgezondheidszorg aanwezig is.

\subsection{De handelingen van de verzekeringsgeneeskundigen}

In de regel begint het optreden van de verzekeringsgeneeskundige met het overleg met de lekenrapporteur op basis van diens bevindingen bij een huisbezoek aan de werknemer naar aanleiding van de ziekmelding. Gemiddeld vindt dit overleg na 2,6 weken plaats. Het tijdsverloop varieert van éen dag tot - in drie gevallen - zeven weken. Na vier weken is bijna $90 \%$ besproken. In ongeveer driekwart van de gevallen volgt een oproep voor het spreekuur. In vrijwel alle andere gevallen blijft de rapporteur belast met de controle. In enkele gevallen neemt de rapporteur of de respondent zelfstandig het initiatief tot een spreekuurcontact.

Het tijdsverloop tussen ziekmelding en het eerste spreekuurcontact bedraagt gemiddeld 5,5 weken. Dit verloop varieert van eén week tot 22 weken. Na vijf weken is iets meer dan de helft door de verzekeringsgeneeskundige gezien, na twee maanden $90 \%$. Drie respondenten zijn na drie maanden voor het eerst op het spreekuur verschenen. Bij éen daarvan was dit het gevolg van een regeling die nogal eens toegepast wordt bij een aantal grotere bedrijven, dat de verzuimcontrole gedurende de eerste tien weken aan het bedrijf is gedelegeerd. Eén respondent ten slotte is als gevolg van langdurige opnames op een PAAZ in het geheel niet gezien door de verzekeringsgeneeskundige.

De belangrijkste redenen voor een oproep voor het spreekuur zijn: de duur van het verzuim $(53 \%)$, de aard van de klachten (24\%), en het verzuimverleden, d.w.z.: er is sprake van een recidive (11\%). In $13 \%$ van de gevallen kon er geen expliciete reden voor de oproep gegeven worden.

In vrijwel alle gevallen werd bij dat contact als diagnose overspanning gesteld, met name in de vorm van situatieve of exogene reactie: 
Tabel 10.2 Diagnosestelling eerste contact

\begin{tabular}{lc}
\hline & $\mathrm{N}=109$ \\
\hline Situatieve of exogene reactie & $91 \%$ \\
Fysiologische functiestoornissen & $6 \%$ \\
met psychische oorzaken & $1 \%$ \\
Overige chronische hartziekten & $1 \%$ \\
Overige ziekten maag-darmkanaal & $1 \%$ \\
Nekklachten & \\
\hline
\end{tabular}

In de drie laatste gevallen heeft er dus een wijziging in diagnose plaatsgevonden naar overspanning. Door Van Eck (1991) wordt gesuggereerd dat het toekennen van de diagnose situatieve of exogene reactie in een aantal gevallen een voorlopige toekenning betreft, waarna op grond van aanvullende gegevens de verzekeringsgeneeskundige kan besluiten tot het definitief vaststellen van de aard van een ernstigere psychopathologie. Ons is hiervan niets gebleken. Diagnosecodes werden niet veranderd. Evenmin bleek er op grond van onze interviews sprake van verborgen gevallen van ernstiger stoornis. Wel kwamen er bijkomende aandoeningen voor die in een enkel geval tot een verlenging van het verzuim leidden na het herstel van de overspanning.

Omtrent de arbeidsgeschiktheid oordelen de verzekeringsgeneeskundigen tijdens het eerste contact dat ruim $75 \%$ arbeidsongeschikt is waarvan $5 \%$ gedeeltelijk. Van ruim $15 \%$ luidt het oordeel: niet arbeidsongeschikt. Bij $25 \%$ wordt direct op werkhervatting aangestuurd.

In bijna $30 \%$ van de gevallen blijft het bij een éénmalig spreekuurcontact met de werknemer. In bijna $15 \%$ vinden vijf of meer contacten plaats. Het gemiddeld aantal contacten is 2,9. Als we de intensiteit van contact meten door middel van deling van het aantal contacten door de verzuimduur, dan blijkt de verzekeringsgeneeskundige in geval van overspanning de werknemer gemiddeld eens in de zes weken te spreken. Voor WAO-intreders ligt de intensiteit lager, namelijk op eens in de veertien weken, voornamelijk als gevolg van een lange contactloze periode aan het eind van het Ziektewetjaar. Er is overigens in een aantal gevallen ook sprake van telefonische contacten of briefwisseling. Huisbezoek vindt sporadisch plaats.

In tabel 10.3 wordt een overzicht geboden van de activiteiten van de verzekeringsgeneeskundige. Per activiteit wordt weergegeven ten aanzien van welk percentage van de respondenten deze éen- of meermalen is uitgevoerd. Tevens is aangegeven bij welk percentage de activiteit op initiatief van de verzekeringsgeneeskundige heeft plaatsgevonden.

Het aantal contacten met de curatieve sector ligt erg laag. In $10 \%$ der gevallen is er contact met de huisarts. Deze - in alle gevallen eenmalige - contacten vinden gemiddeld na ruim 10 weken plaats. In bijna alle gevallen ligt het initiatief hier bij de verzekeringsgeneeskundige. In slechts één geval heeft de huisarts op eigen initiatief contact opgenomen met de verzekeringsgeneeskundige. Van de $10 \mathrm{con}-$ tacten hebben er drie betrekking op WAO-intreders en drie op werknemers die 
Tabel 10.3 Overzicht activiteiten verzekeringsgeneeskundigen

\begin{tabular}{lrc}
\hline N=111 & Totaal & $\begin{array}{l}\text { Op inititiatief van de } \\
\text { verzekeringsgeneeskundige }\end{array}$ \\
\hline Overleg rapporteur & & n.v.t. \\
Spreekuurcontact & $100 \%$ & $87 \%$ \\
Huisbezoek & $99 \%$ & $2 \%$ \\
Ander contact met werknemer & $2 \%$ & $4 \%$ \\
Contact met huisarts & $8 \%$ & $7 \%$ \\
Informatievraag specialist & $10 \%$ & $6 \%$ \\
Contact met bedrijf & $6 \%$ & $13 \%$ \\
Hersteldverklaring & $30 \%$ & $60 \%$ \\
Melding aan GMD & $60 \%$ & $28 \%$ \\
\hline
\end{tabular}

ontslag op medisch gronden genomen hebben. Met de specialisten wordt alleen contact gelegd via schriftelijke verzoeken om informatie. Dit gebeurde in zeven gevallen. Er blijken geen specialisten contact op te nemen met de verzekeringsgeneeskundige.

$\mathrm{Er}$ is geen verschil waargenomen tussen de verzekeringsgeneeskundigen in de mate waarin met de curatieve sector contacten gelegd is.

Het aantal contacten met het bedrijf is iets omvangrijker dan met de curatieve sector. Toch vinden deze nog altijd in de minderheid van de gevallen plaats. In bijna $70 \%$ der gevallen vindt in het geheel geen contact plaats. In ruim $15 \%$ der gevallen waarbij contact plaatsvindt met het bedrijf, is dit éenmalig en in 10 à $15 \%$ twee tot zeven keer. Het eerste contact vindt gemiddeld na ruim 10 weken plaats, maar de spreiding is groot: vanaf de week van de ziekmelding tot 46 weken nadien. De intensiteit bedraagt in geval van contact(en) eens per drie maanden. Ze is het laagst bij WAO-intreders. Daar bedraagt het aantal contacten gemiddeld 0,5 oftewel in ongeveer de helft der gevallen vindt er geen contact met het bedrijf plaats. Meer dan de helft van de contacten wordt geinitieerd door het bedrijf. De consequenties van de contacten zijn zeer verscheiden, in volgorde van frequentie: geen (8x), melding bij de GMD (7x), gedeeltelijke werkhervatting $(6 x)$, hervatting met aangepast werk (4x), ontslag op medische gronden en volledige werkhervatting.

Tabel 10.4 Relatie met bedrijf en contact

\begin{tabular}{lccc}
\hline & \multicolumn{2}{l}{ Contact van de kant van: } \\
\cline { 2 - 3 }$N=111$ & $\begin{array}{l}\text { Verzekerings- } \\
\text { geneeskundige }\end{array}$ & Bedrijf & Totaal \\
\hline Onbekend met bedrijf $(\mathrm{N}=67)$ & $7 \%$ & $14 \%$ & $21 \%$ \\
Bekend met bedrijf $(\mathrm{N}=26)$ & $12 \%$ & $19 \%$ & $31 \%$ \\
Contact-verz geneeskundige $(\mathrm{N}=6)$ & $50 \%$ & $0 \%$ & $50 \%$ \\
Bedrijfsgebonden verz.geneesk. $(\mathrm{N}=9)$ & $33 \%$ & $44 \%$ & $77 \%$ \\
Totaal & $13 \%$ & $17 \%$ & $30 \%$ \\
\hline
\end{tabular}


Het opnemen van contact met een bedrijf van de kant van de verzekeringsgeneeskundige blijkt samen te hangen met de volgende factoren: de verzekeringsgeneeskundige ziet het werk als oorzaak, een grotere mate van bekendheid met het bedrijf, de aanwezigheid van een bedrijfsarts, en een langere verzuimduur. Uit een logistische regressie-analyse met deze factoren als onafhankelijke variabelen blijkt dat deze factoren de voorspelbaarheid van contacten met het bedrijf significant verbeteren. Onderlinge constanthouding voor andere variabelen levert als resultaat op dat alleen de mate van bekendheid met het bedrijf significant samenhangt met het al dan niet contact opnemen met het bedrijf.

In het geval dat de verzekeringsgeneeskundige contactpersoon tussen de medische dienst van het GAK en het bedrijf is, blijkt het aantal contacten het hoogst en komt het initiatief vaker van de verzekeringsgeneeskundige dan van het bedrijf. In het bedrijfsgebonden rayon is er in vrijwel alle gevallen contact. Als we de verzekeringsgeneeskundige aan wie het bedrijfsgebonden rayon is toegewezen, buiten beschouwing laten, blijkt er tussen de individuele verzekeringsgeneeskundigen geen verschil in bedrijfsgerichte activiteiten.

\subsection{De omvang van de wachttijden bij de verzekeringsgenees- kundige begeleiding}

In de onderzoeken van Soeters (1983) en Tordoir c.s. (1978) zijn de contacten met de verzekeringsgeneeskundige buiten beschouwing gebleven, omdat zij niet behoren tot activiteiten van de curatieve gezondheidszorg. Toch is het handelen van de verzekeringsgeneeskundige van belang voor de verzuimduur en de kans op werkhervatting. Bij deze procesanalyse worden twee soorten wachttijden onderscheiden: de tijd die verloopt tussen ziekmelding en eerste spreekuurcontact, aan te duiden met controlewachttijd, en de tijd die verloopt tussen het laatste spreekuurcontact en de beëindiging van het ziekteverzuim. De laatste wordt door ons aangeduid met eindwachttijd.

De omvang van deze wachttijden toont tabel 10.5 Daarbij is een vergelijking gemaakt met twee groepen verzuimgevallen uit de $6 \%$-steekproef van het GAK van verzuimgevallen uit dezelfde regio en dezelfde periode.

Tabel 10.5 Omvang wachttijden bij verzekeringsgeneeskundige

\begin{tabular}{lrrrrrr}
\hline & \multicolumn{2}{c}{$\begin{array}{c}\text { Overspanning } \\
\mathrm{N}=114\end{array}$} & \multicolumn{2}{c}{$\begin{array}{c}\text { Bewegingsapparaat } \\
\mathrm{N}=353\end{array}$} & \multicolumn{2}{c}{$\begin{array}{c}\text { Overige aandoeningen } \\
\mathrm{N}=322\end{array}$} \\
\hline Controlewachttijd & 5,1 & $21 \%$ & 5,2 & $25 \%$ & 5,6 & $31 \%$ \\
Begeleidingstijd & 10,0 & $42 \%$ & 11,4 & $55 \%$ & 7,9 & $43 \%$ \\
Eindwachttijd & 8,7 & $37 \%$ & 4,3 & $21 \%$ & 4,8 & $26 \%$ \\
Verzuimduur & 23,8 & $100 \%$ & 20,9 & $100 \%$ & 18,3 & $100 \%$ \\
\hline
\end{tabular}

Voor een goede interpretatie moet het volgende bedacht worden. Een verzekeringsgeneeskundige is genoodzaakt uit het grote aanbod van ziekmeldingen sa- 
men met de lekenrapporteur een selectie te maken. Eén criterium is dat er sprake is van een langdurig verzuim. Om een correctie aan te brengen zou twee à vier weken afgetrokken moeten worden van de controlewachttijd als zijnde standaardwachttijd. De absolute omvang van de controlewachttijd blijkt dan ook voor alle diagnosecategorieën ongeveer gelijk. Bij statistische toetsing door middel van de Student's t-toets zijn de verschillen desondanks significant bij een waarschijnlijkheidsniveau van .01 . Bij psychische aandoeningen en aandoeningen aan het bewegingsapparaat vindt er eerder contact plaats tussen de verzekeringsgeneeskundige en werknemer.

Gedurende het grootste deel $(58 \%)$ van de verzuimperiode is er in geval van overspanning gemiddeld genomen geen sprake van contactuele begeleiding door de verzekeringsgeneeskundige. Dit blijkt ook bij de meeste andere diagnosegroepen het geval. Alleen bij aandoeningen van het bewegingsapparaat maakt de begeleidingstijd meer dan de helft van de verzuimduur uit. Het onderscheid tussen psychische aandoeningen en de andere diagnosegroepen blijkt zich vooral voor te doen bij de periode tussen het laatste contact en de verzuimbeëindiging. Deze wachttijd is bij overspannen werknemers ongeveer tweemaal zo lang als bij andere ziektegevallen. Het significantieniveau van de verschillen tussen de overspannen werknemers en de beide andere afzonderlijke groepen ligt bij toepassing van de Student's t-toets lager dan .001. Relatief gezien houdt de begeleiding van de overspannen werknemer op na twee derde van de verzuimperiode, terwijl deze bij andere diagnosegroepen pas na ongeveer drie kwart van de verzuimperiode ophoudt.

Ten aanzien van de wachttijd tussen het laatste contact van de werknemer met de verzekeringsgeneeskundige en de verzuimbeëindiging moet in het oog gehouden worden dat, afhankelijk van de wijze van verzuimbeëindiging, er verschillende processen gaande zijn die elk verschillen in betekenis aan deze wachttijd kunnen geven. Het kan bij werkhervatting gaan om uitstelgedrag van de werknemer, bij WAO-intrede om wachttijd voor begeleiding door de GMD, bij ontslag(name) zonder nieuwe werkkring om een onderhandelingsproces tussen verzekeringsgeneeskundige en werknemer omtrent een termijn om ander werk te zoeken dan wel in werkloosheid te berusten, en bij werkhervatting in een nieuwe werkkring om frictietijd in verband met aanstellingsformaliteiten.

Uit de berekening voor elke wijze van verzuimbeëindiging afzonderlijk blijkt dat de controlewachttijden voor de genoemde vier categorieën van verzuimbeëindiging niet veel verschillen. Deze verschillen zijn in tegenstelling tot de overige statistisch niet significant. Bij de verzuimbeëindiging is het verschil tussen WAO-intreders en de overigen wel opvallend. Tussen het laatste contact met de verzekeringsgeneeskundige van het GAK en het moment waarop de maximum-Ziektewettermijn is verstreken, ligt gemiddeld bijna een half jaar. In totaal vindt er voor die categorie gedurende 30 weken oftewel bijna $60 \%$ van de Ziektewettermijn geen contact plaats. Voor degenen die elders het werk hervatten, blijkt de eindwachttijd gering, hetgeen betekent dat de verzekeringsgeneeskundige bij een door de werknemer aangekondigde werkhervatting in een nieuwe werkkring nauwlettend volgt, of deze ook metterdaad plaatsvindt. 
Tabel 10.6 Wachttijden bij verzekeringsgeneeskundige naar wijze van verzuimbeëindiging

\begin{tabular}{lcrrrrrrrr}
\hline & $\begin{array}{l}\text { Hervat } \\
\mathrm{N}=67\end{array}$ & & $\begin{array}{l}\text { Elders hervat } \\
\mathrm{N}=14\end{array}$ & \multicolumn{2}{l}{$\begin{array}{l}\text { Werkloos } \\
\mathrm{N}=10\end{array}$} & \multicolumn{2}{c}{$\begin{array}{l}\text { WAO-intrede } \\
\mathrm{N}=23\end{array}$} \\
\hline Controlewachttijd & 5,1 & $34 \%$ & 4,7 & $24 \%$ & 4,7 & $37 \%$ & 5,2 & $10 \%$ \\
Begeleidingstijd & 5,8 & $38 \%$ & 12,2 & $62 \%$ & 1,9 & $15 \%$ & 22,1 & $42 \%$ \\
Eindwachttijd & 4,3 & $28 \%$ & 2,7 & $14 \%$ & 6,1 & $48 \%$ & 24,7 & $48 \%$ \\
Verzuimduur & 15,2 & $100 \%$ & 19,6 & $100 \%$ & 12,7 & $100 \%$ & 52,0 & $100 \%$ \\
\hline
\end{tabular}

Gezien de veel langere eindwachttijd bij WAO-intreders zou het mogelijk kunnen zijn dat de eerder gevonden verschillen in eindwachttijd en daarmee het aandeel van de overige bestanddelen van de verzuimduur tussen de verschillende diagnosegroepen het gevolg zijn van de eveneens aanwezige verschillen in WAO-intredepercentages. Om die reden hebben wij de wachttijden berekend voor de verschillende diagnosegroepen met uitsluiting van WAO-intreders.

Tabel 10.7 Omvang wachttijden voor niet-WAO-intreders

\begin{tabular}{lcccccc}
\hline & \multicolumn{2}{c}{$\begin{array}{l}\text { Overspanning } \\
\mathrm{N}=85\end{array}$} & \multicolumn{2}{c}{$\begin{array}{c}\text { Bewegingsapparaat } \\
\mathrm{N}=268\end{array}$} & \multicolumn{2}{c}{$\begin{array}{c}\text { Overige aandoeningen } \\
\mathrm{N}=238\end{array}$} \\
\hline Controlewachttijd & 5,1 & $33 \%$ & 5,1 & $39 \%$ & 5,4 & $43 \%$ \\
Begeleidingstijd & 6,3 & $40 \%$ & 6,0 & $46 \%$ & 4,6 & $36 \%$ \\
Eindwachttijd & 4,2 & $27 \%$ & 2,1 & $16 \%$ & 2,7 & $21 \%$ \\
Verzuimduur & 15,6 & $100 \%$ & 13,2 & $100 \%$ & 12,7 & $100 \%$ \\
\hline
\end{tabular}

De invloed van de WAO-intreders op de omvang en het aandeel van de eindwachttijden blijkt bij alle diagnosegroepen aanzienlijk. Na uitschakeling van deze invioed blijft er evenwel nog steeds een relatief groot en, bij uitvoering van de Student's t-toets tussen de categorie overspannen werknemers en de beide andere afzonderlijke categorieën, een statistisch significant verschil beneden een waarschijnlijkheidsniveau van respectievelijk .01 en .05 bestaan tussen overspannen werknemers en de andere langdurige verzuimgevallen. De netto begeleidingstijd ligt nog steeds ruim onder de helft en op een lager niveau dan bij WAO-intreders.

Nu geldt voor de categorie WAO-intreders dat voorafgegaan door een melding van de verzekeringsgeneeskundige van het GAK bij de GMD, de verzekeringsgeneeskundige van de GMD de begeleiding overneemt. Theoretisch gezien is het mogelijk dat de periode tussen het laatste contact en de WAO-intrede niet geheel bestaat uit een verzekeringsgeneeskundige wachttijd. Voor de categorie WAO-intreders is berekend wat het aandeel van de overdracht naar GMD-begeleiding is op de gemiddeld 24,7 weken wachttijd. Daarbij is de wachttijd voor melding aan de GMD gelijkgesteld aan het verschil in weken tussen het laatste contact met de GAK-verzekeringsgeneeskundige en de melding aan de GMD. In het geval dat de melding plaatsvond voor het laatste contact, is het verschil gelijkgesteld aan 0 . Bij de berekening van de wachttijd voor het contact met de GMD is uitgegaan van contact 
met de verzekeringsgeneeskundige of arbeidsdeskundige van de GMD. Hierbij zijn de verschillen gemeten in weken tussen het laatste contact met de verzekeringsgeneeskundige van het GAK dan wel het tijdstip van melding afhankelijk van wat het laatst plaatsvond. Indien het contact met de GMD voorafging aan het laatste contact met de verzekeringsgeneeskundige van het GAK, is het verschil gelijkgesteld aan 0 . Indien er geen contact plaatsvond met de GMD, is het verschil tussen tijdstip van melding en tijdstip van WAO-intrede als wachttijd voor het contact met de GMD genomen.

Tabel 10.8 Wachttijden en begeleidingsperioden bij WAO-intreders

\begin{tabular}{lrr}
\hline & $\mathrm{N}=22$ & \\
\hline Controlewachttijd & 5,2 & $10 \%$ \\
Begeleidingstijd GAK-verzekeringsgeneeskundige & 22,1 & $42 \%$ \\
Wachttijd Melding aan GMD & 6,4 & $12 \%$ \\
Wachttijd Contact GMD & 8,4 & $16 \%$ \\
Begeleidingstijd GMD & 9,9 & $19 \%$ \\
Totaal & 52,0 & $100 \%$ \\
\hline
\end{tabular}

Van de 25 weken eindwachttijd bij WAO-intreders blijkt gemiddeld genomen 10 weken niet uit wachttijd te bestaan maar uit begeleidingsduur vanwege de GMD gedurende de Ziektewetperiode. De verzekeringsgeneeskundige begeleiding is derhalve gedurende $60 \%$ van de totale verzuimduur aanwezig. Een periode van gerniddeld 3 maanden blijkt de WAO-intreder zonder enig contact met de verzekeringsgeneeskundige of arbeidsdeskundige begeleiding te overbruggen. lets meer dan de helft daarvan komt voor rekening van de trage contactlegging van de kant van de GMD. Een bijna evengroot aandeel wordt geleverd door traagheid in melding door de verzekeringsgeneeskundige van het GAK aan de GMD. Overigens blijken de verschillen in meldingsduur aanzienlijk. Gemiddeld vindt er na 24 weken melding aan de GMD plaats, maar de spreiding loopt van 2 tot 47 weken na de ziekmelding. De enkele meldingen aan de GMD aan het begin van de verzuimperiode zijn toe te schrijven aan het gegeven dat er in een paar gevallen al voor de ziekmelding sprake was van een - gedeeltelijke - WAO-uitkering. In deze gevallen is het voorgeschreven dat de met de Ziektewetcontrole belaste verzekeringsgeneeskundige het verzuimgeval meldt aan de GMD. In totaal heeft er bij bijna $30 \%$ van alle respondenten een melding plaatsgevonden.

Evenals bij de wachttijden in de curatieve sector blijkt ook bij de verzekeringsgeneeskundige wachttijden dat er grote verschillen tussen overspannen werknemers optreden.

De controlewachttijd varieert van voor de meeste van 1 tot 11 weken met een drietal uitschieters van 14, 18 en 22 weken. Slechts in én geval is dit het gevolg van het controlesysteem, d.w.z. in het desbetreffende geval is de controle gedurende de eerste tien weken aan het bedrijf gedelegeerd. De eindwachttijden varieren van 0 tot 44 weken. De wachttijden voor de melding aan de GMD varieren van 0 tot 39 weken; die voor het contact met de GMD van 0 tot 31 weken. 


\subsection{Conclusies en beschouwing}

De activiteiten van de verzekeringsgeneeskundige ten aanzien van de begeleiding van de overspannen werknemer speelt zich voornamelijk af binnen de muren van het GAK-kantoor. Overleg met de rapporteur en spreekuurcontacten zijn standaard. Contacten met werkgever en curatieve sector komen beide in nog geen $20 \%$ der gevallen voor. Bij de contacten met de werkgever speelt de mate waarin de verzekeringsgeneeskundige bekend is met het bedrijf, een doorslaggevende rol. Opvallend is daarbij dat het in meer dan de helft der gevallen het bedrijf is dat het initiatief neemt voor het contact. Deze contacten hebben over het algemeen het karakter van overleg. Bij de contacten met de curatieve sector gaat het vrijwel uitsluitend om het inwinnen of natrekken van informatie.

Vergeleken met langdurige verzuimgevallen om andere redenen dan overspanning treedt de verzekeringsgeneeskundige tamelijk snel in contact met de werknemer. Opvallender bevinding is echter de relatief langere periode die verstrijkt tussen het laatste contact met de werknemer en het moment van de verzuimbeëindiging. Dit verschijnsel is evenwel deels toe te schrijven aan een hoger percentage WAO-intreders bij wie deze periode aanzienlijk langduriger is dan bij niet-WAO-intreders. Degenen die de verzuimperiode afsluiten met een ontslag(name) zonder nieuwe werkkring, blijken ook een langere stuurloze periode door te maken. Al met al strekt de betrokkenheid van de verzekeringsgeneeskundige van het GAK zich over minder dan de helft van de gehele verzuimperiode uit.

De tamelijk langdurige periode waarin de WAO-intreder het zonder begeleiding van de verzekeringsgeneeskundige van het GAK moet stellen, wordt slechts in beperkte mate verklaard door overname van de begeleiding door de GMD. Als gevolg van vertraging in melding aan de GMD en in het leggen van contacten van de kant van de GMD met de werknemer is er gemiddeld sprake van een contactloze periode van ruim drie maanden alvorens de GMD gedurende de gemiddeld laatste 10 weken in begeleiding voorziet. 



\section{Hoofdstuk 11}

\section{Methode van data-analyse ter verklaring van verschillen in wijze van verzuimbeëindiging en verzuimduur}

\subsection{Inleiding}

In de volgende hoofdstukken wordt verslag gedaan van een onderzoek naar determinanten van de verschillen in de wijze van verzuimbeëindiging en de verschillen in verzuimduur binnen de groep respondenten die bij de verzuimbeëindiging naar hun oude werkkring zijn teruggekeerd.

Bij de verklaring van de verschillen in wijze van verzuimbeëindiging is een tweestappen-analyse uitgevoerd. Allereerst wordt onderzocht welke factoren bepalen of overspannen werknemers al dan niet hervatten in de oude werkkring. In hoofdstuk 7 signaleerden wij dat hervatting in aangepast werk in geringe mate voorkomt. Daarom is er geen onderscheid aangebracht tussen de vormen van werkhervatting. De aanpassingen hielden overigens geen grote veranderingen in. Vervolgens wordt onderzocht wat binnen de groep die niet terugkeerde naar de oude werkkring, de determinanten zijn van WAO-intrede dan wel werkloosheid of werkhervatting in een nieuwe werkkring. Het zestal respondenten bij wie een andere wijze van verzuimbeëindiging plaats heeft gevonden, is in deze beide analyses buiten beschouwing gelaten.

De redenen voor deze aanpak zijn een theoretische en een statistische. Vanuit theoretisch oogpunt kan men stellen dat na verloop van tijd tijdens de ziekteverzuimperiode allereerst een beslissingsproces plaatsvindt omtrent het al dan niet terugkeren naar de oude werkkring. Slechts wanneer voor de betrokkene(n) duidelijk is geworden dat een poging tot werkhervatting in de oude werkkring zinloos is, zal besloten worden op welke wijze men dan het verzuim zal beëindigen, bij voorbeeld door elders te solliciteren, ontslag te nemen op medische gronden of, als andere beëindigingsmogelijkheden uitblijven, de maximale Ziektewettermijn te voltooien en een beroep te doen op de WAO. Hoewel het denkbaar is dat hervatting in de eigen werkkring plaatsvindt, nadat ander wegen begaan zijn, bij voorbeeld na een mislukte sollicitatie elders, kunnen wij op grond van onze waarnemingen in de onderzoeksgroep aan deze mogelijkheid voorbijgaan. Uitgangspunt is derhalve dat er in geval van voortduring van het ziekteverzuim twee besluitvormingsmomenten optreden waarvan de determinanten van de uitkomst afzonderlijk onderzocht 
kan worden. Nadeel is dat de resultaten minder goed vergelijkbaar zijn met andere onderzoeken die vaak alleen WAO-intrede pogen te verklaren. Daarbij wordt wel voorbijgegaan aan de heterogene samenstelling van de groep niet-WAO-intreders en aan ons perspectief dat WAO-intrede een alternatief is voor andere vormen van uitval. Vanuit statistisch oogpunt is voor deze aanpak gekozen, omdat de verdelingen van de afhankelijke variabelen minder scheef zijn dan bij een indeling in "hervatters" en WAO-intreders.

De beperking van de verklaring van verschillen in verzuimduur tussen alleen die respondenten die naar de oude werkkring teruggekeerd zijn, is ingegeven door de volgende overwegingen. Het insluiten van WAO-intreders leidt tot een tweetal effecten. Op de eerste plaats wordt er een willekeurige bovengrens van 52 weken gelegd, waardoor artefacte verdelingseffecten ontstaan. Ten tweede gaan voorspellers van uitval in de vorm van WAO-intrede mogelijk ten onrechte het beeld bepalen van de factoren die van invloed zijn op de termijn van werkhervatting. Om deze laatste reden zijn ook de andere uitvallers buiten beschouwing gelaten. Imrners bij ontslagname, al dan niet met perspectief op werkhervatting elders, spelen bijzondere factoren een rol. Bij voorbeeld de datum van aanstelling bij de nieuwe werkgever wordt mede bepaald door de snelheid van aanstellingskeuring en overeenstemming over de aanstellingsdatum met een nieuwe werkgever.

De onafhankelijke variabelen hebben betrekking op persoons-en bedrijfskenmerken, kenmerken van de arbeidsplaats, ziektegeschiedenis, ziektekenmerken en ziektegedrag van de werknemer, en kenmerken en gedrag van huisartsen en verzekeringsgeneeskundigen. De belangrijkste eis waaraan deze moeten voldoen, is uiteraard dat ze bepaald zijn op enig moment voorafgaande aan het moment waarop de afhankelijke variabele bepaald is. De keuze van de variabelen die als voorspellers geselecteerd of geconstrueerd zijn, wordt verantwoord in paragraaf 11.2 .

In paragraaf 11.3 wordt kort uiteengezet hoe de verklaringsmodellen zijn opgebouwd en welke statistische technieken gebruikt zijn.

De hoofdstukken 12 tot en met 14 zijn gewijd aan de bespreking van de resultaten met betrekking tot de verklaring van respectievelijk terugkeer naar de oude werkkring, aard van het verloop, en verzuimduur in geval van terugkeer. Daarbij wordt telkens volgens hetzelfde patroon te werk gegaan. Per categorie van onafhankelijke variabelen worden eerst de afzonderlijke bivariate verbanden onderzocht en vervolgens het gezamenlijke multivariate verband. Daarna wordt dezelfde verkenning herhaald onder constanthouding van een klein aantal variabelen die bij de eerste verkenning een relatief sterk verband getoond hebben met de afhankelijke variabele. Op grond van de bevindingen van deze analyses is een selectie gemaakt uit de onafhankelijke variabelen. Deze zijn opgenomen in het uiteindelijke verklaringsmodel. Ten slotte worden de resultaten van een padanalyse gepresenteerd. 


\subsection{Selectie en constructie van de variabelen}

\subsubsection{De afhankelijke variabelen}

Als afhankelijke variabele van het eerste model functioneert de variabele terugkeer*, d.w.z. het al dan niet hervatten in de werkkring waar het ziekteverzuim werd aangevangen. Deze dichotome variabele heeft een verdeling van 61 respondenten die naar het werk terugkeerden, versus 47 die direct na het ziekteverzuim bij het bedrijf vertrokken of een beroep deden op de WAO. De eerste categorie omvat dus ook respondenten die na de werkhervatting alsnog bij het bedrijf vertrokken binnen een jaar na de ziekmelding.

Voor het tweede model is de afhankelijke variabele aard van het verloop. Deze dichotome variabele deelt de 47 uitvallers op in een groep die het verzuim beëindigd heeft met werkhervatting elders dan wel met de aanvang van een periode van werkloosheid, en een groep die de maximumtermijn van de Ziektewet voltooide. Hier bedraagt de verdeling 24 ontslagenen of ontslagnemers versus 23 WAO-intreders.

In het derde model fungeert het aantal weken ziekteverzuim oftewel verzuimduur als afhankelijke variabele. Het betreft de verzuimduur van de 61 respondenten die terugkeerden. Op grond van de scheefheid die deze maat gewoonlijk kenmerkt en in ons onderzoek 1.8 bedroeg bij een range van 5 tot 51 , en op grond van de aanwezigheid van uitbijters d.w.z.: alle gevallen met een verzuimduur langer dan 39 weken, is deze variable logarithmisch getransformeerd met als grondgetal 10 . De scheefheid van deze variabele bedraagt dan nog slechts 0.7 bij een range van 0.7 tot 1.7 .

\subsubsection{De onafhankelijke variabelen}

\section{Inleiding}

Voor elk van de onafhankelijke variabelen is, met het oog op de verschillen in de omvang en de samenstelling van de populaties, per model een analyse gemaakt van de scheefheid en de aanwezigheid van uitbijters. Waar nodig heeft dit geleid tot aanpassing van de structuur van de variabele of tot a priori verwijdering uit het model. Als criteria voor uitsluiting golden bij continue variabelen een scheefheid van 1.0 of hoger en bij dichotome variabelen een verhouding van respectievelijk $85: 15,75: 25$ en 80:20. Dit in verband met de verschillen in grootte van de populaties waarop de analyses verricht zijn. Deze bedragen 108, 47 en 61. Dit betekent dat de diverse modellen verschilien tonen in aanwezigheid of structuur van een aantal onafhankelijke variabelen.

Gezien het multivariate karakter van de modellen is per afzonderlijke analyse een collineariteitstoets uitgevoerd. Indien de Pearson-correlatie tussen twee of meer variabelen in een model gelijk bleek of hoger dan .50, zijn één of meer variabelen

* De term terugkeer is door ons verkozen boven de term reintegratie, omdat deze term in het taalgebruik te veel de betekenis heeft gekregen van terugkeer naar enige werkkring van WAO-uitkeringsgerechtigden. Terugkeer duidt dus in feite reïntegratie in de eigen, oorspronkelijke werkkring tijdens het Ziektewetjaar aan. 
verwijderd. Als eerste - negatief - selectiecriterium heeft daarbij gegolden het aantal variabelen waarmee een variabele collineariteit vertoonde. Als tweede - positief selectiecriterium is de betekenisinhoud gehanteerd. In het vervolg wordt de toepassingen van deze en in sommige gevallen aanvullende criteria ter plaatse beschreven.

Een ander effect van de uitvoering van multivariate analyses is het cumulatief effect van de geringe non-respons per variabele. Tenzij er substitutie van de ontbrekende waarden wordt toegepast, kan het uiteindelijke aantal waarnemingseenheden waarop de multivariate analyse betrekking heeft, dusdanig dalen, dat regressie-analyses onmogelijk of onbetrouwbaar worden. Op grond van onze bevindingen met de omvang van de non-respons heeft er bij de padanalyses van de voorspellers van terugkeer en van de verzuimduur in geval van terugkeer substitutie plaatsgevonden. Bij de beschrijving van de padanalyses in de hoofdstukken 12 tot en met 14 wordt de substitutiemethode toegelicht.

Groepsgewijs wordt eerst een beeld gegeven van de variabelen in het model ter voorspelling van terugkeer en vervolgens de wijzigingen die voor de beide andere modellen aangebracht zijn. Voor de volledige opsommingen van de geselecteerde variabelen en hun relevante eigenschappen verwijzen wij naar bijlage de 11.1 tot en met 11.3. Daar zijn met betrekking tot elk van de afzonderlijke analyses de spreiding der waarden, het gemiddelde, de standaarddeviatie en de scheefheid van de continue variabelen vermeld. Van de dichotome variabelen worden de betekenissen van de scores en de verdeling over de waarden vermeld.

\section{Persoonskenmerken}

Uiteraard zijn de variabelen sexe en leeftijd geselecteerd. Voorts is het opleidingsniveau vastgelegd in een viertal categorieën, namelijk een hoogst voltooide opleiding op het niveau van lager, voortgezet, middelbaar of hoger onderwijs. Dit op basis van de indeling van het ITS. Voorts is de urbanisatiegraad van de gemeente waarin de respondent woonachtig was ten tijde van de ziekmelding, vastgesteld. Een vijftal niveaus zijn daarbij onderscheiden: van plattelandsgemeente tot gemeente met meer dan 100.000 inwoners.

Ook is als variabele meegenomen of de respondent ten tijde van het eerste interview van oordeel was thuis steun te ondervinden van de partner. Gezien de sterke samenhang met de variabele alleenstaand - mede op grond van het feit dat alleenstaanden geen steun kunnen ondervinden van een partner - , de scheve verdeling van deze variabele, namelijk 94 samen met anderen wonenden versus 11 alleenstaanden, en de heterogeniteit van de woonsituatie van niet alleenstaanden en het surplus aan betekenis van de variabele steun thuis, is de aan- of afwezigheid van steun als het betere alternatief gekozen. Voorts is als onafhankelijke variabele het aantal life events, d.w.z. het aantal voor de respondent ingrijpende en negatief gewaardeerde levensgebeurtenissen na het 18 e levensjaar, opgenomen. Met betrekking tot life events voor het 19 e levensjaar zijn een tweetal dichotome variabelen geselecteerd, namelijk het al dan niet doorgemaakt hebben van een ernstige ziekte, ongeval of handicap en het al dan niet meegemaakt hebben van het verlies van één der of beide ouders als gevolg van overlijden of scheiding.

Al deze variabelen zijn geselecteerd ter verklaring van terugkeer. Bij de verklaring van de aard van het verloop is ernstige ziekte, ongeval of handicap tijdens de 
jeugdjaren verwijderd. Bij de verklaring van de verzuimduur zijn sexe en het verlies van ouder(s) tijdens de jeugd niet geselecteerd. Al deze weglatingen zijn het gevolg van te scheve verdelingen.

\section{Bedrijfskenmerken}

Er zijn een vijftal variabelen geselecteerd die bedrijfskenmerken meten. De eerste is de sector waartoe het bedrijf behoort. De omvang van het bedrijf is vastgelegd in zes categorieën van personeelssterkte. Voorts is vastgelegd het aantal steunpunten waarover een respondent in het bedrijf kan beschikken. Deze variabele is samengesteld door middel van een optelling van positieve antwoorden op de vragen naar aanwezigheid van ondernemingsraad, van enige vorm van bedrijfsgezondheidszorgvoorziening en van enige vorm van bedrijfsmaatschappelijk werk. De range van deze variabele varieert derhalve van 0 tot 3 .

Aangezien deze variabele binnen de totale groep respondenten hoog correleert (.69) met de omvang van het bedrijf, omdat voor bedrijven groter dan 100 respectievelijk 500 personeelsleden ondernemingsraad en bedrijfsgezondheidszorg wettelijk verplicht zijn, is in de multivariate analyses van voorspellers van terugkeer op grond van een duidelijkere interpreteerbaarheid de keuze gevallen op de variabele steunpunten.

De vierde variabele betreft een dichotomie gebaseerd op een vraag naar veranderingen die gedurende de laatste twaalf maanden voor de ziekmelding op het werk hebben plaatsgevonden. Indien door de respondent aangegeven werd dat er veranderingen hadden plaatsgevonden met betrekking tot personeelssterkte, de organisatie als zodanig of de aanstelling van chefs of hogere leidinggevenden, is het bedrijf opgevat als gekenmerkt door reorganisaties gedurende het laatste jaar. De laatste variabele heeft betrekking op het probleemoplossend vermogen van het bedrijf. Deze is gemeten aan de hand van de vraag of de respondent voor de ziekmelding ooit klachten over het werk had geuit, en, bij een positief antwoord, of deze volgens de respondent in positieve zin opgelost was. Daarbij zijn klachten die een rol hadden gespeeld bij de ziekmelding, buiten beschouwing gelaten, omdat de oplossing daarvan opgevat kan worden als een interventie van het bedriff in het verzuimproces, hetgeen niet beoogd is te meten met deze variabele.

De vijf variabelen zij̧n alle betrokken in de verklaring van terugkeer en verzuimduur. Als voorspeller voor de aard van het verloop kwamen de laatste twee variabelen niet in aanmerking. Bij de verklaring van de aard van het verloop is bovendien de variabele aantal steunpunten gewijzigd in de dichotomie aanwezigheid versus afwezigheid van enig steunpunt. De variabele omvang heeft in deze analyse slechts vijf in plaats van zes waarden.

\section{Kenmerken van de arbeidsplaats}

Een groot aantal kenmerken van de arbeidsplaats zijn in de analyses opgenomen. Voor een deel is dit toe te schrijven aan de uitkomsten van de factoranalyses die uitgevoerd zijn over de meeste variabelen uit deze groep. Deze leverden slechts enkele factoren op. Derhalve zijn naast de enkele factoren die samengesteld zijn op basis van de factoranalyse en die bovendien goed schaalbaar bleken, ook enkele variabelen samengesteld op grond van theoretische overwegingen, waarbij ter controle een inspectie van de kruistabellen heeft plaatsgevonden. 
De eerste drie variabelen zijn op een andere wijze tot stand gekomen. Zij betreffen de omschrijving die de respondenten van hun functie hebben gegeven. De verzamelde functieomschrijvingen zijn gecategoriseerd in 9 functiegroepen. Op grond van de frequentieverdeling zijn er vervolgens drie dummyvariabelen gecreëerd. De eerste is het vervullen van een kaderfunctie. Tot kader zijn beleidvoerend, hoger en stafpersoneel, leidinggevenden en toezichthoudend personeel gerekend. De tweede is het vervullen van een productieve functie. Dit betreft alleen het directe productiepersoneel in de bedrijven.

De derde betreft het vervullen van transport- of commerciële functies. Bij de multivariate analyses is alleen de variabele productieve functie meegenomen. Dit op grond van de gevonden bivariate samenhangen en de minder scheve scoreverdeling bij deze variabele.

De variabele lengte van het dienstverband in jaren is gebaseerd op de opgave van de respondenten. Als gevolg van de scheve verdeling zijn de waarden van deze variabele getransformeerd door worteltrekking.

Voorts zijn een drietal variabelen opgenomen die de werktijden beschrijven. De dichotome variabele werktijdfactor die onderscheid maakt tussen part-timers en full-timers, de omvang van de werkweek gemeten door het aantal uren dat men opgeeft gemiddeld per week te werken met inbegrip van overwerk, en de dichotome variable werktijden waarmee aangegeven wordt of men op vaste tijden werkt dan wel op onregelmatige tijden of in een stelsel van ploegendienst werkt.

Voor de meting van belastende arbeidsomstandigheden zijn een tweetal schalen opgenomen die eerder in ziekteverzuimonderzoek door Nijhuis en Soeters (1982) en door Schröer c.s. (1984) gebruikt zijn, namelijk de 5-puntsschalen hinder van fysieke werkomstandigheden en hinder van psycho-sociale werkomstandigheden. De Cronbach's $\alpha$ 's bedragen bij deze populatie respectievelijk .91 en .66.

De variable werklast is op theoretische gronden samengesteld door optelling van drie dichotome variabelen, te weten het ervaren van een hoog werktempo, het gevoel te hebben wel eens te veel werk te moeten verrichten, en het regelmatig verrichten van overwerk. De spreiding in score loopt derhalve van 1 tot 3 . De variabele mate van vrijheid resulteert uit de factoranalyse die de volgende vijf items samenbracht: de mate waarin men vrij gelaten wordt bij de concrete uitvoering der werkzaamheden, bij het vaststellen van de tijden waarop men het werk begint en beëindigt, bij het nemen van pauzes, bij het opnemen van snipperdagen, en de mate waarin men zelfstandig de kwaliteit van het afgeleverde werk kan beoordelen. De variabele mate van zelfrealisatie is gebaseerd op een drietal items die op theoretische gronden samengevoegd zijn. Dit betreft de vraag of men de werkzaamheden al dan niet in overeenstemming acht met de eigen opleiding en ervaring, of men het gevoel heeft zich in het werk wel of niet te kunnen ontplooien, en naar de mate waarin men hinder heeft van eentonigheid van het werk. De laatste is een 5-puntsitem afkomstig uit de psycho-sociale hinderschaal. Als consequentie daarvan is zijn de waarden van de twee dichotome items voor optelling met vijf vermenigvuldigd. Een volgende variabele betreft de promotiekansen van de respondent. Deze is gestructureerd in de dichotomie aanwezig of afwezig. Voorts is nog een item van de psycho-sociale hinderschaal als zelfstandige variabele opgenomen, namelijk hinder van onzekerheid. 
Ten slotte zijn een drietal variabelen geselecteerd met betrekking tot werkrelaties. De eerste is een dichotome. Het betreft de vraag of de uitvoering van het werk geschiedt in samenwerking met anderen of dat er sprake is van solistische arbeid. De andere twee betreffen de waarderingen in een 5-puntsschaal van de verhouding met de chef en van de verhouding met collegae. Beide kunnen variëren van zeer slecht tot zeer goed.

Alle variabelen zijn als voorspeller opgenomen in de verklaring van terugkeer. Bij de verklaring van de aard van het verloop konden functietype, werktijdfactor en promotiekansen op grond van een te scheve verdeling niet als voorspeller in het model opgenomen worden. Voor de verklaring van verzuimduur kwamen kaderfunctie en werktijdfactor om dezelfde reden niet als variabele in aanmerking. De variabele verhouding met collegae is op grond van het geringe aantal beoordelingen "slecht" en "zeer slecht" onder hervatters bij de terugkeeranalyse herleid tot een 4-puntsschaal en bij de verzuimduuranalyse tot een 3-puntsschaal.

\section{Ziektegeschiedenis}

Onder deze titel zijn een viertal verzuimmaten opgenomen. De eerste is het aantal ziekmeldingen gedurende de laatste 12 maanden dat naar opgave van de respondent voor het begin van de onderzochte verzuimperiode heeft plaatsgevonden. Voorts zijn via het dossier van de verzekeringsgeneeskundige als variabelen het aantal ziekmeldingen gedurende de laatste 24 maanden, het aantal ziekmeldingen gedurende de laatste 24 maanden met een duur van vier weken of langer en hel totaal aantal ziektedagen gedurende de laatste 24 maanden vastgelegd. Deze laatste variabele is ter reductie van de scheefheid getransformeerd door worteltrekking. Overigens bleek de scheefheidsmaat dan nog iets boven de 1.0 te liggen. De laatste variabele is dichotoom en betreft de vraag of de respondent eerder overspannen is geweest. Een positieve score is toegekend, indien in het verzekeringsgeneeskundig dossier een verzuimgeval vermeld is met de diagnosecode 300,301 , 306,309 of 311, of de respondent desgevraagd gewag maakte van een eerdere periode van verzuim wegens overspanning. Zoals te verwachten valt op grond van de betekenis en de onderlinge afhankelijkheid van de maten, tonen deze variabelen onderling hoge correlaties. Om die reden is de variabele die de frequentie van het langdurig verzuim van de laatste 24 maanden vastlegt, uit de multivariate analyses gehouden. In alle drie analyses zijn zodoende van deze reeks dezelfde variabelen in de modellen opgenomen.

\section{Ziektekenmerken}

Een vijftal variabelen zijn geselecteerd om aard, presentatie, ernst en oorzaak van overspanning vast te leggen. Bij de aard van overspanning is op basis van de in hoofdstuk 7 beschreven typologie een tweedeling aangebracht tussen die gevallen waarin sprake is van een vorm van chronische overspanning, versus gevallen van acute overspanning. De spreiding van de populatie over de 14 typen noodzaakte tot deze reductie. De wijze waarop de overspanning zich aan de respondent presenteerde, is vastgelegd in de variabele klachtenbeeld. Deze dichotome variabele onderscheidt de respondenten in een groep met klachten uit het hyperaesthetisch-emotionele syndroom en een groep met lichamelijke klachten. Voor de ernst zijn een tweetal variabelen gekozen. Allereerst de mate van psychoneuroticisme 
gemeten met de SCL-90. De subschalen zijn in de multivariate analyses buiten beschouwing gelaten. De keuze voor de totale schaal in plaats van de afzonderlijke subschalen is gebaseerd op de bevindingen van hoge intercorrelaties tussen de subschalen onderling (van .29 tot .84) en de dominantie van de eerste algemene factor in de factoranalyse over de 90 items van de schaal. Overigens blijken de correlaties tussen de subschalen en de totale schaal eveneens hoog. Deze variëren van .56 tot .93. De tweede maat voor ernst is de omvang van de uitval, d.w.z.: of er naast de werkstaking al dan niet sprake was van het staken van activiteiten buiten het werk. De oorzaak van de aandoening is een dichotome variabele waarin een verdeling aangebracht wordt tussen gevallen waarin uitsluitend werkgebonden factoren door de respondent als oorzaak van overspanning aangeduid worden, en gevallen waarin (ook) andere oorzaken een rol spelen. Al deze variabelen zijn als voorspellers van terugkeer en verzuimduur geselecteerd. Als voorspellers van de aard van het verloop konden gelet op de scheefheid van de verdeling alleen psychoneuroticisme, omvang van de uitval, en oorzaak van de aandoening in het model opgenomen worden.

\section{Ziektegedrag}

Vier variabelen zijn geselecteerd om de invloed van het ziektegedrag van de respondent op het verzuimbeloop vast te leggen. De eerste is het tijdsverloop tussen het ontstaan van de klachten en de ziekmelding. Omdat hier geen sprake kon zijn van een nauwkeurige registratie van het tijdstip waarop de klachten ontstaan zijn, en de verdeling scheef is, is gekozen voor een structurering door middel van negen duurklassen. De tweede variabele betreft de verhouding van de tijdstippen van ziekmelding en het eerste consult bij de huisarts in verband met de onderzochte aandoening. Deze variabele is een dichotomie met als scores ziekmelding voor respectievelijk na het eerste consult bij de huisarts. De laatste variabele is de presentatie aan de huisarts. Het gaat hier om de dichotomie tussen respondenten die naar opgave van de huisarts psycho-sociale klachten en/of problemen versus respondenten die lichamelijke klachten presenteerden. Deze vier variabelen konden alle in elk der drie modellen opgenomen worden.

\section{Kenmerken van de huisarts}

Gezien het geringe aantal vrouwelijke huisartsen kon er geen sprake van zijn de sexe van de huisarts als variabele op te nemen. Als persoonlijke kenmerken zijn leeftijd en sociaal-geneeskundig verleden geselecteerd. Het laatste heeft betrekking op alle beroepen in deze specialisatie. Positief op deze dichotome variabelen scoren huisartsen die of in het verleden een beroep in de sociale gezondheidszorg uitoefenden of in het verleden of ten tijde van het interview naast hun huisartsenpraktijk een nevenfunctie in de sociale gezondheidszorg uitoefen(d)en. Als eerste praktijkkenmerk is praktijkomvang opgenomen in de vorm van een dichotome variabele met als waarden groot en klein. Dit als gevolg van de grofheid waarmee de meeste huisartsen de omvang geschat hebben en de concentratie van de antwoorden in de twee middelste categorieën van de vier in totaal. De tweede is praktijktype. Hierbij is een tweedeling aangebracht tussen solo-praktijken en de overige typen van duopraktijk tot en met gezondheidscentrum. Voorts zijn de mate van integratie in de eerstelijn en de mate van integratie met de GGZ als variabele 
geconstrueerd door optelling van de scores van de items, waarbij incidenteel contact met 1 punt, regulier contact met 2, en structureel contact met 3 punten gewaardeerd is. Op grond van de antwoordpatronen zijn bij de eerstelijn de contacten met collegae-huisartsen buiten de eigen praktijk, Algemeen Maatschappelijk Werk, wijkverpleegkunde en gezinszorg meegenomen, terwijl bij de GGZ contacten met het RIAGG, vrijgevestigden en intramurale instellingen zijn meegenomen. Gezien de geringe spreiding - vrijwel uitsluitend incidenteel - van contacten met bedrijfs- en verzekeringsgeneeskundigen kon de mate van integratie met de sociale gezondheidszorg niet als variabele geselecteerd worden. Op basis van de NIVEL-vragenlijsten naar omgang met onzekerheid en taakopvatting zijn door middel van factoranalyse van elk twee variabelen geconstrueerd." Met betrekking tot omgang met onzekerheid zijn dat open werkstijl en medicaliserende werkstijl. De Cronbach's $\alpha$ 's bedragen voor deze twee schalen die beiden uit drie items bestaan, respectievelijk .62 en .57. Bij taakopvattingen zijn dat de psycho-sociale taakopvatting en de sociaal-psychiatrische taakopvatting. Deze bestaan beide uit vijf items met $\alpha$ 's van .63 en .62. Bovendien zijn deze twee taakopvattingen opgeteld om een variabele taakbreedte te construeren $(\alpha=.72)$. Deze laatste variabele is niet samen met de twee samenstellende variabelen in de multivariate analyses opgenomen. In de verklaring van de terugkeer en de aard van het verloop zijn al deze variabelen opgenomen. Bij de verklaring van verzuimduur is het sociaal-geneeskundig verleden op grond van een te scheve verdeling weggelaten.

\section{Gedrag van de huisarts}

De eerste variabele onder dit hoofd betreft de diagnosestelling. De huisartsen zijn verdeeld in een groep die als diagnose overspanning formuleren of dat in soortgelijke termen doen, en zij die een andere diagnose stellen. De tweede variable is een dichotomie betreffende aan- dan wel afwezigheid van overeenstemming tussen huisarts en werknemer in visie op de oorzaak van de aandoening. Voorts zijn een vijftal variabelen geselecteerd met betrekking tot het beleid dat de huisarts naar rapportage van de werknemer gevoerd heeft gedurende de eerste twee maanden na de ziekmelding. De keuze voor de rapportage van de werknemer is ingegeven door het verschil in rapportage tussen huisarts en werknemer zoals beschreven in hoofdstuk 9 . De beperking tot handelingen gedurende de eerste twee maanden van het ziekteverzuim heeft als reden het zo goed mogelijk handhaven van het causaliteitscriterium dat de voorspeller vastligt op een tijdstip voorafgaand aan de bepaling van de te verklaren variabele. De vijf variabelen zijn: rust voorschrijven, het terugbestellen van de werknemer, psychofarmaca voorschrijven, overige medicatie voorschrijven, een verwijzing plegen naar een specialist, een fysiotherapeut, het RIAGG of het Algemeen Maatschappelijk Werk. Ten slotte is een dichotome variabele geconstrueerd om een onderscheid te maken tussen huisartsen wier beleid naar eigen zeggen is gericht is geweest op werk, en bij wie dat niet het geval is geweest. Al deze variabelen behoren tot de voorspellers van zowel terugkeer, aard van het verloop als de verzuimduur in geval van terugkeer.

\footnotetext{
* Zie hoofdstuk 9.
} 


\section{Kenmerken van de verzekeringsgeneeskundige}

Een tweetal variabelen zijn hierbij geselecteerd. De bekendheid met de respondent voor de onderzochte verzuimperiode en de mate van bekendheid met het bedrijf waarbij de respondent werkzaam is. Bij deze laatste variabele is de scoreverdeling: onbekend, bekend, contactpersoon of werkzaam in een bedrijfsgebonden rayon. Alleen bij de verklaring van de aard van het verloop is de laatste variabele gereduceerd tot de dichotomie onbekend versus bekend met het bedrijf.

\section{Gedrag van de verzekeringsgeneeskundige}

Als eerste variabele is hier de duur tussen ziekmelding en eerste spreekuurcontact als variabele opgenomen. Het uitbijterprobleem is hier opgelost door de langste duren te samen te voegen met lagere aansluitende scores. Voorts is de visie op de oorzaak van de verzekeringsgeneeskundige in een dichotome variabele vastgelegd. De waarden zijn: alleen werk is oorzaak versus factoren buiten het werk spelen al dan niet samen met werkgebonden factoren een rol. Ten slotte is als variabele het aantal contacten met het bedrijf waarbij de respondent werkzaam is, opgenomen. Alle variabelen zijn opgenomen bij de drie analyses. Bij de verklaring van de aard van het verloop is de laatste variabele gedichotomiseerd tot geen contact versus contact met het bedrijf.

\subsection{Analysetechnieken}

Voor de bivariate analyses wordt bij de verklaring van terugkeer en aard van het verloop gebruik gemaakt van de $\mathrm{x}^{2}$-toets bij onafhankelijke variabelen op nominaal niveau en de F-toets bij variantieanalyse bij onafhankelijke variabelen op intervalniveau.

Bij de bivariate analyses bij de verklaring van verschillen in verzuimduur zijn dat respectievelijk de F-toets bij variantieanalyse en de tweezijdig getoetste Pearsoncorrelatie.

Bij de multivariate analyse van verschillen in wijze van verzuimbeëindiging is gebruik gemaakt van de logistische regressie-analyse. Deze techniek is evenals de discriminantanalyse speciaal ontwikkeld voor de verklaring van dichotome afhankelijke variabelen vanuit een stel continue en dichotome onafhankelijke variabelen. Het voordeel van de logistische regressie-analyse boven de discriminantanalyse is de geringere bias bij aanwezigheid van veel dichotome onafhankelijke variabelen. (Press and Wilson, 1978)

Deze techniek gaat uit van een voorspelling van de kansverhouding tussen de aanwezigheid van een bepaald kenmerk of verschijnsel en de afwezigheid daarvan gegeven bepaalde condities beschreven door de waarde(n) van de onafhankelijke variabele(n).

De kans op aanwezigheid wordt uitgedrukt in de formule: $\pi(x)=\frac{e^{\beta_{0}+\beta_{1}}}{1+e^{\beta_{0}+\beta_{1} x}}$. Door de berekening van de logarithme van de kansverhouding: $\ln \frac{\pi(x)}{1-\pi(x)}$ wordt een functie verkregen die vergelijkbaar is met die van het lineaire regressiemodel: $g(x)=\beta_{0}+\beta_{1 x}$. Daarmee is de kansverhouding begrensd tussen 0 en 1 en de 
logarithme daarvan kan alle waarden aannemen tussen $-\infty$ en $+\infty$. Met behulp van logistische regressiemodellen wordt getracht de $\beta$-parameters te schatten. Dit gebeurt met de maximum-likelihood-methode, d.w.z.: voor de parameters worden die waarden berekend die leiden tot een functie die de waargenomen waarden van de afhankelijke variabele voor elke waarnemingseenheid op basis van de onathankelijke variabele(n) zo goed mogelijk voorspelt.

Hoe goed een bepaald model in relatief opzicht de kansverhouding verklaart, wordt uitgedrukt door de waarde D(eviance). Deze maat wordt berekend door middel van de likelihood-ratio tussen het actueel model dat de waarde van de afhankelijke variabele schat op basis van de onafhankelijke variabelen, en het verzadigd model dat uitgaat van de waargenomen waarden van de afhankelijke variabele en daarbij evenveel parameters berekent als er waarnemingseenheden zijn.

Als maat voor verbetering van het ene verklarend model ten opzichte van een andere dient de G-waarde. Deze is gelijk aan het verschil tussen de D-waarden van de vergeleken modellen. Aldus kan men bij toevoeging of verwijdering van onafhankelijke variabelen nagaan in hoeverre het model beter of slechter de waarden van de afhankelijke variabele voor elke waarnemingseenheid voorspelt. De G-waarde is dus een relatieve maat tussen twee modellen. De significantie van $D$ en $G$ is gebaseerd op de $x^{2}$-toets.

De absolute mate van effectiviteit van een model in het voorspellen van de waarden van de afhankelijke variabele wordt vastgelegd in Goodness of Fit-maten. Als maat voor de Goodness of Fit - een $x^{2}$-score - is gekozen voor de Hosmer-Lemeshowformule. Indien de Goodness of Fit-score boven een gekozen significantieniveau blijft, is er sprake van een model dat in staat is de feitelijke verdeling van de afhankelijke variabele goed te voorspellen op basis van de modelparameters.

Voor de sterkte van de bijdrage van de afzonderlijke onafhankelijke variabelen wordt de maat $\beta$ berekend. De significantie wordt weergegeven door de Wald-statistic die gebaseerd is op de verhouding tussen $\beta$ en de standaardfout. Deze maat is verdeeld volgens de standaard normaalverdeling.

Voor de rekenkundige details van de maten die gebruikt worden in de logistische regressie-analyse, verwijzen wij naar Hosmer en Lemeshow (1989).

Bij de multivariate analyse van verschillen in verzuimduur is gebruik gemaakt van de lineaire regressie-analyse. Met behulp van deze techniek is het mogelijk na te gaan welk percentage van de variantie in verzuimduur verklaard kan worden door een gegeven verzameling van onafhankelijke variabelen. Deze wordt uitgedrukt in de maat $R^{2}$. Bovendien kan voor elk van de onafhankelijke variabelen afzonderlijk, d.w.z.: gecontroleerd voor interveniërende invloeden van andere onafhankelijke variabelen, met behulp van de maat $\beta$ aangegeven worden in welke mate de verzuimduur verandert, indien de waarde van de desbetreffende onafhankelijke variabele verandert. Met behulp van de F- respectievelijk t-toets worden de statistische significanties van $\mathrm{R}^{2}$ en $\beta$ bepaald.

De multivariate analyses worden besloten met zogenaamde padanalyses. De techniek van de padanalyse houdt in dat door middel van multipele regressie-analyse nagegaan wordt welke onafhankelijke variabelen direct samenhangen met de afhankelijke variabelen en welke (tevens) indirect samenhangen, d.w.z. een samenhang vertonen met één of meer direct of indirect met de afhankelijke variabele 
samenhangende onafhankelijke variabelen. Een aantal onafhankelijke variabelen kunnen daarbij in eerste instantie uitsluitend als onafhankelijke optreden om vervolgens successievelijk eenmalig als afhankelijke variabele op te treden. In dat geval wordt gesproken van interveniërende variabelen. Wanneer welke variabele als afhankelijk of onafhankelijke optreedt, is afhankelijk van de causale volgorde die op basis van theoretische aannames wordt vastgesteld. Ten minste éen onafhankelijke variabele fungeert als eerste en dus uitsluitend als onafhankelijke in de causale keten. De padanalyse met behulp van multipele regressie-analyse resulteert niet alleen in een pad maar verdeelt de bivariate correlatiecoëfficient tussen een onafhankelijke en afhankelijke variabele op in zogenaamde padcoëfficienten waarmee de relatieve sterkte van de causale schakels in de diverse paden tussen beide gekwantificeerd kunnen worden. (Davis, 1985)

Bij de padanalyses is in alle gevallen gebruik gemaakt van lineaire regressie-analyse, daar de logistische regressie-analyse niet geschikt is voor padanalyses. Indien in de padanalyses dichotome variabelen optraden als afhankelijke, is op significantie niveau gecontroleerd door middel van de Wald-statistic bij uitvoering van een logistische regressie-analyse met behulp van dezelfde variabelen. In verreweg de meeste gevallen bleken de significantieniveaus $(<.01,<.05$ of $<.10)$ van de t-toets op de $\beta$ 's uit de lineaire regressie-analyses en de Wald-statistics uit de logistische regressie-analyses overeen te komen. 


\section{Hoofdstuk 12}

\section{De verklaring van terugkeer}

\subsection{Inleiding}

Dit hoofdstuk is gewijd aan de verklaring van de afloop van de ziekteverzuimperiode van een overspannen werknemer, voor zover deze betrekking heeft op het al dan niet terugkeren naar de werkkring waarbinnen de werknemer tot het moment van de ziekmelding werkzaam was. Dit betekent dat de afhankelijke variabele gebaseerd is op de volgende tweedeling van de respondenten: degenen die het werk hervatten in de oorspronkelijke werkkring, versus degenen die ontslag hebben genomen al dan niet gevolgd door een nieuwe werkkring, of het stadium van WAO-intrede bereikt hebben, met andere woorden: respondenten bij wie sprake is geweest van terugkeer, versus respondenten bij wie sprake is geweest van enige vorm van verloop.

Nagegaan wordt in hoeverre het in hoofdstuk 5 op basis van de verzuimlitteratuur opgestelde model waarin de invloed van de variabelencategorieën persoonskenmerken, bedrijfskenmerken, kenmerken van de arbeidsplaats, ziektegeschiedenis, ziektekenmerken, ziektegedrag van de werknemer, en de kenmerken en handelingen van huisarts en verzekeringsgeneeskundige op terugkeer verondersteld is, van toepassing is op overspannen werknemers en te specificeren is naar afzonderlijke onafhankelijke variabelen.

Telkens na een eerste verkenning per categorie variabelen van de bivariate samenhangen wordt vervolgd met een multivariate analyse van elke afzonderlijke categorie ter opsporing van een eventuele gezamenlijke invloed op het plaatsvinden van terugkeer naar de werkkring. Daarna wordt dezelfde verkenning herhaald onder constanthouding van een klein aantal variabelen die bij de eerste verkenning een relatief sterk verband getoond hebben met terugkeer. Besloten wordt met een padanalyse op basis van alle variabelen die op enigerlei wijze een statistisch significant, d.w.z. beneden de grenswaarde van .10, verband tonen met de afhankelijke variabele.

Omdat in de verzuimlitteratuur geen precedenten bekend zijn van onderzoeken met terugkeer versus verloop als afhankelijke variabele, zullen verwachtingen omtrent de relaties tussen onafhankelijke en afhankelijke variabelen uitgesproken worden op basis van wat bekend is uit onderzoek naar determinanten van WAO-intrede. 


\subsection{De invloed van persoonskenmerken op terugkeer}

Van de in de litteratuur vermelde bevindingen met betrekking tot het WAO-intrederisico leiden we als verwachting af dat de kansen om terug te keren lager liggen voor ouderen, voor lager opgeleide werknemers en voor werknemers uit de meer verstedelijkte gemeenten. Een lagere kans via dit indirect verband verwachten we ook voor werknemers die tijdens hun jeugd één van beide of beide ouders verloren hebben. Dit zou de kwetsbaarheid verhogen en daarom problemen in de volwassenheid intensiveren. (Brown en Harris, 1978) Voor vrouwen verwachten we een geringere mate van terugkeer op grond van een marginalere positie in het arbeidsbestel en een grotere geneigdheid tot rolwisseling. Eveneens verwachten we een geringere mate van terugkeer, naarmate het aantal life events groter is. Dit op grond van afbraak van de weerstand tegen problemen. Over de rol van steun thuis doen we geen uitspraak over de richting van de verwachte invloed, omdat a priori onduidelijk is in welke richting de steun geboden wordt: blijven of vertrekken? Evenmin doen we dit over het doormaken van een ernstige ziekte in de jeugd. Dit kan de kwetsbaarheid verhogen, maar ook de weerstand die nodig is voor het overwinnen van problemen.

Tabel 12.1 Bivariate samenhangen tussen persoonskenmerken en terugkeer

\begin{tabular}{lllll}
\hline Persoonskenmerken: & hoog $=$ & $\mathrm{x}^{2} / \mathrm{F}$ & richting & $\mathrm{p}$ \\
\hline Sexe & vrouw & 5.57 & - & .02 \\
Leeftijd & hoog & 0.38 & & $\mathrm{~ns}$ \\
Opleidingsniveau & hoog & 0.13 & & $\mathrm{~ns}$ \\
Urbanisatiegraad & stedelijk & 0.08 & $\mathrm{~ns}$ \\
Steun thuis & ja & 0.38 & $\mathrm{~ns}$ \\
Aantal life events & hoog & 0.40 & $\mathrm{~ns}$ \\
Jeugdziekte & ja & 1.99 & $\mathrm{~ns}$ \\
Verlies ouders in jeugd & ja & 0.75 & & \\
\hline
\end{tabular}

Van de persoonskenmerken blijkt alleen sexe bivariaat samen te hangen met de kans op terugkeer. Deze kans ligt voor vrouwen aanzienlijk lager. Terwijl twee op de drie mannen terugkeren naar hun werkkring, is dat slechts bij één op de drie vrouwen het geval.

Verrassend genoeg is er geen bivariate samenhang met leeftij, hoewel deze op grond van de huidige stand van zaken in het onderzoek een bewezen determinant is van WAO-intrede. Twee elkaar niet uitsluitende verklaringen zijn mogelijk: het effect is indirect via elkaar tegenwerkende intermediërende variabelen of komt voort uit een selectieve wijze van verzuimbeëindiging onder oudere werknemers, d.w.z.: zij keren - in gelijke mate - terug naar hun werkkring of bereiken - vaker - het stadium van WAO-intrede. De wijze van verzuimbeëindiging voor de verschillende sexen en leeftijdscategorieën is als volgt. 
Tabel 12.2 Wijze van verzuimbeëindiging naar sexe en leeftijd

\begin{tabular}{|c|c|c|c|c|c|}
\hline & & Terugkeer & Elders hervat & Werkloos & WAO-intrede \\
\hline $\begin{array}{l}\text { Mannen } \\
\text { Vrouwen }\end{array}$ & $\begin{array}{l}N=78 \\
N=30\end{array}$ & $\begin{array}{l}64 \% \\
37 \%\end{array}$ & $\begin{array}{l}12 \% \\
17 \%\end{array}$ & $\begin{array}{r}6 \% \\
17 \%\end{array}$ & $\begin{array}{l}18 \% \\
30 \%\end{array}$ \\
\hline $\begin{array}{l}\leq 29 \text { jaar } \\
30-39 \text { jaar } \\
40-49 \text { jaar } \\
\geq 50 \text { jaar }\end{array}$ & $\begin{array}{l}N=30 \\
N=32 \\
N=30 \\
N=16\end{array}$ & $\begin{array}{l}60 \% \\
50 \% \\
60 \% \\
56 \%\end{array}$ & $\begin{array}{r}20 \% \\
16 \% \\
10 \% \\
0 \%\end{array}$ & $\begin{array}{r}13 \% \\
13 \% \\
3 \% \\
6 \%\end{array}$ & $\begin{array}{r}7 \% \\
22 \% \\
27 \% \\
38 \%\end{array}$ \\
\hline Totaal & $N=108$ & $57 \%$ & $13 \%$ & $9 \%$ & $21 \%$ \\
\hline
\end{tabular}

De geringere mate van terugkeer bij vrouwen blijkt gepaard te gaan met een grotere mate van elke vorm van verloop. Frappant is dat met name de kans op werkloosheid en op WAO-intrede voor vrouwen aanzienlijk hoger is dan voor mannen.

De kansen op terugkeer liggen bij alle leeftijdscategorieën op een vrijwel gelijk niveau. Bij de aard van het verloop is een sterke toename te zien van WAO-intrede, naarmate de leeftijd hoger ligt, met een evenredige afname van de verloopsvormen die een gang naar de arbeidsmarkt inhouden. Psychische aandoeningen mogen dan voor de jongste leeftijdscategorieën de belangrijkste diagnosegroep vormen bij WAO-intrede, toch is er sprake van zeer aanzienlijke selectie. Onder de 40 jaar bedraagt het aandeel van WAO-intreders op het totaal aantal vertrekkers één derde, terwijl dit bij overspannen werknemers boven de veertig jaar $70 \%$ bedraagt. Bij de laatste categorie lijkt gegeven de kwetsbare positie van ouderen op de arbeidsmarkt sprake van een onvermijdelijkheid van WAO-intrede, indien terugkeer naar het eigen werk niet gerealiseerd wordt.

Hoewel de vrouwelijke werknemers gemiddeld jonger zijn, blijven de bevindingen onveranderd, indien we een verdeling maken naar zowel sexe als leeftijd."

We zien hier bij een aantal variabelen dat de afwezigheid van een relatie met terugkeer het gevolg is van een tussenliggende score van degenen die naar het werk terugkeren, ten opzichte van de diverse verloopscategorieëen. Dit geldt voor de variabelen steun thuis en verlies van ouder(s) tijdens de jeugd. Met opleidingsniveau is geen enkel rechtstreeks verband te vinden. Zowel lager als hoger opgeleiden hebben een even grote kans op terugkeer als op WAO-intrede als op een andere wijze van verloop.

De multivariate analyse wijzigt de verbanden tussen terugkeer en persoonskenmerken in beperkte mate. Leeftijd blijkt ook niet van invloed onder constanthouding van andere persoonskenmerken. Sexe blijft het enige persoonskenmerk dat - zij het zwakker dan bivariaat - samenhangt met terugkeer. Alle persoonskenmerken blijken bijeengenomen een model op te leveren, waarvan het verklaringsvermogen voor terugkeer gering is. 
Tabel 12.3 Multivariate samenhang(en) tussen persoonskenmerken en terugkeer

\begin{tabular}{lllllll}
\hline & $\mathrm{N}$ & $\mathrm{D}$ & $\mathrm{G}$ & $\mathrm{p}$ & $\mathrm{GoF}$ & $\mathrm{p}$ \\
Persoonskenmerken & 105 & 134.81 & 8.60 & $\mathrm{~ns}$ & 6.10 & $\mathrm{~ns}$ \\
\hline & hoog= & $\mathrm{B}$ & $\mathrm{SE}$ & Wald & $\mathrm{p}$ \\
\hline Sexe & vrouw & -.92 & .51 & 3.27 & .07 \\
Leeftijd & hoog & -.01 & .02 & .08 & $\mathrm{~ns}$ \\
Opleidingsniveau & hoog & -.05 & .21 & .05 & $\mathrm{~ns}$ \\
Urbanisatiegraad & stedelijk & .02 & .13 & .03 & $\mathrm{~ns}$ \\
Steun thuis & ja & .15 & .50 & .09 & $\mathrm{~ns}$ \\
Aantal life events & hoog & -.15 & .19 & .57 & $\mathrm{~ns}$ \\
Jeugdziekte & ja & .71 & .61 & 1.37 & $\mathrm{~ns}$ \\
Verlies ouders & ja & -.55 & .57 & .95 & $\mathrm{~ns}$ \\
\hline
\end{tabular}

\subsection{De invloed van bedrijfskenmerken op terugkeer}

Omtrent de stimulerende invloed van bedrijfskenmerken als omvang en aanwezigheid van reorganisatieprocessen op WAO-intrede biedt de litteratuur voldoende aanknopingspunten om van deze kenmerken te verwachten dat ze negatief samen hangen met de kans op terugkeer. Voor de kenmerken sector en aantal steunpunten spreken wij geen verwachting uit op grond van tegengestelde bevindingen in de litteratuur. Wat betreft het probleemoplossend vermogen, een nieuwe variabele, verwachten we een positieve bijdrage aan de kans op terugkeer.

Tabel 12.4 Bivariate samenhangen tussen bedrijfskenmerken en terugkeer

\begin{tabular}{llccl}
\hline Bedrijfskenmerken: & hoog $=$ & $x^{2} / F$ & richting & $p$ \\
\hline Sector & diensten & 4.63 & - & .03 \\
Omvang & hoog & 11.92 & + & .001 \\
Aantal steunpunten & hoog & 14.75 & + & .000 \\
Reorganisatie laatste jaar & ja & 3.16 & + & .04 \\
Probleemoplossend vermogen & ja & 7.69 & + & .001 \\
\hline
\end{tabular}

Alle onderzochte bedrijfskenmerken blijken samen te hangen met terugkeer. Ze hangen sterker samen met de kans op terugkeer dan de onderzochte persoonskenmerken. De belangrijkste bedrijfskenmerken blijken de nauw met elkaar samenhangende variabelen omvang van het bedrijf en het aantal steunpunten te zijn en het probleemoplossend vermogen. Allen dragen positief bij aan de kans op terugkeer. Ook sector en veranderingen in de organisatie blijken van invloed. Mogelijk speelt bij de omvang van het bedrijf de invloed van geringe uitval op andere wijze

* Voor de betekenis van de maten D(eviance), G, G(codness) o(f) F(it), 8, S(tandard) E(rror) en Wald verwijzen we naar 11.3 . 
dan WAO-intrede op het verrassende verband. De betere kansen op terugkeer van werknemers in een bedrijf dat reorganisaties (heeft) door(ge)maakt moet vermoedelijk zo verklaard worden dat "overlevers" voor het bedrijf belangrijk genoeg zijn om ze voor het bedrijf te behouden. In de dienstensector zijn de vooruitzichten op terugkeer geringer dan in de industrie. Aangezien daar verhoudingsgewijs meer vrouwen werkzaam zijn, zal de uiteindelijke analyse, waarin beide onafhankelijke variabelen opgenomen zijn, uit moeten maken hoe deze variabelen precies met de afhankelijke samenhangen.

Voor de beide sectoren en de voor het gemak tot drie gereduceerde omvangscategorieën zijn de wijzen van verzuimbeëindiging weergegeven in tabel 12.5 .

Het relatief grote verloop in de dienstensector, bijna $60 \%$, bestaat vooral uit werkhervatting in een nieuwe werkkring en WAO-intrede. Wat de omvang van de bedrijven betreft, komt het verloop grotendeels voor rekening van kleine bedrijven met een personeelssterkte beneden de 50 . Hoewel bij de kleine bedrijven ongeveer $40 \%$ van de respondenten werkzaam zijn, neemt deze categorie ongeveer $60 \%$ van de uitval voor haar rekening. Bij bedrijven met meer dan 500 personeelsleden keert bijna iedereen na de verzuimperiode terug naar het bedrijf. De middelgrote bedrijven laten een gemiddeld patroon zien.

Tabel 12.5 Wijze van verzuimbeëindiging naar sector en omvang bedrijf

\begin{tabular}{|c|c|c|c|c|c|}
\hline & & Terugkeer & Elders hervat & Werkloos & WAO-intrede \\
\hline Industrie & $N=62$ & $66 \%$ & $6 \%$ & $10 \%$ & $18 \%$ \\
\hline Diensten & $N=46$ & $43 \%$ & $22 \%$ & $9 \%$ & $26 \%$ \\
\hline $0-49$ & $N=46$ & $43 \%$ & $17 \%$ & $15 \%$ & $24 \%$ \\
\hline $50-499$ & $N=32$ & $53 \%$ & $16 \%$ & $9 \%$ & $22 \%$ \\
\hline 500 of meer & $N=25$ & $88 \%$ & $4 \%$ & $0 \%$ & $8 \%$ \\
\hline Totaal & $N=108$ & $57 \%$ & $13 \%$ & $9 \%$ & $21 \%$ \\
\hline
\end{tabular}

De multivariate analyse laat niet alleen zien dat de vier opgenomen bedrijfskenmerken alle afzonderlijk een significante bijdrage leveren aan de verklaring van terugkeer maar ook dat zij gezamenlijk een significante modelverbetering bewerkstelligen. Bij het laatste komt in de onderlinge verhoudingen tussen de variabelen geen wezenlijke verandering. Sector blijkt nu een wat sterkere determinant en reorganisatie een wat zwakkere. 
Tabel 12.6 Multivariate samenhang(en) tussen bedrijfskenmerken en terugkeer

\begin{tabular}{lllllll}
\hline \multirow{2}{*}{ Bedrijfskenmerken } & $\mathrm{N}$ & $\mathrm{D}$ & $\mathrm{G}$ & $\mathrm{P}$ & $\mathrm{GoF}$ & $\mathrm{p}$ \\
& 100 & 107.50 & 30.49 & .00 & 8.47 & $\mathrm{~ns}$ \\
\hline & hoog $=$ & $\mathrm{B}$ & $\mathrm{SE}$ & Wald & $\mathrm{p}$ \\
\hline Sector & diensten & -1.20 & .50 & 5.62 & .02 \\
Aantal steunpunten & hoog & .56 & .20 & 7.50 & .01 \\
Reorganisatie & ja & 1.17 & .68 & 2.97 & .08 \\
Probleemoplossend vermogen & ja & 2.35 & .86 & 7.54 & .01 \\
\hline
\end{tabular}

\subsection{De invloed van arbeidsplaatskenmerken op terugkeer}

Op grond van de verzuimlitteratuur mag verwacht worden dat via een verhoogde kans op WAO-intrede de kansen op terugkeer van werknemers met een langere werkweek, onregelmatige werktijden, of meer hinder van fysieke en psycho-sociale werkomstandigheden ongunstiger zijn, terwijl deze kansen voor werknemers die tot het kader behoren, een zwaardere werklast ervaren of in teamverband werken, gunstiger zijn. Voor de overige variabelen geeft de litteratuur geen aanknopingspunten. We verwachten a priori dat werknemers met een lang dienstverband op grond van een hogere gemiddelde leeftijd een geringere kans op terugkeer zouden tonen, maar gezien de afwezigheid van het verband tussen leeftijd en kans op terugkeer doen we geen voorspelling vooraf. We verwachten van part-timers, voornamelijk vrouwen, dat deze in geringere mate terugkeren. Eveneens geldt dat voor werknemers met een geringere mate van vrijheid, met gebrek aan mogelijkheden tot zelfrealisatie, met geringe ontplooiingskansen en die een slechte verhouding hebben met hun baas en/of collegae. Over de invloed van hinder van onzekerheid over het voortbestaan van de arbeidsplaats stellen we geen verwachting op, omdat hierin zowel een motief voor werkhervatting als een motief voor het zoeken van een veilig heenkomen elders kan liggen.

Slechts een beperkt aantal kenmerken van de arbeidsplaats blijkt de kans op terugkeer te bevorderen. In volgorde van sterkte: de lengte van het dienstverband, de aanwezigheid van promotiekansen, een goede verhouding met de chef, gevoel van zekerheid over behoud van arbeidsplaats, en het vervullen van een functie in de directe productie.

De zwak positieve samenhang tussen productieve functie en terugkeer, daar waar we die bij kaderfuncties verwachtten, is verrassend, omdat dit betekent dat bij een type beroep met relatief veel fysieke en een gemiddelde omvang van psychische werkinconveninten de vooruitzichten op terugkeer beter zijn dan in de andere typen beroepen. Voor kaderpersoneel kan misschien als verklaring gelden dat deze categorie voor een groot deel uit (oudere) mannen bestaat. De hoeveelheid werkinconveniënten blijkt tegen de verwachting in geen invloed te hebben op terugkeer. Ook de meeste variabelen die afzonderlijke inconveniënten meten, tonen geen verband met terugkeer. Enige uitzondering is de hinder van onzekerheid. Er blijkt evenmin een bivariate samenhang aanwezig tussen werktijdfactor en kans op 
terugkeer. Dit is deels het gevolg van het geringere animo van part-timers om het arbeidsleven met ontslagname te beëindigen.

Tabel 12.7 Bivariate samenhang(en) tussen arbeidsplaatskenmerken en terugkeer

\begin{tabular}{lllll}
\hline Arbeidsplaatskenmerken: & hoog & $\mathrm{x}^{2} / \mathrm{F}$ & richting & $\mathrm{p}$ \\
\cline { 2 - 5 } Kaderfunctie & ja & 0.10 & $\mathrm{~ns}$ \\
Productieve functie & ja & 3.45 & + & .06 \\
Transport/commercieel & ja & 1.79 & & $\mathrm{~ns}$ \\
Lengte dienstverband & hoog & 15.70 & + & .000 \\
Werktijdfactor & part-time & 0.00 & $\mathrm{~ns}$ \\
Omvang werkweek & hoog & 0.06 & $\mathrm{~ns}$ \\
Werktijden & onregelmatig & 0.20 & $\mathrm{~ns}$ \\
Fysieke hinder & hoog & 0.00 & $\mathrm{~ns}$ \\
Psycho-sociale hinder & hoog & 2.25 & $\mathrm{~ns}$ \\
Werklast & hoog & 1.80 & $\mathrm{~ns}$ \\
Mate van vrijheid & hoog & 0.07 & $\mathrm{~ns}$ \\
Mate van zelfrealisatie & hoog & 0.85 & $\mathrm{~ns}$ \\
Promoliekansen & ja & 7.03 & .008 \\
Hinder van onzekerheid & hoog & 5.90 & + & .02 \\
Samenwerking & ja & 0.05 & $\mathrm{~ns}$ \\
Verhouding met chef & goed & 6.02 & .02 \\
Verhouding met collegae & goed & 0.72 & + & $\mathrm{ns}$ \\
\hline
\end{tabular}

De sterke samenhang met de lengte van het dienstverband is verrassend tegen het licht van de afwezigheid van samenhang tussen leeftijd en terugkeer. Bij de aard van deze samenhang, d.w.z. de causale richting daarvan, moet een kanttekening geplaatst worden.

Het is mogelijk dat respondenten niet zozeer op grond van een lang dienstverband gemakkelijker terugkeren, maar dat bedrijven die er beter in slagen om zieke werknemers weer aan het werk te brengen ook respondenten voortbrengen met een langer dienstverband. Dezelfde redenering kan ook toegepast worden om het positieve verband tussen terugkeer en hinder van onzekerheid te verklaren.

De samenhang tussen promotiekansen en terugkeer is op zich niet verrassend, wel de sterkte van de samenhang. De verhouding met de chef blijkt er voor de vooruitzichten op terugkeer meer toe te doen dan de verhouding met de collegae.

In iets mindere mate dan bedrijfskenmerken blijken ook kenmerken van de arbeidsplaats gezamenlijk een aanzienlijke bijdrage te leveren aan de verklaring van terugkeer. De bijdrage van de afzonderlijke variabelen blijkt echter minder uitgesproken. Alleen de lengte van het dienstverband en de hinder van onzekerheid tonen nog een samenhang die statistisch significant is. De variabele promotiekansen toont nu nog slechts een zwakke samenhang. 
Tabel 12.8 Multivariate samenhang(en) tussen arbeidsplaatskenmerken en terugkeer

\begin{tabular}{|c|c|c|c|c|c|c|}
\hline Arbeidsplaatskenmerken & $\begin{array}{l}N \\
90\end{array}$ & $\begin{array}{l}\mathrm{D} \\
92.75\end{array}$ & $\begin{array}{l}\text { G } \\
28.39\end{array}$ & $\begin{array}{l}\mathrm{p} \\
.01\end{array}$ & $\begin{array}{l}\text { GoF } \\
7.03\end{array}$ & $\begin{array}{l}\mathrm{p} \\
\mathrm{ns}\end{array}$ \\
\hline & hoog= & B & SE & Wald & $p$ & \\
\hline Productieve funclie & ja & .96 & .64 & 2.25 & ns & \\
\hline Lengte dienstverband & hoog & .46 & .18 & 6.71 & .01 & \\
\hline Omvang werkweek & hoog & .01 & .03 & .04 & ns & \\
\hline Werktijden & onregelmatig & -.58 & .73 & .64 & ns & \\
\hline Fysieke hinder & hoog & .01 & .03 & .26 & ns & \\
\hline Psycho-sociale hinder & hoog & .02 & .07 & .06 & ns & \\
\hline Werklast & hoog & -.12 & .30 & 17 & ns & \\
\hline Mate van vrijheid & hoog & .00 & .17 & .00 & ns & \\
\hline Mate van zelfrealisatie & hoog & .07 & .07 & 1.04 & ns & \\
\hline Promotiekansen & ја & 1.18 & .73 & 2.64 & .10 & \\
\hline Hinder onzekerheid & hoog & -.42 & .22 & 3.87 & .05 & \\
\hline Samenwerking & ja & .27 & .54 & .26 & ns & \\
\hline Verhouding met chef & goed & .05 & .23 & .05 & ns & \\
\hline Verhouding met collegae & goed & .23 & .34 & .46 & ns & \\
\hline
\end{tabular}

\subsection{De invloed van de ziektegeschiedenis op terugkeer}

In de litteratuur wordt, op één uitzondering na, voor elke verschillende ziekteverzuimmaat een positieve samenhang gevonden tussen het verzuimpatroon van de werknemer over een bepaalde periode voor de ziekmelding en de kans op WAOintrede. Wij verwachten dan ook dat de vier verzuimmaten negatief samenhangen met de kans op terugkeer. Met betrekking tot eerdere overspanning is het moeilijker een voorspelling te doen. Het is mogelijk dat opeenvolgende episodes een teken zijn van hardnekkige, moeilijk oplosbare problemen die de basis vormen voor opeenvolgende episodes van overspanning. Evengoed kan men aannemen dat, waar een eerdere overspanning niet tot verloop heeft geleid, terugkeer bij latere episodes ook het geval zal zijn als gevolg van een aanpassingsproces bij de werknemer en/of zijn omgeving in het hanteren van die episodes.

Tabel 12.9 Bivariate samenhang(en) tussen ziektegeschiedenis en terugkeer

\begin{tabular}{lllll}
\hline Kenmerken ziektegeschiedenis: & hoog & $x^{2} / F$ & richting & $\mathrm{p}$ \\
\hline Verzuimfrequentie laatsle jaar & hoog & 1.01 & & $\mathrm{~ns}$ \\
Verzuimirequentie laatste 2 jaar & hoog & 5.96 & + & .02 \\
Frequentie langdurige verzuimen & & & & ns \\
laatste 2 jaar & hoog & 2.20 & & .06 \\
Verzuimomvang laatste 2 jaar & hoog & 3.60 & + & ns \\
Eerder overspannen & ja & 0.00 & & \\
\hline
\end{tabular}

Het verzuimverleden blijkt zoals verwacht van enige invloed op terugkeer. Een recidiverend karakter van overspanning blijkt in het geheel geen determinant te zijn. 
Zeer verrassend is wel dat de verzuimfrequentie van de laatste twee jaar alsmede - in beperkte mate - het aantal verzuimde dagen over die periode van positieve invloed blijkt. Het lijkt er hier op dat er voor een overlevingshypothese meer te zeggen valt dan voor een versukkelingshypothese. Dat de verzuimfrequentie van het laatste jaar een aanzienlijk zwakkere samenhang toont dan die over de laatste twee jaar zou toegeschreven kunnen worden aan het verschil in meetwijze. De eerste variabele is gebaseerd op rapportage van de respondent en daardoor afhankelijk van de geheugenretentie, terwijl de tweede berust op het betrouwbaarder te achten verzekeringsgeneeskundig dossier.

Tabel 12.10 Multivariate samenhang(en) tussen ziektegeschiedenis en terugkeer

\begin{tabular}{lllllll}
\hline Ziektegeschiedenis & $\mathrm{N}$ & $\mathrm{D}$ & $\mathrm{G}$ & $\mathrm{p}$ & $\mathrm{GoF}$ & $\mathrm{p}$ \\
& 99 & 123.58 & 11.95 & .02 & 8.39 & $\mathrm{~ns}$ \\
\cline { 1 - 4 } & hoog= & $\mathrm{B}$ & $\mathrm{SE}$ & Wald & $\mathrm{p}$ \\
\hline Verzuimfrequentie laatste jaar & hoog & .11 & .29 & .16 & $\mathrm{~ns}$ \\
Verzuimfrequentie laatste 2 jaar & hoog & .21 & .09 & 4.76 & .03 \\
Verzuimomvang laatste 2 jaar & hoog & .23 & .13 & 3.09 & .08 \\
Eerder overspannen & ja & -.71 & .54 & 1.72 & $\mathrm{~ns}$ \\
\hline
\end{tabular}

De gezamenlijke kenmerken van ziektegeschiedenis blijken het verklaringsmodel ten aanzien van terugkeer significant te verbeteren, waarbij wederom de frequentie en de omvang van het verzuim van de laatste twee jaar als belangrijkste determinanten fungeren.

\subsection{De invloed van ziektekenmerken op terugkeer}

De verzuimlitteratuur biedt met betrekking tot deze variabelen weinig aanknopingspunten voor het uitspreken van verwachtingen vooraf. De enige uitzondering vormt het aantal gezondheidsklachten. Dit blijkt positief samen te hangen met verzuimduur en WAO-intrede. Met betrekking tot werkhervatting als zodanig zijn er geen directe bevindingen, maar dit geldt voor alle variabelen. We nemen aan dat de mate van psychoneuroticisme de WAO-intredekans bevordert en daarmee de kans op terugkeer beperkt. Hetzelfde geldt voor de omvang van de uitval als indicatie voor de ernst van overspanning, en voor het klachtenbeeld. Bij deze laatste variabele veronderstellen wij dat bij lichamelijke presentatie het doorbreken van medicaliserend denken en handelen problematischer is en het oplossen van de achterliggende problemen langer op zich laat wachten. Ten aanzien van de oorzaak van de aandoening verwachten wij dat werknemers die overspannen zijn op grond van werkproblemen, minder geneigd zullen zijn tot terugkeer naar de oude werkkring. Met betrekking tot de aard van overspanning zien wij geen grond tot het uitspreken van enige verwachting. 
Tabel 12.11 Bivariate samenhangen tussen ziektekenmerken en terugkeer

\begin{tabular}{lllll}
\hline Ziektekenmerken: & hoog $=$ & $\mathrm{x}^{2} / F$ & richting & $\mathrm{p}$ \\
\hline Aard overspanning & acuut & 0.00 & $\mathrm{~ns}$ \\
Klachtenbeeld & lichamelijk & 0.10 & $\mathrm{~ns}$ \\
Psychoneuroticisme & hoog & 0.48 & $\mathrm{~ns}$ \\
Omvang uitval & werk+thuis & 0.00 & & $\mathrm{~ns}$ \\
Oorzaak ziekte & alleen werk & 3.53 & - & .06 \\
\hline
\end{tabular}

Noch de aard noch de manifestatie noch de ernst van de overspanning toont een bivariate samenhang met het al dan niet hervatten in de oude werkkring. Alleen de oorzaak van de ziekte in de perceptie van de respondent toont een zwakke samenhang met de kans op terugkeer, d.w.z.: indien de oorzaak enkel en uitsluitend aan de werksituatie toegeschreven wordt, dan is de kans op terugkeer geringer.

Het meest verrassend is de afwezigheid van de invloed van psychoneuroticisme. Deze wordt echter verklaard door de bevinding dat werknemers die terugkeren naar hun werkkring een score tonen die ligt tussen die van de verschillende categorieën uitvallers. Hervatters scoren 182,8, hervatters bij een ander werkgever 143,4 , degenen die na ontslag(name) zonder nieuwe werkkring verkeren 171,3 en WAOintreders 196,0. Een dergelijk beeld nemen ook we waar bij het klachtenbeeld, de omvang van de uitval en de aard van de overspanning.

Het beeld van de samenhangen tussen deze variabelen en terugkeer blijt vrijwel ongewijzigd, indien voor elk constanthouding van de andere ziektekenmerken plaatsvindt.

Tabel 12.12 Multivariate samenhang(en) tussen ziektekenmerken en terugkeer

\begin{tabular}{lllllll}
\hline Ziektekenmerken & $\mathrm{N}$ & $\mathrm{D}$ & $\mathrm{G}$ & $\mathrm{p}$ & $\mathrm{GoF}$ & $\mathrm{p}$ \\
& 92 & 120.61 & 5.36 & $\mathrm{~ns}$ & 4.57 & $\mathrm{~ns}$ \\
\hline & hoog $=$ & $\mathrm{B}$ & $\mathrm{SE}$ & Wald & $\mathrm{p}$ \\
\hline Aard overspanning & acuut & .23 & .56 & .17 & $\mathrm{~ns}$ \\
Klachtenbeeld & lichamelijk & .16 & .55 & .08 & $\mathrm{~ns}$ \\
Psychoneuroticisme & hoog & .00 & .00 & .28 & $\mathrm{~ns}$ \\
Omvang uitval & werk+thuis & -.22 & .48 & .22 & $\mathrm{~ns}$ \\
Oorzaak ziekte & alleen werk &. .88 & .47 & 3.50 & .06 \\
\hline
\end{tabular}

Het gezamenlijk verklaringsvermogen van de ziektekenmerken voor het al dan niet terugkeren van de respondent naar de oorspronkelijke werkkring is blijkens de G-maat gering.

\subsection{De invloed van ziektegedrag op terugkeer}

Voor deze groep variabelen zijn er in de verzuimlitteratuur geen aanknopingspunten te vinden voor het formuleren van verwachtingen. In eerste instantie veronderstel- 
den wij dat het lang wachten met de ziekmelding - deels samenhangend met de chroniciteit van de aandoening - of dat presentatie van lichamelijke klachten aan de huisarts gepaard gaat aan een lagere kans op terugkeer. De bevinding dat de meeste ziektekenmerken niet blijken samen te hangen met de kans op terugkeer, geeft aanleiding deze verwachting te corrigeren.

Tabel 12.13 Bivariate samenhangen tussen ziektegedrag en terugkeer

\begin{tabular}{lllll}
\hline Kenmerken ziektegedrag: & hoog $=$ & $x^{2} / F$ & richting & $p$ \\
\hline Duur klachten ziekmelding & hoog & 1.47 & & ns \\
Relatie melding consult & na consult & 0.00 & ns \\
Presentatie aan huisarts & lichamelijk & 0.00 & ns \\
\hline
\end{tabular}

Inderdaad blijkt geen van de drie variabelen die aspecten van het actuele ziektegedrag meten, bivariaat samen te hangen met terugkeer.

Evenmin blijkt er enige samenhang uit de multivariate analyse. Het ziektegedrag van de respondent met betrekking tot uitstel van ziekmelding, het al dan niet direct presenteren van de overspanning aan de huisarts, of het al dan niet raadplegen van de huisarts alvorens tot ziekmelding over te gaan heeft geen directe invloed op terugkeer.

Tabel 12.14 Multivariate samenhang(en) tussen ziektegedrag en terugkeer

\begin{tabular}{lllllllll}
\hline & $\mathrm{N}$ & $\mathrm{D}$ & $\mathrm{G}$ & & $\mathrm{p}$ & & $\mathrm{GoF}$ & $\mathrm{p}$ \\
Ziektegedrag & 90 & 119.57 & 2.33 & & $\mathrm{~ns}$ & & 6.34 & $\mathrm{~ns}$ \\
\hline & hoog $=$ & $\mathrm{B}$ & & $\mathrm{SE}$ & $\mathrm{Wald}$ & $\mathrm{p}$ & \\
\hline Duur ziekmelding & hoog & -.11 & .08 & & 1.97 & $\mathrm{~ns}$ & \\
Relatie melding consult & na consult & .25 & .46 & .30 & $\mathrm{~ns}$ & \\
Presentatie aan huisarts & lichamelijk & -.07 & .46 & .02 & $\mathrm{~ns}$ & \\
\hline \hline
\end{tabular}

\subsection{De invloed van kenmerken van de huisarts(praktijk) op terugkeer}

Ook hier hebben de verwachtingen, voor zover het mogelijk is ze op te stellen, een volkomen a priori karakter. We veronderstellen dat huisartsen die eerder een sociaal-geneeskundig beroep hebben uitgeoefend, huisartsen die geen medicaliserende werkstijl hebben, en huisartsen met een psycho-sociale taakopvatting dieper op de achtergronden ingaan en door een dergelijk probleemoplossend vermogen de terugkeer bevorderen. 
Tabel 12.15 Bivariate samenhangen tussen huisartskenmerken en terugkeer

\begin{tabular}{lllll}
\hline Kenmerken huisarts: & hoog $=$ & $\mathrm{x}^{2} / \mathrm{F}$ & \multirow{2}{*}{ richting } & $\mathrm{p}$ \\
\hline Leeftijd & hoog & 0.22 & & $\mathrm{~ns}$ \\
Sociaal-geneeskundig verleden & ja & 1.07 & & $\mathrm{~ns}$ \\
Praktijkomvang & groot & 0.00 & & $\mathrm{~ns}$ \\
Praktijktype & meermans & 0.92 & & $\mathrm{~ns}$ \\
Integratie in eerstelijn & hoog & 0.00 & & $\mathrm{~ns}$ \\
Integratie met GGZ & hoog & 1.02 & & $\mathrm{~ns}$ \\
Open werkstijl & hoog & 0.47 & & .03 \\
Medicaliserende werkstijl & hoog & 4.75 & + & $\mathrm{ns}$ \\
Psycho-sociale taaksopvatting & hoog & 1.03 & & .02 \\
Sociaal-psychiatrische taakopvatting & hoog & 5.27 & + & $\mathrm{ns}$ \\
Breedte taakstelling & hoog & 2.03 & & \\
\hline
\end{tabular}

Twee huisartskenmerken tonen samenhang met terugkeer: een medicaliserende werkstijl die tegen de verwachting in een positief verband toont met de kans op terugkeer, en, eveneens in positieve richting, een taakopvatting die inhoudt dat het tot de taak van de huisarts behoort om zelf ambulante psychiatrische problemen te behandelen. De persoonlijke, praktijk- en samenwerkingskenmerken tonen geen bivariate samenhang.

De huisartskenmerken blijken bijeengenomen maar weinig verklaringsvermogen te bezitten voor de kans op terugkeer.

Van deze groep variabelen blijkt bij onderlinge constanthouding alleen de medicaliserende werkstijl een significant verband met terugkeer te tonen.

Tabel 12.16 Multivariate samenhang(en) tussen huisartskenmerken en terugkeer

\begin{tabular}{lllllll}
\hline \multirow{2}{*}{ Kenmerken huisarts } & $\mathrm{N}$ & $\mathrm{D}$ & $\mathrm{G}$ & $\mathrm{p}$ & $\mathrm{GoF}$ & $\mathrm{p}$ \\
& 90 & 110.71 & 13.35 & $\mathrm{~ns}$ & 3.99 & $\mathrm{~ns}$ \\
\hline & hoog= & $\mathrm{B}$ & $\mathrm{SE}$ & Wald & $\mathrm{p}$ \\
\hline Leeftija huisarts & hoog & .03 & .03 & 0.77 & $\mathrm{~ns}$ \\
Sociaal-geneeskundig verleden & ja & -.22 & .55 & .16 & $\mathrm{~ns}$ \\
Praktijkomvang & groot & -.48 & .50 & .92 & $\mathrm{~ns}$ \\
Praktijktype & meermans & .37 & .53 & .49 & $\mathrm{~ns}$ \\
Integratie met eerstelijn & hoog & -.11 & .09 & 1.38 & $\mathrm{~ns}$ \\
Integratie met GGZ & hoog & -.30 & .25 & 1.37 & $\mathrm{~ns}$ \\
Open werkstijl & hoog & -.07 & .09 & .55 & $\mathrm{~ns}$ \\
Medicaliserende werkstij| & hoog & .23 & .11 & 4.45 & .03 \\
Psycho-sociale taakopvatting & hoog &. .02 & .10 & .06 & $\mathrm{~ns}$ \\
Sociaal-psychiatr. taakopvatting & hoog & .14 & .09 & 2.57 & $\mathrm{~ns}$ \\
\hline
\end{tabular}

De afwezigheid van de invloed van deze categorie variabelen, met als enige uitzondering een medicaliserende werkstijl die tot onze verrassing een positieve invloed toont, op de kans op terugkeer kan voor een deel verklaard worden door hun theoretisch grotere afstand tot de afhankelijke variabele. De veronderstelling is uiteraard, dat deze kenmerken van de huisartsen indirect, namelijk via het gedrag 
van de huisarts en dat van de patiënt de kans op terugkeer beïnvioeden. Enige samenhang tussen het gedrag van de huisarts en de realisatie van terugkeer is dan wel een voorwaarde voor het ontstaan van verbanden tussen deze kenmerken van de huisarts en terugkeer.

\subsection{De invloed van het gedrag van de huisarts op terugkeer}

Hierbij verwachten we dat de overeenstemming tussen huisarts en werknemer over diagnose en oorzaak de aanpak van het probleem bevordert en aldus terugkeer kan bewerkstelligen. Eveneens verwachten we een positieve invloed van een beleid waarbij de huisarts expliciet de werksituatie betrekt. Ten aanzien van het voorschrijven van psychofarmaca of andere medicatie en het plegen van verwijzingen veronderstellen wij, omdat ze als medicaliserende activiteiten te beschouwen zijn, dat ze de WAO-intrede bevorderen en daarmee de kans op terugkeer beperken. Omtrent het voorschrijven van rust of het terugbestellen verwachten we geen invloed in een bepaalde richting op de kans op terugkeer.

Bivariate samenhangen komen uit onze analyse niet naar voren. Welk beleid de huisarts ook voert, welke diagnose gesteld wordt, en of de visie op de oorzaak van de huisarts al dan niet overeenstemt met die van de patiënt, enige directe invloed van het gedrag van de huisarts op de kansen op terugkeer van de respondent is niet waarneembaar.

Tabel 12.17 Bivariate samenhangen tussen huisartsgedrag en terugkeer

\begin{tabular}{|c|c|c|c|c|}
\hline Gedrag huisarts: & $\operatorname{hoog}=$ & $x^{2} / F$ & richting & $p$ \\
\hline Diagnose overspanning & ja & 0.02 & & ns \\
\hline Overeenstemming oorzaak & ja & 1.90 & & $\mathrm{~ns}$ \\
\hline Beleid: rust & ja & 0.06 & & $n s$ \\
\hline Beleid: terugkomen & ja & 0.00 & & $\mathrm{~ns}$ \\
\hline Beleid: psychofarmaca & ja & 1.32 & & $\mathrm{~ns}$ \\
\hline Beleid: overige medicijnen & ja & 0.00 & & $\mathrm{~ns}$ \\
\hline Beleid: verwijzing & ja & 0.01 & & ns \\
\hline Beleid gericht op werk & ja & 1.80 & & ns \\
\hline
\end{tabular}

De multivariate analyse levert als resultaat op dat het huisartsgedrag in zijn totaliteit genomen een geringe verklaring geeft voor terugkeer. Twee gedragskenmerken blijken onder constanthouding voor de andere samen te hangen met terugkeer, namelijk het voorschrijven van psychofarmaca en het voeren van een op de werksituatie gericht beleid. Beide hebben een negatieve invloed op terugkeer. Op het eerste gezicht is het verrassend te noemen dat een beleid van de huisarts dat op het werk gericht is, de terugkeer negatief lijkt te beïnvloeden. Bij nader inzien is dit minder verrassend, wanneer we ons de in hoofdstuk 9 gerapporteerde bevindingen voor de geest halen dat dit beleid vooral gericht bleek op het aanmoedigen of het ondersteunen van de ziekmelding. Een tweede verklaring zou kunnen zijn, dat de werksituatie juist ter sprake komt, als aan de overspanning problemen met 
de werksituatie ten grondslag liggen. Zoals we eerder zagen, zijn in die gevallen de vooruitzichten op terugkeer ongunstiger.

Tabel 12.18 Multivariate samenhang(en) tussen huisartsgedrag en terugkeer

\begin{tabular}{lllllll}
\hline Gedrag huisarts & $\mathrm{N}$ & $\mathrm{D}$ & $\mathrm{G}$ & $\mathrm{p}$ & $\mathrm{GoF}$ & $\mathrm{p}$ \\
& 85 & 104.48 & 9.94 & $\begin{array}{l}\mathrm{n} \\
\mathrm{ns}\end{array}$ & 6.45 & $\mathrm{~ns}$ \\
\hline & $\mathrm{hoog}=$ & $\mathrm{B}$ & $\mathrm{SE}$ & Wald & $\mathrm{p}$ \\
\hline Diagnose overspanning & $\mathrm{ja}$ & -.52 & .63 & .69 & $\mathrm{~ns}$ \\
Overeenstemming oorzaak & $\mathrm{ja}$ & .84 & .56 & 2.24 & $\mathrm{~ns}$ \\
Beleid: rust & $\mathrm{ja}$ & .86 & .59 & 2.13 & $\mathrm{~ns}$ \\
Beleid: terugkomen & $\mathrm{a}$ & -.40 & .51 & 0.61 & $\mathrm{~ns}$ \\
Beleid: psychofarmaca & $\mathrm{ja}$ & -.87 & 49 & 3.14 & .08 \\
Beleid: overige medicijnen & $\mathrm{ja}$ & -.45 & .53 & .72 & $\mathrm{~ns}$ \\
Beleid: verwijzing & $\mathrm{ja}$ & -.38 & .60 & .40 & $\mathrm{~ns}$ \\
Beleid gericht op werk & $\mathrm{ja}$ & -1.15 & .57 & 4.11 & .04 \\
\hline
\end{tabular}

\subsection{De invloed van kenmerken van de verzekeringsgeneeskundige op terugkeer}

Met betrekking tot de beide geselecteerde kenmerken verwachten we, dat deze positief samenhangen met de kans op terugkeer. Omdat de bekendheid van de verzekeringsgeneeskundige met de respondent het gevolg is van eerdere verzuimen die ter controle zijn aangemeld, is gezien de eerdere bevindingen omtrent verzuimverleden een positief verband aannemelijk. Bekendheid met het bedrijf wordt mede beïnvloed door de omvang daarvan en vormt derhalve een argument voor de verwachting van een positieve relatie

Tabel 12.19 Bivariate samenhangen kenmerken tussen verzekeringsgeneeskundige en terugkeer

\begin{tabular}{lllll}
\hline Kenmerken verzekeringsgeneeskundige: & hoog $=$ & $x^{2} / F$ & richting & $p$ \\
\hline Bekendheid verz. gen. met patiënt & ja & 0.03 & & ns \\
Mate van bekendheid met bedrijt & hoog & 3.24 & + & .08 \\
\hline
\end{tabular}

Of de verzekeringsgeneeskundige de respondent voor het actuele ziektegeval al dan niet kent, blijkt niet van directe invloed op de kans op terugkeer. Wel is dat het geval met de mate waarin de verzekeringsgeneeskundige het bedrijf kent. Deze samenhang is evenwel zwak. De samenhang kan wellicht gelegen zijn in de invloed van bedrijfsomvang, terwijl voor de zwakte van de samenhang de geringe mate waarin contacten gelegd zijn met het bedrijf, de verklaring kan vormen. 
Tabel 12.20 Multivariate samenhang(en) tussen kenmerken verzekeringsgeneeskundige en terugkeer

\begin{tabular}{lllllll}
\hline & $N$ & $D$ & $G$ & $p$ & GoF & $p$ \\
Kenmerken verz.geneesk. & 105 & 140.34 & 3.60 & ns & 1.11 & ns \\
\hline & hoog $=$ & B & SE & Wald & $p$ \\
\hline $\begin{array}{l}\text { Bekendheid verz.gen. patiënt } \\
\text { Mate van bekendheid met bedrijf }\end{array}$ & ja & -.24 & .43 & .30 & $\mathrm{~ns}$ \\
\hline
\end{tabular}

Als we deze beide kenmerken van de verzekeringsgeneeskundige samen nemen, blijkt de invloed van de afzonderlijke variabelen nauwelijks veranderd. De gezamenlijke bijdrage is uiterst gering.

\subsection{De invloed van het gedrag van de verzekeringsgeneeskundige op terugkeer}

Op grond van de grote mate van overeenkomst in de visie op de oorzaak van overspanning, verwachten we dat, als naar de visie van de verzekeringsgeneeskundige het werk de oorzaak is, de kans op terugkeer geringer is. Omtrent de beide andere gedragswijzen is moeilijker een verwachting uit te spreken. Dit als gevolg van een causaliteitsprobleem. Een sneller eerste contact met de werknemer en een groter aantal contacten met het bedrijf lijkt terugkeer te bevorderen, maar kan op haar beurt ook voortvloeien uit problemen hiermee, met name als er een perspectief ontstaat op WAO-intrede.

Tabel 12.21 Bivariate samenhangen tussen gedrag verzekeringsgeneeskundige en terugkeer

\begin{tabular}{lllll}
\hline Gedrag verzekeringsgeneeskundige: & hoog $=$ & $x^{2} / F$ & richting & $p$ \\
\hline Duur ziekmelding le contact & hoog & 0.13 & & $\mathrm{~ns}$ \\
Visie oorzaak & alleen werk & 2.91 & - & .09 \\
Aantal contacten met bedrijf & hoog & 0.83 & & $\mathrm{~ns}$ \\
\hline
\end{tabular}

Het tijdsverloop tussen ziekmelding en het eerste spreekuurcontact blijkt niet van directe invloed, evenmin het aantal contacten met het bedrijf. De visie van de verzekeringsgeneeskundige op de oorzaak van de overspanning wel. Deze laatste samenhang is evenwel zwak negatief.

Als de gedragskenmerken van de verzekeringsgeneeskundige samengenomen worden, dan blijken deze geen directe determinant van terugkeer. Van de afzonderlijke variabelen blijkt ook nu alleen de visie op de oorzaak samen te hangen. 
Tabel 12.22 Multivariate samenhang(en) gedrag tussen verzekeringsgeneeskundige en terugkeer

\begin{tabular}{lllllll}
\hline & $\mathrm{N}$ & $\mathrm{D}$ & $\mathrm{G}$ & $\mathrm{p}$ & $\mathrm{GoF}$ & $\mathrm{p}$ \\
Gedrag verz.geneesk. & 98 & 130.38 & 4.45 & $\mathrm{~ns}$ & 7.02 & $\mathrm{~ns}$ \\
\hline & hoog= & $\mathrm{B}$ & $\mathrm{SE}$ & Wald & $\mathrm{p}$ \\
\hline Duur ziekmelding 1e contact & hoog & .05 & .09 & .26 & $\mathrm{~ns}$ \\
Visie oorzaak & alleen werk & .79 & .43 & 3.37 & .07 \\
Aantal contacten met bedrijf & hoog & -.36 & .46 & .59 & $\mathrm{~ns}$ \\
\hline
\end{tabular}

\subsection{Samenvatting van de eerste bevindingen}

Als we het totale beeld van de bevindingen tot nu toe bekijken, dan blijkt slechts een gering aantal van de gestelde verwachtingen uit te komen. De meeste variabelen en groepen van variabelen blijken geen directe verklarende waarde te hebben voor de kans op werkhervatting in de werkkring bij de ziekmelding.

Een overzicht van de bevindingen met betrekking tot de groepen variabelen geven we in tabel 12.23 .

Daarbij komt duidelijk naar voren dat de belangrijkste determinanten van terugkeer betrekking hebben op bedrijfskenmerken, op afstand gevolgd door kenmerken van de arbeidsplaats en de ziektegeschiedenis. Afgezien van een enkele individuele variabele doen persoonskenmerken er nauwelijks toe en de ziekte(gedrags) en hulpverleningskenmerken in het geheel niet.

Tabel 12.23 Samenvatting multivariate bevindingen

\begin{tabular}{lrrrrr}
\hline & $\mathrm{N}$ & G-waarde & $\mathrm{p}$ & Goodness of Fit & $\mathrm{p}$ \\
\hline Persoonskenmerken & 105 & 8.60 & $\mathrm{~ns}$ & 6.10 & $\mathrm{~ns}$ \\
Becirifskenmerken & 100 & 30.49 & .00 & 8.47 & $\mathrm{~ns}$ \\
Arbeidsplaatskenmerken & 90 & 28.39 & .01 & 7.03 & $\mathrm{~ns}$ \\
Ziektegeschiedenis & 99 & 11.95 & .02 & 8.39 & $\mathrm{~ns}$ \\
Ziektekenmerken & 92 & 5.36 & $\mathrm{~ns}$ & 4.57 & $\mathrm{~ns}$ \\
Ziektegedrag & 90 & 2.33 & $\mathrm{~ns}$ & 6.34 & $\mathrm{~ns}$ \\
Kenmerken huisarts & 90 & 13.35 & $\mathrm{~ns}$ & 3.99 & $\mathrm{~ns}$ \\
Gedrag huisarts & 85 & 9.94 & $\mathrm{~ns}$ & 6.45 & $\mathrm{~ns}$ \\
Kenmerken verzekeringsgeneeskundige & 105 & 3.60 & $\mathrm{~ns}$ & 1.11 & $\mathrm{~ns}$ \\
Gedrag verzekeringsgeneeskundige & 98 & 4.45 & $\mathrm{~ns}$ & 7.02 & $\mathrm{~ns}$ \\
\hline
\end{tabular}

De belangrijkste afzonderlijke variabelen zijn de omvang van het bedrijf en het daarmee nauw samenhangend aantal steunpunten voor het personeel, het probleemoplossend vermogen van het bedrijf en de lengte van het dienstverband van de werknemer. 


\subsection{Naar een integraal model voor de verklaring van terugkeer}

Tot nog toe hebben we ons beperkt tot bivariate verbanden en multivariate analyses met beperking tot variabelen uit telkens éen categorie. Daarbij is geen rekening gehouden met de mogelijke verstorende invloed van variabelen uit andere categorieën, waardoor verbanden onderdrukt of juist kunstmatig kunnen zijn. Zo hebben we in hoofdstuk 9 laten zien dat het leggen van contact tussen verzekeringsgeneeskundige en bedrijf, afhankelijk is van de mate waarin de verzekeringsgeneeskundige bekend is met het bedrijf, hetgeen weer samenhangt met de omvang van het bedrijf. De bovenstaande analyse is daarom nogmaals uitgevoerd, waarbij aan elke categorie gezamenlijk en aan elke onafhankelijke variabele afzonderlijk de volgende variabelen zijn toegevoegd: sexe, sector, aantal steunpunten, probleemoplossend vermogen, lengte dienstverband en promotiekansen. Niet alleen de sterkte van het bivariaat verband speelt hierbij een rol, maar ook het theoretisch belang van bepaalde variabelen zoals sexe en sector. Leeftijd had op theoretische gronden ook toegevoegd kunnnen worden, maar deze variabele hangt nauw samen met de variabele lengte van het dienstverband $(r=47)$. Bij de categorie kenmerken van de verzekeringsgeneeskundige is de toevoeging van de variabele aantal steunpunten achterwege gelaten in verband met de hoge correlatie $(r=.47)$ met de mate van bekendheid met het bedrijf.

Tabel 12.24 Overzicht variabelen met één of meer samenhangen met terugkeer

\begin{tabular}{|c|c|c|c|}
\hline Variabele $($ hoog $=$ ): & Bivariaat & $\begin{array}{l}\text { Multivariaat } \\
\text { binnen groep }\end{array}$ & $\begin{array}{l}\text { Onder constanthouding } \\
\text { voor controlevariabelen }\end{array}$ \\
\hline Sexe (vrouw) & -- & - & - \\
\hline Leeftijd & & & -- \\
\hline Ziekte tijdens jeugd & & & - \\
\hline Sector (diensten) & -- & -- & -- \\
\hline Aantal steunpunten op bedrijf & +++ & $+t+$ & \\
\hline Reorganisaties laatste jaar & + & + & \\
\hline Probleemoplossend vermogen bedrijf & +++ & +++ & ++ \\
\hline Lengte dienstverband & +++ & +++ & ++ \\
\hline Productiepersoneel & + & & + \\
\hline Promotiekansen & +++ & + & ++ \\
\hline Hinder van onzekerheid & -- & -- & -- \\
\hline Goede relatie met chef & ++ & & \\
\hline Verzuimfrequentie laatste 2 jaar & ++ & ++ & + \\
\hline Verzuimomvang laatste 2 jaar & + & + & \\
\hline Visie werknemer op oorzaak (werk) & - & - & \\
\hline Uitstelgedrag ziekmelding & & & - \\
\hline Praktijktype (meermans) & & & + \\
\hline Open stijl huisarts & & & ++ \\
\hline Medicaliserende stijl huisarts & ++ & ++ & ++ \\
\hline Sociaal-psychiatrische taakopvatting & ++ & & ++ \\
\hline Beleid: psychofarmaca & & - & \\
\hline Beleid gericht op werk & & - & - \\
\hline Bekendheid verz.geneesk. met bedrijf & + & + & \\
\hline Visie verz.geneesk. op oorzaak (werk) & - & - & \\
\hline
\end{tabular}

$+1-=p<.10 ;++1-\cdots=p<.05 ;+++1---=p<.01$. 
Zodoende hebben we 24 afzonderlijke variabelen kunnen traceren die bivariaat en/of onder constanthouding voor soortgelijke kenmerken en/of onder constanthouding voor de controlevariabelen een samenhang met de kans op terugkeer tonen met een statistische significantie van maximaal .10.

Uit de tabel blijkt er als gevolg van constanthouding voor de controlevariabelen alsnog verbanclen aan het licht te komen tussen terugkeer en variabelen als leeftijd, praktijktype van de huisarts alsmede een open wijze van omgang door de huisarts met onzekerheid.

\subsection{Een padanalyse van determinanten van terugkeer}

Bij de tot nu toe gevolgde werkwijze is gestreefd naar een zo ruim mogelijke verzameling van significante verbanden tussen onafhankelijke variabelen en terugkeer. Deels kunnen deze berusten op een zuiver confounder-effect, deels betreft het causale samenhangen als gevolg van spurious of intermediërende verbanden en deels zijn het directe verbanden met de afhankelijke variabele.

Om de aard van de gevonden verbanden op te helderen is een padanalyse verricht op basis van alle in de laatste tabel opgenomen variabelen. Een padanalyse is gebaseerd op aannames omtrent causale ketens, d.w.z.: a priori moet aannemelijk gemaakt worden dat de variabelen in tijd gezien aan elkaar voorafgaan of op elkaar volgen.

Als uitgangspunt hebben wij gekozen voor het moment waarop de variabelen in de biografie en het ziektebeloop van de werknemer hun invloed kunnen uitoefenen. De theoretische volgorde die ook in de presentatie van de 24 variabelen in de laatste tabel is verwerkt, luidt dan ook globaal:

1 persoonskenmerken: leeftijd en sexe voorop,

2 bedrijfskenmerken: sector en aantal steunpunten voorop.

3 arbeidsplaatskenmerken: lengte dienstverband en functie voorop.

4 verzuimverleden: ziektefrequentie voorafgaand aan verzuimomvang,

5 ziektekenmerken,

6 ziektegedrag,

7 kenmerken huisarts: praktijktype voorop,

8 kenmerken verzekeringsgeneeskundige,

9 gedrag huisarts,

10 gedrag verzekeringsgeneeskundige.

Bij de analyse wordt terugwaarts gewerkt. Als eerste stap is een lineaire regressieanalyse uitgevoerd, waarbij terugkeer als afhankelijke en alle geselecteerde 24 variabelen als onafhankelijke variabele zijn opgenomen. De tweede stap betrof een lineaire regressie-analyse met als afhankelijke variabele de volgens de causale redenering "laatste", significant met terugkeer samenhangende, onafhankelijke variabele. In dit geval betreft het de variabele "verzuimfrequentie gedurende de laatste twee jaar". Als onafhankelijke variabelen fungeerden alle geselecteerde variabelen die volgens de causale redenering aan deze voorafgaan. 
Deze procedure is telkens herhaald, waarbij vanaf de derde stap niet alleen de variabelen die significant met de variabele terugkeer samenhangen, aan een lineaire regressie-analyse met alle daar weer aan voorafgaande variabelen als onafhankelijke onderworpen zijn, maar ook die variabelen die ten minste eenmaal significant blijken samen te hangen met een intermediërende variabele. Bij de uiteindelijk twee resterende variabelen sexe en leeftijd is de padanalyse besloten met de berekening van de Pearson-correlatie.

Waar bij de lineaire regressie-analyses sprake is van een dichotome afhankelijke variabele is ter controle ook een logistische regressie-analyse uitgevoerd. Deze controle was gericht op de sterkte van het verband tussen de afzonderlijke onafhankelijke variabelen en de afhankelijke variabele. Als grens voor opname in het uiteindelijke padmodel is gekozen voor een statistisch significantieniveau van de Wald-score van .10. De reden voor deze grens is gelegen in het conservatieve karakter van de Wald-score, d.w.z.: de nulhypothese dat er geen verband aanwezig is tussen onafhankelijke en afhankelijke variabele, wordt in een te geringe mate verworpen. (Hosmer en Lemeshow, 1989)

Alvorens tot de uitvoering van de regressie-analyses te kunnen overgaan moest eerst het probleem van de reductie van het aantal respondenten als gevolg van het cumulatief effect van de non-respons per variabele opgelost worden. Deze reductie omvatte ongeveer $30 \%$ van de respondenten. Bij de meeste variabelen konden wij uit de totale informatie opmaken wat naar alle waarschijnlijkheid de ontbrekende waarden waren. Deze betroffen voornamelijk kenmerken van het bedrijf en van de arbeidsplaats. Voor de verzuimmaten en de uitsteltermijn voor de ziekmelding zijn in geval van non-respons de gemiddelde waarden ingevuld. Dit betrof éen tot zeven respondenten. Bij non-respons inzake de kenmerken en het gedrag van de huisarts is afgezien van substitutie. Dit alles heeft tot gevolg gehad dat de reductie uiteindelijk een omvang had van 21 respondenten.

Noch de eerste lineaire noch de eerste logistische regressie-analyse brachten significante verbanden aan het licht tussen de twee gedragsvariabelen van de huisarts en evenmin tussen de visie van de verzekeringsgeneeskundige op de oorzaak van de overspanning en terugkeer. Bovendien bleken de resultaten van beide typen regressie-analyses niet geheel overeenkomstig. Om die reden zijn de analyses herhaald zonder deze drie variabelen. De volgende paren logistische en lineaire regressie-analyses bleken telkens dezelfde variabelen aan te wijzen die een significant verband tonen met de kans op terugkeer. Achtereenvolgens bleken er geen significante verbanden tussen de afhankelijke variabele en de kenmerken van de huisarts, het uitstelgedrag ten aanzien van de ziekmelding, de visie van de werknemer op de oorzaak van de overspanning, en de omvang van het ziekteverzuim gedurende de laatste twee jaar.

De resultaten van de logistische en lineaire regressie-analyse met betrekking tot de bijdrage van de afzonderlijke variabelen toont tabel 12.25. Op basis van deze resultaten is begonnen met de padanalyse. Als gevolg van het wegvallen de huisartskenmerken hebben deze betrekking op 108 respondenten. 
Tabel 12.25 Resultaat lineaire en logistische regressie-analyse

\begin{tabular}{lllll}
\hline Variabele (hoog=) & $\beta$ & $p$ & Wald & $p$ \\
\hline Sexe (vrouw) & -.11 & $n s$ & 0.96 & $\mathrm{~ns}$ \\
Leettijd & -.15 & $n \mathrm{~ns}$ & 2.71 & $<.10$ \\
Ziekte tijdens jeugd & .10 & $n s$ & 1.84 & $\mathrm{~ns}$ \\
Sector (diensten) & -.12 & $\mathrm{~ns}$ & 1.82 & $\mathrm{~ns}$ \\
Aantal steunpunten op bedrijf & .05 & $\mathrm{~ns}$ & 0.83 & $\mathrm{~ns}$ \\
Reorganisaties laatste jaar & .11 & $\mathrm{~ns}$ & 1.56 & $\mathrm{~ns}$ \\
Probleemoplossend vermogen bedrijf & .22 & $<.05$ & 5.83 & $<.05$ \\
Lengte dienstverband & .27 & $<.05$ & 4.89 & $<.05$ \\
Productiepersoneel & .06 & $\mathrm{~ns}$ & 0.62 & $\mathrm{~ns}$ \\
Promotiekansen & -.09 & $\mathrm{~ns}$ & 0.93 & $\mathrm{~ns}$ \\
Goede relatie met chef & .10 & $\mathrm{~ns}$ & 1.23 & $\mathrm{~ns}$ \\
Hinder van onzekerheid & -.08 & $\mathrm{~ns}$ & 1.40 & $\mathrm{~ns}$ \\
Verzuimfrequentie laatste 2 jaar & .15 & $<.10$ & 2.84 & $<.10$ \\
\hline
\end{tabular}

Met een significantieniveau van .10 als grens blijken beide analysemethodes de volgende variabelen als directe determinanten van terugkeer voort te brengen: het probleemoplossend vermogen van het bedrijf, de lengte van het dienstverband, en de verzuimfrequentie van de laatste twee jaren. Op éen punt verschillen beide methoden, namelijk met betrekking tot de significantie van de invloed van leeftijd. $D e$ lineaire methode onderschat het significantieniveau.

Figuur 12.1 toont het uiteindelijke resultaat van de padanalyse. Gelet op de vertekening door gebruik van de lineaire in plaats van de logistische regressiemethode bij dichotome variabelen, dienen de $\beta$-waarden niet al te absoluut opgevat te worden.

Figuur 12.1 Resultaat padanalyse van de kans op terugkeer

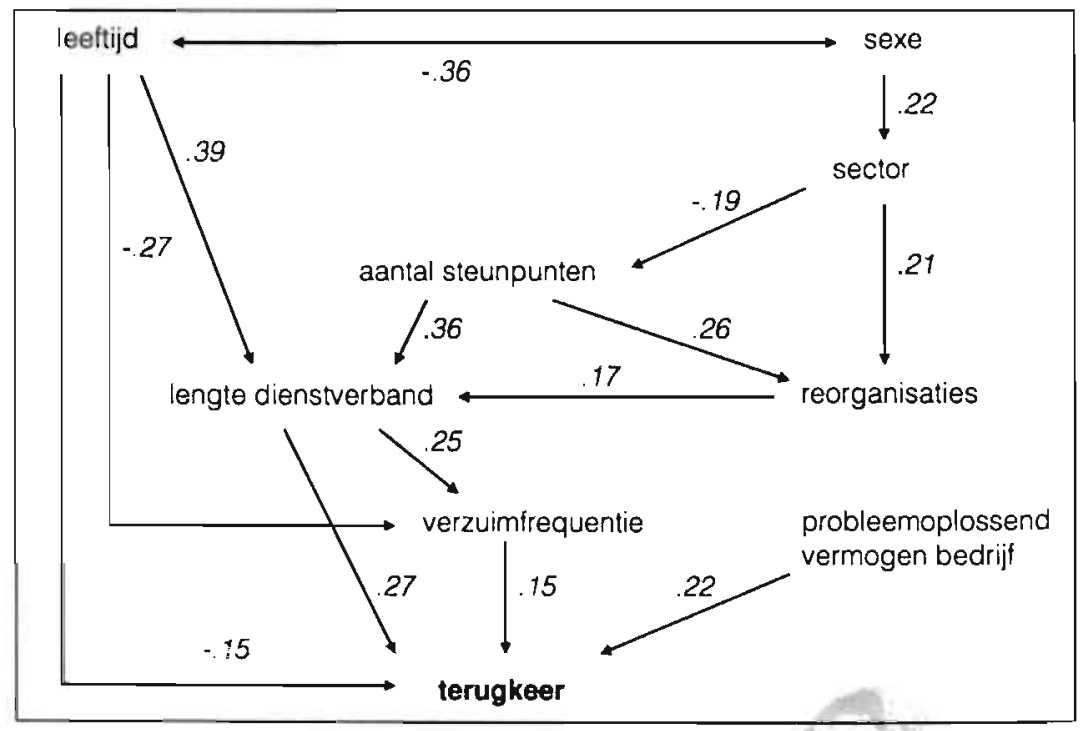




\subsection{Conclusies en beschouwing}

De kans op terugkeer naar de werkkring na een periode van verzuim wegens overspanning van ten minste vier weken blijkt niet beïnvloed door ziektekenmerken of het ziektegedrag van de werknemer en evenmin door de kenmerken en behandelings- of begeleidingsactiviteiten van huisarts en verzekeringsgeneeskundige.

Direct van invloed blijken leeftijd, de lengte van het dienstverband, het aantal malen dat eerder verzuim heeft plaatsgevonden, en het probleemoplossend vermogen van het bedrijf.

Persoonskenmerken blijken van (in)directe invloed. De afwezigheid van enig verband tussen leeftijd en terugkeer in de bivariate analyse blijkt het gevolg van diverse beïnvloedingswijzen die met leeftijd samenhangen. Op zich lopen ouderen een groter risico op verloop, maar met name hun langer dienstverband compenseert deels dit directe leeftijdseffect.

De aanvankelijke bevinding dat vrouwen in aanzienlijk geringere mate terugkeren, blijkt eveneens het effect van diverse andere kenmerken van vrouwelijke werknemers, met name het werkzaam zijn in de dienstensector.

Voorts is de lengte van het dienstverband direct en indirect van invloed op terugkeer. In combinatie met de directe, positieve invloed van verzuimfrequentie op terugkeer lijkt het erop, dat hier sprake is van een overlevingseffect. Er is blijkbaar een categorie werknemers die over een stabiele arbeidsplaats beschikken en/of een sterke binding aan het bedrijf hebben, als gevolg waarvan werkhervattingen na ziekte gemakkelijker tot stand komt. Omgekeerd is er een categorie bedrijven die zich inzetten en erin slagen om werknemers na ziekte voor het bedrijf te behouden.

Dit laatste blijkt nog eens uit de belangrijke invloed van de bedrijfskenmerken. Alle door ons geselecteerde kenmerken blijken direct of indirect van invloed. Hoewel men op grond van de bedrijfskenmerken beter dan elke andere categorie variabelen in staat is te verklaren wie er terugkeren en wie niet, blijkt de invloed voornamelijk indirect. Sector, aantal steunpunten, en reorganisaties behoren namelijk tot de belangrijke determinanten van de lengte van het dienstverband. Het probleemoplossend vermogen van het bedrijf is wel rechtstreeks en onbepaald door andere variabelen van invloed. Dat wil zeggen dat de kans op terugkeer mede afhankelijk is van de inspanning die een werkgever zich getroost om serieus de problemen van de werknemer op te lossen. Gezien de positieve indirecte bijdrage van het aantal steunpunten waarover een bedrijf beschikt, en van de variabele reorganisatie, d.w.z.: er wordt een beleid gevoerd dat flexibel is qua organisatie, en de positieve directe bijdrage van de lengte van het dienstverband en het vaker verzuimen, kan als algemene conclusie getrokken worden dat een consistent beleid van bedrijven om acht te slaan op het behoud en welbevinden van de werknemers doorslaggevend is bij de wijze waarop verzuim wegens overspanning ten slotte beëindigd wordt: met terugkeer of met een definitief vertrek. 


$$
\text { . }
$$




\section{Hoofdstuk 13}

\section{Verklaring van de aard van het verloop}

\subsection{Inleiding}

Dit hoofdstuk is gewijd aan de verklaring van de afloop van de ziekteverzuimperiode van een overspannen werknemer, indien deze niet terugkeert naar de werkkring waar de ziekmelding plaatsgevonden heeft.

Dit betekent dat de afhankelijke variabele gebaseerd is op een tweedeling van de respondenten naar de aard van het verloop, namelijk degenen die ontslag hebben genomen gevolgd door een nieuwe werkkring of door een periode van werkloosheid, versus degenen die het stadium van WAO-intrede bereikt hebben.

Evenals ten aanzien van de kans op terugkeer in het vorige hoofdstuk, wordt nagegaan in hoeverre het in hoofdstuk 5 op basis van de verzuimlitteratuur opgestelde model waarin de invloed van de variabelencategorieën: persoonskenmerken, bedrijfskenmerken, kenmerken van de arbeidsplaats, ziektegeschiedenis, ziektekenmerken, ziektegedrag van de werknemer en kenmerken en gedrag van huisarts en verzekeringsgeneeskundige op de aard van het verloop verondersteld is, van toepassing is op overspannen werknemers en verder is te specificeren naar afzonderlijke onafhankelijke variabelen.

Op iedere afzonderlijke verkenning per categorie variabelen van de bivariate samenhangen volgt een multivariate analyse van elke afzonderlijke categorie ter opsporing van een eventuele gezamenlijke invloed op de aard van het verloop. Daarna wordt dezelfde verkenning herhaald onder constanthouding van een klein aantal variabelen die bij de eerste verkenning een relatief sterk verband getoond hebben met de aard van het verloop. Besloten wordt met een padanalyse op basis van alle variabelen die op enigerlei wijze een statistisch significant, $d$.w.z.: beneden de grenswaarde van .10, verband tonen met de afhankelijke variabele.

Ook hier doet zich het probleem voor dat de constructie van de afhankelijke variabele geen precedent heeft in de verzuimlitteratuur. Daarom zullen de verwachtingen omtrent de relaties tussen onafhankelijke en afhankelijke variabelen worden geformuleerd op basis van wat bekend is uit onderzoek naar determinanten van WAO-intrede, waarbij WAO-intreders gesteld worden tegenover alle andere vergelijkbare verzuimgevallen, ongeacht de vorm van de afloop, of zelfs tegenover gehele werknemerspopulaties. 


\subsection{De invloed van persoonskenmerken op de aard van het verloop}

Op grond van de litteratuur verwachten wij een hoger WAO-intrederisico voor oudere werknemers, lager opgeleide werknemers en werknemers uit de meer verstedelijkte gemeenten. Eveneens geldt dit voor werknemers die tijdens hun jeugd een van beide of beide ouders verloren hebben. Dit zou de kwetsbaarheid verhogen en daarom problemen in de volwassenheid intensiveren. (Brown en Harris, 1978) Voor vrouwen verwachten we op grond van de bevindingen van Bijlsma en Koopmans (1986) een lager WAO-intrederisico. We verwachten een grotere mate van WAO-intrede naarmate het aantal life events groter is. Dit op grond van afbraak van de weerstand tegen problemen en de gevonden relatie met de oorzaak van de overspanning. Over de rol van steun thuis doen we evenals bij de verklaring van terugkeer geen uitspraak omtrent een verwachting, omdat a priori onduidelijk is in welke richting de steun geboden wordt.

Tabel 13.1 Bivariate samenhangen tussen persoonskenmerken en de aard van het verloop

\begin{tabular}{llcll}
\hline Persoonskenmerken: & hoog $=$ & $x^{2} / F$ & richting & $p$ \\
\hline Sexe & vrouw & 0.00 & & $\mathrm{~ns}$ \\
Leeftijd & hoog & 12.38 & + & .001 \\
Opleidingsniveau & hoog & 1.22 & & $\mathrm{~ns}$ \\
Urbanisatiegraad & stedelijk & 0.01 & & $\mathrm{~ns}$ \\
Steun thuis & ja & 4.28 & - & .04 \\
Aantal life events & hoog & 0.47 & & $\mathrm{~ns}$ \\
Verlies ouders in jeugd & ja & 3.45 & + & .06 \\
\hline
\end{tabular}

Sexe blijkt geen determinant van de kans op de aard van het verloop. De kans op WAO-intrede ligt is bij vrouwen en mannen gelijk. Naar alle verwachting is er een sterke samenhang met leeftijd. Met opleidingsniveau en urbanisatiegraad treffen we geen bivariate samenhang aan. Evenmin met het aantal life events. Een zwak verband is er met het verlies van één of beide ouders tijdens de jeugd. Ook is er een verband met het ondervinden van steun thuis. Deze lijkt een stimulerende factor voor het besluit om in het geval dat terugkeer naar de werkplek onhaalbaar wordt geacht, oplossingen te zoeken die een WAO-intrede vermijden.

De multivariate analyse wijzigt het verband tussen de aard van het verloop en de persoonskenmerken slechts in beperkte mate. Het verband met leeftijd zwakt wat af; dat met het verlies van de ouders verdwijnt. Een model waarin alle persoonskenmerken opgenomen worden, blijkt de verklaring van de aard van het verloop te bevorderen. 
Tabel 13.2 Multivariate samenhang(en) tussen persoonskenmerken en de aard van het verloop

\begin{tabular}{|c|c|c|c|c|c|c|}
\hline Persoonskenmerken & $\begin{array}{l}N \\
45\end{array}$ & $\begin{array}{l}D \\
43.89\end{array}$ & $\begin{array}{l}G \\
18.48\end{array}$ & $\begin{array}{l}p \\
.01\end{array}$ & $\begin{array}{l}\text { GoF } \\
7.57\end{array}$ & $\begin{array}{l}\mathrm{p} \\
\mathrm{ns}\end{array}$ \\
\hline & hoog $=$ & $\mathrm{B}$ & SE & Wald & $p$ & \\
\hline Sexe & vrouw & .26 & .91 & .08 & ns & \\
\hline Leeftijd & hoog & .11 & .05 & 5.65 & .02 & \\
\hline Opleidingsniveau & hoog & -.26 & .40 & .41 & ns & \\
\hline Urbanisatiegraad & stedelijk & -.02 & .23 & .01 & ns & \\
\hline Steun thuis & ja & -1.89 & .89 & 4.55 & .03 & \\
\hline Aantal life events & hoog & -.18 & .38 & .23 & ns & \\
\hline Verlies ouders & ja & 1.00 & 1.00 & 1.00 & ns & \\
\hline
\end{tabular}

\subsection{De invloed van bedrijfskenmerken op de aard van het verloop}

Omtrent de stimulerende invloed van de omvang van het bedrijf op WAO-intrede biedt de litteratuur voldoende aanknopingspunten om bij dit kenmerk een samenhang te voorspellen met de kans op WAO-intrede. Ten aanzien van de sector waarvan het bedrijf deel uitmaakt, en de aanwezigheid van steunpunten spreken wij op grond van tegengestelde bevindingen in de litteratuur geen verwachting uit.

Tabel 13.3 Bivariate samenhangen tussen bedrijtskenmerken en de aard van het verloop

\begin{tabular}{lllll}
\hline Bedrijfskenmerken: & hoog $=$ & $x^{2} / F$ & richting & $\mathrm{p}$ \\
\hline Sector & diensten & 0.02 & $\mathrm{~ns}$ \\
Omvang & hoog & 1.15 & $\mathrm{~ns}$ \\
Aanwezigheid steunpunten & ja & 0.70 & $\mathrm{~ns}$ \\
\hline
\end{tabular}

De onderzochte bedrijfskenmerken blijken in tegenstelling tot de kans op terugkeer de aard van het verloop niet te beïnvloeden. Geen enkel bedrijfskenmerk blijkt bivariaat samen te hangen met de kans op WAO-intrede.

De multivariate analyse bevestigt niet alieen dat geen van de drie opgenomen bedrijfskenmerken een significante bijdrage levert aan de verklaring van de aard van het verloop, maar ook dat zij gezamenlijk geen significante modelverbetering bewerkstelligen. Blijkbaar bepalen bedrijfskenmerken wel de mogelijkheid tot terugkeer, waarna andere kenmerken bepalen welke vorm van verloop tot stand komt.

\footnotetext{
- Voor de betekenis van de maten D(eviance), G, G(oodness) of(f) F(it), B, S(tandard E(rror) en Wald verwijzen we naar 11.3.
} 
Tabel 13.4 Multivariate samenhang(en) tussen bedrijfskenmerken en de aard van het verloop

\begin{tabular}{lllllll}
\hline Becirifskenmerken & $\mathrm{N}$ & $\mathrm{D}$ & $\mathrm{G}$ & $\mathrm{p}$ & $\mathrm{GoF}$ & $\mathrm{p}$ \\
& 45 & 60.28 & 1.91 & $\mathrm{~ns}$ & 7.84 & $\mathrm{~ns}$ \\
\hline & hoog $=$ & $\mathrm{B}$ & $\mathrm{SE}$ & Wald & $\mathrm{p}$ & \\
\hline Sector & diensten & -.13 & .62 & .04 & $\mathrm{~ns}$ \\
Omvang & hoog & .12 & .26 & .22 & $\mathrm{~ns}$ \\
Aanwezigheid steunpunten & ja & .60 & .73 & .66 & $\mathrm{~ns}$ & \\
\hline
\end{tabular}

\subsection{De invloed van arbeidsplaatskenmerken op de aard van het verloop}

Op grond van de verzuimlitteratuur mag verwacht worden dat er een verhoogde kans op WAO-intrede bestaat voor werknemers met een langere werkweek, onregelmatige werktijden, of met meer hinder van fysieke en psycho-sociale werkomstandigheden, terwijl de WAO-intredekansen voor werknemers die een hogere werklast ervaren of in teamverband werken, lager zijn. Voor de overige variabelen geeft de litteratuur geen aanknopingspunten. We verwachten dat werknemers die langer in dienst zijn, op grond van een hogere leeftijd een grotere kans op WAO-intrede zullen tonen. Eveneens geldt dat voor werknemers met een geringere mate van vrijheid, met gebrek aan mogelijkheden tot zelfrealisatie, met geringe ontplooiingskansen, en voor werknemers die een slechte verhouding hebben met hun baas en/of collegae. Met betrekking tot de invloed van hinder van onzekerheid over het voortbestaan van de arbeidsplaats spreken we geen verwachting uit.

Tabel 13.5 Bivariate samenhang(en) tussen arbeidsplaatskenmerken en de aard van het verloop

\begin{tabular}{lllll}
\hline Arbeidsplaatskenmerken: & hoog $=$ & $x^{2} / \mathrm{F}$ & richting & $\mathrm{p}$ \\
\hline Lengte dienstverband & hoog & 16.23 & + & .000 \\
Omvang werkweek & hoog & 5.56 & - & .02 \\
Werktijden & onregelmatig & 5.35 & - & .02 \\
Fysieke hinder & hoog & 0.03 & & $\mathrm{~ns}$ \\
Psycho-sociale hinder & hoog & 1.00 & & $\mathrm{~ns}$ \\
Werklast & hoog & 0.11 & & $\mathrm{~ns}$ \\
Mate van vrijheid & hoog & 0.52 & & $\mathrm{~ns}$ \\
Mate van zelfrealisatie & hoog & 0.01 & $\mathrm{~ns}$ \\
Hinder van onzekerheid & hoog & 1.07 & & $\mathrm{~ns}$ \\
Samenwerking & ja & 0.70 & & $\mathrm{~ns}$ \\
Verhouding met chef & goed & 0.17 & & $\mathrm{~ns}$ \\
Verhouding met collegae & goed & 0.54 & & \\
\hline
\end{tabular}

Slechts drie kenmerken van de arbeidsplaats vertonen een bivariate samenhang met de kans op WAO-intrede. In volgorde van sterkte: de lengte van het dienstverband, de omvang van de werkweek, en het werken op onregelmatige tijden. De laatste twee echter in een omgekeerde richting ten opzichte van de verwachte. Werknemers met een langere werkweek en onregelmatige werktijden blijken, indien 
zij na een periode van overspanning niet terugkeren, de verzuimperiode vaker met ontslag(name) te beëindigen dan met WAO-intrede.

In tegenstelling tot de bedrijfskenmerken blijken de kenmerken van de arbeidsplaats gezamenlijk wel een significante bijdrage te kunnen leveren aan de verklaring van de aard van het verloop. De bijdrage van enkele afzonderlijke variabelen blijkt bij de multivariate analyse echter iets minder uitgesproken. Alleen de lengte van het dienstverband toont nog een zwak statistisch significant verband.

Tabel 13.6 Multivariate samenhang(en) tussen arbeidsplaatskenmerken en de aard van het verloop

\begin{tabular}{|c|c|c|c|c|c|c|}
\hline Arbeidsplaatskenmerken & $\begin{array}{l}N \\
36\end{array}$ & $\begin{array}{l}D \\
29.57\end{array}$ & $\begin{array}{l}G \\
20.25\end{array}$ & $\begin{array}{l}\mathrm{p} \\
.04\end{array}$ & $\begin{array}{l}\text { GoF } \\
3.42\end{array}$ & $\begin{array}{l}\mathrm{p} \\
\mathrm{ns}\end{array}$ \\
\hline & hoog= & $\mathrm{B}$ & SE & Wald & $p$ & \\
\hline Lengte dienstverband & hoog & .71 & .40 & 3.05 & .08 & \\
\hline Omvang werkweek & hoog & -.09 & .07 & 1.95 & ns & \\
\hline Werktijden & onregelmatig & -2.57 & 2.16 & 1.41 & $\mathrm{~ns}$ & \\
\hline Fysieke hinder & hoog & .02 & .06 & .09 & $\mathrm{~ns}$ & \\
\hline Werklast & hoog & .70 & 1.04 & .44 & ns & \\
\hline Mate van vrijheid & hoog & .32 & 44 & .52 & ns & \\
\hline Mate van zelfrealisatie & hoog & .21 & .14 & 2.26 & ns & \\
\hline Hinder onzekerheid & hoog & .09 & 34 & .07 & ns & \\
\hline Samenwerking & ja & 2.62 & 2.13 & 1.52 & ns & \\
\hline Verhouding met chef & goed & .27 & 49 & .31 & ns & \\
\hline Verhouding met collegae & goed & .12 & 96 & .01 & ns & \\
\hline
\end{tabular}

\subsection{De invloed van de ziektegeschiedenis op de aard van het verloop}

In de litteratuur wordt op één uitzondering na voor elke verschillende ziekteverzuimmaat een positieve samenhang gevonden tussen het verzuimpatroon van de werknemer over een bepaalde periode voor de ziekmelding en de kans op WAOintrede. Wij verwachten dan ook dat de vier verzuimmaten positief samenhangen met de kans op WAO-intrede. Met betrekking tot eerdere overspanning onthouden we ons op grond van dezelfde argumenten als in het vorige hoofdstuk aangevoerd van het formuleren van verwachtingen vooraf.

Tabel 13.7 Bivariate samenhang(en) tussen ziektegeschiedenis en de aard van het verloop

\begin{tabular}{lllll}
\hline Kenmerken ziektegeschiedenis: & hoog $=$ & $x^{2} / F$ & richting & $p$ \\
\hline Verzuimfrequentie laatste jaar & hoog & 0.51 & ns \\
Verzuimfrequentie laatste 2 jaar & hoog & 0.04 & ns \\
Frequentie langdurig verzuim & & & \\
$\quad$ laatste 2 jaar & hoog & 0.72 & ns \\
Verzuimomvang laatste 2 jaar & hoog & 1.53 & ns \\
Eerder overspannen & ja & 0.00 & ns \\
\hline
\end{tabular}


Geen enkel aspect van het verzuimverleden blijkt, in tegenstelling tot vrijwel alle andere onderzoeken, bivariaat van invloed op de aard van het verloop. Evenmin blijkt een recidiverend karakter van overspanning een determinant van de aard van de uitval. De meest voor de hand liggende verklaring lijkt ons de beperking in dit onderzoek tot langdurige verzuimgevallen. Dat wil zeggen: we veronderstellen dat het verband tussen verzuimverleden en WAO-intrede vooral gebaseerd is op een verband tussen verzuimverleden en kans op langdurig ziekteverzuim.

Tabel 13.8 Multivariate samenhang(en) tussen ziektegeschiedenis en de aard van het verloop

\begin{tabular}{lllllll}
\hline Ziektegeschiedenis & $\mathrm{N}$ & $\mathrm{D}$ & $\mathrm{G}$ & $\mathrm{p}$ & $\mathrm{GoF}$ & $\mathrm{p}$ \\
& 43 & 54.37 & 5.22 & $\mathrm{~ns}$ & 6.30 & $\mathrm{~ns}$ \\
\hline & hoog= & $\mathrm{B}$ & $\mathrm{SE}$ & Wald & $\mathrm{p}$ \\
\hline Verzuimfrequentie laatste jaar & hoog & .56 & .55 & 1.05 & $\mathrm{~ns}$ \\
Verzuimfrequentie laatste 2 jaar & hoog & -.17 & .19 & .77 & $\mathrm{~ns}$ \\
Verzuimomvang laatste 2 jaar & hoog & .54 & .31 & 3.16 & .08 \\
Eerder overspannen & ja & -.83 & .83 & 1.00 & $\mathrm{~ns}$ \\
\hline
\end{tabular}

De gezamenlijke kenmerken van ziektegeschiedenis blijken de aard van het verloop dan ook niet te kunnen verklaren. Wel blijkt de verzuimomvang van de laatste twee jaar bij constanthouding voor de overige verzuimkenmerken zwak positief samen te hangen met de WAO-intredekans.

\subsection{De invloed van ziektekenmerken op de aard van het verloop}

Met betrekking tot ziektekenmerken is de enige aangetoonde determinant van WAO-intrede het aantal gezondheidsklachten. In het vorige hoofdstuk gaven we reeds aan dat WAO-intreders de hoogste scores toonden en de andere categorieën uitvallers de laagste. Op grond daarvan nemen we aan dat de mate van psychoneuroticisme de WAO-intredekans bevordert. Hetzelfde geldt voor de omvang van de uitval als indicatie voor de ernst van overspanning. Ten aanzien van de oorzaak van de aandoening verwachten wij geen samenhang met de aard van het verloop, omdat elke vorm van verloop een onttrekking aan een stresserende werksituatie inhoudt.

Tabel 13.9 Bivariate samenhangen tussen ziektekenmerken en de aard van het verloop

\begin{tabular}{lllcl}
\hline Ziektekenmerken: & hoog $=$ & $\mathrm{x}^{2} / \mathrm{F}$ & richting & $\mathrm{p}$ \\
\hline Psychoneuroticisme & hoog & 7.50 & + & .009 \\
Omvang uitval & werk+thuis & 1.08 & & ns \\
Oorzaak ziekte & alleen werk & 0.13 & - & .06 \\
\hline
\end{tabular}

De ziektekenmerken en zeker de mate van psychoneuroticisme lijken belangrijkere determinanten te zijn van de aard van het verloop dan van het verloop als zodanig. 
De omvang van de uitval als indicatie van ernst van disfunctioneren blijkt geen bivariate samenhang te tonen met de aard van het verloop. De oorzaak van de ziekte in de perceptie van de respondent toont anders dan verwacht een (zwakke) samenhang. Indien de oorzaak van de aandoening naar de mening van de werknemer (mede) op buiten het werk gelegen situaties of gebeurtenissen betrekking heeft, dan is de kans op WAO-intrede groter.

Het beeld van de samenhangen tussen deze variabelen en de aard van het verloop verandert echter aanzienlijk, indien voor elk constanthouding van de andere ziektekenmerken plaatsvindt.

Tabel 13.10 Multivariate samenhang(en) tussen ziektekenmerken en de aard van het verloop

\begin{tabular}{lllllll}
\hline \multirow{2}{*}{ Ziektekenmerken } & $\mathrm{N}$ & $\mathrm{D}$ & $\mathrm{G}$ & $\mathrm{P}$ & $\mathrm{GoF}$ & $\mathrm{p}$ \\
& 40 & 49.78 & 5.57 & $\mathrm{~ns}$ & 3.45 & $\mathrm{~ns}$ \\
\hline & hoog= & $\mathrm{B}$ & $\mathrm{SE}$ & Wald & $\mathrm{p}$ \\
\hline Psychoneuroticisme & hoog & .01 & .01 & 2.64 & .10 \\
Omvang uitval & werk+thuis & .16 & .84 & .04 & $\mathrm{~ns}$ \\
Oorzaak ziekte & alleen werk & .40 & .80 & .25 & $\mathrm{~ns}$ \\
\hline
\end{tabular}

Het gezamenlijke verklaringsvermogen van de ziektekenmerken voor de aard van het verloop is blijkens de G-maat gering. Het verband met psychoneuroticisme is nog slechts zeer zwak. Het verband met de oorzaak van de overspanning blijkt nu weg te vallen.

\subsection{De invloed van ziektegedrag op de aard van het verloop}

Voor deze groep variabelen zijn er in de verzuimlitteratuur geen aanknopingspunten voor verwachtingen. We verwachten dat uitstelgedrag ten aanzien van ziekmelding of inroepen van hulpverlening de overspanning intensiveert en daarmee de kans op WAO-intrede vergroot. Van een lichamelijke klachtenpresentatie aan de huisarts verwachten we op grond van een geringere mogelijkheid tot adequate hulpverlening eveneens een verhoogde kans op WAO-intrede.

Tabel 13.11 Bivariate samenhangen tussen ziektegedrag en de aard van het verloop

\begin{tabular}{lllll}
\hline Kenmerken ziektegedrag: & hoog $=$ & $x^{2} / F$ & richting & $\mathrm{p}$ \\
\hline Duur klachten ziekmelding & hoog & 5.93 & + & .02 \\
Relatie melding consult & na consult & 0.19 & & ns \\
Presentatie aan huisarts & lichamelijk & 1.02 & ns \\
\hline
\end{tabular}

Alleen het lang wachten met de ziekmelding, hetgeen vooral weggelegd is voor werknemers die onder langdurige stress staan, blijkt in de verwachte richting 
samen te hangen met WAO-intrede. De andere kenmerken van het ziektegedrag tonen geen bivariate samenhang.

Als we ziektegedrag in zijn totaliteit bekijken in de multivariate analyse, dan blijkt ziektegedrag bij vertrekkers in belangrijke mate bij te dragen aan de verklaring van WAO-intrede. Alle kenmerken afzonderlijk tonen nu ook een zwak tot zeer sterk verband met WAO-intrede. Wel is er de verrassende bevinding dat werknemers die hun overspanning juist via lichamelijke klachten aan de huisarts presenteren, het verzuim vaker beëindigen met ontslag(name) dan met WAO-intrede.

Tabel 13.12 Multivariate samenhang(en) tussen ziektegedrag en de aard van het verloop

\begin{tabular}{lllllll}
\hline \multirow{2}{*}{ Ziektegedrag } & $\mathrm{N}$ & $\mathrm{D}$ & $\mathrm{G}$ & $\mathrm{p}$ & $\mathrm{GoF}$ & $\mathrm{p}$ \\
& 37 & 34.47 & 16.80 & .00 & 10.64 & $\mathrm{nS}$ \\
\hline & $\mathrm{hoog}=$ & $\mathrm{B}$ & $\mathrm{SE}$ & Wald & $\mathrm{p}$ \\
\hline Duur ziekmelding & hoog & 1.06 & .37 & 8.27 & .00 \\
Relatie melding consult & na consult & 1.79 & 1.04 & 3.00 & .08 \\
Presentatie aan huisarts & lichamelijk & -2.75 & 1.13 & 5.96 & .01 \\
\hline
\end{tabular}

\subsection{De invloed van kenmerken van de huisarts(praktijk) op de aard van het verloop}

Hier hebben de verwachtingen een volkomen a priori karakter. We verwachten dat de huisartsen die eerder een sociaal-geneeskundig beroep hebben uitgeoefend, geen medicaliserende werkstijl en in elk geval een psycho-sociale taakopvatting er op na houden, dieper op de achtergronden ingaan en door een dergelijk probleemoplossend vermogen niet alleen de terugkeer kunnen bevorderen, maar in het geval dat terugkeer achterwege blijt, mogelijk ook andere oplossingen dan WAO-intrede kunnen stimuleren.

Tabel 13.13 Bivariate samenhangen tussen huisartskenmerken en de aard van het verloop

\begin{tabular}{lllcl}
\hline Huisartskenmerken: & hoog $=$ & $\mathrm{x}^{2} / \mathrm{F}$ & richting & $\mathrm{p}$ \\
\hline Leeftijd & hoog & 7.38 & + & .01 \\
Sociaal-geneeskundig verleden & ja & 0.06 & & $\mathrm{~ns}$ \\
Praktijkomvang & groot & 0.59 & & $\mathrm{~ns}$ \\
Praktijktype & meermans & 0.23 & $\mathrm{~ns}$ \\
Integratie in eerstelijn & hoog & 0.10 & $\mathrm{~ns}$ \\
Integratie met GGZ & hoog & 0.12 & $\mathrm{~ns}$ \\
Open werkstijl & hoog & 0.01 & $\mathrm{~ns}$ \\
Medicaliserende werkstijl & hoog & 0.20 & $\mathrm{~ns}$ \\
Psycho-sociale taakopvatting & hoog & 0.67 & $\mathrm{~ns}$ \\
Sociaal-psychiatrische taakopvatting & hoog & 0.13 & $\mathrm{~ns}$ \\
Breedte taakstelling & hoog & 0.48 & & $\mathrm{~ns}$ \\
\hline
\end{tabular}


Er blijkt, op één uitzondering na, geen bivariate relatie tussen welk kenmerk van de huisarts dan ook en de kans op WAO-intrede. De uitzondering betreft de leeftijd van de huisarts. Omdat bij onze groep respondenten geen verband blijkt te bestaan tussen de leeftijd van de werknemer en de leeftijd van de huisarts, is de enige redenering die wij bij dit verband kunnen bedenken, dat oudere artsen meer berustend zijn dan jongere ten aanzien van de toevloed van zieke werknemers naar de WAO.

Als de huisartskenmerken samengenomen worden blijken deze maar weinig invloed te hebben op de kans op WAO-intrede. De leeftijd van de huisarts geeft ook in de multivariate analyse een positieve samenhang te zien. De omvang van de praktijk blijkt nu zwak negatief samen te hangen.

Tabel 13.14 Multivariate samenhang(en) tussen huisartskenmerken en de aard van het verloop

\begin{tabular}{|c|c|c|c|c|c|c|}
\hline Kenmerken huisarts & $\begin{array}{l}N \\
41\end{array}$ & $\begin{array}{l}D \\
42.12\end{array}$ & $\begin{array}{l}G \\
14.70\end{array}$ & $\begin{array}{l}\mathrm{p} \\
\mathrm{ns}\end{array}$ & $\begin{array}{l}\text { GoF } \\
9.69\end{array}$ & $\begin{array}{l}\mathrm{p} \\
\mathrm{ns}\end{array}$ \\
\hline & hoog $=$ & $\mathrm{B}$ & SE & Wald & $p$ & \\
\hline Leeftijd huisarts & hoog & .16 & .06 & 6.14 & 01 & \\
\hline Sociaal-geneeskundig verleden & ja & .86 & .92 & .87 & ns & \\
\hline Praktijkomvang & groot & -1.87 & 1.05 & 3.17 & .07 & \\
\hline Praktijktype & meermans & -1.28 & .97 & 1.75 & ns & \\
\hline Integratie in eerstelijn & hoog & -.13 & .16 & .66 & ns & \\
\hline Integratie met GGZ & hoog & -.13 & .52 & .06 & ns & \\
\hline Open werkstijl & hoog & -.12 & .19 & .39 & ns & \\
\hline Medicaliserende werkstijl & hoog & .03 & .16 & .03 & ns. & \\
\hline Psycho-sociale taakopvatting & hoog & -.06 & .24 & .06 & ns & \\
\hline Sociaal-psychiatr. taakopvatting & hoog & .11 & .15 & .54 & ns & \\
\hline
\end{tabular}

\subsection{De invloed van het gedrag van de huisarts op de aard van het verloop}

Met betrekking tot de samenhang van deze variabelen met WAO-intrede verwachten wij dat enerzijds medicaliserende handelingen als medicatie of verwijzing, anderzijds verschillen in diagnose en visie op de oorzaak van de aandoening het herstelproces in de weg staan en aldus WAO-intrede bevorderen. Van het betrekken van de werksituatie in het beleid van de huisarts verwachten wij dat deze zoveel mogelijk ingebed is in een beleid om WAO-intrede te voorkomen en dus WAO-intrede beperkt.

Uit de resultaten van de bivariate analyses blijken de gedragswijzen van de huisarts geen directe invloed uit te oefenen op de aard van het verloop. 
Tabel 13.15 Bivariate samenhangen tussen huisartsgedrag en de aard van het verloop

\begin{tabular}{|c|c|c|c|c|}
\hline Gedrag huisarts: & hoog $=$ & $x^{2} / F$ & richting & $p$ \\
\hline Diagnose overspanning & ja & 1.01 & & ns \\
\hline Overeenstemming oorzaak & ja & 0.00 & & ns \\
\hline Beleid: rust & ja & 0.46 & & ns \\
\hline Beleid: terugkomen & ja & 0.00 & & ns \\
\hline Beleid: psychofarmaca & ja & 0.00 & & $\mathrm{~ns}$ \\
\hline Beleid: overige medicatie & ja & 1.07 & & ns \\
\hline Beleid: verwijzing & ja & 0.00 & & ns \\
\hline Beleid gericht op werk & ja & 0.00 & & ns \\
\hline
\end{tabular}

De multivariate analyse levert hetzelfde resultaat op. Noch afzonderlijk noch gezamenlijk blijken de handelwijzen van de huisarts enige verklaringswaarde te hebben voor de aard van het verloop.

Tabel 13.16 Multivariate samenhang(en) tussen huisartsgedrag en de aard van het verloop

\begin{tabular}{lllllll}
\hline Gedrag huisarts & $\mathrm{N}$ & $\mathrm{D}$ & $\mathrm{G}$ & $\mathrm{p}$ & $\mathrm{GoF}$ & $\mathrm{p}$ \\
& 34 & 39.31 & 7.70 & \multicolumn{1}{l}{$\mathrm{ns}$} & 12.93 & $\mathrm{~ns}$ \\
\hline & hoog $=$ & $\mathrm{B}$ & $\mathrm{SE}$ & Wald & $\mathrm{p}$ \\
\hline Diagnose overspanning & $\mathrm{ja}$ & -1.65 & 1.18 & 1.95 & $\mathrm{~ns}$ \\
Overeenstemming oorzaak & $\mathrm{ja}$ & -.02 & 1.03 & .00 & $\mathrm{~ns}$ \\
Beleid: rust & ja & -1.09 & 1.11 & .96 & $\mathrm{~ns}$ \\
Beleid: terugkomen & ja & .10 & .86 & .01 & $\mathrm{~ns}$ \\
Beleid: psychofarmaca & ja & 1.21 & .86 & 2.00 & $\mathrm{~ns}$ \\
Beleid: overige medicatie & ja & 1.53 & .94 & 2.67 & $\mathrm{~ns}$ \\
Beleid: verwijzing & ja & -.86 & 1.18 & .53 & $\mathrm{~ns}$ \\
Beleid gericht op werk & ja & 1.07 & 1.00 & 1.16 & $\mathrm{~ns}$ \\
\hline
\end{tabular}

\subsection{De invloed van kenmerken van de verzekeringsgeneeskundige op de aard van het verloop}

Met betrekking tot de bekendheid van de verzekeringsgeneeskundige met het bedrijf verwachten we dat deze positief samenhangt met de kans op WAO-intrede. Dit op grond van de aanname dat de mate van bekendheid deels beïnvloed wordt door de aanwezigheid van verzuim- en WAO-intredeproblematiek bij het bedrijf. Omdat de bekendheid van de verzekeringsgeneeskundige met de overspannen werknemer vooral voortkomt uit eerdere verzuimen die ter controle zijn aangemeld, verwachten we gezien de eerdere bevindingen omtrent verzuimverleden eveneens een positief verband. 
Tabel 13.17 Bivariate samenhangen tussen kenmerken verzekeringsgeneeskundige en de aard van het verloop

\begin{tabular}{lllll}
\hline Kenmerken verzekeringsgeneesk:: & hoog $=$ & $x^{2} / F$ & richting & $p$ \\
\hline Bekendheid verz.geneesk. met patiënt & ja & 0.04 & ns \\
Bekendheid met bedrijf & hoog & 2.24 & ns \\
\hline
\end{tabular}

Geen van beide kenmerken blijkt bivariaat samen te hangen met de aard van het verloop.

Tabel 13.18 Multivariate samenhang(en) tussen kenmerken verzekeringsgeneeskundige en de aard van het verloop

\begin{tabular}{lllllll}
\hline Kenmerken verzekeringsgeneesk. & $\mathrm{N}$ & $\mathrm{D}$ & $\mathrm{G}$ & $\mathrm{p}$ & $\mathrm{GoF}$ & $\mathrm{p}$ \\
& 46 & 60.20 & 3.49 & $\mathrm{~ns}$ & 5.98 & .05 \\
\hline & hoog $=$ & $\mathrm{B}$ & $\mathrm{SE}$ & Wald & $\mathrm{p}$ \\
\hline $\begin{array}{l}\text { Bekendheid verz.gen. patiënt } \\
\text { Bekendheid met bedrijf }\end{array}$ & ja & -.21 & .65 & .10 & $\mathrm{~ns}$ \\
\hline
\end{tabular}

Als we deze beide kenmerken van de verzekeringsgeneeskundige samen nemen, blijkt er wel enige - in de verwachte positieve richting - invloed van de variabele bekendheid met het bedrijf. De gezamenlijke bijdrage is echter van geen betekenis. Bovendien blijkt de door het model voorspelde verdeling van respondenten over de beide waarden van de afhankelijke variabele significant te verschillen van de waargenomen verdeling.

\subsection{De invloed van het gedrag van de verzekeringsgeneeskundige op de aard van het verloop}

Op grond van de grote mate van overeenkomst in de visie op de oorzaak van overspanning, verwachten we dat de visie van de verzekeringsgeneeskundige op de oorzaak niet zal samenhangen met de kans op WAO-intrede. Omtrent het contact met het bedrijf verwachten we een positief verband, omdat de dreiging van WAO-intrede eerder een reden voor contact zal zijn dan de dreiging van ontslagname.

Omtrent de invloed van het aantal weken tussen ziekmelding en eerste contact met de werknemer stellen we geen verwachting.

Er blijkt geen enkele bivariate samenhang tussen de handelwijzen van de verzekeringsgeneeskundige en de aard van het verloop. 
Tabel 13.19 Bivariate samenhangen tussen gedrag verzekeringsgeneeskundige en de aard van het verloop

\begin{tabular}{|c|c|c|c|c|}
\hline Gedrag verzekeringsgeneeskundige: & hoog $=$ & $x^{2} / F$ & richting & $p$ \\
\hline Duur ziekmelding $1 \mathrm{e}$ contact & hoog & 0.50 & & ns \\
\hline Visie oorzaak & alleen werk & 0.04 & & ns \\
\hline Contact met bedrijf & ja & 0.17 & & ns \\
\hline
\end{tabular}

Evenmin blijkt er enig verband, als de gedragskenmerken van de verzekeringsgeneeskundige samengenomen worden.

Tabel 13.20 Multivariate samenhang(en) tussen gedrag verzekeringsgeneeskundige en de aard van het verloop

\begin{tabular}{lllllll}
\hline & $N$ & $D$ & $G$ & $p$ & GoF & $p$ \\
Gedrag verzekeringsgeneesk. & 44 & 58.68 & 2.22 & ns & 5.97 & ns \\
\hline & hoog $=$ & B & SE & Wald & p \\
\hline Duur ziekmelding te contact & hoog & .19 & .14 & 1.80 & $\mathrm{~ns}$ \\
Visie oorzaak & alleen werk & -.48 & .69 & .49 & $\mathrm{~ns}$ \\
Contact bedrijf & ja & .37 & .68 & .29 & $\mathrm{~ns}$ \\
\hline
\end{tabular}

\subsection{Samenvatting van de eerste bevindingen}

Als we naar het totale beeld kijken van de bevindingen tot nu toe dan blijken ook hier slechts een gering aantal verwachtingen uit te komen. De meeste variabelen en groepen van variabelen blijken geen direct verklarende waarde te hebben voor de aard van het verloop, d.w.z.: ontslag(name) of WAO-intrede, in het geval dat een periode van ziekteverzuim wegens overspanning niet met werkhervatting in de oorspronkelijke werkkring beëindigd wordt.

Tabel 13.21 Samenvatting multivariate bevindingen

\begin{tabular}{llccrc}
\hline & $N$ & G-waarde & $p$ & Goodness of Fit & $p$ \\
\hline Persoonskenmerken & 45 & 18.48 & .01 & 7.57 & $\mathrm{~ns}$ \\
Bedrijfskenmerken & 45 & 1.91 & $\mathrm{~ns}$ & 7.84 & $\mathrm{~ns}$ \\
Arbeidsplaatskenmerken & 36 & 20.25 & .04 & 3.42 & $\mathrm{~ns}$ \\
Ziektegeschiedenis & 43 & 5.22 & $\mathrm{~ns}$ & 6.30 & $\mathrm{~ns}$ \\
Ziektekenmerken & 40 & 5.57 & $\mathrm{~ns}$ & 3.45 & $\mathrm{~ns}$ \\
Ziektegedrag & 37 & 16.80 & .00 & 10.64 & $\mathrm{~ns}$ \\
Kenmerken huisarts & 41 & 14.70 & $\mathrm{~ns}$ & 9.69 & $\mathrm{~ns}$ \\
Gedrag huisarts & 34 & 7.70 & $\mathrm{~ns}$ & 12.93 & $\mathrm{~ns}$ \\
Kenmerken verzekeringsgeneesk. & 46 & 3.49 & $\mathrm{~ns}$ & 5.98 & .05 \\
Gedrag verzekeringsgeneesk. & 44 & 2.22 & $\mathrm{~ns}$ & 5.97 & $\mathrm{~ns}$ \\
\hline
\end{tabular}

De determinanten van de aard van het verloop blijken nogal verschillend van die van de kans op terugkeer. Bedrijfskenmerken doen er niet toe, maar wel persoons- 
kenmerken, waarbij nu niet de sexe maar leeftijd doorslaggevend is, arbeidsplaatskenmerken en ziektegedrag. Ook nu komt er een geringe invloed van ziektekenmerken en van de kenmerken en handelwijzen van huisarts en verzekeringsgeneeskundige aan het licht.

\subsection{Naar een integraal model voor de verklaring van de aard van het verloop}

Evenals bij de vorige analyse moeten we rekening houden met het gegeven dat bij deze bevindingen geen rekening is gehouden met verstoring van de verbanden als gevolg van de beperking van de multivariate analyses tot de ałzonderlijke groepen variabelen.

We hebben daarom de multivariate analyse herhaald met toevoeging van de variabelen: psychoneuroticisme, leeftijd, uitstelgedrag ten aanzien van ziekmelding en presentatie aan de huisarts.

Nu blijkt het voorschrijven door de huisarts van andere medicatie dan psychofarmaca alsnog samen te hangen met de aard van het verloop.

Om een zo goed mogelijk model te ontwikkelen hebben we de 16 afzonderlijke variabelen geselecteerd die bivariaat of onder constanthouding voor soortgelijke kenmerken en/of de controlevariabelen een samenhang met de aard van het verloop tonen van een sterkte die een statistische significantie heeft van maximaal .10. Ze worden in de volgende tabel gepresenteerd.

Een plusteken verwijst naar een positief verband met WAO-intrede, een minteken naar een positief verband met ontslag(name).

Tabel 13.22 Overzicht variabelen met éen of meer samenhangen met de aard van het verloop

\begin{tabular}{|c|c|c|c|}
\hline Variabele (hoog): & Bivariaat & $\begin{array}{l}\text { Multivariaat } \\
\text { binnen groep }\end{array}$ & $\begin{array}{l}\text { Onder constanthouding } \\
\text { voor controlevariabelen }\end{array}$ \\
\hline Leettijd & +++ & ++ & \\
\hline Steun thuis & -- & - & \\
\hline Verlies ouder(s) in jeugd & + & & \\
\hline Lengte dienstverband & +++ & + & \\
\hline Omvang werkweek & -- & & \\
\hline Onregelmatige werktijden & - - & & - \\
\hline Verzuimomvang laatste 2 jaar & & + & \\
\hline Visie werknemer op oorzaak (alleen werk) & - & & \\
\hline Psychoneuroticisme & +++ & + & + \\
\hline Duur klachten ziekmelding & ++ & +++ & ++ \\
\hline Relatie melding consult (na consult) & & + & + \\
\hline Presentatie aan huisarts (lichamelijk) & & -- & - \\
\hline Leeftijd huisarts & +++ & +++ & \\
\hline Praktijkomvang & & - & \\
\hline Beleid: overige medicatie & & & ++ \\
\hline Bekendheid verz.geneesk. met bedrijf & & + & \\
\hline
\end{tabular}

$+1-=p<.10 ;++1--=p<.05 ;+++1---=p<.01$. 


\subsection{Een padanalyse van determinanten van de aard van het verloop}

Op dezelfde wijze als beschreven in 12.14 is ook een padanalyse uitgevoerd met de variabelen die op de een of andere wijze een significante samenhang met de aard van het verloop te zien gaven. De veronderstelde causale volgorde is als volgt.

1 persoonskenmerken: leeftijd en verlies ouder(s) voorop,

2 arbeidsplaatskenmerken: lengte dienstverband voorop,

3 verzuimomvang laatste twee jaar,

4 ziektekenmerken: (gepercipieerde) oorzaak voorop,

5 ziektegedrag: als eerste uitstel ziekmelding en presentatie aan huisarts als laatste,

6 kenmerken huisarts: leeftijd van de huisarts voorafgaand aan praktijkomvang,

7 gedrag huisarts,

8 kenmerken verzekeringsgeneeskundige.

Als gevolg van de non-respons op de afzonderlijke variabelen dreigden 12 respondenten, oftewel $25 \%$, bij de regressie-analyses uit te vallen. Om die reden zijn de ontbrekende waarden bij een aantal variabelen als volgt gesubstitueerd. Bij steun thuis, lengte dienstverband, onregelmatige werktijden en presentatie van klachten aan de huisarts werd een waarde op grond van informatie over andere variabelen ingevuld. Bij psychoneuroticisme is de gemiddelde waarde van de verloopscategorie toegekend waartoe de respondent behoort. Bij de omvang van het ziekteverzuim en de duur tussen klachten en ziekmelding de gemiddelde waarde van de gehele populatie. Voor de overige variabelen kon geen betrouwbare waarde gesubstitueerd worden.

De resultaten van de lineaire regressie-analyse op al deze variabelen konden niet getoetst worden aan die van de logistische, omdat als gevolg van de verhouding tussen aantal variabelen en eenheden van waarneming geen enkelvoudige oplossing gevonden kon worden. Om deze redenen is de padanalyse beperkt tot die variabelen met behulp waarvan de logistische regressie-analyse wel een model kon berekenen. Dit bleek pas mogelijk, nadat successievelijk de variabelen met betrekking tot kenmerken van verzekeringsgeneeskundige, gedrag en kenmerken van de huisarts verwijderd waren.

Uit de eerste geslaagde logistische regressie-analyses bleek, dat ziektegedrag, ziektekenmerken, verzuimverleden, omvang van de werkweek, en werktijden geen significante samenhang vertoonden met de aard van het verloop. Ook deze zijn daarom verwijderd. De resultaten van de lineaire en logistische regressie-analyse, van waaruit de padanalyse begonnen is toont de volgende tabel.

Tabel 13.23 Resultaat lineaire en logistische regressie-analyse

\begin{tabular}{lllll}
\hline Variabele (hoog) & $\beta$ & $\mathrm{p}$ & Wald & $\mathrm{p}$ \\
\hline Leeftijd & .30 & $<.05$ & 4.50 & $<.05$ \\
Steun thuis & -.30 & $<.05$ & 5.51 & $<.05$ \\
Verlies ouder(s) in jeugd & .12 & $\mathrm{~ns}$ & 1.26 & $\mathrm{~ns}$ \\
Lengte dienstverband & .33 & $<.05$ & 5.36 & $<.05$ \\
\hline
\end{tabular}


Volgens beide methoden blijkt er sprake van een significante samenhang tussen de aard van het verloop en leeftijd, het ondervinden van steun thuis en de lengte van het dienstverband. Alleen het verlies van éen of beide ouders in de jeugdjaren blijkt geen invloed te hebben.

Figuur 13.1 toont het uiteindelijke resultaat van de padanalyse. Gelet op de vertekening door gebruik van de lineaire in plaats van de logistische regressiemethode bij dichotome variabelen, dienen de $\beta$-waarden niet al te absoluut opgevat te worden.

Figur 13.1 Resultaat padanalyse van de aard van het verloop

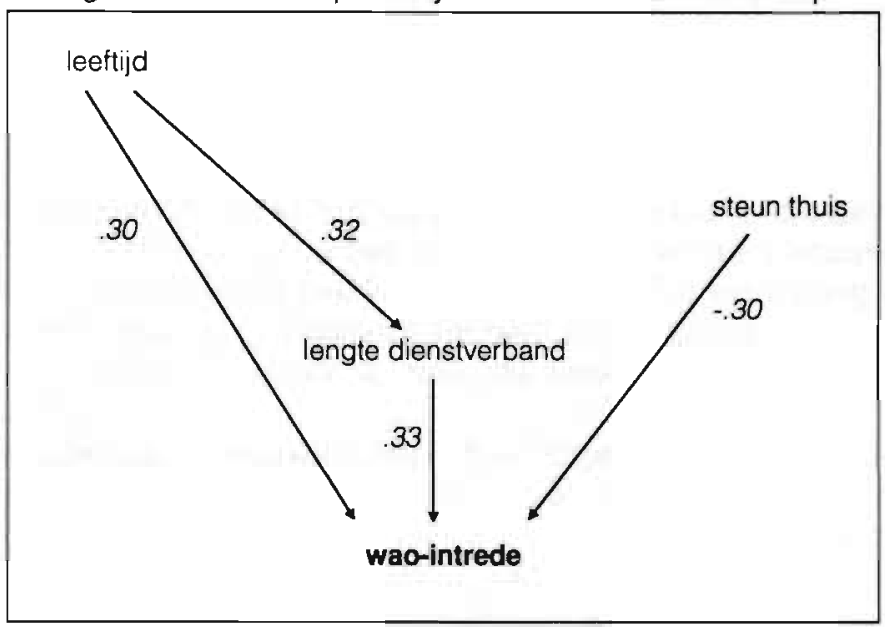

\subsection{Conclusies en beschouwing}

Op de aard van het verloop dat zich voordoet, indien een werknemer na een periode van minimaal vier weken ziekteverzuim wegens overspanning geen terugkeer naar het werk kan realiseren, blijken andere factoren van invloed dan op de terugkeer als zodanig. Wel spelen leeftijd en lengte van het dienstverband ook nu een belangrijke rol, maar er blijkt geen samenhang aantoonbaar met bij voorbeeld de sexe van de werknemer of met bedrijfskenmerken. Wel zijn er onder andere samenhangen te vinden met de aanwezigheid van steun thuis, de werktijden, het ziektegedrag, met name hoelang een werknemer met overspanningsklachten wacht met ziekmelding, de ernst van de overspanning, de leeftijd van de huisarts en het al dan niet voorschrijven van andere medicijnen dan psychofarmacia.

Als gevolg van de in absoluut opzicht geringe omvang van de groep van 47 respondenten zijn we niet in staat geweest om met behulp van de meest adequate techniek, de logistische regressie-analyse een model te ontwikkelen waarin de invloed van alle 16 onafhankelijke variabelen die op een of andere wijze samenhangen met de aard van het verloop, opgenomen zijn. Om deze reden is het niet uitgesloten dat een replicatieonderzoek onder een grotere groep respondenten aanzienlijke aanvullingen te zien zal geven op het model dat wij konden ontwikkelen. 
Vooralsnog kan vastgesteld worden dat oudere werknemers, werknemers die thuis geen steun ondervinden, en werknemers die al geruime tijd in dienst zijn bij de werkgever, een hoger risico lopen om WAO-uitkeringsgerechtigd te geraken, als een verzuim wegens overspanning alleen beëindigd kan worden door vertrek bij de werkgever. 


\section{Hoofdstuk 14}

\section{Verklaring van de verzuimduur bij terugkeer}

\subsection{Inleiding}

Dit hoofdstuk is gewijd aan de verklaring van de verzuimduur in die gevallen waarin de overspannen werknemer na de beëindiging van het verzuim terugkeert naar de werkkring waar de ziekmelding plaatsgevonden heeft. Ter vermijding van foutieve kwantitatieve interpretaties zij nogmaals vermeld dat de afhankelijke variabele niet de absolute verzuimduur in weken is, maar de logarithme met als grondgetal 10 , van de verzuimduur.

Ook nu wordt nagegaan in hoeverre het in hoofdstuk 5 op basis van de verzuimlitteratuur opgestelde model waarin de invloed van de variabelencategorieën persoonskenmerken, bedrijfskenmerken, kenmerken van de arbeidsplaats, ziektegeschiedenis, ziektekenmerken, ziektegedrag van de werknemer, en kenmerken en gedrag van huisarts en verzekeringsgeneeskundige op de verzuimduur verondersteld is, van toepassing is op overspannen werknemers en verder is te specificeren naar afzonderlijke onafhankelijke variabelen.

Telkens na een verkenning per categorie variabelen van de bivariate samenhangen wordt vervolgd met een multivariate analyse van elke afzonderlijke categorie ter opsporing van een eventuele gezamenlijke invloed op de verzuimduur. Daarna wordt dezelfde verkenning herhaald onder constanthouding van een klein aantal variabelen die op grond van de eerste verkenning een relatief sterk verband getoond hebben met de verzuimduur. Besloten wordt met een padanalyse op basis van alle variabelen die op enigerlei wijze een statistisch significant, d.w.z.: beneden de grenswaarde van .10, verband tonen met de afhankelijke variabele.

Weliswaar zijn er in ruime mate onderzoeksbevindingen beschikbaar met betrekking tot determinanten van verzuimduur, maar deze zijn vrijwel allemaal gebaseerd op alle verzuimgevallen tezamen en vaak berekend op basis van de omvang van werknemerspopulaties. Tot de weinige uitzonderingen behoren de analyses van Soeters (1983) en Kaiser (1992) op basis van verzuimgevallen met een minimale duur van vier weken. Hun bevindingen zijn daarom in een aantal opzichten afwijkend. Bij het formuleren van de verwachtingen zijn we vooralsnog ook uitgegaan van de algemene bevindingen. 


\subsection{De invloed van persoonskenmerken op de verzuimduur}

Met betrekking tot leeftijd en aanwezigheid van steun thuis is op grond van de verzuimlitteratuur een positief verband met de verzuimduur te verwachten. Het opleidingsniveau en urbanisatiegraad zijn in het algemeen niet van invloed gebleken. De invloed van life events op verzuimduur is naar ons bekend niet onderzocht. We nemen aan dat er een verzuimverlengend effect van uitgaat. Als ondersteuning voor deze verwachting kunen de bevindingen van Brown en Harris (1978) omtrent de invloed van het verlies van een ouder tijdens de kinderjaren op het ontstaan van depressies in latere levensfasen aangevoerd worden.

Tabel 14.1 Bivariate samenhangen tussen persoonskenmerken en verzuimduur

\begin{tabular}{|c|c|c|c|c|}
\hline Persoonskenmerken: & hoog= & $\mathrm{F} / \mathrm{r}$ & richting & $p$ \\
\hline Leeftijd & noog & .02 & & ns \\
\hline Opleidingsniveau & hoog & .00 & & ns \\
\hline Urbanisatiegraad & stedelijk & -.01 & & ns \\
\hline Steun thuis & ja & 0.17 & & ns \\
\hline Aantal life events & hoog & -.10 & & ns \\
\hline Jeugdziekte & ja & 0.24 & & ns \\
\hline
\end{tabular}

Er blijkt geen enkel bivariaat verband aanwezig tussen enig persoonskenmerk en de verzuimduur bij terugkeer. Zelfs niet tussen leeftijd en verzuimduur.

Evenmin blijkt er een gezamenlijk verband of een afzonderlijk verband onder constanthouding van de overige persoonskenmerken waarneembaar.

Tabel 14.2 Multivariate samenhang(en) tussen persoonskenmerken en verzuimduur

\begin{tabular}{lllll}
\hline Persoonskenmerken & $\mathrm{N}$ & $\mathrm{R}^{2}$ & $\mathrm{~F}$ & $\mathrm{P}$ \\
& 60 & 17 & 0.27 & $\mathrm{~ns}$ \\
\hline & hoog & $\beta$ & $\mathrm{P}$ & \\
\hline Leettijd & hoog & .06 & $\mathrm{~ns}$ & $\mathrm{~ns}$ \\
Opleidingsniveau & hoog & -.06 & $\mathrm{~ns}$ & \\
Urbanisatiegraad & stedelijk & .00 & $\mathrm{~ns}$ & \\
Steun thuis & ja & -.13 & $\mathrm{~ns}$ & \\
Aantal life events & hoog & -.17 & $\mathrm{~ns}$ & \\
Jeugdziekte & ja & .07 & & \\
\hline
\end{tabular}

Het ontbreken van enige samenhang tussen leeftijd en verzuimduur blijkt een gevolg van de beperking van de analyse tot werkhervatters. Voor de totale groep blijkt er een positieve samenhang aanwezig: $r=.28(p=.003)$. Bij uitschakeling van de effecten van WAO-intrede op verzuimduur bestaat er dus geen verband meer tussen leeftijd en verzuimduur. Dit stemt overeen met de bevindingen van Soeters die geen verband vond tussen verzuimduur en de persoonskenmerken leeftijd, sexe en opleidingsniveau. 


\subsection{De invloed van bedrijfskenmerken op de verzuimduur}

Door Soeters (1983) is de invioed van bedriffskenmerken niet onderzocht. Op grond van de overige verzuimlitteratuur mag verwacht worden dat de verzuimduur bij de werknemers uit de dienstensector korter is evenals bij werknemers uit bedrijven waar reorganisaties plaatsvinden. Geen verband mag verwacht worden met de aanwezigheid van voorzieningen als bedrijfsgezondheidszorg. Wat betreft het probleemoplossend vermogen van het bedrijf zijn geen onderzoeksresultaten bekend. Wij verwachten a priori dat een dergelijk vermogen leidt tot beperking van de verzuimduur.

Tabel 14.3 Bivariate samenhangen tussen bedrijfskenmerken en verzuimduur

\begin{tabular}{lllll}
\hline Bedrijfskenmerken: & hoog= & F/r & richting & p \\
\hline Sector & diensten & 1.58 & $\mathrm{~ns}$ \\
Omvang & hoog & .04 & $\mathrm{~ns}$ \\
Aantal steunpunten & hoog & .19 & $\mathrm{~ns}$ \\
Reorganisatie laatste jaar & ja & 0.58 & $\mathrm{~ns}$ \\
Probleemoplossend vermogen & $\mathrm{ja}$ & 1.30 & $\mathrm{~ns}$ \\
\hline
\end{tabular}

Ook hier blijkt geen enkel bivariate samenhang met verzuimduur waarneembaar. De sector waarbinnen de werknemer werkzaam is, blijkt ook geen verband met verzuimduur te tonen als alle respondenten betrokken worden.

Hetzelfde beeld doet zich ook voor bij de multivariate analyse.

Tabel 14.4 Multivariate samenhang(en) tussen bedrijfskenmerken en verzuimduur

\begin{tabular}{lllll}
\hline Bedrijfskenmerken & $\mathrm{N}$ & $\mathrm{R}^{2}$ & $\mathrm{~F}$ & $\mathrm{p}$ \\
& 54 & .01 & 1.02 & $\mathrm{~ns}$ \\
\hline & hoog & $\beta$ & $\mathrm{p}$ & \\
\hline Sector & diensten & -.11 & $\mathrm{~ns}$ & \\
Aantal steunpunten & hoog & .26 & $\mathrm{~ns}$ & \\
Reorganisatie laatste jaar & ja & .14 & $\mathrm{~ns}$ & \\
Probleemoplossend vermogen & ja & -.11 & $\mathrm{~ns}$ & \\
\hline
\end{tabular}

\subsection{De invloed van arbeidsplaatskenmerken op de verzuimduur}

Op grond van de verzuimlitteratuur mag een verzuimverlengende invloed verwacht worden van het aantal dienstjaren en van het werkzaam zijn als productiemedewerker. Een verzuimbeperkende invloed zou uitgaan van een grotere mate van zelfrealisatie en meer hinder van onzekerheid. Geen verbanden mogen verwacht worden met werktijden, hinder van fysieke werkomstandigheden, werklast en de mate van vrijheid in het werk. Voor de overige kenmerken van de arbeidsplaats biedt de litteratuur geen aanknopingspunten. Van het werkzaam zijn in transport- en com- 
merciële functies verwachten we een verzuimduurverlengende invloed evenals van de lengte van de werkweek, de mate van psycho-sociale hinder, gebrek aan promotiekansen en slechte verhoudingen met de chef of collegae. Met betrekking tot het al dan niet solistisch werken formuleren we geen a priori verwachting, omdat twee redeneringen aannemelijk zijn: solistische arbeid kan als belastende factor de terugkeer vertragen maar evengoed de terugkeer bespoedigen op grond van gevoelens van onmisbaarheid.

Alleen de mate van vrijheid in het werk blijkt een zwak negatieve invloed uit te oefenen op de verzuimduur. Voor het overige is er geen enkel verband aantoonbaar.

Ook als we de beperking tot werkhervatters achterwege gelaten hadden dan nog zou er geen verband tussen verzuimduur en, bij voorbeeld, de lengte van het dienstverband of de mate van zelfrealisatie gevonden zijn. Bij hinder van werkonzekerheid zou dit wel het geval geweest zijn. Daar treedt een zwak WAO-effect op. Bij de totale groep respondenten bedraagt de correlatie .18 $(p=.07)$.

Tabel 14.5 Bivariate samenhangen tussen arbeidsplaatskenmerken en verzuimduur

\begin{tabular}{lllll}
\hline Arbeidsplaatskenmerken: & hoog= & $\mathrm{F} / \mathrm{r}$ & richting & $\mathrm{p}$ \\
\hline Productieve functie & ja & 0.02 & $\mathrm{~ns}$ \\
Transport-/commerciële functie & ja & 0.87 & $\mathrm{~ns}$ \\
Lengte dienstverband & hoog & -.08 & $\mathrm{~ns}$ \\
Omvang werkweek & hoog & .11 & $\mathrm{~ns}$ \\
Werktijden & onregelmatig & 0.96 & $\mathrm{~ns}$ \\
Fysieke hinder & hoog & -.04 & $\mathrm{~ns}$ \\
Psycho-sociale hinder & hoog & -.07 & $\mathrm{~ns}$ \\
Werklast & hoog & .08 & $\mathrm{~ns}$ \\
Mate van vrijheid & hoog & -.24 & $\mathrm{0}$ \\
Mate van zelfrealisatie & hoog & 21 & $\mathrm{~ns}$ \\
Promotiekansen & ja & 0.23 & $\mathrm{~ns}$ \\
Hinder van onzekerheid & hoog & -.02 & $\mathrm{~ns}$ \\
Samenwerking & ja & 0.12 & $\mathrm{~ns}$ \\
Verhouding met chef & goed & .17 & $\mathrm{~ns}$ \\
Verhouding met collegae & goed & -.04 & $\mathrm{~ns}$ \\
\hline
\end{tabular}

Uit de multivariate analyse blijkt nauwelijks enige invloed uit te gaan van de arbeidsplaatskenmerken op de verzuimduur. Met behulp van 13 onafhankelijke variabelen kan slechts $21 \%$ van de variantie in verzuimduur verklaard worden.

Bij constanthouding voor de overige kenmerken blijkt de mate van vrijheid in het werk niet langer van invloed. Onze negatieve bevindingen komen in zoverre overeen met die van Soeters (1983) en Kaiser (1992), dat ook zij geen verband aantroffen met belastende factoren in de arbeid. Wel trof Soeters (1983) een negatief verband aan met onzekerheid over de continuiteit van de arbeidsplaats. 
Tabel 14.6 Multivariate samenhang(en) tussen arbeidsplaatskenmerken en verzuimduur

\begin{tabular}{lllll}
\hline & $\mathrm{N}$ & $\mathrm{R}^{2}$ & $\mathrm{~F}$ & $\mathrm{p}$ \\
Arbeidsplaatskenmerken & 54 & 21 & 0.83 & $\mathrm{~ns}$ \\
\hline & hoog & $\beta$ & $\mathrm{p}$ \\
\hline Productieve functie & $\mathrm{ja}$ & .02 & $\mathrm{~ns}$ \\
Transport-/commerciële functie & ja & -.24 & $\mathrm{~ns}$ \\
Lengte dienstverband & hoog & -.06 & $\mathrm{~ns}$ \\
Omvang werkweek & hoog & .09 & $\mathrm{~ns}$ \\
Fysieke hinder & hoog & -.05 & $\mathrm{~ns}$ \\
Werklast & hoog & .18 & $\mathrm{~ns}$ \\
Mate van vrijheid & hoog & -.24 & $\mathrm{~ns}$ \\
Mate van zelfrealisatie & hoog & .32 & $\mathrm{~ns}$ \\
Promotiekansen & ja & -.06 & $\mathrm{~ns}$ \\
Hinder van onzekerheid & hoog & .02 & $\mathrm{~ns}$ \\
Samenwerking & ja & -.07 & $\mathrm{~ns}$ \\
Verhouding met chef & goed & .21 & $\mathrm{~ns}$ \\
Verhouding met collegae & goed & -.17 & $\mathrm{~ns}$ \\
\hline
\end{tabular}

\subsection{De invloed van de ziektegeschiedenis op de verzuimduur}

Er zijn in de verzuimlitteratuur geen aanknopingspunten te vinden voor het formuleren van verwachtingen omtrent de invloed van het verzuimverleden of andere aspecten van ziektegeschiedenis op de verzuimduur van de actuele verzuimperiode. Hoogstens kan vanuit de bevindingen dat verzuimverschillen tussen bedrijven over een periode van enkele jaren redelijk stabiel zijn (Philipsen, 1969), de verwachting geformuleerd worden dat, naarmate de verzuimduren in het verleden langer zijn geweest, er een langere verzuimduur zal optreden.

Tabel 14.7 Bivariate samenhangen tussen ziektegeschiedenis en verzuimduur

\begin{tabular}{|c|c|c|c|c|}
\hline Kenmerken ziektegeschiedenis: & hoog $=$ & $\mathrm{F} / \mathrm{r}$ & richting & $\mathrm{p}$ \\
\hline Verzuimfrequentie laatste jaar & hoog & .11 & & ns \\
\hline $\begin{array}{l}\text { Verzuimfrequentie laatste } 2 \text { jaar } \\
\text { Frequentie langdurige verzuimen }\end{array}$ & hoog & .06 & & ns \\
\hline laatste 2 jaar & hoog & .10 & & ns \\
\hline Verzuimomvang laatste 2 jaar & hoog & -.10 & & ns \\
\hline Eerder overspannen & ja & 0.90 & & $\mathrm{~ns}$ \\
\hline
\end{tabular}

Er blijkt geen enkele bivariate samenhang te vinden tussen ziektegeschiedenis en de verzuimduur in geval van werkhervatting. Dit in tegenstelling met Soeters (1983).

Bij de multivariate analyse is op grond van collineariteit tussen de beide verzuimfrequentiematen alleen die over de laatste twee jaar meegenomen, omdat ze betrouwbaarder is, want afkomstig uit de registratie van het GAK, en minder 
toevalsafhankelijk door de ruimere periode. Ook deze analyse wijst uit dat er geen verband is tussen ziektegeschiedenis en verzuimduur.

Tabel 14.8 Multivariate samenhang(en) tussen ziektegeschiedenis en verzuimduur

\begin{tabular}{lllll}
\hline Ziektegeschiedenis & $N$ & $R^{2}$ & $F$ & $p$ \\
& 56 & .02 & 0.44 & ns \\
\hline & hoog $=$ & $\beta$ & $p$ & \\
\hline Verzuimirequentie laatste 2 jaar & hoog & .12 & ns & \\
Verzuimomvang laatste 2 jaar & hoog & -.12 & ns & \\
Eerder overspannen & ja & -.05 & ns & \\
\hline
\end{tabular}

\subsection{De invloed van ziektekenmerken op de verzuimduur}

De verzuimlitteratuur biedt met betrekking tot twee variabelen aanknopingspunten voor het formuleren van verwachtingen. Dit betreft een positieve samenhang tussen het aantal klachten over de gezondheid en de verzuimduur, en het ontbreken van een verband tussen oorzaak van de aandoening en de verzuimduur. Om die reden verwachten we een langere duur, naarmate de psychoneuroticisme-score hoger ligt, en verwachten we geen invloed van de oorzaak van de overspanning. Met betrekking tot de overige kenmerken verwachten we een langere duur bij chronische gevallen, bij werknemers bij wie de overspanning zich lichamelijk manifesteert, en die niet alleen op het werk uitvallen, maar ook thuis niet meer volledig kunnen functioneren.

Tabel 14.9 Bivariate samenhangen tussen ziektekenmerken en verzuimduur

\begin{tabular}{lllll}
\hline Ziektekenmerken: & hoog $=$ & F/r & richting & $\mathrm{p}$ \\
\hline Aard overspanning & acuut & 2.63 & & $\mathrm{~ns}$ \\
Klachtenbeeld & lichamelijk & 0.62 & & ns \\
Psychoneuroticisme & hoog & .24 & + & .08 \\
Omvang uitval & werk+thuis & 0.89 & & ns \\
Oorzaak ziekte & alleen werk & 0.38 & & ns \\
\hline
\end{tabular}

Een bivariaat, zwak positief verband is alleen waarneembaar bij het aantal gezondheidsklachten zoals gemeten met de SCL-90. Bij de overige ziektekenmerken is geen bivariate samenhang met verzuimduur te zien.

De ziektekenmerken bieden gezamenlijk nauwelijks een verklaring voor de verschillen in verzuimduur. Onder constanthouding voor de andere ziektekenmerken blijkt ook de psychoneuroticisme-score geen samenhang meer te tonen met verzuimduur. Soeters (1983) vond evenmin een verband met ziektekenmerken. 
Tabel 14.10 Multivariate samenhang(en) tussen ziektekenmerken en verzuimduur

\begin{tabular}{|c|c|c|c|c|}
\hline Ziektekenmerken & $\begin{array}{l}N \\
52\end{array}$ & $\begin{array}{l}\mathrm{R}^{2} \\
.08\end{array}$ & $\begin{array}{l}F \\
0.81\end{array}$ & $\begin{array}{l}\mathrm{p} \\
\mathrm{ns}\end{array}$ \\
\hline & hoog= & $\beta$ & $p$ & \\
\hline Aard overspanning & acuut & -.09 & ns & \\
\hline Klachtenbeeld & lichamelijk & -.02 & ns & \\
\hline Psychoneuroticisme & hoog & .25 & ns & \\
\hline Omvang uitval & werk+thuis & .06 & ns & \\
\hline Oorzaak ziekte & alleen werk & .04 & $\mathrm{~ns}$ & \\
\hline
\end{tabular}

\subsection{De invloed van ziektegedrag op de verzuimduur}

Ook hier moeten de verwachtingen geheel a priori geformuleerd worden. Wij verwachten dat zowel uitstelgedrag als een lichamelijke presentatie van de overspanning aan de huisarts door een langere verzuimduur gevolgd worden.

Tabel 14.11 Bivariate samenhangen tussen ziektegedrag en verzuimduur

\begin{tabular}{lllll}
\hline Kenmerken ziektegedrag: & hoog $=$ & F/r & richting & p \\
\hline Duur klachten ziekmelding & hoog & .17 & ns \\
Relatie melding consult & na consult & 0.68 & ns \\
Presentatie aan huisarts & lichamelijk & 0.07 & ns \\
\hline
\end{tabular}

Tussen deze drie kenmerken van het ziektegedrag en verzuimduur blijken geen bivariate verbanden aantoonbaar.

Gezamenlijk bieden zij een vrij geringe verklaring voor verschilien in verzuimduur. Wel blijkt na constanthouding voor de overige kenmerken uitstel van de ziekmelding wel samen te hangen met een langere verzuimduur.

Tabel 14.12 Multivariate samenhang(en) tussen ziektegedrag en verzuimduur

\begin{tabular}{lllll}
\hline & $\mathrm{N}$ & $\mathrm{R}^{2}$ & $\mathrm{~F}$ & $\mathrm{p}$ \\
Ziektegedrag & 53 & .12 & 2.25 & .09 \\
\hline & hoog $=$ & $\beta$ & $\mathrm{p}$ & \\
\hline Duur klachten ziekmelding & hoog & .33 & .02 & \\
Relatie melding consult & na consult & -.16 & $\mathrm{~ns}$ & \\
Presentatie aan huisarts & lichamelijk & .00 & $\mathrm{~ns}$ & \\
\hline
\end{tabular}




\subsection{De invloed van kenmerken van de huisarts(praktijk) op de verzuimduur}

De te verwachten invloed van dit type kenmerken op de verzuimduur, althans in het kader van de correlationele benadering, is voornamelijk indirect te traceren aan de hand van onderzoeksgegevens over verwijsgedrag. We gaan ervan uit, dat verwijzingen een duurverlengend effect hebben. Over de meeste van de door ons vastgelegde kenmerken zijn de verwachtingen a priori opgesteld.

We verwachten, dat met name patiënten van huisartsen in groepspraktijken, grote praktijken, met een sterke mate van integratie in eerstelijn en met GGZ, met een open stijl inzake onzekerheid en een beperkte taakopvatting minder verwijzen en de verzuimduur aldus beperken.

Tabel 14.13 Bivariate samenhangen tussen huisartskenmerken en verzuimduur

\begin{tabular}{|c|c|c|c|c|}
\hline Huisartskenmerken: & hoog= & $\mathrm{F} / \mathrm{r}$ & richting & $p$ \\
\hline Leeftijd & hoog & -0.00 & & $\mathrm{~ns}$ \\
\hline Praktijkomvang & groot & 0.95 & & ns \\
\hline Praktijktype & meermans & 0.13 & & ns \\
\hline Integratie in eerstelijn & hoog & 10 & & ns \\
\hline Integratie met GGZ & hoog & -.15 & & ns \\
\hline Open werkstijl & hoog & .01 & & ns \\
\hline Medicaliserende werkstijl & hoog & .14 & & ns \\
\hline Psycho-sociale taakopvatting & hoog & -.11 & & $\mathrm{~ns}$ \\
\hline Sociaal-psychiatrische taakopvatting & hoog & -.03 & & ns \\
\hline Breedte taakstelling & hoog & -.04 & & ns \\
\hline
\end{tabular}

Er blijkt geen enkele bivariate samenhang te vinden.

De multivariate analyse toont geen significante gezamenlijke bijdrage aan de verklaring van verschillen in verzuimduur. Wel blijken een tweetal kenmerken onder constanthouding van de overige enige samenhang met verzuimduur te tonen. Patiënten van solisten blijken langer te verzuimen evenals patiënten van huisartsen, die minder intensief contacten onderhouden met de Geestelijke Gezondheidszorg. Geen invloed treffen wij aan van de praktijkomvang. Dit in tegenstelling tot de bevindingen van Soeters (1983). 
Tabel 14.14 Multivariate samenhang(en) tussen huisartskenmerken en verzuimduur

\begin{tabular}{lllll}
\hline Huisartskenmerken & $\mathrm{N}$ & $\mathrm{R}^{2}$ & $\mathrm{~F}$ & $\mathrm{p}$ \\
& 49 & .16 & 0.82 & $\mathrm{~ns}$ \\
\hline Leeftijd & hoog & $\beta$ & $\mathrm{p}$ & \\
Praktijkomvang & hoog & -.02 & $\mathrm{~ns}$ \\
Praktijktype & groot & .20 & $\mathrm{~ns}$ \\
Integratie in eerstelijn & meermans & -.37 & .05 \\
Integratie met GGZ & hoog & .22 & $\mathrm{~ns}$ \\
Open werkstijl & hoog & -.32 & .06 \\
Medicaliserende werkstijl & hoog & .00 & $\mathrm{~ns}$ \\
Psycho-sociale taakopvatting & hoog & .14 & $\mathrm{~ns}$ & \\
Sociaal-psychiatrische taakopvatting & hoog & -.09 & $\mathrm{~ns}$ & \\
\hline
\end{tabular}

\subsection{De invloed van het gedrag van de huisarts op de verzuimduur}

Ook hier geldt dat in de verzuimlitteratuur directe aanwijzingen omtrent te verwachten verbanden vrijwel ontbreken. Alleen met betrekking tot verwijzing is een verzuimduurverlengend effect vastgesteld. A priori verwachten we dat overeenstemming in diagnose en in visie op de oorzaak, evenals een werkgericht beleid de behandelingsduur en daarmee de verzuimduur beperken, en dat rust en medicatie beide verlengen.

Tabel 14.15 Bivariate samenhangen tussen huisartsgedrag en verzuimduur

\begin{tabular}{|c|c|c|c|c|}
\hline Kenmerken huisartsgedrag: & hoog= & $\mathrm{F} / \mathrm{r}$ & richting & $p$ \\
\hline Diagnose overspanning & ja & 0.00 & & ns \\
\hline Overeenstemming oorzaak & ja & 0.40 & & $\mathrm{~ns}$ \\
\hline Beleid: rust & ja & 0.04 & & $\mathrm{~ns}$ \\
\hline Beleid: terugkomen & ja & 0.76 & & $\mathrm{~ns}$ \\
\hline Beleid: psycholarmaca & ja & 1.47 & & ns \\
\hline Beleid: overige medicatie & ja & 1.34 & & ns \\
\hline Beleid: verwijzing & ja & 0.59 & & ns \\
\hline Beleid gericht op werk & ja & 0.85 & & $\mathrm{~ns}$ \\
\hline
\end{tabular}

Geen enkel gedragskenmerk van de huisarts blijkt bivariaat met de verzuimduur samen te hangen.

Onder constanthouding van de andere variabelen blijkt het voorschrijven van medicijnen anders dan psychofarmaca het enige gedragskenmerk van de huisarts dat - negatief - samenhangt met verzuimduur. Het gezamenlijke verklaringsvermogen van de acht gedragskenmerken blijft beperkt tot $14 \%$ van de variantie in verzuimduur. 
Tabel 14.16 Multivariate samenhang(en) tussen huisartsgedrag en verzuimduur

\begin{tabular}{|c|c|c|c|c|}
\hline Gedrag huisarts & $\begin{array}{l}N \\
51\end{array}$ & $\begin{array}{l}\mathrm{R}^{2} \\
.14\end{array}$ & $\begin{array}{l}F \\
0.86\end{array}$ & $\begin{array}{l}\mathrm{p} \\
\mathrm{ns}\end{array}$ \\
\hline & hoog= & $\beta$ & $p$ & \\
\hline Diagriose overspanning & ja & .02 & ns & \\
\hline Overeenstemming oorzaak & alleen werk & .19 & ns & \\
\hline Beleid: rust & ja & -.04 & ns & \\
\hline Beleid: terugkomen & ja & .00 & ns & \\
\hline Beleid: psychofarmaca & ja & .27 & ns & \\
\hline Beleid: overige medicatie & ja & $-3 i$ & .05 & \\
\hline Beleid: verwijzing & ja & .08 & ns & \\
\hline Beleid gericht op werk & ja & -.09 & ns & \\
\hline
\end{tabular}

\subsection{De invloed van kenmerken van de verzekeringsgeneeskundige op de verzuimduur}

A priori verwachten wij dat in de gevallen dat de verzekeringsgeneeskundige bekend is met de werknemer of het bedrijf, deze sneller in staat is adequate maatregelen te treffen en zodoende de verzuimduur te beperken.

Tabel 14.17 Bivariate samenhangen tussen kenmerken van de verzekeringsgeneeskundige en verzuimduur

\begin{tabular}{lllll}
\hline Kenmerken verzekeringsgeneeskundige: & hoog $=$ & F/r & richting & P \\
\hline Bekendheid met patiënt & ja & 0.96 & ns \\
Mate van bekendheid met bedrijf & hoog & 20 & ns \\
\hline
\end{tabular}

Geen van beide kenmerken blijkt bivariaat samen te hangen met de verzuimduur.

Evenmin is dat het geval volgens de multivariate analyse.

Tabel 14.18 Multivariate samenhang(en) tussen kenmerken van de verzekeringsgeneeskundige en verzuimduur

\begin{tabular}{lllll}
\hline & $\mathrm{N}$ & $\mathrm{R}^{2}$ & $\mathrm{~F}$ & $\mathrm{P}$ \\
Kenmerken verzekeringsgeneeskundige & 59 & .06 & 1.87 & $\mathrm{~ns}$ \\
\hline & hoog & $\beta$ & $\mathrm{P}$ \\
\hline Bekendheid met patient & ja & -.16 & $\mathrm{~ns}$ \\
Mate van bekendheid met bedrijf & hoog & $\begin{array}{ll}.10 \\
\text { ns }\end{array}$ & $\mathrm{ns}$ \\
\hline
\end{tabular}




\subsection{De invloed van het gedrag van de verzekeringsgeneeskundige op de verzuimduur}

Op grond van de verzuimlitteratuur verwachten wij dat het langer wachten met het eerste contact en a priori dat het achterwege laten van contact(en) met bedrijven leiden tot langere verzuimduren. Omtrent de invloed van de visie van de verzekeringsgeneeskundige op de oorzaak van de overspanning op de verzuimduur zijn wij niet in staat een verwachting in een bepaalde richting motiveren.

Tabel 14.19 Bivariate samenhangen tussen gedrag verzekeringsgeneeskundige en verzuimduur

\begin{tabular}{llrll}
\hline Gedrag verzekeringsgeneeskundige: & hoog $=$ & F/r & richting & $p$ \\
\hline Duur ziekmelding 1e contact & hoog & 0.32 & + & .02 \\
Visie oorzaak & alleen werk & -.07 & & ns \\
Contact met bedrijf & ja & 14.70 & + & .000 \\
\hline
\end{tabular}

Twee gedragswijzen van de verzekeringsgeneeskundigen blijken van relatief belangrijke invloed op de verzuimduur. Het uitstellen van het eerste contact blijkt naar verwachting met een langere verzuimduur gepaard te gaan. Het plaatsvinden van contact met het bedrijf blijkt tegen de verwachting in eveneens met een langere verzuimduur gepaard te gaan. Het lijkt dus waarschijnlijker dat contacten gelegd worden tussen verzekeringsgeneeskundige en bedrijf, omdat de verzuimduur een bepaalde "grens" voor betrokkenen overschrijdt of naar hun verwachting zal overschrijden dan dat het leggen van contacten langere verzuimduren voorkomt.

Bij constanthouding voor de overige gedragswijzen van de verzekeringsgeneeskundige blijven de bevindingen gelijk. Het verklaringsvermogen van de gedragskenmerken van de verzekeringsgeneeskundigen ten aanzien van de verzuimduur is aanzienlijk. Van de variantie in verzuimduur kan $25 \%$ verklaard worden.

Tabel 14.20 Multivariate samenhang(en) tussen gedrag verzekeringsgeneeskundige en verzuimduur

\begin{tabular}{lllll}
\hline & $N$ & $R^{2}$ & $F$ & $p$ \\
Gedrag verzekeringsgeneeskundige & 56 & .25 & 5.45 & .003 \\
\hline & hoog $=$ & $\beta$ & $p$ & \\
\hline Duur ziekmelding 1e contact & hoog & .27 & .04 \\
Visie oorzaak & alleen werk & -.03 & $\mathrm{~ns}$ & \\
Contact met bedrijf & ja & .39 & .00 & \\
\hline
\end{tabular}

\subsection{Samenvatting van de eerste bevindingen}

Het totale beeld bekijkend komen we tot een eerste indruk dat, of als gevolg van beperking tot eén diagnosegroep of als gevolg van beperking tot werkhervatters, de directe determinanten van de verzuimduur van een ander karakter zijn dan 
gebruikelijk naar voren komt in ander verzuimonderzoek. Dit wordt bevestigd door de grote mate van overeenkomst met de bevindingen van Soeters (1983).

Persoons-, bedrijfs- en arbeidsplaatskenmerken lijken, een enkele uitzondering daargelaten, van gering belang voor de verklaring van de verzuimduur. Hetzelfde geldt voor ziektekenmerken en ziektegeschiedenis. Evenmin blijken er samenhangen aangetroffen te worden tussen verzuimduur enerzijds en kenmerken van huisarts (praktijk) en verzekeringsgeneeskundige anderzijds. Een geringe mate van invloed daarentegen blijken het ziektegedrag van de werknemer en éen enkele gedragswijze van de huisarts te hebben. Het gedrag van de verzekeringsgeneeskundige daarentegen blijkt in eerste instantie de belangrijkste determinant van de verzuimduur. De door de gezamenlijke gedragskenmerken van de verzekeringsgeneeskundige verklaarde variantie van de verzuimduur blijkt ongeveer $25 \%$ te bedragen. Een redelijke verklaring van de variantie bieden ook de kenmerken van de arbeidsplaats, maar dat is meer het gevolg van het aantal variabelen.

Tabel 14.21 Samenvatting multivariate bevindingen

\begin{tabular}{lllll}
\hline & $\mathrm{N}$ & $\mathrm{R}^{2}$ & $\mathrm{~F}$ & $\mathrm{p}$ \\
\hline Persoonskenmerken & 60 & .17 & 0.27 & $\mathrm{~ns}$ \\
Bedrijfskenmerken & 54 & .01 & 1.02 & $\mathrm{~ns}$ \\
Arbeidsplaatskenmerken & 54 & .21 & 0.83 & $\mathrm{~ns}$ \\
Ziektegeschiedenis & 56 & .02 & 0.44 & $\mathrm{~ns}$ \\
Ziektekenmerken & 52 & .08 & 0.81 & $\mathrm{~ns}$ \\
Ziektegedrag & 53 & .12 & 2.25 & .09 \\
Huisartskenmerken & 49 & .16 & 0.82 & $\mathrm{~ns}$ \\
Gedrag huisarts & 51 & .14 & 0.86 & .06 \\
Kenmerken verzekeringsgeneeskundige & 59 & .06 & 1.87 & $\mathrm{~ns}$ \\
Gedrag verzekeringsgeneeskundige & 56 & .25 & 5.45 & .003 \\
\hline
\end{tabular}

\subsection{Naar een integraal model voor de verklaring van de verzuimduur}

Evenals bij de vorige analyses moeten we rekening houden met het gegeven dat bij deze bevindingen geen rekening is gehouden met verstoring van de verbanden als gevolg van de beperking van de multivariate analyses tot de afzonderlijke groepen variabelen. Om die reden zijn wij nagegaan hoe de verbanden tussen de onafhankelijke variabelen en de verzuimduur zijn bij constanthouding voor de variabele tijdsverloop tussen ziekmelding en eerste contact met de verzekeringsgeneeskundige en de variabele contact tussen verzekeringsgeneeskundige en bedrijf.

De variabelen die onder constanthouding van de twee controlevariabelen alsnog een significant verband tonen met de verzuimduur blijken de volgende te zijn: een functie als commercieel of transportmedewerker, de verzuimfrequentie over de afgelopen twee jaar, de aard van overspanning, uitstelgedrag ten aanzien van ziekmelding, praktijktype, het voorschrijven van psychofarmaca en het verwijzen door de huisarts.

Om een zo goed mogelijk model te ontwikkelen ter verklaring van de verzuimduur 
hebben we al die variabelen geselecteerd die op één of andere wijze een significante samenhang te zien gegeven hebben met de verzuimduur. De volgende tabel geeft een overzicht.

Tabel 14.22 Overzicht variabelen met éen of meer samenhangen met verzuimduur

\begin{tabular}{llll}
\hline $\begin{array}{l}\text { Variabele (hoog): } \\
\text { Bivariaat }\end{array}$ & $\begin{array}{l}\text { Multivaraat } \\
\text { binnen groep }\end{array}$ & $\begin{array}{l}\text { Onder constanthouding } \\
\text { voor controlevariabelen }\end{array}$ \\
\hline $\begin{array}{l}\text { Transport-/commerciële functie } \\
\text { Vrijheid in het werk }\end{array}$ & - & - \\
$\begin{array}{l}\text { Aard overspanning (acuut) } \\
\text { Psychoneuroticisme }\end{array}$ & + & & - \\
$\begin{array}{l}\text { Verzuimfrequentie } \\
\text { Duur klachten ziekmelding }\end{array}$ & & + & + \\
$\begin{array}{l}\text { Praktijktype (meermans) } \\
\text { Mate van integratie met GGZ }\end{array}$ & - & + \\
$\begin{array}{l}\text { Beleid: psychofarmaca } \\
\text { Beleid: overige medicatie } \\
\text { Beleid: verwijzing }\end{array}$ & & - & + \\
$\begin{array}{l}\text { Duur ziekmelding 1e contact verz.gen. } \\
\text { Contact verz.geneesk. met bedrijf }\end{array}$ & ++ & +++ & ++ \\
\hline
\end{tabular}

$+/-=p<.10 ;++/--=p<.05 ;+++1---=p<.01$.

\subsection{Een padanalyse van determinanten van de verzuimduur}

Bij deze padanalyse kon, gezien het continue karakter van de afhankelijke variabele, in eerste instantie direct uitgegaan worden van de lineaire regressie-analyse. Omdat er collineariteit optrad tussen praktijktype en mate van integratie van de huisarts met de GGZ, blijkens een Pearson's r tussen beide variabelen van .54 , is de laatste variabele verwijderd uit de analyse.

De causale ordening van de onafhankelijke variabelen in de padanalyse is als volgt: 1 Kenmerken van de arbeidsplaats: eerst de functie, vervolgens de mate van vrijheid,

2 Ziektekenmerken: eerst aard van overspanning dan mate van psychoneuroticisme,

3 Ziektegeschiedenis: verzuimfrequentie,

4 Uitstelgedrag ten aanzien van ziekmelding,

5 Kenmerken van de huisarts: praktijktype

6 Gedrag huisarts: voorschrijven van medicatie en verwijzing,

7 Gedrag verzekeringsgeneeskundige: uitstel eerste contact met werknemer voorafgaand aan contact met bedrijf.

Ook hier doet zich het probleem voor van een aanzienlijke reductie van het aantal respondenten als cumulatief effect van matige non-respons op de afzonderlijke variabelen. Deze reductie bedraagt 21 oftewel $30 \%$ der respondenten. Om die reden hebben we bij het ontbreken van een waarde de gemiddelde waarde van de variabele gesubstitueerd. 
Tabel 14.23 Resultaten van lineaire regressie-analyse met gelijktijdige invoer

\begin{tabular}{lllll}
\hline & $N$ & $\mathrm{~F}^{2}$ & $\mathrm{~F}$ & $\mathrm{p}$ \\
& 61 & .48 & 3.65 & .001 \\
\hline Variabele (hoog) & $\beta$ & $\mathrm{p}$ & & \\
\hline Transport-/commerciele functie & -.15 & $\mathrm{~ns}$ & \\
Vrijheid in het werk & 19 & $\mathrm{~ns}$ & \\
Verzuimfrequentie & .05 & $\mathrm{~ns}$ & \\
Aard overspanning (acuut) & .00 & $\mathrm{~ns}$ & \\
Psychoneuroticisme & .06 & $\mathrm{~ns}$ & \\
Duur klachten ziekmelding & .10 & $\mathrm{~ns}$ & \\
Praktijktype (meermans) & -.06 & $\mathrm{~ns}$ & \\
Beleid: psychofarmaca & .21 & .08 & \\
Beleid: overige medicatie & -.04 & $\mathrm{~ns}$ & \\
Beleid: verwijzing & .30 & .02 & \\
Duur ziekmelding 1e contact verz.geneesk. & .27 & .02 & \\
Contact verzekeringsgen. met bedrijf & .51 & .02 & \\
\hline
\end{tabular}

De 12 variabelen verklaren samen $48 \%$ van de variantie in verzuimduur.

Vier variabelen tonen onder constanthouding voor de overige een significant verband met de verzuimduur: het voorschrijven van psychofarmaca en het verwijzen door de huisarts, het uitstelgedrag van de verzekeringsgeneeskundige en het plaatsvinden van contact tussen verzekeringsgeneeskundige en bedrijf.

Op basis van dit resultaat van de regressie-analyse is de padanalyse uitgegaan van de variabele contact verzekeringeneeskundige met bedrijf, vervolgens van duur ziekmelding eerste contact werknemer met verzekeringsgeneeskundige enzovoorts. Het resultaat toont figuur 14.1.

Figuur 14.1 Resultaat padanalyse verzuimduur

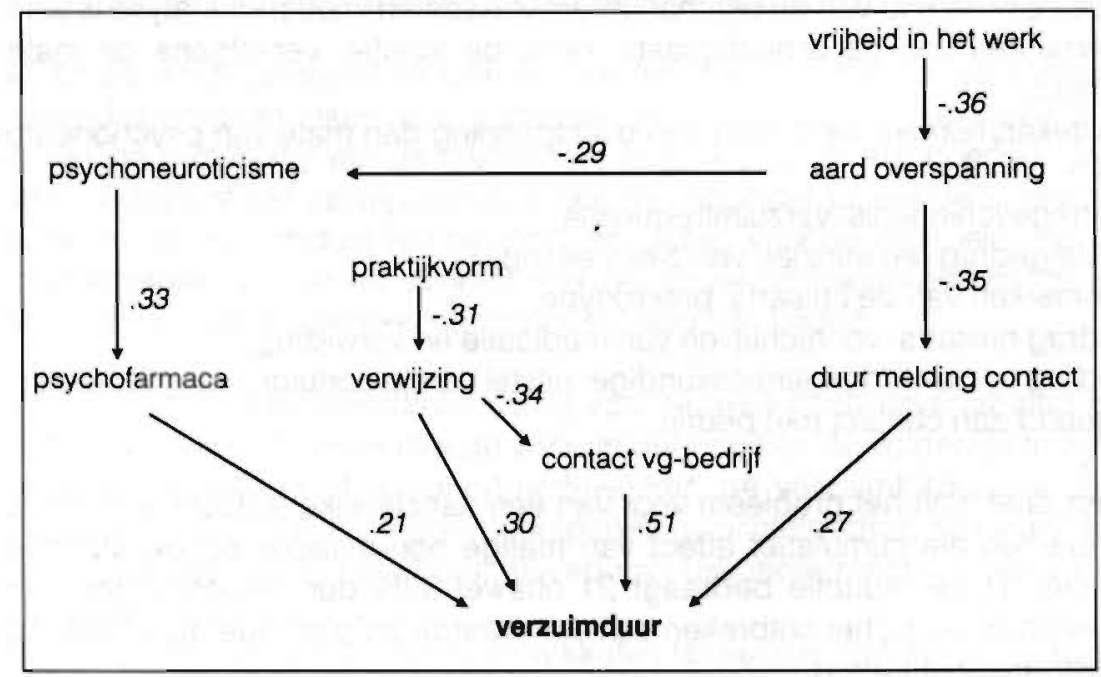




\subsection{Conclusies en beschouwing}

Als belangrijkste en directe determinanten van de verzuimduur bij overspannen werknemers die het werk hervatten in de oorspronkelijke werkkring, komen vooral het beleid van de huisarts en de verzekeringsgeneeskundige naar voren. Voorts is er een indirecte invloed van éen enkel kenmerk van de arbeidsplaats, namelijk de mate waarin de werknemer beslissingsvrijheid heeft in het werk, van een tweetal kenmerken van overspanning en van de praktijkvorm van de huisarts.

De verwijzing door de huisarts blijkt de verzuimduur niet alleen in directe zin te verlengen, maar ook indirect, omdat ze aanleiding blijkt te zijn voor het leggen van contact tussen de verzekeringsgeneeskundige en het bedrijf. Dit contact blijkt ook gepaard te gaan met een langere verzuimduur. Weliswaar is niet uitgesloten dat hier sprake kan zijn van een (anticiperende) reactie op het lang uitblijven van werkhervatting, maar evengoed is het mogelijk dat dit contact het gevolg is van een problematisch herstel, hetgeen kan leiden tot meer activiteiten van verschillende kanten, waardoor organisatorische vertraging kan ontstaan in de begeleiding van de werknemer naar werkhervatting.

De verwijzing van de huisarts blijkt overigens vooral bepaald door de praktijkvorm. Vooral solistisch werkende huisartsen neigen tot verwijzing. Dit komt overeen met de bevindingen van Wijkel (1986). Het voorschrijven van psychofarmaca blijkt vooral ingegeven door de ernst van de overspanning die weer bepaald lijkt door de mate waarin de overspanning chronisch van karakter is. De chronische vorm van overspanning blijkt ook langs een andere weg tot langere verzuimduren te leiden. De verzekeringsgeneeskundige lijkt geneigd om acute overspanningsgevalien eerder op het spreekuur uit te nodigen dan chronische. Opvallend is dat, naarmate werknemers een grotere vrijheid in het werk bezitten, overspanning vaker van chronische dan van acute aard is. Mogelijk is hier sprake van het effect van langer ziek door kunnen werken, omdat men meer regelcapaciteit heeft om bij een verminderd vermogen om te werken de werkbelasting daarop af te stemmen.

Uiteraard is de verzuimduur niet de belangrijkste, laat staan de enige, parameter om de kwaliteit van het werk van de betrokken artsen te meten. Wel kan vastgesteld worden dat huisarts en verzekeringsgeneeskundige een essentiële rol spelen.

De bevindingen wijken af van die uit de meeste onderzoeken naar determinanten van verzuimduur, waarbij onder andere sexe, leeftijd, bedrijfsomvang en arbeidsomstandigheden als determinanten naar voren komen. Zoals wij diverse malen eerder benadrukt hebben, zijn de verschillen in opzet tussen de onderzoeken verantwoordelijk. In de meeste onderzoeken wordt niet de verzuimduur als zodanig verklaard, maar een met het ontstaan van een - langdurig - verzuimgeval en met WAO-intrede gecontamineerde verzuimduur. Reeds eerder vond Soeters (1983), die ten onzent als eerste de determinanten van verschillen in verzuimduur tussen langdurige verzuimgevallen beëindigd met werkhervatting onderzocht, dat persoonskenmerken, bedrijfskenmerken en arbeidsomstandigheden nauwelijks of geen invloed uitoefenen op de verzuimduur. Daarentegen vond hij wel samenhangen tussen verzuimduur en, onder meer, ziektekenmerken en kenmerken van de huisarts. Onze bevindingen komen globaal met de zijne overeen. Ze bevestigen ook de bevindingen van Kaiser (1992) dat de verzekeringsgeneeskundige een 
brikngrijke invlued uitoefent op de verzuimduur evenals het besluit van de huisarts om een patiënt al dan niet naar een specialist te verwijzen. 


\section{Hoofdstuk 15}

\section{Conclusies en beschouwing}

\section{$15.1 \quad$ Inleiding}

In dit afsluitende hoofdstuk worden de belangrijkste bevindingen van de onderzoeken die naar aanleiding van de probleemstellingen zijn verricht, samengevat. Allereerst betreft dit de vraag naar de aard van overspanning, d.w.z. de betekenis van het begrip, de kwaliteit van de diagnostiek, en het bij de overspannen werknemers uit het veldonderzoek waargenomen ziektebeeld. Voorts worden de bevindingen samengevat met betrekking tot het beloop van het verzuim wegens overspanning. Het gaat daarbij zowel om het verzuimbeloop als om het herstel van de aandoening zelf. Hoewel dit onderwerp geen expliciet onderdeel van de probleemstelling vormde, zijn in ons onderzoek dusdanige verrassende bevindingen naar voren gekomen, dat het hieraan wijden van een afzonderlijke slotbeschouwing gerechtvaardigd is. Hierna wordt ingegaan op de aard en de kwaliteit van de hulpverlening aan overspannen werknemers en de gevolgen die dit heeft voor het verzuimbeloop. Vervolgens worden de onderzoeksresultaten met betrekking tot de determinanten van verzuimduur en wijze van verzuimbeëindiging op een rij gezet. Dit wordt besloten met een integraal model waarin voor de afzonderlijke stadia van het verzuimproces van overspannen werknemers de determinanten van het beloop worden weergegeven. Dit hoofdstuk wordt afgesloten met een aantal algemene slotopmerkingen, waarbij de onderzoeksresultaten afgezet worden tegen de door ons gebruikte onderzoeksmethoden en in het licht geplaatst worden van de in het eerste hoofdstuk beschreven ontwikkelingen van het ziekteverzuim en de arbeidsongeschiktheid. Ook worden enkele aanbevelingen geformuleerd voor nader onderzoek en verbetering in hulpverlening en verzekeringsgeneeskundige begeleiding.

\subsection{De aard van overspanning}

In het eerste hoofdstuk is door ons beschreven hoezeer het aandeel van eén der diagnosecategorieën in het bestand van ziekteverzuimgeveallen en gevallen van blijvende arbeidsongeschiktheid is toegenomen. In aansluiting op het algemeen taalgebruik hebben wij deze aangeduid met de term overspanning, alhoewel in het medisch taalgebruik tal van synoniemen en aanverwante begrippen gehanteerd worden. 
Eén van de probleemstellingen van ons onderzoek is geweest wat onder overspanning verstaan moet worden en wat voor ziektegevallen daaronder begrepen moeten worden.

In ons onderzoek hebben we ons op vier verschillende wijzen beziggehouden met onderzoek naar de aard van overspanning.

Allereerst hebben we een litteratuuronderzoek verricht om na te gaan, hoe overspanning "theoretisch" geconceptualiseerd is. Vervolgens hebben we de operationalisatie van dit theoretisch begrip in de praktijk van de verzekeringsgeneeskundige diagnostiek onderzocht door middel van een panelonderzoek onder toepassing van de beginselen van de Delphi-methode. Daarbij hadden wij weliswaar niet de pretentie om de validiteit van het verzekeringsgeneeskundig oordeel als meetinstrument voor overspanning vast te stellen, maar wel om inzicht te krijgen in de interbeoordelaar-betrouwbaarheid. Deze exercitie is niet alleen van belang voor het onderzoek met betrekking tot de conceptualisering van overspanning maar ook voor het vaststellen van de kwaliteit van de operationalisatie van overspanning die door ons in het veldonderzoek toegepast is, oftewel van de waarde die gehecht moet worden aan de selectie van gevallen van overspanning door verzekeringsgeneeskundigen. Een derde, directe informatiebron over de inhoud van het ziektebeeld overspanning verschafte ons het veldonderzoek. Enerzijds verstrekten de respondenten ons zelf informatie over hun overspanningsverschijnselen en de oorzaken van deze verschijnselen. Deze informatie konden wij grotendeels verifiëren bij de betrokken huisarts en verzekeringsgeneeskundige. Anderzijds zijn we nagegaan of de bij de overspannen werknemers afgenomen SCL-90 vragenlijst een bruikbaar instrument is om aard en ernst van overspanning vast te leggen.

Uit het litteratuuronderzoek blijkt een alomtegenwoordigheid in tijd en plaats van allerlei begrippen ter beschrijving van het ziektebeeld overspanning. De belangrijkste termen die naast overspanning voor dit ziektebeeld worden gehanteerd, zijn surmenage, neurasthenie en adjustment disorder. Daarnaast worden heden verwante of synonieme concepten gebezigd als burnout en acute fatigue syndrome. Het beeld dat van overspanning geschetst wordt als zijnde een typisch Nederlands verschijnsel, is dus ongefundeerd. De aandoening wordt wereldwijd onderkend en beschreven. Ook blijkt er internationaal overeenstemming in zowel de definitie van als de kritiek op de conceptualisering en het gebruik van dit ziektebeeld.

De belangrijkste omschrijvingen van het ziektebeeld noemen als afgeleide van een algemeen kenmerk, namelijk de verstoring van het evenwicht tussen psycho-emotionele belasting en psycho-emotionele belastbaarheid, ten minste een aantal van de volgende waarneembare kenmerken: het klachtenpatroon komt geheel of gedeeltelijk overeen met het hyperaesthetisch-emotionele syndroom of is geconcentreerd op bepaalde lichamelijke klachten die meestal ook in het syndroom vermeld staan, de oorzaak is een identificeerbare psycho-sociale stressor, de ontstaans-en beloopsduur is - bij een klein aantal auteurs overigens - aan zekere een beperking onderhevig, er is sprake van een verminderd sociaal functioneren en de klachten zijn niet volledig te verklaren uit lichamelijke of psychische defecten.

De terminologische vaagheid en het diagnostisch misbruik, met name in het verzekeringswezen, zijn verwijten die het gebruik van deze termen van meet af aan hebben vergezeld. Het eerste argument negeert een aantal kenmerken die deze 
aandoening eigen is. Het klachtenpatroon is gevarieerd, toont overlap met andere vooral psychiatrische aandoeningen die historisch gezien nogal eens oorspronkelijk onder dit ziektebeeld gediagnostiseerd werden, en kent een ogenschijnlijke veelvuldigheid van oorzaak en beloop. Bovendien betreft het een aandoening die in de meeste gevallen niet ter behandeling staat van klinische specialisten, maar van huisartsen of onderwerp is van medische claimbeoordelingen. Dit non-klinisch karakter heeft de ontwikkeling van de conceptualisering en van het empirisch en ontwikkelingsgeneeskundig onderzoek van overspanning belemmerd.

Medici blijken overigens in de praktijk van hun beroepsuitoefening goed uit de voeten te kunnen met het begrip overspanning, hoewel zij vaak vanuit de behoefte aan vakjargon de term surmenage verkiezen. Uit onderzoeken van Gerritsen (1988) en Terluin (1986) komt een grote mate van overeenstemming naar voren onder verzekeringsgeneeskundigen respectievelijk huisartsen over de kenmerkende verschijnselen van overspanning. Bovendien blijkt uit ons panelonderzoek dat artsen uit verschillende disciplines weinig moeite hebben met het bereiken van overeenstemming over de toepassing van overspanning als diagnose. Voorwaarde is wel dat de bovenvermelde kenmerken als stricte criteria gehanteerd worden, d.w.z. de vereiste van een identificeerbare psycho-sociale stressor als oorzaak van de klachten mag niet achterwege gelaten worden ten gunste van het uitgangspunt dat onverklaarde klachten hoogstwaarschijnlijk psychisch bepaald zijn en dus een teken van overspanning. Indien aan genoemde voorwaarde voldaan wordt, bereiken de kappa-waarden in de regel scores van boven de 80 .

Het verwijt van misbruik is op zich niet erg ter zake, want in principe niet specifiek voor overspanning. Het verwijt gaat er van uit dat overspanning zich door een vage conceptualisering beter leent voor simulatie en slechter voor verificatie dan andere ziektebeelden. Uit het veldonderzoek bleek simulatie bij éen enkel geval een rol te spelen. We nemen daarbij aan dat de non-respons niet deels bepaald is door de aanwezigheid van simulanten die vrezen door deelname aan onderzoek ontmaskerd te worden. Het probleem van de verificatie van overspanning is overigens betrekkelijk. Uiteraard is de aandoening, afgezien van momenten van expressieve mimiek en houding, niet erg zichtbaar en evenmin aan de hand van anatomische en fysiologische parameters voldoende aantoonbaar. Congruentie in stemmingen en uitspraken en de consistentie van de verbale rapporten en van de gedragingen en dergelijke kunnen echter als voldoende basis voor verificatie beschouwd worden.

Afgaande op de rapportages van de in het veldonderzoek betrokken werknemers blijkt uit de weergave van de klachten, de duur van de klachten, en de duiding van de oorzaken dat het ziektebeeld duidelijk overeenkomt met overspanning zoals in de litteratuur beschreven is. Niet altijd konden de respondenten aan het begin van de verzuimperiode psycho-sociale stressoren als oorzaak vermelden, maar na verloop van tijd kregen een aantal werknemers alsnog zicht daarop, terwijl bij de overigen de informatie van de huisarts of van de verzekeringsgeneeskundige, of aanhalingen door de respondent van mensen uit de directe omgeving, psychosociale stressoren aan het licht brachten. Omtrent de ontstaansduur van de klachten na blootstelling aan de stressoren beschikken we niet over exacte informatie, maar ons zijn grote tijdsverschillen opgevallen tussen het ontstaan van de klachten 
en de ziekmelding. Daarbij moet wel de kanttekening gemaakt worden dat bij een chronische aanloop sprake is van een langzame toename van het aantal en/of de intensiteit van de klachten. De duur van de aandoening zelf blijkt niet in alle gevallen beperkt tot de soms genoemde maximale perioden van zes maanden. Het gaat ons evenwel te ver om, op grond van een onvermogen om de problemen binnen deze termijn de baas te worden, te besluiten dat er sprake is van een andere aandoening. Wij geven de voorkeur aan een indeling van overspanning in acute en chronische vormen. Bovendien treedt er juist in geval van ziekmelding na enige tijd niet alleen ontspanning op, maar wordt het voortduren van de uitval zelf een stressor. Voor zover lichamelijke en psychische defecten aanwezig bleken, waren de ziekteverschijnselen daarvan geen rechtstreeks afgeleide, maar een signaal dat, als gevolg van de beperkte belastbaarheid die daaruit voortvloeide, een normaal geachte belasting tot overspanning leidde. In engere zin betrof het $8 \%$ van de 114 gevallen maar, indien men verouderings- en involutie-effecten meerekent, ruim $10 \%$. Voor het verminderd vermogen tot sociaal functioneren beschikken wij over een voor de hand liggend criterium, namelijk het misschien niet in alle gevallen noodzakelijk, maar in elk geval wel door de omgeving aanvaard besluit tot werkstaking. Bij ongeveer de helft ging dit gepaard met vermindering van activiteiten buiten het werk.

Vanuit het perspectief van de verschijnselen en de oorzaken van de overspanning zijn door ons bij de 114 werknemers de volgende vier typen overspanning het meest frequent waargenomen: hyperaesthetisch-emotionele klachten als gevolg van langdurige werkstress, lichamelijke klachten als gevolg van werkstress, hyperaesthetisch-emotionele klachten als gevolg van een incident op het werk en als gevolg van een incident in de thuissituatie. Deze betreffen binnen de groep respondenten ongeveer $60 \%$ der gevallen. Daarbij moet wel aangetekend worden dat wij geen zicht hebben op de effecten van de non-respons op deze verdeling. Bevindingen uit andere onderzoeken suggereren dat in onze onderzoeksgroep de gevallen van overspanning als gevolg van werkproblemen enigszins oververtegenwoordigd zijn.

Een laatste weerlegging van de stelling dat de diagnose overspanning primair toegepast wordt als medisch etiket voor dubieuze ziektegevallen, vormen de bevindingen met betrekking tot de scores van de respondenten op de SCL-90, een schaal voor psychoneuroticisme. De acht stemmingsbeelden die binnen deze schaal te onderscheiden zijn, tonen geen specifieke configuratie voor overspannen werknemers in vergelijking met andere (patiënten)populaties. De verschillen zijn voor alle subschalen en de totale schaal verhoudingsgewijs ongeveer even groot. Bovendien blijkt er sprake van een gemiddelde totale score die niet ver beneden het niveau ligt van de score van poliklinisch-psychiatrische patiënten. Voor overspannen werknemers die het werk niet binnen een jaar hervat hebben of ontslag genomen hebben en derhalve aanspraak maken op een WAO-uitkering, is de gemiddelde score vrijwel gelijk aan die van poliklinisch-psychiatrische patiënten. De SCL-90 is niet bedoeld en evenmin geschikt gebleken als diagnostisch instrument voor specifieke aandoeningen; wel meet zij de mate van psychopathologie. In dat licht kan de conclusie getrokken worden dat de categorie werknemers die geruime tijd verzuimen wegens overspanning, qua score op de SCL-90 vrij grote 
overeenkomst toont met een populatie van poliklinischı patiënten met psychische aandoeningen.

\subsection{Het (verzuim)beloop van overspanning}

Het beloop van overspanning hebben wij vanuit vier gezichtspunten bekeken: de wijze van verzuimbeëindiging, de duur van het verzuim, de mate, waarin werkhervatting op termijn succesvol is gebleken, en het herstel van de overspanning als zodanig.

Aannemende dat onder de niet-gediagnostiseerde verzuimgevallen korter dan vier weken er vrij zelden sprake zal zijn van overspanning, omdat er in die gevallen sprake is van een te geringe mate van verstoring van het psycho-emotioneel evenwicht, zijn we tot de bevinding gekomen dat een verzuimgeval wegens overspanning een gemiddelde duur heeft van ruim vijf maanden. Een groot deel van de verzuimdagen komt voor rekening van WAO-intreders. Zij omvatten 20 a $25 \%$ van de groep en ontvangen gedurende 12 maanden een uitkering krachtens de Ziektewet. Ongeveer $33 \%$ wordt hersteld verklaard na een verzuimperiode langer dan drie maanden. Ruim $40 \%$, dus minder dan de helft, beëindigt het verzuim binnen drie maanden. De gemiddelde verzuimduur van degenen die hersteld verklaard worden, bedraagt ongeveer drie maanden. Langdurige afwezigheid wegens ziekte en een hoog risico op WAO-intrede kenmerken dus de overspannen werknemer.

De volle ernst van de gevolgen van overspanning is aan deze cijfers nog niet af te lezen. De WAO-intrede als wijze van verzuimbeëindiging geeft maar een beperkt beeld van het totale verloop dat volgt op verzuim wegens overspanning. De WAO-intreders maken slechts de helft uit van de groep uitvallers, want de "hersteldverklaringen" door de verzekeringsgeneeskundige blijken voor een groot deel betrekking te hebben op werknemers die bij een ander bedrijf aan de slag gaan of een periode van werkloosheid(suitkering) aanvangen. In totaal keert iets meer dan de helft, namelijk zo'n 56\%, terug naar de oorspronkelijke werkgever.

Een jaar na de datum van ziekmelding blijkt een aanzienlijk deel van de terugkeerders alsnog vertrokken bij het bedrijf. Uiteindelijk werkt nog maar $40 \%$ bij dezelfde werkgever als een jaar tevoren. Ziekteverzuim wegens overspanning kan daarom gezien worden ais een voorportaal van vertrek bij het bedrijf. Gezien de belangrijke invloed van bedrijfskenmerken op het besluit om al dan niet terug te keren, de veelvuldig toegeschreven invloed van de werksituatie op het ontstaan van overspanning en de nog grotere invloed daarvan op het besluit om tot ziekmelding over te gaan, kan de conclusie getrokken worden dat de meeste bedrijven in geen enkel stadium van de overspanning er veel werk van maken om de werkproblemen die geleid hebben tot overspanning, op te lossen. Vooral bij de kleinere bedrijven is het verloop groot. Een tweede conclusie is dat de relatief omvangrijke groep WAO-intreders onder werknemers die verzuimen wegens overspanning, een selectie vormen van een groter potentieel aan WAO-intreders. Met name jongeren, waaronder zich verhoudingsgewijs meer vrouwen bevinden, slagen, soms gestimuleerd door de verzekeringsgeneeskundige, aanzienlijk vaker dan ouderen erin om te ontkomen aan een WAO-carrière. 
Een jaar na de ziekmelding blijken lang niet alle overspannen werknemers hersteld. Een fenomeen dat eigen lijkt aan dit type aandoeningen. Uit bevolkingsonderzoeken blijkt dat onder groepen met geestelijke gezondheidsproblemen na een jaar slechts in geringe mate herstel is opgetreden, ongeacht of er behandeling heeft plaatsgevonden of deze om welke reden dan ook achterwege is gebleven. In totaal voelt $70 \%$ van de respondenten zich hersteld. Daaronder bevinden zich ook enige WAO-intreders, bij wie dit waarschijnlijk te danken is aan de onttrekking uit de belastende arbeidssituatie. Restverschijnselen zijn er echter bij ruim $69 \%$ van de respondenten. De psychoneuroticisme-score is bij degenen die door de verzekeringsgeneeskundige "hersteld" verklaard zijn, weliswaar aanzienlijk gedaald, maar ligt nog steeds op een hoger niveau dan dat van een "normale" populatie.

Wanneer de combinatie van hersteldverklaring door de verzekeringsgeneeskundige, het zich aanzienlijk of geheel hersteld voelen, en de afwezigheid van restverschijnselen als herstelcriterium genomen wordt, dan blijkt slechts $30 \%$ een jaar na ziekmelding hersteld. Kortom niet alleen bij WAO-intreders onder de overspannen werknemers, maar maar ook bij de overigen laat de aandoening langdurig sporen na.

De conclusie die hieruit getrokken kan worden, is dat het hanteren van WAO-intredecijfers als parameters voor het al dan niet succesvol beëindigen van verzuim wegens overspanning een ernstige onderschatting betekenen van het onvermogen tot reïntegratie tijdens het Ziektewetjaar bij de oorspronkelijke werkgever en van de mate waarin herstel van de aandoening uitgebleven is.

\subsection{De hulpverlening aan overspannen werknemers}

Als belangrijkste medische specialismen voor de begeleiding van langdurig verzuimende werknemers worden de huisarts, de bedrijfsarts en de verzekeringsgeneeskundige genoemd. Deze specialismen voeren elk de pretentie de aangewezene te zijn voor het case management, hetgeen de coördinatie tussen de diverse instanties van begeleiding en hulpverlening inhoudt. Voor overspannen werknemers wordt in dat opzicht geen uitzondering gemaakt, maar gelden de aanspraken a forteriori, omdat er geen duidelijke specialistische instantie blijkt te functioneren in de curatieve gezondheidszorg die zich met de behandeling en begeleiding van overspanning belast. De bij overspanning ingeschakelde hulpverlening is immers zeer heterogeen. Dit blijkt ook uit het door ons in hoofdstuk 8 gepresenteerde stroomdiagram van overspannen werknemers door de gezondheidszorg. Naast de huisarts bereikt geen enkele afzonderlijke (para)medische discipline een betrokkenheid bij $10 \%$ of meer der gevallen. Het vaakst betrokken blijkt de fysiotherapeut. De somatische specialisten blijken vaker betrokken te worden in de behandeling dan hulpverleners uit de Geestelijke Gezondheidszorg. lets meer dan $40 \%$ van de overspannen werknemers komt binnen de curatieve gezondheidszorg verder dan de huisarts, ruim $50 \%$ ontvangt uitsluitend de hulpverlening van de huisarts en $5 \%$ kan het zonder de curatieve sector af. De huisarts zelf blijkt alleen in de verwijzingen naar somatische specialisten en fysiotherapeuten een groot aandeel te hebben. De vaak aanwezige structurele of reguliere werkrelaties met het Algemeen Maatschap- 
pelijk Werk leiden niet tot veelvuldige verwijzing naar of betrokkenheid van deze vorm van hulpverlening.

Op grond van een mate van betrokkenheid van $95 \%$ lijkt de huisarts een aangewezen instantie voor het case management. Ook blijkt bij huisartsen een grote mate van overeenstemming in de opvatting dat het type psycho-sociale problemen dat in de meeste gevallen de basis vormt voor overspanning, zoals langdurige werkproblemen, tot de taak van de huisarts behoort. Hoewel er sprake is van een aanzienlijke spreiding, vinden er gemiddeld vijf contacten plaats tussen overspannen werknemers en hun huisarts. Daar staat tegenover dat in een groot aantal gevallen de werknemer een ander gezondheidsprobleem presenteert dan het probleem dat tot de ziekmelding leidde, of slechts een deel van dat probleem. De werksituatie als zodanig komt slechts in een beperkt aantal gevallen ter sprake. Dit gebeurt dan vooral in de eerste contacten en betreft voornamelijk de vraag of er tot ziekmelding overgegaan moet worden dan wel of het ziekteverzuim enige tijd gecontinueerd moet worden. Besprekingen en afspraken over werkhervatting zijn een betrekkelijke zeldzaamheid. De huisarts stelt zich nogal afwachtend op tegenover zijn patiënt en, als de keten van terugbestellingen verbroken is, roept de huisarts de patiënt niet uit eigener beweging op om na te gaan in hoeverre de problemen opgelost zijn en hoe het gesteld is met het ziekte- en verzuimbeloop. Bovendien blijkt de huisarts vrijwel geen contacten te leggen met het bedrijf, de bedrijfsarts en de verzekeringsgeneeskundige.

Niet alleen vanuit de curatieve, maar ook vanuit de sociaal-geneeskundige sector bekeken, is de huisarts een type hulpverlener die overspannen werknemers graag onder eigen beheer houdt. Voorschrijven van rust, terugbestellen, diagnostiek en, veel meer dan de huisarts zelf rapporteert, voorschrijven van medicatie zijn de belangrijkste middelen die de huisarts ter oplossing van overspanning inzet. Het actieterrein van de huisarts is bijna uitsluitend de spreekkamer, het contactuele netwerk beperkt zich, voor zover aanwezig, in vrijwel alle gevallen tot de eerstelijn. in dit licht is het niet verbazingwekkend dat het wachttijdenprobleem zich in veel mindere mate voordoet bij overspannen werknemers dan bij werknemers die om andere redenen verzuimen. Daar staat tegenover dat in een aantal gevallen zich langdurige stuurloze perioden kunnen voordoen, waarin er vanuit de curatieve sector geen behandelingsplan wordt uitgevoerd of is uitgezet. Het aandeel van de wachttijden en de stuurloze perioden bij overspannen werknemers blijkt gezien de resultaten van het onderzoek van Soeters (1983) over een periode van tien jaar onveranderd. Aangezien de stuurloze perioden in de meeste gevallen gepaard gaan met eveneens een inactiviteit van andere hulpverleners, betekent dit dat de werknemer in een situatie van isolement ten opzichte van de hulpverlening verkeert.

In beginsel beschikt de bedrijfsarts over goede mogelijkheden voor het case management. Deze kent het bedrijf, kent vaak ook de werknemer, beschikt over contacten en mogelijkheden om in het bedrijł gewenste hulp en aanpassingen te stimuleren, is in de meeste gevallen niet belast met claimbeoordeling maar bij uitstek met de belastende factoren in het werk en kan ook in het stadium voor de ziekmelding al interveniëren. Kortom de bedrijfsarts heeft een duidelijke voorsprong op andere hulpverleners. 
De bevindingen bij de overspannen werknemers, zoals weergegeven in het stroomdiagram, wijzen echter uit dat de bedrijfsarts de grote afwezige is in het hulpverleningspatroon. In 60\% van de gevallen is er geen bedrijfsarts aanwezig. En, indien er een bedrijfsarts beschikbaar is, blijkt er in slechts de helft der gevallen een contact tot stand te komen tussen werknemer en bedrijfsarts. Op éen uitzondering na vinden deze contacten soms eerst geruime tijd na de ziekmelding plaats, hoewel in veel gevallen de klachten en problemen al geruime tijd voor de ziekmelding manifest zijn en door de werknemer al een beroep gedaan is op hulpverlening uit de curatieve sector. Als de bedrijfsarts al betrokken is, is contactlegging met huisarts of verzekeringsgeneeskundige schaars.

Het komt voornamelijk bij werknemers van grote bedrijven, voorzien van een bedrijfsgezondheidszorgvoorziening, voor dat in geval van overspanning de bedrijfsarts het case management op zich neemt. Hoe effectief dit handelen is onttrekt zich aan onze directe waarneming. Het belang lijkt wel ondersteund door de bevinding dat bedrijven met steunpunten voor het personeel, zoals de bedrijfsgezondheidszorg, er beter in slagen de werknemer na verzuim wegens overspanning weer terug te laten keren naar hun werk en zodoende het risico van WAO-intrede of werkloosheid te beperken.

In vrijwel alle gevallen, de uitzondering betreft het geval van langdurige opname, vindt er contact plaats tussen werknemer en de verzekeringsgeneeskundige die niet alleen belast is met de claimbeoordeling in het kader van de Ziektewet, maar het ook uitdrukkelijk tot zijn taak rekent de werknemer zo goed mogelijk te begeleiden. De verzekeringsgeneeskundige heeft als opdracht, waar nodig, informatie te verzamelen bij en contact op te nemen met de curatieve sector, de bedrijfsgezondheidszorg en het bedrijf, en de GMD in te schakelen bij het uitblijven van een perspectief op een werkhervatting zonder loonverlies.

In de praktijk van de begeleiding van overspannen werknemers is niet alleen de betrokkenheid van de verzekeringsgeneeskundige van een beperkte duur gebleken, maar is er, afgezien van meldingen aan de GMD, in geringe mate sprake van contactlegging met anderen.

Gemiddeld genomen blijkt de verzekeringsgeneeskundige gedurende minder dan de helft van de verzuimperiode in contact te staan met de werknemer. Dit geldt overigens niet alleen de gevallen van overspanning, maar alle langdurige verzuimgevallen. De verhouding tussen de periode met contacten ten opzichte van de totale verzuimperiode ligt het gunstigt bij werkhervatters. Bij werklozen is er een relatief lange periode zonder contacten na het laatste contact; absoluut bedraagt deze periode ruim een maand. Hierbij is vooral sprake van een overeenkomst tussen verzekeringsgeneeskundige en werknemer over een termijn voor de werknemer om eventueel uit te kijken naar een andere baan. Vooral bij WAO-intreders doen zich lange contactloze periodes voor. Het ziektewetjaar van de WAO-intreder is in grote lijnen als volgt opgebouwd: de eerste anderhalve maand vindt er, zoals gebruikelijk bij alle verzuimgevallen, nog geen direct contact plaats met de verzekeringsgeneeskundige, gedurende vijf maanden komt hij regelmatig op het spreekuur, dan heeft de werknemer als gevolg van het besluit tot melding en overdracht aan de GMD drie en een halve maand lang geen enkel contact. Deze drie en een halve maand zonder voortgang komt in gelijke mate voort uit de vertraging in 
melding aan de GMD en uit de contactlegging vanwege de GMD. Gedurende de laatste twee maanden vinden er éen of enkele contacten met de GMD plaats, voornamelijk voor loontechnisch, medisch of arbeidskundig onderzoek.

Naast de beperktheid in begeleidingstijd is ook de beperktheid van het activiteitenpatroon opvallend. In vrijwel alle gevallen is er overleg met de rapporteur in de fase voor het eerste contact en vinden er éen of meer spreekuurcontacten plaats. Maar evenals bij de huisarts blijft de plaats van de begeleiding van het ziektegeval beperkt tot de spreekkamer. Contacten met de curatieve sector betreffen een kleine minderheid der gevallen en hebben voornamelijk het opvragen van informatie ten doel. In ongeveer $30 \%$ der gevallen is er contact met het bedrij, maar vaker op initiatief van het bedrijf dan van de verzekeringsgeneeskundige. De scheiding van behandeling en controle, alsmede de onbekendheid van de verzekeringsgeneeskundige met de meeste bedrijven waarbij de werknemers werkzaam zijn, vormen een sterke belemmering voor een coördinerende of actief sturende rol van de verzekeringsgeneeskundige. Deze ontbreekt vooral bij de kleinere bedrijven, waar juist de kans het grootst is dat overspannen werknemers niet terugkeren.

In de regel ontmoet de werknemer die het werk staakt met een ziekmelding wegens overspanning, geen hulpverlener die zich met zijn case management belast. Huisarts en verzekeringsgeneeskundige beperken zich voornamelijk tot spreekuurcontacten, daarbij de volledige verzuimperiode lang niet uitdienend, en een bedrijfarts is er meestal niet of blijft afzijdig. Dit betekent dat het aan de werknemer overgelaten worden het herstel- en verzuimbeëindigingsproces zelf te sturen in een situatie, namelijk van overspanning, dat deze nu juist daartoe het minst in staat is. In dit licht is de grote mate van verloop als uiting van onopgeloste problemen en de geringe mate van herstel die een jaar na de ziekmelding geconstateerd is, niet verbazingwekkend.

\subsection{De verklaring van de verschillen in wijze van verzuimbeëindiging en in verzuimduur}

De laatste probleemstelling van ons onderzoek betrof de vraag naar de invloed van persoons-, bedrijfs- en arbeidsplaatsgebonden factoren, kenmerken van de overspanning, het ziektegedrag en de hulpverlening op de verzuimduur en op de wijze van verzuimbeëindiging. Deze omvat een veelheid van verschillende categorieën variabelen.

Enerzijds is dit het gevolg van het gebrek aan consistente resultaten van het verzuimonderzoek met betrekking tot een groot aantal variabelen. Dit wekt geen verwondering gezien de verschillen onder andere in tijdstip van waarneming, keuze van verzuimparameters, keuze en constructie van de variabelen, toepassing van statistische technieken, niveau van waarnemingseenheden en onderzoekspopulaties. Veel onderzoek is verricht naar determinanten van (gemiddelde) verzuimduur en WAO-intrede, maar nauwelijks naar determinanten van verzuimduur en WAO-intrede onder populaties langdurige verzuimers. Anderzijds is de veelheid der categorieën variabelen het gevolg van een nieuwe opzet van de analyse, waaraan een model ten grondslag ligt dat het verzuimproces opsplitst in een aantal fasen die door afzonderlijke beslissingsmomenten afgebakend zijn. We hebben aldus achter- 
eenvolgens onderzocht, wat de determinanten zijn van de mogelijkheid tot terugkeer naar het bedrijf, van de aard van het verloop, indien geen terugkeer kon plaatsvinden, en de duur van het verzuim, indien de terugkeer wel gerealiseerd werd.

Ons uitgangspunt is dus dat van elke fase andere determinanten de uitkomst bepalen. Dit idee werd sterk gevoed door de afwijkende bevindingen van Soeters (1983) die onderzoek verrichte onder een populatie die in een aantal opzichten overeenkomt met die uit ons onderzoek. In de afzonderlijke analyses is dit dan ook duidelijk naar voren gekomen. De terugkeer wordt vooral beïnvloed door persoonsen bedrijfskenmerken, de lengte van het dienstverband, en het verzuimverleden. Vervolgens bepalen in het geval dat er geen terugkeer plaatsvindt, leeftijd, lengte van het dienstverband en de aan- of afwezigheid van steun thuis of het verloop de vorm van ontslag(name) dan wel van WAO-intrede aanneemt. In geval van terugkeer bepalen de mate van vrijheid in het werk, ziektekenmerken en praktijkvorm van de huisarts indirect en de handelwijze van huisartsen en verzekeringsgeneeskundigen direct de verzuimduur.

Opvallend is de geringe rol van de arbeidsomstandigheden bij het verzuimbeloop. Vermoedelijk zijn de vele gevonden verbanden tussen arbeidsomstandigheden en verzuimduur toe te schrijven aan de rol die arbeidsomstandigheden waarschijnlijk spelen in het ontstaan van aandoeningen, naast factoren die betrekking hebben op de privéomstandigheden en de constitutie van de werknemers. Waarschijnlijk spelen arbeidsomstandigheden ook een rol bij de ziekmelding naast ziektekenmerken en de adviezen van de behandelende arts(en) met betrekking tot het al dan niet voortzetten van de beroepswerkzaamheden. Op de volgende stadia van het verzuimproces blijkt de invloed van de arbeidsomstandigheden echter beperkt of afwezig. De conditione relatie tussen werksituatie en het verzuimbeloop strekt dus niet verder dan de ziekmelding.

Aangezien ons onderzoek uitgegaan is van werknemers die zich reeds ziek hadden gemeld, konden wij niet op dezelfde wijze onderzoeken of de zojuist genoemde factoren inderdaad een rol spelen bij de "pre-medische" fasen van het ziekteverzuim, namelijk bij het ontstaan van overspanning en gegeven de aanwezigheid van overspanning, bij het besluit tot ziekmelding. Toch beschikken wij op grond van ons onderzoeksmateriaal en vergelijkingsmateriaal tussen onze onderzoeksgroep en de actieve beroepsbevolking over aanwijzingen.

Ons onderzoeksmateriaal bevat de beoordelingen van de overspannen werknemers zelf, van de huisartsen en de verzekeringsgeneeskundigen over de oorzaken van de overspanning. Deze bleken op de eerste plaats gelegen in de werksituatie, met name in werkdruk, onzekerheid, conflicten en gebrek aan afstemming van de functie op het niveau van kennen en kunnen van de werknemer, voorts in de privésituatie en ten slotte in een aantal gevallen in de - verslechterende - constitutie van de werknemer. Ook bij de beoordeling van de werksituatie blijken overspannen werknemers in vergelijking tot "gezonde" werknemerspopulaties te getuigen van een grotere arbeidsbelasting. Voorts blijken er, althans bij omslagleden van de bedrijfsverenigingen, tussen bedrijfstakken verschillen op te treden in het aantal ziekmeldingen gediagnostiseerd als psychische aandoening per verzekerd mensjaar. 
Met betrekking tot de ziekmelding is ons duidelijk geworden dat de werksituatie een belangrijke rol heeft gespeeld, onafhankelijk van de oorzaak van de overspanning. Voorts blijkt de huisarts nogal eens te adviseren tot werkstaking. Ten slotte wordt de ziekmelding uiteindelijk bepaald door de (kenmerken van de) aandoening zelf. Op basis van deze bevindingen hebben we een model opgesteld van het verzuimbeloop wegens overspanning waarin de determinanten per stadium van het verzuimbeloop vermeld staan. Daarbij zijn de determinanten van overspanning en ziekmelding cursief afgedrukt op grond van de afwijkende en/of minder betrouwbare methodes, op basis waarvan zij bepaald zijn. Om die reden moet dit deel van het model vooralsnog als hypothetisch worden beschouwd.

Figuur 15.1 Determinanten van het verzuimbeloop in geval van overspanning

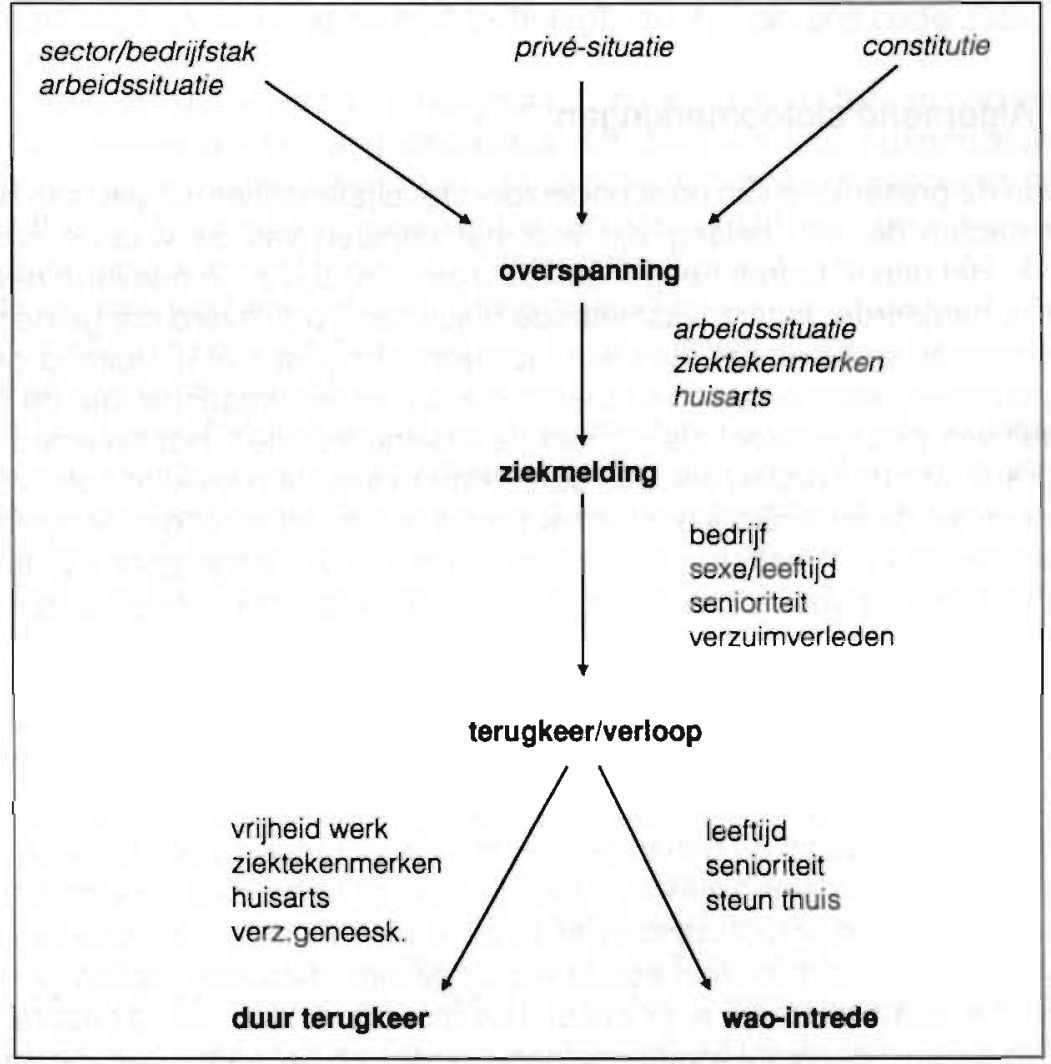

Een kanttekening die bij dit model gemaakt moet worden, is dat met name bij de vaststelling van de determinanten van de aard van het verloop, het aantal waarnemingseenheden gering is. De kans is daarom groot dat de aan- of afwezigheid van sommige variabelen min of meer toevallig is. Een tweede kanttekening is de beperkte mogelijkheid om bedrijfskenmerken vast te leggen als gevolg van de selectie van de informatiebronnen. De merkwaardig genoeg terugkeerbevorderen- 
de invloed van een hogere verzuimfrequentie in de laatste twee jaar moet hoogstwaarschijnlijk toegeschreven worden aan een daaraan ten grondslag liggende bedrijfscultuur en/of -politiek ten aanzien van zieke werknemers die zich manifesteert in een grotere tolerantie ten opzichte van ziekteverzuim en een grotere binding van de werknemer aan het bedrijf. Een laatste kanttekening die we hier willen plaatsen, heeft betrekking op onze bevinding dat wij geen invloed van het handelen van huisarts en verzekeringsgeneeskundigen op de terugkeer of op de aard van het verloop aantreffen. Dit moet vooral toegeschreven worden aan het gebrek in handelingsvariatie van deze medische professionals. Een dermate gering aantal huisartsen blijft zich op de hoogte houden van de verzuimstatus van de patiënt, en verzekeringsgeneeskundigen ondernemen zo weinig initiatieven naar de bedrijven en de curatieve sector toe, dat op een aantal van ruim 100 aselect verzamelde verzuimgevallen het effect van deze gedragswijzen niet waarneembaar is.

\subsection{Algemene slotopmerkingen}

Tot slot van de presentatie van onze onderzoeksresultaten willen wij stilstaan bij een drietal aspecten die van belang zijn voor het bepalen van de waarde van ons onderzoek. Het eerste betreft het generalisatiedomein, d.w.z.: in hoeverre heeft de door ons gehanteerde onderzoeksmethode resultaten opgeleverd die gelden voor alle overspannen werknemers, dan wel resultaten die juist niet uitsluitend gelden voor overspannen werknemers? Het betreft hier zowel het vraagstuk van de representativiteit van de steekproef als dat van de externe validiteit. Het tweede aspect is de bijdrage van ons onderzoek aan de verklaring van de ontwikkelingen van het ziekteverzuim en de arbeidsongeschiktheid zoals geschetst in het eerste hoofdstuk. Het derde aspect heeft betrekking op de bijdrage die ons onderzoek kan leveren aan een verbetering van hulpverlening en aan de verzuimbegeleiding van overspannen werknemers.

\subsubsection{Het generalisatiedomein van de onderzoeksresultaten}

Onze bevindingen zijn gebaseerd op de gegevens en de uitspraken van maximaal 114 werknemers en de bij de behandeling van hun aandoening en de begeleiding van het daaruit voortvloeiend ziekteverzuim betrokken huisartsen en verzekeringsgeneeskundigen. In absoluut opzicht een beperkt aantal dat, gezien de kosten van een longitudinaal onderzoek met een breed opgezette dataverzameling, voor ons vrijwel het maximaal haalbare is geweest. Het grootste nadeel van dit aantal is de verhouding tussen het aantal waarnemingseenheden en het aantal variabelen in de multivariate analyses geweest. Relatief gezien valt de omvang mee. Ze bedraagt ongeveer de helft van het aantal gevallen dat binnen een tijdsbestek van zes maanden op één der districtskantoren van het GAK wordt aangeboden.

De vastgestelde ondervertegenwoordiging van jongeren en oververtegenwoordiging van verzuimgevallen met een duur van zes tot twaalf maanden en een vermoedelijke ondervertegenwoordiging van werknemers wier overspanning veroorzaakt is door problemen in de thuissituatie, leiden ertoe dat de kwaliteit van de steekproef voor de toetsing van generalisatiehypothesen enigszins aangetast kan 
zijn. Daarom moeten een aantal beschrijvende uitspraken van dit onderzoek met enige voorzichtigheid bekeken worden. De meeste bevindingen met betrekking tot het beloop van de overspanning en de hulpverlening zijn echter nauwelijks beïnvloed gebleken door de leettijd van de werknemer. Waar dit wel het geval is, bedraagt de afwijking in de verdelingen ten hoogste 1 of $2 \%$. Met uitzondering van de verdeling van de oorzaken van overspanning heeft voor de verklaring van verschillen in verzuimbeloop deze lichte vertekening eerder voor- dan nadelen gehad, omdat de spreiding der waarden over de variabelen leeftijd en verzuimduur verbeterd is en daarmee de mogelijkheid tot het toetsen van substantiële hypothesen. Wel is er enige kans dat de sterkte van het verband tussen de oorzaak van overspanning en de kans op terugkeer enigszins onderschat is. Overigens is het vermoeden van onderschatting gebaseerd op de resultaten van een onderzoek waarin de oordelen van verzekeringsgeneeskundigen gevraagd is over een aantal overspanningsgevallen dat de helft bedraagt van dat van ons onderzoek.

Onze onderzoekspopulatie is samengesteld op basis van de toekenning van enkele door ons geselecteerde diagnosecodes die door verzekeringsgeneeskundigen aan verzuimgevallen toegekend zijn. De selectie van de diagnosecodes hield naar maatstaf van de overspanningstypologie van Kraft (1972) een zekere beperking in van het domein van overspanning. Alleen overspanning in engere zin, gecompliceerde en een deel van de gemaskeerde vormen van overspanning zijn in ons onderzoek betrokken. Psychosomatoses en decompensatoire vormen vallen buiten het bestek van ons onderzoek.

Het onderzoek betreft derhalve die vormen die in principe direct als overspanning direct herkenbaar zijn voor hulpverleners en niet met daaruit voortvloeiende lichamelijke of psychische defecten gepaard gaan. Een selectiebias als gevolg van het afgaan op het diagnostisch oordeel van én enkele verzekeringsgeneeskundige moet blijkens de resultaten van het panelonderzoek vrijwel uitgesloten geacht worden.

Wel kan er sprake zijn van problemen met de generaliseerbaarheid van onze resultaten door de keuze voor een GAK-populatie. Dit houdt in dat er een selectie opgetreden is naar bedrijfstak en bedrijfsgrootte en via deze naar de methodiek van verzuimbegeleiding. Zo komt het door Kaiser (1992) gevonden effect van de vereniging van de functies bedrijfsarts en verzekeringsgeneeskundige in én persoon op het verzuimbeloop niet aan bod en evenmin de invloed van afwijkende begeleidings-, herplaatsings- en afkeuringsprocedures bij ambtenaren. We hebben in ons onderzoek een duidelijke invloed waargenomen van het aantal steunpunten binnen het bedrijf ten dienste van het personeel, hetgeen zeer sterk samenhangt met de bedrijfsomvang en van de sector op de kans op terugkeer. We mogen dus niet zonder meer aannemen dat de door ons gevonden omvang van het verloop bij overspanning representatief is voor alle gevallen van verzuim wegens overspanning binnen de beroepsbevolking. Daar staat tegenover dat het GAK een zeer omvangrijk deel van de actieve beroepsbevolking verzekert waarin de meeste categorieën bedrijven en werknemers vertegenwoordigd zijn. Om die reden trekken wij de conclusie dat de representativiteit van onze bevindingen voor de Nederlandse beroepsbevolking door de keuze van de onderzoekspopulatie niet wezenlijk aangetast is, maar dat er rekening mee gehouden moet worden, dat er onder 
bepaalde categorieën werknemers of binnen bepaalde bedrijfstakken afwijkende resultaten gevonden kunnen worden. Replicatieonderzoeken zullen dit echter moeten uitwijzen.

Een ander kenmerk van onze onderzoekspopulatie is de regionale beperking. De verzuimkenmerken van de overspanningsgevallen uit deze regio wijken volgens de gegevens van het GAK nauwelijks af van de landelijke gemiddelden. Wel is het mogelijk dat culturele invloeden generalisatie naar geheel Nederland beperken. Deze zouden dan voor zover bekend betrekking moeten hebben op uitstelgedrag, d.w.z:. in Limburg raadpleegt men eerder een huisarts, indien zich ziekteverschijnselen voordoen, en rapporteert men meer gezondheidsklachten. Wij kunnen niet uitsluiten dat een populatie uit een ander deel van Nederland een langere aanlooptijd te zien kan geven bij het raadplegen van de huisarts. Uitstelgedrag is echter in ons onderzoek niet van wezenlijk belang gebleken voor het verzuimbeloop. Met betrekking tot de regionale verschillen in gezondheidsklachten is het niet zonder meer uit te sluiten dat deze bepaald zijn door de verschillen in gezondheid als zodanig die aan de hand van andere gezondheidsparameters ooit tussen Limburg en andere delen van Nederland zijn vastgesteld (Soeters, 1980). De kans op vertekening die alleen de SCL-90-score en de vergelijking van deze scores tussen de onderzoeksgroep en andere populaties zou kunnen betreffen, achten wij echter gering.

Onze conclusie luidt derhalve dat de bevindingen op basis van onze steekproef, afgezien van bepaalde werknemerscategorieën en van bepaalde decompensatoire en psychosomatische vormen van overspanning, een getrouw beeld geven van het ziekte- en verzuimbeloop van overspannen werknemers.

Daarmee is niet gezegd dat onze bevindingen in alle opzichten specifiek zijn voor verzuimgevallen wegens overspanning. Om dit te kunnen vaststellen was een vergelijkend onderzoek met andere langdurige verzuimgevallen en een ruimer onderzoeksbudget noodzakelijk geweest. De mogelijkheden om op basis van een secundaire analyse een vergelijking te maken van enkele kenmerken van het verzuimbeloop en van de determinanten van verzuimduur en wijze van verzuimbeëindiging, bleken vrijwel afwezig. De databestanden van het GAK zijn sterk gericht op uitvoeringstechnische verrichtingen en bevatten slechts weinig (betrouwbare) achtergrondgegevens van werknemers. Ze zijn vrijwel ongeschikt voor epidemiologisch of sociaal-wetenschappelijk onderzoek.

Uiteraard is de specificiteit van de door ons aangetroffen kenmerken van het ziektebeeld zelf niet in het geding en waarschijnlijk evenmin die van de aard van de hulpverlening vanuit de curatieve sector met uitzondering mogelijk van enkele behandelwijzen van de huisarts. De vraag of het bij langdurig verzuim wegens ander aandoeningen dan overspanning anders gesteld is met de hulpverlening vanuit de bedrijfsgezondheidszorg en met het onderhouden van contacten met het bedrijf, kunnen wij niet beantwoorden. Van de wachttijden in de curatieve sector was reeds bekend, dat overspannen werknemers meer met stuurloze perioden geconfronteerd worden dan met verwijzingswachttijden. (Soeters, 1983) Gezien de stabiliteit van bevindingen hieromtrent kan aangenomen worden dat deze verschillen zich nog steeds voordoen. Uit de schaarse vergelijkingen die we konden opstellen met betrekking tot het verzuimbeloop, blijkt dat de (relatieve) omvang van 
de verzekeringsgeneeskundige wachttijden, wanneer rekening gehouden wordt met de verschillen in de verdeling over de wijzen van verzuimbeëindiging, niet vee! samenhang vertoont met de diagnose. Met betrekking tot de duur van het verzuim en de wijze van verzuimbeëindiging zijn er wel duidelijke verschillen met de meeste andere diagnosegroepen. Het is de vraag of in geval van langdurig verzuim wegens een andere reden dan overspanning eveneens sprake is van een dergelijk groot verloop naast WAO-intrede. Daaraan is ook de vraag verbonden of de gevonden determinanten van terugkeer en aard van het verloop ook op een gelijke wijze de terugkeer en WAO-intrede beïnvloeden in geval van andere aandoeningen. De bevindingen van Hellinga (1991) dat er geen verschil bestaat tussen diagnosegroepen in determinanten van WAO-intrede kan niet zonder meer van toepassing verklaard worden op de resultaten van ons onderzoek, omdat zijn populatie niet beperkt is tot langdurige verzuimgevallen en zijn afhankelijke variabele WAO-intrede versus niet-WAO-intrede is. De databestanden van het GAK maken helaas geen onderscheid bij de registratie van "hersteldverklaringen", of daar werkhervatting bij de eigen werkgever op volgt of ontslag(name). Met betrekking tot de determinanten van verzuimduur bij werkhervatters achten wij het aannemelijker dat deze ook vastgesteld zullen worden bij verzuimgevallen met andere diagnoses. Onze bevinding komen enigszins overeen met die van Soeters (1983) die geen invloed aantrof van de diagnose, door hem geoperationaliseerd door de aanwezigheid van een diagnose uit de Ziekten der Bewegingsorganen, op de verzuimduur.

\subsubsection{De betekenis van de onderzoeksresultaten voor de verklaring van trends in ziekteverzuim en arbeidsongeschiktheid}

Vanuit het perspectief van de onderzoeksopzet zelf kan het onderzoek beschouwd worden als longitudinaal. Gedurende een jaar lang zijn 114 werknemers gevolgd die verzuimden wegens overspanning. Op deze wijze is de toevoeging van causale interpretaties aan een aantal gevonden samenhangen te rechtvaardigen. Vanuit het perspectief van de ziekteverzuim- en arbeidsongeschiktheidstrends over meer jaren is het onderzoek eerder transversaal van karakter. Het cohort waarop het onderzoek betrekking had, maakte deel uit van slechts één jaurgang van langdurige verzuimgevallen en WAO-intreders. Dit houdt in dat de gevonden determinanten van het verzuimbeloop wel een aanwijzing kunnen vormen, waarom de verzuimduur en WAO-intrede (juist) bij overspannen werknemers relatief zo sterk is toegenomen maar geen afdoende verklaring. Er zal immers aangetoond moeten worden, dat de toename van de verzuimduur en de WAO-intrede gepaard is gegaan met een verandering in de aard of de omvang van de determinanten. Zelfs al kunnen we dit op basis van gegevens van buiten ons onderzoek aannemelijk maken, ook dan moet rekening gehouden worden met de invloed van type variabelen die niet in ons onderzoek konden worden opgenomen, zoals stelselwijzigingen in de Sociale Zekerheid.

De verklaring voor de toenames behoeven niet gezocht te worden in de determinanten van overspanning of van ziekmelding wegens overspanning. Beide bleken over de laatstse decennia niet toegenomen. Daarmee valt de grond weg onder de theorie dat de toename van arbeidsongeschiktheid het gevolg is van een toegeno- 
men arbeidsbelasting en in het bijzonder werkstress. De rol van de arbeidsbelasting kan echter wel gelegen zijn in het belemmeren van werkhervatting voor werknemers die als gevolg van een overspanningsepisode verminderd belastbaar zijn. In dit geval kan men deze situatie evengoed beschouwen als een kenmerk van hel bedriff, namelijk de (in)flexibiliteit ten aanzien van de inrichting van functies.

De toename van arbeidsongeschiktheid kan het gevolg zijn van een relatief grotere participatie van vrouwen in het arbeidsbestel. Zij hebben een geringere kans op terugkeer na verzuim wegens overspanning dan mannen en een gelijke kans op WAO-intrede als vorm van verloop. Dit effect is echter moeilijk los te zien van het grotere aandeel van de dienstensector, waarin vrouwen relatief vaker werkzaam zijn, in de totale werkgelegenheid. De invloed van de leeftijdssamenstelling van de beroepsbevolking kan een rol spelen. Ouderen hebben per saldo een even grote kans op terugkeer als jongeren, maar indien dit niet lukt, is de kans op WAO-intrede aanzienlijk hoger. Alhoewel er de laatste decennia geen vergrijzing van de beroepsbevolking valt waar te nemen, mede als gevolg van een stimulerend beleid ten aanzien van oudere werknemers om uit te treden, is het risico groot dat in de toekomst, bij ongewijzigde omstandigheden en beleid, wanneer de gemiddelde leeftijd van de beroepsbevolking stijgt, de WAO-intredecijfers als gevolg van overspanning zullen stijgen.

De belangrijkste invloed op de toename van arbeidsongeschiktheid wegens overspanning moet op grond van onze bevindingen gezocht worden in de veranderingen van de bedrijven. Naast de aantoonbare verschuiving van de werkgelegenheid van de industriële naar de dienstensector, kan ook een verschuiving in de bedrijfsomvang een rol gespeeld hebben, gepaard gaande met relatief minder werkgelegenheid in grote ondernemingen of instellingen die vaak ook nog beter voorzien zijn van personeelsondersteunende instanties. In de jaren zeventig en tachtig heeft er eerst in de industriële en later in de diensten- en overheidssector een omvangrijk proces van bedrijfsinkrimpingen plaatsgevonden en is de groei van de werkgelegenheid vooral geconcentreerd in kleine bedrijven. Deze blijken minder goed in staat overspannen werknemers te laten terugkeren naar het bedrijf. Dit kan vooral gelegen zijn in geringere mogelijkheden om werknemers zonodig over te plaatsen of om intern een beroep te doen op een bemiddelende instantie bij wrijvingen tussen leidinggevenden en ondergeschikten.

Naast de veranderingen in structurele kenmerken is ook een verandering in bedrijfscultuur mogelijk van invloed geweest op de toename van arbeidsongeschiktheid wegens overspanning. Een van de bepalende factoren van verloop is namelijk het vermogen om problemen van werknemers met het werk op te lossen. De afgelopen decennia zijn gekenmerkt door een overvloedig aanbod van arbeidskrachten, hetgeen werkgevers stimuleert om minder omzichtig te zijn met vervangbare werknemers. De jaren tachtig zijn tevens het toneel geweest van een krachtige revitalisering van het kapitalisme, waarbij economische waarden in de (bedrijfs)politiek sterker zijn gaan prevaleren ten opzichte van sociale waarden. Het welzijn van de werknemer is ten gunste van een zo maximaal mogelijke benutting van zijn arbeidskracht verder op het tweede plan gebracht. Op zich lijkt dit niet geleid te hebben tot een grotere werkstress, wel tot een snellere uitstoot van werknemers die voor het weer vervullen van hun functies concessies vragen van hun werkgever, hetgeen bij overspannen werknemers een belangrijke voorwaarde is. Afhankelijk van de mate 
waarin dit oudere werknemers en werknemers met een langdurig dienstverband overkomen is, is deze factor mede bepalend geweest voor de toename van arbeidsongeschiktheid wegens overspanning.

De toename van de gemiddelde duur van het verzuim wegens overspanning wordt uiteraard voor een groot deel bepaald door het groeiende aandeel van WAO-intreders op de verzuimgevallen. Daarnaast zouden op grond van onze bevindingen met betrekking tot de determinanten van de verzuimduur in geval van terugkeer naar het bedrijf, verandering in werkwijze van huisarts en verzekeringsgeneeskundige als verklaring in aanmerking kunnen komen. Ons zijn echter geen gegevens bekend die inzicht zouden kunnen geven in eventuele varanderingen in werkwijze van huisartsen en verzekeringsgeneeskundigen. Veeleer zijn er aanwijzingen dat de wijze van beroepsuitoefening, in elk geval wat de onderlinge afstemming van de activiteiten betreft, de laatste decennia weinig veranderd is. (Buijs, 1985) Wel is er enige afname van het percentage huisartsen dat in solo-praktijken werkt, maar dit zou eerder een verwijzingsbeperkende en daardoor verzuimduurbeperkende invloed gehad moeten hebben.

\subsubsection{Aanbevelingen voor onderzoek en beleid}

Uit de voorgaande beschouwing is op te maken dat onze gedachten voor vervolgonderzoek onder meer in de richting gaan van replicaties van ons onderzoek met betrekking tot determinanten van verzuimbeloop. Er zijn nog maar weinig onderzoeken gedaan naar verzuimcarrières. Bovendien is het aantal waarnemingseenheden in ons onderzoek te beperkt gebleken om een volledig model ter verklaring van de aard van het verloop te ontwikkelen. Ook is het aan te bevelen naar wegen te zoeken om meer informatie over het bedrijf te verwerven, met name met betrekking tot personeelsbeleid, in het bijzonder het beleid ten aanzien van langdurig zieke werknemers. Het belangrijkste motief voor deze aanbeveling is het onopgeloste vraagstuk van het generalisatiedomein. We weten niet welke determinanten specifiek gelden voor overspanning en welke gelden voor langdurig verzuim in het algemeen. Bijzondere aandacht verdient daarbij de constructie van de onafhankelijke variabele: wijze van verzuimbeëindiging. Bij overspanning blijkt de tweedeling hersteldverklaring door de verzekeringsgeneeskundige versus WAO-intrede het zicht op het totale verloop te verduisteren. Ook achten wij het zinvol dat het onderzoek herhaald wordt onder andere contexten van de (uitvoering van de) sociale zekerheid dan onder die van de omslagleden van het GAK. Vooral denken wij daarbij aan onderzoek naar het verzuimbeloop van ambtenaren, onderwijzers en werknemers bij bedrijven die zelf zorg dragen voor de uitvoering van de Ziektewet.

Voor het ophelderen van de rol van de arbeidssituatie in het verzuimproces bij overspanning zou een vergelijkend retrospectief onderzoek aangewezen zijn, waarbij als controlegroepen in elk geval werknemers die langdurig verzuimen om andere redenen, en werknemers die geen enkele keer verzuimen gedurende de waarnemingsperiode, gekozen worden. Wanneer in een dergelijk onderzoek ook de aandacht gericht wordt op de voortekenen van verzuim wegens overspanning, wat met name bij de chronische vormen mogelijk moet zijn, kan dit leiden tot kennıs van 
risicogroepen en van vroegtijdige signalen van overspanning en van het daarop volgend ziekteverzuim.

Een andere richting, waarin onderzoek onzes inziens noodzakelijk is, is het uitvoeren van zogenaamde meta-analyses van verzuimonderzoeken. Daarmee zou nagegaan moeten worden wat de waarde van de - vaak tegenstrijdige - resultaten is en wat, in het geval er geen methodologische of statistische deficiënties aantoonbaar zijn, de verklaring zou kunnen zijn voor de tegenstrijdigheden oftewel wat de rol is van de verschillen in ondere andere verzuimparameter, tijd, plaats of populatie. Dit zou een belangrijke ondersteuning kunnen bieden bij de selectie van variabelen in toekomstig onderzoek.

Een tweede belangrijke ondersteuning voor verder onderzoek zou in eerste instantie gegeven kunnen worden door de databestanden van het ziekteverzuim uit te breiden met een specifiekere beschrijving van de wijze van verzuimbeëindiging en van een aantal kenmerken van het bedrijf en van de arbeidsplaats. Het type onderzoek dat door ons verricht is en dat wij ook ter vervolg aanbevelen is zeer arbeidsintensief. Alhoewel secundaire analyses geen vervanging kunnen zijn voor veldonderzoek, kunnen ze wel de efficiëntie daarvan verhogen, omdat ze informatie opleveren voor de ontwikkeling van probleemstellingen en hypothesen en voor de selectie van variabelen voor veldonderzoek.

Voorts willen wij pleiten voor onderzoek naar de determinanten van de werkwijze van huisartsen, bedrijfsartsen en verzekeringsgeneeskundigen, in het bijzonder van het gebrek aan samenwerking. Bij voorkeur snel opgevolgd door experimenteel actie-onderzoek. Voor dit laatste bieden de reeds ingezette veranderingen bij de medische diensten van de bedrijfsverenigingen mogelijkheden.

Hoewel nog veel over de meest adequate hulpverlening aan en begeleiding van overspannen werknerners onbekend is en aanvullend onderzoek noodzakelijk, zijn er op basis van onze onderzoeksbevindingen een aantal aanbevelingen te doen omtrent veranderingen in beleid die ten minste de moeite van het experiment waard lijken.

Betwijfeld moet worden of de huisartsen in staat zijn een actieve interveniërende rol naar de bedrijven toe te ontwikkelen. Ten aanzien van overspannen werknemers zou de huisarts wel iets meer kunnen doen dan in de regel vrijblijvend uit te nodigen voor een gesprek, begrip te tonen en betrokkenen adviezen mee te geven. Bij de algemeen aanvaarde opvatting dat het bespreken en begeleiden van psycho-sociale problemen tot de taak van de huisarts behoort, past een werkroutine waarbij de huisarts de langdurig wegens overspanning verzuimende werknemer langer blijft volgen en zonodig directiever uitnodigt. Evenzeer behoort daarbij dat de huisarts naast de gezondheidstoestand en de staat van de hulpverlening als standaard informeert naar de stand van zaken met betrekking tot het herstelproces en het al dan niet hervatten van werkzaamheden.

Ten slotte is gebleken dat nogal wat overspannen werknemers bij de huisarts zijn geweest, voordat zij zich ziek melden. Daar liggen mogelijkheden voor de huisarts om de bedrijfsarts een signaal te geven om diens verzuimpreventief werk te bevorderen. Het is echter niet goed bekend, waarom huisartsen zoveel decennia lang zo terughoudend zijn in het zelf leggen van contacten met de sociaal-geneeskundige sector. Binnen onze populatie is er niets te bemerken geweest van weerstand bij werknemers tegen contacten tussen artsen, wel vanuit de artsen naar 
werkgevers toe, indien dit niet ten volle met de werknemer vooraf besproken en door deze gefiatteerd was.

Noch de professionele deskundigheden noch de organisationele context noch eventuele weerstanden bij werknemers behoeven een betere communicatie tussen huisarts en verzekerings- en bedrijfsartsen in de weg te staan. Het is vooral een kwestie van attitudevorming en het ontwikkelen van een verzuimbegeleidingsprotocol bij huisartsen.

Een goede aanzet daartoe blijkt reeds gegeven in de werkwijze van het gezondheidscentrum Holendrecht te Amsterdam. Daar wordt het ziekteverzuim systematisch door de huisarts geregistreerd en besproken. De follow-up wordt bewaakt door middel van vervolgafspraken. (Van Dijk en Hogervorst, 1991)

De bedrijfsverenigingen zouden in overleg met huisartsverenigingen initiatieven kunnen nemen om vervolg te geven aan het "Holendrecht-experiment" en daarbij in een "in-service-training van verzuimbegeleiding" voorzien door middel van terugkoppeling analoog aan de activiteiten van het Diagnostisch Coördinerend Centrum te Maastricht dat door terugkoppeling erin slaagde huisartsen tot selectief gedrag te brengen inzake het aanvragen van diagnostisch onderzoeken. (Pop en Winkens, 1989)

Waarom de bedrijfsarts of de bedrijfsmaatschappelijk werker niet of pas na de ziekmelding betrokken wordt of zich er mee gaat bemoeien, weten we niet. Misschien zijn zij teveel gericht op de uitersten van het continuum preventie van ziekte en reïntegratie van zieke werknemers, om de nodige aandacht te geven aan signalen die werknemers voor de ziekmelding afgeven, dat zij het werk of de privésituatie niet aankunnen. Uiteraard biedt het spreekuur mogelijkheden voor de werknemer om zijn problemen voor te leggen, maar dat lijkt te veel verwacht van een werknemer, bij wie de problemen toch al boven het hoofd dreigen te groeien. Misschien kan er aan de toegankelijkheid van het spreekuur het een en ander verbeterd worden. Een andere invalshoek is dat er een signaallijst en een risicoprofiel ontwikkeld wordt om werknemers die overspannen dreigen te raken, tijdig op te sporen en zodoende ziekteverzuim te voorkomen.

Voor de meeste werknemers is een verbetering van de inzet van bedrijfsartsen en personeelswerkers niet weggelegd. Het bedrijf beschikt er domweg niet over. Gezien het relatief grote risico dat werknemers bij kleine bedrijven zonder personeelsvoorzieningen lopen om bij langdurig verzuim in de WAO terecht te komen, is het noodzaak om in het beleid ter terugdringing van de groei van de arbeidsongeschiktheid meer nadruk te leggen op het verzuimbeleid in de kleine bedrijven. De meeste initiatieven hebben betrekking op of zijn op de maat gesneden van grote bedrijven. Naast uitbreiding van de wettelijke verplichting tot bedrijfsgezondheidszorg en het door de medische diensten van de bedrijfsverenigingen overnemen van deze zorg binnen het kader van verzuimbeleid, kan alleen al vanuit dit perspectief ook aanbevolen worden dat er een speciale functionaris komt belast met het case management van de verzuimgevallen bij de kleine bedrijven die in staat is de nodige activiteiten binnen die bedrijven tot stand te brengen.

Met betrekking tot de verzekeringsgeneeskundige lijken ons de volgende maatregelen ernstig te overwegen. De geografische rayonvorming dient te worden losge- 
laten. Weliswaar dient deze het gemak van de rapporteur of lekencontroleur die met de verzekeringsgeneeskundige in teamverband werkt, maar voor het onderhouden van contacten met de huisartsen of curatieve sector is een dergelijke afbakening van het werkterrein van weinig waarde gebleken. In plaats daarvan dient zo spoedig mogelijk bedrijfs- of bedrijfstakgebonden werkterreinen aan verzekeringsgeneeskundigen toegekend te worden. Immers contacten met een bedrijf, beoordelingsvermogen en mogelijkheden tot interventie hangen sterk af van de mate waarin de verzekeringsgeneeskundige met het bedrijf bekend is. Een bijzondere aandacht dient uit te gaan naar de kleinere bedrijven, waar het verloop-en WAO-intrederisico het hoogst ligt. Wellicht gaat, gezien de spreiding van het aantal gevallen over het aantal bedrijven, het opbouwen van een werkrelatie de macht van de verzekeringsgeneeskundige te boven. Daar kan niet volstaan worden met afstemming op daar aanwezige professionele mogelijkheden voor gevalsbehandeling. Om die reden willen wij de bedrijfsverenigingen in overweging geven, met name ten behoeve van kleinere bedrijven, een specialisme in het verlengde van bedrijfsgeneeskundige diensten, bedrijfsmaatschappelijk werk en bedrijfspsychologische diensten in het leven te roepen die belast wordt met het case management van overspannen werknemers met bijzondere nadruk op het slechten van psychische en sociale barrières voor terugkeer. Een dergelijke specialist zou ook ingezet kunnen worden bij het wegwijs maken van overspannen werknemers in de voorzieningen waaronder die van de curatieve en geestelijke gezondheidszorg, maar ook voorzieningen in de juridische en de maatschappelijke sfeer. Voor veel overspannen werknemers en soms ook huisartsen blijkt het nogal moeilijk de weg naar de juiste instelling te vinden.

Afgezien van een dergelijke aanvulling op het team van de verzekeringsgeneeskundige, is het even zo noodzakelijk dat de verzekeringsgeneeskundige meer gelegenheid krijgt om meer werk buiten de spreekkamer te verrichten. Coördineren of begeleiden is meer dan gespreksvoering met en advisering aan werknemers en telefoneren naar artsen en bedrijven. Verdere actie en het moment waarop af te laten hangen van de aanwezigheid van een sociaal-medisch team en het afgesproken tijdstip van bijeenkomst met zo'n team leidt in de meeste gevallen tot geen of vertraagde actie. Voorts is het aan te bevelen dat de verzekeringsgeneeskundige er op toeziet alle gevallen binnen een termijn van zes weken te zien, ook al bestaat er de meestal oppervlakkige indruk dat er op korte termijn geen werkhervatting mogelijk is, of dat door het bedrijf hard aan het geval gewerkt wordt. Ten slotte is $\mathrm{er}$, wat de verzekeringsgeneeskundige betreft, het probleem van de afstemming met de GMD dat direct al tot uiting komt in het tijdsverlies bij de overdracht. De overgang naar de GMD brengt veelal verwarring en ergernis mee voor de werknemer die zich overvallen voelt door onbekende functionarissen die inlichtingen vragen of onderzoeken doen in het kader van een procedure die voor de werknemer niet inzichtelijk (gemaakt) is. Te overwegen valt om de begeleiding van de GMD en van de bedrijtsvereniging te integreren in een team, waarbij de verzekeringsgeneeskundige van de bedrijfsvereniging de directe begeleider blijft van de werknemer, deze voorlicht over de procedures die gevolgd worden, en toeziet op een efficiënte en onderling goed afgestemde werkwijze van de diverse functionarissen. 


\section{Samenvatting}

Het onderzoek dat tot dit proefschrift heeft geleid, is uitgevoerd tegen de achtergrond van de ontwikkelingen van het ziekteverzuim en de arbeidsongeschiktheid gedurende de laatste decennia in Nederland. Hoewel de toename van het risico om arbeidsongeschikt te worden de laatste jaren weliswaar niet veel hoger ligt dan de toename van de beroepsbevolking, is er wel sprake van een stijgend aandeel van arbeidsongeschiktheid wegens psychische aandoeningen. Ook heeft er een toename plaatsgevonden van de gemiddelde duur van het ziekteverzuim wegens psychische aandoeningen. Verandering in diagnostiek ten gevolge van een betere herkenning van psychische problemen achter lichamelijke klachten lijkt voor deze ontwikkelingen geen verklaring te bieden, aangezien er eveneens een (relatieve) toename van arbeidsongeschiktheid wegens ziekten der bewegingsorganen plaats heeft gevonden. Verklaringen die uitgaan van een toename van psychische aandoeningen en van het aantal ziektegevallen dientengevolge, worden ontkracht door de bevinding dat er noch een toename heeft plaatsgevonden van het gemiddeld aantal ziekmeldingen per werknemer wegens psychische aandoeningen noch een toename van het percentage consulten bij huisartsen op grond van psychische problemen. Twee belangrijke bevindingen geven wel enig idee in welke richting gezocht moet worden: de gezondheidszorg heeft grote moeite met het hanteren van ziekte(verzuim) wegens psychische aandoeningen en aan ruim $80 \%$ van de gevallen worden diagnoses toegekend die onder éen titel samengevat kunnen worden, namelijk overspanning.

Ons onderzoek is derhalve uitgegaan van de volgende probleemstellingen:

Wat is de aard van overspanning oftewel wat is de betekenis van het begrip overspanning en hoe manifesteert de aandoening overspanning zich in klachten en verschijnselen? Welke hulpverlening wordt verleend aan werknemers die zich wegens overspanning hebben ziekgemeld? Op welke wijze en in welke mate bepalen persoons-, bedrijfs- en arbeidsplaatsgebonden factoren, verzuimverleden, kenmerken van de overspanning, het ziektegedrag en de hulpverlening de verzuimduur en de wijze van verzuimbeëindiging?

Door ons is een systematisch litteratuuronderzoek gedaan naar het voorkomen en de betekenissen van overspanning en de volgende synonieme of verwante begrippen: het hyperaesthetisch-emotionele syndroom, surmenage, neurasthenie en adjustment disorder.

Vooral sociaal-psychiaters, arbeidsgeneeskundigen en huisartsen besteden aandacht aan dit ziektebeeld, terwijl klinisch psychiaters dit nauwelijks doen, hetgeen een weerspiegeling is van het niet-klinische karakter van deze aandoening.

De geschiedenis laat internationaal een periodieke op- en neergang van de populariteit van de termen overspanning, surmenage en neurasthenie zien. De laatste 
decennia wordt er weer in toenemende mate gebruik gemaakt van deze en andere termen. Overigens blijkt de vaagheid van de begrippen en hun misbruik bij medische claimbeoordelingen tot verwerping van deze begrippen te leiden. Zo blijkt de diagnose adjusment disorder die deel uitmaakt van de DSM-III, nogal moeilijk afgrensbaar van andere stoornissen of van psycho-sociale hulpvraag zonder aanwijsbare stoornis. De betekenis van het hyperaesthetisch-emotionele syndroom blijkt beperkt tot een symptomatologie die niet uitsluitend bij overspanning voorkomt en omgekeerd niet de enige wijze is waarop overspanning zich manifesteert. Bij overspanning en surmenage heeft er een verschuiving in betekenis plaatsgevonden van aetiologische factor naar aandoening.

Door een aantal auteurs worden verschillende vormen van overspanning onderscheiden, meestal gebaseerd op klachtenpatroon en oorzaak.

Het verslag van de litteratuurstudie wordt besloten met de volgende definitie van overspanning: "Overspanning is een dusdanige verstoring van het evenwicht tussen psychische belasting en psychische belastbaarheid als gevolg van veranderingen in individuele belastbaarheid en/of psycho-sociale belasting, dat bij het getroffen individu een proces ontstaat van verminderd vermogen tot sociaal functioneren, gepaard gaande met lichamelijke klachten, stemmings- en/of gedragsveranderingen."

Door ons is als aanvulling op het litteratuuronderzoek naar de conceptualisering van overspanning een onderzoek naar de toepassing van het concept in de verzekeringsgeneeskundige diagnostiek ondernomen. De probleemstelling luidt: In welke mate is er sprake van overeenstemming in diagnose tussen verschillende artsen bij het ziektebeeld overspanning? In welke mate is overeenstemming tussen artsen alsnog bereikbaar in die gevallen waarbij in eerste instantie een verschillende diagnose gesteld wordt?

Aan een panel bestaande uit twee huisartsen, een psychiater en een gepensioneerde verzekeringsgeneeskundige werden 112 casus voorgelegd die eerder door verzekeringsgeneeskundigen uit een ander district dan waar het veldonderzoek plaatsvond, gediagnostiseerd zijn. Deze casus betroffen verzuimgevallen uit die diagnosecategorieën die op theoretische gronden gevallen van overspanning kunnen bevatten. Aan de leden van het panel werden gestandaardiseerde verslagen voorgelegd op basis van de informatie die de verzekeringsgeneeskundige gebruikte voor het stellen van de diagnose. Daarbij is de Delphi-methode toegepast om onder meer de onafhankelijkheid der beoordelingen te waarborgen.

De mate van overeenstemming tussen de beoordelaars, inclusief de betrokken verzekeringsgeneeskundige, is in het algemeen hoog gebleken. Enige uitzonderinng betrof een panellid dat als afwijkend beginsel hanteerde dat onverklaarde lichamelijke aandoeningen psycho-sociaal bepaald zijn, terwijl de overigen in overeenstemming met de definitie van overspanning alleen overspanning vaststelden, indien er een aanwijsbare psycho-sociale stressor aanwezig was die de klachten en verschijnselen kon verklaren.

In een tweede becordelingsronde na anonieme confrontatie met de oordelen van de andere panelleden bleek er een geringe toename in consensus. De belangrijkste conclusies uit dit onderzoek zijn: 
- tussen artsen is een hoge mate van consensus bereikbaar over de diagnose overspanning, mits de criteria volgend uit de theoretische conceptualisering strict worden toegepast

- het diagnostisch oordeel van de verzekeringsgeneeskundige omtrent de aanwezigheid van overspanning is naar maatstaf van de interbeoordelaar-betrouwbaarheid een betrouwbaar instrument

Als laatste voorbereiding voor het hoofdonderzoek is een litteratuurstudie verricht naar de determinanten van verzuimduur en WAO-intrede. Onderzoek specifiek gericht op verzuimduur en WAO-intrede in geval van overspanning blijkt vrijwel geheel afwezig. De onderzoeken naar deze determinanten zijn in te delen naar de volgende typen: correlationele onderzoeken ter verklaring van verschillen tussen bedrijven of individuele werknemers in gemiddelde verzuimduur, van verschillen in verzuimduur tussen afzonderlijke verzuimgevallen, van verschillen tussen bedrijven in WAO-intredepercentages, tussen individuele werknemers in kans op WAO-intrede en procesanalytische onderzoeken naar de invloed van de curatieve sector op de verzuimduur. Als determinanten zijn onderzocht: persoonskenmerken, bedrijfskenmerken, kenmerken van de arbeidsplaats, verzuimverleden, gezondheidstoestand en ziektekenmerken, ziektegedrag en gezondheidszorg, verzuimbeleid en verzuimbegeleiding.

Opvallend zijn de vele inconsistenties in de bevindingen omtrent samenhangen tussen verklarende variabelen van allerlei aard en (gemiddelde) verzuimduur of kans op WAO-intrede. Naast verschillen in onderzoeksopzet is dit gelegen in populatieverschillen, verschillen in tijdstip van waarneming, in selectie en constructie van de variabelen, en in statistische analysetechnieken. Voor de vooruitgang van de kennis in de zin van verwijdering van variabelen uit het hypothetische model ter verklaring van verzuimduur en arbeidsongeschiktheid vormt dit een ernstige hinderpaal.

In ons hoofdonderzoek zijn zowel de procesanalytische benadering als de correlationele toegepast.

Het procesanalytisch model is eerder toegepast in de onderzoeken van Tordoir c.s. (1978) en Soeters (1983). In ons onderzoek hebben wij dit model niet alleen toegepast op de curatieve sector maar ook op de sociaal-verzekeringsgeneeskundige sector.

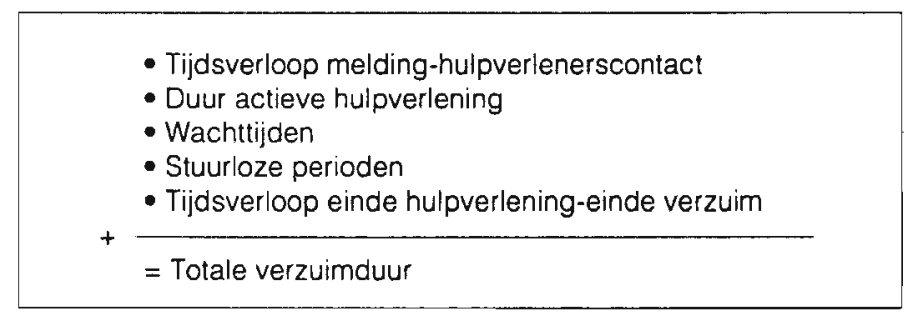


De correlationele analyse is uitgevoerd ter verklaring van verschillen in wijze van verzuimbeëindiging en in verzuimduur bij terugkeer.

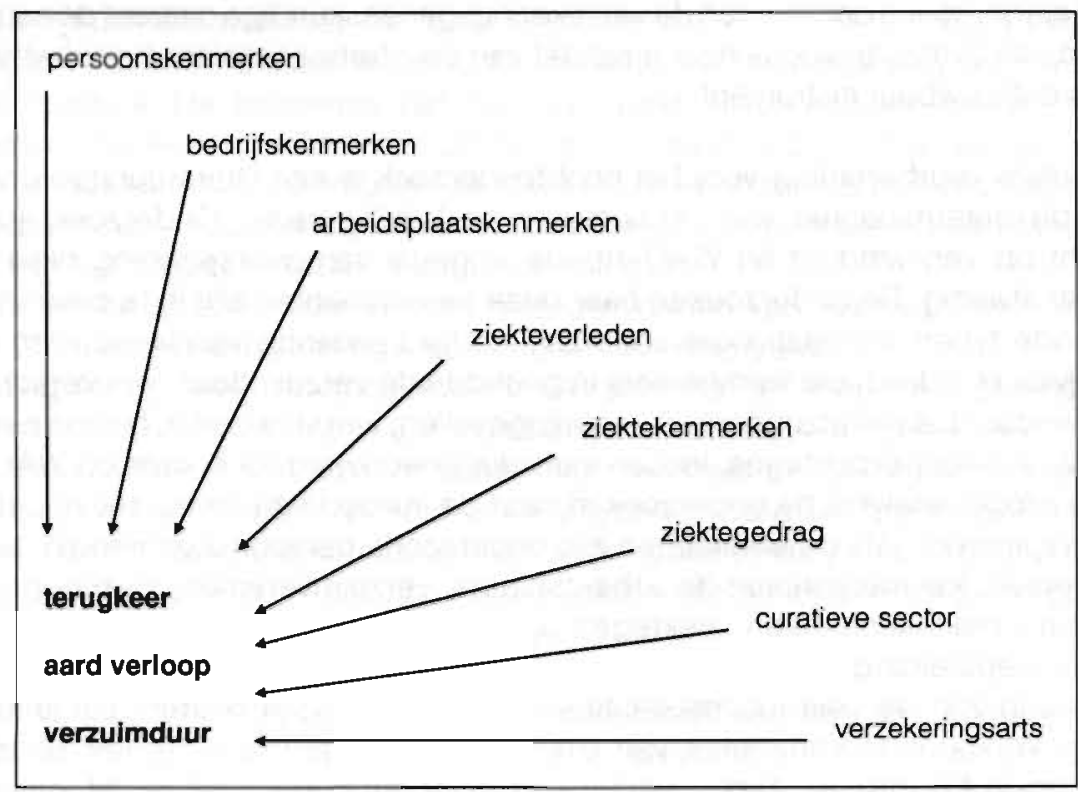

Het hoofdonderzoek is een beschrijvend prospectief cohortonderzoek uitgevoerd onder een steekproef van werknemers die verzekerd zijn bij een bij het GAK aangesloten bedrijfsvereniging en vier weken of langer verzuimen wegens overspanning. Van een vergelijkend onderzoek met werknemers die wegens andere aandoeningen langdurig verzuimen, is om budgettaire redenen afgezien.

De steekproeftrekking vond plaats bij eén der districtskantoren en was geproportioneerd per rayon. Van de 208 aangeschreven potentiële respondenten bleken er 114 bereid tot deelname aan het onderzoek. Dit hield in: deelname aan een interview ongeveer één à twee maanden na datum ziekmelding, deelname aan periodieke interviews tot verzuimbeëindiging of WAO-intrede plaatsvond, en aan een interview ongeveer één jaar na datum ziekmelding. De uitval tijdens het onderzoek was gering. Naast de werknemer zijn, indien deze zijn toestemming verleende, ook de huisarts en de verzekeringsgeneeskundige benaderd voor een interview. Zij waren in vrijwel alle gevallen daartoe bereid en in staat. Van 94 respondenten konden alle interviews afgenomen worden.

Met behulp van de interviews van de werknemers konden gegevens vastgelegd worden met betrekking tot persoonskenmerken, enkele bedrijfskenmerken, kenmerken van de arbeidsplaats, ziektebeeld, ziektegeschiedenis, ziektegedrag, hulpverleningscontacten, verzuimbeloop en herstel. De interviews met huisartsen verschaften ons gegevens over ziektebeeld, kenmerken van de huisarts, contacten tussen huisarts en werknemer, en beleid van de huisarts. Door middel van de interviews met de verzekeringsgeneeskundige werden gegevens verzameld over 
ziektebeeld, verzuimverleden, kenmerken van de verzekeringsgeneeskundige, diens beleid en verzuimbeloop.

De non-respons blijkt aangaande de onafhankelijke variabelen alleen effect gehad te hebben op de leeftijdsverdeling van de deelnemers. In de verdeling naar sexe, bedrijfstak en verzuimverleden treden nauwelijks verschillen op tussen deelnemers en weigeraars. De categorie jonger dan 30 jaar is enigszins ondervertegenwoordigd. Als gevolg daarvan is de verdeling over de leeftijdscategorieën bij de deelnemers minder scheef dan in de steekproef.

Hoewel de beperking tot GAK-verzekerden in één regio een nauwkeurige vergelijking met de beroepsbevolking belemmert, valt op dat de groep overspannen werknemers naar samenstelling in sexe en leeftijd en vermoedelijk ook in opleidingsniveau niet veel verschilt van de beroepsbevolking. Wel is de dienstensector enigszins oververtegenwoordigd. Alle beroepsgroepen blijken vertegenwoordigd. Ten opzichte van vergelijkbare onderzoeken naar de (beleving van) arbeidsbelasting valt op dat overspannen werknemers vooral meer werk te doen hebben, langere werktijden en geringere promotiekansen hebben.

De symptomatologie blijkt bij driekwart van de overspannen werknemers die van het hyperaesthetisch-emotionele syndroom te zijn. Bijna een kwart heeft lichamelijke klachten van allerlei aard. De gemiddelde score op de SCL-90, een vragenlijst die de mate van psychoneuroticisme meet, blijkt iets onder die van poliklinisch-psychiatrische patiënten te liggen en ruim boven die van een normale populatie. Vooral slaapproblemen doen zich voor. Ongeveer $90 \%$ is zich ervan bewust overspannen te zijn. Als oorzaken worden zowel door de respondenten als door de huisartsen en de verzekeringsgeneeskundigen vooral de werksituatie of de thuissituatie genoemd. De huisartsen noemen iets vaker dan de anderen de thuissituatie, de persoonlijkheid en lichamelijke defecten van de werknemer als oorzaken. Deels zijn de afwijkende oordelen te verklaren, doordat een aantal werknemers niet het overspanningsprobleem aan de huisarts voorleggen, maar slechts een bijkomende lichamelijke klacht presenteren. Op basis van de klachten en verschijnselen en de oorzaken van overspanning blijken de meest voorkomende typen van overspanning de volgende te zijn: overspanningsklachten ten gevolge van chronische werkstress, lichamelijke klachten ten gevolge van werkstress, overspanningsklachten ten gevolge van een incident op het werk en overspanningsklachten ten gevolge van een incident in de privésfeer.

De verzuimduur van overspannen werknemers bedraagt gemiddeld ruim vijf maanden. Ruim $20 \%$ haalt de maximale termijn van de Ziektewet en doet een beroep op de AAW en de WAO. Als deze categorie buiten beschouwing wordt gelaten, bedraagt de gemiddelde verzuimduur ongeveer drie maanden. De deelnemers aan het onderzoek blijken gemiddeld wat langer te verzuimen en een iets grotere kans op WAO-intrede te hebben dan de weigeraars. De wijze waarop het verzuim beëindigd wordt, en de arbeidsstatus éen jaar na datum ziekmelding geven niet alleen een hoog percentage WAO-intreders te zien maar ook een zeer hoog verloop om andere redenen. $\mathrm{Na}$ de verzuimperiode keert slechts $55 \%$ terug naar de oorspronkelijke werkkring. Eén jaar na de datum van ziekmelding is daar nog 
ongeveer $40 \%$ werkzaam. Dus sommigen die eerst terugkeerden, verlieten om verschillende redenen het bedrijf alsnog.

Opvallend is de betrekkelijk geringe mate van herstel bij overspannen werknemers na een jaar. Bij WAO-intreders is er in sommige opzichten zelfs sprake van enige achteruitgang. Volledig herstel is bij slechts $30 \%$ van de respondenten opgetreden.

Het ziektegedrag van overspannen werknemers heeft als opvallendste kenmerk dat er in ruime mate sprake is van uitstelgedrag, zowel ten aanzien van de ziekmelding als ten aanzien van de inschakeling van de hulpverlening. Twee derde van de respondenten heeft bij de ziekmelding al twee maanden last van gezondheidsklachten, terwijl dit voor een derde al langer dan een jaar het geval is. De huisarts, in verreweg de meeste gevallen de eerst geraadpleegde hulpverlener, wordt daarentegen slechts door $20 \%$ van de respondenten meer dan een maand voor de ziekmelding geraadpleegd.

De invloed van werkgebonden factoren op de beslissing tot ziekmelding is groot. Voor ruim de helft is de werksituatie directe aanleiding tot ziekmelding. Van diegenen bij wie de overspanning geen verband houdt met de werksituatie, besluit een kwart toch op grond van de werksituatie tot ziekmelding. Slechts een kwart van de ziekmeldingen houdt geen enkel verband met de werksituatie.

Het patroon van de hulpverlening aan overspannen werknemers toont een zeer heterogene carrière van overspannen werknemers door de gezondheidszorg. Ten aanzien van de ingeschakelde hulpverlening valt de beperkte inzet van de Geestelijke Gezondheidszorg en het Algemeen Maatschappelijk Werk op. Wel blijkt de Geestelijke Gezondheidszorg vooral betrokken te worden bij ernstiger overspannen werknemers. Hoewel de onderzochte groep patiënten typisch lijdt aan geestelijke gezondheidsproblemen, blijken ze even gemakkelijk doorverwezen te worden naar sormatische specialisten of fysiotherapeuten als naar de Geestelijke Gezondheidszorg of maatschappelijk werk. Dit kan nauwelijks verklaard worden door de wijze waarop de patiënt zijn overspanning presenteert. Weliswaar wordt de huisarts bij ruim een derde van de gevallen geconfronteerd met somatische problematiek, maar het verwijzingsgedrag blijkt geenszins bepaald door de wijze van presentatie. De beperkte beschikbaarheid van bedrijfsartsen en bedrijfsmaatschappelijk werk is bekend. Slechts $40 \%$ van de werknemers beschikt over een dergelijke hulpverlening. Het blijkt dat bij langdurig verzuim wegens overspanning deze hulpverlening slechts in de helft der gevallen dat ze op het bedrijf beschikbaar is, werkelijk ingeschakeld wordt en in een aantal gevallen bovendien nog in een vrij laat stadium. Van preventieve inschakeling, althans voorafgaand aan en zo mogelijk ter voorkoming van ziekmelding, is vrijwel niets gebleken.

Globaal ziet het "stroomdiagram" van overspannen werknemers binnen de hulpverlening er ais volgt uit. 


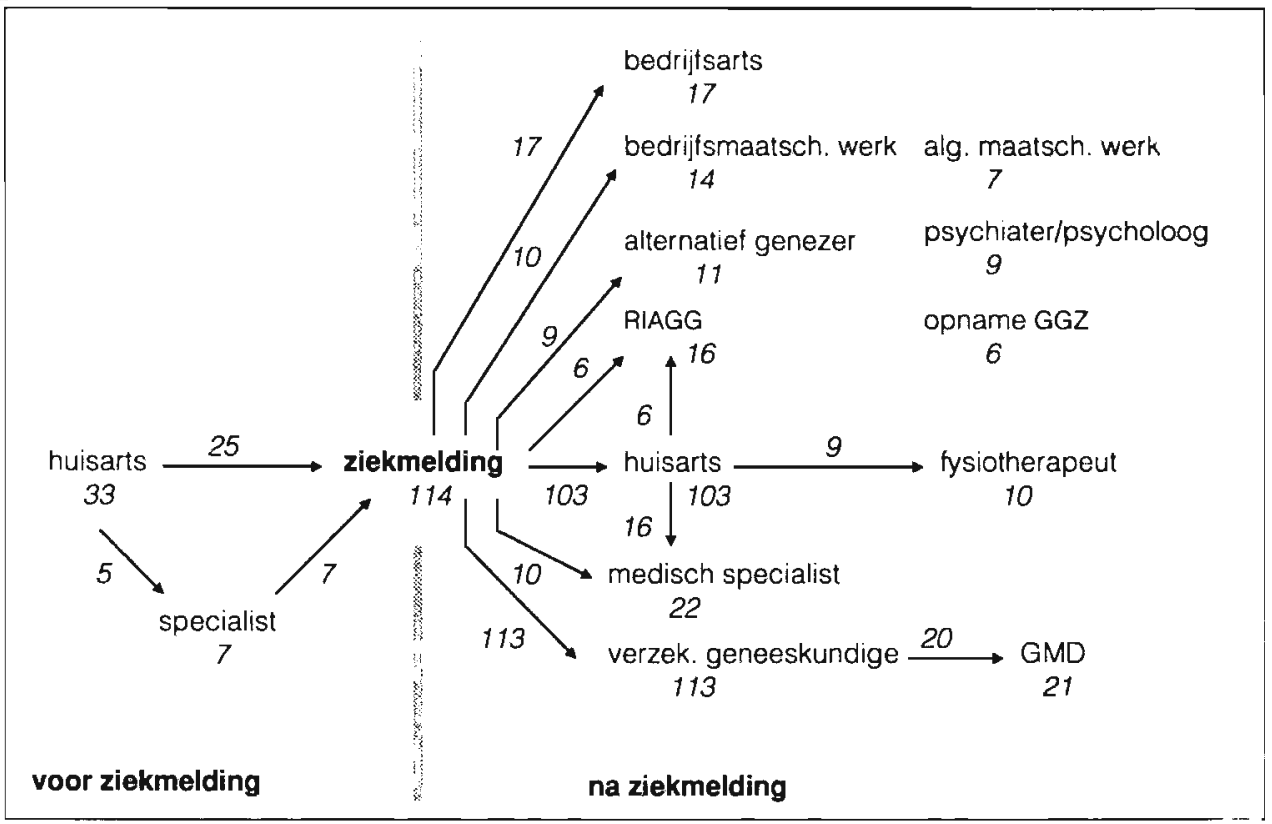

In het algemeen wordt tijdens de ziekteperiode contact onderhouden tussen de overspannen werknemer en het bedrijf. Wel blijken de contacten bij degenen die niet naar de oorspronkelijke werkkring terugkeren, minder regelmatig onderhouden te worden. Dit komt vooral neer op een daling van de frequentie van de contacten na enige tijd. Er lijkt dus sprake van een - wederzijds - anticipatieproces met betrekking tot het vertrek.

De huisartsen die in ons onderzoek participeren, vormen onder meer naar verdeling in sexe, leeftijd, en taakopvatting ten opzichte van psycho-sociale problemen in het algemeen een goede afsplegeling van de Nederlandse huisartsenpopulatie. Er blijken echter relatief minder huisartsen in solo-praktijken en in praktijken met minder dan 2.000 patiënten te werken. Ruim de helft heeft meer dan incidenteel contact met andere hulpverleners uit de eerste lijn. De contacten met de Geestelijke Gezondheidszorg, bedrijfsartsen en verzekeringsgeneeskundigen zijn in de regel incidenteel.

Niet alle overspannen werknemers nemen contact op met een huisarts ter behandeling van hun aandoening. Van degenen die dat wel doen, presenteren sommige de aandoening zo onduidelijk, dat de huisarts de overspanning niet opmerkt. Bij bijna $85 \%$ der werknemers komt het probleem bij de huisarts wel duidelijk op tafel. De feitelijke hulpveriening van de huisarts blijkt in de meerderheid der gevallen te bestaan uit het adviseren van rust, het voorschrijven van medicijnen, en een uitnodiging aan de patiënt om nog eens op gesprek te komen. Het is overigens opmerkelijk dat patiënten veel vaker het voorschrijven van psychofarmaca vermelden dan de huisartsen zelf rapporteren.

Gemiddeld ziet de huisarts de overspannen werknemer ongeveer vijf keer. 
Verwijzing vindt bij de minderheid der overspannen werknemers plaats. Als verwijzing plaatsvindt, geschiedt dit vaker naar specialisten en fysiotherapeuten dan naar het RIAGG of het Algemeen Maatschappelijk Werk. In verreweg de meeste gevallen houdt de huisarts de patiënt onder eigen hoede. Daar staat tegenover dat in een groot aantal gevallen de patiënt zelfstandig of via andere hulpverleners zijn weg vindt naar andere hulpverleningsinstanties.

Hoewel de aandoening waarvoor de huisarts geraadpleegd wordt, tot meer dan vier weken verzuim leidt en in de meeste gevallen gezien wordt als (mede) veroorzaakt door de werksituatie, blijft in iets meer dan de helft der gevallen de werksituatie onbesproken. Voorzover dit wel het geval is, blijkt de huisarts vooral te adviseren tot werkstaking of, indien deze reeds heeft plaatsgevonden, (continuering van) de werkstaking te ondersteunen.

Opvallend is in dit verband het vrijwel ontbreken van verwijzingen naar de bedrijfsen verzekeringsgeneeskundige sector. Ook blijkt er van de kant van de huisarts bijna geen enkel contact gelegd te worden met bedrijfs- of verzekeringsgeneeskundigen. In een enkel geval heeft een huisarts contact opgenomen met de werkgever of de verzekeringsgeneeskundige.

Het probleem van de wachttijden en de stuurloze perioden in de gezondheidszorg doet zich ook en nog steeds voor bij werknemers die verzuimen wegens overspanning. In overeenstemming met de bevindingen van Soeters (1983) blijkt het aandeel van de wachttijden en de stuurloze perioden op de totale verzuimduur ruim $25 \%$ te zijn.

Daarvan wordt het overgrote deel voor rekening genomen door stuurloze perioden. Verwijzingen en het uitstellen door de werknemer van het eerste bezoek aan een hulpverlener, meestal de huisarts, leiden tot een veel geringer tijdverlies. Bij de verwijzingen is dit deels het gevolg van het betrekkelijk geringe aantal verwijzingen. Daarbij blijken overigens vrijwel uitsluitend de verwijzingen naar de Geestelijke Gezondheidszorg met wachttijden gepaard te gaan. Zowel uitstelgedrag als verwijzingswachttijden als stuurloze perioden blijken verschijnselen te zijn die zich slechts bij een beperkt deel van de respondenten voordoen. Deze drie vormen van stagnatie treden niet cumulatief, maar alternatief op.

Tussen uitstelgedrag en verzuimbeloop bestaat nauwelijks enige relatie. Wel geldt dit voor verwijzingen en verwijzingswachttijden. Verwijzingen leiden tot lange verzuimduren - gemiddeld ruim een half jaar -, waarbij de wachttijden met name optreden bij werkhervatters en in mindere mate bij WAO-intreders. Stuurloze periode hebben een U-vormige samenhang met verzuimduur en de wijze van verzuimbeëindiging: het ontbreken van stuurloze perioden of juist een lange duur ervan blijkt samen te gaan met een lange verzuimduur en een grotere kans op WAO-intrede.

De verzekeringsgeneeskundigen kennen ongeveer een derde van de overspannen werknemers al voor de actuele verzuimperiode. In iets minder dan $40 \%$ der gevallen is de verzekeringsgeneeskundige min of meer bekend met het bedrijf.

De meest voorkomende activiteiten van de verzekeringsgeneeskundige ten aanzien van de begeleiding van de overspannen werknemer zijn overleg met de rapporteur en spreekuurcontacten. Contacten met werkgever en curatieve sector 
komen beide in nog geen $20 \%$ der gevallen voor. Bij de contacten met de werkgever speelt de mate waarin de verzekeringsgeneeskundige bekend is met het bedrijf, een doorslaggevende rol. Opvallend daarbij is dat het in meer dan de helft der gevallen het bedrijf is dat het initiatief neemt voor het contact. Deze contacten hebben over het algemeen het karakter van overleg. Bij de contacten met de curatieve sector gaat het vrijwel uitsluitend om het inwinnen of natrekken van informatie.

Vergeleken met langdurige verzuimgevallen om andere redenen dan overspanning treedt de verzekeringsgeneeskundige tamelijk snel in contact met de werknemer. Een opvallender bevinding is echter de veel langere periode die verstrijkt tussen het laatste contact met de werknemer en het moment van de verzuimbeëindiging. Dit verschijnsel is echter deels toe te schrijven aan een hoger percentage WAOintreders bij wie deze periode aanzienlijk langduriger is dan bij de niet-WAO-intreders. Degenen die de verzuimperiode afsluiten met een ontslag(name) zonder nieuwe werkkring, blijken ook een wat langere stuurloze periode door te maken.

De overname van de begeleiding door de GMD gaat gepaard met een gemiddelde wachttijd van bijna drie en halve maand. Daarom blijt de WAO-intreder gedurende een tamelijk lange periode van begeleiding door de verzekeringsgeneeskundigen van het GAK en de GMD verstoken. Al met al strekt de betrokkenheid van de verzekeringsgeneeskundige van het GAK zich over minder dan de helft van de gehele verzuimperiode uit.

Bij de verklaring van de verschillen in verzuimbeëindiging is een twee-stappen-analyse uitgevoerd. Allereerst is de voorspelbaarheid onderzocht van het al dan riet terugkeren naar de werkkring waar de ziekmelding plaatsvond. Vervolgens is bij de groep die niet terugkeerde, de voorspelbaarheid van de aard van het verloop onderzocht, d.w.z.: ontslag(name) of WAO-intrede. Ten slotte is de voorspelbaarheid van de verzuimduur onderzocht voor degenen die terugkeren. Als onafhankelijke kenmerken zijn geselecteerd: persoonskenmerken (sexe, leeftijd e.d), bedrijfskenmerken (sector, omvang e.d.), kenmerken van de arbeidsplaats (functie, lengte dienstverband, werklast e.d.), ziektegeschiedenis en verzuimverleden, ziektekenmerken (klachtenbeeld, mate van psychoneuroticisme e.d.), ziektegedrag (o.a. uitstel van ziekmelding), kenmerken van de huisarts (leeftijd, praktijktype, taakopvatting e.d), gedrag van de huisarts (diagnose, medicatie, verwijzing e.d.), kenmerken van de verzekeringsgeneeskundige (bekendheid met werknerier en bekendheid met bedrijf) en het gedrag van de verzekeringsgeneeskundige (o.a. aantal contacten met bedrijf).

Bij de bivariate analyses zijn afhankelijk van de meetniveaus als technieken de $x^{2}$-toets, de variantie analyse met de F-toets en Pearson's $r$ toegepast. Bij de multivariate analyses de logistische regressie-analyse bij dichotome afhankelijke variabelen en de lineaire regressie-analyse bij continue afhankelijke variabelen. De multivariate analyses van terugkeer, aard van het verloop, en verzuimduur zijn besloten met padanalyses met behulp van lineaire regressie-analyses. Waar sprake was van een dichotome afhankelijk variabele is door middel van logistische regressie-analyse de houdbaarheid van de gevonden significantieniveaus gecontroleerd. Op grond van het grote aantal onafhankelijk variabelen ten opzichte van het aantal waarnemingseenheden zijn eerst multivariate analyses per categorie onafhankelij- 
ke variabelen uitgevoerd; vervolgens zijn deze analyses onder constanthouding van enkele zeer sterk met de afhankelijke variabelen samenhangende onafhankelijke variabelen herhaald. Alle variabelen die op een of ander wijze significant bleken samen te hangen met de afhankelijke variabele zijn in de uiteindelijke (pad)analyse opgenomen.

Vooral de bedrijfskenmerken en de lengte van het dienstverband blijken sterk samen te hangen met de kans op terugkeer. Daarnaast blijken ook de volgende variabelen samen te hangen met de kans op terugkeer: sexe en enkele kenmerken van de arbeidsplaats zoals hinder van onzekerheid en de aanwezigheid van promotiekansen, kenmerken van het verzuim van de laatste twee jaar, de oorzaak van de ziekte, de wijze van omgang met onzekerheid en de taakopvatting van de huisarts, beleidskenmerken van de huisarts als het betrekken van het werk in het beleid en het voorschrijven van psychofarmaca, en de mate van bekendheid van de verzekeringsgeneeskundige met het bedrijf.

Bij padanalyse blijken leeftijd, het probleemoplossend vermogen van het bedrijf, de lengte van het dienstverband, en de verzuimfrequentie van de laatste twee jaar direct van invloed op de kans op terugkeer. Sexe en de overige bedrijfskenmerken blijken indirect van invloed.

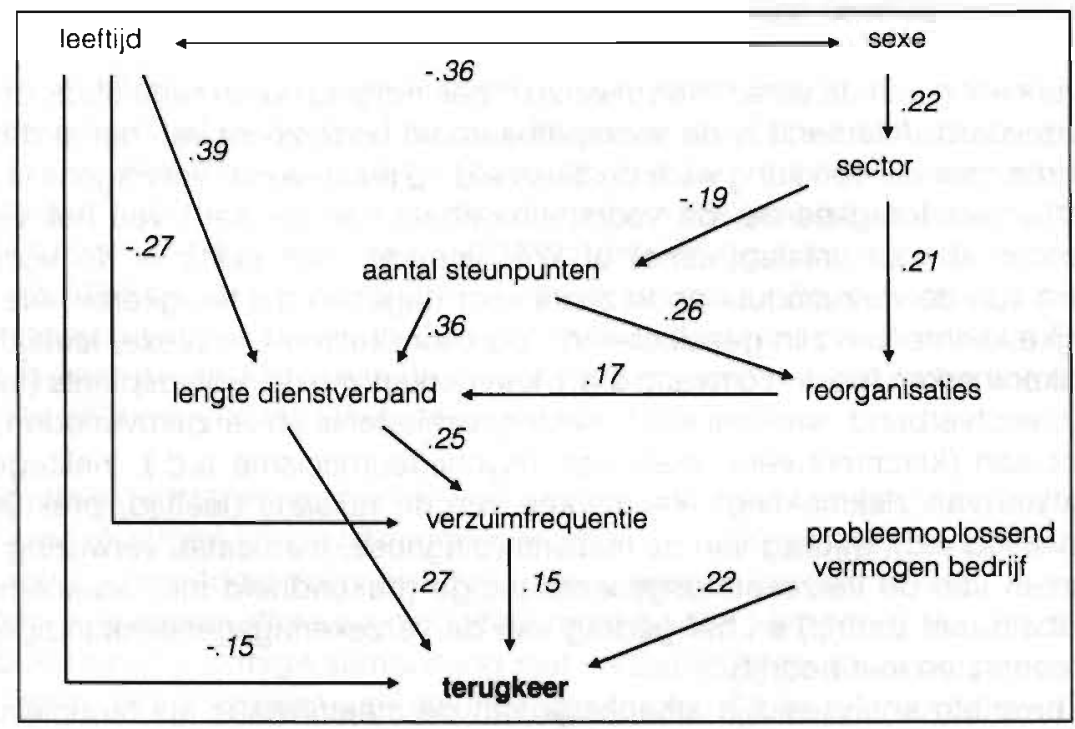

De aard van het verloop hangt het sterkst samen met de leeftijd en de lengte van het dienstverband. Daarnaast zijn er samenhangen met onder meer steun thuis, de omvang van de werkweek, de werktijden, de mate van psychoneuroticisme, het tijdsverloop tussen het ontstaan van de klachten en de ziekmelding, de andere kenmerken van het ziektegedrag, de leeftijd van de huisarts, de praktijkomvang en de mate van bekendheid van de verzekeringsgeneeskundige met het bedrijf. Bedrijfskenmerken blijken in het geheel geen invloed te hebben op de aard van het 
verloop. Gezien de beperkte omvang van de groep (47) die niet terugkeert naar het werk, ten opzichte van het aantal onafhankelijke variabelen (16) dat enig verband toont met de aard van het verloop, was het niet mogelijk met al deze variabelen een logistische regressie-analyse uit te voeren. In de padanalyse kon derhalve de invloed van de kenmerken en het gedrag van de huisarts en de verzekeringsgeneeskundige niet meegenomen worden. In het uiteindelijke model blijken leeftijd, de aanwezigheid van steun thuis, en de lengte van het dienstverband de aard van het verloop te bepalen.

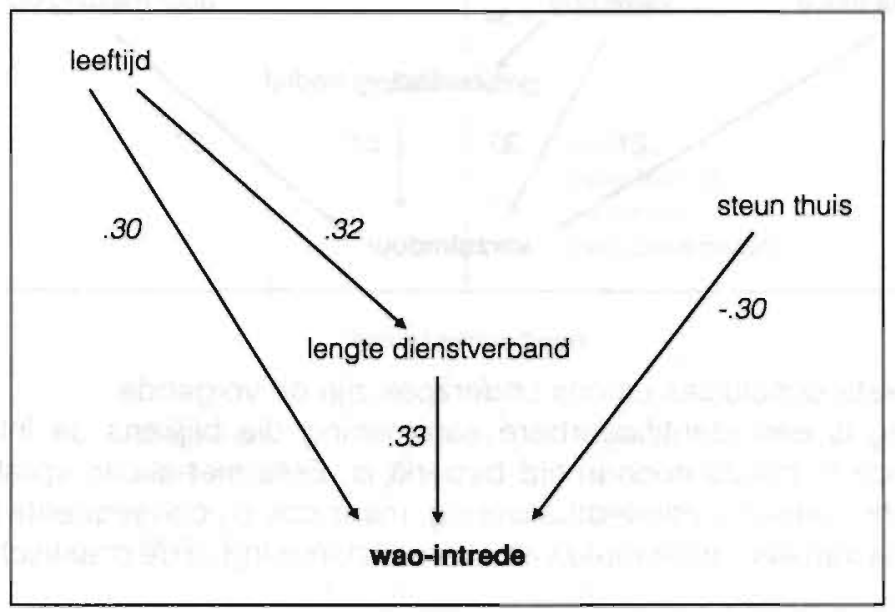

De verschillen in verzuimduur blijken vooral samen te hangen met het ziektegedrag van de werknemer, met name het uitstelgedrag ten aanzien van de ziekmelding, het gedrag van de huisarts en het gedrag van de verzekeringsgeneeskundigen. Persoons- en bedrijfskenmerken, kenmerken van de arbeidsplaats - met uitzondering van de mate van vrijheid in het werk - en verzuimverleden tonen geen van alle samenhang met verzuimduur. Wel is er enige samenhang met de aard van de overspanning, de mate van psychoneuroticisme, de praktijktype van de huisarts en, in samenhang hiermee, de mate van integratie van de huisarts met de GGZ.

Uit de padanalyse blijkt dat het voorschrijven van psychofarmaca en het verwijzen door de huisarts, het tijdsverloop tussen ziekmelding en eerste spreekuurcontact met de verzekeringsgeneeskundige en de totstandkoming van contact tussen verzekeringsgeneeskundige en het bedrijf direct samenhangen met de verzuimduur, terwijl de mate van vrijheid in het werk, de aard van de overspanning, de mate van psychoneuroticisme en de praktijkvorm van de huisarts de verzuimduur indirect bepalen. 


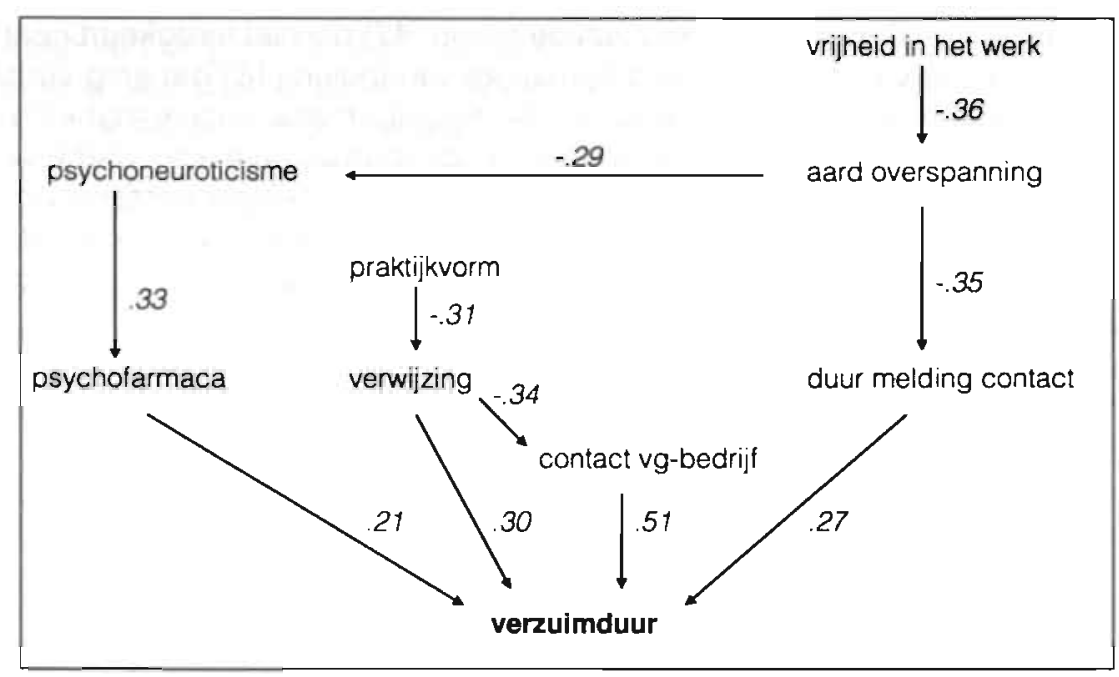

De belangrijkste conclusies uit ons onderzoek zijn de volgende.

Overspanning is een identificeerbare aandoening die blijkens de internationale litteratuur noch in plaats noch in tijd beperkt is. $\mathrm{Er}$ is niet alleen sprake van een eénduidige theoretische conceptualisering, maar ook bij consequente toepassing van de criteria van een grote mate van overeenstemming in de praktische diagnostiek.

Ziekteverzuim wegens overspanning wordt gekenmerkt door een gemiddeld lange verzuimduur en een zeer hoog verloop bij verzuimbeëindiging, niet alleen in de vorm van WAO-intrede maar ook in de vorm van ontslag(name). Daarnaast blijkt volledig herstel slechts bij een kleine minderheid binnen een jaar op te treden.

De hulpverlening is heterogeen, terwijl coördinatie tussen huisarts, bedrijfsarts en verzekeringsgeneeskundige ontbreekt. De huisarts houdt de gevalsbehandeling meestal in eigen - passief - beheer en bemoeit zich in slechts de helft der gevallen met de verzuimstatus en dan nog beperkt tot de ziekmelding. Een bedrijfsarts is in de meeste gevallen niet aanwezig. Voor zover wel aanwezig, is deze in de helft der gevallen in een laat stadium actief. De verzekeringsgeneeskundige beperkt in de meeste gevallen de begeleidingsactiviteiten tot spreekuurcontacten. De overspannen werknemer zelf blijkt dus als case manager te moeten functioneren. Zowel bij de behandeling door de curatieve sector als bij de begeleiding door de verzekeringsgeneeskundige treden aanzienlijke stuurloze perioden op. Bij de overdracht van potentiële WAO-intreders aan de GMD is er bovendien sprake van een gemiddeld lange wachttijd.

Bij de verklaring van het verzuimbeloop is gebleken dat er voor elke fase van het verzuimproces een ander stel factoren het beloop bepalen. Dit betreft op grond van onze correlationele analyse zeker de terugkeer naar de werkkring, WAO-intrede en verzuimduur in geval van terugkeer en vermoedelijk op grond van aanvullende gegevens ook het ontstaan van overspanning en het besluit tot ziekmelding. Het volledige, hoewel deels hypothetische, model van verzuimbeloop en zijn determinanten ziet er bij overspanning als volgt uit. 


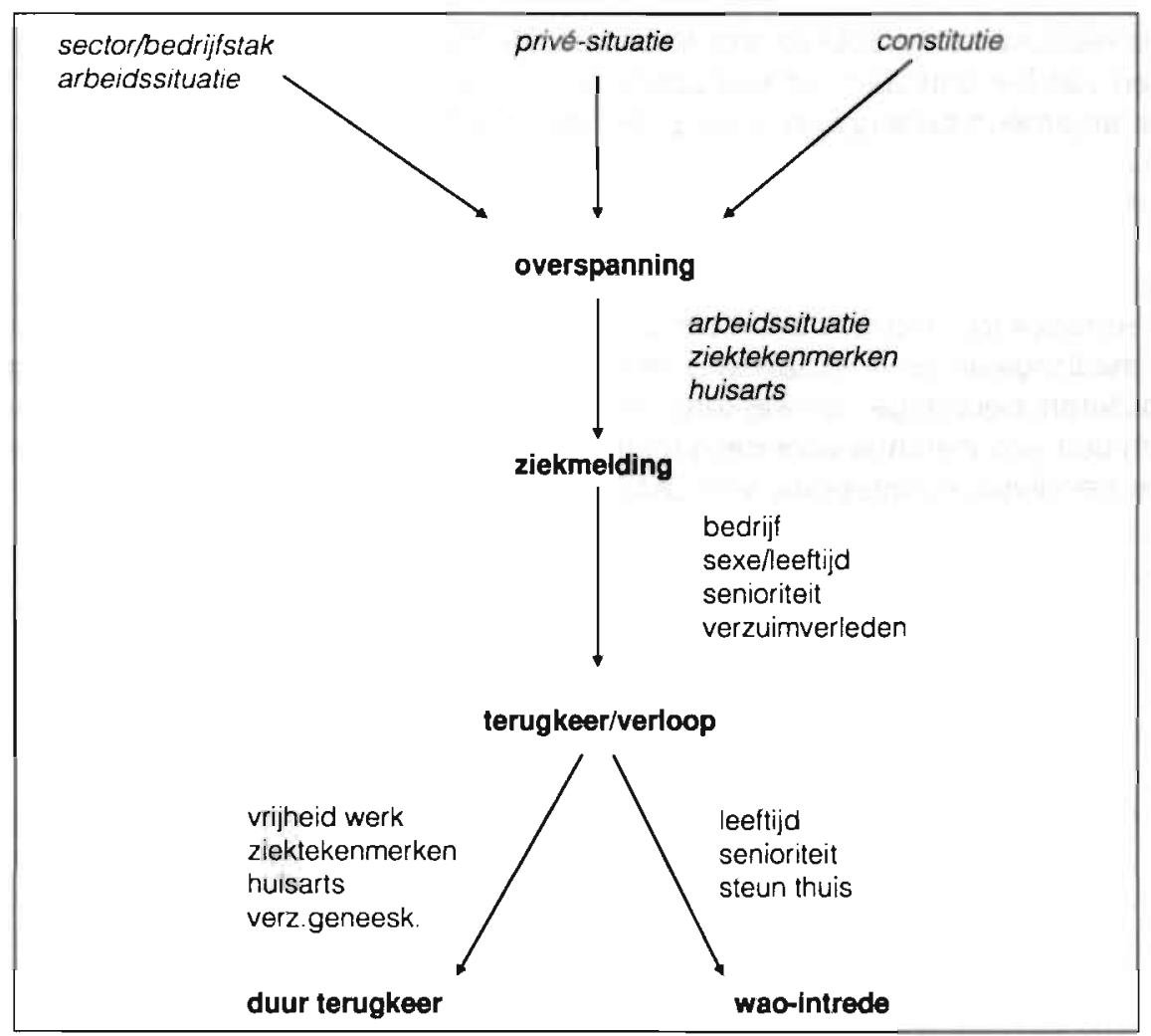

De beschreven bevindingen zijn gebaseerd op een onderzoek onder overspannen werknemers, werkzaam bij omslagleden van het GAK. Dit betekent op de eerste plaats dat de resultaten niet specifiek behoeven te gelden voor overspannen werknemers, en op de tweede plaats dat in geval van overspanning bij een ander "verzekeringsgeneeskundig regime" er afwijkende resultaten kunnen optreden. Vermoedelijk heeft er enige selectieve uitval plaatsgevonden naar oorzaak en verschijningsvorm van overspanning. Replicatieonderzoeken onder andere populaties worden derhalve door ons aanbevolen. Gezien de hoge kosten van een prospectief cohortonderzoek wordt aanbevolen dat de databestanden van de verzuimregistrerende instanties uitgebreid worden met gegevens die relevant zijn voor (secundaire) analyses in het kader van sociaal(-geneeskundig) wetenschappelijk onderzoek.

De betekenis van ons onderzoek ter verklaring van de in de inleiding geschetste trends in verzuim en arbeidsongeschiktheid is beperkt. Op grond van onze bevindingen wordt het vermoeden uitgesproken dat verschuiving van werkgelegenheid naar de kleinschalige dienstensector en een geringere aandacht voor en bereidheid tot concessies aan het welzijn van werknemers in de bedrijfsvoering een bijdrage aan de toename van de arbeidsongeschiktheid en daarmee aan die van de verzuimduur hebben geleverd. 
Naast replicatieonderzoeken worden ook onderzoeken aanbevolen naar determinanten van het ontstaan van overspanning en van de ziekmelding. Voorts worden in het algemeen belang van onderzoek naar ziekteverzuim meta-analyses van de tot nu toe uitgevoerde verzuimonderzoeken aanbevolen. Ten slotte wordt actieonderzoek gericht op experimenten in de hulpverlening en begeleiding aanbevolen.

Onze beleidsaanbevelingen betreffen uitbreiding van experimenten met inbegrip van feedback training ter bevordering van een actiever verzuimbeleid door huisartsen, maatregelen om inschakeling van bedrijfsartsen e.a. voor de ziekmelding te bevorderen, bedrijfsgericht werken door de verzekeringsgeneeskundige, het vormgeven aan een instantie voor case management voor overspannen werknemers in kleine bedrijven, en integratie van GMD en bedrijfsvereniging(en). 


\section{Summary}

The study is motivated by the development of changes in absenteeism from work because of illness and changes in disability rates during the last decades in The Netherlands". While the increase in the number of workers becoming eligible for disablement benefits does not differ much from the increase in the labour force, there has been an increase in the number of mental disorders among those eligible for disablement benefits as well as an increase in the duration of sickness absences because of mental disorders. Since there also was a nearly parallel increase in the numbers of workers becoming eligible for disablement benefits because of musculo-skeletal disorders, a better recognition of mental disorders hidden behind somatic complaints does not seem to explain these increases. The increases can be neither explained as a result of an increase in mental disorders because, e.g., work stress is on the increase. Because there has not been an increase in the percentage of consultations with general practitioners because of psychological problems nor an increase in the percentage of sickness absences because of mental disorders. Two important findings might give an idea where to search for an explanation. Firstly, the dutch health care system has considerable difficulties to deal with mental disorders. Secondly, in more than $80 \%$ of all cases the mental disorder is diagnosed "overspanning", best to be translated into "overstrain".

Therefore the present investigation was undertaken to answer the following problems:

What is "overstrain", how does it manifest itself in complaints and symptoms? What kind of treatment is provided for a worker whose sickness leave has been caused by "overstrain"? In which way and to what extent do individual, company and job characteristics, history of sickness absence, characteristics of "overstrain", sickness behaviour, and medical or non-medical care determine length and outcome of the sickness absence?

A systematic study of the literature has been done on the prevalence and the meanings of overspanning and the following synonymous or related terms: hyper-

\footnotetext{
- When a worker in a private enterprise in The Netherlands reports sick, he receives a benefit from the Sickness Benefits Act during twelve months at most. When the worker is still incapable of work after twelve months, he is eligible for a benefit partly from the General Disablement Benefits Act and partly from the Employee Disablement Insurance Act. In The Netherlands the occupational associations are responsible for the implementation of several social security schemes, like the Sickness Benefits Act, the Disablement Acts and the Unemployment Insurance Act. Social insurance physicians employed by occupational associations are charged with the guidance of the worker receiving sickness benefit. The guidance of disabled workers is the task of the GMD which is a joint medical service institute in behalf of the occupational associations.
} 
aesthetic-emotional syndrome, surmenage*, neurasthenia, and adjustment disorder. Social psychiatrists, industrial physicians, and general practitioners, but hardly clinical psychiatrists have paid attention to "overstrain". This finding indicates the non-clinical nature of the disorder.

History shows internationally a periodic rise and fall of the popularity of the terms overspanning, surmenage, and neurasthenia. The last decades show an increased use of these and similar terms. The lack of precision of these terms and misuse at medical judgements of claims often led to a rejection of the use of these terms. The diagnosis adjustment disorder which is included in the DSM-III has proven to be hard to distinguish from other disorders or from psychosocially based needs for help without demonstrable disorder. The meaning of hyperaesthetic emotional syndrome has proven to be limited to symptomatology which does not exclusively belong to "overstrain" and which is not the only way by which "overstrain" manifests itself. The meaning of overspanning and surmenage has been shifting from aetiological factor to disorder.

By some authors, different types of "overstrain" have been distinguished, mostly based on symptomatology and causes.

The study of the literature has led us to the following definition of "overstrain":

"Overstrain" is a disturbance of the balance between what the individual is able to do and the demands made upon him as a consequence of changes in the capacity of the individual and/or the psychological demands and bringing about a diminished ability of the individual to social functioning together with the onset of somatic complaints and changes in mood and/or behaviour.

In addition to our study of the literature on the conceptualization of "overstrain", a study has been carried out of the application of the concept in the diagnostic practices of the social insurance physicians. The problems are:

To what extent do different physicians agree on the diagnosis in case of "overstrain"? To what extent does the existing conceptualization of "overstrain" offer a possibility to arrive at agreement with regard to those cases in which, initially, they did not agree wether the diagnosis has to be "overstrain" or not?

One hundred and twelve cases were presented to a panel consisting of two general practitioners, a psychiatrist, and a retired social insurance physician**. These cases have been diagnosed before by social insurance physicians, working in a district different from the district in which the main study was carried out. The cases included only sickness leaves diagnosed as a disorder which, theoretically, could belong to some type of "overstrain". The members of the panel were given standardized reports, based on the information which the social insurance physician

- A french term translated by Tuke (1882) as follows: "The bodily or mental condition produced by overexertion or overpressure"

*" Social insurance physicians are working in the occupational associations. Their task is to examine workers who have left for sickness in order to give an advise to the occupational association wether. from the medical point of view, the claim of the worker for a sickness or a disablement benefit is justifiable or not. A second task is the guidance of the sick worker in order to promote resumption of work. 
used in order to assign his diagnosis. The Delphi method has been applied in order to guarantee the independence of the judgements.

The level of agreement between the physicians prove to be high. The only exception is a panel member who holds a different point of view that unexplained somatic complaints have to be determined by psychosocial factors, whereas all others, in agreement with the definition of "overstrain", use the diagnosis "overstrain" only in the presence of a recognizable psychosocial stressor that could explain the complaints and symptoms.

When the members of the panel are confronted anonymously with the other diagnoses in order to give them an opportunity to revise their original diagnoses, there is a small increase in agreement.

The most important conclusions of this study are: it is possible to arrive at a high level of agreement on the diagnosis "overstrain", if criteria following from the theoretical conceptualization are properly applied, and the diagnostic judgement of the social insurance physician about the presence of "overstrain" is an instrument with a high interobserver reliability.

Finally a preliminary study was undertaken of the litterature on determinants of length of sickness absence and determinants of disablement. Research, exclusively geared to sickness absence or disablement because of "overstrain", is almost completely lacking. The studies of the above determinants can be divided in the following types: correlational studies to explain differences between companies in average duration of sickness absence, between individual workers in average length of sickness absence, differences in length between separate cases of sickness absence, differences between companies in disability rates, between individual workers in chance of becoming eligible for disablement benefits, and processanalytic studies of the way health care system influences the length of sickness absence. Litterature shows the following categories of determinants important: individual characteristics, characteristics of the company, job characteristics, history of sickness absences, health of the worker, characteristics of the disorder, sickness behaviour, health care, policies regarding sickness absence, and the way the sick worker is guided by the social insurance physician and the like.

The many inconstencies in the results with respect to the correlations between explanatory variables of all kinds and (average) length of sickness absence or chance of becoming eligible for disablement are remarkable. Differences between studies in design, population, time of observation, selection and construction of the variables, and methods of statistical analysis may offer an explanation. These inconsistencies are a serious barrier for the progression of knowledge because it is very difficult to eliminate variables out of the hypothetical models for explanation of length of sicknesss absence and becoming eligible for disablement benefits.

In our main study both the processanalytic and the correlational approach have been used. The processanalytic approach computes the length of different treatment periods during sickness absence. The model looks as follows. 


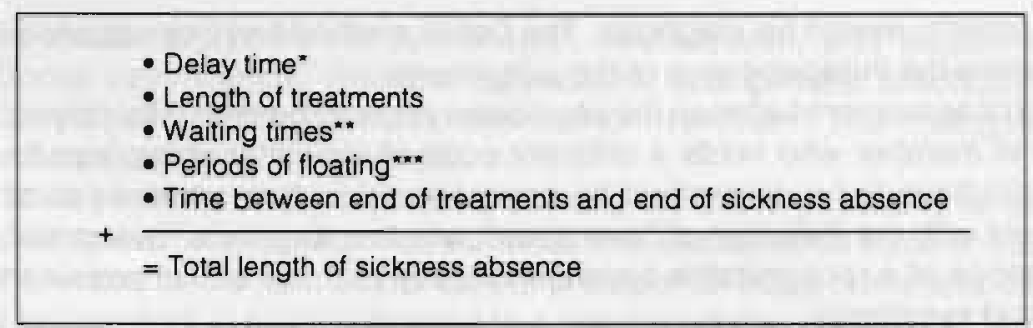

"Delay time is the time lag between reporting sick and the first contact of the worker with (non-)medical care. "* Waiting times are periods which are spent to waiting for medical examinations, waiting for the first contact with a specialist after a referral, etc. "** Periods of floating are periods during which the patient is left alone without any appointment with or guideline from physicians and the like

This model has previously been applied in the studies of Tordoir and others (1978) and Soeters (1983). In our study we have applied this model not only to the health care system but also to the guidance by the social insurance physicians.

We have carried out a correlational analysis for the explanation of outcome of sickness absence, and, in the case of return to the company, length of sickness absence. The correlational model looks as follows.

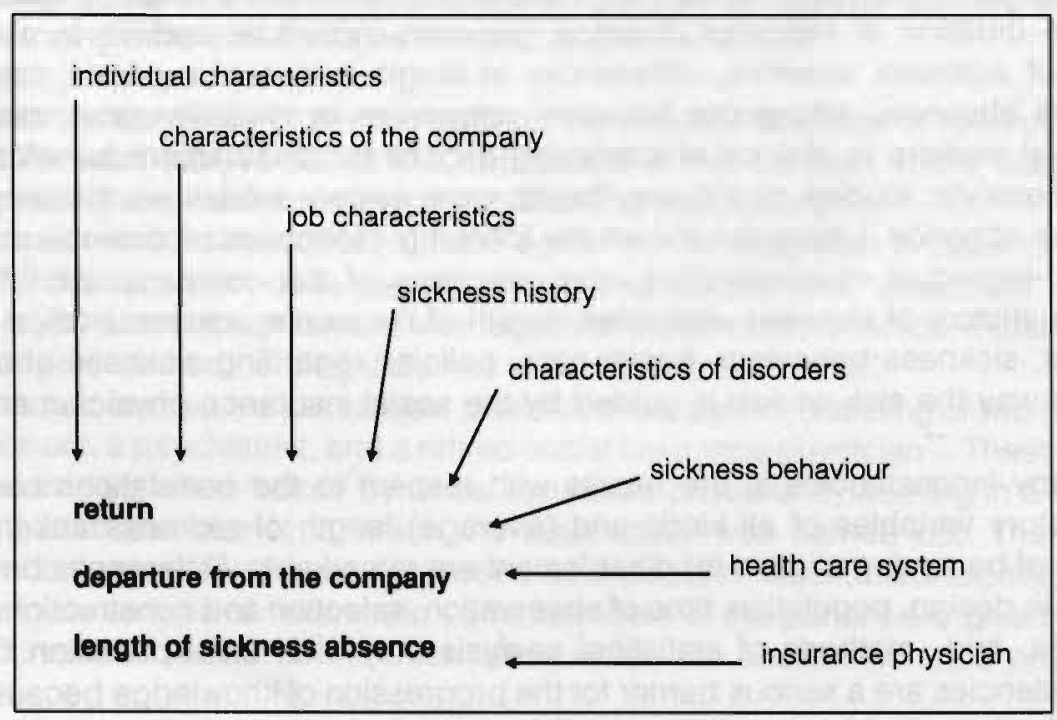

The main study is a descriptive one using a prospective cohort design. It has been carried out with a sample of workers insured by an occupational association participating in the GAK*. The workers had a sickness absence of four weeks or longer, in the opinion of the social insurance physician, as a consequence of

* The GAK is a joint administrative office of 13 occupational associations. 
"overstrain". A comparative study between these workers and workers who had a long-term sickness absence because of other disorders has been given up for financial reasons.

The sample was chosen from a regional office of the GAK located in the Province of Limburg and was proportionally stratified to each district. Out of 208 potential participants, who were approached by letter, 114 were willing to participate in the study. They participated in an interview about one or two months after reporting sick, periodic interviews during the time they received sickness benefit, and a final one about one year after reporting sick. The number of drop-outs during the study was low. Besides the worker, the general practitioner and the social insurance physician were approached for an interview, if the worker consented. Almost all workers gave their consent and almost all physicians were willing and able to complete all interviews. In regard to 94 respondents all interviews are held.

The interviews of the workers provided information about individual, company, and job characteristics, about the disorder, sickness history, sickness behaviour, medical and non-medical care, sickness absence, and recovery. The interviews of the general practitioners provided information about the disorder, characteristics of the general practitioner, contacts of the worker with the general practitioner, and actions of the physician, like referral and prescription of drugs. Through the interviews of the social insurance physicians data were obtained about the disorder, sickness absence history, characteristics of the physician, actions of the physician, like frequency of contacts with the sick worker and contacts with the employer, and length and outcome of the sickness absence.

Respondents and non-respondents hardly differ in regard to sex, type of industry, and absence history. They differ only in regard to age: those younger than 30 years of age are slightly underrepresented among the respondents. As a consequence the distribution of age categories within the group of respondents is less skewed than that within the sample. Though the fact that the study is restricted to workers insured by the GAK in one region does not allow for an exact comparison with the total occupational population in The Netherlands, it is striking, however, that our sample of "overstrained" workers hardly differs from the total occupational population in respect to sex, age, and, presumably, educational level. Workers in the service industries, however, are slightly overrepresented. Among the "overstrained" workers all kinds and levels of professions are represented. Interestingly, we found that the "overstrained" workers have a higher workload, longer working times, and less promotion prospects than workers in previous studies.

Three cases out of four turned out to have symptoms of the "hyperaesthetic emotional syndrome". Nearly one fourth of all cases showed only somatic complaints of all kinds. The average score on the SCL-90, a scale used to measure psychoneuroticism, is slightly under that of psychiatric out-patients and largely above that of a normal population. Especially sleeping problems occur frequently. About $90 \%$ are aware to be "overstrained". Respondents as well as physicians mention mainly the work situation or the situation at home as the cause of "overstrain". The general practitioners mention more often than the others the personality 
of the worker, physical infirmities, and the situation at home as well. These differences in judgements can be partly explained because some workers present to the general practitioner only somatic complaints but do not report that they suffer from excessive stress. The following types of "overstrain" most frequently occur: complaints of "overstrain" because of chronic workstress, somatic complaints because of workstress, complaints of "overstrain" because of some incident at work, and because of some incident at home.

The length of sickness absence amounts on the average to five and one half months. About $23 \%$ are receiving sickness benefits for one year and so become eligible for disablement benefits. Disregarding these $23 \%$, the average length of sickness absence amounts to about three months. The participants tended to be absent for a slightly longer duration than the non-participants and to have a slightly bigger chance of becoming eligible for disablement benefits. The outcome of the sickness absence is often departure from the company not only by eligibility for disablement benefits but also by other ways of departure from the company like dismissal or resignation. After the period of receiving sickness benefit, only $55 \%$ actually return. One year after reporting sick only $40 \%$ is still working in their original job. Thus some of those who initially returned still left the company for a variety of reasons.

The relatively low degree of recovery from "overstrain" after one year is remarkable. Among those who became eligible for disablement benefits there was even a slight deterioration. Complete recovery has taken place by only $30 \%$ of the respondents.

The illness behaviour of "overstrained" workers has as its most remarkable characteristic that workers often delay to leave for sickness and to seek medical care. At the date of reporting sick two third of the respondents complains about having health problems longer than two months and one third even more than one year. The general practitioner, far mostly the one to be called upon first, has been consulted by only $20 \%$ of the respondents more than one month before reporting sick. Work related factors have a large influence on the decision to report sick. In more than half of the cases it is the work situation which causes the "overstrain" resulting in reporting sick. Among those where the "overstrain" is not related to the actual work situation, it was nevertheless the reason to report sick in one of four cases. Actually, only one fourth of sickness reports is in no way related to the work situation.

The pattern of the various types of medical and non-medical care received by the "overstrained" workers shows a very heterogeneous course through the health care system and the non-medical agencies. The limited involvement of mental health care and social work in behalf of the sick workers is striking. As far as mental health care is involved, it is provided mainly to more seriously "overstrained" workers. The "overstrained" workers who are obviously suffering from typical mental health problems are as often referred to non-psychiatric clinical specialists and to physiotherapists as to mental health care and social workers. This can hardly be explained by the way the patient presents "overstrain" to the general practitioner. One third of the "overstrained" workers indeed reports somatic problems. We did not find any relation between the nature of the complaint and the nature of the referral. 


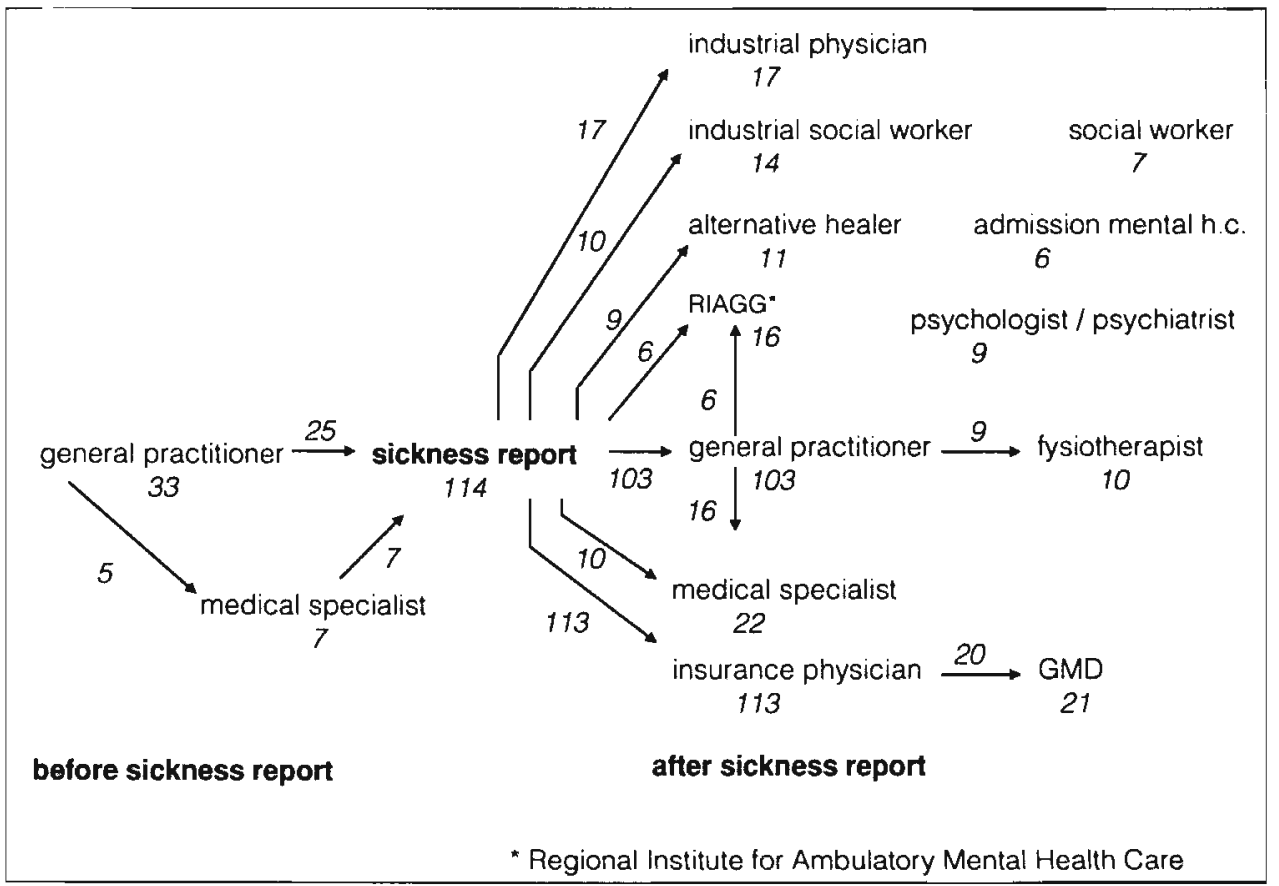

It is well-known that there is no industrial physician or industrial social worker available in many companies in The Netherlands. Only $40 \%$ of the dutch workers have these services at their disposal. Where these services are available in our sample, they are in fact used in only one half of the cases and sometimes only in a rather late stage of the absence. Preventive care for the workers suffering from "overstrain" is almost completely lacking.

Roughly the pathway of "overstrained" workers through the medical and non-medical care system is as follows.

Generally the "overstrained" worker and the company keep in contact with each other during the sickness absence. These contacts however occur less regularly in the group which does not return to the company. This means that there is a decrease in the frequency of contacts after a certain period. It seems there may be a mutual process of anticipation of the departure from the company.

The general practitioners participating in our study, are in regard to sex, age, and task perception about psychosocial problems, generally very representative for the dutch population of general practitioners. They appear, however, to a lesser extent to work in solo practices and in practices with fewer than 2,000 patients. Over fifty percent has more than occasional contacts with other workers in primary health care. Contacts with mental health care, industrial and social insurance physicians occur as a rule less frequently. 
A few "overstrained" workers do not visit a general practitioner. Of those who go $85 \%$ state the problem of "overstrain" clearly. The remainder presents it so unclearly that the general practitioner does not notice the "overstrain".

The general practitioner usually deals with the problem by advicing to take a rest, prescribing pharmaceuticals, or inviting the patient to come back for a talk. By the way, it is interesting to note that the patient reports more frequently that tranquillizers were prescribed than the physician does. On the average the general practitioner has about five contacts with the "overstrained" worker.

Only a minority of the "overstrained" workers are referred by the general practitioner. When referral takes place, this occurs more often to somatic care than to mental health care or social work. The general practitioner usually tends to hold on to the patient. Though, many patients find their own way to the different sources of help. Although in most cases the sickness absence is considered to be (also) caused by the work situation and has lasted during more than four weeks, this subject matter is not discussed between patient and general practitioner in more than half of the cases. As far as it is discussed, the general practitioner mainly limits himself to advise to start or to continue the sick leave.

Remarkably referrals by the general practitioner to industrial or social insurance physicians hardly ever take place. He also seldomly communicates with the industrial or the social insurance physician. In only one or two cases the general physician got in touch with the employer or the social insurance physician.

According to the processanalyses by other dutch investigators, the waiting times and the periods of floating in health care do still occur with workers who leave for sickness because of "overstrain". In agreement with Soeters' (1983) findings, it has been shown that more than $25 \%$ of the days of absence is lost, mainly due to periods of floating. Delays by the worker in seeking help and referrals account for a much smaller amount of time. With respect to the referrals this is partly a consequence of the low number of referrals. With a few exceptions there are waiting times when one is referred to mental health care. Delays, referral waiting times, and periods of floating all appear to be phenomena which occur only in a limited number of cases and never go together.

There is hardly a relation between delaying the first visit to someone who can give professional help, on the one hand, and the length and outcome of the sickness absence, on the other hand. There is, however, a relation between the occurence of referral or referral waiting times and the length and outcome of sickness absence. Referrals influence the amount of days the worker is absent: half a year on the average. The waiting times occur more frequently with those who return to the job and to a lesser extent with those who become eligible for disablement benefit. Periods of floating show an U-shape relation to length of sickness absence and to the outcome of sickness absence: the absence of periods of floating as well as a long period of time of floating both are related to length of sickness absence and becoming eligible for disablement benefit. 
One third of the "overstrained workers" were known to the social insurance physicians from former periods of sickness absence. In slightly less than $40 \%$ of the cases the social insurance physician has some acquaintance with the company.

The work of the social insurance physicians appears to consist mainly of contacts with the insurance employee whose task is to gather information from the workers on the sickness leaves and with the worker at consulting hours. Wether contacts are made with the employer, depends largely upon the extent to which the social insurance physician is acquainted with the company. It is remarkable that in more than half of the cases the company takes the initiative for the contact. These contacts generally are spent in mutual information gathering and/or possible steps to problem-solving. Contacts with the treating physician mostly are made by the social insurance physician in order to obtain or to check information.

The social insurance physician gets fairly quickly in touch with the "overstrained" worker compared to the workers who are absent due to other disorders.

It is a striking observation that in the case of "overstrain" compared with other disorders, there is a long period between the date of the last contact of the social insurance physician with the worker and the last date that the sickness benefit is paid. This is partly due to the fact that a higher percentage of the "overstrained" workers become eligible for disablement benefits because for them these period takes much longer. Those who end the sickness absence by resignation or dismissal without being hired in a new job are also for a long period without attention by the social insurance physicians. The referral to the GMD involves an average waiting time of nearly three and a half month. That is why the worker who becomes eligible for disablement benefit is lacking the guidance of the social insurance physician for such a long period. All in all the involvement of the insurance physician covers less than half of the total period of sickness absence.

A two-step analysis has been carried out in order to explain the differences in outcome of the sickness absence. First, the factors determining wether return to the job takes place or not have been investigated. Next, within the group of workers who did not return the factors determining the kind of departure from the company, that is wether dismissal or resignation, on the one hand, or eligilibity for disablement benefit, on the other hand, have been investigated. Finally, within the group of workers, the factors determining the length of sickness absence who have returned to their job, have been investigated. The selected independent variables are: individual characteristics (sex, age, etc.), characteristics of the company (type of industry, size, etc.), job characteristics (type of job, seniority, workload, etc.), sickness absence history, characteristics of the disorder (symptoms, degree of psychoneuroticism, etc.), illness behaviour (a.o. length of delay to leave for sickness), characteristics of the general practitioner (age, type of practice, task perception etc.), actions of the general practitioner (diagnosis, prescription of drugs, referral, etc.), characteristics of the social insurance physician (acquaintance with worker, with company, etc.), and actions of the social insurance physician (a.o. number of contacts with company). 
For the bivariate analyses the $\mathrm{x}$-test, analysis of variance and the F-test, and Pearsons'r has been applied dependent on the levels of measurement. For the multivariate analyses the logistic regression analysis has been applied in the case of a dichotomous dependent variable and the linear regression analysis in the case of a continuous dependent variable. The multivariate analyses of return to the job, kind of departure from the company, and length of sickness absence have been completed by path analyses through linear regression analyses. In the case of a dichotomous dependent variable a check through logistic regression analysis on the tenability of the observed significance levels has been carried out.

Because of the large number of independent variables in relation to the number of the observed cases, firstly, multivariate analyses have been done for each category of independent variables, next, these analyses have been repeated controlling for some variables which has proven to correlate very strongly with the dependent variable. All variables which in one way or another have appeared to correlate with the dependent variable, have been selected for the final (path) analysis.

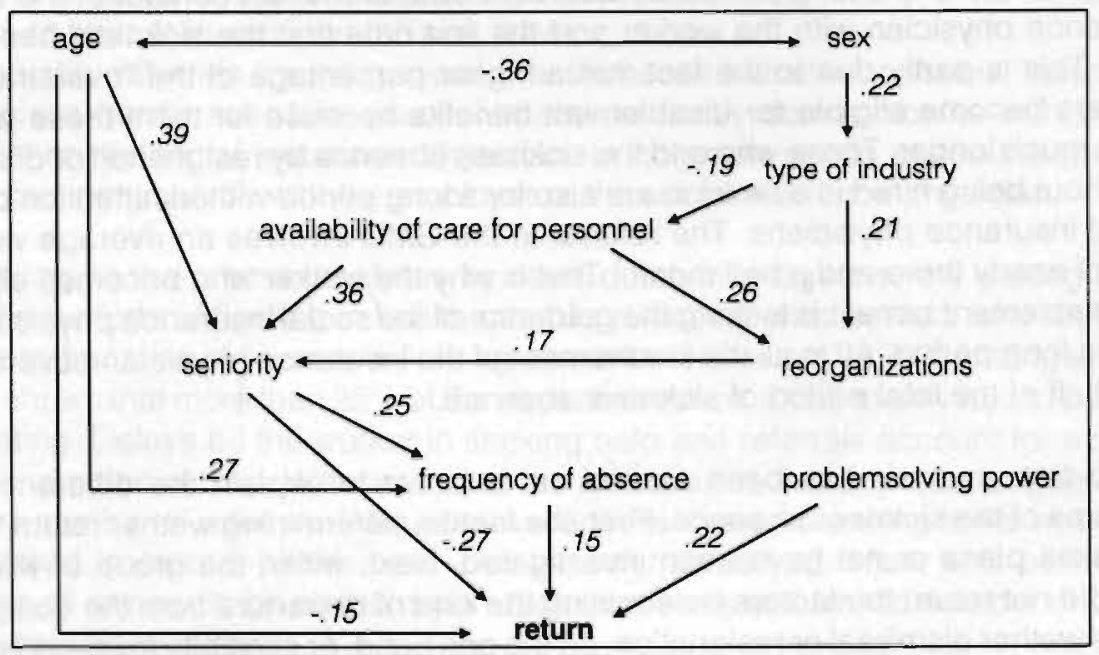

Seniority and the characteristics of the company appear to be the most strongly related to the chance of return. Also, a relation has proven to exist between chance of return and the following independent variables: sex, some job characteristics like promotion prospects and fear of job loss, frequency of sickness absence and number of days lost by it during the last two years, the cause of "overstrain", the task perception of general practitioners and their coping with uncertainties, wether or not the general practitioner discusses the work situation, wether he prescribes tranquillizers or not, and the degree of acquaintance of the social insurance physician with the company.

Path analysis shows that age, the problem-solving power of the company, seniority, and the frequency of sickness leaves during the last two years have a direct 
influence on the chance of return whereas sex and the other characteristics of the company appear to have only an indirect influence.

Age and seniority are the most strongly related to the way of departure from the company. In addition, there is a relationship between the kind of departure and wether or not there is social support at home, length of working week, working times, degree of psychoneuroticism, length of time between onset of complaints and reporting sick, wether or not the first consultation of the general practitioner takes place before or after reporting sick, wether the "overstrain" is masked by somatic complaints or not, age of the general practitioner, size of the practice, and the extent to which the social insurance physician is acquainted with the company. The characteristics of the company do not show any influence on the kind of departure. It was impossible to carry out a logistic regression analysis with all these variables because there were 16 independent variables which appeared to be related to the kind of departure and only 47 respondents who did not return. Characteristics and actions of both the general practitioner and the social insurance physician were therefore excluded from the path analysis. Path analysis then shows that age, social support at home, and seniority appear to determine the kind of departure.

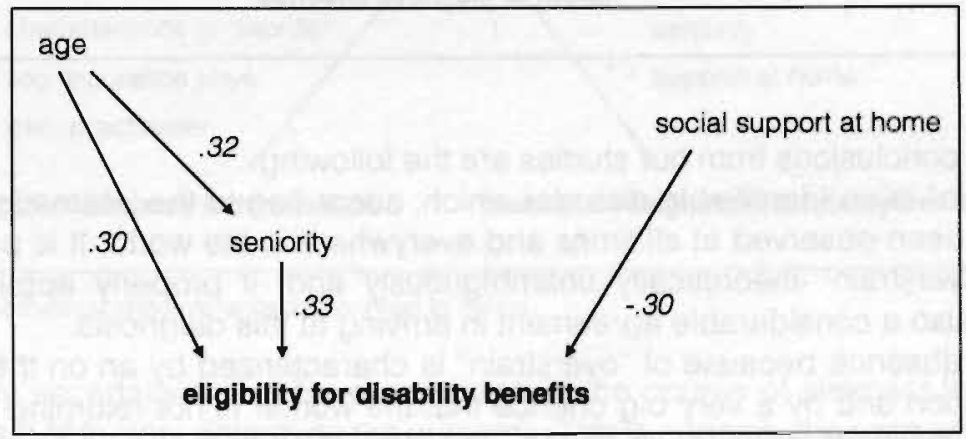

Differences in length of sickness absence appear mainly to be related to the length of period between onset of complaints and reporting sick, the actions of the general practitioner, and the actions of the social insurance physician. There is no relationship between length of sicknes absence and individual characteristics, characteristics of the company, job characteristics, except the degree of freedom at work, and sickness absence history. There is some relationship with nature of "overstrain", degree of psychoneuroticism, wether the general practitioner is working in a solo or in a group practice, and intensity of cooperation between the general practitioner and mental health care.

Path analysis shows that prescription of tranquillizers and referral by the general practitioner, length of period between reporting sick and first contact between the social insurance physician and the worker, and occurence of contact between the social insurance physician and the company appear to have a direct influence on length of sickness absence. Degree of freedom at work, nature of "overstrain", degree of psychoneuroticism, and type of practice of the general practitioner prove to have an indirect influence on length of sickness absence. 


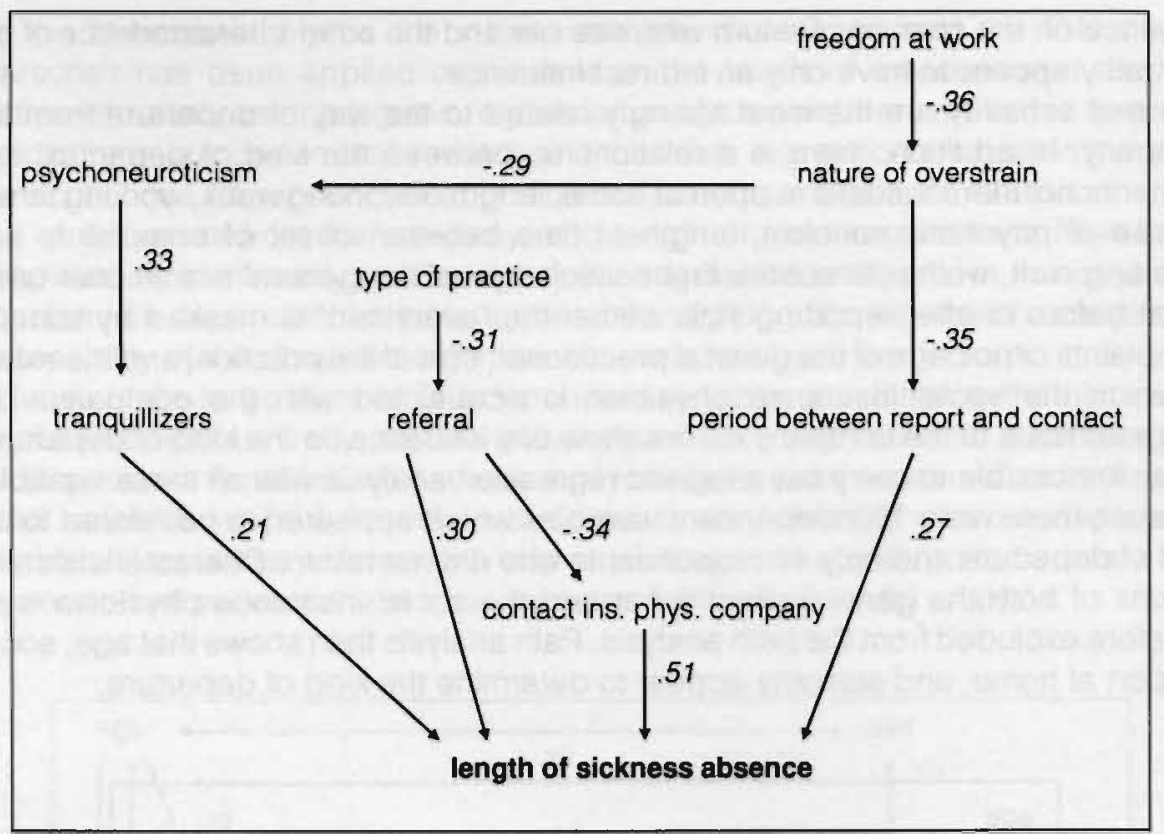

The main conclusions from our studies are the following.

"Overstrain" is an identifiable disorder which, according to the international literature, has been observed at all times and everywhere in the world. It is possible to define "overstrain" theoretically unambiguously and, if properly applied, there appears also a considerable agreement in arriving at this diagnosis.

Sickness absence because of "overstrain" is characterized by an on the average long duration and by a very big chance that the worker is not returning to his job when the sickness absence is ended. The departure from the company occurs either by eligibility for disablement benefits, dismissal, or resignation.

Only a small minority of the "overstrained" workers recovers completely within one year after the date of reporting sick.

Medical and non-medical care received by the "overstrained" worker has proven to be of all kinds. Coordination between general practitioner, industrial physician and social insurance physician is lacking. The general practitioner usually tends to hold on to the patient. In only half of the cases he pays attention to the fact that his patient is on sick leave. Mostly this attention limits itself to the decision to take or continue a sickness leave or not.

In most cases an industrial physician is not available to the worker and, if he is, his activities often start very late. The social insurance physician restricts his guidance mostly to his consulting hours. Thus it appears that the "overstrained" worker has to function as his own case manager. During the treatment by physicians and the like substantial periods of floating occur. Moreover, there is on the average a long waiting time for those who seem to become disabled when referral from the GAK to the GMD takes place. 


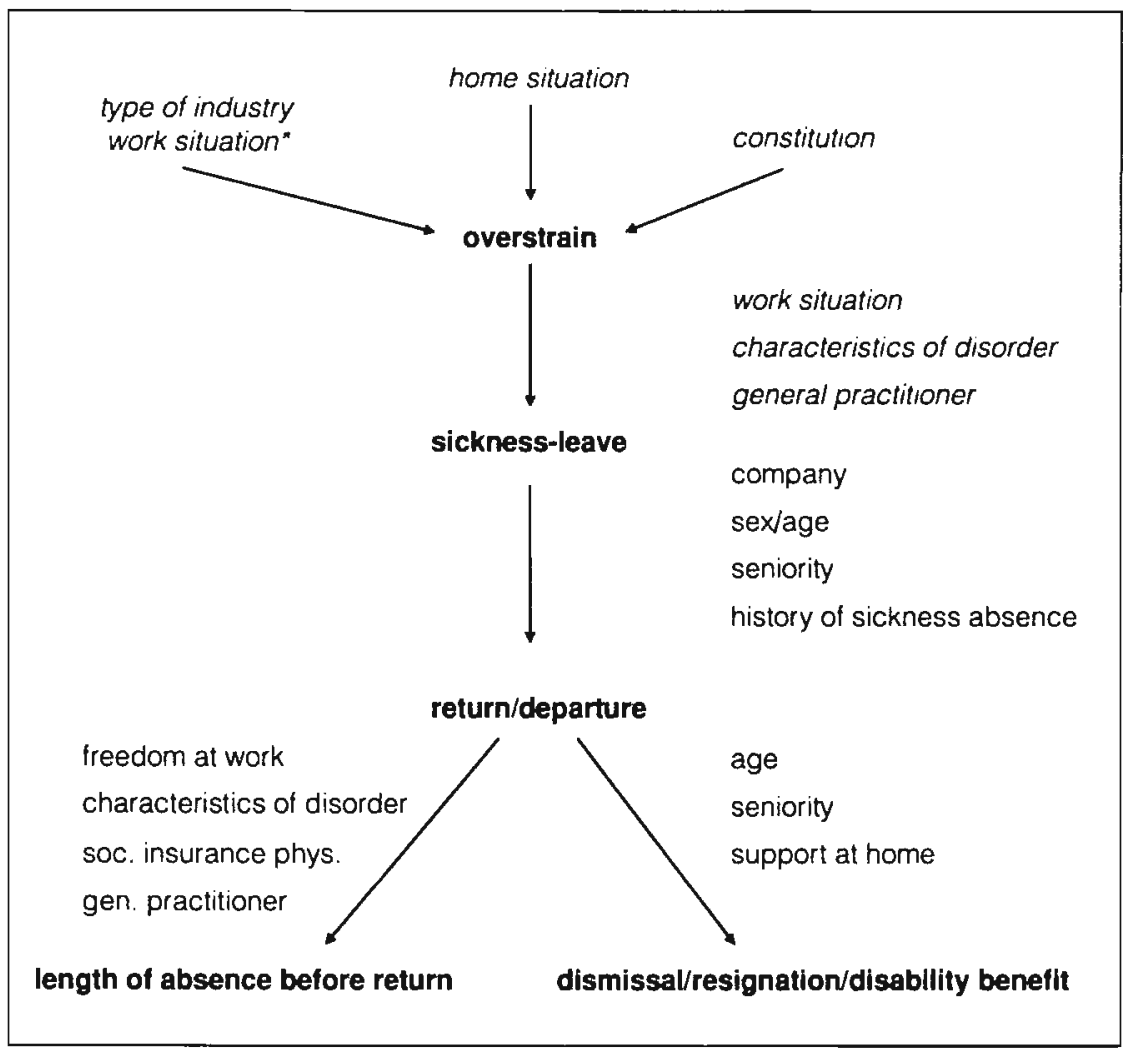

* Hypothetical determinants are printed in italics.

This study ascertained that for every stage of the course of sickness absence a different set of factors determine the outcome. This is certainly the case with respect to return to the job, becoming eligible for disablement benefit, and length of sickness in the case of return. Additional data suggests that this is probably the case with respect to the onset of "overstrain" and the decision to report sick. The complete though partly hypothetical model of the course of sickness absence because of "overstrain" and its determinants looks as follows.

This study has exclusively dealt with "overstrained" workers employed in companies insured by the GAK. This means that we do not know for sure wether the findings can be generalized to workers on sick leave because of other disorders and to "overstrained" workers otherwise insured. Also there has been some selective non-respons with respect to cause and manifestation of overstrain. Therefore replications of this study among other populations are recommended. In view of the high costs of prospective cohort studies, another recommendation is the extension of databases of the sickness absences with variables relevant for secondary analyses to be done by sociomedical scientists.

The impact of our study for the explanation of the trends in sickness absence and disability in The Netherlands is limited. From our results we guess that the two 
developments which have contributed to the growth of the disability rates and thus to the growth of sickness duration are: firstly, shift in employment towards small scale service industries and, secondly, less attention to the well-being of workers and less willingness to concede to it within the policies of the companies.

Studies of determinants of the onset of "overstrain" and of the decision to report sick are also recommended. In the general interest of research into sickness absence we recommend meta-analyses of the studies which have already been carried out. Finally, action research directed to experiments in care and guidance to "overstrained" workers is recommended.

Our recommendations to improve present policies imply training by feedback for general practitioners with regard to guidance at sickness absence, measures to promote the involvement of industrial physicians and industrial social workers prior to sickness absence, a shift in activities of social insurance physicians from their office to the companies, creating a special agent or agency for case management of "overstrained" workers employed in small firms, and an integrated organisation providing guidance by the same social insurance physician if a worker becomes eligible for disablement benefit. 


\section{Litteratuur}

Aarts, L. en $\mathrm{Ph} . \mathrm{R}$. de Jong Arbeidsverleden en uitkeringshoogte als determinanten van WAO-toetreding. Deelrapport determinantenonderzoek WAO. Sociale Verzekeringsraad, Zoetermeer, 1987.

Aarts, L. et al. Beschrijving van WAO-toetreders. Deelrapport determinantenonderzoek WAO. Sociale Verzekeringsraad, Zoetermeer, 1982

Abbey, S.E. en P.E. Garfinkel Neurasthenia and chronic fatigue syndrome: the role of culture in the making of diagnosis. American Journal of Psychiatry, 148, 1991, 1638-1646

Aert, van J.H. en B.H. Hoeksma De polikliniek als schakel in de gezondheidszorg. Medisch Contact, 35, 1980, 45-59

Ager, J.E. en P.A.B. Raffle Patterns in sickness absence; experience of London transport staff over two decades. London Transport Executive, London, 1973

Andlauer, P. en R.Z. Kaufmann Les troubles nerveux en Médecine du Travail et leur prévention. Archives des Maladies Professionelles, 3, 1959, 233-253

Andriessen, J.H.T.H. Interne of externe beheersing. Nederlands Tijdschrift voor Psychologie, 27, 1972, 173-191

Arrindell, W.A. en J.H.M. Ettema SCL-90. Handleiding bij een multidimensionele psychopathologie-indicator. Swets en Zeitlinger, Lisse, 1986

Barr, A. Absenteeism among hospital nursing staff. Hospital, 63, 1967, 9-12

Baruk, H. Traité de psychiatrie. Masson et cie., Paris, 1959

Bax, E.H. Macro-determinanten van arbeidsongeschiktheid. Economisch-Statistische Berichten, 23-01-1985, 81-89

Beard, G.M. Neurasthenia or nervous exhaustion. Boston Medical Surgery Journal, 3, 1869, 217-220

Beard, G.M. The American nervousness. Richmond, 1880

Bégoin, J. Le travail et la fatigue. Névrose des téléphonistes et des mécanographes. La Raison, 1958, 20-21

Beinum, H.J.J. van et al. Taakontwerp en werkorganisatie; een sociotechnisch veldexperiment. NIPG/TNO, Leiden, 1967

Beljaew, W.N. Diagnostik und Therapie von funktionellen Herzstörungen bei Kurgästen mit Neurasthenie. Psychiatrie, Neurologie, Medizinische Psychologie, 26, 1974, 738-746

Berger, D.M. The return of neurasthenia. Comprehensive Psychiatry, 14, 1973, 557-562

Besseling. J.J.M. Diagnose en arbeidsongeschiktheid 1977-1983. GMD, Amsterdam, 1986

Besseling, J. et al. WAO-toetreders uit 1985. Een beschrijving. GMD, Amsterdam, 1987

Bize, R. en P. Goguelin Le surmenage des dirigeants. Ed. de l'entreprise moderne, Paris, 1956

Bleuler, E. Handbuch der Psychiatrie. 1975

Boenink, $A$. et al. Moeheid: verschillen in benadering tussen huisarts en internist. Medisch Contact, 41, 1986, 54-57

Bonhöffer, K. Die symptomatischen Psychosen im Gefolge von akuten Infektionen und inneren Erkrankungen. Deuticke, Leipzig/Wien, 1910

Boots, J.M.J. Het werk van de huisarts. Rijksuniversiteit Limburg, Maastricht, 1983

Bosch, F.A.J. van den en C. Petersen De omvang van de verborgen werkloosheid in de WAO. Economisch-Statistische Berichten, 65, 1980, 52-58 
Broeke, J. ten Een eerste analyse van het ziekteverzuim naar aard en grootheidsklasse van de bedrijven. ElB, Amsterdam, 1976

Broersen. Th. et al. Arbeidsongeschiktheid onder ambtenaren. Ministerie van Binnenlandse Zaken, Den Haag, 1991

Brown, G.W. en T. Harris Social origins of depressions. Tavistock, London, 1978

Brown, Ph. Diagnostic conflict and contradiction in psychiatry. Journal of Health and Social Behaviour, 28, 1987, 37-50

Bryson, D. Factors influencing sickness absence in young workers. Transcriptions of the Society of Occupational Medicine, 18, 1968, 101-104

Burg-van Walsum, M. van der et al. De dokter in gesprek. Psychosociale hulpverlening door de huisarts. Bunge, Utrecht, 1988

Buijs, P.C. Curatieve gezondheidszorg, ziekteverzuim en arbeidsongeschiktheid. CCOZ, Amsterdam, 1985

Buzzard, R.B. en W.J. Shaw An analysis of absence under a scheme of paid sick leave. British Journal of Medicine, 9, 1952, 282-295

Bijl, R.V. en E. Ketting Toekomstscenario's Arbeidsongeschiktheid ten gevolge van psychische stoornissen 1990-2010. Tijdschrift voor Sociale Gezondheidszorg, 69, 1991, 394-402

Bijlsma, T. en F. Koopmans De uitbreiding van het ziektebegrip en de WAO. Sociaal Maandblad Arbeid, 37, 1982, 803-819

Bijlsma, T. en F, Koopmans Van ZW naar WAO, verschillen tussen mannen en vrouwen. Sociaal Maandblad Arbeid, 41, 1986, 705-709

Bijlsma, T. en F. Koopmans Over de voor vrouwen grotere kans op voortijdige beëindiging van de ziektewetperiode. Sociaal Maandblad Arbeid, 42, 1987, 553-559

Carp, E.A.D.E. De neurosen. Scheltema en Holkema, Amsterdam, 1947 (3e Druk)

Cassee. E.Th. Leiderschap en rolbegrenzing in een ziekenhuisorganisatie. Sociologische Gids, 14, 1967, 86-100

Enquête beroepsbevolking 1989. CBS, Voorburg/Heerlen, 1990

Chatel, J.C. en R. Peele A centennial review of neurasthenia. American Journal of Psychiatry, 126, 1970, 1404-1413

Chevrolle, J. Comparaison de la fréquence et de la durée de l'absentéisme chez des ouvriers travaillant en horaire normal et en équipe $2 \times 8$. Archives des Maladies Professionelles, 30 , $1969,348-351$

Cohen, J. A coefficient of agreement for nominal scales. Educational and Psychological Measurement, 20, 1960, 37-46

Cohen, M.E. en P.D. White Life situations, emotions and neurocirculatory asthenia. (Anxiety neurosis, neurasthenia, effort syndrome) Psychosomatic Medicine, 13, 1951, 335-355

Collis, G.M. Kappa, measures of marginal symmetry and intraclass correlations. Educational and Psychological Measurement, 45, 1985, 55-62.

Dam, F. van en L. Hingstman Statistische gegevens per 1 januari 1988 over huisartsen en verloskundigen en statistische gegevens per 1 januari 1987 over fysiotherapeuten. NIVEL, Utrecht, 1988

Dantzig. A. van en J. Waage Almacht en onmacht; het verband tussen psychasthenie en neurasthenie. Huisarts en Wetenschap, 5, 1962, 239-245

Davis, J.A. The logic of causal order. Sage, Beverly Hills, 1985

Dogle, N.V. en T.P. Yakovleva Comprehensive assessment of the possibility of asthenization of females engaged in neural-stress work as examplified by telephone operators in interurban lines. Cigiena truda i professionalnije zabolevanija, 11, 1982, 16-19

Draaisma, D. en P.G.W. Smulders Ziekteverzuim en het bedrijf. NIPG/TNO, Leiden, 1978

DSM-III, American Psychiatric Association, Washington, 1980

DSM-IV, Options book; work in progress 9/1/91. American Psychiatric Association, Washington, 1991 
Duxbury, M.L. et al. Head nurse leadership style with staff nurse burnout and job satisfaction in neonatal intensive care units. Nursing Research, 33, 1984, 97-101

Dijk, F.J.H. et al. WAO-toetreding: trends en risicogroepen in een groot industrieel bedrijt. Tijdschrift voor Sociale Gezondheidszorg, 65, 1987, 654-662.

Dijk, P. van en W. Hogervorst Arbeidsongeschiktheid en verzuimbegeleiding. De belangrijke rol van de huisarts. Medisch Contact, 46, 1991, 691-694

Dijkstra, A. Inkrimping van het personeelsbestand in produktiebedrijven en afwezigheid wegens ziekte; een longitudinale sekundaire analyse. Sociologische Gids, 21, 1974, 3-15

Dijkstra, A. Determinanten van ziekteverzuim in produktieorganisaties voor gehandicapten. NIPG/TNO, Leiden, 1977

Dijkstra, A. Werkgroepgrootte, doktersbezoek en ziekteverzuim; enige bevindingen op basis van een onderzoek in produktieorganisaties voor gehandicapten. Tijdschrift voor Sociale Geneeskunde, 55, 1977a, 99-105

Eitner, S. Der gerohygienische Aspekt bei Beurteilung der Fehlzeitenkomponenten Fallhäufigkeit und Falldauer. Arbeitsmedizin, Sozialmedizin, Arbeitshygiene, 1, 1966, 387-390

Eck, M.A.A. van Het beslissingsproces van de medische functie van het GAK. Universiteit van Amsterdam, Amsterdam, 1990

Eck, M.A.A. van De diagnosestelling: 'Categorie V'. In: Bijl,R. en D.Bauduin (red.) Categorie V. Arbeidsongeschikt wegens psychische stoornissen. NCGV, Utrecht, 1991, p. 79-94

Ekker, W. Ziekteverzuim als bedrijfskenmerk. Mens en Onderneming, 20, 1966, 1-11

Ekkers, C.L. et al. Menselijke stuur- en regeltaken. NIPG/TNO, Leiden, 1980

Es, J.C. van Patiènt en huisarts. Oosthoek, Scheltema en Holkema, Utrecht, 1974

Eschweiler, W. et al. Beschreibung und Ergebnisse einer empirischen Untersuchung zur Erfassung der Ursachen von Fehlzeiten. In: Nieder,P. et al. Fehlzeiten, ein Unternehmersoder Arbeitnehmersproblem? Verlag Paul Haupt, Bern/Stuttgart, 1979

Beroepsbevolking naar onderwijsniveau in Zuid-Limburg. ETIL, Maastricht, 1983

Ey, H. Manuel de Psychiatrie. Masson et cie., Paris, 1963

Fenn, P. Sickness duration, residual disability, and income replacement: an empirical analysis. Economic Journal, 91, 1981, 158-173

Figlio, K. How does illness mediate social relations? In: Wright,P. en A.Treacher The problem of medical knowledge. Edinburgh University Press, Edinburgh, 1982

Fink, A. et al. Consensus methods: characteristics and guidelines for use. American Journal of Public Health, 74, 1984, 979-983

Fleury, M. de Les grands symptômes neurasthéniques. Alcan, Paris, 1902

Foets, $M$. et al. De huisartsenquête van de nationale studie: datareductie door schaalconstructie. Basisrapport. Een nationale studie van ziekten en verrichtingen in de huisartspraktijk. NIVEL, Utrecht, 1991

Forssman, S. Arbeitsabwesenheit. In: Wittgens, H. Handbuch der gesamten Arbeitsmedizin. Band 5: Arbeitsphysiologie, medizinische Berufskunde und Grenzgebiete. Urban \& Schwarzenberg, Berlin, 1961, 739-767

Gerritsen, R.M. Welke symptomen en etiologische factoren zijn voor de verzekeringsgeneeskundige van belang voor het stellen van de diagnose surmenage? Scriptie SSG, Utrecht, 1988

Giel, R. Het dilemma van de medische beroepsuitoefening. Medisch Contact, 31, 1976, 1021-1026

Giel, R. et al. De filters in het model van Goldberg \& Huxley in de praktijk. Diagnostiek en verwijzing van psychische stoornissen in de eerste lijn. Huisarts en Wetenschap, 34, 1991 , 169-172

Goldberg, D. en P. Huxley Mental illness in the community; the pathway to psychiatric care. Tavistock, London, 1980

Gordon, C. et al. Patterns of sickness absence in a railway population. British Journal of Industrial Medicine, 16, 1959, 230-243 
Grewel, F. De waarde van herstellingsoorden voor "overwerkten" en "zenuwzwakken". Nederlands Tijdschrift voor Geneeskunde, 95, 1951, 3228-3236

Griffiths, M. et al. Sickness absence after inguinal herniorraphy. Journal of Epidemiology and Community Health, 33, 1979, 121-126

Groot, J. de Over ziekencontrole en ziekteverzuim. Tijdschrift voor Sociale Geneeskunde, 48, $1970,2-12$

Groot, M.J.W. de Controlegewoonten en ziekteverzuim. Mens en Onderneming, 8, 1954, 332-348

Grool, M.J.W. de Elementaire kwantitatieve analyse van ziekteverzuimcijfers. Mens en Onderneming, 12, 1958, 219-233

Groot, M.J.W. de Kwantitatieve benadering van het verzuim door neurosen bij Nederlandse fabrieksarbeiders. NIPG, Leiden, 1958

Groothoff, J.W. Gezondheidszorg en 3-maands verzuimgevallen. Tijdschrift voor Sociale Geneeskunde, 59, 1981, 42-49

Groothoff, J.W. Gezondheidstoestand van de beroepsbevolking. Van Denderen, Groningen, 1986

Grosfeld, J.A.M. De voorspelbaarheid van individuele verzuimduur. Swets \& Zeitlinger, Amsterdam/Lisse, 1988

Grosfeld, J.A.M. Psychisch arbeidsongeschikt of arbeid psychisch ongeschikt? In: Bij|,R. en D.Bauduin (red.) Categorie V. Arbeidsongeschikt wegens psychische stoornissen. NCGV, Utrecht, 1991, p. 27-37

Gründemann, R.W.M. et al. Arbeidsgebondenheid van WAO-intrede. Ministerie van Sociale Zaken en Werkgelegenheid, Den Haag, 1991

Heine, E.J.H. ter Wat zijn psychosociale problemen? Een voorstel voor een begripsomschrijving. Gezondheid en Samenleving, 4, 1983, 119-122

Hellinga, P. Risicoverschillen in arbeidsongeschiktheid vanwege psychische aandoeningen. In: Bijl,R. en D.Bauduin (red.) Categorie V. Arbeidsongeschikt wegens psychische stoornissen. NCGV, Utrecht, 1991, p. 104-108

Hilverink, H.G. Arbeidsongeschikt of arbeid ongeschikt? Tijdschrift voor Sociale Geneeskunde, 56, 1978, 621-626

Hoftmann, F.A. Über neurasthenisch-depressive Krankheitsbilder. Medizinische Welt, 43, $1967,2563-2569$

Holthuis, R. De betekenis van de krachtens de Ziektewet uitgeoefende geneeskundige controle. Van der Loeff, Enschede, 1961

Holthuis, R. Verzekeringsgeneeskunde. Stichting CCOZ, Amsterdam, 1980

Horst, F.G.E.M. van der Gezondheid en niet werken. Rijksuniversiteit Limburg. Maastricht, 1988

Hosmer, D.W. en S. Lemeshow Applied logistic regression. John Wiley \& Sons, New York, 1989

Huet, G.D.L. Over functioneele neurosen. Nederlands Tijdschrift voor Geneeskunde, 22, 1886, 53-71

Hughes, Ch.C. Culture-bound or structure-bound? The syndroms and DSM-III. In: Ch.C. Hughes en R.C.Simons (red.), The culture-bound syndromes: folk-illnesses of psychiatric and anthropological interest, D. Reidel, Dordrecht, 1985, 3-24

Hullenaar, R.H.J. van 't en D.B.J. van Koningsveld Afgebrand of afgedankt: een onderzoek naar oorzaken van arbeidsongeschiktheid. Swets \& Zeitlinger, Lisse, 1986

Hunfeld, A. Werkloosheid, WAO en ABP. In: V.Vrooland et al. WAO en werkgelegenheid. Stichting CCOZ, Amsterdam, 1980, p.26-56

Hutschemaekers, G. Is Nederland ziek? Arbeidsongeschiktheid vanwege psychische stoornissen. Psychologie en Maatschappij, 15, 1991, 170-181

Huygen, F.J.A. et al. Nerveus-functionele klachten in de huisartsenpraktijk. Nederlands Tijdschrift voor Geneeskunde, 128, 1984, 1321-1327 en 1372-1376 
Jacobs, C. en R. Bijl GGZ in getallen, 1991. NCGV, Utrecht, 1991

Janet, P. Obsessions et psychasthénie. Alcan, Paris, 1908

Jelgersma, G. Leerboek der functioneelen neurosen. Scheltema en Holkema, Amsterdam, 1898

Jelgersma, G. La civilisation comme cause prédisposante aux maladies nerveuses. Nederlands Tijdschrift voor Geneeskunde, 51, 1907, 790-798

Jenkins, R. Minor psychiatric morbidity in employed young men and women and its contribution to sickness absence. British Journal of Industrial Medicine, 42, 1985, 147-154

Jong, Ph. de et al. DeterminantenonderzoekWAO; fase 1: Determinanten van WAO-toetreding: een eerste totaalbeeld. Sociale Verzekeringsraad, Zoetermeer/Leiden, 1981

Jonge, R. de De binnenkant van een professie: de huisarts en zijn beroepsgroep. Tilburg University Press, Tilburg, 1988

Jongerius, J.A.C. Decompensatie. Draaglast en draagkracht in relatie tot decompensatie bij het neurastheen syndroom. Huisartsenpers, Utrecht, 1984

Kabela, M. Psychiatrisch oordeel beoordeeld. De psychiatrische beoordelimg van arbeidsongeschiktheid. Swets \& Zeitlinger, Amsterdam/Lisse, 1988

Kaiser, C.P. Het verzekeringsgeneeskundig handelen en de verzuimduur. Universitaire Pers Maastricht, Maastricht, 1992

Kam, F. de en F. Nypels Het stuwmeer loopt over. Op weg naar anderhalf miljoen arbeidsongeschikten. Intermediair, 9 november 1990, 28-33

Kleinman, A. Neurasthenia and depression: a study of somatization and culture in China. Culture, Medicine and Psychiatry, 6, 1982, 117-190

Klerk, J.M. et al. Diagnosecategorie V Psychische stoornissen. Verslag 1: Algemene beschrijving. GMD, Amsterdam, 1982

Klerk, J.M. de et al. Diagnosecategorie V: psychische stoornissen en de WAO: een beschrijving. Tijdschrift voor Sociale Gezondheidszorg, 61, 1983, 434-440

Klerk, J.M. de et al. Psychische stoornissen. Verslag 2: dossierstudie. GMD, Amsterdam, 1985

Knepper, S. Naar een miljoen arbeidsongeschikten: wat kan de GGZ doen? Maandblad voor Geestelijke Volksgezondheid, 44, 1989, 1065-1078

Knepper, S. De epidemiologie van psychische arbeidsongeschiktheid. Feiten en achtergronden. In: Bijl,R, en D.Bauduin (red.) Categorie V. Arbeidsongeschikt wegens psychische stoornissen. NCGV, Utrecht, 1991, p. 7-26

Kocken, Th.J. Psychische stoornissen in een huisartspraktijk. Katholieke Universiteit Nijmegen, Nijmegen, 1984

Kompier, M. et al. Onderzoek naar de relatie tussen ziekteverzuim en arbeidsongeschiktheid van stadsbuschauffeurs. Tijdschrift voor Sociale Gezondheidszorg, 64, 1986, 477-480

Koten, J.W. en M. Timmer Zicht op handikaptechnologie. Tijdschrift voor Sociale Geneeskunde, 58, 1980, 481-484

Kraft, Th.B. Overspanning, een psychosomatische en sociale zaak. De Erven F.Bohn, Haarlem, 1972

Kraft, Th.B. Tien stellingen inzake overspanning. Tijdschrift voor Sociale Geneeskunde, 53, 1975, 208-210

Kraft, Th.B. Overspanning in de dagelijkse praktijk. Tijdschrift voor Ziekenverpleging, 29, 1976. $611-616$

Kraft, Th.B. Overspanning en de relatie hiervan met het begrip "stress". Hexagon Roche, 3 , 1980, nr. 3, 1-6 en nr. 5, 5-11

Kraft, Th.B. Overspanning en verkoudheid. Medisch Contact, 46, 1991, 1551-1552

Kraus, G. Het hyperaesthetisch-emotionele syndroom. Nederlands Tijdschrift voor Geneeskunde, 99, 1955, 246-252

Kruidenier, H.J. Ziekteverzuim 1977-1980; enkele cijfers uit het registratiesysteem van de Stichting CCOZ. Stichting CCOZ, Amsterdam, 1982 
Kuné, J.B. Enige ontwikkelingen rondom de AAWNAO, II. Tijdschrift voor Sociale Geneeskunde, 58, 1980, 485-489

Kuypers, C.A. "Psychosomatische" stoornissen in een plattelandspraktijk. Huisarts en Wetenschap, 9. 1966, 42-58

Ladee, G.A. Encyclopedie van de psychiatrie en de psychotherapie. Elsevier, Amsterdam, 1976

Lamberts, $H$. en B. Hartman Psychische en sociale problemen in de huisartsenpraktijk. Huisarts en Wetenschap, 25, 1982, 333-342 en 376-393

Lancée, W.H.J. Psychologisch onderzoek inzake arbeids(on)geschiktheid. Psychologisch Adviesbureau Lancée, Alkmaar/Assen, 1988

Le Guillant, L. et al. La névrose des téléphonistes. Presse Médicale, 66, 1956, 274-277

Limbeek, J. van Het gebruik van symptoomvragenlijsten bij de meting van psychische problemen in de huisartspraktijk. Tijdschrift voor Sociale Gezondheidszorg, 69, 1991, 87-120

Link, B.G. en B.P. Dohrenwend The epidemiology of mental disorders. In: Freeman,H.E. en S.Levine (red.) Handbook of medical sociology. Prentice Hall, Englewood Cliffs, 1989, 102-127

Linstone, H.A. en M. Turoff (eds.) The Delphi Method: Techniques and Applications. AddisonWesley, 1975

Lisdonk, E. van der Ziekten in de huisartspraktijk. Bunge, Utrecht, 1990

Luyckx, R.Th. De lotgevallen van de langverzuimer. Rijksuniversiteit Groningen, Groningen, 1982

Maas, P.J. van der Arbeidsverzuim en arbeidsongeschiktheid in verband met psychische afwijkingen. Tijdschrift voor Sociale Geneeskunde, 53, 1975, 440-451

Maasen, J.H.W. Verzuimbegeleiding en overspanning. Katholieke Universiteit Nijmegen, Nijmegen, 1985

Mann, A.H. et al. The twelve-month outcome of patients with neurotic illness in general practıce. Psychological Medicine, 11, 1981, 535-550

Mechanic, D. The management of mental illness. Progress, prospects and policy considerations. In: Freeman,H.E. en S.Levine (red.) Handbook of medical sociology. Prentice Hall, Englewood Cliffs, 1989, 262-283

Meeuwissen, L. et al. Psychometrisch kwaliteiten van de Symptom Checklist (SCL-90) bij poliklinische patiënten met buikpijn of lage rugklachten. Tijdschrift voor Sociale Gezondheidszorg, 70, 1992, 123-131

Merens-Riedstra, H.S. Leven zonder werk: een sociaalwetenschappelijk onderzoek naar arbeidsongeschiktheid. Rijksuniversiteit Limburg, Maastricht, 1981

Merens-Riedstra, H.S. en W.J. van Ende Verslag van een onderzoek naar samenwerking tussen artsen. Medisch Contact, 28, 1973, 717-721

Michels, J.J.M. De behandeling van overspanning veroorzaaakt door oneconomisch gebruik van geestelijke krachten. Huisarts en Wetenschap, 3, 1960, 317-319

Mierlo, G. van en A. Smits Nerveus-functionele klachten - De huisarts en het gezinsgesprek - De klacht en de huisarts. Huisarts en Wetenschap, 17, 1974, 52-55

Missenard, A.R. Introduction à l'étude de la fatigue. Concours Médical, 1960, 1755-1764

Mouton Aetiologie en profylaxis van nerveuze toestanden bij scholieren in inrichtingen voor middelbaar en hoger onderwijs. Nederlands Tijdschrift voor Geneeskunde, 35, 1899, 548-550

Nederlands Tijdschrift voor Geneeskunde, 23, 1887, 87

Noshpitz, J.D. en R.D. Coddington Stressors and the adjustment disorders. John Wiley \& Sons, New York, 1990

Nijhuis, F. en J. Soeters Werk en ziekte: een onderzoek naar afwezigheid wegens ziekte en arbeidsongeschiktheid bij 51 organisaties in Zuid-Limburg. Rijksuniversiteit Limburg, Maastricht, 1982 
Oliemans, A.P. Morbiditeit in de huisartsenpraktijk. Stenfert Kroese, Leiden, 1969

O'Muircheartaigh, C.A. Absenteeism in Irish industry. Irish Production Centre, Dublin, 1975

Orlemans, J.G.W. en R.J.A. ten Doesschate Hartziektefobie; een gedragstherapeutisch werkmodel voor behandeling. Huisarts en Wetenschap, 19, 1976, 323-337

Ormel, J. en R. Giel Omvang, beloop en behandeling van psychische stoornissen. Tijdschrift voor Psychiatrie, 25, 1983, 688-710

Omark, R.C. Nervous breakdown as a folk illness. Psychological Reports, 47, 1980, 862

Owens, A.C. Sick leave among railwaymen threatened by redundancy: a pilot study. Occupational Psychology, 40, 1966, 43-52

Pas, J.H.R. van der Koekoekseieren van de WAO. Sociaal Maandblad Arbeid, 34, 1979, 175-179

Pauchard, D. Neurasthénie, psychasthénie. Evolution des concepts. Revue Médicale de Suisse Romande, 102, 1982, 621-627

Petermann, A. Ergebnisse und Schlußfolgerungeren einer Krankenstandsanalyse von Frauen eines Büromaschinenwerkes. Zeitschrift für gesundheitliche Hygiene, 21, 1975, 501-508

Peters, U.W. Wörterbuch der Psychiatrie und medizinischen Psychologie. Urban und Schwarzenbeck, München, 1977

Philipsen, $H$. Enkele aspecten van het stijgend ziekteverzuim. III. De verzuimgelegenheid, 'eigen risico' en het verzuimpatroon. Mens en Onderneming, 20, 1966, 342-352

Philipsen, H. Afwezigheid wegens ziekte. Wolters-Noordhoff, Groningen, 1969

Philipsen, $H$. Omvang van de gezondheidszorg onder invloed van maatschappelijke ontwikkelingen. Tijdschrift voor Sociale Geneeskunde, 54, 1976, 198

Pop, P. en R.A.G. Winkens Periodieke persoonlijke feed-backover het diagnostisch handelen. Ervaringen uit het Diagnostisch Centrum Maastricht. Huisarts en Wetenschap, 32, 1989, 205-207

Post, D. latrogene ziekten. Een visie vanuit de algemene gezondheidszorg. Tijdschrift voor Sociale Gezondheidszorg, 63, 1985, 740-743

Post, D. et al. Verwijzen en voorschrijven op het platteland. Een onderzoek naar regionale verschillen in medische consumptie in vijf regio's. Tijdschrift voor Sociale Gezondheidszorg, 69, 1991, 101-106

Press, S.J. en S. Wilson Choosing between logistic regression and discriminant analysis. Journal of the American Statistical Association, 73, 1978, 699-705

Prins, R. Sickness absence in Belgium, Germany (FR) and The Netherlands. A comparative study. Rijksuniversiteit Limburg, Maastricht, 1990

Pugh, D.S. et al. Sickness absence among railway clerical staff. British Journal of Industrial Medicine, 16, 1959, 269-273

Putten, P. van der De arbeidsongeschikt verklaarde ambtenaar. Een dossieronderzoek. ABP, Heerlen, 1981

Putten, P. van der Overheidsspecifieke arbeidsongeschiktheid. Tijdschrift voor Sociale Gezondheidszorg, 61, 1983, 618-622

Putten, P. van der Arbeidsongeschiktheidsverklaring bij overheidswerknemers. Oorzaakspecifieke incidentie en samenhang van funktie met afkeurings(leeftijd). Tijdschrift voor Sociale Gezondheidszorg, 63, 1985, 281-286

Putten, $P$. van der et al. Medische bevindingen als risicofactoren voor een pathologisch einde van het arbeidsleven. Tijdschrift voor Sociale Gezondheidszorg, 67, 1989, 22-27

Ramondt, J.J. Verantwoordelijkheid in het werk; verslag van experimenten in zes industriële bedrijven. Samson, Alphen aan de Rijn, 1968

Ridder, D. de Determinanten van psychische gezondheid. Een verkenning van de litteratuur. NCGV, Utrecht, 1988

Ridder, D. de en Visser, J. Tussen de lijnen. De relatie tussen eerstelijn en geestelijke gezondheidszorg onderzocht. NCGV/NIVEL, Utrecht, 1987 
Ris, B.G.M. Personeelsbeleid en ziekteverzuim; verslag van een onderzoek bij 39 bedrijven. NIPG/TNO, Leiden, 1978

Rooijmans, H.G.M. Chronisch klaaggedrag en depressie. Tijdschrift voor Sociale Geneeskunde, 53, 1975, 607-615

Saan, M. Arbeidsconflict, problemen in de werksfeer. Tijdschrift voor Verzekeringsgeneeskunde, 24, 1986, 71-74

Schaufeli, W. Burnout. Een overzicht van empirisch onderzoek. Gedrag en Organisatie, 3, 1990, 3-31

Schmidt, W. Psychologische Aspekte der krankheitsbedingten Fehlzeiten im Betrieb; empirische Untersuchungen unter besonderer Berücksichtigung sozialpsychologischer Faktoren. Beuth-Vertrieb GmbH., Berlin, 1967

Schouten, H.J.A. Statistical measurement of interobserver agreement. Analysis of agreements between observers. Elinkwijk, Utrecht, 1985

Schouten, J.A.M. Anamnese en advies. Stafleu, Alphen aan de Rijn, 1982

Schröer, C.A.P. et al. Werk en ziekte. Deel 2; de werknemersenquete. Rijksuniversiteit Limburg, Maastricht, 1984

Schröer, C.A.P. et al. Gebruik en betekenis van de term overspanning in de geneeskundige litteratuur. Rijksuniversiteit Limburg, Maastricht, 1987

Schröer, C.A.P. et al. Gebruik en betekenis van de term overspanning in de geneeskundige litteratuur. Tijdschrift voor Sociale Gezondheidszorg, 66, 1988, 163-167

Semmence, A. Time off work after herniorraphy. Journal of Social and Occupational Medicine, $23,1973,36-48$

Shannon, H.S. et al. Sickness absence of lead workers and controls. British Journal of Industrial Medicine, 33, 1976, 236-242

Shepherd, R.D. en J. Walker Absence of work in relation to wage level and family responsibility. British Journal of Industrial Medicine, 15, 1958, 52-61

Sivadon, P. Psychopathologie du travail. L'Élan, 1957

Smit, H.G. Het neuroseverschijnsel in verband met de uitvoering van de Ziektewet. Tijdschrift voor Sociale Geneeskunde, 30, 1952, 371-376

Smulders, P.G.W. Balans van 30 jaar ziekteverzuimonderzoek; de resultaten van 318 studies samengevat. NIPG/TNO, Leiden, 1984

Smulders, P.G.W. Bedrijfskenmerken en ziekteverzuim in de jaren zestig en tachtig. Een vergelijkende studie. NIPG/TNO, Leiden, 1984a

Smulders, P.G.W. en A. Bloemhoff Arbeid, gezondheid en welzijn in de toekomst. Toekomstscenario's arbeid en gezondheid 1990-2010. Bohn Stafleu Van Loghum, Houten/Antwerpen, 1991

Soeters. J. Afwezigheid wegens ziekte in het herstructureringsgebied Zuid-Limburg. Rijksuniversiteit Limburg, Maastricht, 1980

Soeters, J.M.L.M. Patiënt, gezondheidszorg en langdurige ziekte. Een onderzoek onder 213 langdurig zieke werknemers in Z-Limburg. Rijksuniversiteit Limburg, Maastricht, 1983

Soeters, J. et al. Sociaal-gezondheidskundige aspecten van arbeidstijdverkorting. In: Grumbkow,J. von en J.J.Godschalk (red.) Sociale aspecten van arbeidstijdverkorting. Swets \& Zeitlinger, Lisse, 1984, p. 135-144

Spit, W.J.L. Epiloog. In: Bijl,R. en D.Bauduin (red.) Categorie V. Arbeidsongeschikt wegens psychische stoornissen. NCGV, Utrecht, 1991, p. 181-186

Spitzer, R.L. en J.L. Fleiss A re-analysis of the reliability of psychiatric diagnosis. British Journal of Psychiatry, 125, 1974, 341-347

Staal, J.L. et al. Het beloop van psychopathologie en sociale beperkingen. Een exploratieve studie onder psychiatrische polikliniek patiënten. Tijdschrift voor Sociale Gezondheidszorg. $67,1989,92-95$ 
Taylor, P.J. Shift and day work; a comparison of sickness absence, lateness, and other absence behaviour at an oil refinery from 1962 to 1965 . British Journal of Industrial Medicine, 24, 1967, 93-102

Taylor. P.J. et al. Absenteeism of shift and day workers; a study of six types of shift system in 29 organizations. British Journal of Industrial Medicine, 29, 1972, 208-213

Terluin, B. De begeleiding van "overspannen" patiënten door de huisarts. De Papieren Visite, $1,1984,18-23$

Terluin, B. Surmenage in een huisartspraktijk. Een explorerend onderzoek. Huisarts en Wetenschap, 29, 1986, 261-264

Timmer, M. en J.W. Koten Verzekeringsgeneeskunde als medebeheerder van de WAO/AAW. Tijdschrift voor Sociale Geneeskunde, 59, 1982, 777-784

Tordoir, W.F. et al. Gezondheidszorg en lange ziekteduren. NIPG/TNO, Leiden, 1978

Tourette, G. de la Les états neurasthéniques. Ballière et Fils, Paris, 1899

Tromp. L.H. Grote aantal code 309-gevallen en verzuimduur roepen vragen op. Medinfo-GAK, $31,1985,29-31$

Tuke, D.H. A dictionary of psychological medicine. Arno Press, New York, 1882

Umesh, U.N. et al. Interjudge agreement and the maximum value of Kappa. Educational and psychological measurement, 49, 1989, 835-850

Verbeek, J. et al. Arbeidsongeschiktheid in het Amsterdamse onderwijs. Tijdschrift voor Sociale Gezondheidszorg, 67, 1989, 161-164

Verhaest, S. De neurasthene neurose. Universiteit van Amsterdam, Amsterdam, 1976

Verhaest, S. en R. Pierloot An attempt at an empirical delimitation of neurasthenic neurosis and its relation with some character traits. Acta Psychiatrica Scandinavica, 62, 1980. 166-176

Verhaest, S. en R. Pierloot De la neurasthénie a la névrose asthénique. L'Évolution Psychiatrique $46,1981,183-199$

Verkade, W.J. Het WAO-syndroom in de gezondheidszorg. Medisch Contact, 31, 1978. 963-964

Verslag van de inleidingen en discussie gehouden op de Studiedagen voor Sociale Verzekeringsgeneeskunde 1975. Tijdschrift voor Sociale Geneeskunde, 53, 1975, 437-457, 607$615,858-865$.

Vrooland, V. Ziekteverzuim, arbeidsongeschiktheid en werkloosheid. In: V.Vrooland et al. WAO en werkgelegenheid. CCOZ, Amsterdam, 1980 p.7-15

Vrooman, J.C. en A.A.M. Kemp Trends tot arbeidsongeschiktheid. Economisch-Statistische Berichten, 75, 1990, 808-812.

Walker, C.R. en R.H. Guest The man on the assembly line. Harvard University Press, Cambridge, 1952

Walker, J. en G. De La Mare Absence from work in relation to length and distribution of shift hours. British Journal of Industrial Medicine, 28, 1971, 36-44

Weyel, J.A. Arbeidsongeschiktheid en psyche. Tijdschrift voor Sociale Geneeskunde, 39, 1961, 683-689

Weyel, J.A. Neurose en neurotische verschijnselen in het arbeidsleven. In: Nap,A. et al. Validiteitsonderzoek. Stafleu, Leiden, 1970, 25-43

Wiersma, D. Psycho-sociale stress en arbeidsongeschiktheid. Konstapel, Groningen, 1980

Wiersma, D. De betekenis van psychosociale stress bij langdurige arbeidsongeschiktheid. Tijdschrift voor Sociale Geneeskunde, 59, 1981, 871-877

Wijkel, D. Samenwerken en verwijzen. NIVEL, Utrecht, 1986

Wouden, J.C. van der et al. De medewerking van artsen aan postenquêtes. Tijdschrift voor Sociale Gezondheidszorg, 66, 1988, 379-381

Wouters, P.H.M. Handboek ICD 9. GMD, Amsterdam, 1984

Zaal, M.J. van Arbeidsongeschikt: invalide of onrendabel? Maandblad Geestelijke Volksgezondheid, 30, 1975, 639-653 


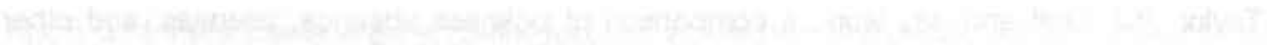

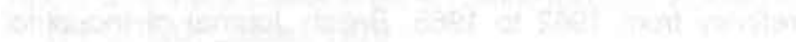

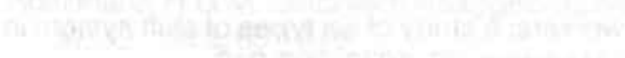

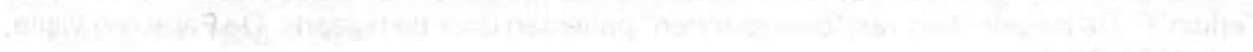
ant

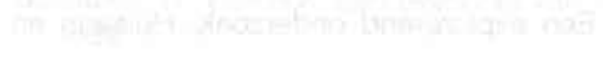

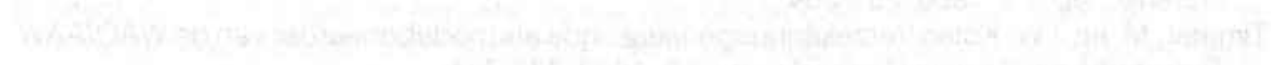

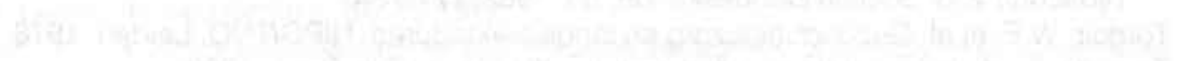

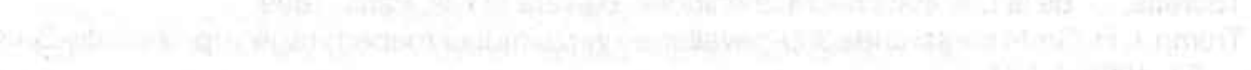

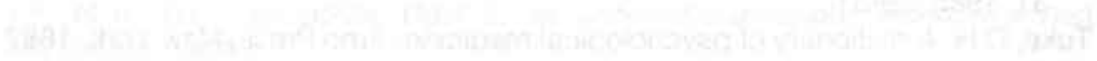

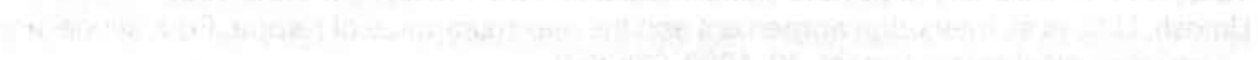

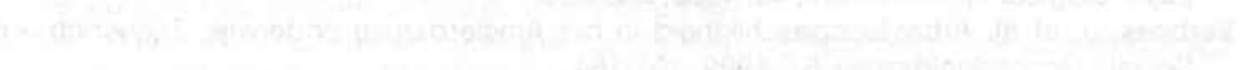

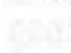




\section{Bijlagen}

De nummers verwijzen naar het nummer van het hoofdstuk waartoe de bijlage behoort.

\section{BIJLAGE 3.1 Overzicht van toegelaten diagnosecodes}

\begin{tabular}{ll}
\hline Hoofdgroep V & Psychische afwijkingen met uitzondering van mentale retardaties. \\
Code 346 & Migraine \\
Hoofdgroep VII & Ziekten van het Circulatieapparaat \\
Code 493 & Astma \\
Code 496 & CARA \\
Hoofdgroep IX & Ziekten van de Spijsverteringsorganen met uitzondering van mond-keelholte \\
& en lever-, galblaas- en pancreasaandoeningen \\
Code 692 & (Contact)dermatitis; eczeem \\
Code 709 & Overige en niet gespecificeerde huidziekten \\
Hoofdgroep XIII & Ziekten der Bewegingsorganen \\
Hoofdgroep XVI & Onvoldoende omschreven klachten en symptomen \\
Hoofdgroep XVII & Verwondingen en Vergiftingen
\end{tabular}

\section{BIJLAGE 3.2 Voorbeelden gestandaardiseerde casusomschrijving}

De patiènt deelt schriftelijk mede dat er een opname in het ziekenhuis heeft plaatsgevonden i.v.m. stripping varices. De patiënt is onder behandeling van chirurg door wiens aanvullende therapie na stripping sclerosering zal plaatsvinden.

Tijdens spreekuur:

De patiënt vertelt dat hij geopereerd is. Het lopen is pijnlijk. De pijn trekt tot in zijn liezen tijdens het lopen.

Onderzoek vg.:

De vg. ziet bij inspectie een fraai genezen litteken, er zijn geen varıces meer zichtbaar. De patiënt loopt ongestoord en heeft geen oedeem in de benen.

\section{Rapporteur meldt:}

De patient zegt een depressie te hebben.

Tijdens spreekuur:

De patiënt zegt last te hebben van een depressie t.g.v. familiegebeurtenissen. Zijn schoonmoeder is overleden en zijn schoonzoon heeft suilcide gepleegd.

Patiènt heeft slaapstoornissen, voornamelijk doorslaapstoornissen. Hij voelt zich somber, net alsof hij buiten de wereld staat, ziet het niet meer zitten en huilt vaak. De patient zegt, dat de werkgever een achterstand heeft van $\mathrm{f} 3.000$, - met de uitbetaling van zijn salaris. De problernen gaan 20 maar door. Volgens de patiènt heeft de huisarts ludiomil voorgeschreven. Patiënt is ondertussen gestopt met de inname ervan. De huisarts zegt, dat hij er overheen moet komen en ertegen moet vechten. 
BIJLAGE 6.1 Overzicht vergelijkingspopulaties

\begin{tabular}{llll}
\hline Benaming: & Jaar: & Aantal: & Populatieomschrijving: \\
\hline CBS & 1989 & 132.000 & $\begin{array}{l}\text { Werknemers woonachtig in de provincie Limburg die deel- } \\
\text { genomen hebben aan de enquête beroepsbevolking in 1989. }\end{array}$ \\
ETIL. & 1979 & 7.446 & $\begin{array}{l}\text { Werknemers woonachtig in de provincie Limburg die deel- } \\
\text { genomen hebben aan de enquête beroeps-bevolking in 1979. }\end{array}$ \\
GAK & $1988 / 9$ & 914 & $\begin{array}{l}\text { Een 6\%-steekproef van de ziektegevallen gemeld bij het GAK } \\
\text { met een minimumduur van vier weken in de regio Maastricht, } \\
\text { Heuvelland, Westelijke Mijnstreek en Midden-Limburg ten }\end{array}$ \\
zchiden van Roermond in de periode 1988 tot en met 1989.
\end{tabular}


BIJLAGE 8.1 Volledige stroomdiagram overspannen werknemers.

\section{A. Voor de ziekmelding}

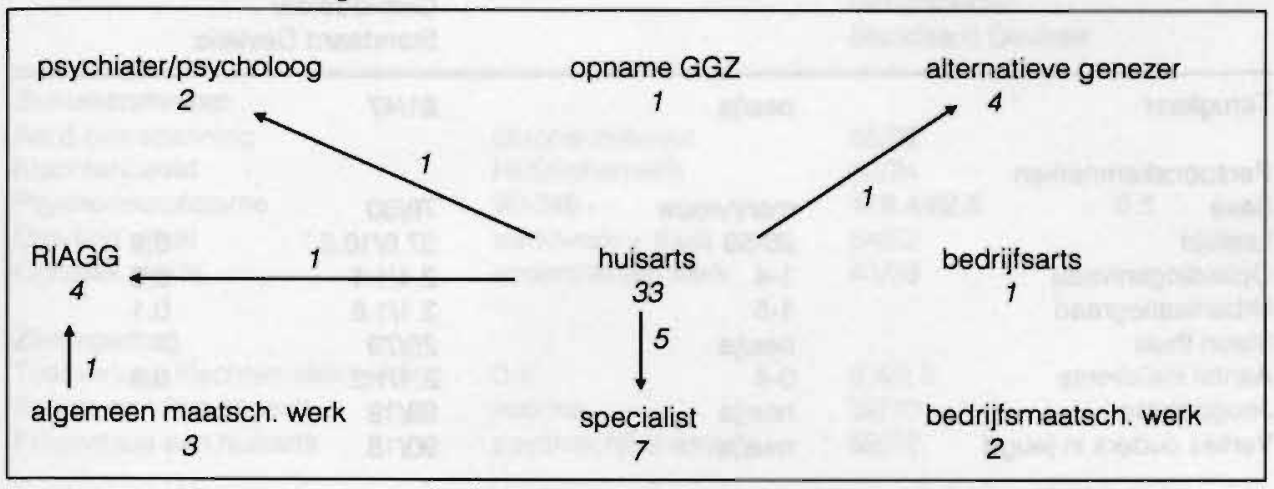

\section{B. Na de ziekmelding}

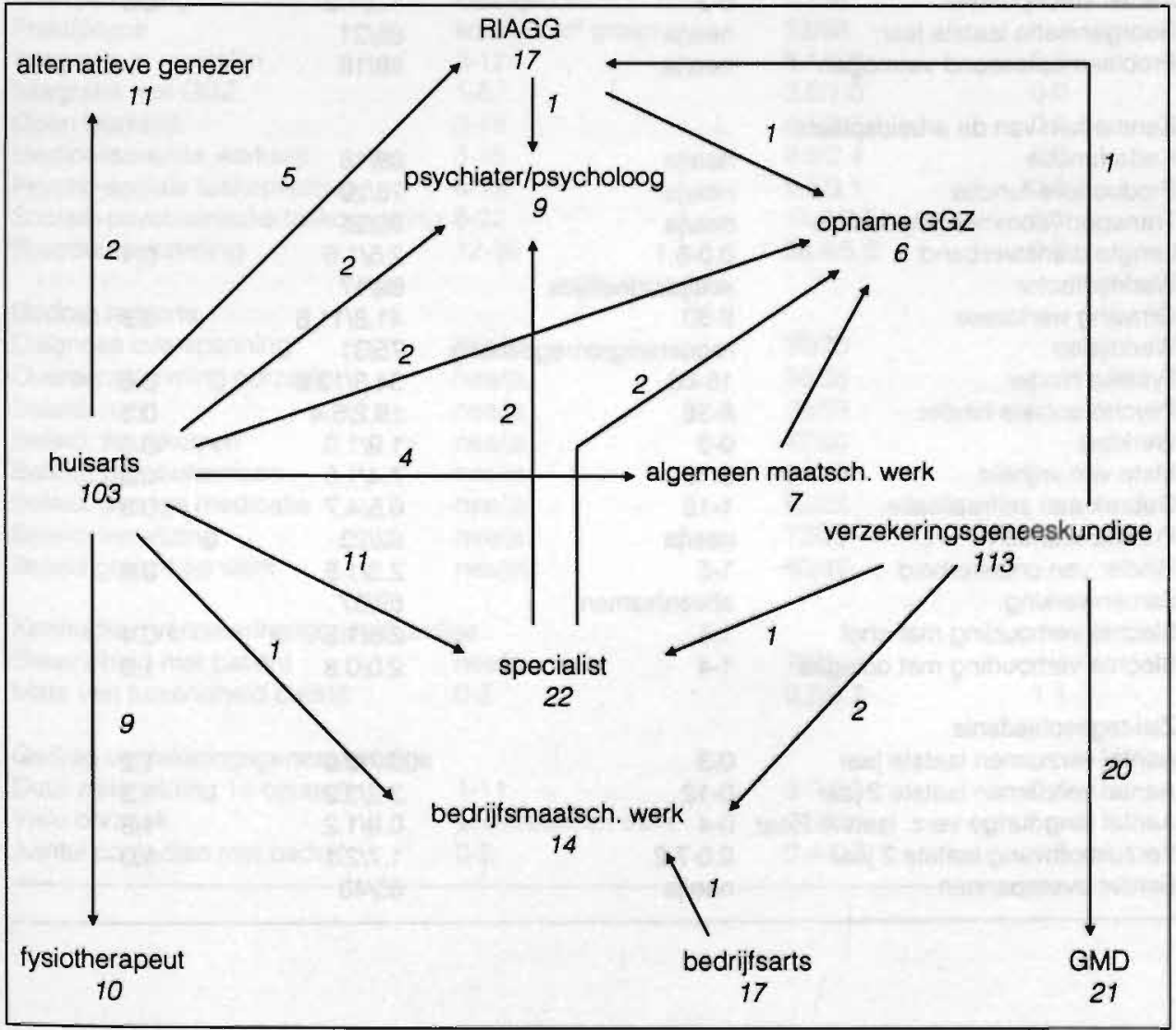




\begin{tabular}{|c|c|c|c|}
\hline & Range & $\begin{array}{l}\text { Verdeling c.q. } \\
\text { Gemiddelde/ } \\
\text { Standaard Deviatie }\end{array}$ & Scheefheid \\
\hline Terugkeer & nee/ja & $61 / 47$ & \\
\hline \multicolumn{4}{|l|}{ Persoonskenmerken } \\
\hline Sexe & man/vrouw & $78 / 30$ & \\
\hline Leeftijd & $20-59$ & $37.0 / 10.5$ & 0.3 \\
\hline Opleidingsniveau & 1.4 & $2.4 / 1.1$ & 0.2 \\
\hline Urbanisatiegraad & $1-5$ & $3.1 / 1.6$ & 0.1 \\
\hline Steun thuis & nee/ja & $26 / 79$ & \\
\hline Aantal life events & 0.4 & $2.1 / 1.2$ & 0.3 \\
\hline Jeugdziekte & nee/ja & $89 / 19$ & \\
\hline Verlies ouders in jeugd & nee/ja & $90 / 18$ & \\
\hline \multicolumn{4}{|l|}{ Bedrijfskenmerken } \\
\hline Sector & industrie/diensten & $62 / 46$ & \\
\hline Omvang & $1-6$ & $2.8 / 1.9$ & 0.9 \\
\hline Aantal steunpunten & $0-3$ & $1.2 / 1.2$ & 0.5 \\
\hline Reorganisatie laatste jaar & nee/ja & $85 / 21$ & \\
\hline Probleemoplossend vermogen & nee/ja & $88 / 18$ & \\
\hline \multicolumn{4}{|l|}{ Kenmerken van de arbeidsplaats } \\
\hline Kaderfunctie & nee/ja & $89 / 18$ & \\
\hline Productieve functie & nee/ja & $78 / 29$ & \\
\hline Transport-/commerciële functie & nee/ja & $86 / 21$ & \\
\hline Lengte dienstverband & $0.0-6.1$ & $2.5 / 1.6$ & 0.1 \\
\hline Werktijdfactor & voltijds/deeltijds & $89 / 17$ & \\
\hline Omvang werkweek & $9-80$ & $41.8 / 11.6$ & 0.5 \\
\hline Werktijden & regelmatig/onregelmatig & $75 / 31$ & \\
\hline Fysieke hinder & $16-68$ & $34.3 / 13.8$ & 0.6 \\
\hline Psycho-sociale hinder & $8-36$ & $19.2 / 6.4$ & 0.3 \\
\hline Werklast & $0-3$ & $1.9 / 1.0$ & -0.5 \\
\hline Mate van vrijheid & 3-10 & $7.4 / 1.8$ & -0.5 \\
\hline Gebrek aan zelfrealisatie & $1-15$ & $6.5 / 4.7$ & 0.3 \\
\hline Promotiekansen & nee/ja & $82 / 23$ & \\
\hline Hinder van onzekerheid & $1-5$ & $2.3 / 1.5$ & 0.6 \\
\hline Samenwerking & alleen/samen & $69 / 37$ & \\
\hline Slechte verhouding met chef & $1-5$ & $2.8 / 1.3$ & 0.4 \\
\hline Slechte verhouding met colegae & $1-4$ & $2.0 / 0.8$ & 1.0 \\
\hline \multicolumn{4}{|l|}{ Ziektegeschiedenis } \\
\hline Aantal verzuimen laatste jaar & $0-3$ & $0.7 / 0.9$ & 1.2 \\
\hline Aantal verzuimen laatste 2 jaar & $0-12$ & $3.2 / 3.2$ & 1.3 \\
\hline Aantal langdurige verz. laatste 2jaar & $0-4$ & $0.9 / 1.2$ & 1.3 \\
\hline Verzuimomvang laatste 2 jaar & $0.0-7.2$ & $1.7 / 2.1$ & 1.0 \\
\hline Eerder overspannen & nee/ja & $65 / 43$ & \\
\hline
\end{tabular}


VERVOLG BIJLAGE 11.1 Overzicht variabelen terugkeer-analyse

Range
Verdeling c.q

Gemiddelde/

Standaard Deviatie
Scheefheid

d

\section{Ziektekenmerken}

Aard overspanning

Klachtenbeeld

Psychoneuroticisme

Omvang uitval

Oorzaak ziekte

chronisch/acuut
HES/lichamelijk

90-346

werk/werk + thuis

anders/alleen werk

$85 / 22$

$82 / 24$

$178.4 / 62.5$

0.8

$54 / 52$

$43 / 59$

\section{Ziektegedrag}

Tijdsverloop klachten ziekmelding

Relatie melding consult

Presentatie aan huisarts

0-9

voor/na

$6.4 / 2.8$

$-0.9$

psychisch/lichamelijk

$32 / 70$

$59 / 32$

\section{Kenmerken huisarts}

\section{Leeftijd}

Sociaal-geneeskundig verleden

29-67

nee/ja

klein/groot

solo/duo of groep

Praktijktype

Integratie in eerstelijn

Integratie met GGZ

Open werkstijl

Medicaliserende werkstijl

3-12

1-6

3-15

3-15

4-19

Psycho-sociale taakopvatting

\section{5-22}

Breedte taakstelling

12-39

\section{Gedrag huisarts}

\section{Diagnose overspanning}

Overeenstemming oorzaak

Beleid: rust

Beleid: terugkomen

Beleid: psychofarmaca

Beleid: overige medicatie

Beleid: verwijzing

Beleid gericht op werk
43.3/9.0

$74 / 22$

$56 / 38$

$38 / 58$

$8.1 / 2.8$

$3.6 / 1.0$

$8.1 / 2.9$

$8.8 / 2.4$

$9.8 / 3.1$

$14.3 / 3.5$

$26.4 / 5.6$

$25 / 70$

$38 / 55$

$29 / 68$

$47 / 50$

$54 / 43$

$69 / 28$

$72 / 25$

$50 / 42$
0.0

$-0.0$

0.5

$-0.0$

0.8

0.1

0.3

Kenmerken verzekeringsgeneeskundige
Bekendheid met patiēnt
nee/ja
$72 / 34$
Mate van bekendheid bedrijf
$0-2$
$0.5 / 0.7$

\section{Gedrag verzekeringsgeneeskundige}

Duur ziekmelding $1 \mathrm{e}$ contact

Visie oorzaak

Aantal contacten met bedrijf

1-11

anders/alleen werk

$0-2$
$5.0 / 2.3$

$41 / 61$

0.4-0.7
0.4

1.1

1.3 
BIJLAGE 11.2 Overzicht variabelen verloop-analyse

Range

ontslag/WAO-intrede

$24 / 23$

Aard verloop

Persoonskenmerken

Sexe

Leeftijd

Opleidingsniveau

Urbanisatiegraad

Steun thuis

Aantal life events

Verlies ouders in jeugd

Bedrijfskenmerken

Sector

Omvang

Aanwezigheid steunpunt

Kenmerken van de arbeidsplaats

Lengte dienstverband

Omvang werkweek

Werktijden

Fysieke hinder

Psycho-sociale hinder

Werklast

Mate van vrijheid

Gebrek aan zelfrealisatie

Hinder van onzekerheid

Samenwerking

Slechte verhouding met chef

Slechte verhouding met collegae

Ziektegeschiedenis

Aantal verzuimen laatste jaar

Aantal verzuimen laatste 2 jaar

Aantal langdurige verz. laatste $2 \mathrm{j} r$.

Verzuimomvang laatste 2 jaar

Eerder overspannen

\section{Ziektekenmerken}

Psychoneuroticisme

Omvang uitval

Oorzaak ziekte

\section{Ziektegedrag}

Tijdsverloop klachten ziekmelding

Relatie melding consult

Presentatie aan huisarts man/vrouw

20-57

$1-4$

$1-5$

nee/ja

0-4

nee/ja

industrie/diensten

$1-5$

nee/ja

$0.0-4.8$

9-70

regelmatig/onregelmatig

16-68

8-33

$0-3$

3-10

1-15

1-5

alleen/samen

$1-5$

$1-5$

$0-2$

0-7

0-2

0.0-6.6

nee/ja

90-317

werk/werk + thuis

anders/alleen werk

0-4

voor/na

$2.5 / 1.5$

psychisch/lichamelijk

$24 / 14$
$28 / 19$

$36.3 / 10.2 \quad 0.2$

$\begin{array}{ll}2.5 / 1.0 & 0.2\end{array}$

$3.1 / 1.6 \quad-0.1$

$13 / 32$

$2.2 / 1.1 \quad 0.3$

$37 / 10$

$21 / 26$

$2.0 / 1.4$

$29 / 17$

$\begin{array}{ll}1.8 / 1.5 & 0.3\end{array}$

42.2/13.1 -0.1

$31 / 15$

$34.3 / 15.3 \quad 0.6$

20.3/6.3 $\quad 0.2$

$2.0 / 0.9 \quad-0.6$

$7.4 / 1.9 \quad-0.5$

$\begin{array}{ll}7.0 / 4.9 & 0.1\end{array}$

$\begin{array}{ll}2.7 / 1.6 & 0.2\end{array}$

$31 / 15$

3.1/1.4 $\quad 0.4$

$\begin{array}{ll}2.1 / 0.9 & 0.7\end{array}$

$\begin{array}{ll}0.5 / 0.7 & 1.1\end{array}$

$\begin{array}{ll}2.1 / 2.2 & 0.9\end{array}$

$\begin{array}{ll}0.6 / 0.8 & 0.9\end{array}$

$1.3 / 1.9 \quad 1.3$

$28 / 19$

$184.0 / 58.5$

0.7

$23 / 22$

$13 / 30$

$-0.5$ 
VERVOLG BIJLAGE 11.2 Overzicht variabelen verloop-analyse

\section{Range}

Verdeling c.q. Scheefheid

Gemiddeldel

Standaard Deviatie

\section{Kenmerken huisarts}

Leeftijd

29-67

nee/ja

$46.2 / 9.2$

09

Sociaal-geneeskundig verleden

Praktijkomvang

Praktijktype

Integratie in eerstelijn

klein/groot

$29 / 12$

$24 / 17$

solo/duo of groep

$19 / 20$

Integratie mel GGZ

3-12

$1-5$

Open werkstijl

4-15

Medicaliserende werkstijl

3-15

6-14

Psycho-sociale taaksopvatting

Sociaal-psychiatrische taakopvatting 5-22

Breedte taakstelling

14-39

$8.1 / 3.0$

0.1

$3.8 / 1.0$

$8.3 / 2.7$

$-0.4$

$8.2 / 2.5$

0.5

$9.4 / 2.4$

0.6

13.3/3.7

$25.5 / 5.5$

0.7

0.4

04

\section{Gedrag huisarts}

Diagnose overspanning

Overeeenstemming oorzaak

nee/ja

nee/ja

nee/ja

nee/ja

nee/ja

nee/ja

nee/ja

nee/ja

$10 / 31$

$13 / 28$

$13 / 27$

$19 / 21$

$19 / 21$

$28 / 12$

$29 / 11$

$17 / 21$

Kenmerken verzekeringsgeneeskundige

Bekendheid met patiënt

nee/ja

$31 / 16$

Bekendheid met bedrijf

nee/ja

$33 / 13$

\section{Gedrag verzekeringsgeneeskundige}

Duur ziekmelding 1e contact

Visie oorzaak

Contact met bedrijf

$1-11$

anders/alleen werk

nee/ja
$5.0 / 2.5$

0.5 
BIJLAGE 11.3 Overzicht variabelen verzuimduur-analyse

\begin{tabular}{|c|c|c|c|c|}
\hline 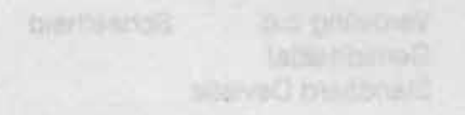 & Range & & $\begin{array}{l}\text { Verdeling c.q. } \\
\text { Gemiddelde/ } \\
\text { Standaard Deviatie }\end{array}$ & Scheefheid \\
\hline Verzuimduur & $0.7-1.7$ & $168=$ & $1.1 / 0.3$ & 0.7 \\
\hline Persoonskenmerken & & 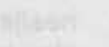 & 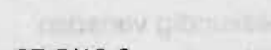 & 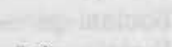 \\
\hline Leeftijd & $21-59$ & 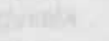 & $37.5 / 10.8$ & 0.3 \\
\hline Opleidingsniveau & 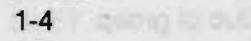 & $16=x+2$ & $2.4 / 1.1$ & 0.2 \\
\hline Urbanisatiegraad & $1-5$ & $3 x^{2}=$ & $3.1 / 1.5$ & 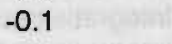 \\
\hline Steun thuis & nee/ja & $c^{2}$ & $13 / 47$ & 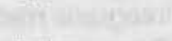 \\
\hline Aantal life events & $0-4$ & $1=$ & $2.0 / 1.2$ & 0.4 \\
\hline Jeugdziekte & nee/ja & $\sqrt{31}=$ & $47 / 14$ & 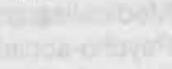 \\
\hline Bedrijfskenmerken & & $\ln ^{2}=3$ & 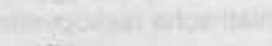 & 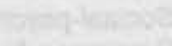 \\
\hline Sector & industrie/diensten & 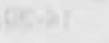 & $41 / 20$ & 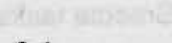 \\
\hline Omvang & $1-6$ & & $3.3 / 2.0$ & 0.1 \\
\hline Aantal steunpunten & $0-3$ & & $1.6 / 1.3$ & -0.1 \\
\hline Reorganisatie laatste jaar & nee/ja & 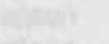 & $44 / 16$ & 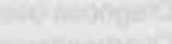 \\
\hline Probleemoplossend vermogen & nee/ja & 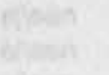 & $44 / 16$ & 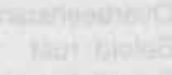 \\
\hline Kenmerken van de arbeidsplaats & & watey & & 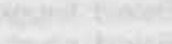 \\
\hline $\begin{array}{l}\text { Productieve functie } \\
\text { Transport/commercięle functie }\end{array}$ & nee/ja & 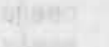 & 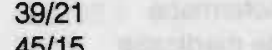 & 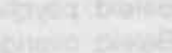 \\
\hline $\begin{array}{l}\text { Transport/commercięle functie } \\
\text { Lengte dienstverband }\end{array}$ & $\begin{array}{l}\text { nee/ja } \\
0.0-6.1\end{array}$ & 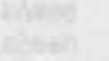 & $\begin{array}{l}45 / 15 \\
3.0 / 1.5\end{array}$ & 0.1 \\
\hline Omvang werkweek & $4.5-8.9$ & $x_{1}$ & $6.4 / 0.7$ & 0.8 \\
\hline Werktijden & regelmatig/onregel & Imatig & $44 / 16$ & \\
\hline Fysieke hinder & $16-63$ & & $34.4 / 12.7$ & 0.6 \\
\hline Psycho-sociale hinder & $8-36$ & $(x-201$ & $18.4 / 6.4$ & 0.4 \\
\hline Werklast & $0-3$ & axton & $1.7 / 1.1$ & -0.3 \\
\hline Mate van vrijheid & $3-10$ & & $7.3 / 1.8$ & -0.6 \\
\hline Gebrek aan zelfrealisatie & $1-15$ & & $6.2 / 4.5$ & 0.4 \\
\hline Promotiekansen & nee/ja & & $40 / 19$ & (1) \\
\hline Hinder van onzekerheid & $1-5$ & $1507+5$ & $2.0 / 1.4$ & 0.9 \\
\hline Samenwerking & alleen/samen & $4=20$ & $38 / 22$ & -1 \\
\hline Slechte verhouding met chef & $1-5$ & & $2.5 / 1.3$ & 0.7 \\
\hline Slechte verhouding met collegae & $1-3$ & & $1.8 / 0.6$ & -0.1 \\
\hline \multicolumn{5}{|l|}{ Ziektegeschiedenis } \\
\hline Aantal verzuimen laatste jaar & $0-3$ & & $0.8 / 1.0$ & 0.9 \\
\hline Aantal verzuimen laatste 2 jaar & $0-12$ & & $3.8 / 3.4$ & 1.1 \\
\hline Aantal langdurige verz. laatste $2 \mathrm{jr}$. & $0-4$ & & $1.1 / 1.3$ & 1.0 \\
\hline Verzuimomvang laatste 2 jaar & $0.0-7.2$ & & $2.1 / 2.3$ & 0.8 \\
\hline Eerder overspannen & nee/ja & & $37 / 24$ & \\
\hline \multicolumn{5}{|l|}{ Ziektekenmerken } \\
\hline Aard overspanning & chronisch/acuut & & $48 / 13$ & \\
\hline Klachtenbeeld & HES/lichamelijk & & $46 / 15$ & \\
\hline Psychoneuroticisme & $98-346$ & & $182.8 / 67.0$ & 0.9 \\
\hline $\begin{array}{l}\text { Omvang uitval } \\
\text { Oorzaak ziekte }\end{array}$ & $\begin{array}{l}\text { werk/werk + thuis } \\
\text { anders/alleen werk }\end{array}$ & & $\begin{array}{l}31 / 30 \\
30 / 29\end{array}$ & \\
\hline
\end{tabular}


VERVOLG BIJLAGE 11.3 Overzicht variabelen verzuimduur-analyse

\begin{tabular}{|c|c|c|c|}
\hline 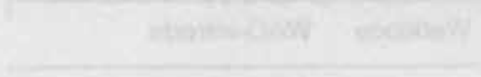 & Range & $\begin{array}{l}\text { Verdeling c.q. } \\
\text { Gemiddelde/ }\end{array}$ & Scheefheid \\
\hline$\sqrt{2}$ & 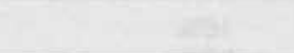 & Standaard Deviatie & \\
\hline \multicolumn{4}{|l|}{ Ziektegedrag } \\
\hline Tijdsverloop klachten ziekmelding & $0-9$ & $6.1 / 2.8$ & -0.6 \\
\hline $\begin{array}{l}\text { Relatie melding consult } \\
\text { Presentatie aan huisarts }\end{array}$ & $\begin{array}{l}\text { voor/na } \\
\text { psychisch/lichamelijk }\end{array}$ & $\begin{array}{l}18 / 41 \\
35 / 18\end{array}$ & \\
\hline \multicolumn{4}{|l|}{ Kenmerken huisarts } \\
\hline Leeftijd & $30-65$ & $44.7 / 8.9$ & 0.9 \\
\hline Praktijkomvang & klein/groot & $32 / 21$ & \\
\hline Praktijktype & solo/duo of groep & $19 / 36$ & \\
\hline Integratie in eerstelijn & $3-12$ & 8.1/2.7 & -0.1 \\
\hline Integratie met GGZ & $2-6$ & $3.5 / 1.1$ & 0.3 \\
\hline Open werkstijl & $3-15$ & $7.9 / 3.1$ & 0.6 \\
\hline Medicaliserende werkstijl & $5-13$ & $9.2 / 2.3$ & -0.5 \\
\hline Psycho-sociale taaksopvatting & $4-19$ & $10.1 / 3.6$ & 0.7 \\
\hline Sociaal-psychiatrische taakopvatting & $7-22$ & $14.9 / 3.2$ & 0.1 \\
\hline Breedte taakstelling & $12-39$ & $27.1 / 5.6$ & 0.2 \\
\hline \multicolumn{4}{|l|}{ Gedrag huisarts } \\
\hline Diagnose overspanning & nee/ja & $15 / 39$ & \\
\hline Overeenstemming oorzaak & nee/ja & $25 / 27$ & \\
\hline Beleid: rust & nee/ja & $16 / 41$ & \\
\hline Beleid: terugkomen & nee/ja & $28 / 29$ & \\
\hline Beleid: psychofarmaca & nee/ja & $35 / 22$ & \\
\hline Beleid: overige medicatie & nee/ja & $41 / 16$ & \\
\hline Beleid: verwijzing & nee/ja & $43 / 14$ & \\
\hline Beleid gericht op werk & nee/ja & $33 / 21$ & \\
\hline \multicolumn{4}{|l|}{ Kenmerken verzekeringsgeneeskundige } \\
\hline Bekendheid met patiënt & nee/ja & $41 / 18$ & \\
\hline Mate van bekendheid met bedrijf & $0-2$ & $0.6 / 0.8$ & 0.8 \\
\hline \multicolumn{4}{|l|}{ Gedrag verzekeringsgeneeskundige } \\
\hline Duur ziekmelding le contact & $1-11$ & $5.1 / 2.2$ & 0.4 \\
\hline Visie oorzaak & anders/alleen werk & $28 / 30$ & \\
\hline Contact met bedrijf & nee/ja & $43 / 15$ & \\
\hline
\end{tabular}




\section{BIJLAGEN}

BIJLAGE 12.1 Samenhang sexe en leeftijd met wijze van verzuimbeëindiging

\begin{tabular}{lrllcl}
\hline & N & Terugkeer & Elders hervat & Werkloos & WAO-intrede \\
\hline Mannen < 40 jaar & 37 & $65 \%$ & $16 \%$ & $8 \%$ & $11 \%$ \\
Vrouwen < 40 jaar & 25 & $40 \%$ & $20 \%$ & $20 \%$ & $20 \%$ \\
Mannen 2 40 jaar & 41 & $63 \%$ & $7 \%$ & $5 \%$ & $24 \%$ \\
Vrouwen 2 40 jaar & 5 & $20 \%$ & - & - & $80 \%$ \\
\hline
\end{tabular}




\section{Dankwoord}

Op de titel van het proefschrift prijkt alleen de naam van de auteur. Toch hebben zeer velen bijgedragen aan de totstandkoming van dit boek. Het is onmogelijk hen allen hier te noemen.

Paul Kaiser en Rini Verhagen legden in het GAK de organisatorische basis voor het promotieonderzoek. De uitvoering vond plaats bij een districtskantoor in het Zuiden des Lands. Daar ondervond ik de loyale en plezierige medewerking van de artsen en de administratieve medewerkers van de Medische Dienst. Daarbij wil ik met name Wim Jansen, Lei Baeten en Wil van Erk-Jansen bedanken voor hun coördinerende activiteiten. Een bijzondere plaats in mijn dankbetuiging is Toine Smeets waard. Meer nog dan zijn grote inzet die onmisbaar was om het project te doen slagen, blijven mij zijn interesse en enthousiasme voor dit onderzoek bij. Voorts bedank ik Jos van Loo die mij op vele manieren vanuit het Stafbureau van de Medische Dienst van het GAK heeft bijgestaan met de opzet van het onderzoek, de verzameling van gegevens en de rapportage.

Voorts ben ik de respondenten buitengewoon erkentelijk voor hun medewerking die zij in de voor hen zo moeilijke situatie verleenden aan een langdurig en intensief onderzoek. Ook de betrokken huisartsen en verzekeringsgeneeskundigen ben ik dankbaar voor hun medewerking en de moed zich kwetsbaar op te stellen voor het ongenadig oog van de onderzoeker.

Paul Peeters ben ik dankbaar voor zijn stimulerend doorzettingsvermogen bij de organisatie van het panelonderzoek. Eveneens dank ik de deelnemers, zowel de verzekeringsgeneeskundigen als de panelleden. Guiseppe di Giuglio en Tanja van Kan leverden bij het verzamelen en uitwerken van de gegevens van het panelonderzoek een belangrijke bijdrage.

Onmisbaar was de bijdrage van Voncka Schaffers aan de afname van de talloze interviews en aan het verwerken van de gegevens. Op alle momenten, hoe ongelegen soms ook, was ze in de weer voor de realisatie van het onderzoek. Ze deed dit met een stimulerende betrokkenheid bij het wel en wee van de respondenten zonder haar opgewektheid en gevoel voor humor ooit te verliezen. Naast Voncka droeg Truus Custers bij aan het litteratuuronderzoek. Jan van Houthem bedank ik voor zijn hulp bij de uitvoering van de logistische regressie-analyses.

Gerhart en Maria Saenger-Ceha ben ik buitengewoon dankbaar voor hun intensieve en leerzame begeleiding bij de redactie van de Engelstalige samenvatting.

De leden van de beoordelingscommissie bedank ik voor hun critische en constructieve commentaren. Ik heb daar dankbaar gebruik van kunnen maken. In het bijzonder dank ik daarbij Joost Bremer en André Knottnerus voor de grondige wijze waarop zij te werk zijn gegaan.

De medewerkers van de vakgroep medische sociologie en van het deelproject bedrijfsgezondheidkundige interventies ben ik erkentelijk voor hun belangstelling 
en adviezen gedurende al de jaren waarin ik aan het promotieonderzoek en het proefschrift werkte. Daarnaast wil ik ook Herro Kraan, Mark Richartz en Berend Terluin bedanken voor hun belangstelling en adviezen.

Hans Philipsen dank ik voor zijn onmisbare rol als initiator van het promotieonderzoek en zijn ondersteuning bij het schrijven van dit proefschrift.

Gedurende de vele jaren van het onderzoek ondervond ik de standvastige, inspirerende en vriendschappelijk begeleiding van Frans Nijhuis. Van de eerste organisatorische activiteiten van het onderzoek tot het schrijven van dit proefschrift toe deed ik nooit vergeefs een beroep op zijn ondersteuning.

Loke en Stefje dank ik voor hun geweldige tolerantie voor de onplezierige kanten van een promotieonderzoek. Een forse aanslag op de gemeenschappelijke vrijetijdsbesteding en het gezinsbudget, zonder welke het werk niet gedaan kan worden, viel hen als onschuldige slachtoffers ten deel.

Ten slotte wil ik mijn dank uitspreken aan Henk Lebens en Wim van Zutphen. Henk Lebens moest als gevolg van een fatale ziekte zijn werk voor mijn onderzoek staken. Wim van Zutphen ondersteunde mij zowel bij het litteratuuronderzoek als bij het panelonderzoek en gaf mij tal van waardevolle adviezen voor het hoofdonderzoek. De oprechte belangstelling van Henk en Wim - ook voor de persoonlijke kant aan het werk - gaf me vaak een extra impuls om door te gaan. Binnen eén maand tijd verloor ik hen evenals Evelien die voor mij zoveel betekend heeft. Het doet me pijn dat zij de verschijning van mijn proefschrift en mijn promotie niet meemaken. 


\section{Curriculum vitae}

Kees Schröer werd geboren op 20-01-1949 te Tricht (gem. Buurmalsen). Hij bracht zijn jeugd door in Beverwijk en Utrecht. In 1968 behaalde hij het diploma gymnasium- $\beta$ aan het Sint Bonifatiuslyceum te Utrecht.

Hij maakte aansluitend een aanvang met de studie Westerse Sociologie aan de Rijksuniversiteit Groningen en behaalde in 1976 het doctoraal examen met als specialisatie arbeids- en organisatiesociologie. De hoofdvakken waren theoretische en empirische sociologie en methoden en technieken. Als bijvakken koos hij economie en wetenschapsfilosofie. Hij was een actief deelnemer aan de studentenbeweging en was als zodanig onder meer lid van de universiteitsraad en van het bestuur van de subfaculteit.

Hij is 1 januari 1977 in dienst getreden van de Rijksuniversiteit Limburg bij de Vakgroep Medische Sociologie.

Hij heeft daar in de loop der jaren ten behoeve van het onderwijs in de Faculteit der Geneeskunde o.a. functies vervuld als blok- en jaarcoördinator en als lid van de onderwijscommissie. Hij maakt momenteel onder andere deel uit van de Begeleidingscommissie Vernieuwing Basiscurriculum en van de Stageplanningsgroep Sociale Gezondheidszorg.

Hij verrichtte diverse onderzoeken zoals een surveyonderzoek naar het ziekteverzuim in Zuid-Limburg, een onderzoek naar gezondheidseffecten van onregelmatige werktijden en een onderzoek naar sociaal-economische gezondheidsverschillen. De laatste jaren werden vooral in beslag genomen door de onderzoeksactiviteiten waarvan dit proefschrift het resultaat vormt.

Hij vervulde diverse bestuurlijke functies binnen de Rijksuniversiteit Limburg, waaronder het lidmaatschap van de Universiteitsraad en het Georganiseerd Overleg in Ambtenarenzaken, het penningmeesterschap van de Stichting Maffius, die optreedt als de uitgever van het Universiteitsblad Observant, en het voorzitterschap van de Medezeggenschapscommissie van de Faculteit der Geneeskunde.

Naast zijn beroepsgebonden activiteiten besteedt hij graag en veel tijd en energie aan wielrennen - hij is bestuurslid van TWC De Specht te Maastricht - schaken, lange afstandswandelingen, gastronomie en vooral aan Loke en Stefje. 


\section{Publicaties van de auteur}

Nijhuis, F., C. Schröer en J. Soeters Gezondheidszorg en arbeidsongeschiktheid. Openbare Uitgaven, 2, 1983, 90-93;

Schröer, C.A.P., J. Soeters, F. Nijhuis, T. Custers en H. Philipsen Werk en ziekte. Deel 2; de werknemersenquête. Rijksuniversiteit Limburg, Maastricht, 1984;

Schröer, K. en J. Soeters Ziekte en Sociale zekerheid. In: Aakster,C.W. et al. (red.) Leerboek Medische Sociologie. Wolters-Noordhoff, Groningen, 1984 en 1991 (3e resp. 4e druk);

Soeters, J., K. Schröer en H. Philipsen Arbeidstijdverkorting en arbeidsverzuim. In: Grumbkov, J. von en J.J. Godschalk (red.) Sociale aspecten van arbeidstijdverkorting. Swets \& Zeitlinger, Lisse, 1984;

Nijhuis, F., J. Soeters, K. Schroer en H. Philipsen, Twee onderzoeksmethoden bij studie van arbeid en ziekteverzuim. Tijdschrift voor Sociale Gezondheidszorg, 63, 1985, 301-363;

Schröer, C.A.P., L. de Witte en H. Philipsen Slaapkwaliteit, gezondheidsbeleving en medisch consumptie bij vrouwelijke verpleegkundigen in wisseldienst. Gezondheid en Samenleving, 7, 1986, 103-114;

Schröer, C.A.P., F.J.N. Nijhuis en W. van Zutphen Gebruik en betekenis van de term overspanning in de geneeskundige litteratuur. Rijksuniversiteit Limburg, Maastricht, 1987:

Schröer, C.A.P., F.J.N. Nijhuis en W. van Zutphen Gebruik en betekenis van de term overspanning in de geneeskundige litteratuur. Tijdschrift voor Sociale Gezondheidszorg, 66, 1988, 163-167;

Schröer, C.A.P. en R.S. Bullinga Gezondheidsverschillen tussen sociaal-economische statusgroepen: effect van verschillen in leefwijze of arbeidsbelasting? Rijksuniversiteit Limburg, Maastricht, 1990;

Schröer, C.A.P. en R.S. Bullinga Gezondheidsverschillen tussen sociaal-economische statusgroepen: effect van verschillen in leefwijze of arbeidsbelasting? In: Mackenbach, J.P. (red.) Sociaal-economische verschillen onderzocht. Deel III. DOP, Den Haag, 1991; 


\section{ZIEKTEVERZUIM WEGENS OVERSPANNING}

door Kees Schröer

Wat houdt het begrip overspanning in? Wat zijn de typische klachten en verschijnselen van overspanning? Welke hulpverlening wordt er verleend aan overspannen werknemers? Van welke factoren is de verzuimduur en de wijze van verzuimbeëindiging in geval van overspanning afhankelijk?

Om deze vragen te kunnen beantwoorden heeft de auteur, werkzaam als Universitair Docent aan de Rijksuniversiteit Limburg, een aantal onderzoeken verricht:

- een onderzoek van de internationale medische vaklitteratuur vanaf circa 1880 ;

- een onderzoek onder artsen naar de diagnostiek van overspanning;

- een onderzoek onder 114 overspannen werknemers, hun huisartsen en verzekeringsartsen naar de hulpverlening en het ziekte(verzuim)beloop.

De auteur wil met dit boek een bijdrage te leveren aan de verklaring van de toename van arbeidsongeschiktheid wegens psychische aandoeningen en aan de beantwoording van de vraag hoe deze arbeidsongeschiktheid in een vroegtijdig stadium voorkomen kan worden. 